Historic, archived document

Do not assume content reflects current scientific knowledge, policies, or practices. 



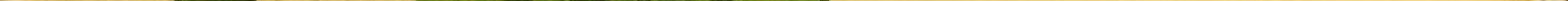


Prices and Terms. The prices quoted are those ruling at this date, and are suBJEct тo FudCtuAtion without notice. Our terms of payment are net cash.

Quotations with samples will be cheerfully given for such variable articles as Grass and Clover Seeds.

Do Not Forget Your Name and Address. We frequently receive orders without the name of the sender or with insufficient address. Customers should be particular to give the full Name, Post-Office, County and State, number of Street or P. O. Box, and the Nearest Express Office.

Changes of Residence. In order that our Catalogues may be forwarded regularly, we shall feel obliged if Customers will inform us of any change of residence. To any Customer who may fail to receive a Catalogue at the usual time we will gladly send another copy on receipt of a postal card.

Remittances. Remittances should be rade either in the form of a P. O. Money Order, Bank Draft, Regiatered Letter, or Express Money Order.
Order Early. It will greatly facilitate shipments if orders are sent in early. We aim to send off all ordere the same or next day after receipt, but during the rush season this may be impossible - hence the advisability of ordering early.

We Deliver Free in the United States to any Post Office, Railroad Express Office or Station, at our option all Vegetable and Flower Seeds at the packet, ounce, $\frac{1}{4}$ pound, $\frac{1}{2}$ pound and 1 pound prices, and also books. Purchaser pays transit charges on pints, quarts, pecks, bushels : also Farm Seeds, Bulbs and Plants, except where otherwise stated; Tools, Fertilizers, Insecticides, etc. If pints and quarts of Peas, Beans, and Corn are wanted, post or express paid, please remit extra at the rate of 8 cents per pint and 15 cents per quart.

Discount. A discount of $5 \%$ is allowed on orders of VEGETABLE and Flower Skeds when accompanied by cash. This offer is made to limit our book-keeping and making of detailed bills. It does not apply to seeds that are charged; nor to anything except Vegetable and Flower Seeds.

Bags and Packing. No charge for boxes or packing, nor for delivery to Freight Depots or Express Offices. Two Bushel Cotton Bags only we charge for at 25 cents each, and if returned in good condition free of expense, they will be credited as charged.

\section{NURSERY AND GREENHOUSE DEPARTMENT.}

Shipping Seasons. Deciduous Trees, Shrubs, Roses and Vines, March 20 up to the unfolding of the foliage, which is ususlly about May 10 to 15 in this locality; also through the monthe of October and November.

Evergreens. April and May; also in August and early September during a wet period.

Hardy Porennials. .April, May, August and September.

Bedding Plants. May 20 to early July.

Shipping Directions and Time of Delivery. Please specify at time of ordering whether goods are wanted by freight or express, also desired approximate date of delivery. We shall use our best judgment in these matters when definite instructions are not given.

Packing Freo. Customers in comparing prices should note that we do not charge for boxes and packing; nor for delivery to any Express, Freight, or Steamship line in Boston.
Cash with Order. We decline sending Trees, Shrubs and Plants "Collect on delivery," but we will ship by Express C.O. D. when desired, provided 50 per cent of the amount of the order accompanies the same as a guarantee. Said guarantee is only required from parties with whom we have insufficient business acquaintance: it does not apply to our regular credit customers.

\section{Clnumoutuealth of engsarhusetta}

STATE BOARD OF AGRICULTURE

Official Certificate No.2

Boston, July 14, 1908.

To Whом It May CoNCern: This is to Certify, that I have this Sixteenth day of July, 1907, completed the inspection of the Nursery Stock of $R$. \& J. Farquhar \& Co., grown at Roslindale, Dedham and Sharon, State of Massachusetts, and find it to be apparently free from all injurious insects and diseases which might be transferred on nursery stock from the nursery to the orchard or garden.

This Certificate is good until July 1, 1909.

(Signed) H. T. FERNALD, Inspector.

Planting and Improvement of Private Estates and Public Grounds. We have a large assortment of the best hardy Nursery stock suitable for the Northern States. We invite correspondence from those contemplating improvements or additional plantations of hardy trees, shrubs, vines, and perennial plants. We can also furnish competent gardeners to carry out such work.

NON-WARRANTY. R. \& J. Farquhar \& Co. give no warranty, express or implied, as to description, quality, productiveness, or any other matter of any seeds, bulbs, or plants they send out, and they will not be in any way responsible for the crop. If the purchaser does not accept the goods on these terms, they are at once to be returned.

\section{GARDENERS AND SUPERINTENDENTS}

We are always able to find Competent Gardeners and Superintendents for the management of estates.

We recommend no man unless we know him or have satisfactory reference as to his character and ability. In consequence of this care, the men we recommend rarely fail to give satisfaction. We make no charge to either party for this service. 


\section{FARQuhaR'S RELIABLE Vegetable SEEDS.}

ARTICHOKE. Alcachofa.

A most delicious vegetable, rapidly gaining in popularity. The heads are usually boiled, and the bottom of each scale eaten with butter and salt. In France they are more frequently baked with a dressing of fresh butter, forming a most savory dish.

Culture. Sow seeds in April or May, and when large enough, transplant in rows 4 feet apart and 2 feet in the rows. They yield the second year, and require protection during winter by earthing up and mulching. In the Northern States it is better to treat this plant as an annual, sowing seeds under glass and keeping the seedlings growing vigorously until May, when they should be set out in rich soil, when they will produce fine heads the first season.

Large Globe or Paris. The best of all Artichokes. Pkt., .15; 0z., 1.00 Large Green Globe. $\quad$ Pkt., .10; oz., .35; per lb., 3.50

Plants of Globe Artiehoke. Spring delivery ... Per doz., 2.00 Jerusalem Artichoke. Helianthus tuberosus. Cultivated for its edible tubers. Tubers

\section{ASPARAGUS. Esparrago Spargel.}

Culture. Sow the seeds thinly in drills one foot apart and one inch deep. The permanent bed should be trenched very deeply, and well manured with rich, thoroughly decayed manure. Wide drills should then be made, 3 feet apart, and deep enough to admit of the top of the plants being covered 6 inches. Set the plants, one or two years old, 12 inches apart in the rows, carefully spreading out and separating the roots. For the sake of convenience one drill should be made at a time, and the planting and covering completed before another is commenced. In November the plants should have their annual top dressing of manure after the stalks have been cleared away. The dressing should be forked in as soon as the ground can be worked in spring, and the bed neatly raked. One ounce of seed sows 60 feet of drill; 5 pounds sow one acre.

Argenteuil. The largest and finest sort in cultivation.

Pkt., .10; oz., .20; $\frac{1}{4}$ lb., .60; lb., 2.00 Conover's Colossal. A standard sort, large and very prolific. Columbian Mammoth. Whiте. Large, white stalks.

Pkt., .05; oz., .10; $\frac{1}{4}$ lb., .30; lb., 1.00

ASPARAGUS R00TS. April Delivery.

Argenteuil. 2 years ...

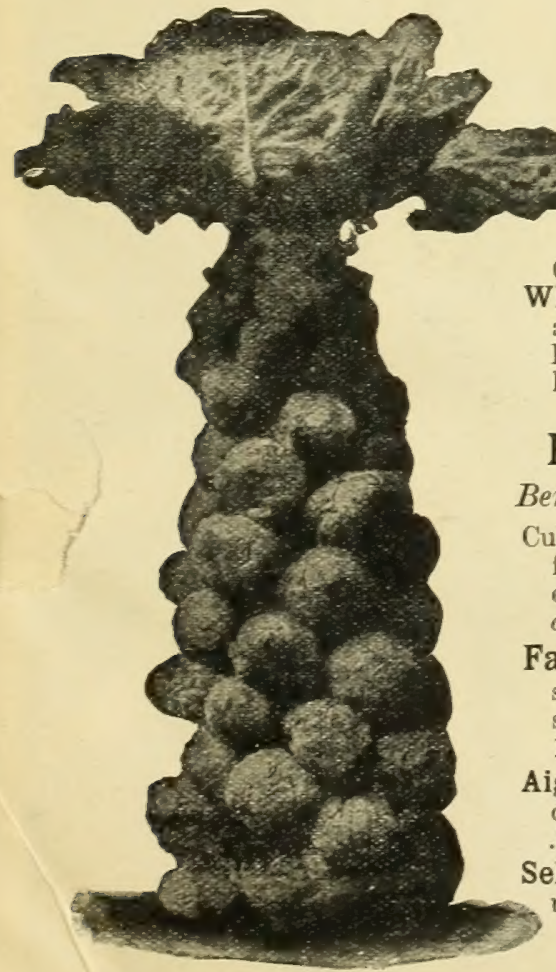

Farquhar's Matchless Brussels Sprouts.
Per $100,1.50$; per $1,000,12.00$
Conover's C 0 lossa 1.2 Conover's Colossal. 2 per $1,000,8.00$.

Columbian M a m moth White. 2 years, Per 100 , 1.25 ; per $1,000,10.00$.

\section{BROCCOLI.}

Broculi. Spargel Kohl. This vegetable resembles the Cauliflower, but is hardier.

White Cape. Heads white, close, and compact; a standard sort. Pkt., .10; oz., .40; $\frac{3}{4}$ lb., 1.25 ; lb., 4.00

\section{BRUSSELS SPROUTS.}

Berza de Brusels. Sprossen Kohl.

Cultivate like Cabbage. It is ready for use late in autumn, after the early frosts. One ounce of seed produces about 1,500 plants.

Farquhar's Matehless. The surest strain, producing large, solid sprouts. Pkt., .10; oz., .35; 1 lb. $1.00 ; \mathrm{lb} ., 3.50$.

Aigburth. Compact heads, very productive. Pkt., .05; oz., .25; 1 lb. 75 ; 1b., 2.50.

Selected English. Tender and of rich flavor. Pkt., .05; oz., 20; $1 \mathrm{lb}$. 60 ; lb., 2.00.

Serymger's Giant. Large compact sprouts. Pkt...05; oz., .20; $\frac{1}{4}$ lb., .50; lb., 1.75 .

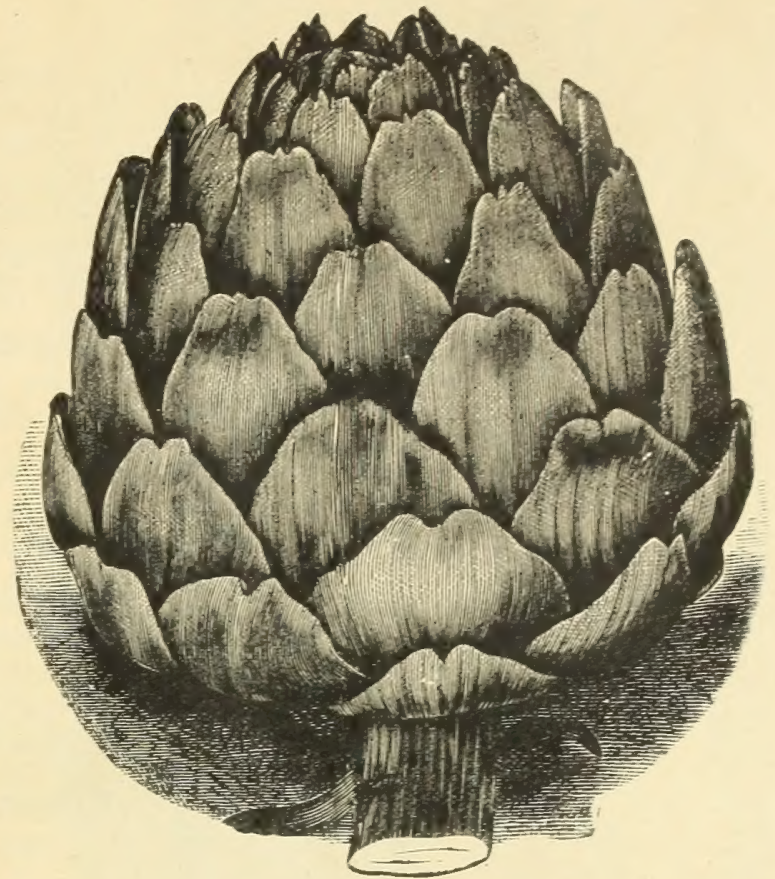

Artichoke, Large Globe or Paris.

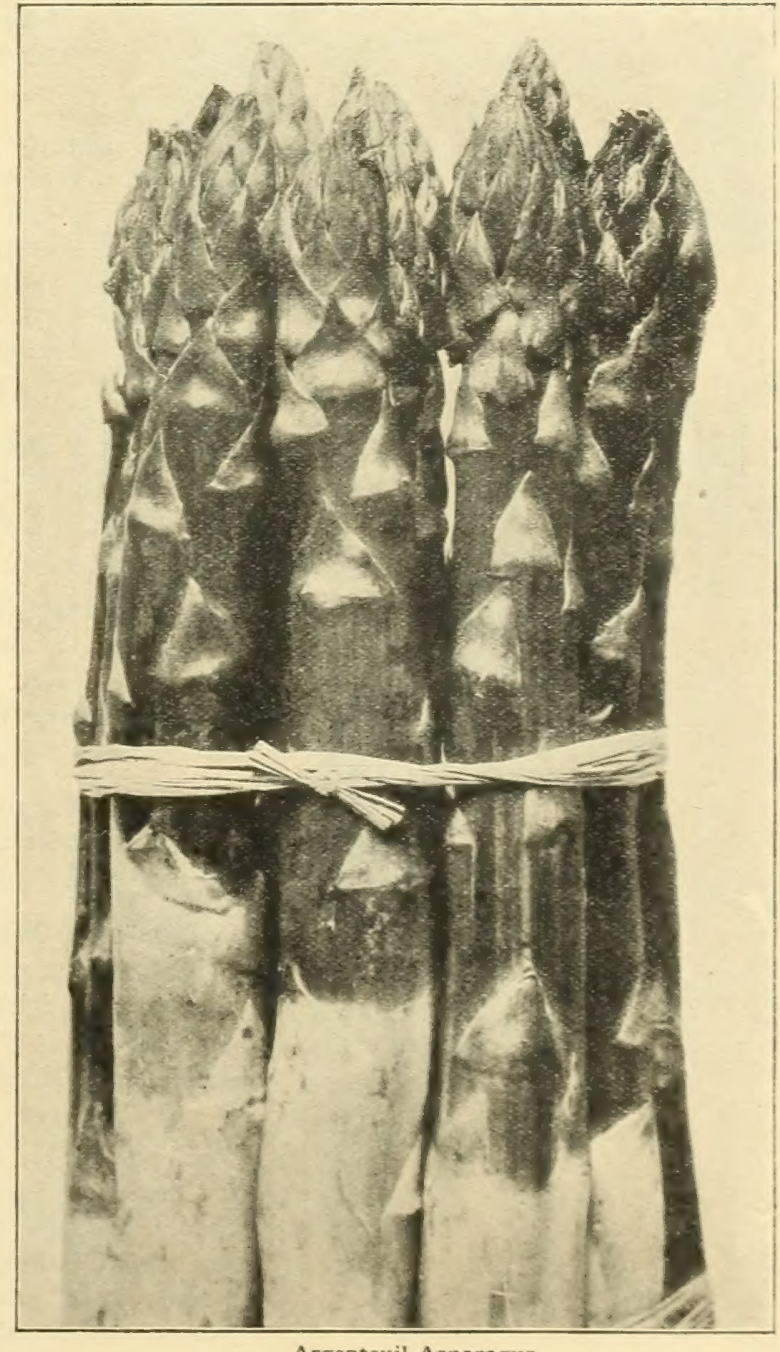

Argenteuil Asparagus. 


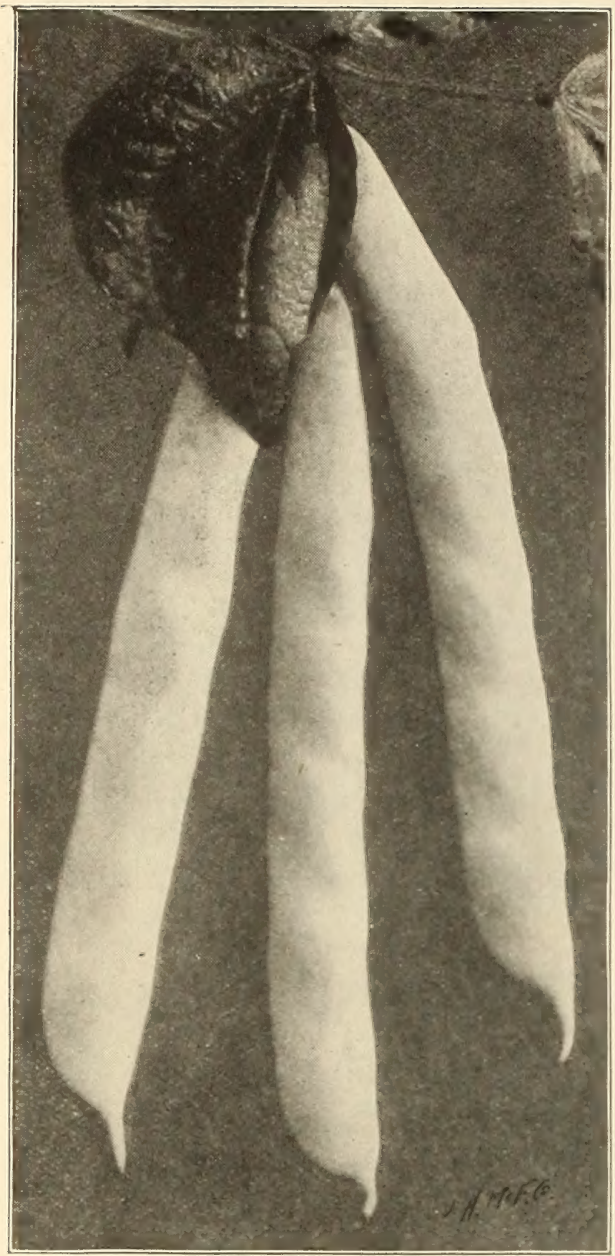

Farquhar's Rustless Golden Wax Bean.

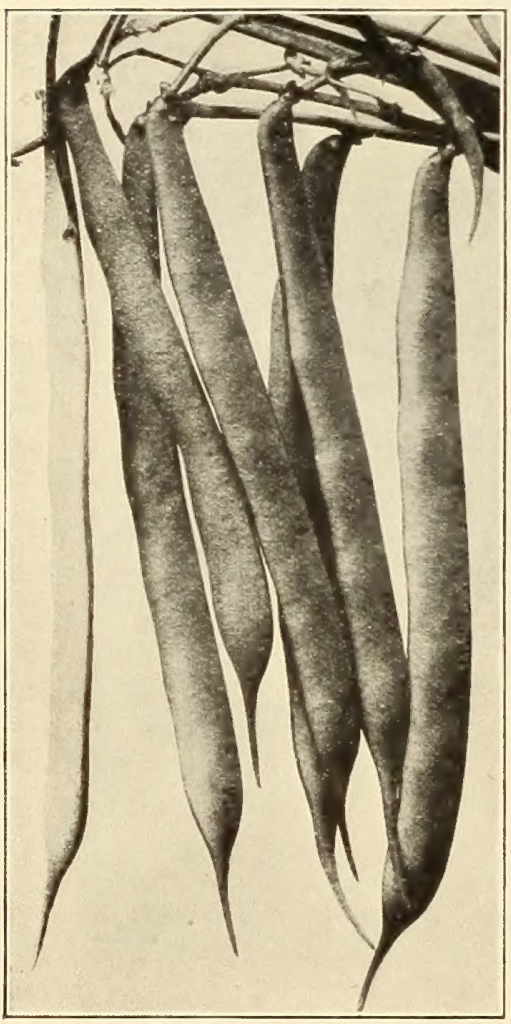

Triumph of the Frames Bean.

\section{BEANS, DWARF OR BUSH.}

\section{Wax-Podded Varieties.}

Beans succeed well in almost any well-worked soil. Plant when the weather has become warm, in drills 2 to 3 feet apart. Cover the seed about 2 inches. For succession plant every two weeks from the first of May until August. One quart of seed is sufficient for 100 jeet of drill, two bushels for one acre in drills.

Packets of all varieties of beans at 10 eents each, postpaid. If larger quantities are wanted by mail, add at the rate of 8 eents per pint and 16 eents per quart extra for postage.

Farquhar's Rustless Golden Wax. A strong growing, remarkably productive variety, throwing out long tendrils, but not xumning. 'The pods are very tender and entirely stringless, $\quad \ldots \quad \ldots \quad$ Pt., $\$ 0.30 ; q t ., \$ 0.50 ;$ pk., 3.00

Improved Golden Wax. A most valuable sort, which has proved remarkably free from spot or rust. It is early, a hardy and robust grower, productive and tender. Pods nearly straight and flat. Pt., .20; qt., .40; pk., 2.25 ; bush., 8.00

The Hodson Wax. A distinct type of excellent quality, bearing enormous quantities of tender fleshy pods of a creamy yellow color. The plant is vigorous, and comes into crop about two weeks later than the early sorts. The pods of this variety often measure 7 to 8 inches in length, and are remarkably free from spot or rust,

Pt., .15; qt., .30; pk., 2.00 ; bush., 7.00

Farquhar's Stringless White Wax. A large, white-seeded variety, of strong growth, remarkably free from string and very tender,

Wardwell's Kidney Wax. Very long, tender pods; straight and very handsome ... Pt., .20; qt., .35; pk., 2.00 ; bush., 7.00

Round Pod Kidney Wax. A round-podded bean of extra fine quality, almost devoid of string. Pods exceedingly beautiful and uniformly perfect in form, meaty and tender, ... Pt., .20; qt., $.35 ;$ pk., 2.25 ; bush., 8.00 .

Pencil Pod Black Wax. An extra fine bean, with round pods averaging 6 inches long, stringless and tender,

Pt., .25; qt., .40; pk., 2.25; bush., 8.00

Davis' Kidney Wax. An early and very productive sort with long, straight, white waxy pods of excellent flavor; the hardiest wax-podded bush bean,

Pt., .20; qt., .35; pk., 2.25; bush., 8.00

Yosemite Mammoth Wax. Very long, thick pods; flavor delicious, a splendid late sort, Pt., .25; qt., .40; pk., 2.25

Golden-eye Wax. One of the best, usually grows free from rust. Pods long, straight, flat, and handsome,

Pt., .15; qt., .30; pk., 2.00 ; bush., 7.00

E. Gangloff, Esq., 37 Park Avenue, Yonkers, N. Y., March 19th, 1908, writes : " $I$ received in good condition the Seeds that I ordered from you on Mar. 13th, for which I thank you. I have bought Seeds from your firm for over twenty years, and in all that time I have only praise to give."
Pt., .30; qt., .50; pk., 3.00

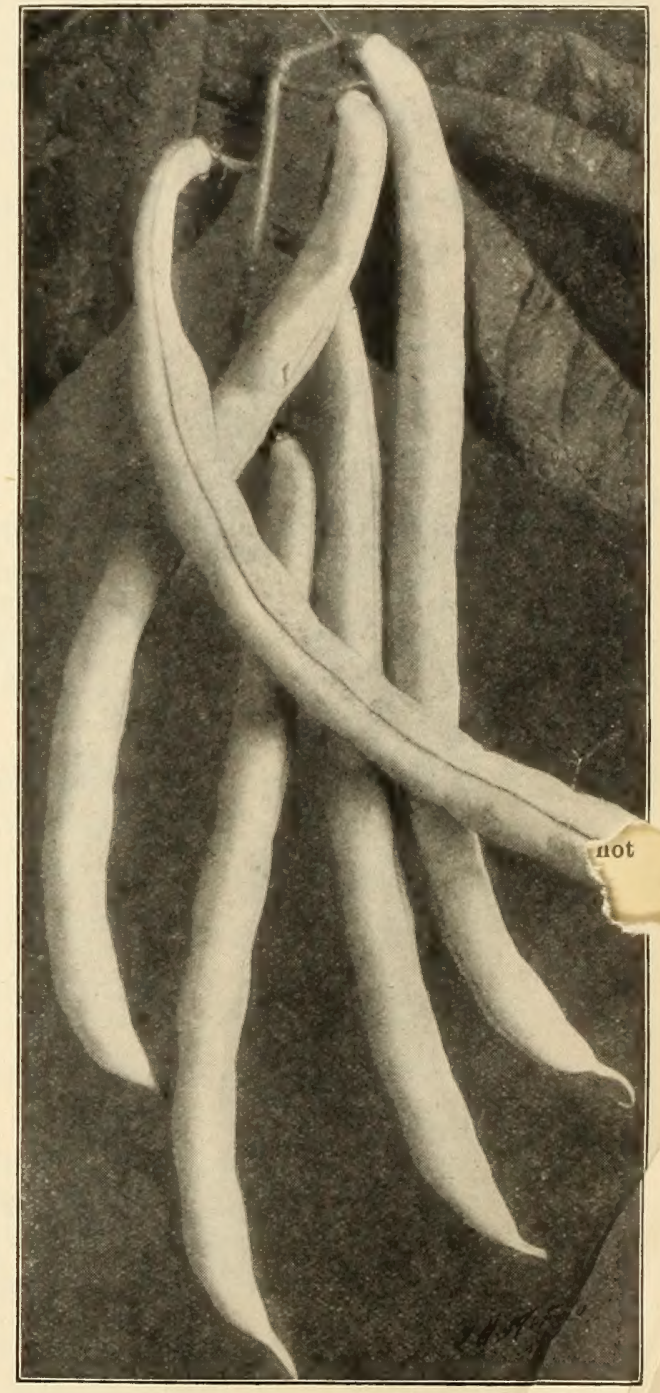

The Hodson Wax Bean. 
R. \& J. FARQUHAR \& CO., BOSTON. VEGETABLE SEEDS.

\section{BEANS, DWARF. Green-Podded.}

Triumph of the Frames. The earliest of the French forcing varieties, producing an abundant crop of long, finely shaped pods, flesh thick and very tender when young,

Pt., .50; qt., .75

Ne Plus Ultra. A superior sort for foreing; dwarf and compact in habit; very productive, and of excellent quality,

Pt., .20; qt., .35; pk., 2.00; bush., 7.00

Bountiful, or Improved Yellow Six Weeks. One of the best early flat-podded sorts, perfectly stringless, very tender, and prolific bearer,

Pt., .15; qt., .30; pk., 1.50; bush., 5.50

Stringless Green Pod. One of the earliest varieties, pods round, quite stringless, very erisp and tender,

Pt., .20; qt., .35; $\frac{1}{2}$ pk., 1.25 ; pk., $2.00 ;$ bush., 7.00

Giant Stringless Green Pod. Very early, absolutely stringless, round pods, very thick and tender,

Pt., .20; qt., .35; $\frac{1}{2}$ pk., $1.25 ;$ pk., $2.00 ;$ luush., 7.00

Low's Early Champion. Pods large, flat, and stringless; can be used as a snap bean when young, and an excellent shell bean when full grown ... Pt., .20; qt., .30; $\frac{1}{2}$ pk., 1.00; pk., 1.75; bush., 6.50

The Hodson Green Pod. A distinct type of excellent quality, maturing about ten days later than the early sorts; pods round, very tender and productive,

Pt., .15; qt., .30; $\frac{1}{2}$ pk., $1.10 ;$ pk., $2.00 ;$ bush., 7.00

Early Mohawk. Very early, hardy, and productive, pods long and

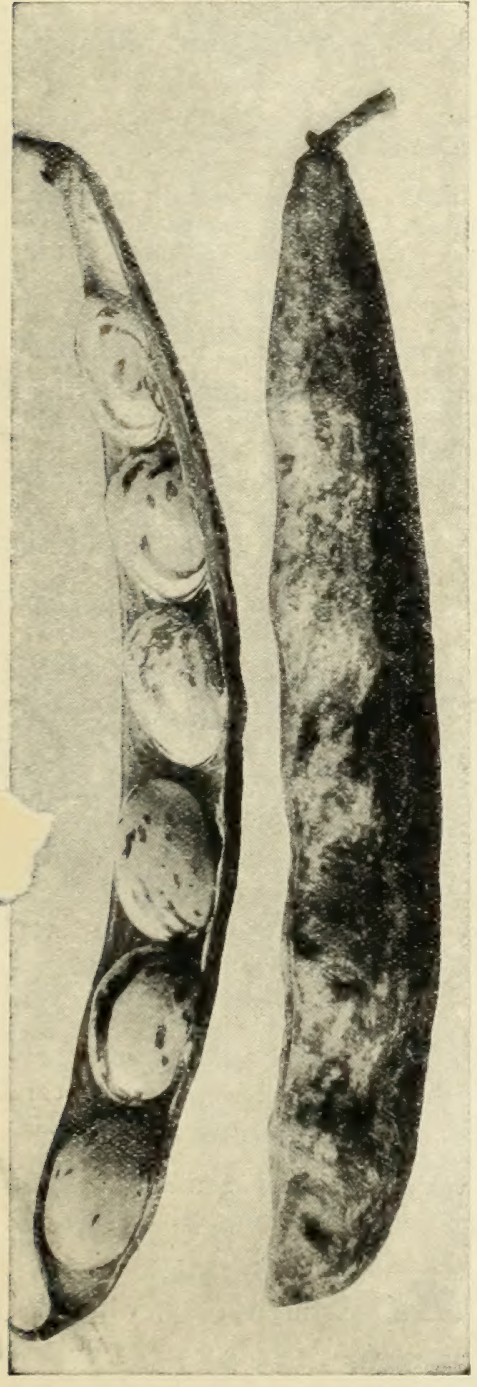

Dwarf Horticultural,

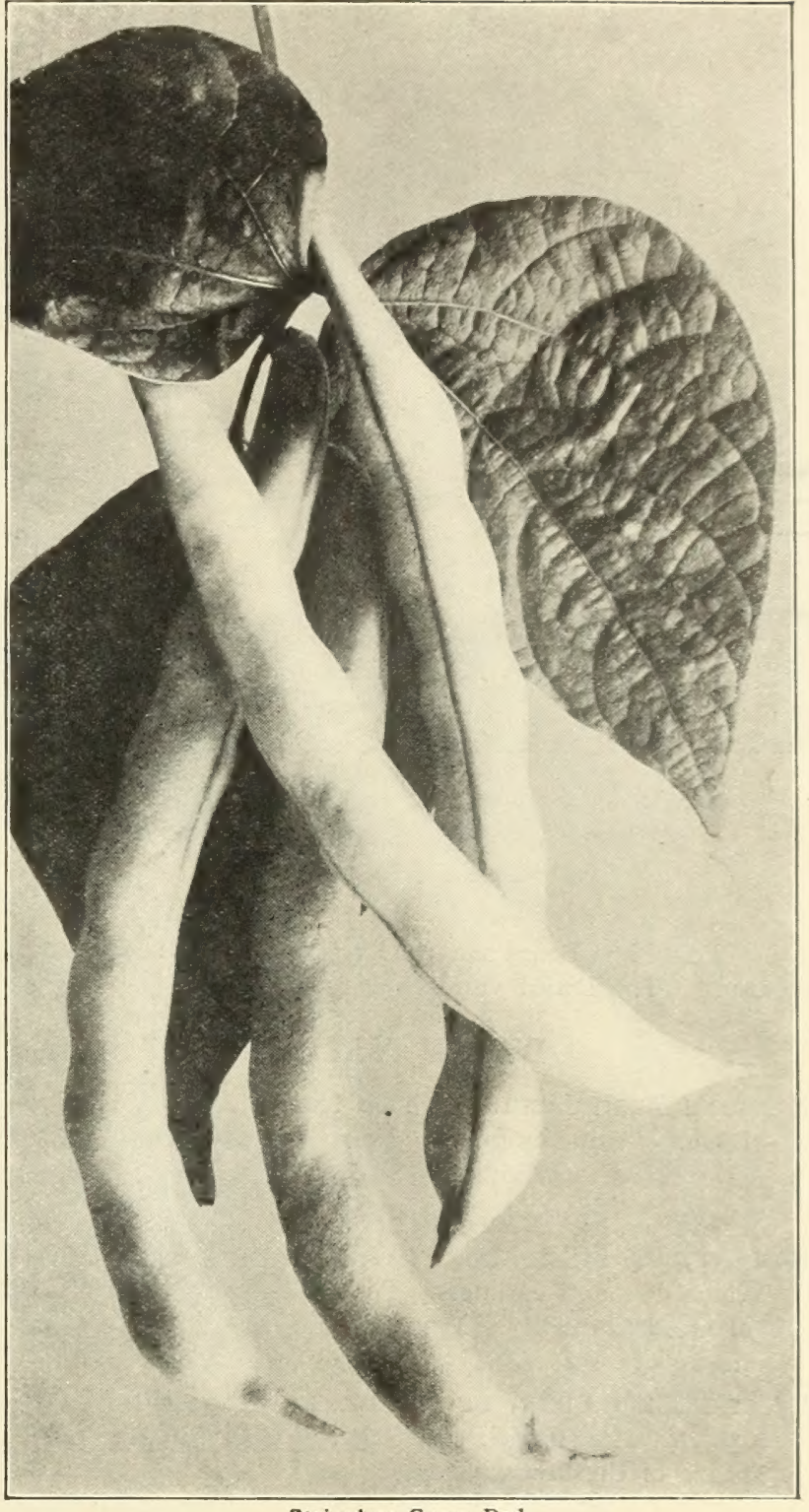

Stringless Green Pod. flat, an old favorite, Pt., .15; qt., .25; $\frac{1}{2}$ pk., .90; pk., 1.75 bush., 6.00

Dwarf Horticultural. One of the best shell beans; pods long and heavily splashed with crimson, very productive, $\mathrm{Pt}$, $.15 ;$ qt., .30; $\frac{1}{2}$ pk., $1.10 ;$ pk., 2.00 ; bush., 7.00

Improved Goddard. A long flat-podded variety, used as a

snap bean when young and as a shell bean when fully developed, being beautifully striped and splashed with bright crimson .... Pt., .20; qt., .35; $\frac{1}{2}$ pk., 1.25 ; pk., 2.25 ; bush., 8.00

Early Valentine. A large round-podded sort, erect, strong growing vines, pods curved, quite fleshy and tender

Pt., .20; qt., .30; $\frac{1}{2}$ pk., 1.00; pk., 1.75; bush., 6.00

Refugee. A popular variety for late planting, with large, handsome, tender pods, very productive

Pt., .15; qt., .25; $\frac{1}{2}$ pk., .85; pk., 1.50 ; bush., 5.00

Wonder of France. Flageolet Vert. A valuable French variety, with long tender pods of a bright green color, very early and prolific

Pt., .50; qt., .75

Improved Yellow Eye. One of the best sorts for baking, extremely productive, and of superior quality

Pt., .15; qt., .25; $\frac{1}{2}$ pk., 75 ; pk., 1.40 ; bush., 5.00

Prolifle Tree. A most productive small white baking variety, of superior quality,

Pt., .15; qt., .25; $\frac{1}{2}$ pk., .85; pk., 1.50; bush., 5.00

\section{BEANS, ENGLISH. Haba. Grosse Bohnen.}

Plant 4 inches deep as early in the spring as the ground can be worked. The rows should be 3 feet apart, and the seed set 4 inches apart in the rows.

Broad Windsor. The best variety; very hardy; height, 3 feet, 


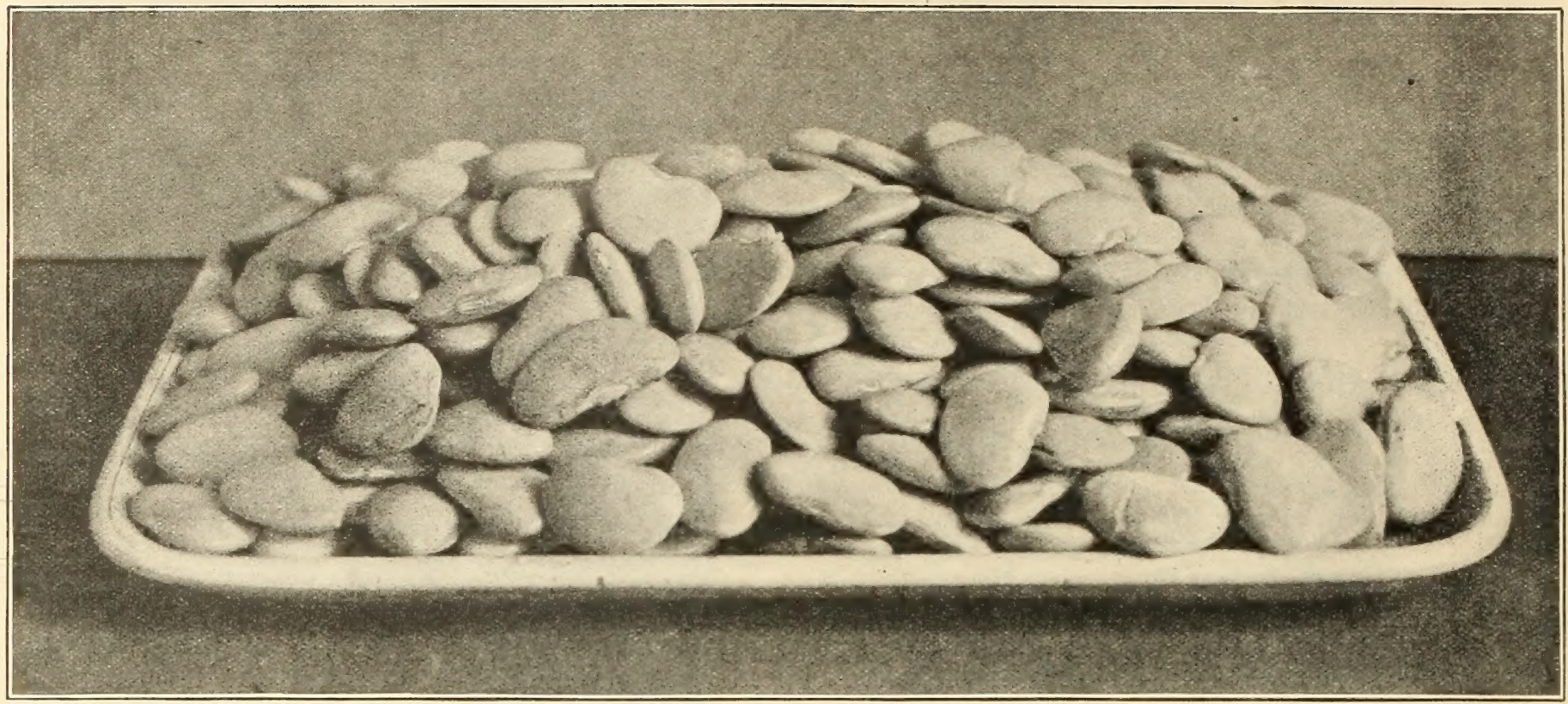

King of the Garden Pole Lima Bean.

\section{LIMA BEANS.}

Pole Lima Beans are usually grown in hills 4 feet apart each way, 5 or 6 plants to each hill. Sow in a light sandy soil, with warm exposure. The Dwarf varieties may be planted in rows 4 feet apart and 6 inches distant in the row.

\section{DWARF VARIETIES.}

Burpee's Bush Lima. A bush form of the true large White Lima. Plants uniformly dwarf and enormously productive. Pods large, containing 3 to 5 large flat beans of superior quality, Pt., .25; qt., .40; $\frac{1}{2}$ pk., 1.25 ; pk., 2.25; bush., 8.00

Henderson's Bush Lima. A dwarf form of the Sieva Lima, valuable for its earliness. Pods short, containing 2 to 4 beans of excellent quality. Vines continue to grow and set pods until frost ... Pt., .25; qt., .40; $\frac{1}{2}$ pk., 1.25; pk., 2.25 ; bush., 8.00

Dreer's Bush Lima, or Kumerle. An excellent large-seeded variety. Pods thick and large, each containing 3 to 5 thick beans of the best quality,

Pt., .25; qt., .40; $\frac{1}{2}$ pk., 1.25 ; pk., 2.25 ; bush., 8.00

\section{POLE VARIETIES.}

King of the Garden Pole Lima. A vigorous and productive sort, pods very long, cach contain 5 to 6 large beans of delicious flavor ... Pt., .25; qt., .40; $\frac{1}{2}$ pk., 1.25; pk., 2.25 ; bush., 8.00

Sieva, or Small Pole Lima. A popular small-seeded variety, vigorous grower, pods short, very productive,

Pt., .25; qt., .40; $\frac{1}{2}$ pk., 1.25; pk., 2.25; bush., 8.00

Dreer's Improved, or Challenger Pole Lima. The vines of this variety are vigorous and productive, the pods thick, and contain 4 to 5 beans of excellent quality,

Pt., .25; qt., .40; $\frac{1}{2}$ pk., 1.25; pk., 2.25; bush., 8.00

Early Leviathan Pole Lima. The earliest large pole Lima, with long, broad pods, containing 5 or 6 beans of unexcelled quality, remarkably productive.

Pt., .25; qt., .40; $\frac{1}{2}$ pk., 1.25 ; pk., 2.25 ; bush., 8.00

Packets of all varieties of Lima Beans, 10 cents each.

\section{POLE BEANS.}

Golden Carmine. A handsome variety, with golden yellow pods beautifully striped with bright crimson. It is very productive and is of excellent quality both as a Snap and Shell Bean,

Pt., .20; qt., .35; $\frac{1}{2}$ pk., 1.25 ; pk., 2.25 ; bush., 8.00

Worcester Pole. A very early and remarkably productive form of Horticultural Pole Bean. The long pods are highly colored, being beautifully striped and splashed with bright crimson. One of the best Shell Beans,

Pt., .20; qt., .30; $\frac{1}{2}$ pk., $1.10 ;$ pk., 2.00 ; bush., 7.00

old Homestead, or Kentueky Wonder. A valuable green podded variety. The pods, hanging in clusters, are large, entirely stringless, and tender,

$$
\text { Pt., .20; qt., .30; } \frac{1}{2} \text { pk., } 1.15 \text {; pk., } 2.00
$$

Arlington Red Cranberry. A fine variety for string or snap, almost stringless, tender and productive. Largely used as a dry Bean when ripe $\quad . . \quad \ldots \quad$ Pt., .20; qt., .35; pk., 2.00
Indian Chief, or Wax. An excellent variety, with long white fleshy pods, quite stringless and tender,

$$
\text { Pt., .20; qt., } 35 ; \text { pk., } 2.25
$$

Mont d'Or, or Golden Butter. One of the best early sorts, with long fleshy pods produced in clusters, very tender,

Pt., .25; qt., .40; pk., 2.25

Dreer's Golden Cluster. An early and beautiful sort, producing an abundance of bright golden yellow pods which are thick, fleshy and tender ... Pt., 25; qt., 40; pk., 2.00

Searlet Runner. A popular variety, for ornamental as well as culinary purposes, with large green pods, very productive,

Pt., .20; qt., .35; pk., 2.00

Yard Long Pod. A curious and interesting variety, with pods 30 to 36 inches long $\quad \ldots \quad \ldots \quad \ldots \quad \ldots \quad$. $\quad \ldots \quad \frac{1}{2}$ pt., .25 Packets of all varieties of Pole Beans, 10 cents each 
R. \& J. FARQUHAR \& CO., BOSTON. VEGETABLE SEEDS.

BEET. Remolacha. Salatrübe.

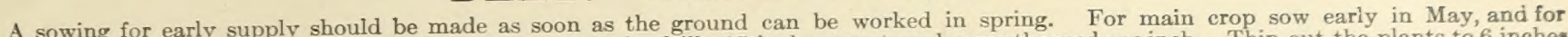

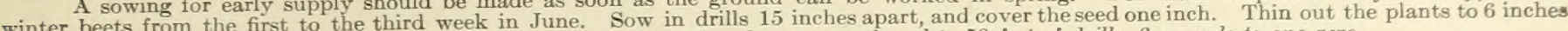
apart. The soil should be deeply manured and well cultivated. One ounce of seed to 50 feet of drill; 6 pounds to one acre

Crosby's Egyptian. One of the best sorts for early planting. Very smooth with small top; color deep crimson; sweet and tender, Pkt. .05; oz., .10; 1 lb., .30; 1b., 1.00

Improved Early Egyptian. A remarkably smooth turnip-shaped variety, with small top and small tap root; flesh fine grained and of a rich crimson color, tender and delicious, Pkt., .05; oz., .10; 1 lb., .25; 1b., .75 Arlington Favorite. A valuable sort for main crop, smooth and almost globular in shape; flesh dark blood-red color, very sweet, Pkt., .05; oz., .10; $\frac{1}{4}$ lb., .35; 1b., 1.00

Farquhar's Mid-Summer. The finest Beet grown. It is very uniform in size and shape. The flesh is of dark crimson color, fine grained, and of delicious sweet flavor, Pkt., $.10 ;$ oz.. .15; 1 lb., .50; lb., 1.50

Detroit Dark Red Turnip. A superior sort for medium and late planting. Top small, upright growing; color of skin, dark blood red; flesh deep crimson, tender and very sweet, Pkt., .05; oz., .10; $\frac{1}{4}$ lb., .20; lb., .60

Edmand's Early Blood Turnip. One of the best for main and late crops. Tops small; roots dark red; flesh fine grained, of rich crimson color; crisp, tender, and a good keeper, Pkt., .05; oz., . 10 ; $\frac{1}{4}$ lb., .25; lb., .75

Early Eelipse. A very early globe-shaped variety with small tap root; flesh bright red, streaked with white, very sweet, crisp, and tender, Pkt., .05; oz., .10; $\frac{1}{1}$ lb., .20 ; lb., .60

Crimson Globe. A splendid variety of medium size, very handsome, with small top and small tap root; flesh deep crimson, tender and delicious, Pkt.,.10; oz., 15 ; 1 lb.,.50; 1b., 1.25

Dewing's Early Blood Turnip. A handsome sort for medium planting. Roots dark red with large tap tapering to a point; flesh rich dark blood red, tender; a good keeper, Pkt., .05; oz., .10 ; $\frac{1}{4} \mathrm{lb} ., .20 ; 1 \mathrm{~b} ., .50$

Long Smooth Blood. An excellent late sort. Skin is dark purple; flesh dark red, sweet and tender, Pkt., .05; oz., . 10 ; 1 lb., .20; lb., .60

Perpetual Spinach. A valuable variety, producing a continuous supply of bright green leaves, used in the same manner as Spinach, Pkt., .05; oz., .10; 1 lb., .25; lb., .75

Swiss Chard. The leaves are used as greens, the leaf stalks also are used like Asparagus, Pkt., .05; oz., .10; $\frac{1}{1} 1 \mathrm{lb} ., .25$; lb., .75

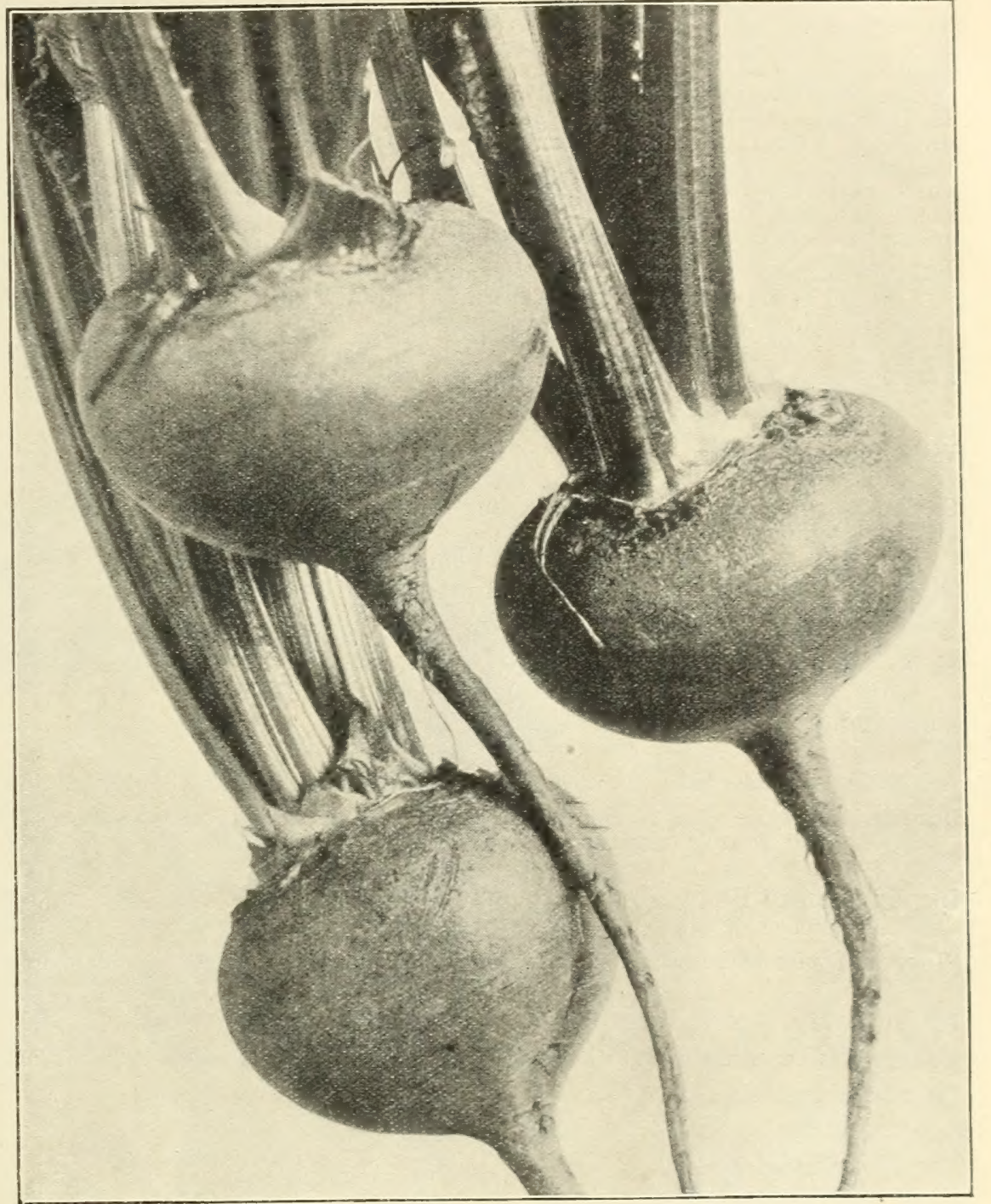

Farquhar's Mid-Summer Beet.

Beet for Greens. The leaves, eut when young, make delicious greens $\quad \ldots \quad \ldots \quad$... Pkt., .05; oz.,.10; $\frac{1}{4} \mathrm{lb} . . .15$; lb.,.50

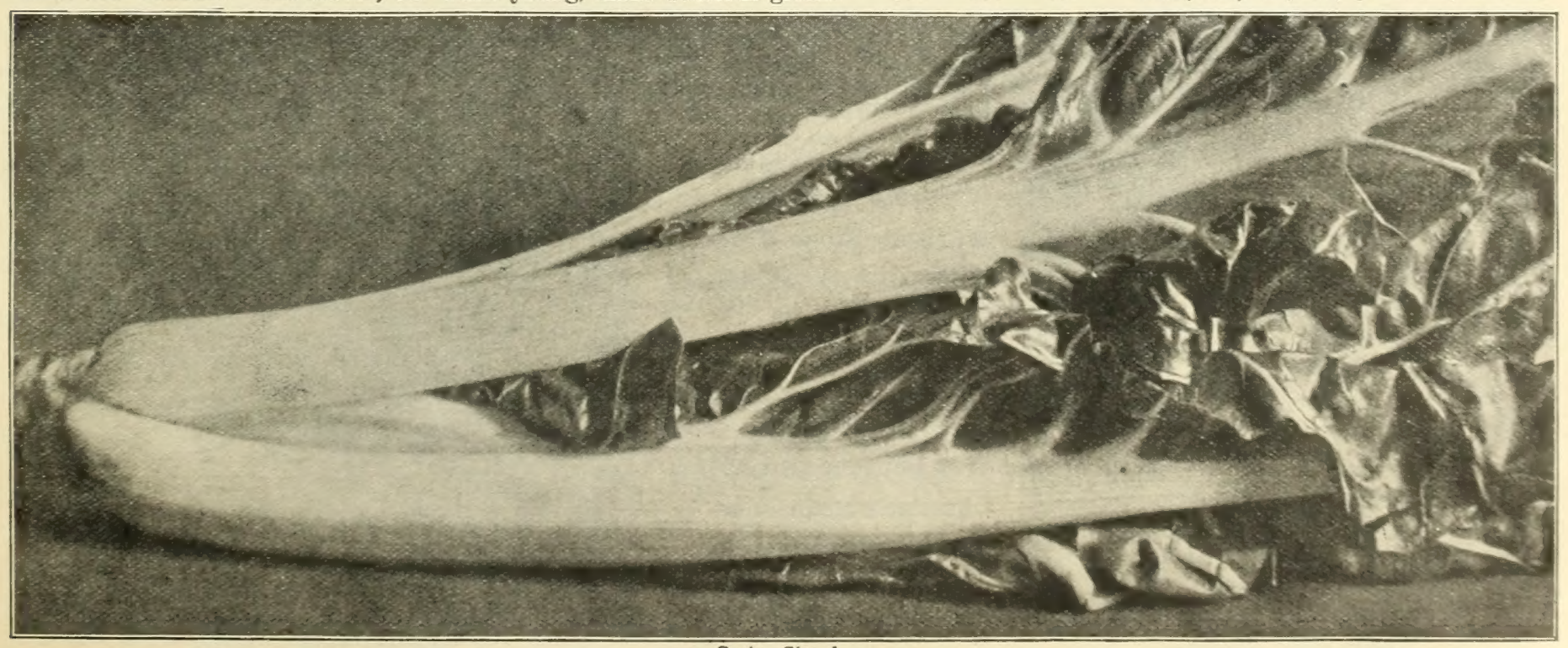




\section{R. \& J. FARQUHAR \& CO., BOSTON. VEGETABLE SEEDS.}

\section{CABBAGE. Berza de repollo. Kopfkohl.}

Culture. For very early use sow in January or February in hot-beds, prick out when the plants are strong enough into other hot-beds, or sow in hot-beds in March. Transplant to the open ground when danger from killing frosts has passed, in rows 2 feet apart and 18 inches from plant to plant. For succession, sow in the open ground the last of March or early in April. The autumn and winter varieties may be sown in April or early in May in shallow drills 3 or 4 inches apart; transplant early in July, making the rows about $2 \frac{1}{2}$ feet apart, and setting the plants 2 feet apart in the rows. Cabbage succeeds best in a fresh, rich soil, well manured and deeply dug or ploughed. One ounce of seed produces about 3,500 plants.

Early Spring. A round, flat-headed, extra early variety, coming in with the Wakefield. The heads are uniform and solid, even when quite young,

Pkt., \$0.10; oz., .30; $\frac{1}{4}$ lb., .85; lb., 3.00

Express Extra Early. The earliest medium-sized variety, solid heads, very tender and delicious,

Pkt., .05; oz., .20; $\frac{1}{4}$ lb., .60; lb., 2.00

Winnigstadt. Pointed head, adapted for light soils; early to medium, Pkt., .05; oz., .20; $\frac{3}{4} \mathrm{lb} ., 60$; lb., 2.00

Early Jersey Wakefleld. The leading early sort; very solid, pyramidal-shaped heads,

Pkt., .05; oz., .25; $\frac{1}{4}$ lb., .75; lb., 2.50

Glory of Enkhuizen. Large early ball shaped heads, very solid, and of fine quality,
Pkt., .10; oz., .35; $\frac{1}{1} \mathrm{lb} ., 1.00 ; 1 \mathrm{~b} ., 3.50$

Early Summer. The best second-early sort; large and solid heads $\quad .$. Pkt., .05; oz., .20; $\frac{1}{1} \mathrm{lb} ., .60 ; \mathrm{lb} ., 2.00$

Succession. Very fine for second-early or late crops,
Pkt., .05; oz., $25 ; 1$ lb., $.75 ;$ lb., 2.50

All Seasons; Selected. Excellent for main crop; large; reliable header,

Pkt., .05; oz., .25; +1 lb., .75; lb., 2.50

Danish Ballhead. The favorite winter cabbage. One of the hardiest eabbages in cultivation, and endures both frost and drought that would destroy other varieties. The hardest heading cabbage we know of and of the very best quality.

Danish Round Head. This splendid variety produces large globular heads of great solidity, tender and of excellent

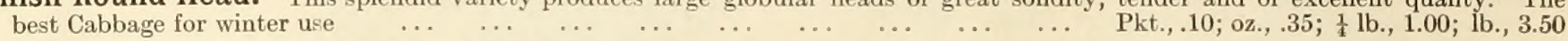

Wapren Stone-Mason. We have a superior strain of this excellent winter sort. Large and round, very solid and a splendid keeper.

Pkt., .10; oz., .25; 1 lb., .75; lb., 2.50

Premium Flat Duteh. Well known late sort with large flattened heads

$.05 ;$ " $.20 ;$ " $.60 ;$ " 2.00

Marblehead Mammoth. The largest late cabbage; very solid and an excellent keeper . . . " . . 05 ; " .20; " .60; " 2.00

Improved American Savoy. Finely crumpled, solid, round heads; fine flavor _.. . . . " .05; " .25; " .75; " 2.50

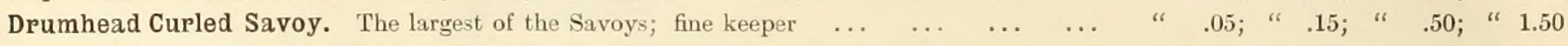

Early Dark Red Duteh. Remarkably solid; beautiful dark color; fine texture ... ... " . .10; " .30; " .85; " 3.00

Dark Red Drumhead. Heads very dark red, round and solid; choice stock

.05 ; “ $.25 ;$ “ $\quad .75 ; . \star 2.50$

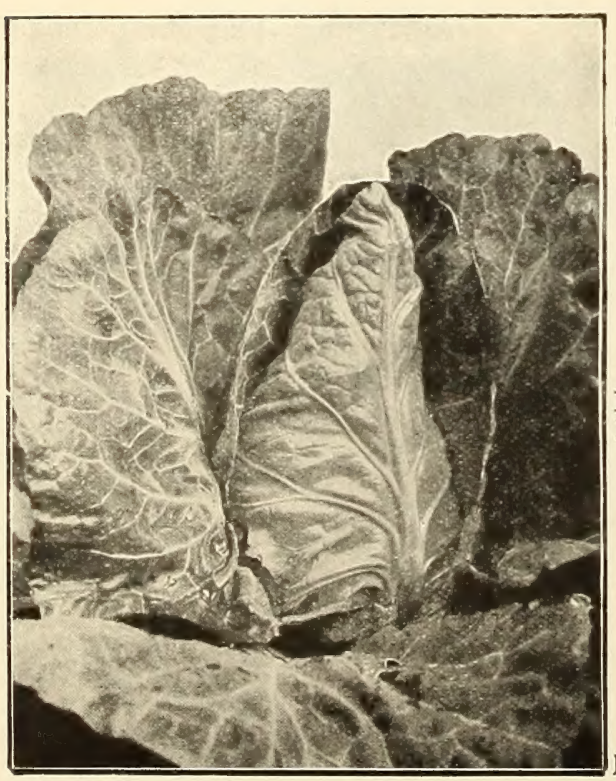

Early Jersey Wakefield.

\section{CABBAGE PLANTS.} Delivery April and May.

Early Jersey Wakefleld.

Early Summer.

Warren's Stone-Mason.

Each of the above varieties, Doz., .20; per 100, 1.00; per $1,000,7.00$

For Winter Crop, Ready June and July.

Savoy Improved American.

Fottler's Brunswick.

Warren's Stone-Mason.

Each of the above varieties, Per $100, .75$; per $1,000,5.00$

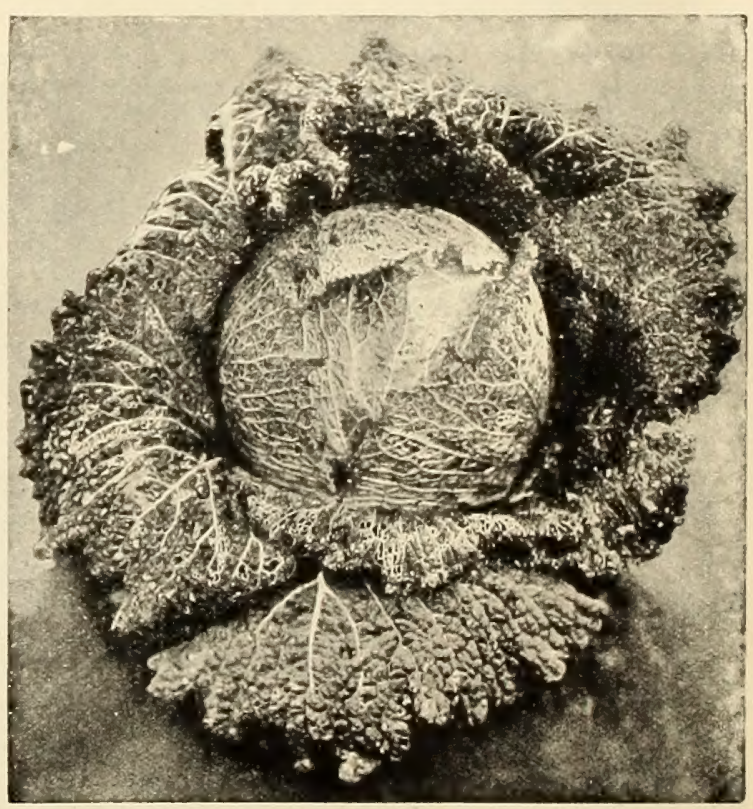

Improved American Savoy. 
R. \& J. FARQUHAR \& CO., BOSTON. VEGETABLE SEEDS.

\section{CAULIFLOWER}

\section{Coliflor. Blumen Kohl.}

Cauliflower succeeds well in any soil where Cabbages will grow. It delights in a rich soil and abundance of water. By sowing the early varieties in a hot-bed in February or March, fine heads can be obtained in May or June. For a later supply, sow seed in a prepared bed in May, choosing a cool, moist place. When large enough, transplant, making the rows about $2 \frac{1}{2}$ feet apart and 18 inches between the plants. Transplanting should be done in moist weather. One ounce of seed produces about 3,000 plants.

\section{Farquhar's Earliest Dwarf Erfurt Cauliflower.}

Best for early, best for late, best for foreing, and the surest header of all.

This strain is growu especially for us, by the most reliable grower in Northern Europe, where the finest Cauliflower is produced; and we believe there is nothing finer offered. This strain is short-stemmed, small-leaved with large, finely grained heads. Good seed is absolutely necessary for success in growing Cauliflower. This strain is most earefully grown, and with reasonable care every plant should produce a fine head, Pkt., .25 and $50 \% 1$ oz, 1.50; oz. $5.00 ; \frac{1}{4} \mathrm{lb} . .15 .00$

Kronk's Perfection Dwarf Erfurt. A very early, carefully selected strain with large, solid, and beautiful heads; one of the most reliable croppers, Pkt., .25; 1 oz., 1.00; oz., 3.00; $\frac{1}{4} \mathrm{lb}$., 10.00

Erfurt Earliest Dwarf. A very early, reliable sort, producing large. white heads: plants are low, with small leaves, Pkt., .25; $\frac{1}{3}$ oz., 1.00; oz., $3.60 ; \frac{1}{4} \mathrm{lb} ., 10.00$

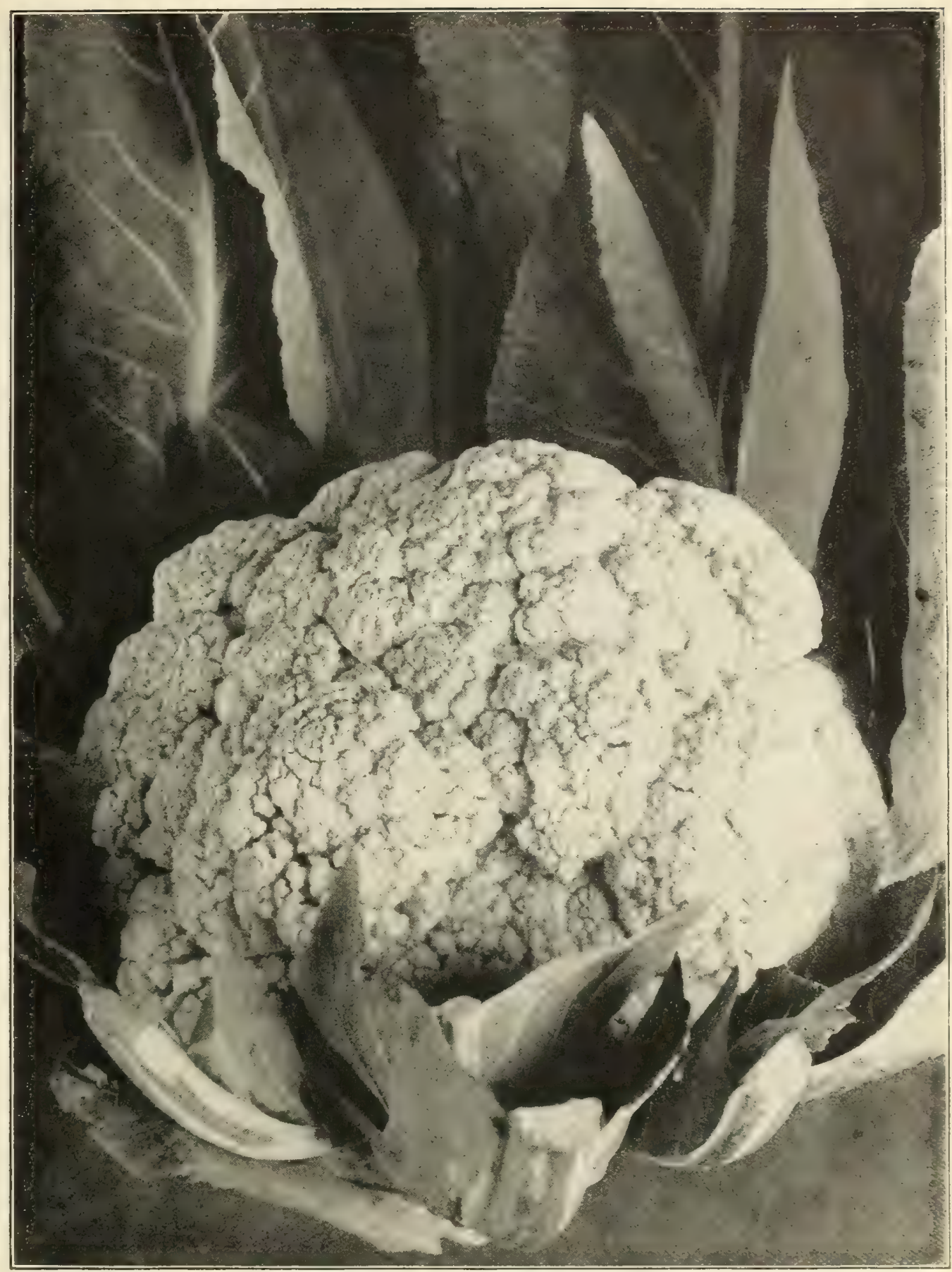

Farquhar's Earliest Dwarf Erfurt Cauliflower.

Early Snowball. Of dwarf habit; heads white and solid; largely grown for early crops,

Pkt., .25; $\frac{1}{4}$ oz., $1.00 ; \quad 0 z ., 3.00 ;+1 b ., 10.00$

Autumn Giant. A remarkably strong growing late sort; taking longer to mature than other kinds and in conseyuence should be planted not later than May,

Pkt., .10; $\frac{3}{4}$ oz. .15; oz., .50; + lb., 1.25

Danish Giant. Large, white, solid heads, with large leaves, keeps well in hot and dry weather; about ten days later than our Earlies Dwarf Erfurt

\section{CAULIFLOWER PLANTS.}

Delivery May to July.

Farquhar's Earliest Dwarf Erfurt

Early Snowball

-..

Doz., .25; per 100, 1.50; per 1.000, 12.00

Doz., .25; per $100,1.50$; per $1.000,120()$

A. Perregaux, Mgr., Fair Oaks Farm, Lincoln, R. I., Dec. 29, writes:-Will say that the seeds we had from you last season were entirely satisfactory. Our Celery is the best we ever had. 


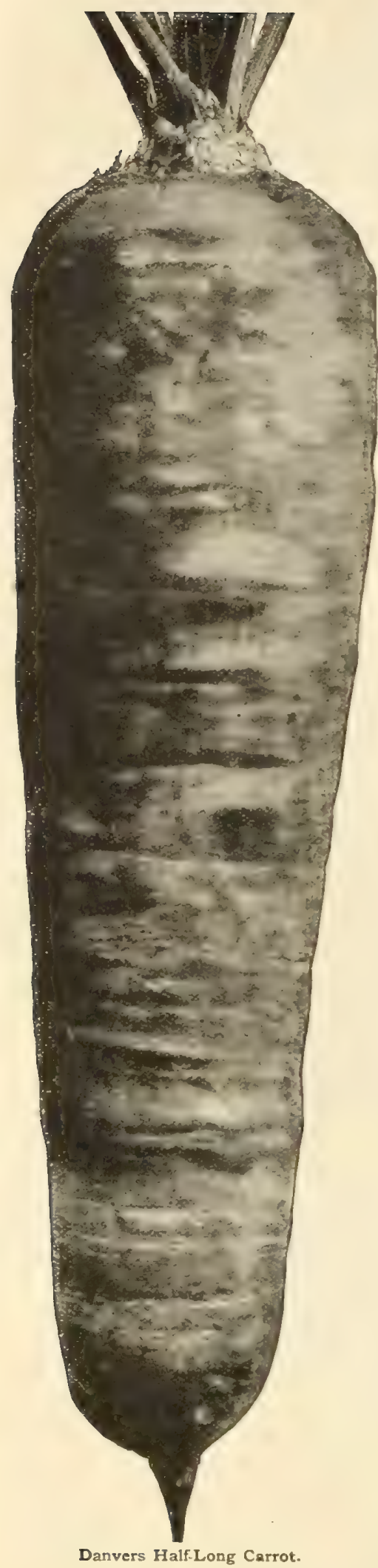

\section{CARR0T. Zanahoria. Moehre.}

Sow in April and May, in drills about half an inch deep and a foot apart. Thin out, leaving the plants from 3 to 8 inches apart, according to variety. One ounce of seed is sufficient for 100 feet of drill; 4 pounds for an acre.

Farquhar's Forcing. A handsome half-long Carrot of deep orange red color, almost coreless; very desirable for forcing ... ... Pkt., .10; oz., .25; +1 lb., .75; lb., 2.50

Earliest Searlet French Foreing. Small roundish roots, very early, valuable for forcing.

l'kt.. .10; oz., .20; 1 lb., .50; lb., 1.7.5

Early Searlet Horn. Flesh deep red, tender and of delicate flavor ... Pkt., .05; 0z., .15; + lb., .40; lb., 1.25

Farquhar's Intermediate. The best intermediate variety, tapering to a point, small core and of fine flavor. Pkt., .10; oz., .20; + lb., .60; lb., 2.00

Guerande, or 0x Heart. Short, thick; much larger than Early Horn ... Pkt., .05; oz., .15; $\frac{1}{4}$ lb., .40; lb., 1.25

Chantenay. Form half long, stump-rooted; fine-grained; small core ... Pkt., .05; oz., .15; \& lb., .40; lb., 1.25

Danver's Half-Long. Selected. Best main crop variety; fine form and color; half-long with small tap-root; productive and keeps well.

Rt., .05; oz, .15; + lb., .50; lb., 1.50 Pange. Roots large and long; enormous yielder. Splendid for stock.

Pkt., .05; oz., .10; + lb., .30; lb., 1.00

White Belgian. Large, long-rooted variety; valuable for stock

\section{CARD00N. Cardo. Kardon.}

Grown for the mid-ribs of the leaves, which are blanched in the same manner as Celery

Pkt.. .05; oz... .25; + 1b., .75; lb., 2.50

CHERVIL. Perifollo. Gartenkerbel.

Curled Chervil. The young leaves are used for seasoning soups and for flavoring salads.

Pkt., .05; oz., .10; $\frac{1}{4}$ lb., .30; lb., 1.00

CHICORY. Achicoria. Cichorien.

Large Rooted. Barbe de Capucin. The leaves when blanched are delicious for salad.

l'kt., .05; oz., .15; $\frac{1}{4} \mathrm{lb} ., .50 ; \mathrm{lb} ., 1.50$

Witloof. Brussels Chicory. A most delicious salad plant The seeds are sown in the spring in rows like carrots and the roots stored in autumn; the leaves being cut off. The roots are later allowed to form new tops in a dark situation. These blanched tops constitute the salad. Pkt., .05; oz., .15; + lb., .50; 1b., 1.50

\section{CHIVES.}

Grown for their tops, which are used wherever the flavor of onion is required. Perfectly hardy, and should be in every garden.

Chives, Seed. ... Pkt,, .20; oz., .75; $\frac{1}{4}$ 1b., 2.50; 1b., 7.50

Chives, Roots. Per bunch, .15; 6 bunches, .75; 12 bunches, 1.25. By mail, add 10 cents each extra

CORN SALAD. Macha o Valerianilla. Ackersalat. Round-Leaved. In Europe this plant is used as a substitute for Endive when scarce, the French even preferring it Pkt., .05; oz., .15; $\frac{1}{4}$ lb., .40; lb., 1.00

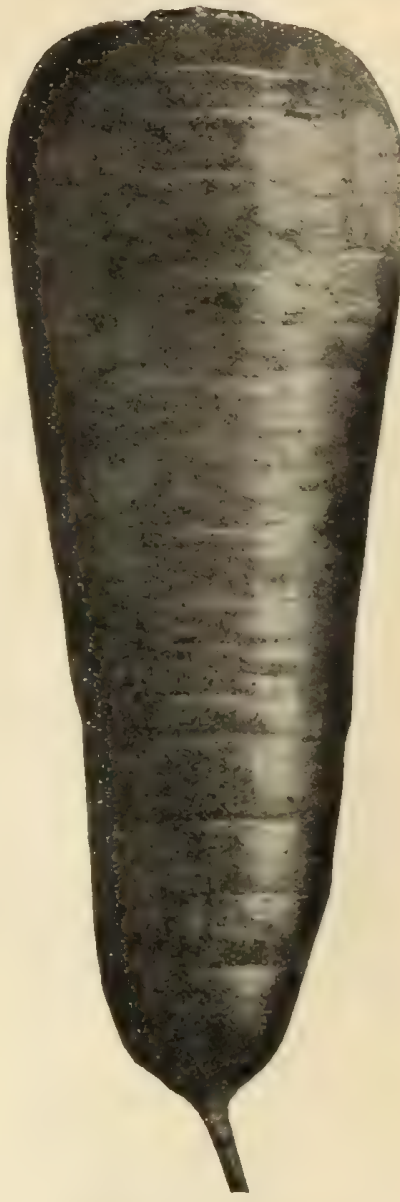

Farquhar's Forcing Carrot.

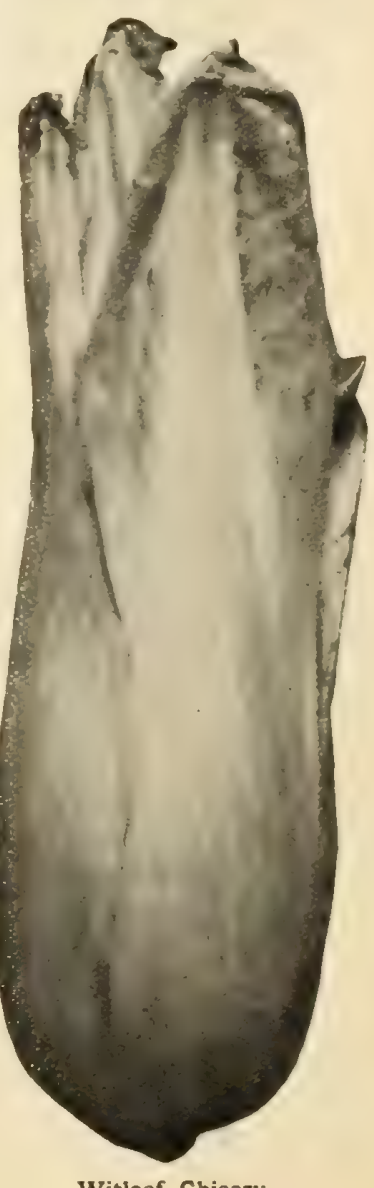


R. \& J. FARQUHAR \& CO., BOSTON. VEGETABLE SEEDS.

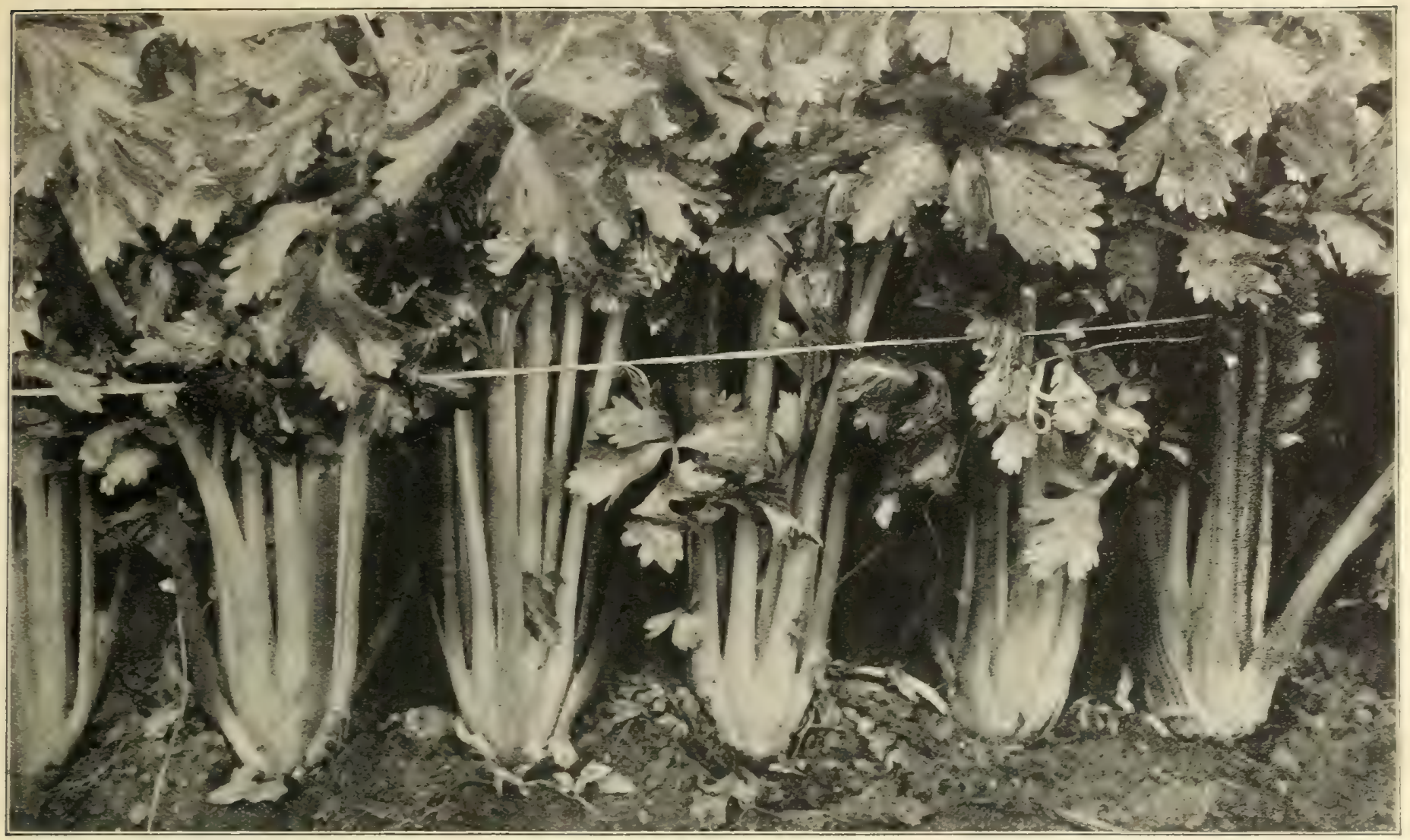

Crosby's Original Boston Market Celery.

\section{CELERY. Apios. Seleri.}

Sow the seeds in March or April in a hot-bed or cold frame. As soon as the plants are 3 inches high, transplant into a prepared border, setting them 4 inches apart. When grown 6 inches, and fine stocky plants, set in richly manured, deep soil, in rows 3 feet apart, and about 9 inches from plant to plant. Water, if dry weather follows transplanting. During the next two months all the attention reat intervals until only the tops of the leaves are visible late in autumn. Never hoe or earth up when the plants are wet. 1 ounce of seed produces about 4,000 plants.

Crosby's Original Boston Market. The finest-flavored variety in cultivation; solid, crisp, and of excellent, nutty flavor; of dwarf, branching habit;

blanches perfectly white; a splendid keeper. Fine home-grown seed, $1 \mathrm{~b}, 2.50$

Perfected White Plume. Best for early use; the stalks and portions of the leaves, being naturally white, are fit for table early in the season; fine stock,

Paris Golden Self-Blanching. The best very early Celery, now extensively grown for summer and early autumn use. The stalks are solid, crisp, tender,

Rose Ribbed Paris Golden Self-Blanching. A Celery of very high quality; color rich yellow with rose-tinted stalks; very tender, crisp, and of excellent flavor. In Europe the rose-tinted Celeries are often preferred to the white sorts, being considered of richer flavor and better keeping quality.

Giant Paseal. An easily-blanched and fine-keeping sort of excellent flavor. It grows about 2 feet high, the stalks being broad, thick, crisp, and stringless. It is of wonderful keeping quality

Carter's Dwarf Crimson. Crisp, tender, and delicious; stalks beautifully rase-tinted. The best sort for very late keeping.

\section{CELERY PLANTS.}

Transplanted. Delivery June and July.

Boston Market

Paris Golden Self-Blanching

White Plume

Giant Paseal
Doz, .20; 100, 1.00; 1,000,7.50

". $20 ;$ "

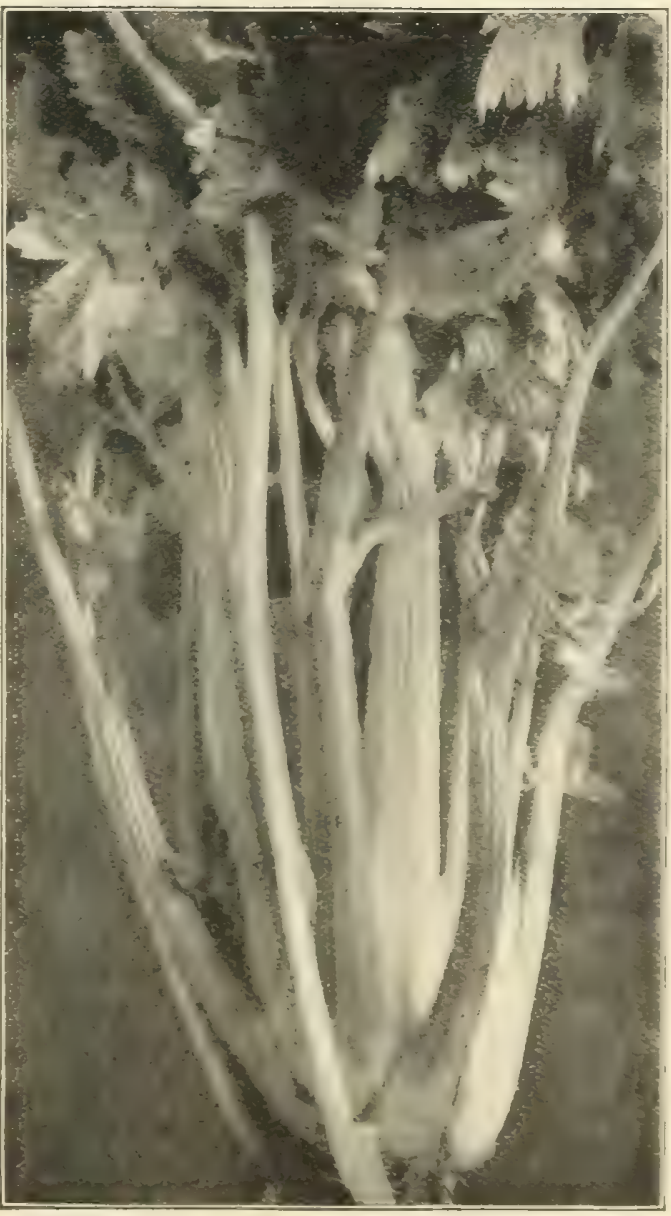

Paris Golden Self-Blanching Celery.

Celeriae, Erfurt Giant (Turnip rooted). The round, solid heads are used as a salad when boiled and sliced

Pkt., .05; oz., .20; + lb., .60; lb., 2.00 


\section{CORN, SWEET. Maiz. Welschkorn.}

Culture. Select a warm soil, if possible, especially for the earlier varieties, which should not be planted before the middle of May. Successive plantings should be made every two weeks until July. Plant in hills 3 or 4 feet apart, in thoroughly manured soil. One quart to 200 hills; 10 quarts to an acre.

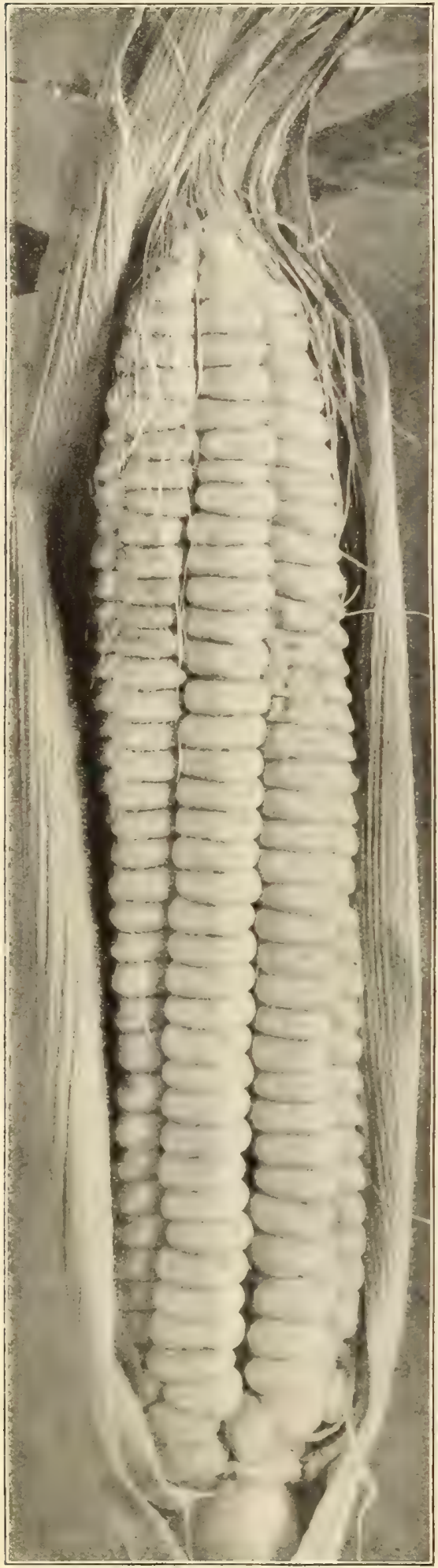

Farquhar's First Crop Sugar Corn.

\section{EARLY.}

Farquhar's First Crop Sugar. The best early. White cob, eight rowed, quality superior to all other extra early sorts; very sweet,

Pt., .1.5; qt., .2.); 1 pk., .85; pk., 1.50; bush., 5.00 .

Crosby, Josiah Crosby's Strain. This second early variety has been a favorite in Boston market for many years, because of its excellent quality. The ears average 6 to 7 inches in length, with 12 to 16 rows of small white kernels which are sweeter than any other second early sort,

Pt., .20; qt., .35; $\frac{1}{2}$ pk., 1.00 ; pk., 1.75; bush., 6.00

Early Crosby. Dwarf, remarkably sweet, usually twelve rowed,

Pt., .15; qt., .30; $\frac{1}{2}$ pk., 1.00 ; pk., 1.75; bush., 6.00

Golden Bantam. Extra early, yellow, very sweet and tender.

Pt., .20; qt., .35; $\frac{1}{2}$ pk.., $1.00 ;$ pk., $1.75 ;$ bush., 6.00

Extra Early White Cory. Grain sweet and tender; 8 rowed,

Pt., .15; qt., .25; $\frac{1}{2}$ pk., .85; pk., 1.50 ; bush., 5.00

Peep o' Day. An extremely early dwarf sort with ears average about 6 inches in length, of perfect form. The stalks being so small, they may be allowed to stand very closely together. This variety is frequently forced under glass,

Pt., .20; qt., .35; $\frac{7}{2}$ pk., 1.15; pk., 2.00; bush.. 7.00 MEDIUM.

Farquhar's Epicure. An excellent variety with large handsome ears, the quality and flavor being unsurpassed,

Pt., .20; qt., .35; $\frac{1}{2}$ pk., 1.15; pk., 2.00; bush., 7.00

Early Evergreen. Similar to Stowell's Evergreen, but one to two weeks earlier.

Pt., 15 ; qt., $25 ; \frac{1}{2}$ pk., .75; pk., 1.25; bush., 4.50

Potter's Excelsior (Original). Unsurpassed in sweetness and tenderness, 12 rowed, one of the best main crop varieties,

Pt., .15; qt., .25; $\frac{1}{2}$ pk., .85; pk., 1.50; bush., 5.00

Early Champion. Very large, 12 rowed, of the very best quality,

Pt., .15; qt., .25; $\frac{1}{2}$ pk., .75; pk., 1.25; bush., 4.50

\section{LATE.}

Stowell's Evergreen. A handsome late variety; ears large, 12 to 16 rowed; remains fit for use longer than any other variety. Hardy and productive,

Pt., .20; qt., .35; $\frac{1}{2}$ pk., 1.25; pk., 2.00; bush., 7.50

White Evergreen. A very valuable sweet corn for main crop. The stalks are of vigorous growth. The ears are well filled to the tip with pure white kernels of delicious flavor.

Pt., .20; qt., .30; $\frac{1}{2}$ pk., 1.00; pk., 1.75; bush., 6.00

Mammoth. The largest ears of any sort, and of excellent quality,

Pt., .20; qt., .30; $\frac{1}{2}$ pk., 1.00; pk., 1.75 ; bush., 6.00

Farquhar's Banana. One of the finest varieties in cultivation,

Pt., .20; qt., .30; $\frac{1}{2}$ pk., 1.00; pk., 1.75 ; bush., 6.00

Country Gentleman. Cob small, irregular rowed, long, slender, white kernels,

Pt., .20; qt., .30; $\frac{1}{2}$ pk., 1.00 ; pk., 1.75 ; bush., 6.00

Black Mexican. Very tender, bluish black when ripe, cooking almost white,

Pt., .20; qt., .30; $\frac{1}{2}$ pk., 1.00 ; pk., 1.75 ; bush., 6.00

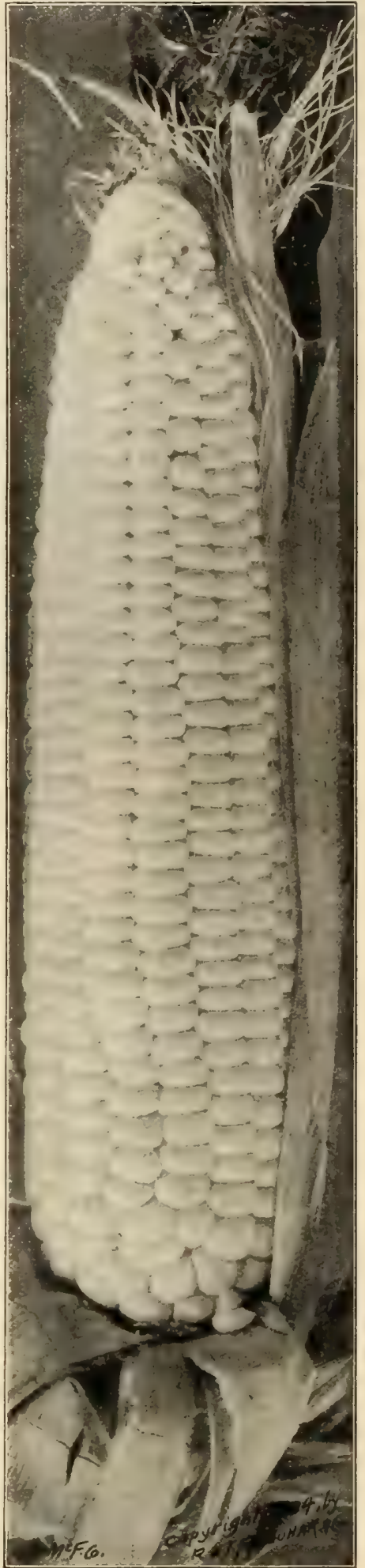

Sweet Corn.

Crosby, Josiah Crosby's Strain.

SELECTED EARS OF THE FOLLOWING VARIETIES, at 10 Cents Each; 75 Cents per Doz.

Farquhar's First Crop Sugar, Mammoth, Stowell's Evergreen, Potter's Excelsior (Original), Early Crosby, Black Mexican, Country Gentleman, Farquhar's Banana

Packets of all varieties, $10 \mathrm{cts}$. each 


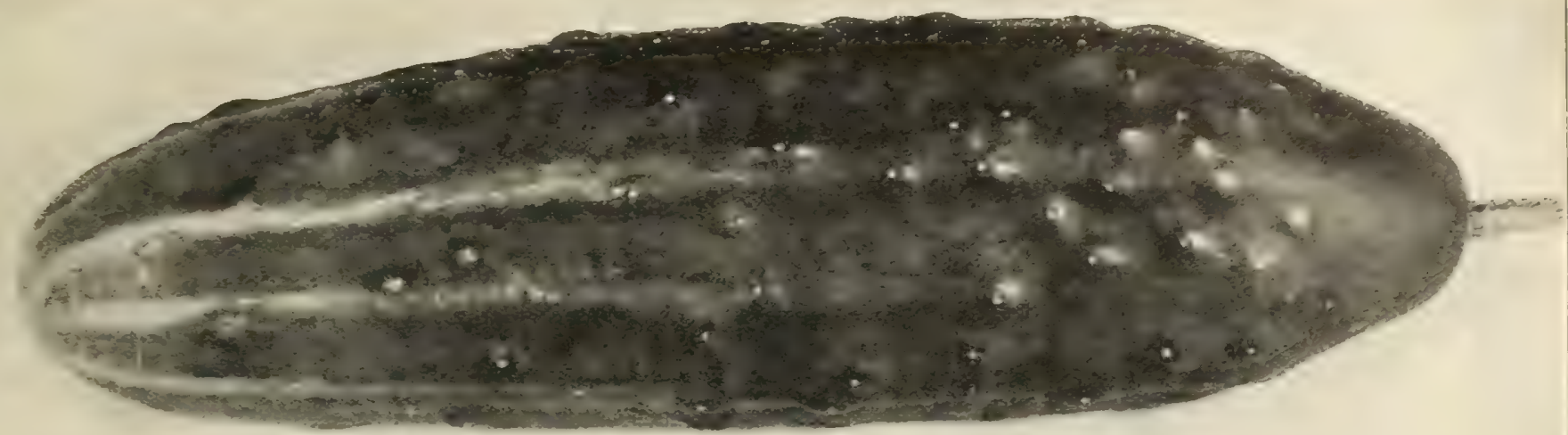

Farquhar's Perfection Forcing Cucumber.

\section{CUCUMBER. Pepino. Gurke.}

For vert early use. seed may be started in heat and the plants set out in May. Pieces of inverted sod are an excellent medium for starting and growing early (cucumber plants, as they can be readily lifted from the hot-bed to the garden without disturbing the young plants growing upon them. For main crop, plant in hills 4 feet apart, in the end of May. Leave 4 strong plants to each hill. One ounce to 50 hills; 2 to 3 pounds to an acre.

\section{FARQUHAR'S PERFECTION FORCING.}

The finest type of White Spine Cucumber in cultivation, and one of the most prolific varieties. The fruits are large and svnmetrical in shape, and of a rich dark green color, which is permanent. The flesh is pure white, firm and crisp, with comparatively few seeds, and is unsurpassed for quality. This is an ideal forcing variety, and succeeds equally well when planted out of doors, Pkt., .25; $\frac{1}{4} \mathrm{oz} ., .35 ; 0 z ., 1.00 ; \frac{1}{4} \mathrm{lb} ., 3.00 ; 1 \mathrm{~b} ., 10.00$

The Cumberland. A variety of the hardy, white spine type, is a rapid, strong and vigorous grower and very prolific in fruit. The flesh is firm, but very crisp and tender at all stages,

Early Russian. Short and very early; valuable for small pickles,

Improved White Spine. Early and good for table use or for pickling; of medium length, dark green color; flesh crisp and excellent ... Pkt., .05; $0 \mathrm{z} ., .15 ; \frac{1}{4} \mathrm{lb} ., .40 ; 1 \mathrm{~b} ., 1.25$

Arlington White Spine. Very productive; fruit even in size and of beautiful cylindrical form, dark green, excels in crispress and flavor ... Pkt., $.10 ; 0 \mathrm{oz} . .15 ; \frac{1}{1 \mathrm{lb} ., .50 ; 1 \mathrm{~b} ., 1.75}$

Fordhook Famous. A handsome strain of white spine, very crisp and tender; remarkably productive $\ldots \ldots \ldots$. . . . . . . Pkt., .05; 0z., .15; \& lb., .50; lb., 1.50 Green Prolifle. Dark green; medium length; very free, Pkt., .05; oz., .10; $1 \mathrm{lb} ., 35 ; 1 \mathrm{~b} ., 1.00$ Nichols' Medium Green. Medium size, always straight and smooth. Color dark green, flesh crisp and tender. Splendid table variety ... Pkt., .05; 0 . . . $10 ; \frac{1}{4} \mathrm{lb} ., .35 ; 1 \mathrm{~b} ., 1.00$ Boston Pickling. Fine stock. A valuable variety for pickles; short, straight fruit,

Long Green. Fruit about 12 inches long, very tender, Pkt.. $05 ; 0 z ., 15 ; 1$. $1 \mathrm{~b} ., .40 ; 1 \mathrm{~b} ., 1.25$ Japanese Climbing. A strong growing variety, throwing out tendrils, which enables them to climb trellises ... ... ... ... ... Pkt., .10; oz., .15; $\frac{1}{4}$ lb., .50; lb., 1.50 West India Gherkin. "Used only for pickles; the smallest of all varieties

$$
\text { Pkt., .05; oz., .20; } \frac{1}{+} \mathrm{lb} ., .60 ; \mathrm{lb} ., 2.00
$$

\section{ENGLISH FORCING, or Frame Cucumbers.}

Telegraph. A superior variety, handsome, with small neck and very prolific ... Pkt., .50 Tender and True. A handsome dark green sort, very productive and of splendid quality, Pkt., .50 The Rochford. Remarkably good in shape, almost without neck, crisp and tender ... Pkt., .50

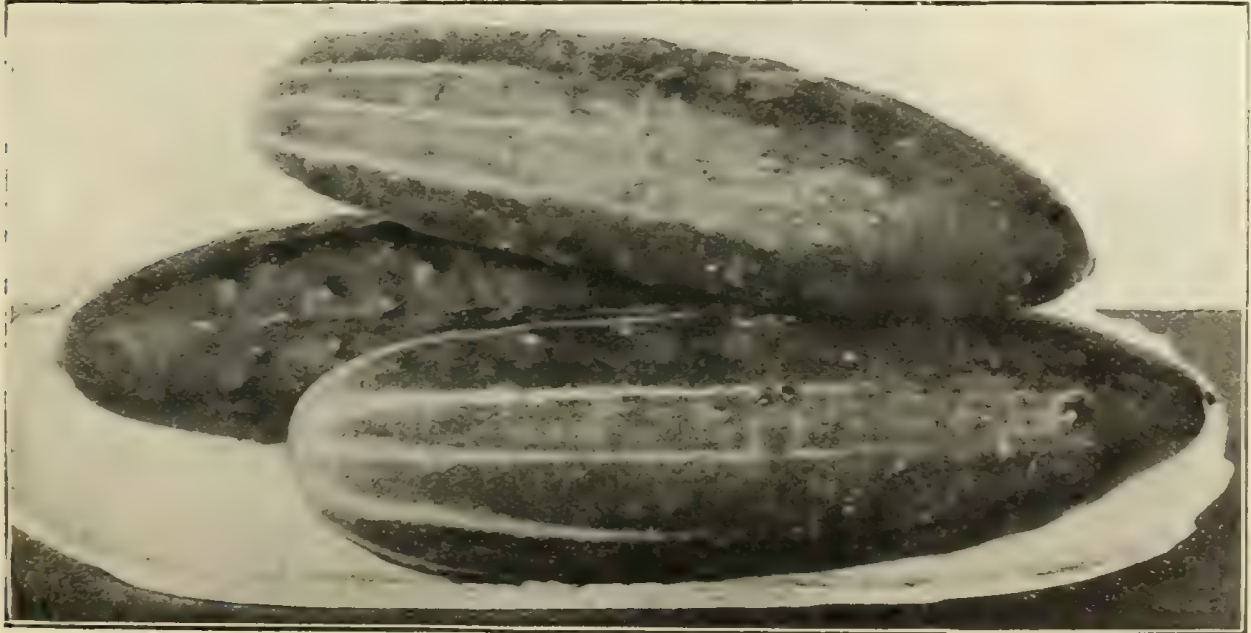

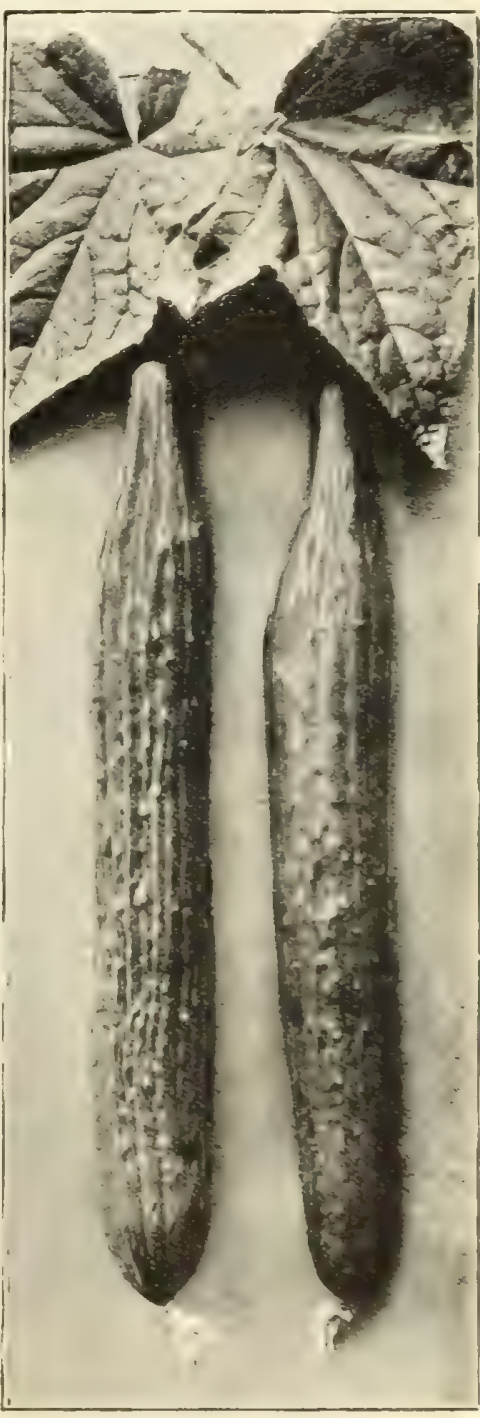

Telegraph English Cucumber. 


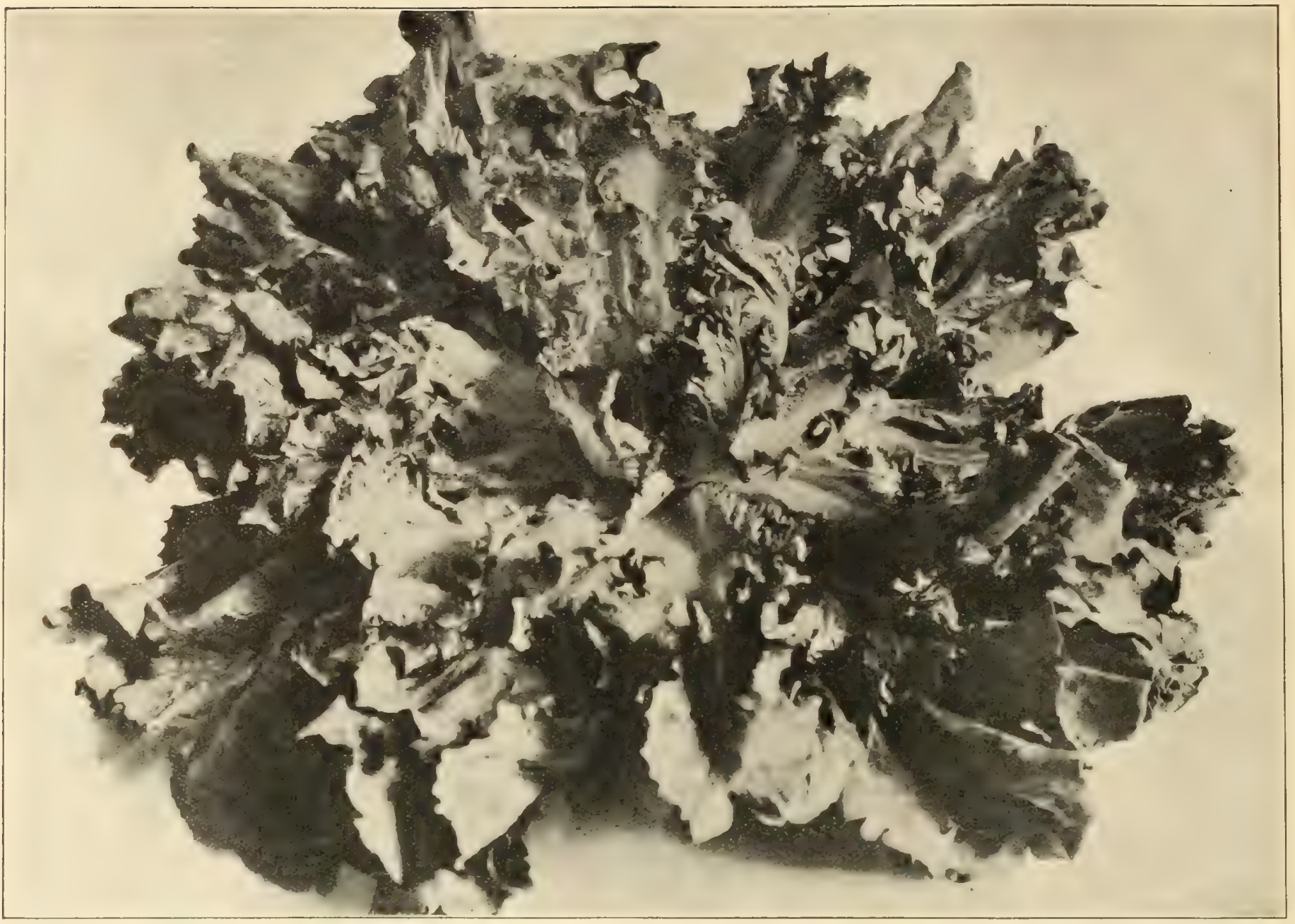

Broad-leaved Batavian Endive or Escarolle.

DANDELION. Amargon. Lowenzahn.

Used as early spring greens and considered very healthful. The seed should be sown in May or June, in drills half an inch deep and 15 inches apart. The crop will be ready for use next spring. A moist, heavy soil is preferable. One ounce of seed is sufficient for 200 feet of drill.

Improved Large-Leaved. The finest variety; home-growu seed

Pkt., .10; oz., .50; $\frac{1}{4} \mathrm{lb} ., 1.75$; lb., 6.00

\section{EGG PLANT. Berengena. Eierpflanze.}

For perfection of growth, a very rich soil, plenty of moisture, and warm weather are required, with the addition of frequent hoeing. Sow in a gentle heat about the first of April. Transplant about the middle of June, setting the plants 3 feet apart each way. One ounce gives about 1,500 plants.

Black Beauty. A valuable variety, ready for use two weeks earlier than any other sort. The fruit is thick and of a rich purplish black color,

Pkt., .10; oz., .40; $\frac{1}{4}$ lb., $1.25 ;$ lb., 4.00

Black Pekin. Very large, globular fruit, of a dark, glossy purple color,

Pkt., .10; oz., .50; $\frac{1}{4}$ lb., 1.50; 1b., 5.00

New York Improved. The most popular main crop variety; the fruit being the

largest and handsomest of all. It is very solid and of rich shining deep purple

color

Egg Plants. Black Pekin, New York Improved. Ready in June,

\section{ENDIVE. Escarola o Endivia. Endivien.}

One of our best salad plants, especially valuable for winter use. For a first crop, sow about the middle of April; for succession, small sowings may be made every month until August, when the main planting is made. Set out the plants 1 foot apart, in rows 3 feet distant, and when well grown effect blanching by folding the leaves in their natural position around the heart, and tying the outer leaves together by their tips in cone form. One ounce of seed for 75 feet of drill.

Green Curled. Hardy, finely curled; easily blanched; one of the best, Pkt., .05; oz. .15; 1 lb., .50; lb., 1.50

French Moss-Curled. Very finely curled, with close, dense leaves, Pkt., .05; oz., .20; $\frac{1}{4} \mathrm{lb} ., .60 ; \mathrm{lb} ., 2.00$

White Curled. Blanches rapidly; excellent, and very tender,

Pkt., .05; oz., .15; $\frac{1}{4} \mathrm{lb} ., .50 ; 1 \mathrm{~b} ., 1.50$

Broad-Leaved Batavian. Escarolle. Leaveslong and broad, thick and succuNew York Improved Egg Plant.

lent. One of the choicest salads Pkt., .10; oz., .20; + lb., .50; lb., 1.50 


\section{R. \& J. FARQUHAR \& CO., BOSTON. VEGETABLE SEEDS.}

\section{HORSERADISH.}

Grown from small pieces of the roots. Plant the sets 12 inches distant in rows $2 \frac{1}{3}$ feet apart.

Small Sets,

Doz., .15; 100, .75; 1,000, 5.00

\section{KALE, or BORECOLE.}

\section{Col. Blatter Koht.}

The Kales are highly esteemed for winter greens. They are extremely hardy, and are improved in flavor after frost. For fall use, sow early in May, in a prepared bed, transplant in June, and treat in the same manner as Cabbages. One ounce of seed produces about 3,500 plants.

Dwarf Green Curled. Leaves bright green and beautifully curled,

Pkt., .05; oz., .10; $\frac{1}{4} \mathrm{lb} ., .30 ; 1 b ., 1.00$

Winter, or German Greens. (Sprouts.)

Sow in the end of August and treat as

Spinach; excellent as spring greens,
Plt., .05; oz., .10; 1 lb., .25; lb., .75

\section{KOHL-RABI.}

Sow in May or June, in rows 18 inches apart. Any ordinary soil, moderately rich, will answer. The bulbs, when about half grown, are boiled and served like turnips.

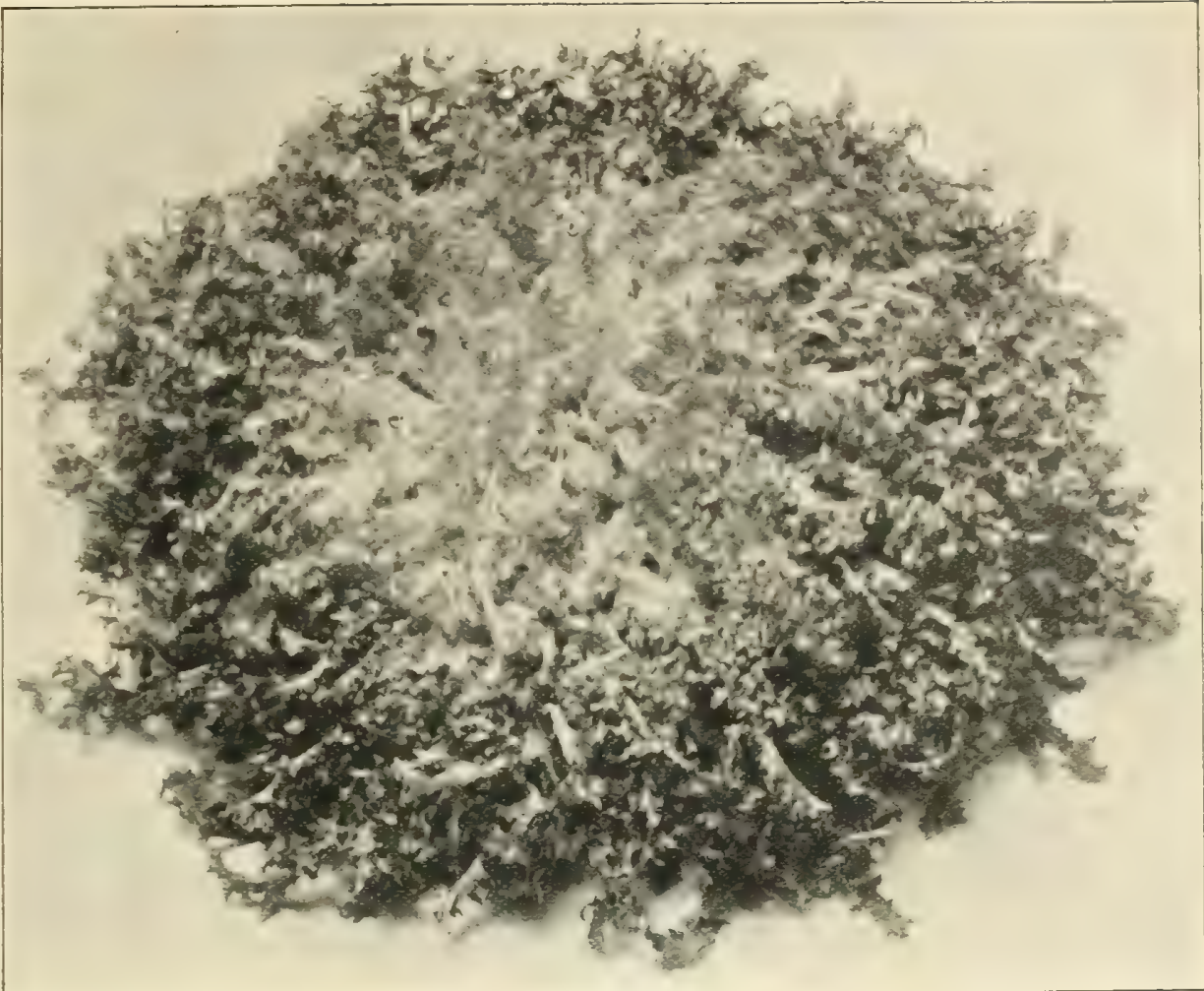

Early White Vienna. The best for early and main crop; flesh white

Green Curled Endive.

Pkt., .05; oz., .25; 1 lb., .75; lb., 2.50 Pkt., .10; oz., .30; $\frac{1}{4}$ lb., .85; lb.. 3.00

\section{LEEK. Lauch.}

The Leek is generally considered superior to the Onion for soups, being of milder and more agreeable flavor; it is very hardy, and easily cultivated. Sow in drills, a foot apart, in April, and transplant in July, in rows $2 \frac{1}{2}$ feet apart, and 6 inches from plant to plant. Plants should be set 5 inches deep in rich, moist soil. One ounce will produce about 1,000 plants.

Musselburgh, or Seoteh. Of large size and extra fine quality,

Pkt., .05; cz., .20; $\frac{1}{4}$ lb., .60; lb., 2.00

Giant Carentan. Of mammoth size; hardy and excellent,

Pkt., .05; oz., .20; $\frac{1}{4}$ lb., .60; lb., 2.00

London Flag. Leaves broad with short, very large stem,

Pkt., .05; oz., .15; $\frac{1}{4}$ lb., .50; lb., 1.50

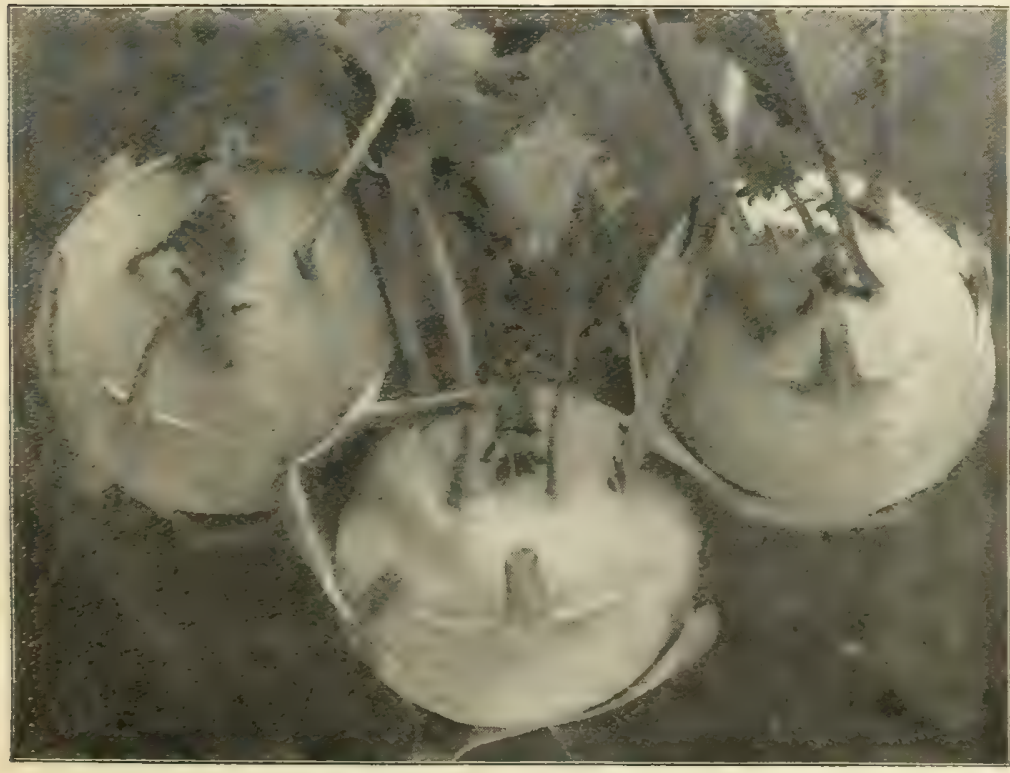

Kohl-Rabi. Early White Vienne.

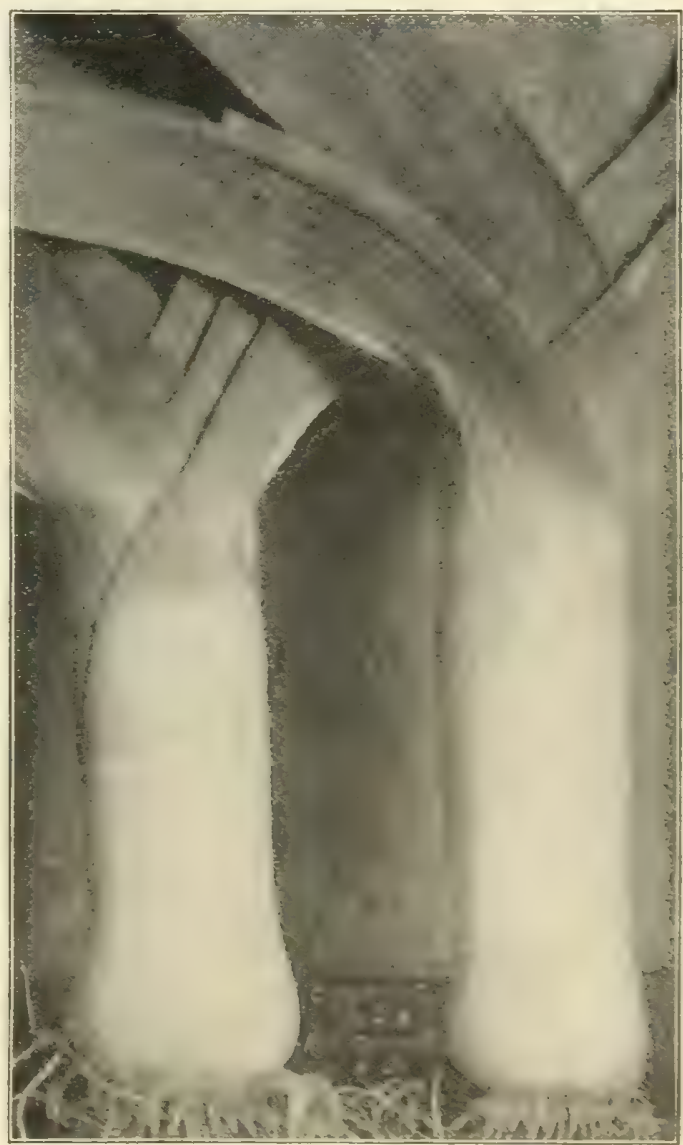

Giant Carentan Leek. 


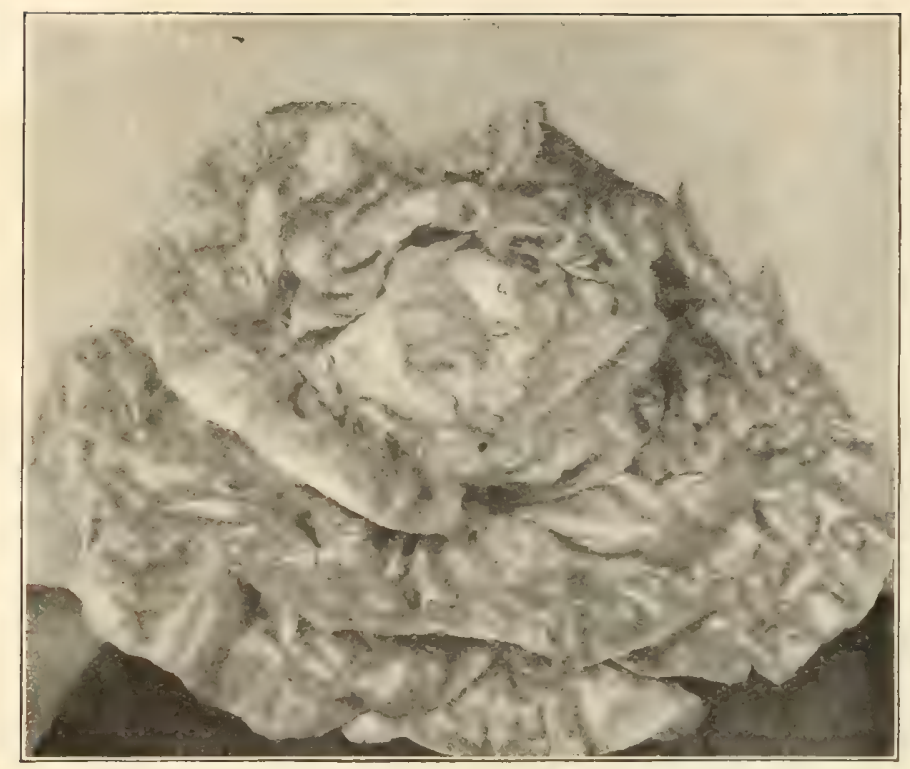

Farquhar's Long Standing Lettuce.

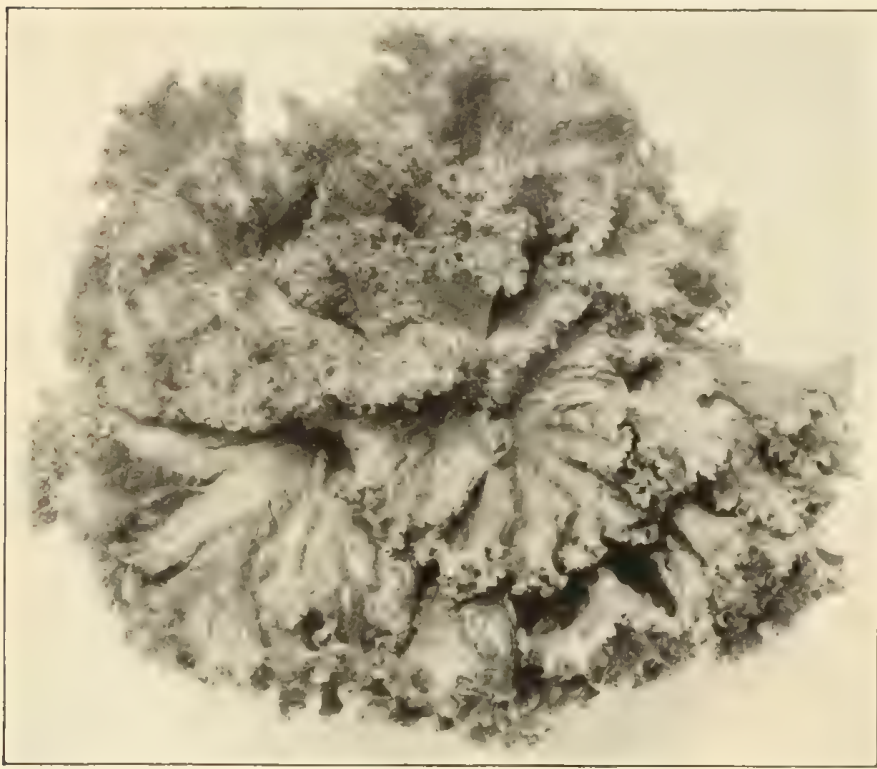

Boston Fine Curled Lettuce.

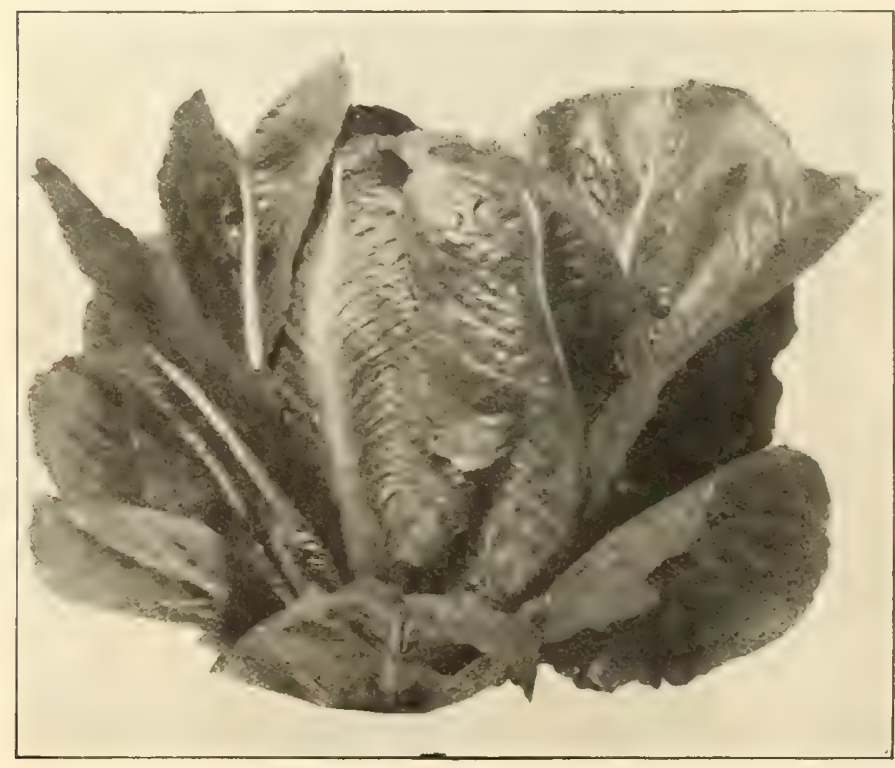

Trianon Cos Lettuce or Romaine.
R. \& J. FARQUHAR \& CO., BOSTON. VEGETABLE SEEDS.

\section{LETTUCE. Lechuga.' Lattich Salat.}

Lettuce thrives best in a light, very rich, moist soil For first crop sow in gentle heat in February, and transplant to 10 inches apart. For a summer supply, sow thinly in shallow drills 18 inches apart, and transplant or thin out, leaving a foot between the plants. Sowings may be made from April to the end of August. One ounce of seed gives about 4,000 plants.

CABBAGE HEADED VARIETIES.

Boston Forcing Tennisball; White-Seeded. Forms fine, perfect heads very rapidly; crisp and very tender. Our seed is of the finest growth and from perfect heads,

Pkt., .10; oz., .50; $\frac{1}{4} \mathrm{lb} ., 1.50 ; \mathrm{lb} ., 5.00$

Hittinger's Belmont Foreing. Larger than the above and almost as early; of excellent quality and highly recommended for forcing

Pkt., 25 ; oz., .75; $\frac{7}{1} \mathrm{lb} ., 2.50$

Crumpled Leaf. A fine, large, solid head, leaves dark green, slightly ruffled or crumpled, tender, flavor unsurpassed,

Pkt., .10; oz., .50; 子 lb., 1.50; lb., 5.00

May King. The head is of globular shape, hard and well closed; the leaves are light green, with delicate ribs and lightly waved; the interior is of a clear yellow, very tender and of fine flavor, Pkt., .10; oz., .30; 1 lb., .75; lb., 2.50 Golden Queen. An excellent forcing sort, early, medium size, golden yellow, solid heads, Pkt., .05; oz., $.20 ; \frac{1}{1} \mathrm{lb} ., .60 ; 1 \mathrm{~b} ., 2.00$

Farquhar's Long-Standing. Farliest and finest head Lettuce for summer crops; every plant should produce a fine, large. firm head; flavor excellent; tender and free from bitterness,

Pkt.,.10;0z., .50; J lb., $1.50 ; \mathrm{lb} . .5 .00$

Black-Seeded Tennisball. Excellent; forms a very fine head; compact, crisp, tender, Pkt., .05; oz., .20; 1 lb., .50; lb., 1.50 White-Seeded Tennisball. Early, tender, and free from bitterness Mammoth Black-Seeded Butter. A very large Cabbage Lettuce, solid, smooth leaved. The outer leaves are thick and brittle; the inner ones becoming very white and tender, Pkt., .0.5; oz.. .15; + 1b., .40; 1b., 1.25

Wonderful. Solid head, crisp, tender. The largest and best of all Cabbage Lettuces ... Pkt., . $10 ; \mathrm{oz} ., 25 ; \frac{1}{4} \mathrm{lb} ., .60 ; \mathrm{lb} ., 1.50$ Hanson. All excellent summer Lettuce with very large heads,

New York. Of unusual size and solidity; crisp and tender, Pkt... 10.; 0z. .25; $11 \mathrm{~b}, .60 ; 1 \mathrm{~b}, 1.50$ Iceberg. A handsome, solid-headed variety, very tender, Pkt., .0.; 0z., $15 ;+1 \mathrm{lb} ., .40 ; 1 \mathrm{H} ., 1.25$ Tom Thumb. A favorite for hot-bed use: One of the earliest to mature, forming compact heads, crisp and free from coarseness, Pkt., .10; oz.. .20; $\frac{1}{4} \mathrm{lb} ., .50 ; \mathrm{lb} ., 1.50$

All the Year Round. Hardy, compact, elose-heading Cabbage variety... Pkt., $05 ;$ oz., $.15 ; \frac{1}{1} \mathrm{lb} ., 30 ; \mathrm{lb} ., 1.00$ Salamander Head. Very crisp and fine; resists summer heat, Pkt., $10 ; \mathrm{oz}_{.}, .25 ; \frac{1}{\mathrm{l}} \mathrm{lb} ., .60 ; \mathrm{lb} ., 1.50$ Deacon. Heads large, compact, inner leaves tender; one of the Big Boston. Very large, tender heads; good for both frame and open culture … Pkt., $.05 ; 0 z ., .20 ;+1 b ., .60 ; 1 b ., 2.00$ California Cream Butter. Large, solid head; tinged brown, white inside ... Pkt.. 05 ; oz., $.15 ; \frac{1}{4} \mathrm{lb} ., .30 ; \mathrm{lb} ., 1.00$

Trout or Spotted. Most tender Lettuce on the list; leaves spotted brown … Pkt., .05; oz., .20; $\frac{1}{4} \mathrm{lb} ., .60 ; \mathrm{lb} ., 2.00$

Brown Duteh. The hardiest Lettuce grown; best for very early ont-of doors crop, Pkt., .05; oz., .15; 1 lb., .50; lb., 1.50 Mignonette. Small head, long standing, hardy, resisting drought; brownish leaves ... Pkt. .05; oz., .15; $\frac{1}{1} 1 \mathrm{~b} ., .40 ; 1 \mathrm{~b} ., 1.25$ CURLED-LEAVED VARIETIES.

Boston Fine Curled. Attractive on table and of good quality, Pkt , .10; oz., .20; + lb., .50; lb., 1.50 Grand Rapids Foreing. Crisp and tender; leaves frilled; heads of fair size .... Pkt.. .05; oz., .15; I lb., .40; lb., 1.25 Black-Seeded Simpson. A superior variety; large and compact heads ... .... Pkt., .05; oz., .15; $\frac{1}{4} \mathrm{lb} ., .30 ; \mathrm{lb} ., 1.60$

Early Curled Simpson. A leading early sort; very tender, ROMAINE, or COS VARIETIES.

Trianon Self-Closing Cos. Leaves long. narrow. forming close upright heads, ... Pkt.,.10; oz., .20; $1 \mathrm{lb} ., .50 ; \mathrm{lb}, 1.75$ Paris White Cos. Very early, requires tying to blanch,

\section{LETTUCE PLANTS.}


R. \& J. FARQUHAR \& CO., BOSTON. VEGETABLE SEEDS.

\section{MELON, MUSK. Melone.}

A light, rich soil is the most suitable for Melons of áll kinds. They should be planted in well enriched hills 6 feet apart. About the middle of May, plant the seeds half an inch deep, six or eight in each hill. When the plants are well up, thin out, leaving three to a hill. One ounce of seed for 60 hills; 2 to 3 pounds for an acre.

Farquhar's Honey-Drop. For earliness and delicious flavor this splendid Melon is without a rival; it is unquestionably the sweetest and best. It is of beautiful form, good size, and very productive. The flesh is very thick, sweet and melting; and of a deep orange color ... Pkt., .10; oz., .35

Hackensack. Early, of large size, round shape, and deeply ribbed; flesh green; very sweet, Pkt., .05; oz., .15; lb., 1.25

Early Green Nutmeg. Green flesh; very sweet and early,

Pkt., .05; oz., .10; lb., 1.00

Early Christiana. Yellow-fleshed; very rich flavor and juicy,

l'kt. (1): : (1). .15: $11,, 1.00$

Arlington Nutmeg. A farorite in Boston market; flesh green; early and delicious … ... Pkt., .05; $0 z_{.}, .15 ; 1 \mathrm{~b} ., 1.25$

Montreal Nutmeg. The largest and handsomest form of Nutmeg Melon, of richest flavor. Flesh green,

Emerald Gem. Small, extra early and very sweet; flesh orange .... ..... Pkt., .10; oz., .30; 1b., 2.50

Long Island Beauty. Round; flesh deep orange; one of the earliest and best ... ... ... Pkt., 10; oz., 20; lb., 1.75

Petoskey, or Paul Rose. The fruit is oval, about five inches in dianeter; flesh firm, sweet, and of a rich orange-red color,

Rocky Ford. One of the best second early Velons, oblong in shape, and possessing fine shipping and keeping qualities. Flesh thick, green, sweet, and highly flavored,

Delmonico, Perfected. Round, flesh deep rich orange and of highest quality; a strong, hardy grower and very productive.

Miller's Cream, or 0sage. Most delicious; flesh salmon

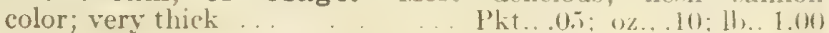

\section{MELONS FOR FORCING.}

Royal Sovereign. The fruit will average in weight about five pounds, occasionally rising to eight pounds and over, and is of a beautiful golden color, slightly netted, flesh white, faintly tinged with green, and very deep; rind very thin. Grand variety for the exhibition table

Invincible Scarlet. Form globular; skin orange-red when perfectly ripe, finely and evenly netted; thick bright searlet flesh, of exquisite flavor, the fruit averaging about four pounds in weight. Scarlet Invincible is a first-class Melon for frame or hot-house culture, and is an easy setter ... ... Pkt...50

Blenheim Orange. Well known handsome scarlet-fleshed variety; of delicious flavor and beautifully netted. Sets well and is very prolific

Hero of Lockinge. Fruit handsome, with white lacing on a rich yellow ground. Flesh white and of fine flavor. Succeeds well in cold frames ... ... . Pkt...50

Frogmore Scarlet. A handsome scarlet-fleshed variety. The fruit is oval-shaped, closely netted, and of excellent flavor,

Ne Plus Ultra. Fruit of a handsome globe shape, flesh white, very thick, and of fine flavor ... ... ... Pkt., .50

\section{MELON, WATER. Wassermelone.}

Treat the same as Musk Melon, but plant in hills 8 to 10 feet apart.

Cole's Early. One of the earliest; fine for northern latitudes, Pkt., .10; oz.. 20; 1b. 1.00

Vick's Early. Very early, long, smooth, with bright pink flesh; Phinney's Early. Early, productive, and fine flavor; rich flesh,

Early Fordhook. Outer color uniform green, flesh bright very sweet ... ... ... Pkt., .05; 0z. .10; 1b. .70 Ice Cream. Nearly round; flesh scarlet, solid, crisp, and delicious, Pkt., 05; 0z, 10; 1b. 75

Mammoth Ironelad. Of large size and great weight; solid and juicy ......... Pkt., .05; 0z., .10; lb., .75 Mountain Sweet. Oblong, with green skin; flesh solid and sweet Citron Por Preserving. Used only for preserves; round; productive and hardy ... ....... Pkt., .05; oz., .10; lb., .60

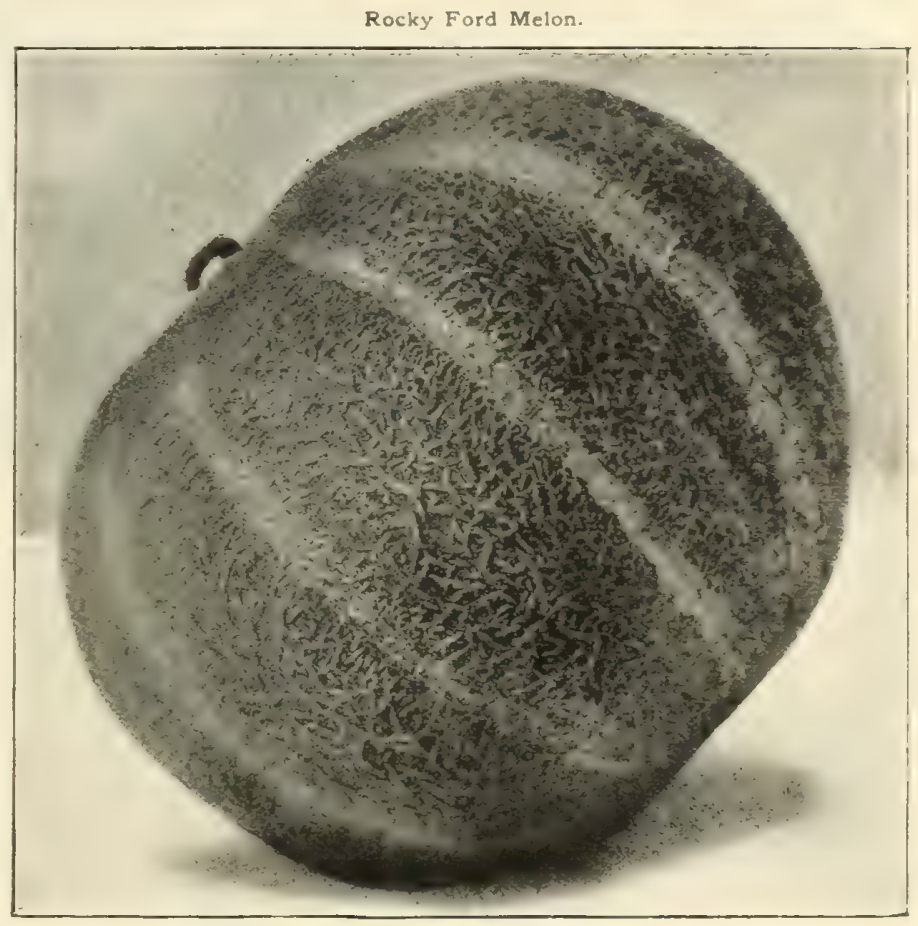

Farquhar's Honey-Drop Melon.

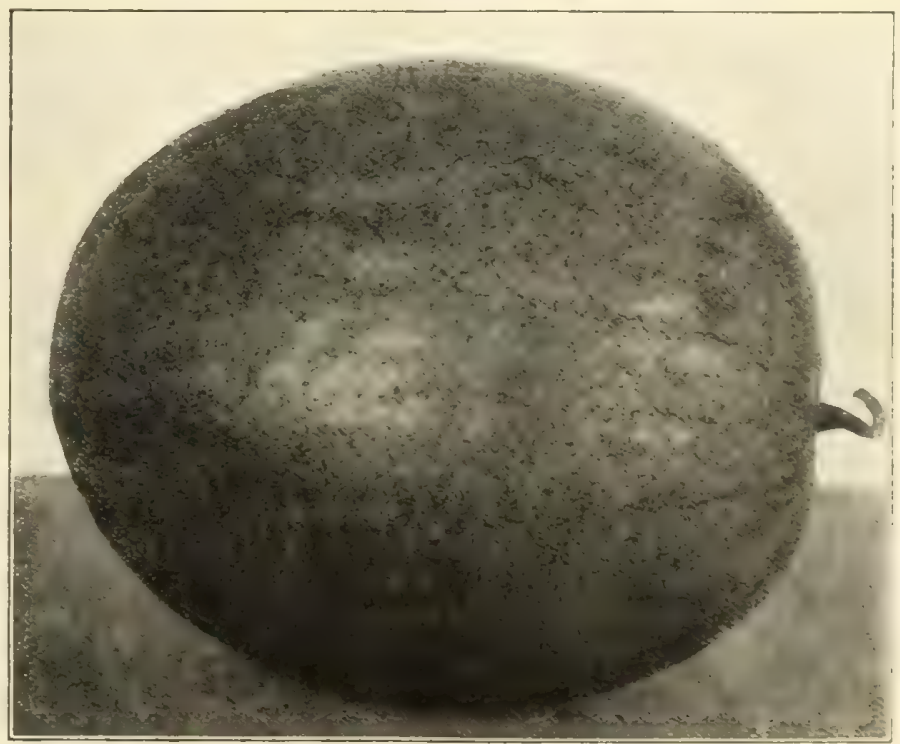

Cole's Early Water Melon. 


\section{MUSHR00M. Seta. Agaricus Campestris.}

\section{CULTURE.}

Mushrooms are more easily cultivated than many people imagine, and may be grown in any room or cellar where the temperature can be maintained at from fifty to sixtyfive degrees. For the bed; use fresh stable manure, which should consist of balf droppings and half shori litter; this must be thoroughly turned and mixed; many growers prefer a mixture of three parts horse droppings and one part good fresh loam. Before being placed in the bed, let the manure be put in some dry place to sweeten, mixing it thoroughly and turning it three or four times, when, if preferred, the loam may be added. Upon a dry, firm bottom or shelf, proceed to make the bed by spreading a thin layer of the prepared mixture, pounding it firm, and continue thus till the bed is 12 inches thick. Leave it thus for about a week, or until the temperature has subsided to eighty-five degrees. Then make holes about 10 inches apart, and put in each a piece of spawn about the size of an egg. Press the

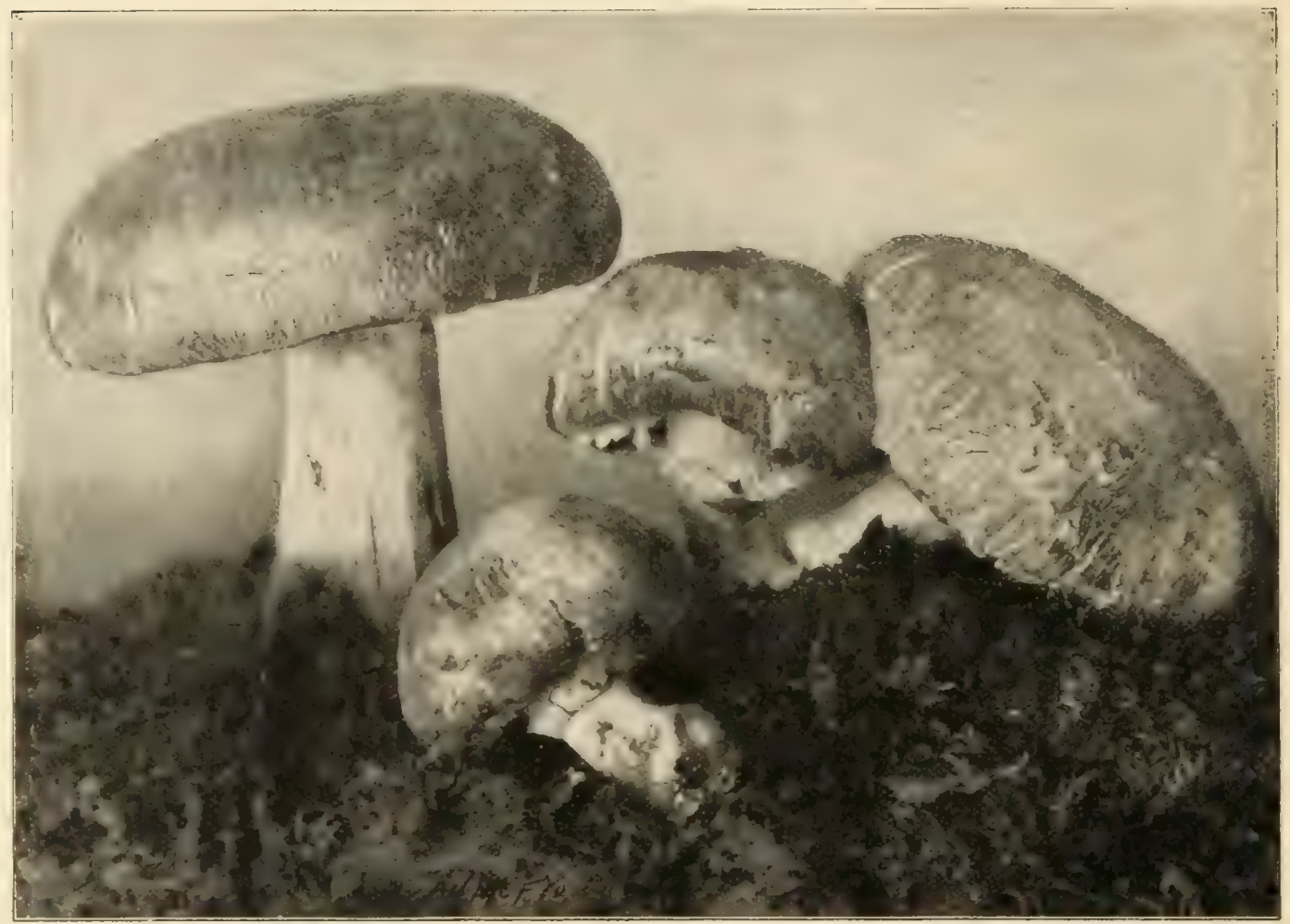
spawn firmly into the compost about 2 inches, leaving the top uncovered to allow the excess of heat and moisture to pass off without injury to the germs. After ten days fill the holes and cover the whole bed with 2 inches of fresh loam, and over this place a few inches of straw. If the temperature is right, mushrooms will appear in six to eight werks from time of spawning. 'The bed will continue bearing from four to six weeks. If the surface of the bed becones dry at any time, it should be moistened freely with water at at temperature of eighty to eighty-five degrees. To stimulate the bed when it seens exhausted, the following treatment will sometimes give wonderful results: Soak the whole bed thoroughly with water at a temperature of one hundred and ten degrees, adding one pound of sheep manure to every five gallons. One pound of Farquhar's English Mushroom spawn is sufficient for six square feet of bed.

The following works on Mushroom culture will be mailed post-paid on receipt of price. Both authors are authorities on the subject, and they give plain and full directions.

Mushroom Culture. By Robinson, 50 cents. How to Grow Mushrooms. By Wm, Falconer, $\$ 1.00$.

English Mill-Track Mushroom Spawn.

French Mushroom Spawn. Our direct importation
Lb., .15; 8 lbs., 1.00; 2.5 1bs., 2.7.; $50 \mathrm{lbs.,5.00;100} \mathrm{lbs.,} \mathrm{9.00.} \mathrm{By} \mathrm{mail,} \mathrm{lb.,} \mathrm{.25}$

\section{TISSUE CULTURE PURE SPAWN.}

Dr. B. MI. Dugarar, of the University of Missouri, who had charge of the Mushron Investigations for the United States Department of Agriculture, has developad a method of growing Mushroom Spawn from pure cultures made from the tissue of the Mushroom. Spawn made by this method has been extensively tested and has been found to be of quick growth and very prolific.

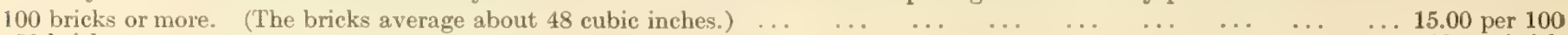
50 bricks or over

25 bricks or over ...

5 bricks or over.

One or more bricks sent prepaid, .35 each.
$2 \mathrm{lb}$. boxes, eacb 1.00

MARTYNIA. Gemsenhorn.
Proboseidea. The green seed pods make excellent pickles. Plant the seed early in June, and thin to 2 feet apart.
Pkt.,.10; oz., .30; lb., 3.00

MUSTARD. Mostaza. Senf.

Sow in shallow drills one foot apart; several sowings may be made for a succession. One ounce to 40 feet of drill.

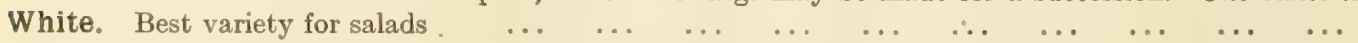

Pkt., .05; 1 lb., .15; lb., .40

Brown. More pungent than the white

\section{MINT ROOTS.}

.10 each; .75 per dozen; 5.00 per 100 . 
R. \& J. FARQUHAR \& CO., BOSTON. VEGETABLE SEEDS.

\section{ONION.}

Cebolla. Zwiebel.

The Onion has been cultivated as an article of food from the earliest times, and is perhaps at the present day more universally grown than any other vegetable. A good crop is impossible unless the soil is very rich and kept clean. Use well-rotted manure freely, and get the crop in as early as possible in spring, even should the Teather be cold anid unpleasant. Sow in drills one foot apart and cover about one-third of an inch, treading or rolling after sowing so that the hot, dry atmosphere may not destroy the sprouting seed. When three inches high, thin to two inches apart. Stir the ground freely without disturbing the young plants and keep free from weeds. One ounce of seed to 100 feet of drill; 4 to 5 pounds an acre.

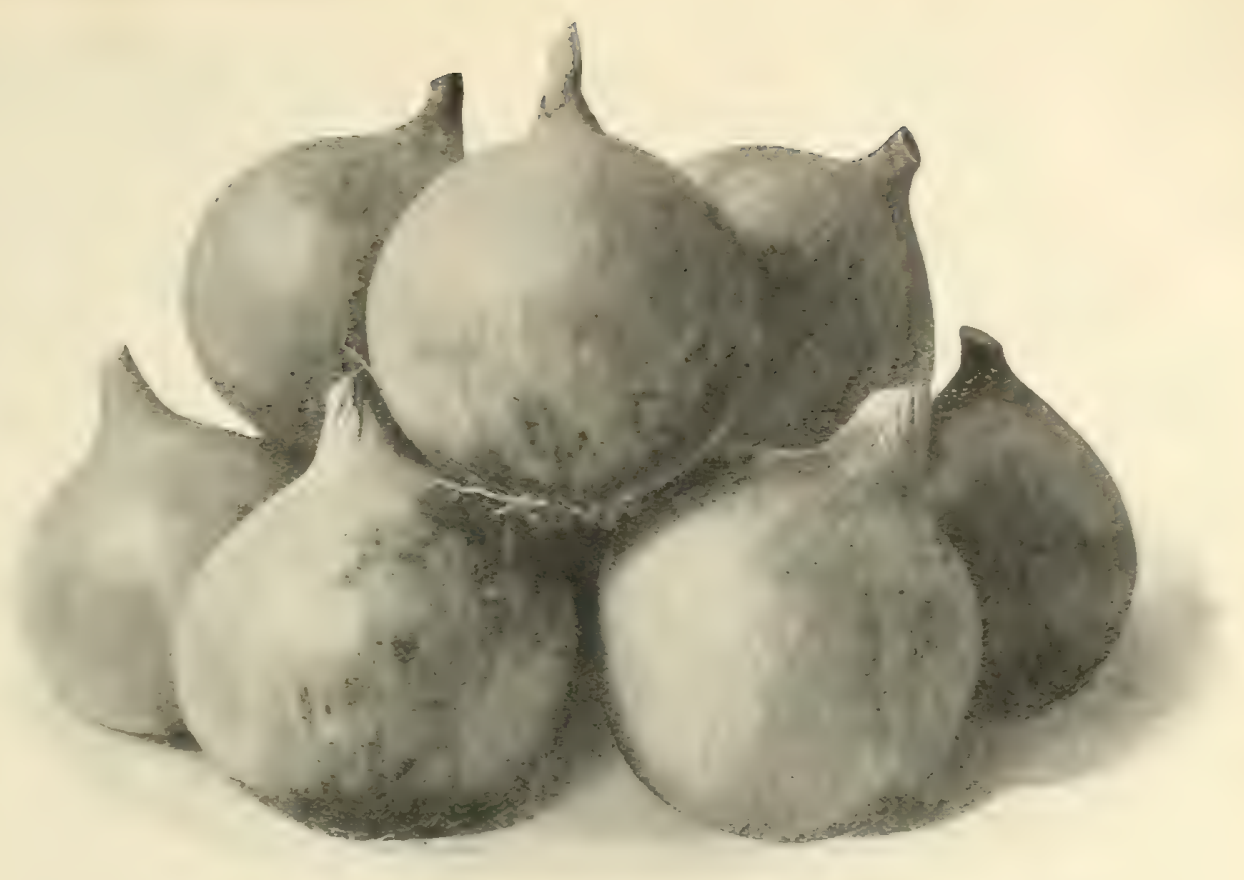

Farquhar's Yellow Globe Danvers Onion.

\section{FARQUHAR'S YELLOW GLOBE DANVERS.}

The finest type of this farorite American variety, which is more extensively grown than any other Onion. It is of smooth globular form, with small neck, consequently ripening very early. The solid character of Farquhar"s Yellow Globe Danvers makes it one of the best keeping sorts as well the most popular for market puposes,

Pkt., .10; oz., .30; $\frac{1}{4}$ lb., 1.00; lb., 3.00

Yellow Globe Danvers (California grown)

Southport Yellow Globe. Handsome, with mild flavor; one of the best

Pkt., .05; oz., .20; $\frac{1}{4}$ lb., .60; lb., 2.00

Pkt., .05; oz., .25; $\frac{1}{1}$ lb.. .75; lb., 2.50

Ailsa Craig. A handsome globular variety, growing to an enormous size, with pale yellow skin, flesh white, a good keeper and valuable

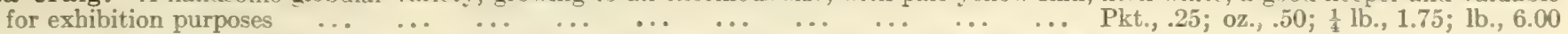

Early Yellow Flat, or Cracker. Earliest yellow variety; of good quality and keeps well,

Southport Red Globe. Of beautiful shape; splendid quality and a long keeper

White Pophal, excellent for first crop $\ldots$
....

Southport White Globe. A handsome Onion. Flesh firn, fine grained, mild . . . . Pkt., .10; oz., .50; 1 b., 1.50; lb., 6.00

Queen. The earliest of all Onions, particularly valuable for summer use. It is of small size, somewhat flat, and of silvery white color. It is highly prized for slicing on account of its very mild flavor, and being small is popular for pickling,

Giant Rocea. An enormous globe-shaped variety; mild and sweet

Australian Brown. An early variety, medium size, color amber brown, of good keeping quality

Giant White Tripoli, or Silver King. Excellent; of quick growth and mild

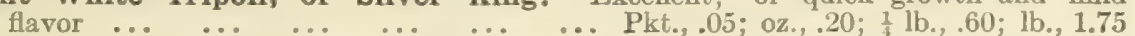

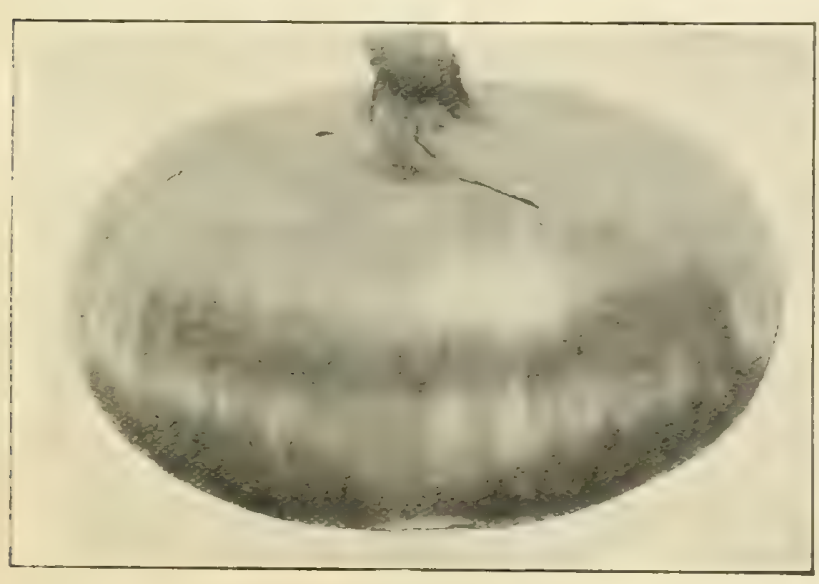

Large Red Wethersfield Onion.
Adriatie Barletta. Extremely early, small, silvery white skin, flesh white and mild, invaluable for pickling, Pkt., .10; oz., .30; $\frac{1}{4}$ lb. 1.00 ; lb., 3.00

Prize-Taker. Color yellow, flesh white; globular; of immense size; medium early, mild, Pkt., .05; oz., .20; $\frac{1}{1} \mathrm{lb},, .60$; lb., 1.75

Large Red Wethersfleld. The best keeping red variety. Shape oval, somewhat flat, skin deep purple-red. A good sort for poor or dry soil, and a good keeper, Pkt., .05; oz. .20 ; lb., .75; lb., 2.50
... Pkt., .05; oz., .20; $\frac{1}{1}$ lb., .60; lb., 1.75

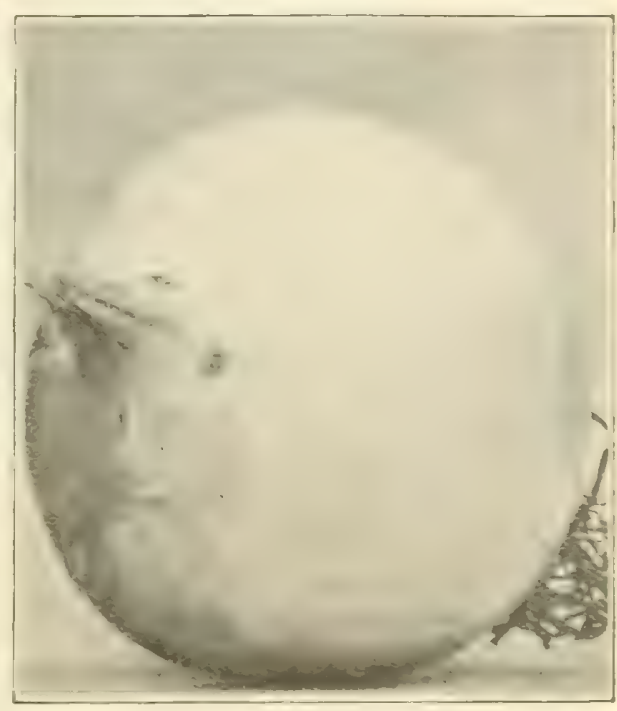

Southport White Globe Oaion. 


\section{ONION SETS. Prices variable.}

These are small Onions grown the previous year, ripened off and taken up when mere bulblets.

They produce a very early crop, and grow in any good soil. Set them in rows one foot apart, 4 inches from set to set, as early as possible after the ground is in good workable condition in spring.

White Sets

$\frac{1}{2}$ pk., .85 ; pk., 1.50 ; bush., 4.50

Yellow Sets, Qt., 25; $\frac{1}{2}$ pk.,

.75 ; pk., 1.25 ; bush., 4.50

Potato Onion Sets ... Qt., .20;

$\frac{1}{2}$ pk., $.75 ;$ pk., 1.25 ; bush., 4.00

White Multiplier Sets

30 ; $\frac{1}{2}$ pk., .85; pk., 1.50; bush., 4.50

Shallots. Prized for salads.

$.30 ; \frac{1}{2}$ pk., $.85 ;$ pk., 1.50 ; bush., 4.50

Garlle. Used for flavoring. ... Bunch, .25

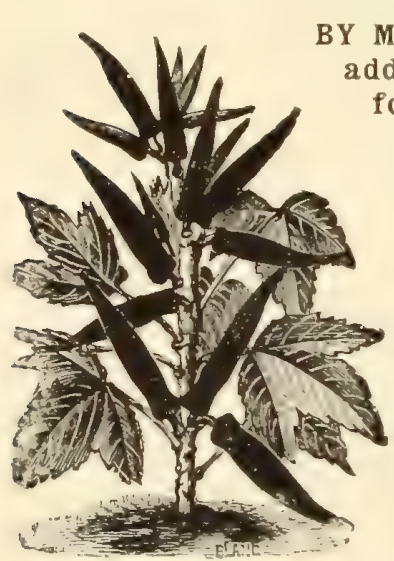

Dwart Green Okra

BY MAIL, add 10 eents per quart for postage, on all Onion Sets.

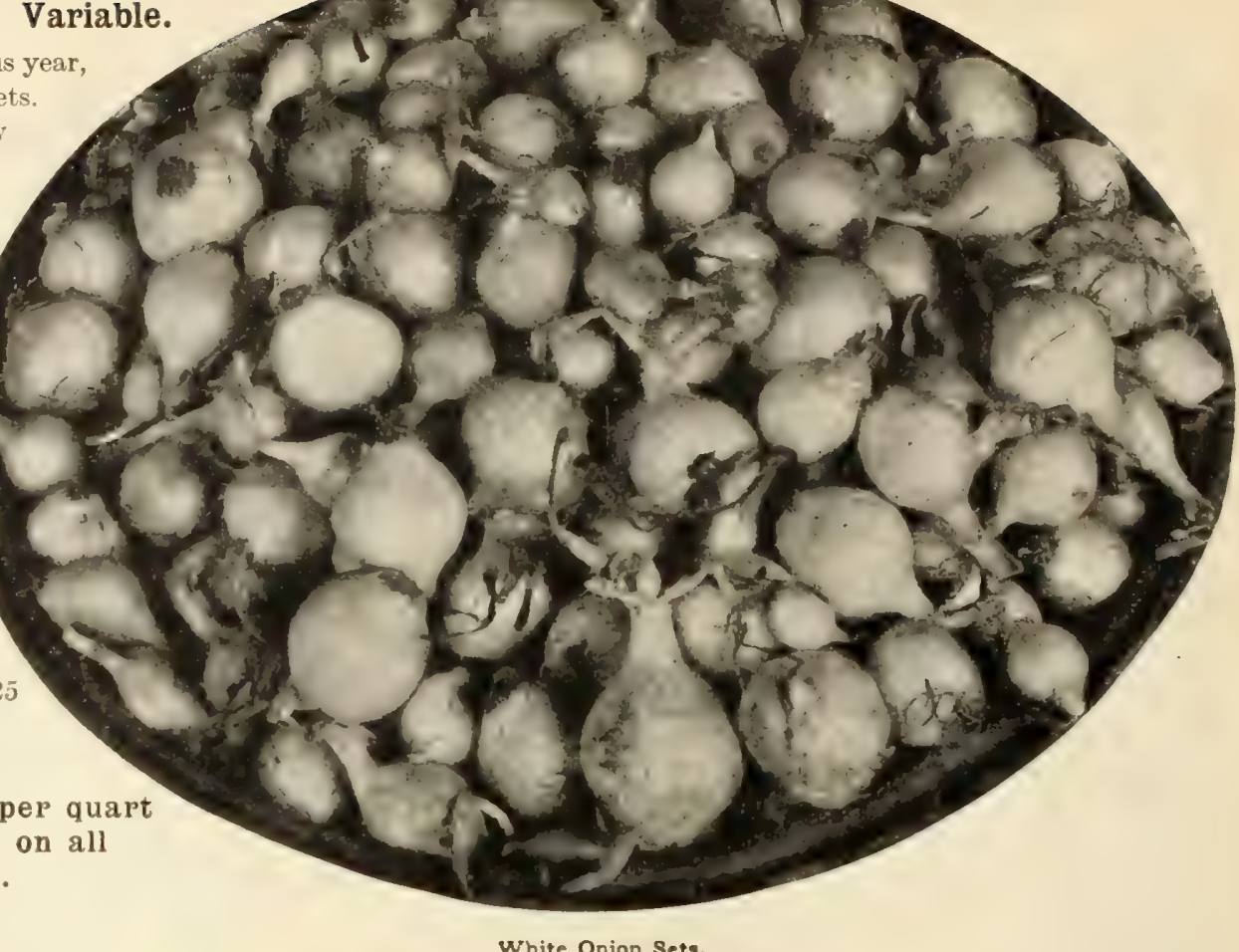

OKRA, or GUMBO. Guimbomo. Essbarren Hibiscus.

The young pods are used to flavor soups and stews. Sow in spring in rows 3 feet apart and 2 inches deep; thin, so that the plants stand about one foot apart. One ounce to 40 leet of drill.

White Velvet. Tender white pods, large and smooth ... Pkt., .05; oz., .10; $\frac{1}{4} \mathrm{lb} ., .25 ; \mathrm{lb} ., .75$ Dwarf Green. Produces large, tender pods; very productive, Pkt., .05; 0z., .10; 1 lb., .30; lb , 1.00

\section{PARSNIP. Chirijia. Pastinake.}

Sow in rich soil, in drills about 18 inches apart an early in the spring as the ground can be worked One ounce will sow 100 fect of drill; 5 pounds an acre.

Farquhar's Market Model. This admirable Parwip hats becone very popular both for family use and for exhibition purposes. Its

perfect form, smooth skin, and tender white flesh readily give it first place over all others ... Pkt., .10; oz., .20; $\frac{1}{4} 1 \mathrm{~b}$., $.50 ; 1 \mathrm{~b}$., 1.50 Student. A favorite English variety; smooth; tender

Hollow Crown. Fair, smooth skin; fine quality Pkt., .05; oz., $.10 ;$; lib., $.25 ; 1 \mathrm{~b} ., .75$

Long Smooth White. Straight, smooth, and handsome Pkt., .05; oz., .10; lb., $20 ; 1 \mathrm{lb} ., .60$

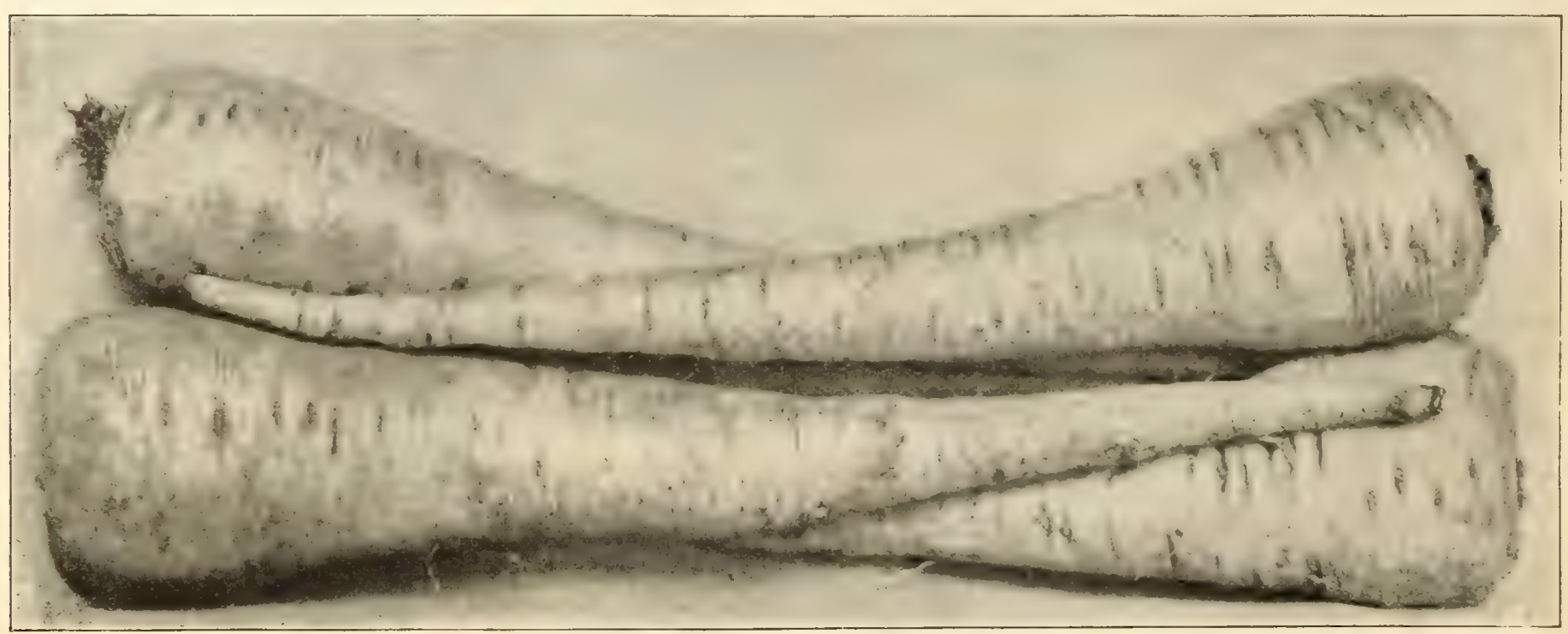


R. \& J. FARQUHAR \& CO., BOSTON. VEGETABLE SEEDS.

PEPPER. Pimiento. Spanischer Pfeffer.

Sow in March or April, in a hot bed, or when the weather becomes quite warm, in the open ground. Transplant when large enough.

Chinese Giant. Very large, flesh thick and mild; bright scarlet color,

Pkt., .10; oz., .50; $\frac{1}{1}$ lb., $1.75 ; 1 b ., 5.00$

Squash or Piekling. Best for pickling; tomato-shaped; medium size; thick,

Pkt., .10; oz., .50; $\frac{1}{4} \mathrm{lb}, 1.50 ; \mathrm{lb} ., 4.50$

Sweet Mountain Mammoth, or Improved Bull Nose. A very popular and

desirable sort; color bright red when ripe; fruit large with thick, mild flesh,

New Uppight Sweet Salad. The fruit is of a bright scarlet color; flesh very thick sweet and crisp -

Procopp's Giant. Very long and large, scarlet fruit, flesh thick

Pkt., .10; oz., .30; $\frac{1}{4} \mathrm{lb} ., .85 ; 1 \mathrm{~b} ., 3.00$

Ruby King. A popular, large fruiting variety; very thick flesh of fine mild

flavor ... … … ... ... Pkt., .10; oz., .25; $\frac{1}{4} \mathrm{lb} ., .75 ; \mathrm{lb} ., 2.50$ Long Red Cayenne. Long, slender and very pungent; beautiful color,

Pkt., .05; oz., .25; $\frac{1}{4}$ lb., .75; lb., 2.50

Golden Dawn. Golden yellow; thick and fine, Pkt., $10 ; \mathrm{oz}_{.}, 30 ; \frac{1}{4} \mathrm{lb} ., 85 ; \mathrm{lb} ., 3.00$

Celestial. Very early and profuse bearer; vivid scarlet when ripe,

Pkt...05; oz, .25; 1b. $75 ; 1 \mathrm{~b} ., 2.50$

Red Cherry. Small round, glossy scarlet fruit, Pkt., $10 ; 0 z_{.}, 30 ; \frac{1}{4} 1 \mathrm{~b} ., .85 ; 1 \mathrm{lb}, 3.00$

Coral Gem Bouquet. A handsome plant covered with small, bright coral red fruits which are quite hot and valuable for seasoning,

Pkt., 10; oz., 35; $\frac{1}{4}$ lb., 1.00; Ib., 3.50

Chili. The best for pepper sauce; small, slender, bright scarlet pods,

Pkt., .05; oz., .25; $\frac{1}{4} \mathrm{lb}, .75 ; \mathrm{lb} ., 2.50$

PEPPER PLANTS. Delivery May and June.

Sweet Mountain Mammoth or Improved Bull Nose. Doz., .25; 100, 1.50 Squash

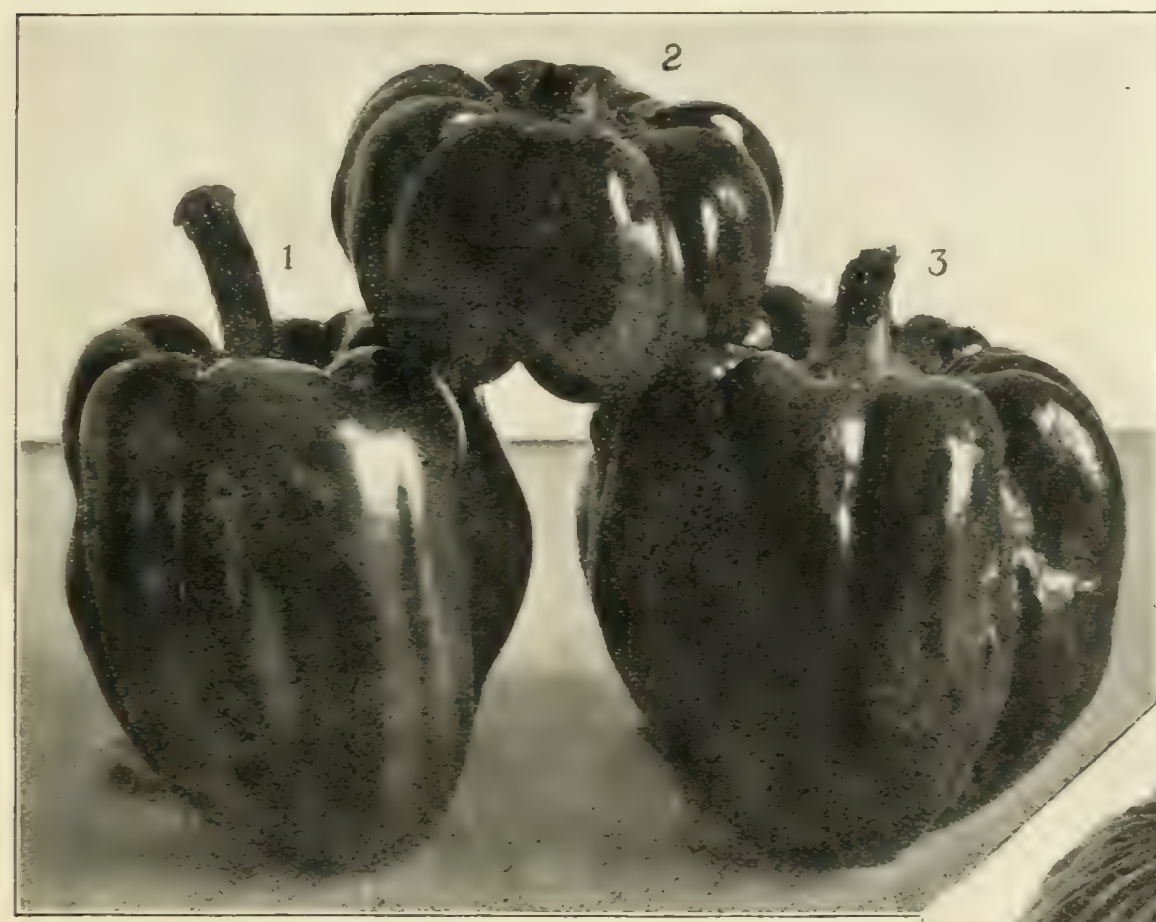

Doz $25 ; 100,1.50$

Peppers. No. 1, Ruby King. No. 2, Squash. No. 3, Sweet Mountain.

\section{PUMPKIN. Calabaza. Curbis.}

Mammoth. Sared from specimens weighing over 100 pounds, Pkt., .05; oz., .15; $\frac{1}{4}$ lb., .40; lb., 1.25

Connecticut Field. Excellent for stock.

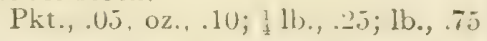

Sugar, or Sweet. Fine grained; sweet and prolific; excellent for pies $\ldots . \quad \ldots \quad \ldots$ Pkt., .05; oz., .10; $\frac{1}{4}$ lb., .25; lb., .75

Cheese. Flat; one of the best for family use,

Pkt., .05; 0z., .10; $\frac{1}{4}$ lb., .20; lb., .75

Nantucket, or Negro. Small, dark shell, warted; fine flavor; the old-time favorite for pies, Pkt.,.05; oz., .10; $\frac{1}{4} \mathrm{lb} ., .30 ; 1 \mathrm{~b} ., 1.00$

Winter Luxury. A round Pumpkin with smooth yellow skin, finely netted; flesh very thick and of excellent flavor,

Pkt., .05; 0z., .10; l lb.; .30; lb., 1.00

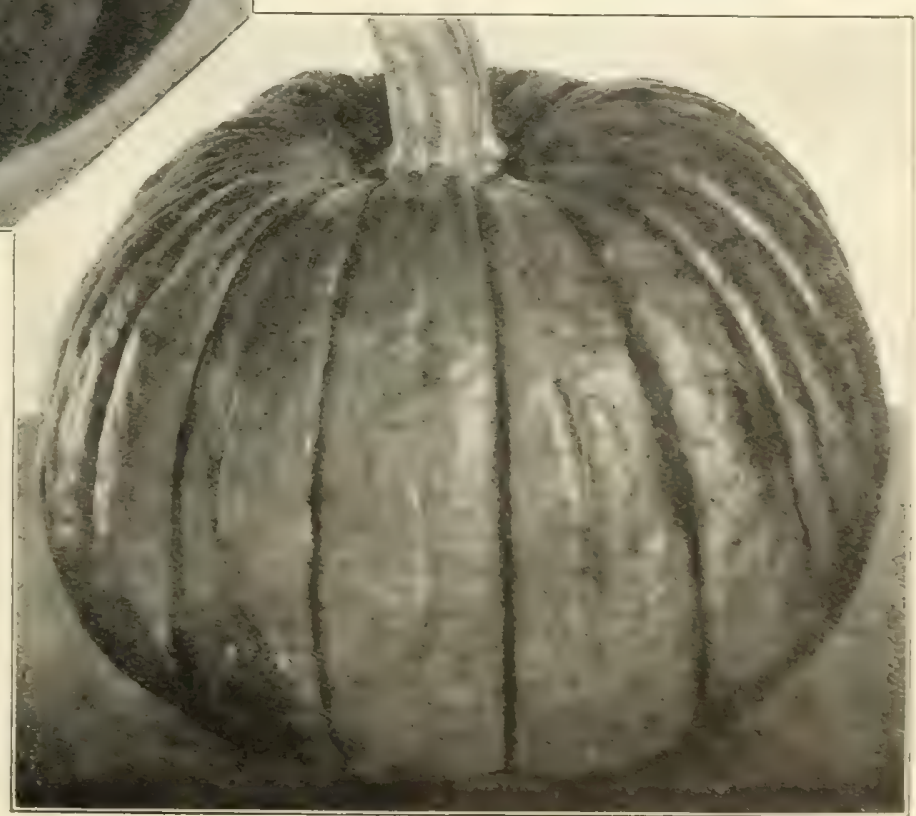

\section{PARSLEY. Perijil. Petersilie.}

Sow as early in spring as possible, covering the seed one-half inch. The drills should be about 15 inches apart. The plants appear in 2 to 4 weeks. Thin to 3 inches apart. One ounce of seed to 150 feet of drill.

Farquhar's Triple Curled. Dwarf, dark green, densely curled, excellent for table and edgings, Pkt., .10; oz., . $20 ; \frac{1}{4} \mathrm{lb} ., .50 ; \mathrm{lb} ., 1.50$ Champion Moss. Fine habit; mossy and beautiful, Pkt., .05; oz., .10; 1 lb., .25; lb., .75 Dobbie's Selected. The standard exhibition

Fern Leaved. Very ornamental,

Pkt., .05; oz., .10; 子 lb., .25; lb., .75

Turnip-Rooted or Hamburg. Edible roots, esteemed for flavoring soups,

Pkt., .05; oz., .10; llb., .20; lb., .60 


\section{GARDEN PEAS.}

\section{Chicharos o Guisantes. Erbson. Pois.}

Culture. Smooth round-seeded varieties for early crops, should be sown as early in spring as the ground can be worked; the sweeter wrinkled sorts from the middle of April until July. Sow in rows 3 feet apart, 3 inches deep, using of the smooth round-seeded sorts one quart to 100 feet of drill, of the wrinkled sorts one quart to 80 feet.

Those marked with an asterisk (*) are wrinkled marrows and are the sweetest and best flavored Peas.

\section{EARLY GARDEN PEAS.}

Farquhar's Prolific Early. The earlisst of the early varieties. Vines are strong and hardy, each bearing 4 to 7 straight pods, well filled with peas of fine quality. Height, $2 \frac{1}{2}$ feet $\ldots \quad \ldots \quad$ Pt., .20; qt., .30; 考 pk., .85; pk., 1.50; bush., 5.00

First and Best. One of the best of the early sorts. Vines are vigorous and produce an abundance of pods, well filled with peas of superior quality. Height, $2 \frac{1}{2}$ feet,

Pt. .15; qt., 25 ; $\frac{1}{2}$ pk., .75; pk., 1.25 ; bush., 4.50

Earliest of All, or Alaska. A valuable early, round blue Pea, with slender vines producing a large number of dark green pods, well filled and of excellent flavor,

Pt., .20; qt., .30; $\frac{1}{2}$ pk., 1.00 ; pk., 1.75 ; bush., 6.00

Petit Pois. This is the small, delicate Pea so highly prized by French chefs. It grows well here, producing an abundance of long slender pods, well filled with extremely small peas, which should be used when very young,

Pt., .20; qt., .35; $\frac{1}{2}$ pk., $1.00 ;$ pk., $1.75 ;$ bush., 6.50

*Witham Wonder. An early dwarf wrinkled sort, producing an abundance of long, curved pods, well filled and of delicious flavor,

Pt., .25; qt., .40; $\frac{1}{2}$ pk., $1.50 ;$ pk., $2.75 ;$ bush., 10.00

* Sutton's Harbinger. One of the best varieties for early use. The plant is of dwarf habit and covered with pods similar to those of American Wonder, but broader and more prolific. For flavor it is unsurpassed. Height; 9 inches

Pt., .25; qto, .40; $\frac{1}{2} \mathrm{pk} ., 1.50$

* Early Morn. An early variety, producing a large number of well-filled pods, each containing 8 to 10 wrinkled marrow peas of the highest quality. Height, $2 \frac{3}{2}$ feet,

Pt., .25; qt., .40; $\frac{1}{2}$ pk., 1.50 ; pk., 2.50; bush., 9.00

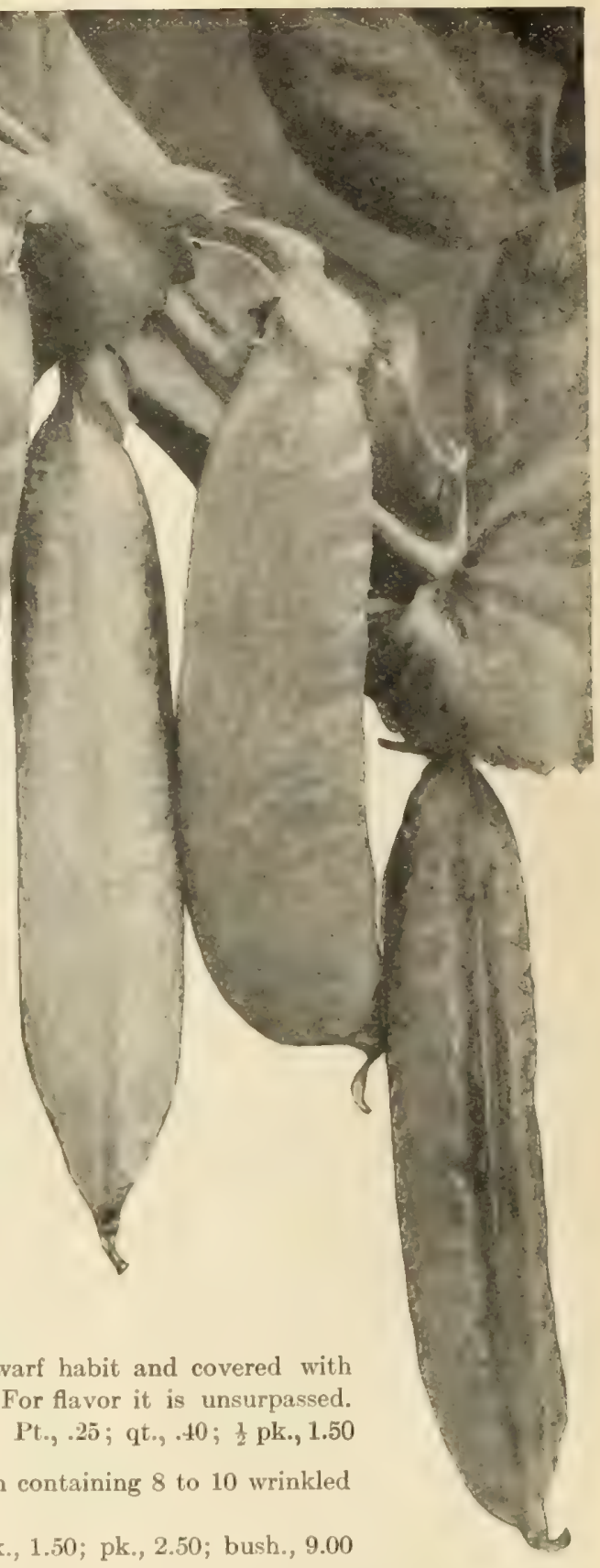

* Sutton's Excelsior. A dwarf early Marrowfat Pea, growing about 18 inches high. Pods large and well filled with deliciously flavored peas. Ready for picking with Nott's Excelsior,

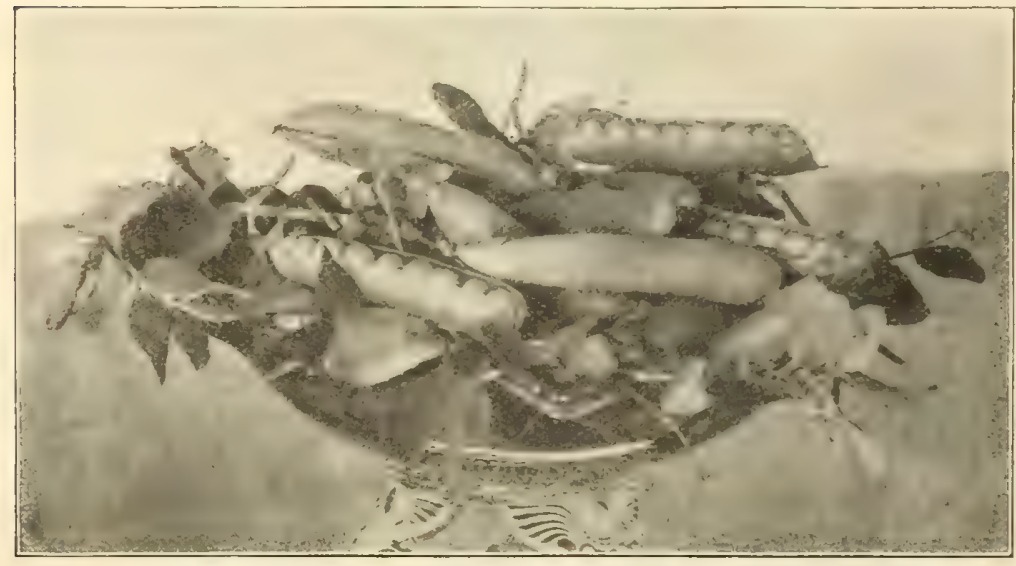

Farquhar's Early Prolific Pea.
Pt., .25; qt., .40; $\frac{1}{2}$ pk., 1.50 ; pk., 2.75 ; bush.; 10.00

* Thomas Laxton. An early variety of great merit. Similar to Gradus, but hardier and more productive. Pods large and long with square ends well filled, the quality being unsurpassed ... Pt., .25; qt., .40; $\frac{1}{2}$ pk., 1.50; pk., 2.75; bush., 10.00

Mr. Arthur Dixon, Gardener for R. G. Hazard, Esq., Peace Dale, R. I., August 26, writes: $-I$ must also speak of Farquhar's Prolific Early Pea. With me this time it grew six feet, and two feet from the ground it was loaded with peas. It was a beautiful sight to see the two double rows. Many people came to see them. I wish. I had them photographed, but I failed to do it. It is a fine Pea and one of the greatest croppers and the largest bearing Peas I have grown. Gentlemen, I hope this will be of interest to you as I felt I could not let it go by without writing you. 
R \& J. FARQUHAR \& CO., BOSTON. VEGETABLE SEEDS.

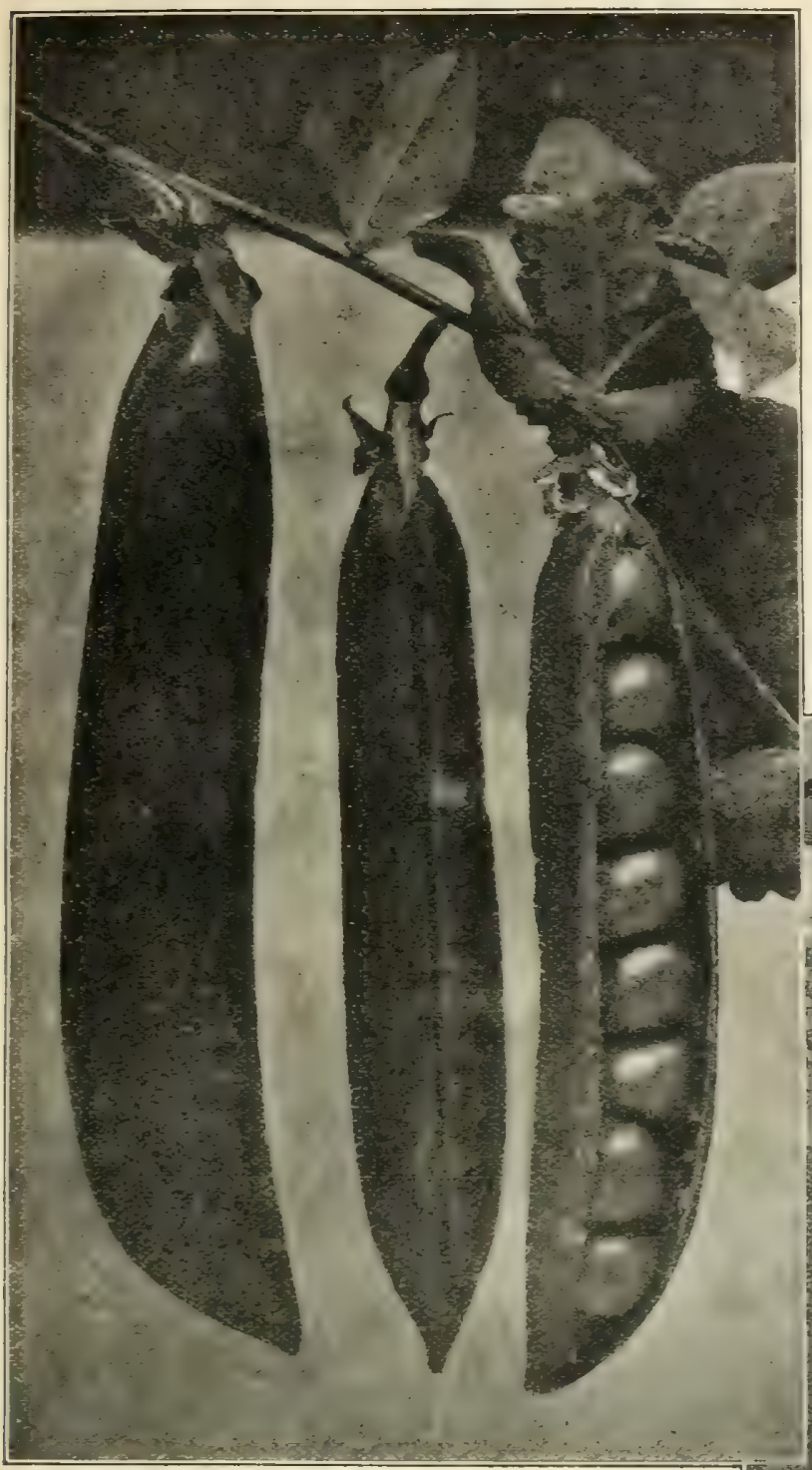

\section{EARLY GARDEN PEAS-Continued.}

* Gradus or Prosperity. An extra early large-podded marrow Pea. The pods resemble Telephone in size and shape, and are well filled with large peas of delicious flavor. Height, $2 \frac{1}{2}$ feet,

Pt., .25; qt., .40; $\frac{1}{2}$ pk., 1.50 ; pk., 2.75 ; bush., 10.00

* Nott's Excelsior. A splendid dwarf wrinkled Pea; hardy and vigorous, may be planted as early as the round varieties, and will mature almost as soon. Pods almost square and contain 7 to 9 large peas the quality being unsurpassed. Height, 1 foot,

Pt., .20; qt., .35; $\frac{3}{2}$ pk., 1.25 ; pk., 2.25; bush., 8.00

* American Wonder. A very dwarf and remarkably fine wrinkled variety; extra early, producing a multitude of large, closely filled pods; of delicious flavor.

Pt., .20; qt., .35; $\frac{1}{2}$ pk., 1.25; pk., 2.00; bush., 800

Mrs. John Kendrick Bangs, Ogunquit, Maine, July, 1908, writes :I feel impelled to write and tell you what wonderful Peas we have been getting from the Seeds I purchased from you this Spring. The pods of the Stratagem, Cox's Improved (with one or two exceptions only), have held nine or ten peas."

Gradus Pea.

* MeLean's Little Gem. A dwarf green wrinkled Pea; very early, and of excellent flavor. Height, 1 foot,

Pt., .20; qt., .35; $\frac{1}{2}$ pk., 1.25; pk., 2.00; bush., 7.00 .

* Premium Gem. A very desirable dwarf variety. The pods are of medium size and well filled with small sugary peas.

Pt., .15; qt., .25; $\frac{1}{2}$ pk., .90; pk., 1.75; bush., 6.00 .

* Duke of York. A vigorous and productive sort, bearing an abundance of large pods. closely packed with peas of extra fine quality. Height, $2 \frac{1}{2}$ feet,

Pt., .25; qt. . 10 ; $\frac{1}{2}$ pk., 1.50 ; pk., 2.50 ; bush., 9.00 .

\section{MEDIUM GARDEN PEAS.}

* Alderman. A valuable variety of recent introduction. The vines are vigorous and average 18 to 20 pods, each containing 7 to 10 large peas of a most delicious flavor, Pt., .25; qt., .40; $\frac{1}{2}$ pk., 1.50 ; pk., 2.75 ; bush.,
9.00 .

* Senator. A handsome large, round-podded variety. The vines are very vigorous, and carry a heavy crop of pods, closely filled with peas of excellent quality. Height, 2 feet,

Pt., .25; qt., .40; $\frac{1}{2}$ pk., 1.50 ; pk., 2.75; bush. 9.00 .
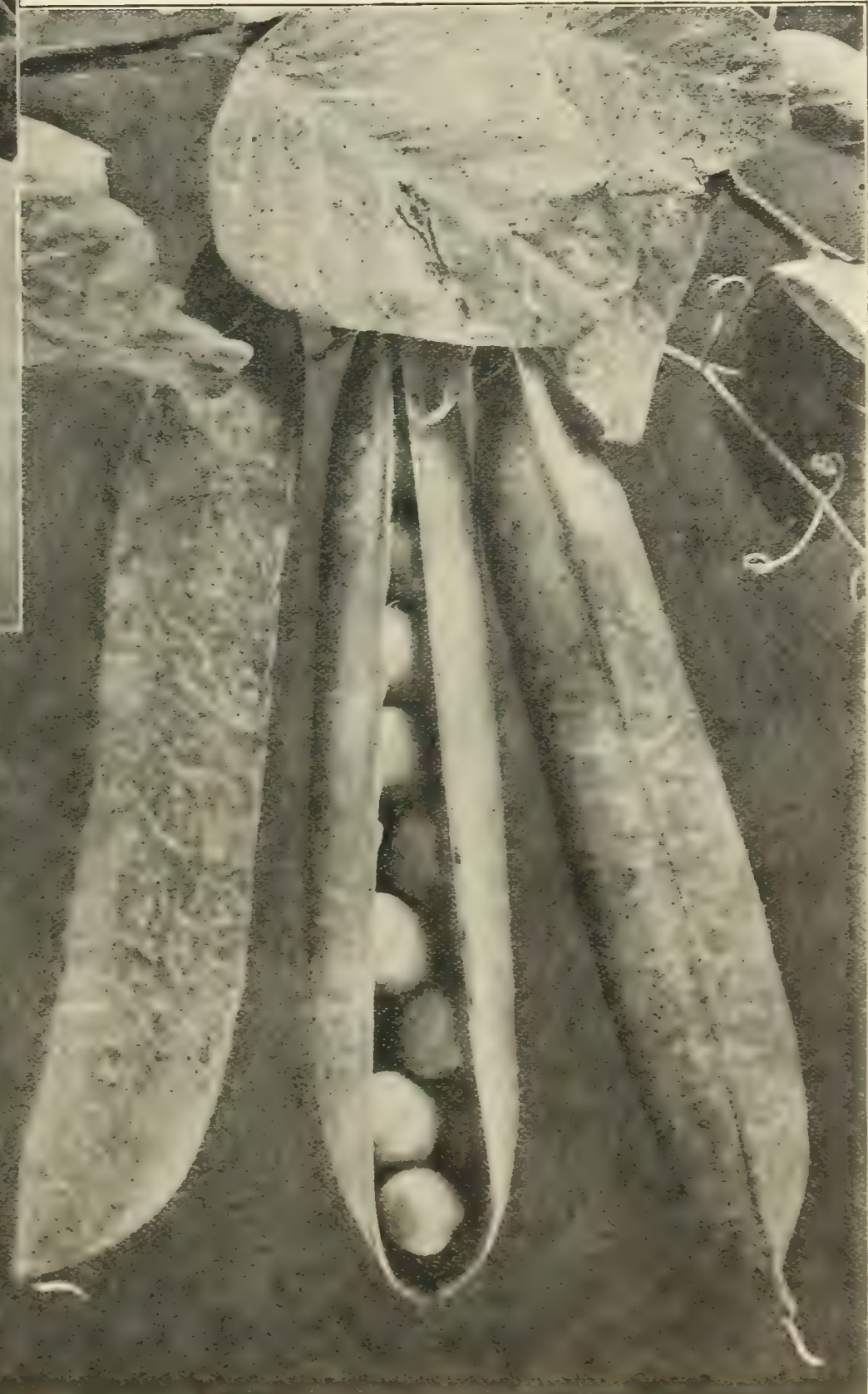


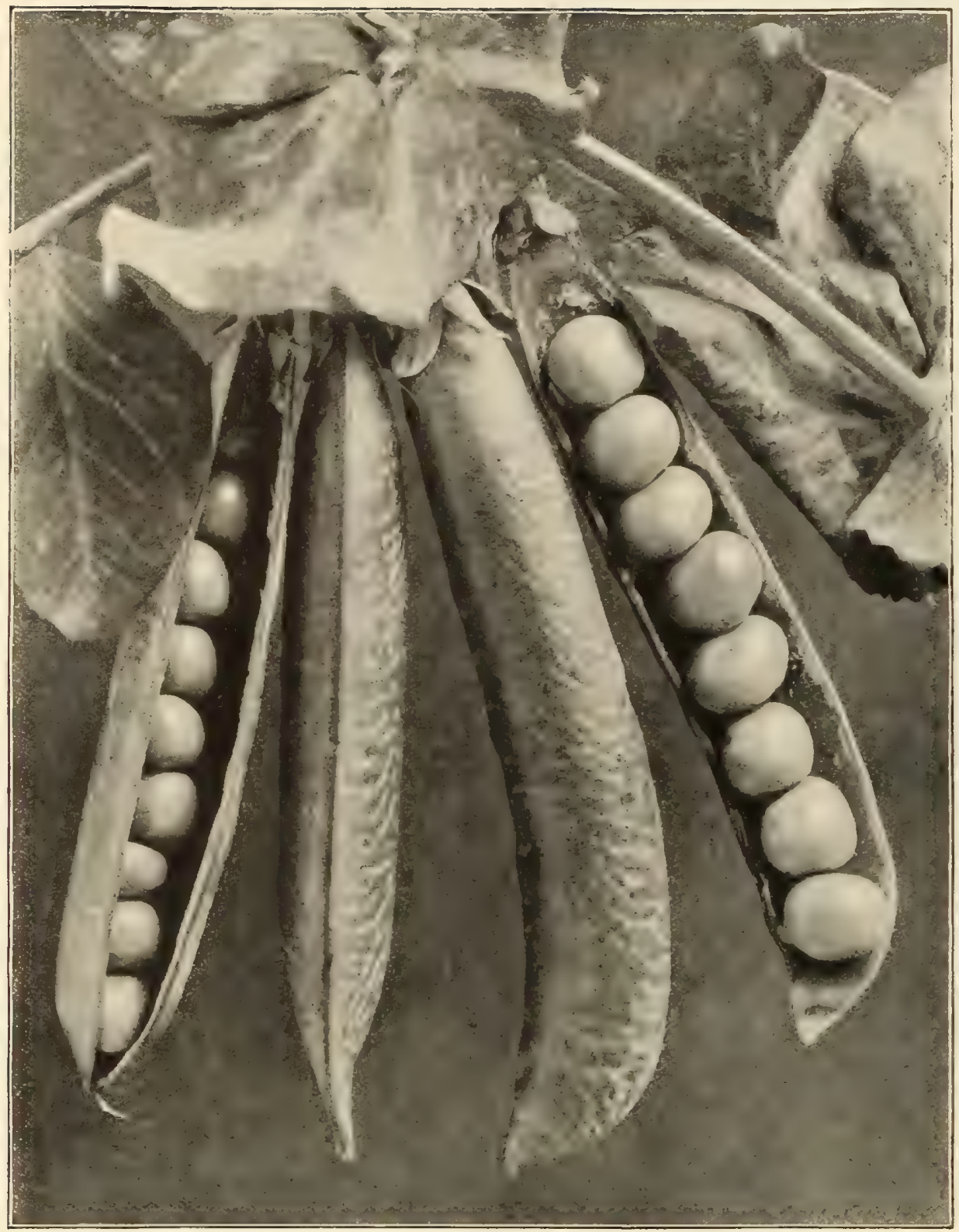

MEDIUM GARDEN PEAS,-Cont'd.

* McLean's Advancer. A dwarf green wrinkled marrow pea, with numerous long well-filled pods, containing peas of the finest quality. Height, 2 feet, Pt., .15; qt., .30; $\frac{1}{2}$ pk., 1.00 ; pk., 1.75; bush., 6.00

* Everbearing. An excellent variety, of branching habit. Pods about 3 inches long and well filled. Sweet and of fine flavor, Pt., .20; qt., .30; $\frac{1}{2}$ pk., 1.10; pk., 2.00; bush., 6.50 .

* Abundance. A popular sort, branching from the bottom of the vine, bearing a large quantity of well-filled pods, sweet and delicious, Pt., .15; qt., .25; 妾 pk., .85; pk., 1.50; bush. 5.50 .

* Heroine. An excellent green wrinkled variety, with large pods, containing 8 to 10 large peas, very tender, rich and sweet. Height, $2 \frac{1}{2}$ feet, Pt., .20; qt., .30; $\frac{1}{2}$ pk., 1.00 ; pk., 1.75; bush., 6.00 .

Melting Sugar: Edible Podded. The pods are cooked like Snap Beans, and are very sweet and tender. Height, 3 feet, Pt., .25; qt., .40; pk., 3.00 .

\section{MAIN CROP AND LATE GARDEN PEAS.}

* Champion of England. A prolific and vigorous sort, producing immense pods well filled with large peas, unsurpassed for flavor and sweetness. Height, 4 feet, Pt., .15; qt., .25; $\frac{1}{2}$ pk., .85; pk., 1.50 ; bush., 5.50 .

Cox's Improved Stratagem Pea

\section{MEDIUM GARDEN PEAS.-Continued.}

* Stratagem, Cox's Improved. One of the best of the large podded sorts. The vine is strong, and of branching habit, very prolific, being covered with pods of the largest size, uniformly filled with peas of the finest quality, Pt., .25; qt., .40; $\frac{1}{2}$ pk., 1.35; pk., 2.50 ; bush., 9.00

* Carter's Daisy. An excellent sort, of dwarf, stocky, vigorous habit, uniform in height, producing large handsome pods which contain 8 to 10 large tender peas, of superior flavor,

Pt., .25; qt., .40; $\frac{1}{2}$ pk., 1.35 ; pk., 2.50; bush., 9.00

* Farquhar's Dwarf Defiance. One of the best second early Peas. The vines are densely covered with long straight pods, closely filled with large peas of superior flavor. . Pt., .25; qt., .40

* Sutton's Peepless. A splendid variety of sturdy growth. The vines are laden with large dark green pods, peas are large and of extra fine quality. A valuable sort for exhibition purposes. Height, 3 feet. ... ... ... Pt., .25; qt., .40

* Farquhar's Best of All. A superior variety of the highest quality. The pods are of a rich dark green color, containing 8 to 10 large peas of delicious flavor. Height, $3 \frac{1}{2}$ feet,

Pt., .30; qt., .50
* Telephone. A tall and very robust grower, bearing pods of unusual length closely filled with peas of large size. Superb flavor and tender,

Pt., 20 ; qt., .35; $\frac{1}{2}$ pk., 1.25; pk., 2.00 ; bush., 7.50

* Duke of Albany. American Champion. A strong growing variety, with large light-colored leaves, and producing an abundance of very large pods well filled with peas, tender and sweet. Height, 5 feet,

Pt., .25; qt., .40; $\frac{1}{2}$ pk., 1.25; pk., 2.00 ; bush., 7.00

Pride of the Market. A robust growing variety of medium height, producing a good crop of large well filled pods; peas are of large size, sweet and tender,

Pt., . 20; qt., .30; $\frac{1}{2}$ pk., 1.00 ; pk., 1.75 ; bush., 6.00

* Sharpe's Queen. A vigorous, branching sort, which should be sown thinly. Pods are long and slightly curved, filled with peas of delicious flavor. Height, $2 \frac{1}{2}$ feet,

Pt., .15; qt., .25; $\frac{1}{2}$ pk., .90; pk., 1.75; bush, 6.50

* Yorkshire Hero. A hardy and productive pea for late use, being almost entirely free from mildew. Pods broad, and well filled with peas of fine quality,

Pt., .15; qt., .25; $\frac{1}{2}$ pk., .90; pk., 1.75 ; bush., 6.00

White Marrowfat. A very hardy and productive sort, with large pods well filled with peas, which are inferior in quality, however, to the foregoing main-crop and late sorts,

Pt., .15; qt., .25; $\frac{1}{2}$ pk., .65; pk., 1.00; bush., 3.50 


\section{POTATOES.}

\section{Prices Subject to Variations of the Market.}

A good, sandy loam produces the best potatoes, but they can he grown on all kinds of soil. New or pasture land, with the tur freshly turned, produces the finest crop. Make furrows of good depth, 3 feet apart. Scatter a liberal dressing of phosphate or decayed stable manure along the drill. and set the sesil ahout 10 inches apart in the rows. Cover with about 2 inches of soil, and begin to cultirate when the plants are rell up. At each succesive hoeing, hring additional soil about the plants. A change of seed is the best anti dote for disease. Four barrels are sufficient to plant one acre in drills.

\section{EARLY VARIETIES.}

Noroton Beauty. A productive first early variety. The tubers are almost round, the eyes shallow and the skin flaked with crimson. The cooking qualities are unsurpassec,

$$
\text { Bhl., } 6.00 ; \text { bush., } 2.50 ; \mathrm{pk}_{.}, .75
$$

Bovee. One of the best very early sorts, maturing before the Early Rose and much more productive than that favorite sort. The plants are compact and admit of close planting. The tubers are smooth, pinkish in color, and of uniform medium size. A most desirable early sort,

$$
\text { Bbl., 4.50; bush., 2.00; pk., .60 }
$$

Irish Cobbler. A fine extra early sort, producing plump, handsome tubers of good size and excellent quality. The tubers are a beautiful creamy white with strong well-developed eyes slightly indented. A popular variety,

Bbl., 4.50 ; bush., 2.00 ; pk., .60

Early Rose. The popular standard early variety. Skin red and white, uniform in size and very productive,

Bbl., 4.50; bush., 2.00; pk., .60

Early Norther. This standard early variety originated in Aroostook County, Maine. It is a seedling from the Early Rose, which it closely resembles in shape and color, but is still earlier and very much more prolific. It has strong, vigorous habits of growth, and is of fine eating quality, cooking dry and mealy, whether baked or boiled. It is highly esteemed by large growers for the early market trade,

Bbl., 4.50; bush., 2.00; pk., .60

New Queen. A grand potato, resembling Beauty of Hebron in color, size, and shape, but much earlier and more prolific, with few small tubers. The quality is excellent, the flesh being pure white and of the dry, mealy texture so much desired in a table potato ... ... B Bbl., 4.50; bush., 2.00; pk., .60

Beauty of Hebron. An early and popular variety extensively grown for winter use. The tubers are smooth, white slightly tinged with pink, and of superb flavor,

Bbl., 4.50; bush., 2.00; pk., .60

\section{MAIN CROP AND LATE VARIETIES.}

Green Mountain. This is unsurpassed for main crop. The tubers are white, of flat oval shape, smooth, handsome, and of excellent quality. It is a heavy cropper, small tubers being seldom present. ... ... Bbl., 4.50 ; bush., 2.00 ; pk., .60

Carmen III. One of the best late varieties, enormously prolific, skin and flesh pure white ... BbI., $4.50 ;$ bush., $2.00 ; 1$ kk., .60

Carmen I. An intermediate variety, yielding a heary crop of smooth white tubers of medium size and superior quality. Excellent keeper ... ... Bbl., 4.50; bush., 2.00; pk., .60

Lady Finger. A popular baking variety in New England.

$$
\text { loush., } 3.00 ; \text { Pk., } 1.00
$$

\section{SWEET POTATOES.}

Rooted slips ready in May. The young plants should be set in May in hills about 4 feet apart and 5 inches above the ground level. A light soil and sunny location is preferable.

Yellow Nansemond. Early; productive; the best for general culture

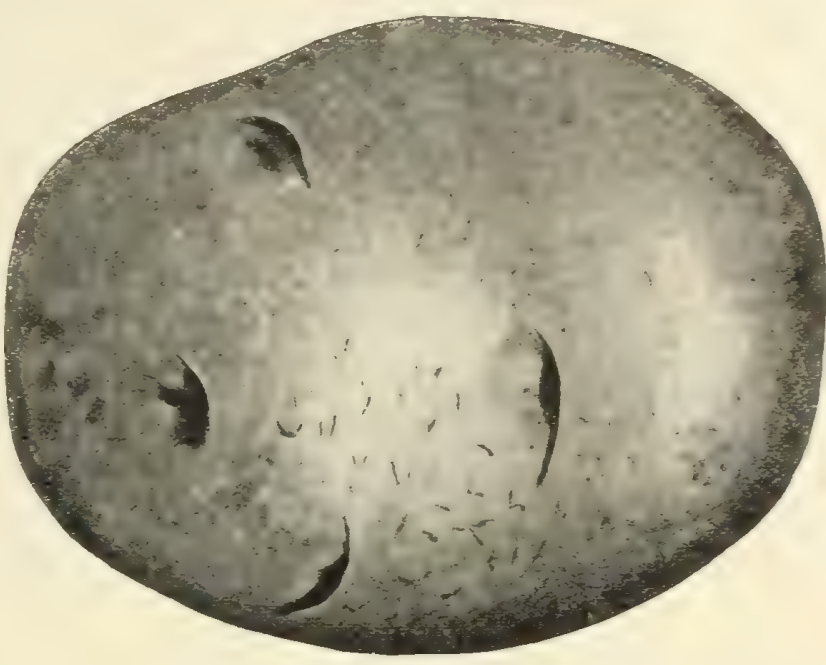

Irish Cobbler.

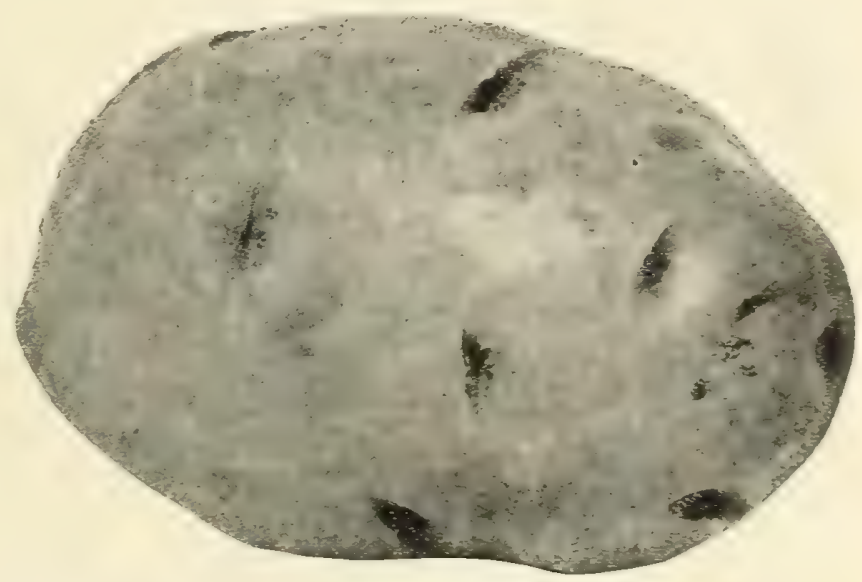

New Queen.

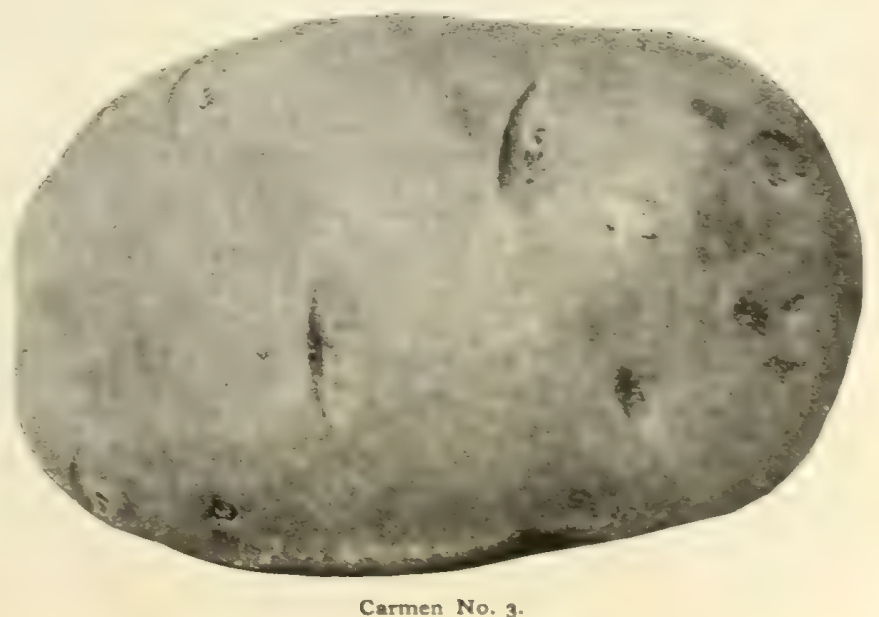

Carmen No. 3. 


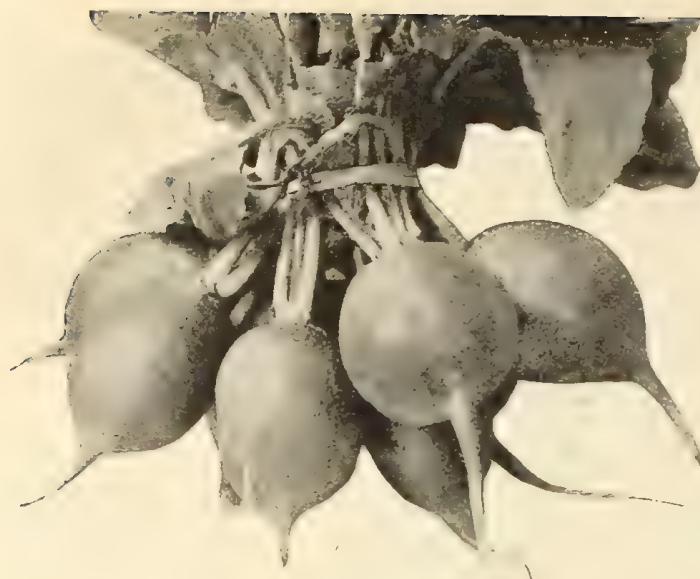

Early Scarlet Globe Radish.

\section{RADISH.}

Rabanos y Rabanitos. Rettig.

Radishes require a light, loamy soil, moderately fertile, which should be deeply dug and well pulverized. The situation should be warm and sheltered. For an early supply sow in January or February in hotbeds, keeping well ventilated. In April they may be sown out-of-doors. Successive sowings should be made every two weeks. Radishes to be crisp and tender should make rapid growth. One ounce of seed to 100 feet of drill; 10 pounds an acre.

Barly Deep Scarlet, Olive-Shaped, Short Leaf. One of the most desirable varieties for forcing. The skin is deep bright red; flesh crisp, tender, and spicy. Leaves few, short, and small ... … Pkt., .05 ; oz., .10; I lb., .25; lb., .75

Non Plus Ultra. The earliest of all; fit for use in about 20 days; short-leaved; brilliant red; good for forcing,

Pkt., .05; oz., .10; + lb., .30; lb., 1.00

Early Searlet Globe. Admirable for forcing or out-of-door culture; deep scarlet; flesh white and tender,

$$
\text { Plit., .05; oz.. .10; } 1 \text { lb., .25; 1b.,.75 }
$$

Early Searlet Turnip-Rooted. Very early, crisp, and beautiful

Early Searlet Turnip, White-Tipped. Very early; for frames or out-of-doors, Pkt., .0e, oz., .10; $\frac{1}{4} \mathrm{lb} ., .25 ; \mathrm{lb} ., .75$

Early White Turnip, or Box. Suitable for forcing; pure white; sweet $\quad .$. Pkt., .05; oz., .10; $\frac{1}{4}$ lb., .25; lb., .75

Early French Breakfast. Oval form; color searlet with white tip; excellent quality and of quick growth,

Pkt., .05; oz., .10; 1 lb., .25; lb., .75

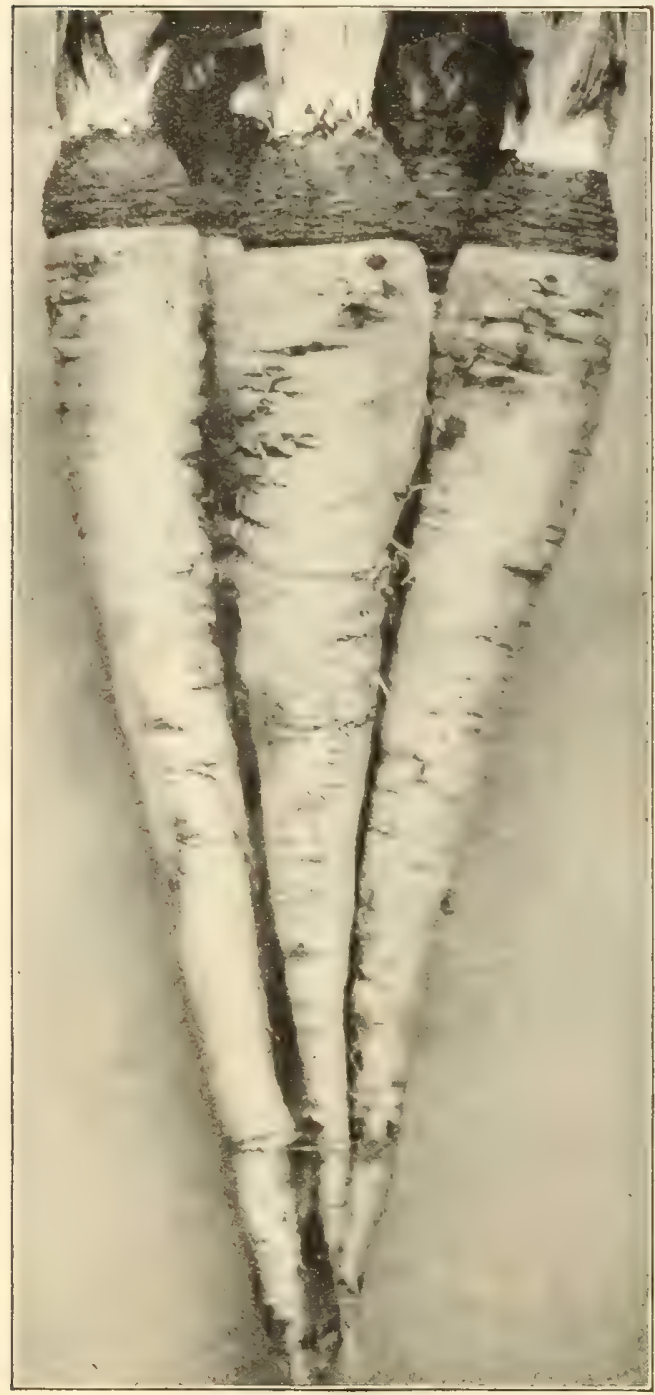

Salsify.
Early Long Scarlet, Short Top. Very long and crisp; for frames or open ground P.... P.. .05; oz, $.10 ; \frac{1}{4} 1 \mathrm{~b} ., .25 ; 1 \mathrm{~b} ., .75$ Long Brightest Scarlet, White Tip. Matures in 25 days from planting; continuing crisp until full grown ... ... Pkt, . .05; oz., .10; 1 lb., .25; lb., .75 Long Black Winter, or Spanish. Sown in early autumn, the roots keep crisp all

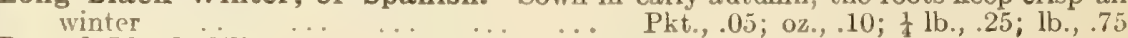
Round Black Winter, or Spanish. Fine keeper during winter, Pkt., .05; oz., .10; + lb., .20; lb., .65

White Giant Stuttgart Winter. Very crisp, Pkt. .05; oz., $10 ; 1 \mathrm{lb} ., 25 ; 1 \mathrm{~b} ., .75$ Sakurajima (Mammoth Japan). A Japanese variety of large size; pure white; flesh crisp and tender with agreeable sharp flavor, Pkt., .10; oz.,.25; $\frac{1}{4} \mathrm{lb}, .75 ; 1 \mathrm{~b} ., 2.50$

RHUBARB. Rhabarber.

A deep, rich soil, trenched to the depth of 2 feet, is best for Rhubarb. It is usually propagated from plants.

Linnæus. Early, large, tender,

Victoria, Large, late, good old sort, Each, Pkt., .05; oz., .20; 1 lb., .50; roots: each, .15; doz., 1.50; 100, 8.00 Monarch. The best sort; very tender. Does not come true from seeds,

\section{SAGE PLANTS.}

Roots: each, .30; doz., $3.00 ; 100,20.00$

For flavoring

\section{SALSIFY, or OYSTER PLANT.}

Ostion Vegetal. Haferwurzel. - A most delicious vegetable. It is used stewed, boiled, or fried, and sometimes as a salad. When cooked, it has an oyster flavor. Cultivation the same as for Carrots or Parsnips. One ounce will sow 50 feet.

Mammoth Sandwich Island. Large roots, Pkt., .10; oz., .20; $\frac{1}{4} \mathrm{lb} ., .50 ; \mathrm{lb} ., 1.50$ Long White Froneh. Delicious when cooked, Pkt., .10; oz., .20; 1 lb.,.50; lb., 1.25

\section{SEA KALE. Meerkohl.}

Sow one inch deep in drills; thin to 6 inches; transplant the following spring 3 feet apart. The blanched shoots are used like Asparagus; very tender,

Seeds : Pkt., .10;07.. . $30 ; \frac{1}{4}$ 1b., .85. Foreing Crowns: doz., 1.50; 100, 12.00 SPINACH. Espinaca. Spinat.

Spinach to oe tender and succulent must be grown in very rich soil. For summer use sow early in spring in drills 15 inches apart, and make successive sowings every 2 weeks. For spring use sow in September, and cover lightly in November with light litter. One ounce will sow 100 feet of drill; 10 to 12 pounds an acre.

Round Thiek-Leaved. A standard sort; equally good for early spring or fall sow-

ing: leaves are thick, succulent, and tender, Pkt., .05; oz., .10; $+1 \mathrm{lb} ., .15 ; \mathrm{lb} ., .35$ Long-Standing. Of delicious, tender quality; dark green leaves,

Pkt., .05; oz., .10; $\frac{1}{4} 1 \mathrm{~b} ., .15$; lb., 35 Savoy-Leaved, or Bloomsdale. Large, tender, crumpled leaves,

Vietoria. A new variety with thick dark green leaves, The best long standing Spinach Pkt., .05; oz., .10; $\frac{1}{4} \mathrm{lb} ., .15 ; \mathrm{lb} ., .35$ Priekly Seeded. Very hardy and vigorous; leaves arrow-shaped, Pkt., 05; oz., .10; 1 lb, .15; lb. .35

New Zealand. Makes a low spreading plant from which tender greens can be gathered the entire summer. May be started in a hot-bed and transplanted or sown out-of-doors when the ground is warm, allowing 2 feet between the plants, Pkt., .05; oz., .15; $\frac{1}{1} \mathrm{lb} ., .30 ; 1 \mathrm{~b} ., 1.00$ 
R. \& J. FARQUHAR \& CO., BOSTON. VEGETABLE SEEDS.

\section{SQUASH. Calabaza. Speise Kurbiss.}

Squashes should not be planted until all danger from frost has passed. They delight in a warm, thoroughly pulverized, very rich soil. Plant in hills in May, mixing with the soil in each hill a shovelful or two of rotted manure. For bush varieties the hills should be from 5 to 6 feet apart, for running sorts 10 feet apart. Put 8 or 10 seeds in each hill, and when well grown thin, leaving 2 or 3 of the strongest plants to a hill. Small seeded sorts, one ounce to 50 hills; large seeded sorts, one ounce to 15 hills.

The Delicious. One of the best sorts for winter use. Its color is almost uniformly of a green shade; it usually weighs between five and ten pounds. In thickness of flesh it surpasses nearly every variety, the color being a dark orange. For table use no squash compares with it in its remarkable combination of fineness and compactness of grain, dryness, sweetness, and exceeding richness

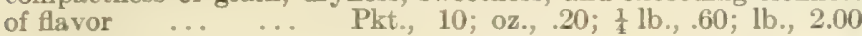

Early Mammoth White Bush. The best early scalloped summer sort ... ... ... Pkt., .05; oz., .10; $\frac{1}{4}$ lb., .30; lb., 1.00

Early Golden Custard. Scalloped, early; golden yellow, Pkt., .05; oz., .10; $\frac{1}{4}$ lb., .25; lb., .90

Early Summer Crookneek or Warted. The best flavored of the early bush squashes; bright yellow; fruits average 12 inches long $\ldots . . . \quad \ldots$ Pkt., .05; oz., .10; 1 lb., .30; lb., 1.00

Boston Marrow. Highly esteemed for autumn use; a good keeper and of excellent flavor ... Pkt., .05; oz., .10; $\frac{1}{4} \mathrm{lb} ., .30 ; \mathrm{lb} ., 1.00$

Early Prolific or Orange Marrow. A superior strain of Ifarrow, excelling in earliness, productiveness, and keeping qualities. Fruit of medium size, bright orange-red; flesh fine grained and dry when cooked,

Pkt., .05; oz., .15; $\frac{1}{4}$ lb., .40; lb., 1.25

Essex Hard Shell Turban or Hybrid. A cross between American Turban and Hubbard, combining the superior qualities of both these excellent sorts. Rich in flavor, fine grained, and sweet. Flesh thick, richly colored, and solid. A superior winter sort and an excellent keeper,

$$
\text { Pkt., .05; oz., .15; } \frac{1}{4} \mathrm{lb} ., .50 ; \mathrm{lb} ., 1.50
$$

The Warpen. Similar to Essex Hybrid, but the shell is generally harder and thicker than that splendid sort, and the color a richer and deeper orange,

$$
\text { Pkt., .05; 0z., .15; } \frac{1}{4} \mathrm{lb} ., .40 ; 1 \mathrm{~b} ., 1.25
$$

The Golden Bronze. Size averaging from eight to ten pounds; color, a dark, grayish green; flesh bright golden yellow; fine grained, very sweet and delicious in flavor. A squash combining the qualities desired for the table and pies,

Pkt., .10; oz., .20; $\frac{1}{4} \mathrm{lb} ., .50 ; \mathrm{lb} ., 1.50$

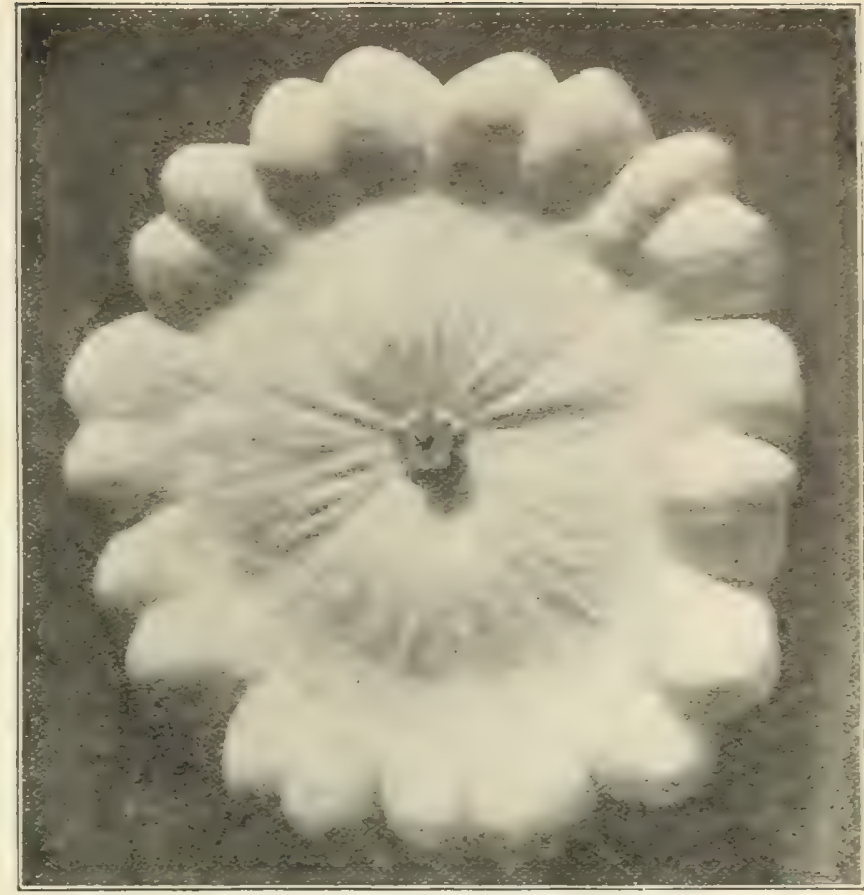

Early Mammoth White Bush Squash.

Marblehead. A great farorite; outer skin a light bluish green; flesh a remarkable combination of dryness, sweetness, and delicious flavor ... Pkt., .05; oz., $.15 ;$ i lb., .40; lb., 1.25

Canada or Winter Crookneek. Excellent for winter, close grained, sweet, and of fine flavor,

$$
\text { Pkt., 05; oz., .10; } \frac{1}{4} \text { ib., .25; lb., } 90
$$

Yellow Mammoth. Grows to an enormous size, often weighing nearly two hundred pounds; requires high cultivation,

Pkt., .10; oz., .20; $\frac{1}{4}$ lb., .60; lb., 2.00

Vegetable Marrow. For summer use; a favorite English bush squash; cream-colored, flesh white,

Pkt., .10; oz., .30; $\frac{1}{4}$ lb., .75; lb., 2.50

Bay State. Exceedingly heavy, excellent quality, superior keeper, abundantly productive and extremely early. In color its shell is green, adapting it to markets demanding a green squash for winter use; the meat is bright golden yellow in color, very attractive, dry, and of exquisite flavor when cooked, Pkt., .05; oz., .10; $\frac{1}{4}$ lb., .35; lb., 1.00

Hubbard. The most popular winter Squash; color dark olive green; flesh very rich, fine grained and dry. An excellent keeper-in condition from September to May, Pkt., .05; oz., .15; $\frac{1}{4}$ lb., .40; lb., 1.25

Chicago Warted Hubbard. Differs from the well known Hubbard in appearance, being rather more heavily warted. An excellent strain.worthy of cultivation,

Pkt., .05; oz., .15; $\frac{1}{\text { l lb., .40; lb., } 1.25}$

\section{TARRAGON PLANTS.}

French Estragon. Plants of our own growing of the genuine French Tarragon. The leaves impart a delicious flavor to salads, soups, pickles, etc. Plants, well established, .25 each; dozen, 2.50. By mail 5 cents each extra.

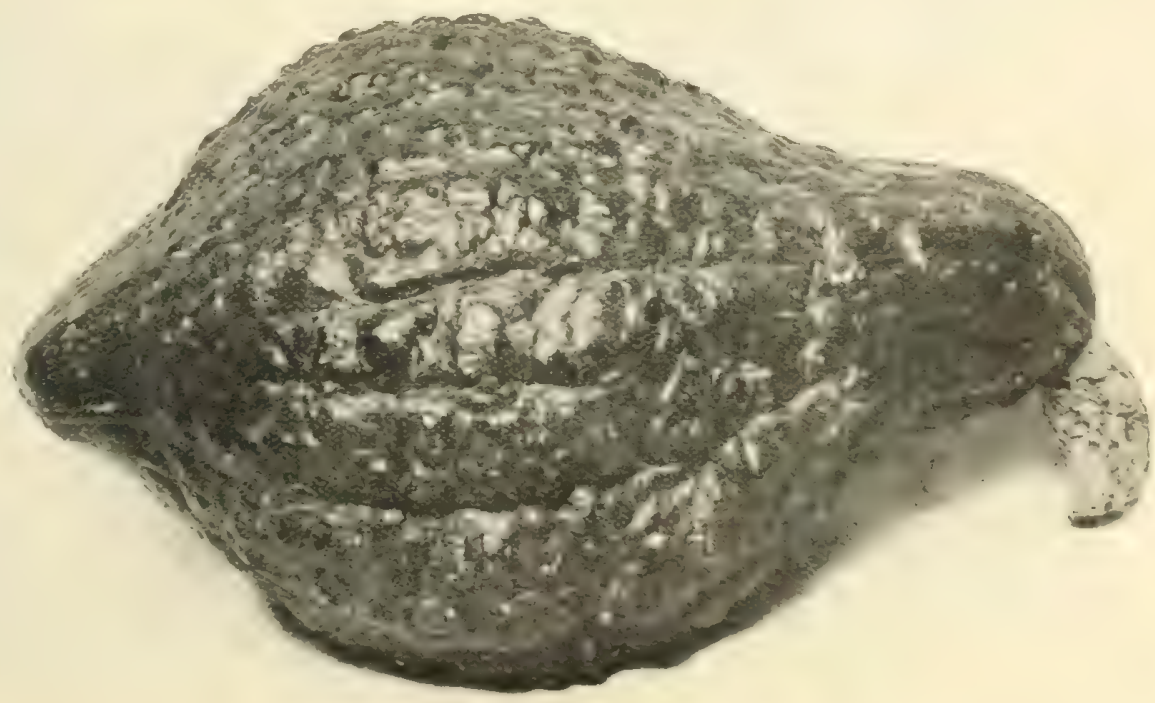




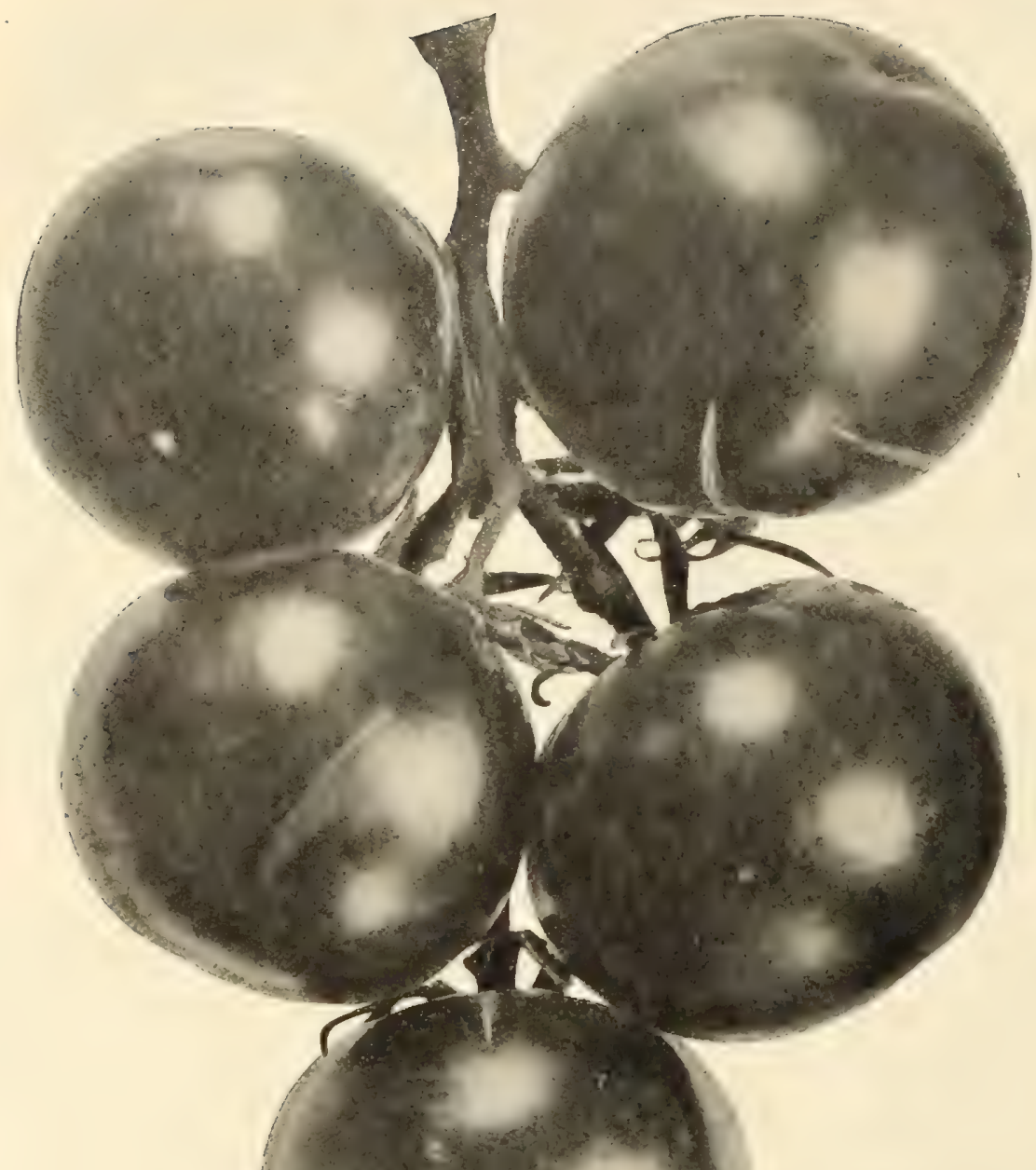

\section{TOMAT0.}

\section{Tomates. Liebes Apfel.}

Sow thinly about the first week in March in a hot-bed, greenhouse, window, or sitting room, where the temperature is never below 60 degrees. When two inches high set out the plants in boxes about four inches apart, or pot singly. About the first of June they may be transferred to the open ground. Set them deeply, four feet apart, and a shovelful of rotted manure should be mixed in the earth of each hill. If the vines are trained on trellis the fruit will be finer and larger.

Hubert's Marvel. This variety is a selection from Stirling Castle. The fruit is round, of medium size, and produced in very large clusters.

The growth is very short-jointed and seems to be free from disease. Per packet, 25 cents.

Winter Beauty. An excellent, smooth fruited variety, very early, which comes from the Island of Guernsey. Highly recommended for forcing. Per packet, 25 cents

Comot. This is a splendid variety for either indoors or out. It is very short-jointed, fruiting close up to the stem. The tomatoes are of good medium size, quite smooth, very solid, and of a deep scarlet color. Per packet, 25 cents; per $\frac{1}{6}$ ounce, $\$ 1.25$; per ounce, $\$ 4.00$

Stirling Castle. We have a specially selected stock of this variety. One of the best cropping of all the round fruited varieties. Excellent for forcing as well as for out-door culture. Fruit is of medium size, reddish scarlet in color, and of very delicious flavor. This variety sets very freely. Per packet, 25 cents; per ounce, \$2.50.

The Rochford. A grand forcing Tomato, combining great productiveness with excellent form and splendid quality. The fruit is round, perfectly smooth, medium in size, and of a deep rich scarlet color. The flesh is very solid, something of much importance in a forcing Tomato. The fruit is produced in bunches which average 6 to 10 tomatoes each. Per packet, 15 cents; per oz. 50 cents; per $\frac{1}{\frac{1}{3}} \mathrm{lb} ., \$ 1.50$

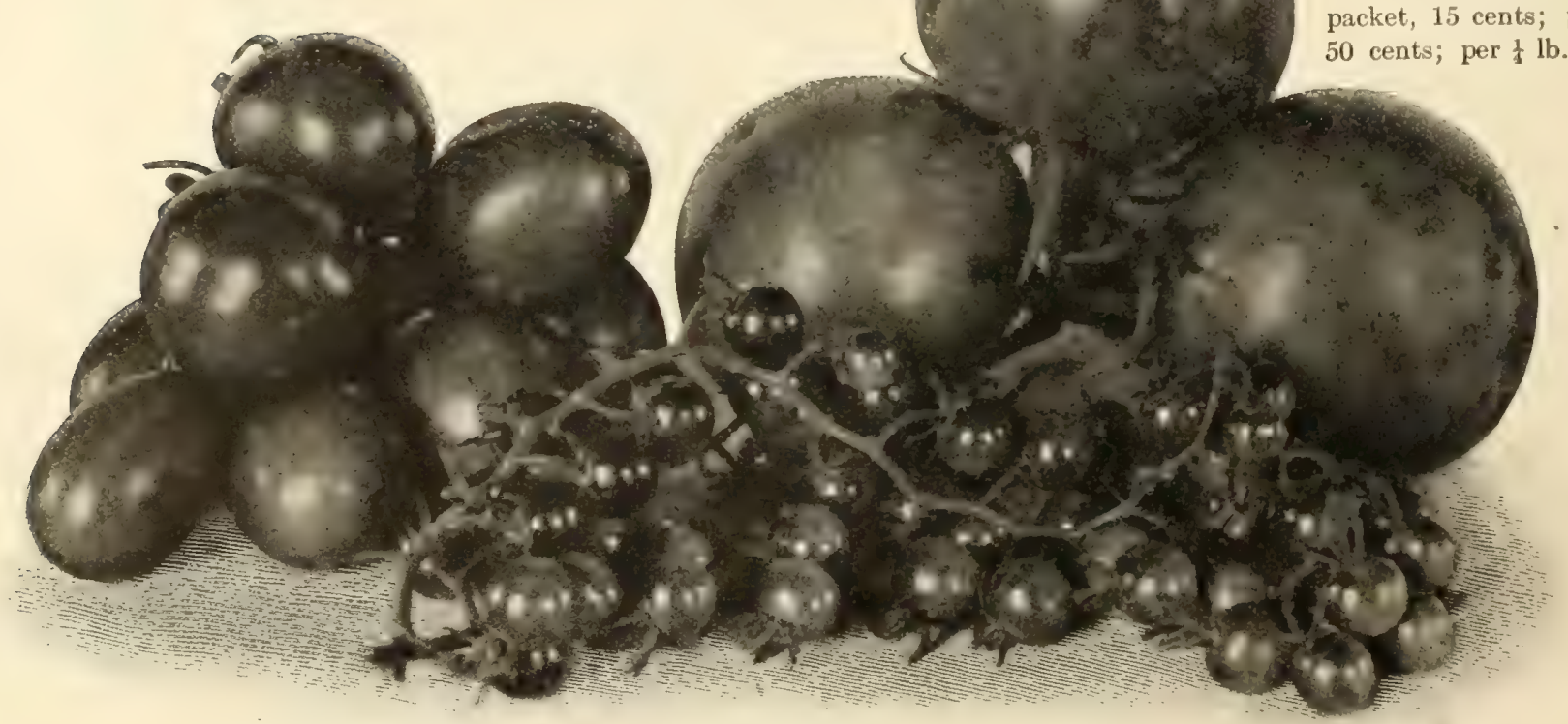

Tomatoes, Yellow Plum 
R. \& J. FARQUHAR \& CO., BOSTON. VEGETABLE SEEDS.

\section{TOMATO.-Continued.}

Spark's Earliana. The earliest and most prolific large Tomato. Color a beautiful red, handsome, uniform, remarkably solid and productive,

Pkt., .10; oz., .40; 1 lb., 1.25; lb., 400

Chalk's Early Jewell. One of the best early varieties of medium size, solid, bright searlet in color, with very few seeds,

Pkt, 10;0z., .75: $\frac{1}{4} \mathrm{lh}, 0.2 .00$ Farquhar's Faultless Early. The standard early Tomato. Uniformly medium size; handsome, perfectly round fruit, of great density,

Pkt., 10; oz, 35; 1 lb., 1.00; lb., 3.50

Dwarf Champion. Quite distinct and very early; stem upright with few branches; beautiful and solid fruit close to the stem,

Pkt., .10; oz., .30; $\frac{1}{4}$ lb., $.85 ; 1 \mathrm{~b}$., 3.00

Freedom. An extra early; bright, scarlet, smooth, round, and handsome,

Pkt., . 10; oz., .30; lb., .85; lb., 3.00

Sutton's Best of All. An excellent sort for forcing, or early outdoor crop. Sets freely and an immense cropper. Color, deep scarlet, Pkt., .10; oz., .40; 1 lb., $1.25 ; \mathrm{lb}$., 4.00

Stone. Livingstone. Large, perfectly smooth, scarlet; one of the best,

Pkt. .05; oz., .25; 1 lb., .75; lb., 2.50

Beauty. Livingstone. Pinkish red; large, smooth, thick flesh,

Pkt., .05; oz., .25; $\frac{1}{4} \mathrm{lb} ., .75 ; 1 \mathrm{~b} ., 2.50$

Perfection. Livingstone. Early; evenly large, and very productive,

Pkt., .05; oz., $.25 ; \frac{1}{3} 1 \mathrm{~b} ., .75 ; \mathrm{lb} ., 2.50$
Trophy. Large; very solid, productive, and keeps well,

Pkt., .0.5; oz.. .2.5; $\frac{1}{4} \mathrm{lb} . . .5 ; 1 \mathrm{l}, .2 .50$

Golden Queen. Yellow; medium size; fine; remarkably attractive,

Pkt., .10; oz., .30; 1 lb., 1.00; lb., 3.00

Peach. Resembles the peach in color; small; good for preserves,

Pkt., 10; oz, . 30; $\frac{1}{4}$ lb, 1.00; lb., 3.00

Plum. Yellow, oval, small size; used for preserves, Pkt., .10 ; oz., . 30 ; $\frac{1}{4}$ lb., 1.00 ; lb., 3.00

Pear, or Fig. Bright red, pear-shape, small; for preserves, Pkt., .10; oz., $.30 ; \frac{1}{4} \mathrm{lb}$., $1.00 ; \mathrm{lb} ., 3.00$ Red Cherry. Used for preserves; small, round fruit, Pkt., $.10 ; \mathrm{oz}_{\text {., }} .30$; ll lb., $1.00 ; 1 \mathrm{~b} ., 3.00$

Currant, or Grape. Very small, bright red fruit in clusters,

Pkt., .10; oz.. .50; $\frac{1}{16}$., 1.50 ; lb., 4.50

Strawberry, or Ground Cherry. Physalis alkekengi. The fruit, which grows in a busk, will keep all winter; makes an excellent preserve, Pkt., .10; oz., .40; $\frac{1}{4}$ lb., $1.25 ; 1 \mathrm{lb} ., 4.00$

\section{TOMATO PLANTS.}

Delivery May and June.

Transplanted. .25 per dozen; 2.00 per 100 Dwarf Champion. Perfection. Stone.
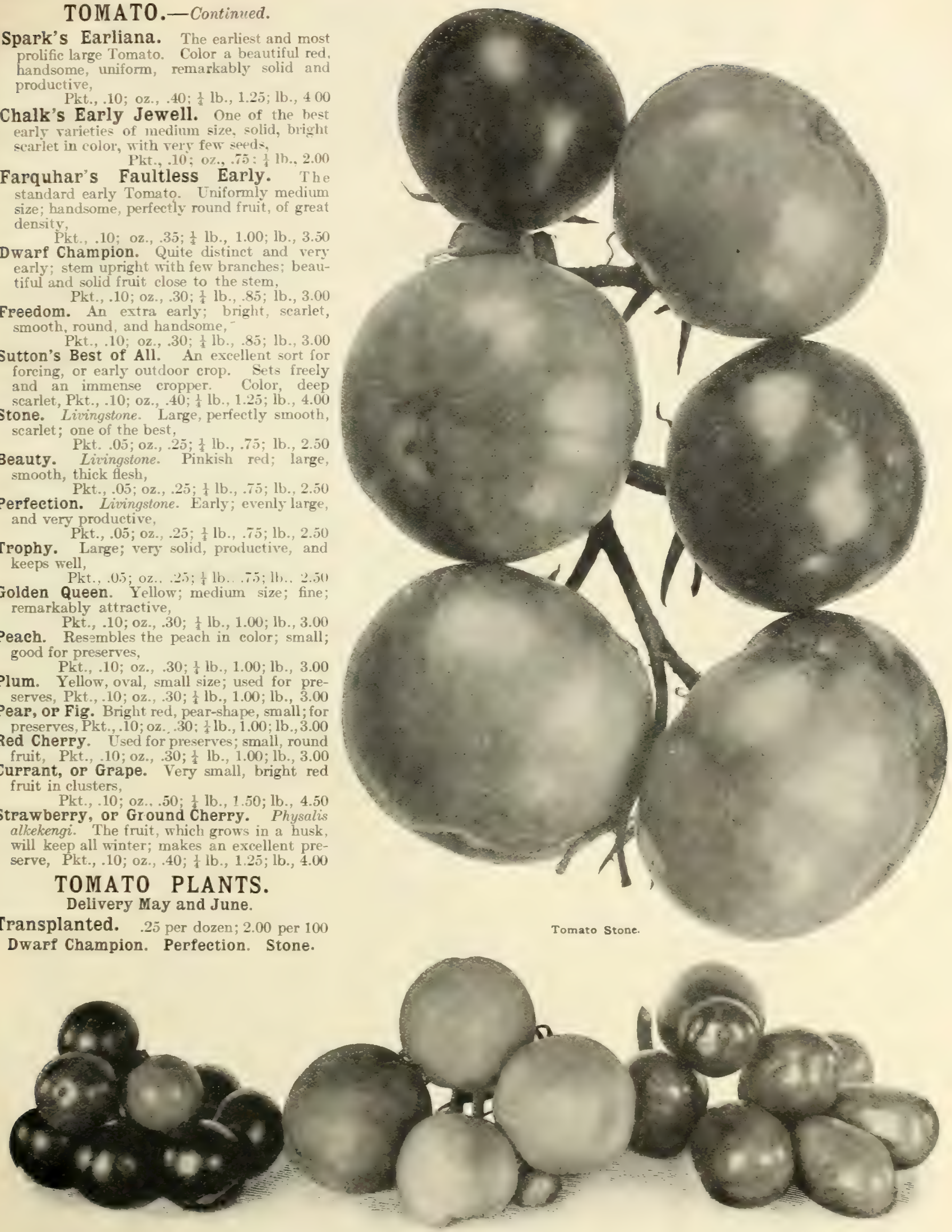


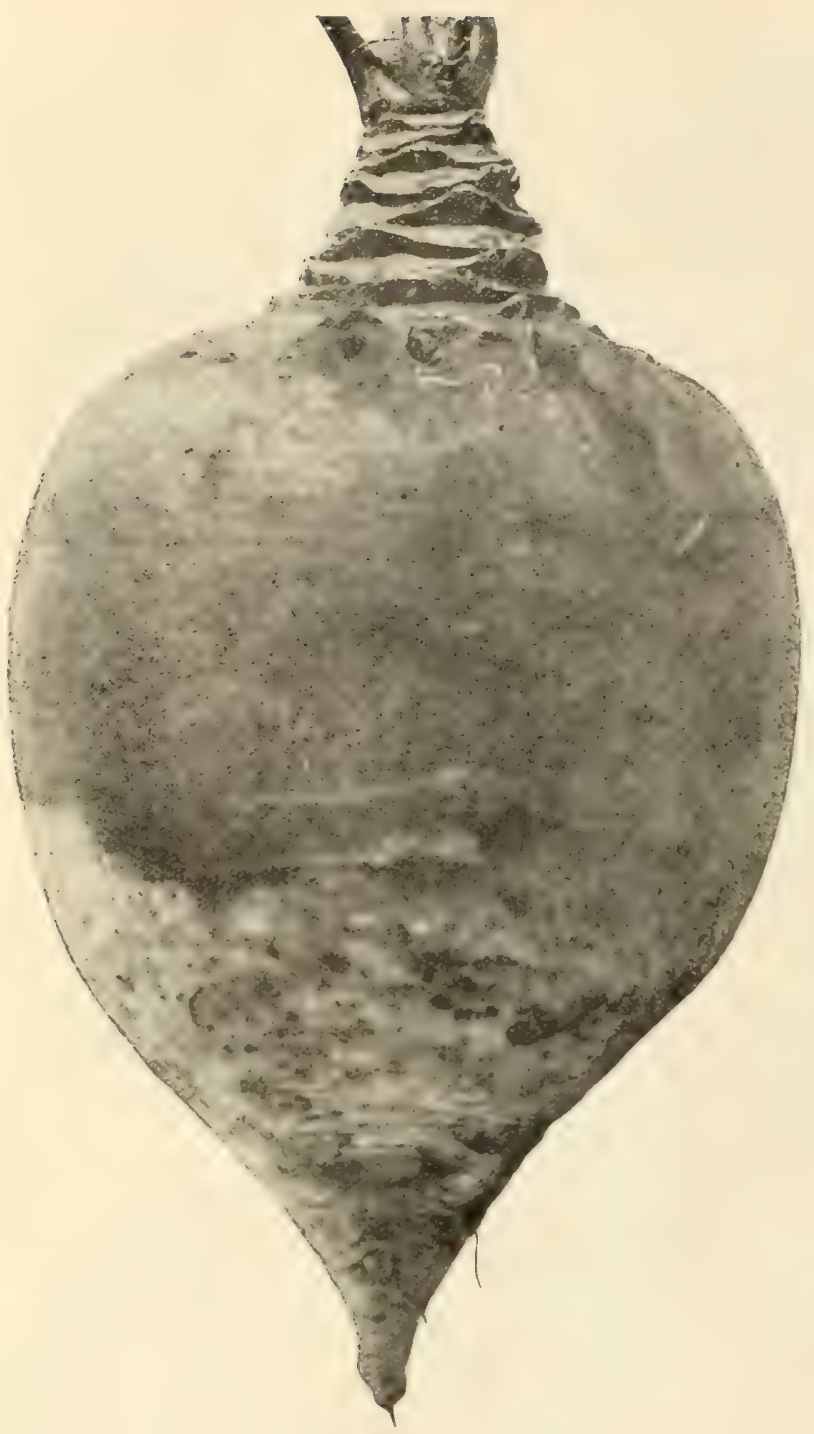

Improved American Ruta-Baga.

\section{TURNIP. Nabo. Rube.}

For early Turnips, sow as soon as the ground is dry enough. Fall Turnips may be sown from the first week in July to the end of September. Ruta-bagas should be sown in June or early in July, in drills 18 inches apart. Turnips should be thinned when large enough, 6 to 9 inches apart in the drills, according to size. Sowings should be made before rain, if possible. The soil should be rich and well worked. One ounce will sow 150 feet of drill; two pounds will sow an acre in drills; one pound will sow an acre broadcast.

Purple Top White Flat, Strap-Leaf. A popular sort for early and fall sowing; flesh white, tender, and very sweet,

Pkt., .05; oz., .10; $\frac{1}{4} \mathrm{lb} ., .20$; lb., .50 Early, smooth, white, fine,

Pkt., .05; oz., .10; 7 lb., .20; lb., .50

Extra Early White Milan. The most beautiful white variety in cultivation and one of the earliest to mature. The roots are very smooth; small tops; flesh tender and sweet. Adapted for growing in cold frames ... ... Pkt., $.10 ; \mathrm{oz}_{2}, .15 ; 1 \mathrm{lb} ., 35 ; 1 \mathrm{~b} ., 1.00$ Purple Top Milan. 'The earliest and best of the Flat Turnips; white with purple top; delicious quality; small, compact strap leaves, Pkt., .05; oz.,.10; 1 lb., .25; lb., .75 White Egg. Oval; remarkably handsome; sweet, Purple Top White Globe. Very early; very fine grained; beautiful in alppearance; tender and delicious,

White Globe. Large white variety; quick grower,

Pkt., .05; 0z., .10; $\frac{1}{4} \mathrm{lb} ., .20 ; 1 \mathrm{~b} ., .50$

Pkt., .05; oz., .10; $\frac{1}{4} 1 \mathrm{~b} ., .20 ; 1 \mathrm{~b} ., .50$ Yollow Aberdeen. Yellow; solid; fine quality; keeps well,

Pkt, .05; oz., .10; 1 lb., .20; lb., .50 Yellow Stone, or Globe. Of large size; flesh yellow; fine fall sort, Pkt., .05; oz.,. $10 ;+1 \mathrm{~b} ., .20 ;$ lb., .50

Cowhorn, or Long White. Form oblong; flesh white; early and very good ... ... ... Pkt., .05; oz., .10; $\frac{1}{1} \mathrm{lb}, 2.25 ; 1 \mathrm{~b} ., .75$

\section{RUTA-BAGA, or SWEDISH TURNIP.}

American Purple Top. A strain of purple top yellow. The roots grow to a large size and are of the finest quality, short neck and small

top
Budlong's White Swede. Grown from selected roots, the best of this section; very sweet; excellent flavor and keeps well,

Pkt., .05; oz., .10; 1 lb., .20; lb., .50 Sweet German. White flesh; sweet, and fine flavor; good keeper, Pkt., .05; oz., .10; + lb., .20; lb., .50

White French. Similar to Sweet German, but larger, Pkt., 05; oz., 10; 1 lb., 20 ; lb., .50

Shamrock. Yellow flesh; solid as a rock; remarkably fine flavor; neck short; a very heavy cropper and one of the best,

Pkt., .05; oz., .10; 1 lb., .20; lb., .50

\section{SWEET, POT, AND MEDICINAL HERBS.}

Anise. Annual. Aromatic. Used medicinally

Arnica. Perennial. Valuable medicinal qualities.

Balm. Perennial. Leaves used medicinally

Basil. Annual. Used for flavoring

Borage. Annual. Valuable for bees

Burnett. Perennial. Useful for salads and soups,

Chamomile. Perennial. Has medicinal qualities, Caraway. Annual. Seeds used in confectionery, Catnip. Perennial. Used for medicinal purposes, Coriander. Annual. Seeds used in confectionery. Dill. Annual. Used for flavoring pickles.

Fennel. Perennial. Used for flavoring fish

Fennel, Florence. Annual. The roots are used
Pkt. Oz.

$.05 \quad .15$

.151 .00

$.05 \quad .30$

$.05 \quad .20$

$.05 \quad .20$

(1) 1.15

$.1 .5)$

$10 \quad .50$

$.05 \quad .10$

$.05 \quad .20$

$.05 \quad .10$

$.05 \quad .20$
Horohound. Perennial. Used medicinally

Hyssop. Perennial. Has medicinal qualities

Lavender. Perennial. Valuable for its perfume...

Lovage. Perennial. Has medicinal qualities ...

Marjoram, Sweet. Perennial. For flavoring ...

Pennypoyal. Perennial. Useful for medicine ..

Rosemary. Perennial. Valuable as a hair wash ..

Rue. Perennial. Very bitter. Used as medicine

Saffron. Annual. Useful for medicinal purposes,

Sorrel. Perennial. Used for salads and "Greens",

Summer Savory. Annual. Used in cookery ...

Thyme. Perennial. Used for seasoning Plants of Thyme. Per doz, 1.00

Wormwood. Perennial. Used medicinally
Sage. Perennial. Used for dressing and flavoring,

$\begin{array}{rr}\text { Pkt. } & \text { Oz. } \\ .05 & .25 \\ .05 & .25 \\ .10 & .30 \\ .25 & 1.00 \\ .05 & .20 \\ .25 & 1.00 \\ .10 & .40 \\ .05 & .15 \\ .05 & .10 \\ .05 & .15 \\ .05 & .20 \\ .05 & .15 \\ .10 & .30 \\ .05 & .25\end{array}$

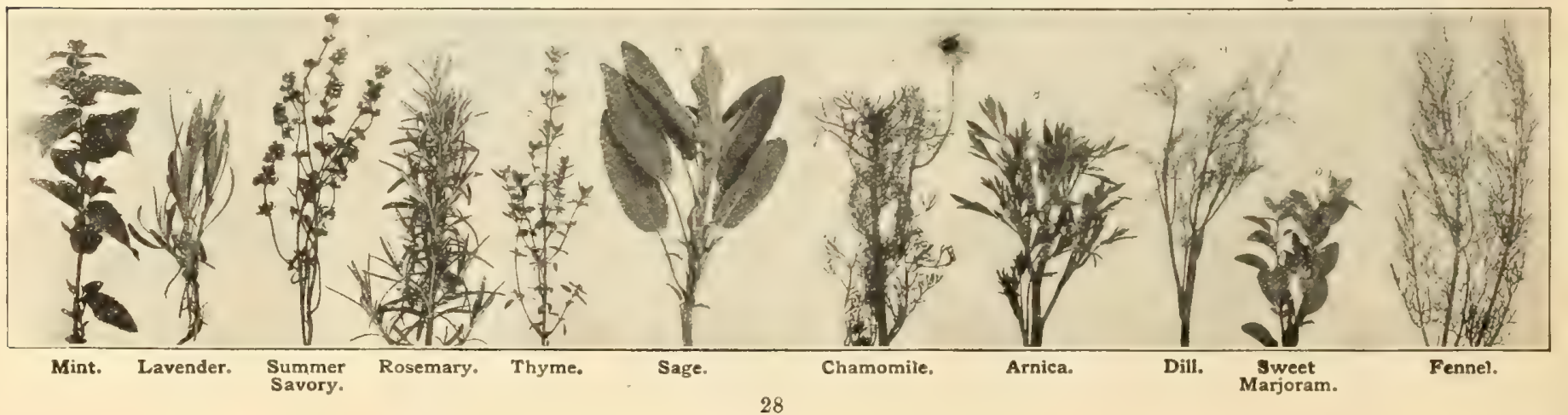


R. \& J. FARQUHAR \& CO., BOSTON. LAWN GRASSES.

\section{FARQUHAR'S EVERGREEN LAWN GRASS.}

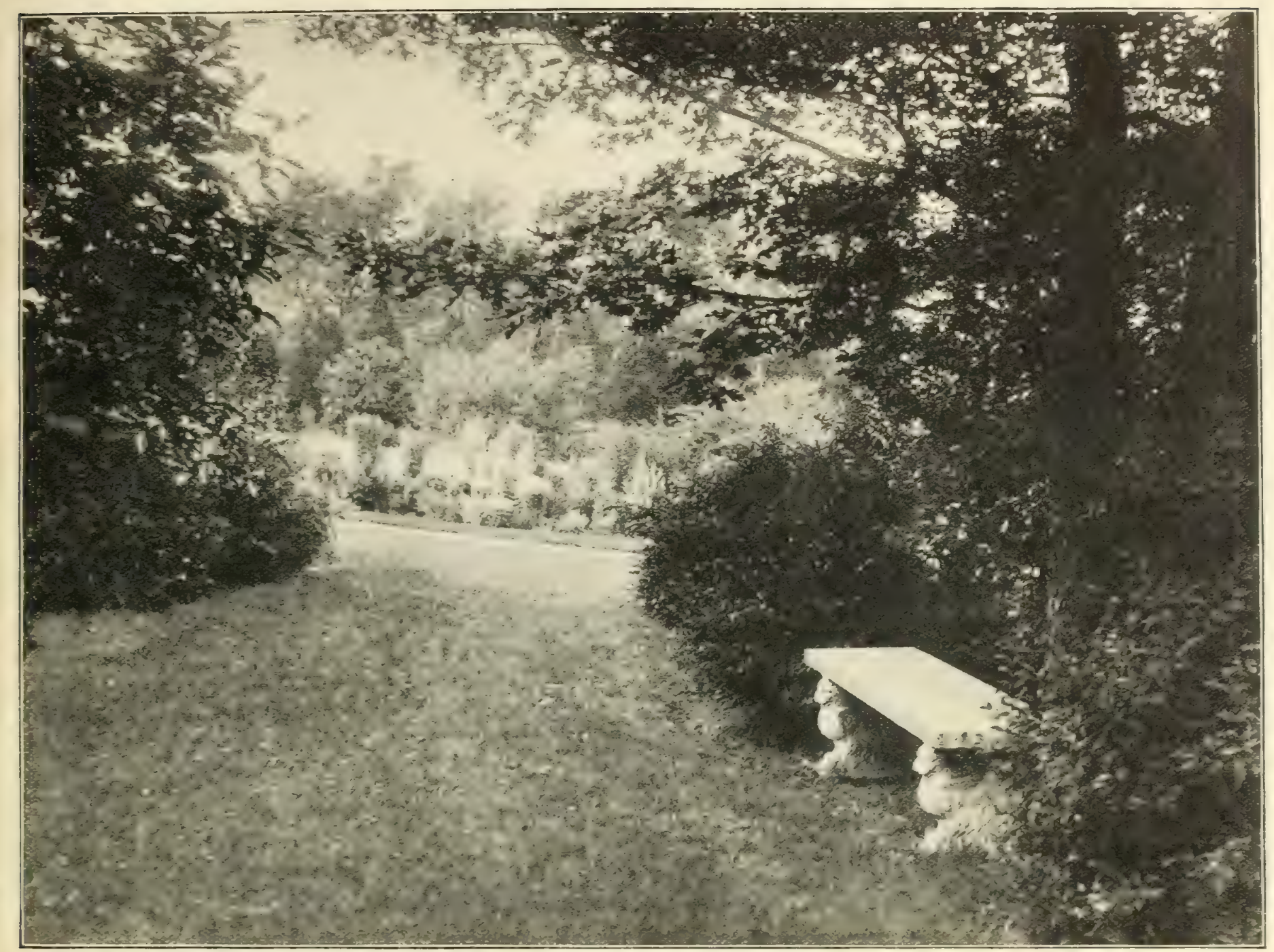

FARQUHAR'S EVERGREEN LAWN GRASS is a mixture of the finest Imerican and European gratens atipterl to lawn-making. The formula for this mixture is the result of life-time practical experience in making and maintaining lawns.

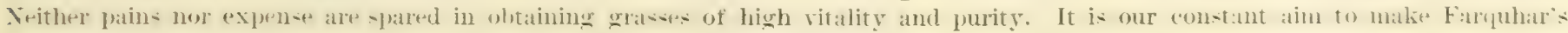
Evergreen Lawn Grass the best, purest and most permanent Lawn Grass sold.

One quart will sow 300 square feet. Price per quart, 25 eents; by mail, 30 eents.

Four quarts will sow 1,200 square feet. Price, 75 eents; by express only.

One peek will sow 2,400 square feet. Price, 1.25 ; by express only.

One bushel (20 lbs.) will sow 10,000 square feet. Priee, 5.00; by express or freight. Four bushels ( $80 \mathrm{lbs}$.$) will sow one aere.$

R. I. Farquhar \& Co., Boston, Mass.

Weld Garden, Brookline, Dec. 7, 1907.

Gentlemen:--It gives me great pleasure to inform you of the good results $I$ have had with your Lavn Grass Spes?s
I have usad them extensively, not only in Massachusetts, but in Washington, D. C., and in St. Loais, Mo., at both

is difficulty in getting good Lawns, and where the successful results from your seeds have been remarkable.

The Weld Garden in Bronkline which has been so frequently described and ill

Your Mixtures for various situations and for different parts of the country, I consider especially valuable.

Fours truly,

Duncan Finlayson.

\section{NEW BOSTON PARKS LAWN SEED.}

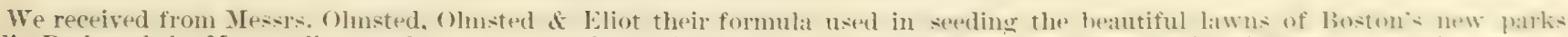

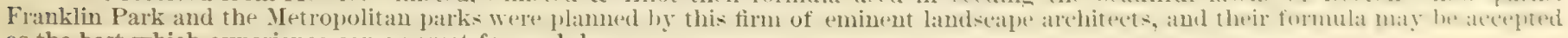
as the best which experience can suggest for park lawns.

Sow at the rate of 64 lbs. per aere. Price, 30 eents per lb.; by mail, 40 cents; 10 lbs., 2.75; 100 lbs., 25.00; 25 lbs. and upwards at the $100 \mathrm{lb}$. rate.

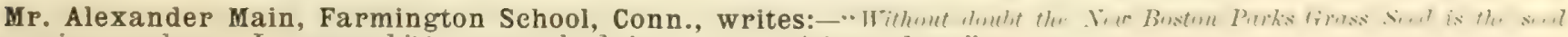
to make a nice green lavon. I recommend it to anyone who desires to get a satisfactory lacon. 


\section{FARQUHAR'S SPECIAL GRASS SEED MIXTURES.}

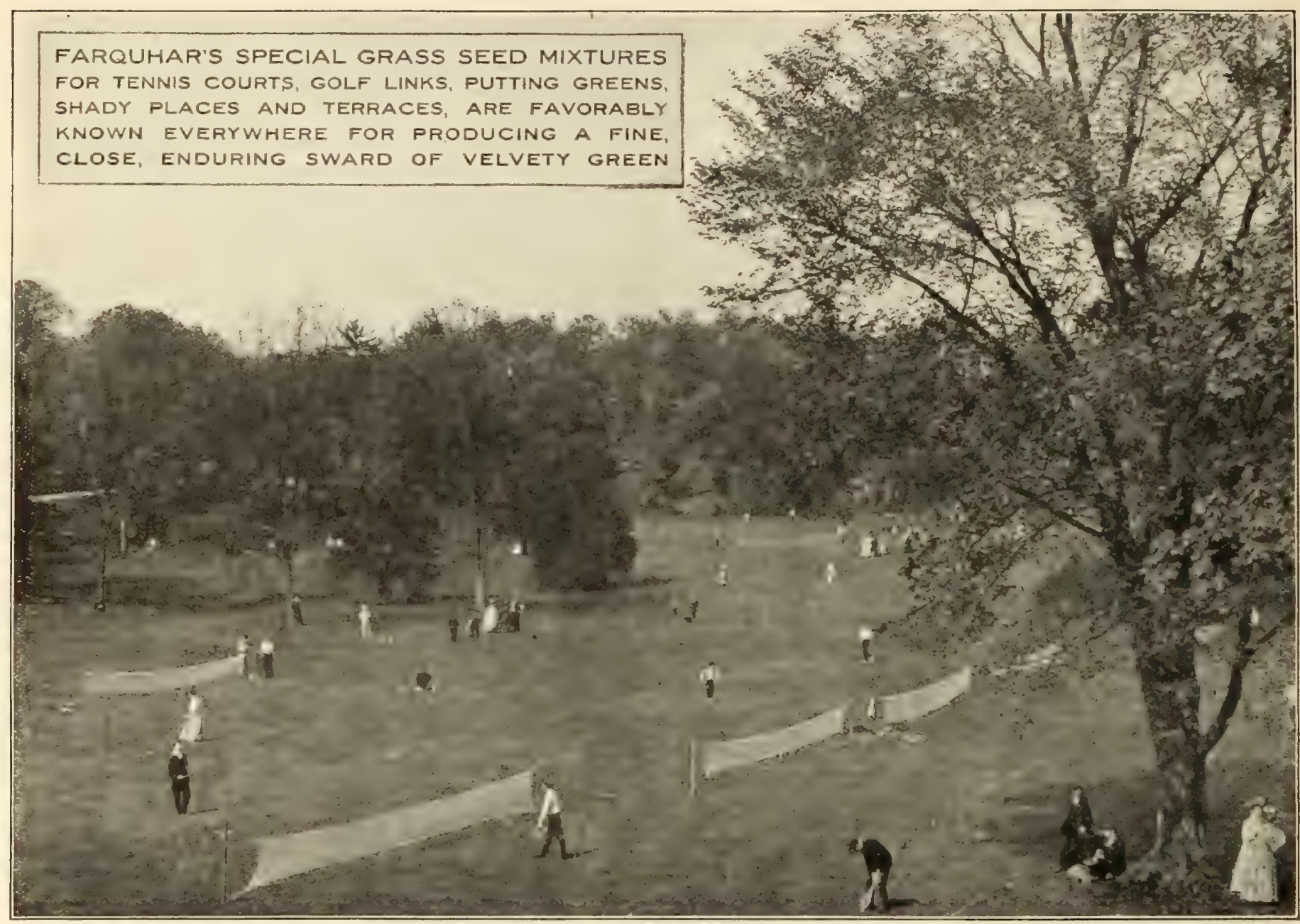

Messrs. R. \& J. Farquhar \& Co., Boston, Mass.

Bretton Woods Golf Club, Bretton Woods, N. H. Gentlemen:- I have used your Lawn Grasses for the past eight years and have found them of extra fine quality and entirely free from foul seeds. Four Putting Green Mixture is the finest I have ever seen-the greens at Bretton Woods produced from it are unrivalled.

Fours truly,

G. S. MERRITT, Prof. Golfer

\section{FARQUHAR'S FAIR GREENS MIXTURE.}

This is composed mainly of peremnial native grasses and two very important European grasses which have proven of great value for Fair-Green use. They are all of dwarf, spreading growth, forming a close velvety surface which improves from year to year if given proper care. It contains no clover, which is objectionable on account of making the surface slippery. If white clover is desired the quantity sown should not exceed one-half pound per bushel of grass seed. Per lb.. .20; per 100 lbs., at 18 cents per lb.; per 1000 lbs., at 16 cents per lb. Sow 50 lbs per acre.

\section{THE FOLLOWING SPECIAL GRASS SEED MIXTURES,}

Quart, .30; by mail, .45; peck, 1.50 ; per bushel of $20 \mathrm{lbs} ., 6.00$.

\section{FARQUHAR'S PUTTING-GREEN MIXTURE.}

The hardiest and finest low growing Grasses are contained in this Mixture. It produces a beautiful and lasting green turf calculated to withstand hard tear and wear.

\section{FARQUHAR'S TERRACE MIXTURE.}

A mixture of strong, deep-rooted Grasses for banks or terraces. Although the Grasses are strong and deep rooted, they will produce a fine green velvety surface, and also prevent washing away during heavy rains.

\section{FARQUHAR'S MIXTURE FOR SHADY PLACES.}

This is a mixture of extra fine grasses adapted for growing in the shade and under trees. We recommend the use of this mixture wherever other grasses on account of shade have failed to make a close sward.

Mrs. W. V. Chapin, Pomfret, Conn., writes:- "Some grass seed bought of you last spring has been underfully fine. I wish you could see my thick, green, grassy walk, 1,200 feet long, under some apple trees. This "St. Dorothy s' path is along a stone wall, and hardy perennials are opposite side from apple trees, and your grass seed made a beautiful path even this first year." 
R. \& J. FARQUHAR \& CO., BOSTON. GRASS SEEDS.

FARQUHAR'S FARM AND FIELD GRASSES. PRICES SUBJECT TO

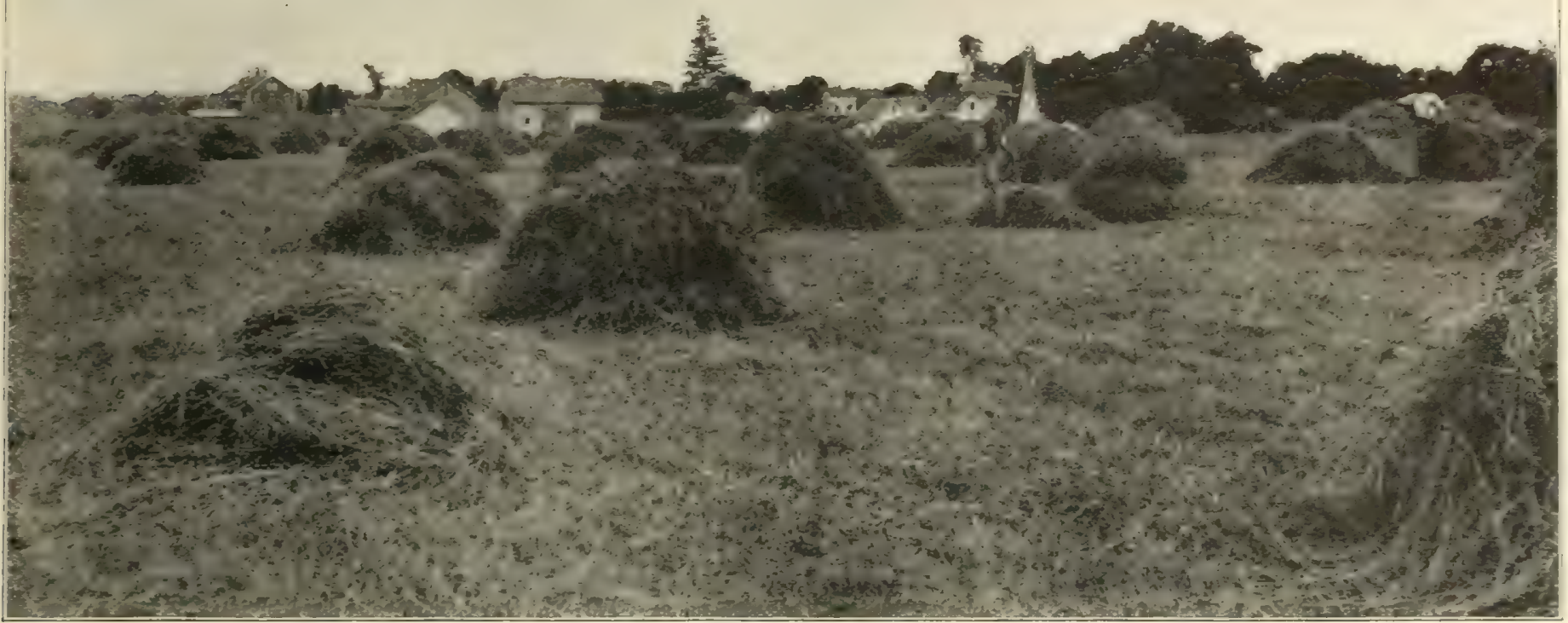

\section{GRASSES FOR PERMANENT HAY CROPS AND PASTURES.}

These contain only the most suitable (irasses, the proportionate quantity of each being regulated by soil, situation and nurpose for which desired. The object to be attained is a constant, successive growth of rich pa-turage fromspring until fall. It is a well-established fact that soil sown with a variety of ditferent grasses which are aclapted to the soil, and which attain perfection at alternate month: from April to September, produce very much larger and more sutisfactory crops, buth for hay and pasturage, than when only one or two kinds of grasses or clorers are sown. The good results obtained from our special (irass seed mixtures are demonstrated by the constantly increasing demand for them. Fall seeding is preferable, but spring sowing will he successful if done early, while the land is cool and moist In addition to the (irasses, we advise sowing $10 \mathrm{lbs}$. of Mixed Clover fieed per acre. Clover seed should be sown separately as it is heavier than firass seeds and settles at the bottom when mixed with them, and in consequence is likely to be sown unevenly. Clovers in their young state are tender in our climate, and should therefore be sown in spring.

PERMANENT MIXTURES FOR HAY CROPS FOR ONE ACRE.

\section{FOR GOOD SOILS, COOL AND MOIST.}

17 lbs. Timothy.

5 "Fancy Red Top.

Orchard Grass.

Perennial Rye Grass.

Meadow Foxtail.

Tall Oat Grass.

Hard Fescue.

Sheep's Fescue.

Italian Rye Grass.

Various Leaved Fescue.

Perennial Sweet Vernal.

$40 \mathrm{lbs}$. per aere, 7.00 .

\section{FOR HIGH, DRY SOILS.}

\section{5 lbs. Timothy.}

5 "Fancy Red Top.

7 " Orchard Grass.

4 " Tall Oat Grass.

3 " Hard Fescue.

3 " Sheep's Fescue.

1 “ Sheep's Fescue, fine leaved.

1 " Rough Stalked Vleadow Grass.

1 " Crested Dogstail.

40 lbs. per acre, 7.00.
FOR WET SOILS.

\author{
12 lbs. Timothy. \\ Rhode Island Bent. \\ Fancy Red Top. \\ Orchard Grass. \\ Perennial Rye Grass. \\ Italian Rye Grass \\ Tall Oat Grass. \\ Various Leaved Fescue. \\ Meadow Fescue. \\ Tall Fescue.
}

40 lbs. per acre, 7.00 .

\section{MIXTURES FOR PERMANENT PASTURES FOR ONE ACRE.}

\section{FOR GOOD SOILS, COOL AND MOIST.}

8 lbs. Timothy.

5 "Fancy Red Top.

Orchard Grass.

Perennial Rye Grass.

Sheep's Fescue.

Hard Fescue.

Meadow Fescue.

Tall Oat Grass.

Meadow Foxtail.

Kentucky Blue Grass

Perennial Sweet Vernal.

40 lbs. per aere, 7.50 .
FOR DRY SOILS.

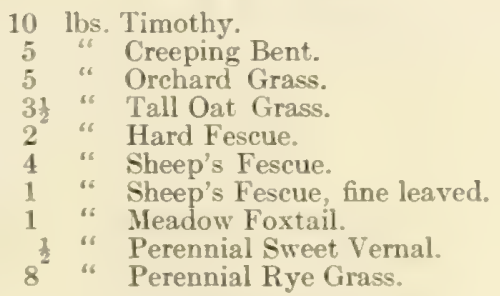

40 lbs. per acre, 7.50 .
FOR WET SOILS.

10 lbs. Timothy.

4 "Fancy Red Top.

Kentucky Blue Grass.

Orchard Grass.

Perennial Rye Grass.

Meadow Fescue.

Tall Fescue.

Meadow Foxtail.

Rough Stalked Meadow Grass

Various Leaved Fescue.

40 lbs. per acre, 7.50 .

10 lbs. Mixed Clover Seed sufficient for one acre, 2.25. 


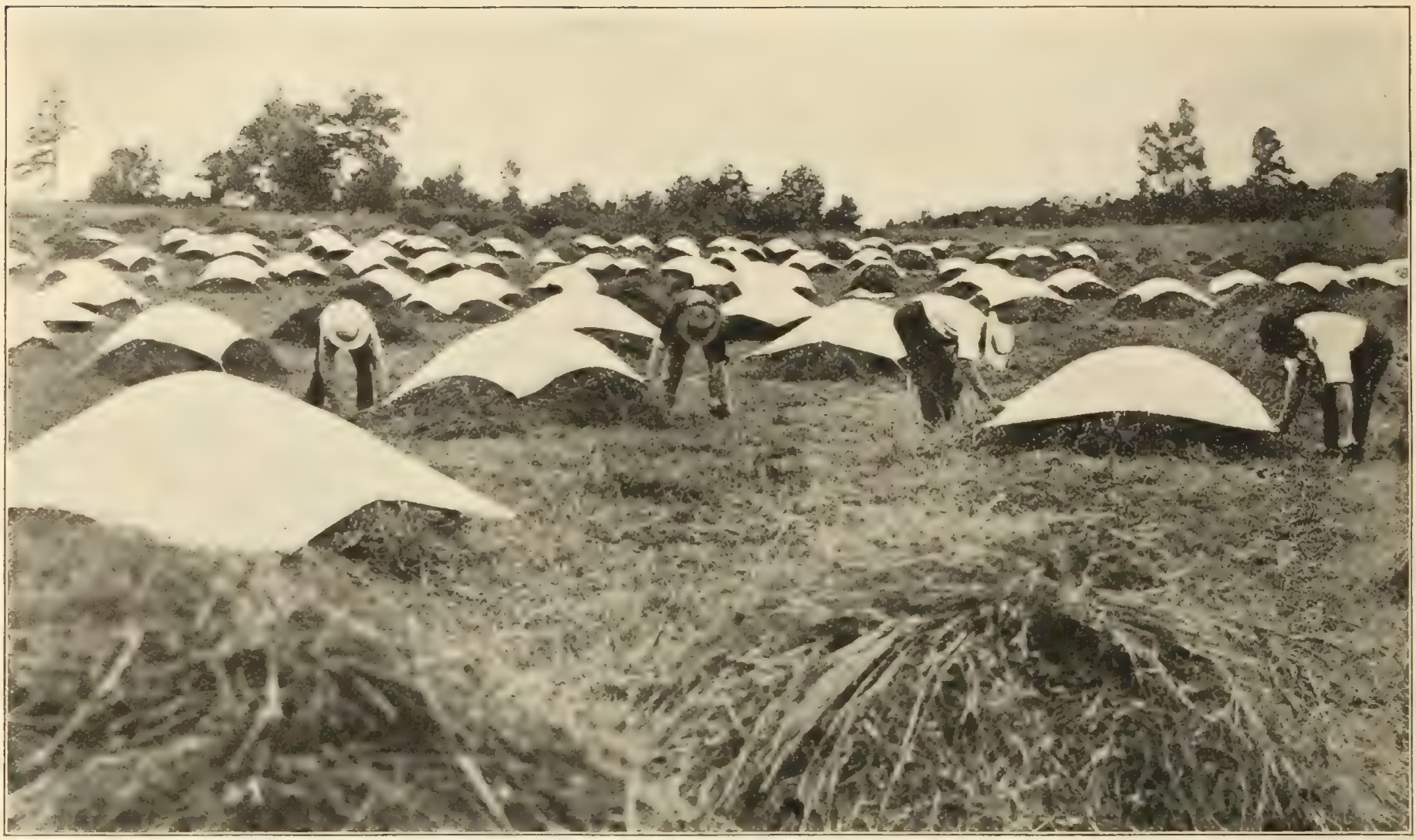

\section{FARQUHAR'S FARM AND FIELD GRASSES.-Continued.}

AWNLESS BROME GRASS. Bromus Inermis. A hardy perennial, standing extremes of heat, cold, and drought better than any other of our cultivated Grasses. It grows with wonderful rapidity, and produces heavy hay crops and luxuriant pasture. The seed should be sown as early in the spring as the ground can be worked. Sow 35 to 40 lbs. to the acre.

CRESTED DOG'S TAIL. Cynosurus cristatus. A perennial valued for its dwarf labit and its hardiness.

HARD FESCUE. Festuca duriuscula. This splendid Grass is found in all the best lawns and permanent pastures; invaluable for dry soils; of low dense-growing habit.

ITALIAN RYE GRASS. Lolium Italicum. A biennial which grows in broad, compact tufts, producing a large number of stalks from a single root. Succeeds best in warm, rich, moist soils. A rapid grower and a good crop to rid land of weeds, as it quickly overtops them, preventing them from ripening seeds. Sow three bushels per acre.

KENTUCKY BLUE. Poa Pratensis. Known as June Grass. A perennial, especially adapted to dry limestone soils, but will thrive on any good ground which is not too wet. Very nutritious, hardy, and early. Sow three bushels per acre if alone.

MEADOW FESCUE. Festuca pratensis. A perennial which succeeds best on rich, moist loams. A heavy yielder and also an excellent pasture Grass.

MEADOW FOX TAIL. Alopecurus pratensis. Very valuable in mixtures for permanent pastures exposed to heat and drought, early and rapid in growth.

ORCHARD. Dartylis glomerata. Fine imported seed. A deep rooted perennial, growing in tufts. A strong, vigorous grower, which succeeds best on rich lauds or clay soils. Should be cut for hay at the time of first flowering. Sow three bushels per acre if alone.

PERENNIAL RYE GRASS. Lolium perenne. A perennial forming large and broad tufts. Grows best on stiff, wet soils, and on heavy clay or marshy lands where the soil is good it is one of the best pasture Grasses.

RED OR CREEPING FESCUE. Festuca Rubra. A splendid Grass for light sandy soils. Extreme drought resister. Valuable in seeding banks and exposed locations, binding drifting sands, and as lawn grass for shady spots. Forms a very close, durable turf, suitable for putting greens.

RED TOP. Agrostis vulgaris. A good permanent Grass, which grows naturally in cold wet soils. It should be grown in cultivation in similar situations. A perennial with long creeping stems and underground runners; one of the best bottom grasses bearing large numbers of fine root leaves, making it invaluable for sowing with erect tufted Grasses, such as Orchard and Timothy, filling in between the clumps and producing a continuous turf. Sow four bushels per acre if alone.

RED TOP. CLEAN SEED. Chaff and weeds sifted out; pure fancy seed. We recommend this to all who desire the best results, as its purity and excellence insure satisfaction for farm, park, or lawn. Excellent for restoring worn-out swards. Sow thirty pounds per acre if alone.

REED CANARY GRASS. Phalaris Arundinacea. A creeping perennial. Grows in alluvial marshy lands, sides of rivers, lakes, ditches, and rivulets. Its seed affords food for trout and wild fowl. A strong growing grass, but eaten with apparent relish by cattle and horses when cut prior to flowering.

\begin{tabular}{|c|c|c|c|}
\hline $\begin{array}{l}\text { Weight } \\
\text { Per } \\
\text { Bush. }\end{array}$ & $\begin{array}{c}\text { Per } \\
\text { Bush. }\end{array}$ & Per lb. & $\mid \begin{array}{c}\text { Per } \\
100 \mathrm{lbs} .\end{array}$ \\
\hline 12 & 2.50 & .25 & 18.00 \\
\hline 30 & 13.50 & .50 & $4 \overline{1} .00$ \\
\hline 14 & 3.00 & .25 & 20.00 \\
\hline 22 & 2.50 & .15 & 10.00 \\
\hline 14 & 2.75 & .20 & 18.00 \\
\hline 15 & 4.75 & .35 & 30.00 \\
\hline 8 & 3.50 & .45 & 40.00 \\
\hline 14 & 4.00 & .30 & 28.00 \\
\hline 24 & 3.00 & .15 & 12.00 \\
\hline 24 & 8.50 & .40 & 35.00 \\
\hline 10 & 1.60 & .18 & 15.00 \\
\hline 36 & 7.25 & .25 & 20.00 \\
\hline 30 & טo & f0 & 35.00 \\
\hline
\end{tabular}


RHODE ISLAND BENT. Agrostis canina. A bottom Grass, suitable for sowing with tufted varieties. Hardy and early and a grass that will withstand heat and dry weather. Sweet and nutritious and relished by all kinds of stock. Sow four bushels per acre if alone.

ROUGH-STALKED MEADOW. Poa trivialis. An excellent permanent firass to mix with other varietie: for moist pastures. Produces a constant supply of nutritious herbage. Suitable for growing in shade.

SHEEP'S FESCUE. Festuca ovina. Of dense growth, ezcellent for dry situations and sheep pastures. Sow two and one-half bushels per acre.

FINE LEAVED SHEEP'S FESCUE. Festuca ovina tenuifolia. A very fine leaved Grass; dwarf in habit. Will succeed in dry, high locations and inferior soils. Hardy and durable.

SWEET VERNAL, TRUE PERENNIAL. Invaluable in lawns on account of its very early growth anri fragrant odor which it imparts to the other grasses in drying. Remains green very late. Hardy and permanent.

TALL FESCUE. Festuca elatior. Excellent for permanent pastures on moist soils on which it yields immensely. Cattle and stock eat it greedily.

TALL OAT GRASS. Avena elatior. A perennial which grows in loose tufts and throws up an abundance of leaves, and tall stalks. Succeeds best on rich upland soils, and when once established is a great drought resister. Early. Makes its heaviest growth the second year.

TIMOTHY or HERDS GRASS. Phleum pratense. This Grass is usually considered and treated as a short-lived perennial, and hence is the best grass to grow in a short rotation. It succeeds best on moist loams and clays naturally rich in humus or on those which have been heavily manured. It grows in loose tufts, with few short leaves, so that Red Top or Red Clover should be sown with it to furnish heavy bottom growth of leaves. Sow one bushel per acre if alone.

VARIOUS LEAVED FESCUE. Festuca heterophylla. Early, hardy perennial two or three feet high. Valuable for permanent pasture. Thriving in high altitudes and in shady locations.

WATER MEADOW GRASS. Poa aquatica. A creeping rooted perennial; grows in alluvial marshy soils. slow running streams, margins of fresh water, lakes, etc. An excellent pasture Grass, for wet situations. Trout and wild ducks relish the seeds and young shoots as food.

WOOD MEADOW. Poa nemoralis. Well adapted for growing under trees and in shaded situations. Dwarf and fine growing. Sow two and one-half bushels to an acre.

\section{GRASSES SUITABLE FOR BEACH USE AND FOR MAKING EMBANKMENTS.}

SAND or MAT GRASS. Ammophila Arundinacea. A creeping rooted perennial which grows naturally among shifting sea sands. Adapted for consolidating Sand, Embankments, or Terraces.

SEA LAND LYME GRASS. Elymus Arenarius. A creeping rooted perennial; grows among shifting or blowing sea sands, for binding which, along with Ammophila Arundinacea, thereby preventing the encroachments of the sea, its numerous strong spreading roots render it most suitable.

\section{CLOVERS.}

ALFALFA. TURKESTAN. Medicago sativa. The chief merit of Alfalfa is the fact that it can be cut three or four times in a season. The soil should be deep, rich, and well prepared. It does not succeed on compact clay, nor on land with impervious subsoil. The roots shoot downwards, reaching ten to fifteen feet below the surface, and will therefore resist the driest weather.

ALSIKE OP SWEDISH. Trifolium hybridum. This Clover will thrive where the soil is quite wet, and will even stand flooding without being killed. Productive and sweet and extremely valuable for both pasturage or soiling.

MAMMOTH or LARGE RED NORTHERN. Trifolium protense. On rich loamy soils this variety grow. nearly twice as large as the Medium Red Clover; and is earlier in starting growth.

RED MEDIUM. Trifolium pratense. The best clover for all practical purposes. Succeds best on rich, warm loams, containing humus. Lime and potash are essential for its best development. A biennial. but by close pasturage may be made to last several years.

SCARLET oP CRIMSON CLOVER. Trifolium incarnatum. This annual Clover thrives best on warm, loose, sandy soil. Its chief value is as a winter or early spring pasture crop and as a green manure. A rapid growing, nitrogen-storing plant, and as such is invaluable for growth in orchards and wherever it can occupy the land from July to December. Sow twenty pounds per acre. May be sown at any time from May to October.

WHITE CLOVER. Trifolium repens. This Clover should always be sown on permanent or temporary pastures. Will grow on any soil, but especially adapted to low meadows, where the surface soil is mellow and rich. Sweet and nutritious.

YELLOW TREFOIL. Iedicago lupulina. On very light, dry, or poor ground this variety is valuable for a sheep pasture.

\section{FARQUHAR'S FARM AND FIELD SEEDS.}

PRICES SUBJECT TO MARKET FLUCTUATION.

\begin{tabular}{|c|c|c|c|}
\hline 60 & 13.301 & .25 & 22.50 \\
\hline 60 & 15.00 & .311 & 25.00 \\
\hline 60 & 12.00 & 2.7 & 20.00 \\
\hline 60 & 12.00 & i. & 20.00 \\
\hline 60 & 7.20 & .15 & $1.9(H)$ \\
\hline & 13.50 & is & 20.211 \\
\hline & 7.20 & ז. & $1 \geq .(K)$ \\
\hline
\end{tabular}

\begin{tabular}{l|lll}
14 & 6.00 & .45 & 40.00 \\
12 & 2.25 & .20 & 18.00
\end{tabular}

\begin{tabular}{l|lll}
20 & $9.50 \quad$. 11 & 45.00
\end{tabular}

$7 \quad 5.00 \quad-7$

60.00

20

7.25

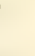




\section{FARQUHAR'S FARM AND FIELD SEEDS.-Continued.}

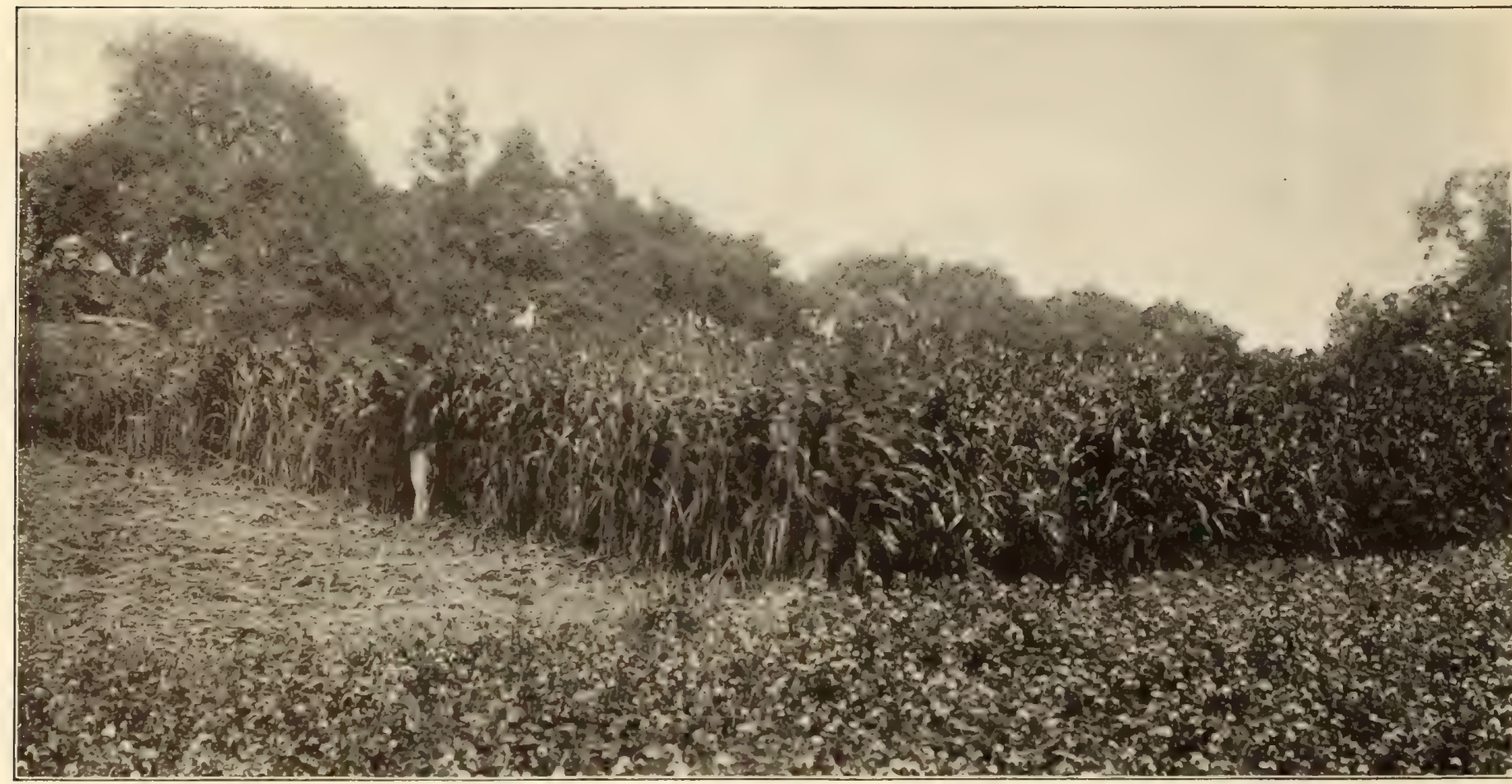

Japanese Millet.

Cow Peas. For fodder or soiling. A valuable and nutritlous green forage or hay crop. Enriches poor land; improves good land. One of the best and cheapest ways of improving soil is the plowing under of luguminous crops. Cow Peas have been found superior for this purpose, especially on medium or light soils. Like Clover they absorb nitrogen from the atmosphere, the roots reach deep into the soil and bring up the necessary potash, thus making a complete and natural festilizer. For fertilizing purposes, Cow Peas are superior to Clover from the fact that the foliage is greater, besides making full growth in from 3 to 4 months. Sow as early as May 10 or as late as July, one (1) bushel to the acre in drills, $2 \frac{1}{2}$ bushels to the acre broadcast.

oats, Welcome. This is now a well-known and extensivcly grown variety, and is one of the heaviest. handsomest, and most productive white varieties grown. They stool heavily with extra strong, straight straw, standing well. Succeds well in a wide range of climate, and under a great variety of soils and methods of culture. 10 bushels, 12.50 .

Oats, Hamilton. Imported. A handsome English white Oat. Very early, ext ra heavy and an enormous cropper

Peas for Field Culture Only. White Canada. This variety and the Green Field are the best two Peas for general cultivation, and they afford most profitable crops for fattening stock. They have been grown by dairymen with very satisfactory results, following winter Rye, which was cut green in June for dairy cows, then stubble turned under and sown to mixed Peas and Oats, furnishing a large amount of forage in August, when Grass pastures usually short, and producing a supply of milk as abundant as in early summer months. Sow 2 bushels to the acre; if with Oats, one bushel of each. Per peck, .75. Green Field. Per peck, .75. Each.

Rape, Dwapf Essex. A forage plant of great merit, easily grown in any part of the United States, and of great value for sheep and lambs. One acre of Rape is sufficient to pasture 10 to 15 lambs for two to two and one-half months. It is often sown broadcast, about $5 \mathrm{lbs}$. to the acre, but will yield much better if drilled about $2 \mathrm{lbs}$. to the acre, in rows 22 inches apart, and cultivated until the plants are too large. Seed may be sown in May, but preferably in June or July.

Rye, Spring. Sow as a "catch" crop, where winter grain has failed. The straw is shorter and stiffer than the winter variety, and is always easily secured, while the grain is of equal value.

Rye, Fall or Winter. Sow in August and September. Prepare the ground as for Wheat and sow at the rate of $1 \frac{1}{2}$ bushels per acre. This has no equal as a crop to be used for late fall and early spring pasture, and is one of the best to turn under for green manure.

Sand Vetch, or Hairy Veteh. Iria villosa. An annual, a native of western Asia, has been cultivated in this country and Europe for about 50 years. It should be sown at the rate of from 4 to 6 pecks per acre, broadcast or in drills, from August 15 to October 1, and with it as a supporting crop to raise the vines up off the ground there should be planted from 2 to 4 pecks of winter Wheat, Oats, or Rye. It should be cut while the Vetch is in full bloom. It may be planted in spring in order to supply an early green cгор for soiling purposes, or in midsummer for late autumn forage

Spring Vetehes or Tares. Vicia sativa. A valuable plant grown extensively for stock and sometimes mixed with Oats for soiling. Culture the same as field Peas.

Sunflower, Mammoth Russian. This is highly prized by poultry raisers and farmers as a cheap food for fowls, stock, and also for fuel. It is immensely productive, and can be raised cheaper than corn, as any waste piece of ground will suffice. It is the best egg-producing food known.

Wild Rice. Zizania aquatica. The only one of our native plants furnishing food for wild fowl, ducks geese, etc.. which has been made an article of commerce. This seed can be sown on the borders of lakes, ponds, and along small streams to great advantage, attracting all of these wild birds from September on. It purifies the water and affords refuge to the small fry from the large fish. It makes good hay, and in the South two crops can be cut. Sow in water having a mud bottom.

Wheat. Spring Saskatehewan. Winter, White Clawson. Each,

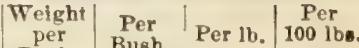

\begin{tabular}{c|c|c|c|} 
Weight & Per & Per \\
per & Bush. & Per lb. & 100 lbe
\end{tabular} 
R. \& J. FARZUHAR \& CO., BOSTON. AGRICULTURAL SEEDS.

FARQUHAR'S FARM AND FIELD SEEDS.-c'ontinued.

\section{MILLETS.}

Nothing on the market is as well adapted to cover up shortages in hay crops as are the Millets. They can be sown up to the end of July, and will make a valuable catch crop.

Yillets will yield quick pasturage on almost any soil. They are rank feeders, however, and do best on a fertile, mellow soil, which has had a liberal application of baruyard manure. Sow in June or July, broadcast, one to one and one-half bushels of seed per acre, or drill one-half bushel. Cut (if for hay) as soon as the heads are formed.

MILLET, HUNGARIAN. Panicum Hungariensis. An annual forage plant, which germinates readily and withstands drought. If cut early, makes an excellent hay, often yielding two or three tons per acre.

- Sow from June to August, using about one and one-half bushels to the acre.

MILLET, COMMON. Panicum . Hiliaceum. Excellent for forage. Requires a dry light, rich soil. Height, $2 \frac{1}{2}$ to $4 \mathrm{ft}$.

MILLET, GERMAN or GOLDEN. Panicum Germanicum. An improved variety, growing from three to five feet high. Under some circumstances it will yield more per acre than the preceding.

MILLET, JAPANESE. Panicum Crus Gali. Imported from Japan by Professor Brooks, of the Massachusetts Agricultural College. Has yielded in America about 7 tons dry straw and 90 bushels of seed per aere. Height, $6 \mathrm{ft}$. Has numerous side leaves and heads a foot in length. The fodder is relished by cattle and horses, and the ground seed makes an excellent feed for poultry and cattle. Sow one to two pecks per acre.

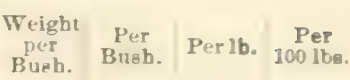

48

$50 \quad 1.50$

$.50 \quad 1.7 .5$

32

$2 .+40$

10

8.00

\section{MANGEL WURZEL.}

An invaluable crop for stock feeding. Highly relished by cattle, resulting in improved health and condition, increasing the yield of milch cows. Sow from April to June on well cultivated, deep, rich soil, in drills 24 to 30 inches apart. Six to $8 \mathrm{lbs}$. of seed are required per acre. Price of all varieties, .10 per oz.; .15 per $\frac{1}{4} \mathrm{lb}$; .35 per $1 \mathrm{~b}$. ; $10 \mathrm{lbs}$. and upwards at .25 per lb. If by mail, add .08 per lb. extra for postage.

MAMMOTH LONG RED. The largest and heaviest cropper of all the long red sorts. It grows well out of the ground, and is easily harvested. Color blood red; a most valuable and distinct variety, and very popular on account of its nutritious and milk-producing qualities. Our seed is produced from the largest selected roots and is a most superior strain.

GOLDEN TANKARD. A greater weight per acre may be obtained from this variety than from any other large growing sort. It is of excellent shape and of very neat habit. Flesh bright golden yellow, differing in this respect from all other varieties which cut white. Rich in saccharine matter and feeding properties.

YELLOW GLOBE. This variety has a very fine top and single tap root, adapted for growing in shallow soils. Skin smooth, good size, and of excellent quality.

RED GLOBE. Very similar to Yellow Globe, but differing in color.

\section{SUGAR BEET.}

One of the best paying crops for stock feeding. When fed to milch cows will increase the flow and quality of the milk. They keep well throughout the winter. They are not such heavy yielders as Mangel Wurzel, but are of superior quality and rich in saccharine matter. Oz., .10 ; ll lb., .15; lb., .35. If by mail, add .08 per $\mathrm{lb}$. extra for postage. 10 lbs. and upwards, .30 per ltb.

KLEIN WANZELEBEN. The most popular variety; root conical, straight, and even; large shoulder, rapidly tapering to a point. Heavy yielder, remarkably rich in sugar.

LANE'S IMPROVED. An old standard sort, one of the most valuable for stock feeding Hardy and productive.

\section{CARROT.}

IMPROVED LONG ORANGE. Roots large and long; enormous yielder. Splendid for stock.

Pkt., .05; 0z., .10; + lb., . 30 ; lb., 1.00

WHITE BELGIAN. Large, long-rooted variety; valuable for stock,

$$
\begin{aligned}
& \text { Pkt., } .05 ; \text { oz., } .10 ; \frac{1}{4} \mathrm{lb} ., 25 ; 1 \mathrm{~b} ., .60 \\
& \text { For table carrots see page } 8 \text {. }
\end{aligned}
$$

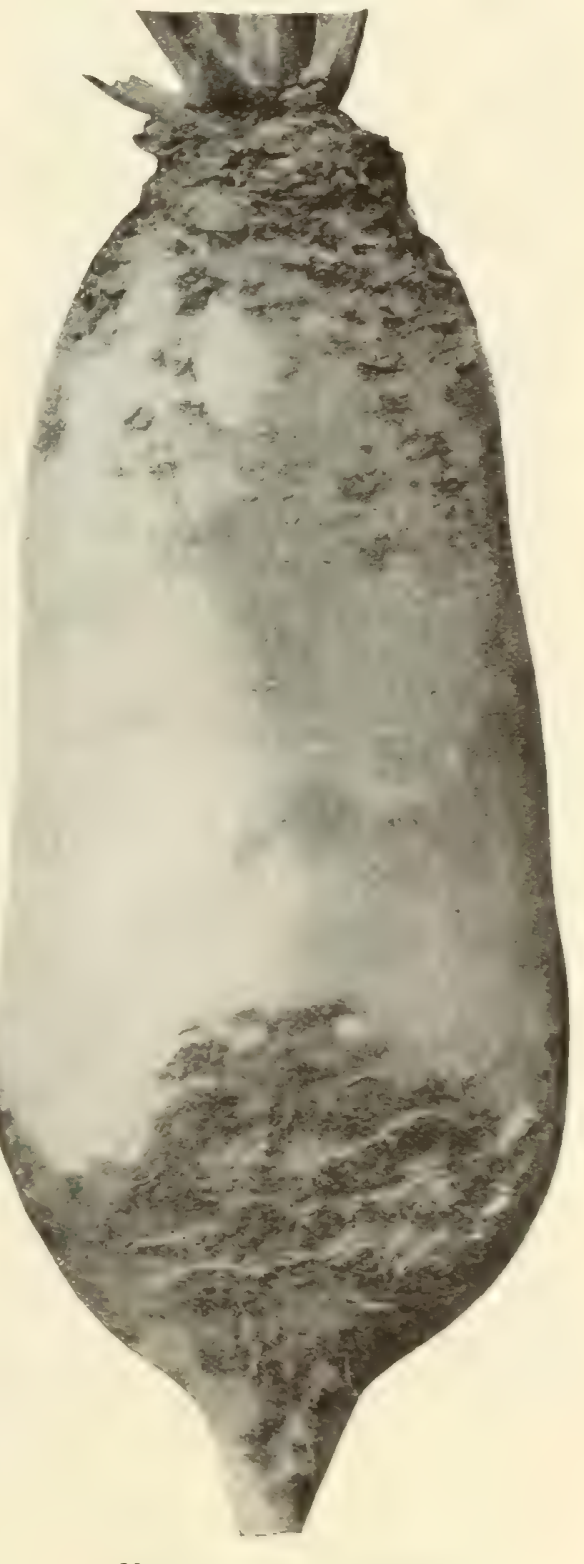

Mammoth Long Red Mangel. 


\section{FARQUHAR'S FARM AND FIELD SEEDS.-Continued. \\ CHOICE SEED CORN. \\ FOR FODDER AND ENSILAGE.}

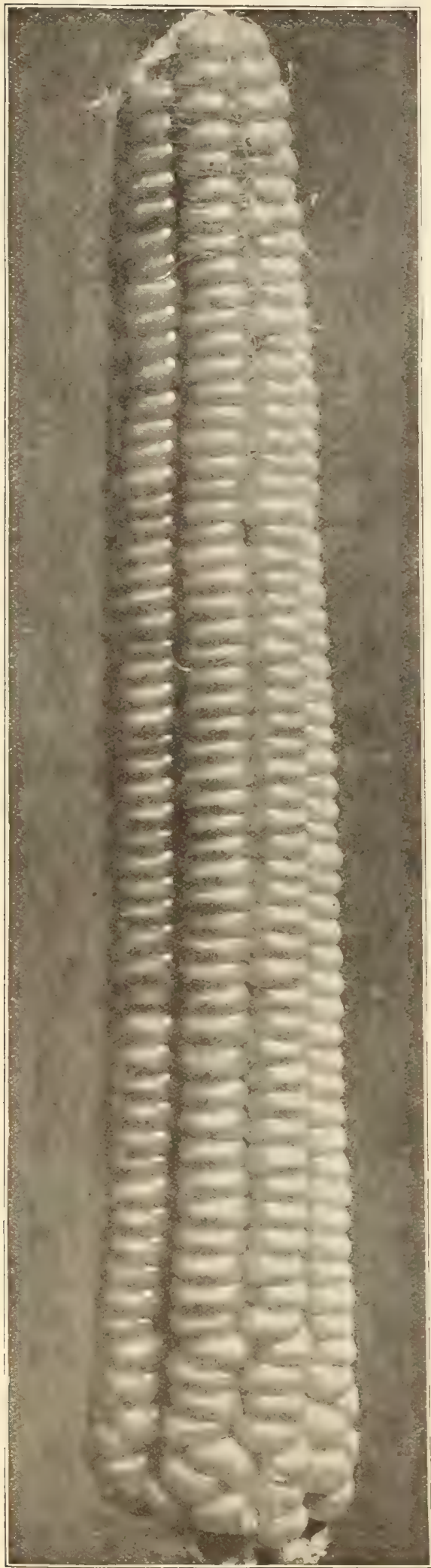

\section{EXTRA SELECTED HAND PICKED GRADE.}

For farmers who may desire to change, add to, or renew their planting seed stock, we recommend our "Extra Selected Hand Picked" quality, selected on the ear from crib prior to being shelled-thoroughly Rescreened, "Tipped" and "Butted" and thoroughly hand picked.

Plant in hills, 8 to 12 qts. per acre, and for soiling 3 to 4 bushels per acre.

Quart of any variety, .15; by mail, .30. When ordering to go by express or freight please add for 2 bus. cotton bags, 20 each; no charge for smaller bags.

Early Mastodon. The earliest large eared dent corn, has been known to ripen in 96 to 100 days. Heavy yielder, large grained and of extra early quality. Hardy, height medium, but a strong rapid rank grower, Peck, .75; bushel. $2.00 ; 10$ bushels, 17.50

Early Yellow Dent, or Pride of the North. Remarkably early, maturing in 90 to 100 days, ripening where nearly every other variety failed on account of bad season. Can be successfully grown further north than any other dent sort. Ears are of good size, with 12 to 16 rows of long kernels of a deep yellow color,

Peck, .75; bushel, $2.00 ; 10$ bushels, 17.50

Improved Leaming. An early, very heavy, long-eared corn, maturing in 100 to 120 days. Stock grows medium tall, with large amount of foliage. A good ensilage corn, very much relished by stock. Cob small and red, with a deep, large grain of bright yellow,

Peck, .75; bushel, $2.00 ; 10$ bushels, 17.50

Early Sanford. A well established variety, and uniformly adapted to New England. Medium size ear, averaging about 10 inches long; 8-rowed; kernels large and broad, and of a silvery white flint color. An excellent fodder and ensilage sort,

Peck, .75; bushel $2.00 ; 10$ bushels, 17.50

Longfellow. An 8-rowed yellow flint sort; ears average 10 to 15 inches long; cob small, kernels large and broad. Heavy yielder, and particularly adapted to New England. An extraordinary heavy yielder in Massachusetts, Peck, .75; bushel, 2.50; 10 bushels, 22.50

Improved Early Yellow Canada. An early, 8-rowed flint variety, with a deep grain and very small cob. Where a flint corn is desirable for earliness or other reasons, this is one of the best sorts to plant, seldom failing to produce a crop,

Peck, .75; bushel, $2.50 ; 10$ bushels, 22.50

Angel of Midnight. An early, 8-rowed, flint corn of the Canada type. Ears long, kernels long and deep, color a rich, glossy yellow, Peck, .75; bushel, 2.00; 10 bushels, 17.50 Blount's White Prolifle, or Mammoth Ensilage. A well-known popular variety of half dent ensilage corn, producing a very large amount of foliage and a good yield of grain. One of the best ensilage varieties for our cold northeast climate,

Peck, .50; bushel, $1.50 ; 10$ bushels, 13.50

Red Cob Ensilage. A red-cobbed white dent corn, large growing, very popular in northern dairy districts. Fodder sweet, tender and juicy. Heavy yielder,

Peck, .50; bushel, $1.75 ; 10$ bushels, 15.00

Stowell's Evergreen Sweet. The standard main crop variety, excelling all other late sorts in sweetness and productiveness. Our seed is of strictly first quality,

Peck, .75; measured bushel, 2.75; 10 bushels, 25.00

Sweet Fodder. Succulent and nutritious as a green fodder. Useful for soiling or ensilage. Peck, .60; bushel, $2.00 ; 10$ bushels, 17.50

\section{BIRD SEEDS. prices varable.}

Early Sanford.

$\begin{array}{llllll}\text { SICILY CANARY } & \ldots & \ldots & .10 & 6.00 \\ \text { GERMAN RAPE } & \ldots & \ldots & .10 & 5.00 \\ \text { HEMP } \ldots & \ldots & \ldots & \ldots & .10 & 5.00 \\ \text { FLAX } \ldots & \ldots & \ldots & \ldots & .10 & 4.00 \\ \text { LETTUCE } & \ldots & \ldots & \ldots & .30 & \\ \text { MAW OP POPPY } & \ldots & \ldots & .20 & 15.00 \\ \text { MILLET, GOLDEN } & \ldots & \ldots & .10 & 3.50\end{array}$

MOCKING BIRD FOOD. A food for all soft-bill birds PEAS FOR PIGEONS
25 pounds and upwards at 100 -pound rates.

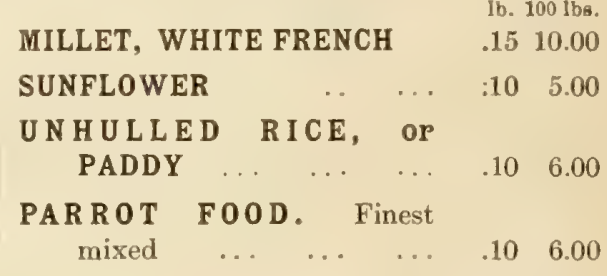

.35 per bottle. Not mailable. 


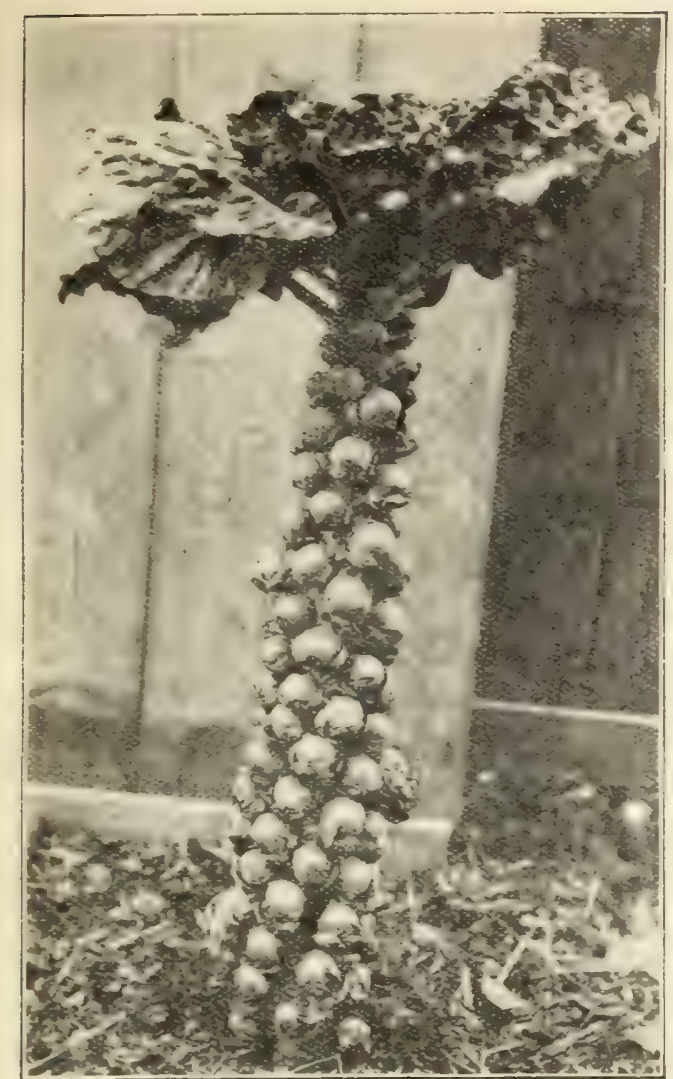

Brussels Sprouts. Farquhar's Ideal.

\section{NOVELTIES AND SPECIALTIES IN VEG- ETABLE SEEDS, 1909.}

CHICORY, FARQUHAR'S RUBY LEAF. Not only is this one of the most delicious and delicate salads, but the bright ruby-red, translucent leaves give to the salad when prepared a novel and fascinating appearance. Pkt., .25; oz., .75.

CHICORY, FARQUHAR'S CARMINE STRIPED. 'This new Chicory, like the preceding, is of delicious quality. The leaves when blanched are creamy white striped with bright carmine, and in effect are charming, whether served alone or in combination with other salads. Pkt., .25; oz., .75.

LETTUCE, EXPRESS COS. Early-heading Romaine. A crisp and tender tallgrowing Lettuce. It is very compact, entirely self-folding, and withstands heat and drought admirably. It is also valuable for forcing. Pkt., .10; oz., .50.

MUSK MELON, Farquhar's Honey Drop. Extra Seleeted. This is a reselected strain of our famous melon. The vines are exceedingly strong, bearing an abundance of fruit during the entire season. The flesh is very thick, of a rich orange color, ripening clear to the rind. It is of large size, and of very sweet, delicious flavor. Pkt., .25; oz., \$1.00.

TOMATO. FARQUHAR'S BOUNTIFUL. A new forcing Tomato of superior flavor, perfect in shape, of good size, and setting freely. The fruits are bright red in color, very solid, and grow in clusters of 10 to 12 . This variety was awarded a First Class Certificate by the Mass. Hort. Society, when exhibited last spring as "Farquhar"s New Tomato," and was pronounced by the judges to be the finest dish of indoor Tomatoes they had seen. Pkt., .50.

KAN UDO SALAD. (Aratia cordata.) The tender young shoots of this ornamental plant are used extensively in Japan, both as a salad and as a boiled regetable. The roots require the same treatment as Asparagus and as Sea Kale in the forcing hed. 'The tender growth is the part used for the salad. Strong forcing roots. Doz., \$2.00; per 100, \$15.00. Delivery Jamuary to March only.

BRUSSELS SPROUTS. FARQUHAR'S IDEAL. A very hardy variety, producing an abundant crop of large solid sprouts, which remain firm for a long time. It is of robust constitution and grows to a height of about 3 feet. For flavor it is unsurpassed. Pkt., .25; 5 jkts., \$1.00.
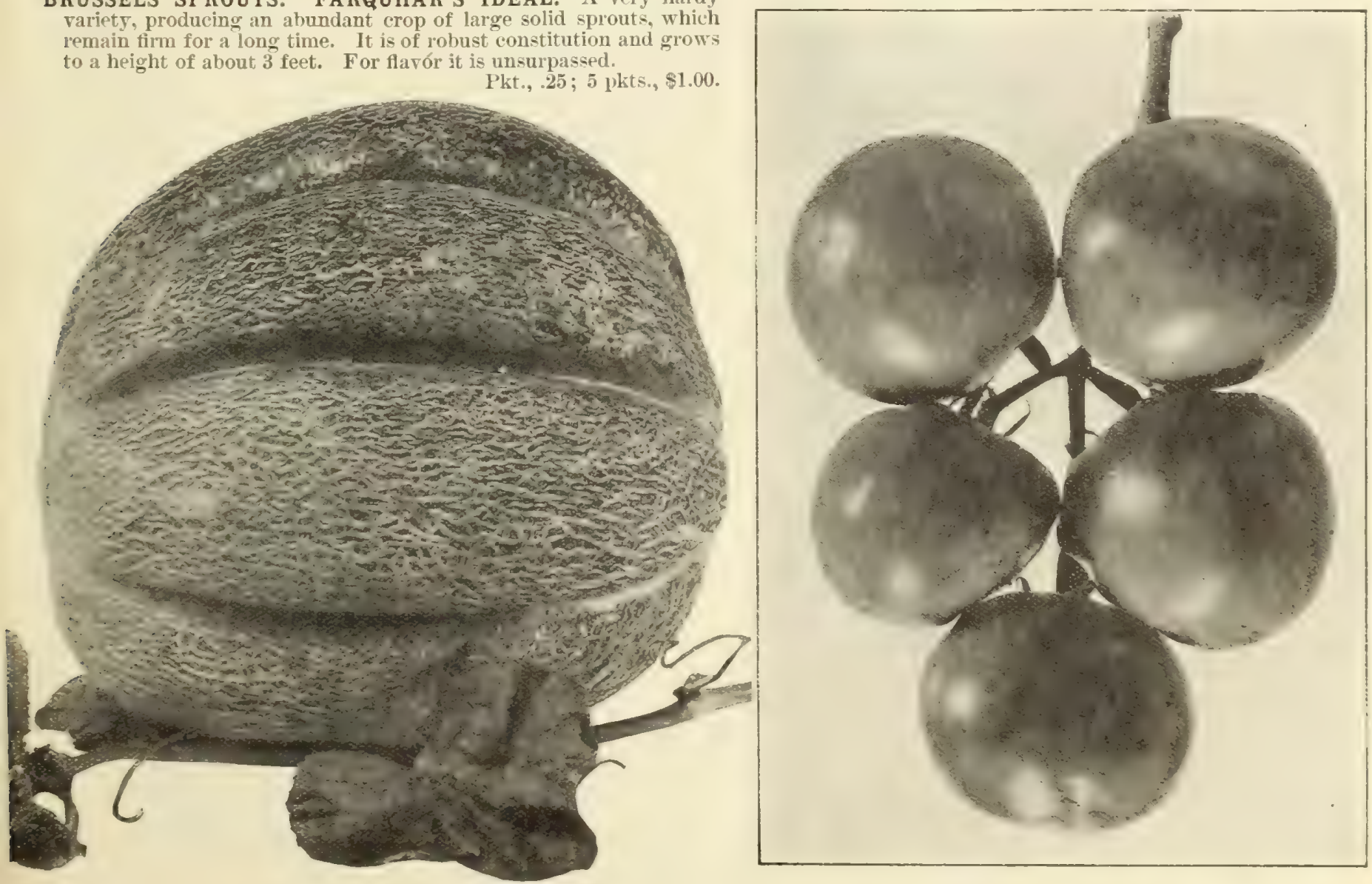

Melon. Farquhat's Honeydrop. 


\section{FARQUHAR'S FLOWER SEEDS.}

Mailed free at catalogue prices to any address in the United States. In ordering it is unnecessary to write the names-the numbers are sufficient. The minimum charge for seeds by weight is ten cents. Fractions of an ounce and quarter pounds, where not quoted, will be charged at a slight advance over the ounce and pound rates.

\section{NOVELTIES AND SPECIALTIES, 1909.}

5 ACONITUM Wilsoni. This recent introduction from China, with large pale-blue trusses, is the latest-flowering of all the Monk"s-IIoods. It attains a height of about 4 feet. After the terminal flower truss is over lateral shoots are pro- Pkt. duced which continue flowering until late in the season

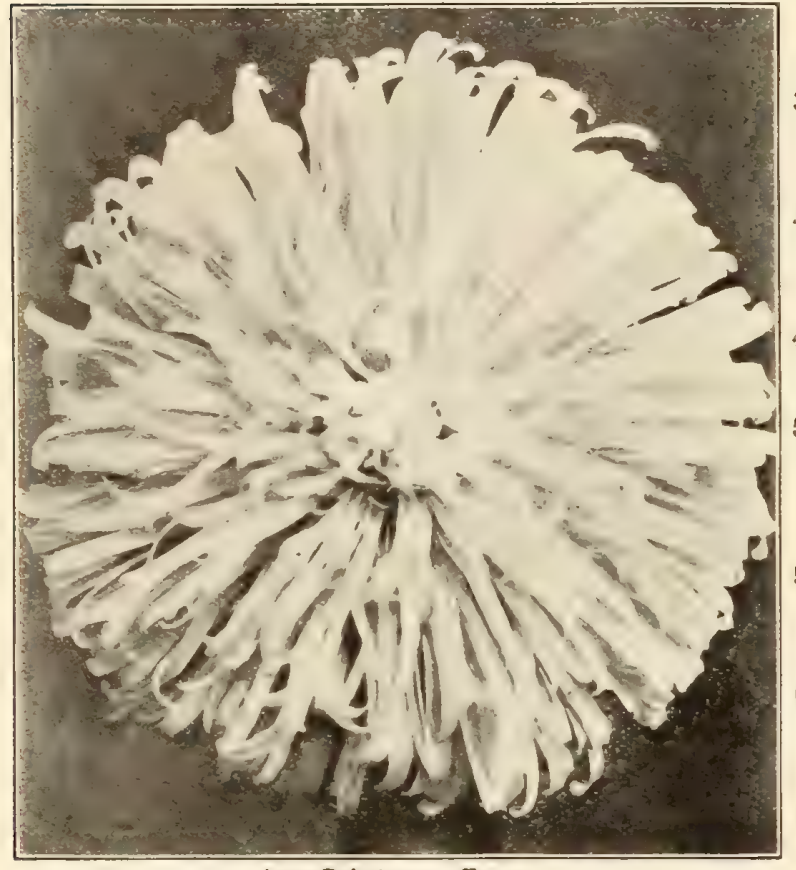

Aster Debutante. No. 25 .

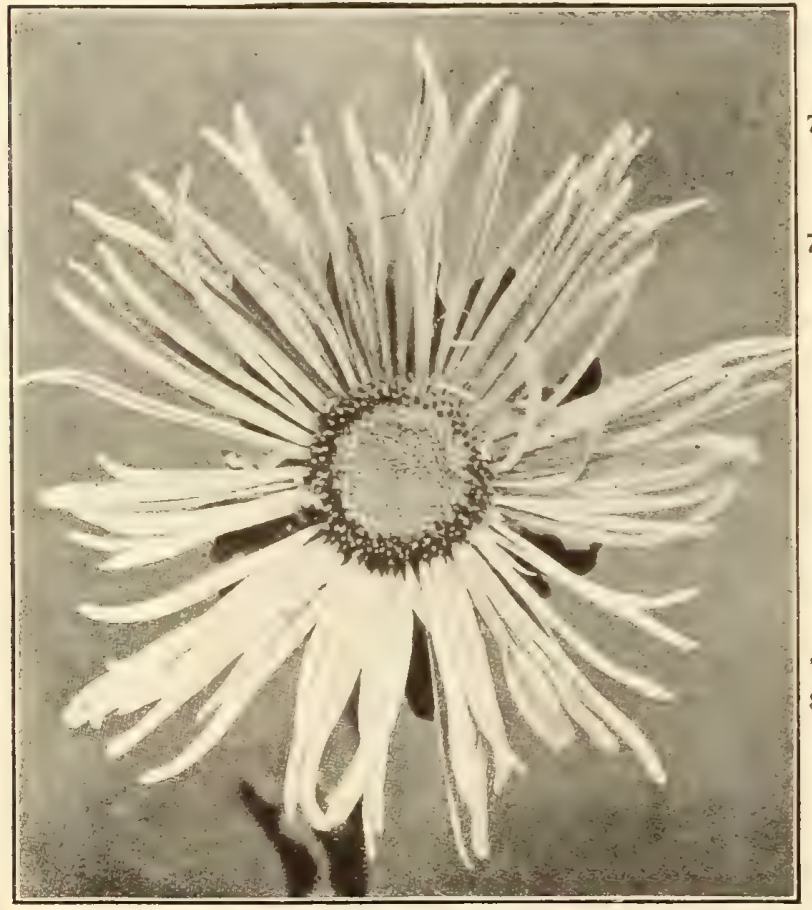

Aster Elegance. No. 50 .

\section{ASTERS.}

25 Debutante. A beautiful pure white delicately feathered Aster, coming into bloom three to four weeks earlier than the popular Pkt. Comet Asters, and rivaling them in size and elegance, $\mathrm{Oz} ., 3.00 ; \mathrm{oz}, 1.00 ; .20$

30 Enchantress. This Aster has become popular for early cutting. It blooms in July, producing large double flowers of a lovely flesh pink color and having stems a foot in length,

$\mathrm{Oz}, .3 .00 ; \frac{1}{4} \mathrm{oz} ., 1.00 ; .20$

35 General Jacqueminot. One of the most beautiful sorts, with large, full and perfectly formed double flowers. The color is rich crimson, almost identical with that of the General Jacqueminot Rose. Height 2 feet ... ... Oz., 3.50; $\frac{1}{4}$ oz., 1.00;

40 Lady Washington. 'This superb, tall Aster produces large perfectly double flowers, white shaded with pale rose, a delicate and popular color. It is one of the best sorts for August and September cutting ... … ‥ ... Oz.,4.00; $10 \mathrm{oz}, 1.25$;

Royal Purple. A grand and stately Aster growing to a height of about two feet, with flower's about four inches across, of a rich shade of dark blue

Oz., 3.50; $10 z ., 100$;

Aster Elegance. A very graceful form of the single Aster, especially useful for cut flower's. The blooms are borne on long stems and resemble Marguerites of various colors. The petals are beautifully twisted and fluted.

Collection of 5 colors, separate

.. .50

55 ASTER Amellus Roseus. A very pretty new perennial Aster. The plants are of dwarf bushy growth, covered in fall with large trusses of flowers of delicate pink color, a shade very unusual in hardy asters. $1 \frac{1}{2}$ feet ... ... ... ... 3 pkts., .50;

60 BEGONIA, gracilis multiflora Rosea. A new form of this exquisite bedding plant producing flowers of a soft pink, in the greatest profusion throughout the summer. V'ery effective when massed in large beds or borders

65 CHRYSANTHEMUM Inodorum Bridal Robe. This new introduction received an award of Merit from the Royal Horticultural Society of London. The plant is compact with double flowers of the purest white carried well above the dark green, finely cut foliage. 'The cut flowers are admirably adapted for all kinds of floral work. This plant is also worthy of attention as a bedding plant. Hardy annual; 1 foot ... ... ... 4 pkts., .50;

COSMOS Lady Lenox. A handsome new variety of strong and vigorous growth with flowers of extraordinary size and beauty. The color is a light pink, a shade much in demand for table decoration. 6 feet,

i5 CINERARIA hybrida grandiflora "Matador" 'The brilliant scarlet flowers of this novelty add an entirely new shade of color to this valuable greenhouse plant. The plant is of compact growth and the dark green foliage forms a striking contrast to the bright color of the flowers. 'This is considered in Europe the best novelty of the season.

First Size, pkt., $\$ 1.00:$ No. 76 Second size ... $\quad$ Pkt., .50

85̃ DIASCIA Barberæ. A freeflowering half-hardy annual with beautiful rosy pink flower's bolne in great profusion during the summer months, splendid for dwarf borders also useful as a pot plant for greenhouse decoration. 1 foot. Pkt.,

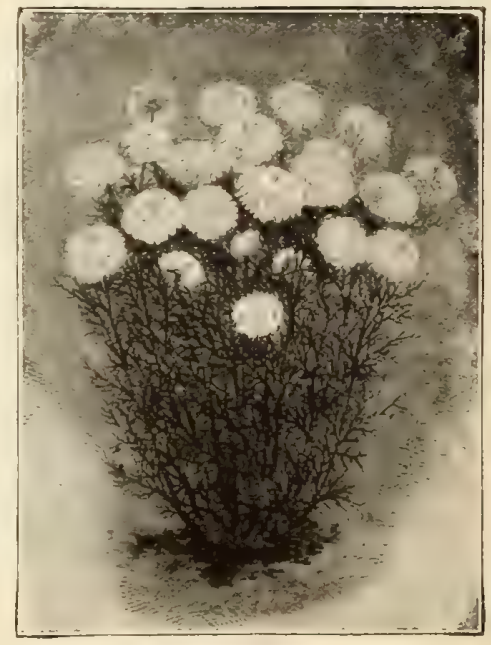

25 Chrysantbemum Bridal Robe. No. 65 
R. \& J. FARQUHAR \& CO., BOSTON. FLOWER SEED NOVELTIES.

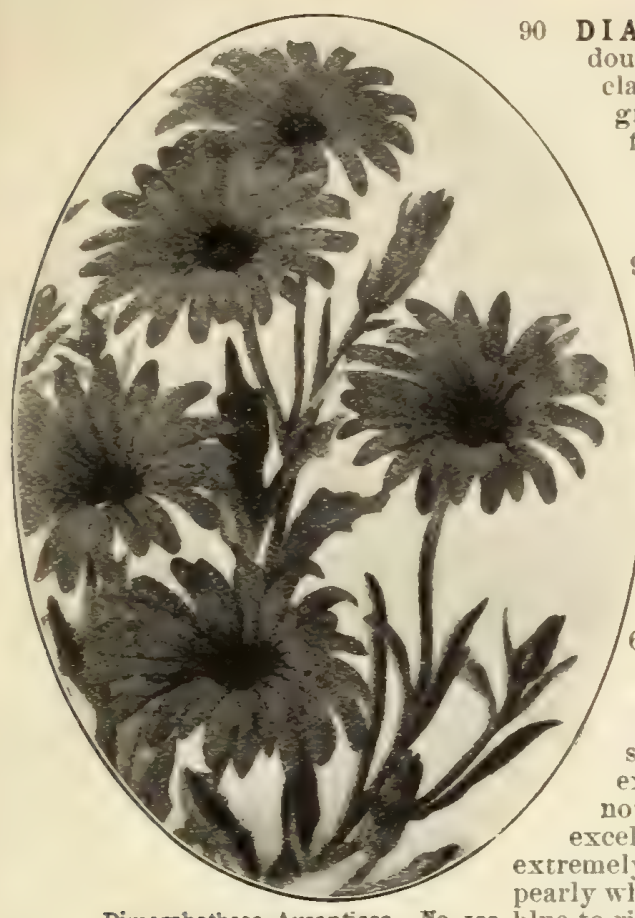

Dimorphotheca Aurantiac

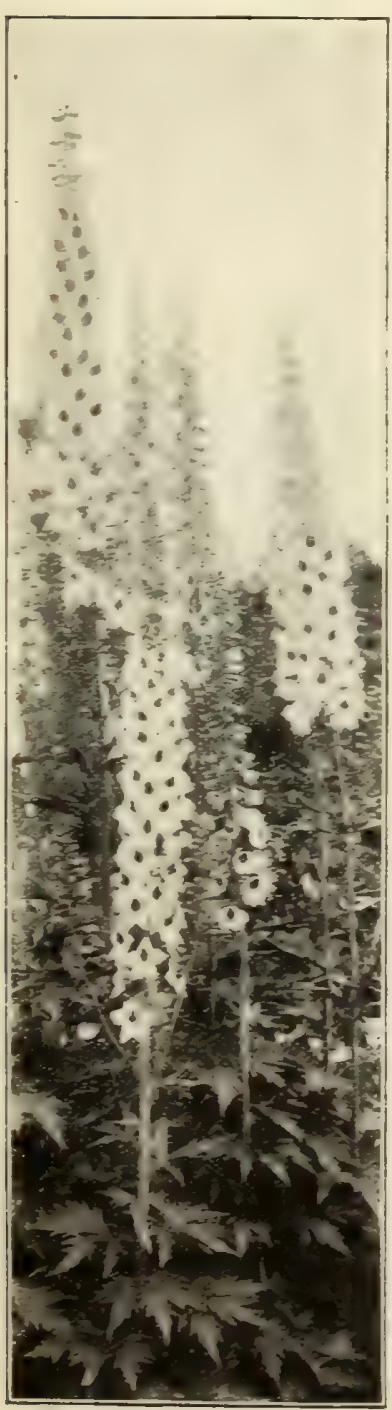

Delphinium, Farquhar's Hybrids, No. 6565 . summer
D T T US Snowdrift. This ouble white Dianthus may be classed among the very best. It grows about a foot high, is very floriferous, the blooms frequently measuring 3 to 4 pkt. inches across and very double

2 pkts., .25;

95 DAHLIA Pæony - flowered mixed. 'I'his new class has flowers resembling semi-double Pronies, borne on tall erect stems. The brilliaut flowers make a handsome display in the garden and last well when cut. To obtain the best results, seeds should be sown in doors during Mareh or April ... 3 pkts., .40; 6565 DELPHINIUM. Farquhar's Selected Hybrids Mixed. It is our aim to procure for this mixture seeds saved from the finest plants in existence and we feel that those now offered are of unsurpassed xcellence. The flower spikes are perce large and vary in color from No. roo. blue to rich indigo ... t $0 z_{.}, 75$;

100 Dimorphotheca aurantiaca. A rare and extremely showy annual from Namaqualand, South Africa. The plants, of very neat branchy habit, grow about 12 to 15 inches high and are exceedingly profuse in flowering. Its Marguerite-like blossoms, $2 \frac{1}{2}$ in. in diameter, show a unique glossy rich orange-gold, which brilliant coloring is rendered the more conspicuous by the dark colored dise surrounded by a black zone ... ... 5 pkts., $\$ 1.00$;

105 DOLICHOS Lablab Searlet Hyacinth Bean. An entirely new color of this splendid annual Japanese climber with clusters of bright scarlet bean-like flowers followed by red seed pods. Oz., .75; .1

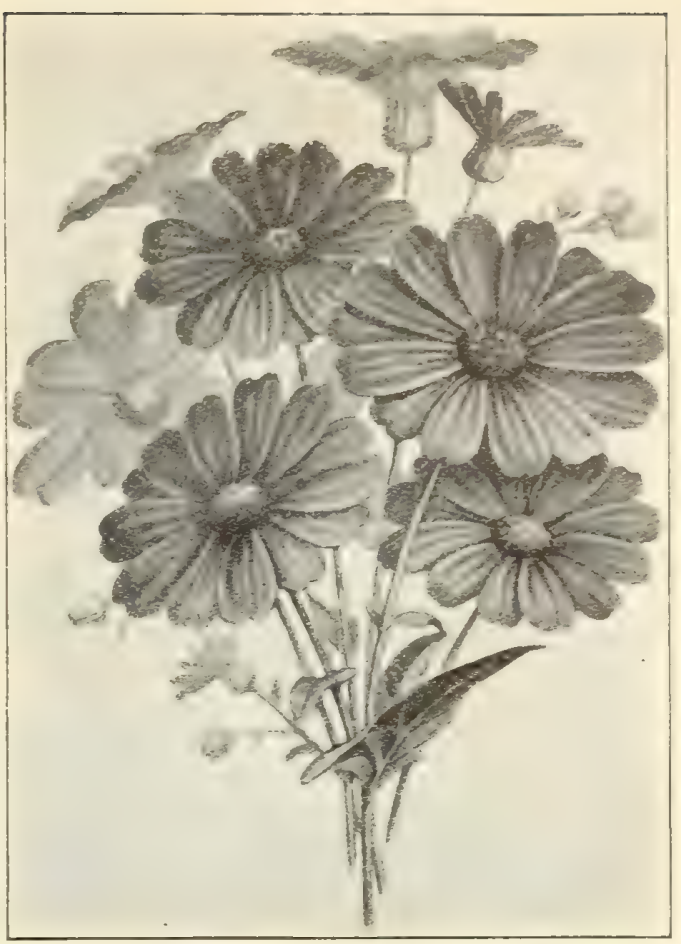

Clneraria "Matador." No. 75.

120 GL O XIN I A hybrida Imperialis Mixed (Sinningia.) These new hybrids, the result of a cross between Sinningia regina and the Gloxinia. The erect Gloxinia-like flowers are borne in the greatest profusion and in a variety of colors with foliage of dark green veined Pkt. white. This introduction will prove of value for greenhouse cultivation ....

25125 HIBISCOS Immutabilis albus, A new large-flowered white perennial mallow which blooms continuously throughout the summer. 'The plants are of bushy growth and very ornamental, they should be protected in winter.

3 pkts. . .50: .20

106 GILIA coronopifolia. A ver: $y$ handsome half-hardy biennial, bearing large spikes of brilliant scarlet flowers. The plants attain a height of $2 \frac{1}{2}$ to 3 feet and remain in bloom Pkt. the greater part of the

110 GLAUCIUM Leiocarpum. Th is new Horn-Poppy from Asia Minor is doubtless the showiest and most effective species of the whole genus. The plants grow from 15 to 18 inches in height, developing their large cup-shaped flowers from June to August. The individual flowers measuring 2 to $2 \frac{1}{2}$ inches across, are of brilliant deep orange scarlet with large black spots at the base of the petals, a striking and rich coloring ... 3 pkts., .50

11 GODETIA Schamini fl. pl. A beautiful variety with long sprays of large double rose-colored flowers. The cut flowers retain their beauty for several dars in water. Hardy annual. 1 font ... ...3 3 plits., . $40 ; .15$

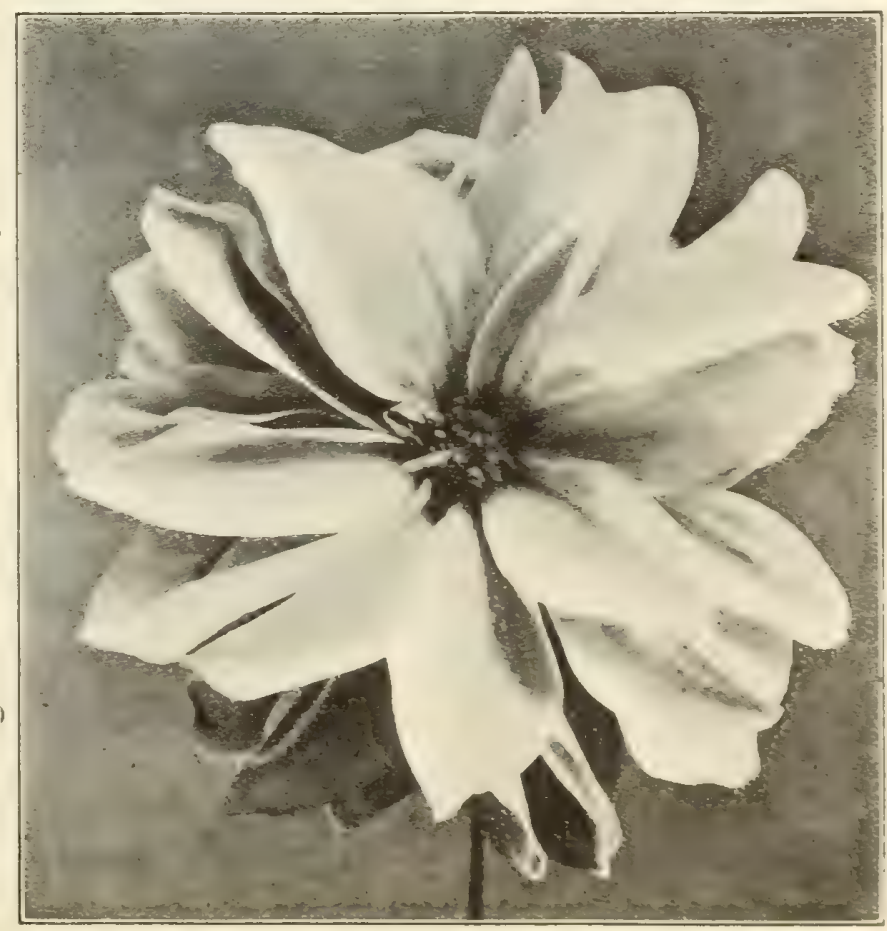

Dahlia Pseony-flowered. No. 05 


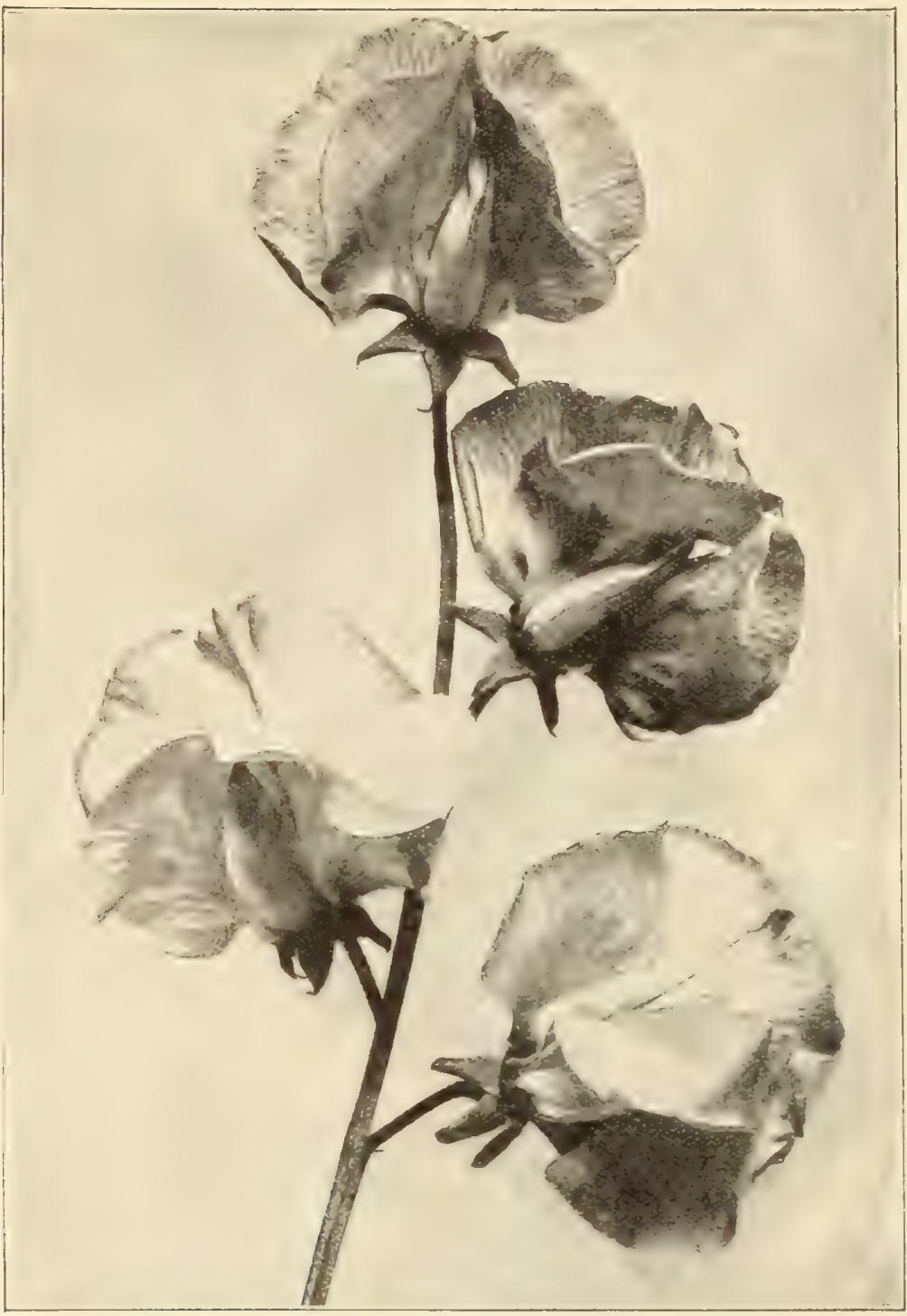

Sweet Pea Asta Ohn. No. 160.

130 IPOMGEA. Japanese Morning Glory Dwarf Pigmy. This Pkt. dwarf annual is an acquisition for bedding purposes, the flow ers are of large size and of very brilliant color's. A fine form for pot culture. 1 foot

140 CENOTHERA speciosa Rosea. A dwarf bushy perennial with fragrant flowers of light pink

145 PRIMULA Chinensis His Majesty. A lovely new primrose with giant-fringed flowers of a rich velvety crimson. The plant is robust, with dark red stems and very free-flowering

150 PRIMULA obeoniea gigantea. A new form of P. obconica with very large foliage and flower trusses, the latter running in the same colors as in the type

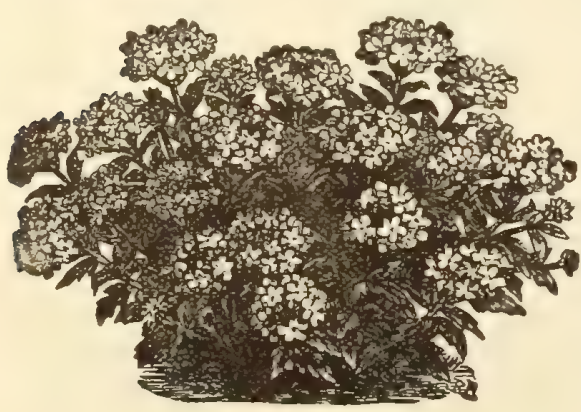

Verbena compacta lutescens. No. 190.

\section{NEW SPENCER SWEET PEAS.}

160 Asta Ohn. Spencer. This selection is lavender, suffused or tinted with mauve. It is of the true Spencer type, with large, wavy standard and wings. It comes uniformly four blossoms to the stem and the stems are pit. particularly long and sturdy.

5 pkts., 1.00 ; pkt. of 25 seeds, .25

165 Beatrice Spencer. One of the most delicate and dainty varieties. The ground is white suffused with soft pink and buff.

5 pkts., 1.00 ; pkt. of 25 seeds, .25

170 Mrs. Sankey. A pure white variety showing a tint of pink while in the bud. The seed is black consequently it is easy to germinate. 5 pkts., $1.00 ;$ pkt. of 25 seeds, .25

175 Ramona Spencer. A new variety of fine form and immense size. The standards and wings are fluffy and there are usually four flowers to a stem. The color is clear white delicately lined and flaked with blush pink. 5 pkts., 1.00 ; pkt. of 25 seeds, .25

180 Tennant Spencer. The flowers of this selection are of large size, wavy and beautiful the color is a deep heliotrope. 5 plits, 1.00 ; pkt. of 25 seeds, .25

For other Spencer varieties see pages 64-65.

185 Sunflower, Starlight. The flowers of this new sort are of very graceful appearance with twisted petals resembling the Single ('actus Dahlia. They are of rich canary yellow on long stems and are splendid for cutting. ... ... ... 3 pkts., 40 ; pkt.,

190 VERBENA hybrida eompacta lutescens. Compact variety bearing large trusses of creamy yellow flowers carried well above the foliage

4930 Zinnia Dwarf Searlet Gem. A charming Zinnia, the compact plants fairly bristling with double blooms of intense dazzling scallet. $1 \frac{1}{1}$ feet ... Oz., $1.25 ;$ t oz., .35; pkt., .10

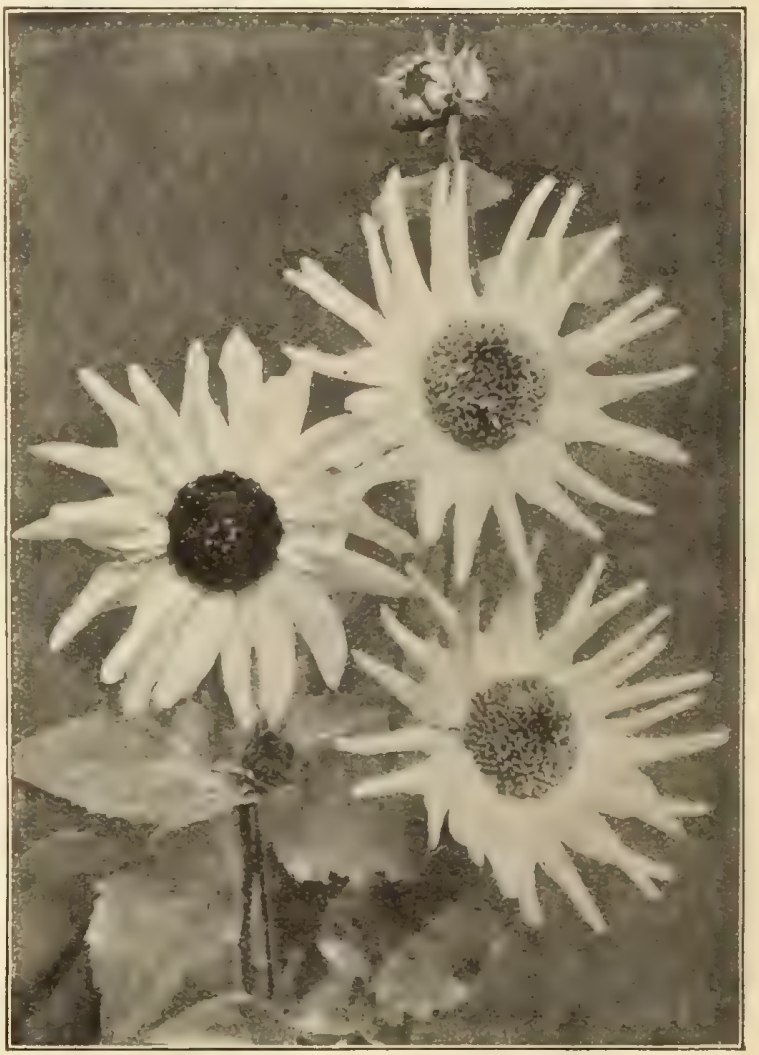

Sunflower Starlight. No. $\times 85$. 


\section{FARQUHAR'S FLOWER SEEDS, ANNUALS}

The plants in the following list all bloom the first season from seeds. because they bloom the first season, and for cultural purposes may be treated as annuals.

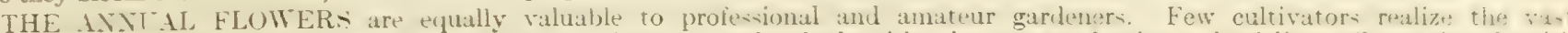
possibilities they afford at a minimum of cost. For cut flowers, garten beds, either in maves of color or for foliage effects, they firmin. ample material. A few of them like the Asters, Poppies, Sweet Peas, and Nasturtiums are well known and largely used; there are however, many beautiful species which we enumerate in the following list, which are seldom seen, and which would be appreciated were they once grown.

ADONIS. Flos Adonis.

505 Estivalis. A beautiful free flowering annual with small crimson flowers,

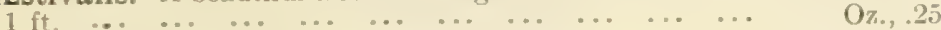

\section{AGERATUM.}

These half-hardy annuals are most useful for bedding, remaining in bloom throughout the summer. The taller varieties are excellent for bouquets.

5lo Mexicanum. Light blue, $1 \frac{1}{2} \mathrm{ft}$.

51.5 Mexicanum album. White, $1 \frac{1}{2} \mathrm{ft}$.

$\mathrm{Oz}, .30 \quad .05$

i.) Blue Perfection. Dark blue; large, $1 \frac{1}{2} \mathrm{ft}$. ... Oz., $1.00 ; \frac{1}{4}$ oz., .35

125 Dwarf Blue. Dark blue; fine bedding variety, 9 inches. Oz., 75: 1 oz., .25

5:30 Dwarf White. 9 inches

53.) Princess Victoria Louise. Iwarf light blue. white centre. inches ... ............... Oz., 1.25; $\frac{1}{4}$ oz., 40

5 \$1) Little Blue Star. A miniature variety with beautiful mauve colored flowers, 3 inches

\section{AGROSTEMMA.}

jt.; Cœli rosa. Rose of Heaven. Flowers of a bright rose color; excellent

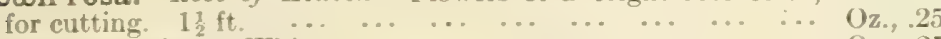

5.) Coli rosa alba. White

$\mathrm{Oz}, .25$

\section{ALONSOA. Mask Flower.}

5.5.) Finest mixed. Suitable for small beds and borders. $1 \mathrm{ft}$. ... Oz., .30

\section{ALYSSUM.}

Free blooming annuals with white flowers suitable for bed and borders.

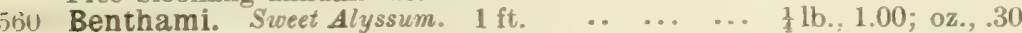

56.5 White Fleece. A miniature variety of great beauty with masses of fragrant white flowers. Very desirable for dwarf beds and edgings. 4 inches

...

\$.0 Little Gem. A free flowering variety of erect growth suitable for bor-

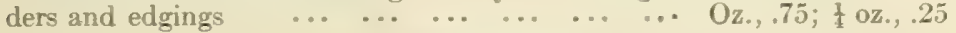

\section{AMARANTHUS.}

Showy annuals, suitable for sub-tropical gardens and borders, where the brilliant foliage is very effective.

575 Caudatus. Love-lies-bleeding. Drooping crimson racemes; $2 \mathrm{ft}$. Oz., .25

i8 Cruentus. Prince's Feather. Dark red feathery flowers; $3 \mathrm{ft}$. " .25

185 Salicifolius. Fountain Plant. Ornamental foliage. $3 \mathrm{ft}$. " .75 Tricolor splendens. Joseph's Coat. Red, scarlet and yellow foliage.

Tricolor Splendens. Joseph's Coat. Red, scarlet and yellow foliage.
$2 \mathrm{ft}$.

\section{AMBROSIA Mexicana.}

59.5 Yellow, sweet annual; esteemed for bouquets

\section{ANCHUSA Capensis.}

bu0 Attractive annual with azure blue flowers. $1 \frac{1}{2} \mathrm{ft}$.

\section{ANTIRRHINUM. Snapdragon.}

One of the finest bedding plants, being constantly in bloom throughout the summer. The tall varieties are extensively used for cut flowers.

Tall Varieties. 2 feet.

b05 Giant Rose-pink. A charming shade

610 Giant Blood Red. Rich deep color

615 Giant Dark Searlet. Very brilliant

620 Giant Deep Crimson.

625 Giant White. Fine for cutting

630 Giant Crimson and Gold. A chirming combination

635 Giant Yellow. Clear daffodil yellow

640 Coral Red. A soft and pleasing color

615 Delicate Rose. A beautiful shade of light pink

650 Fairy Queen. Orange salmon with white throat
Bridesmaid. White, tipped with pale pink

Striped Varieties. Mixed

Giant Mixed. In great variety

Collection of 12 varieties. Our selection

Collection of 6 varieties. Our selection

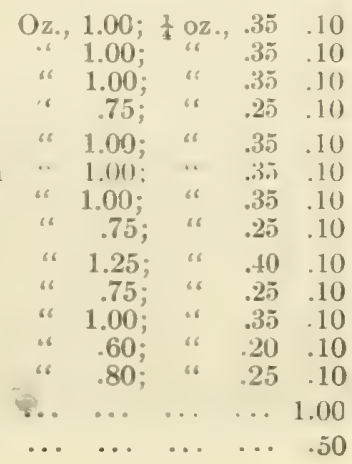

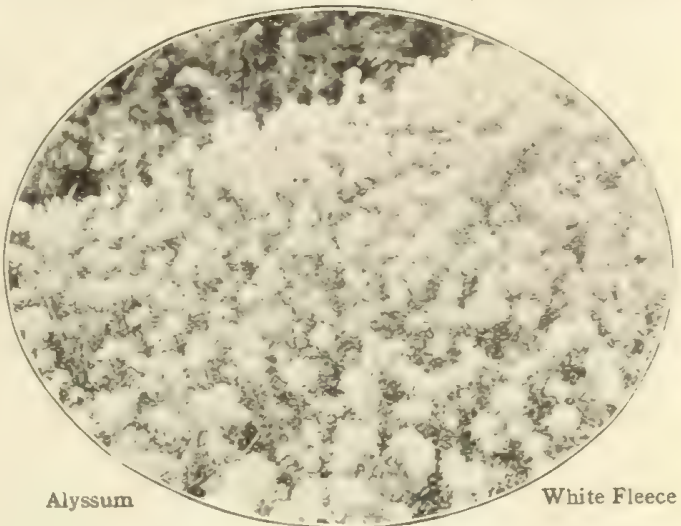

ANTIRRHINUM - Dwarf Varieties. 1 foot.

680 Firebrand. Deep Scarlet ... Pkt., .10

685 Queen of the North. Pure white "6 .10

$\begin{array}{lllll}690 & \text { Golden Queen. Yellow } & \ldots & 6 & 6 \\ 695 & \text { Mixed. Many Colors ... } & \ldots & 6 & .10\end{array}$

Each of the above colors and mixture, Oz.., .75; $\frac{1}{4} \mathrm{Oz} ., .25$.

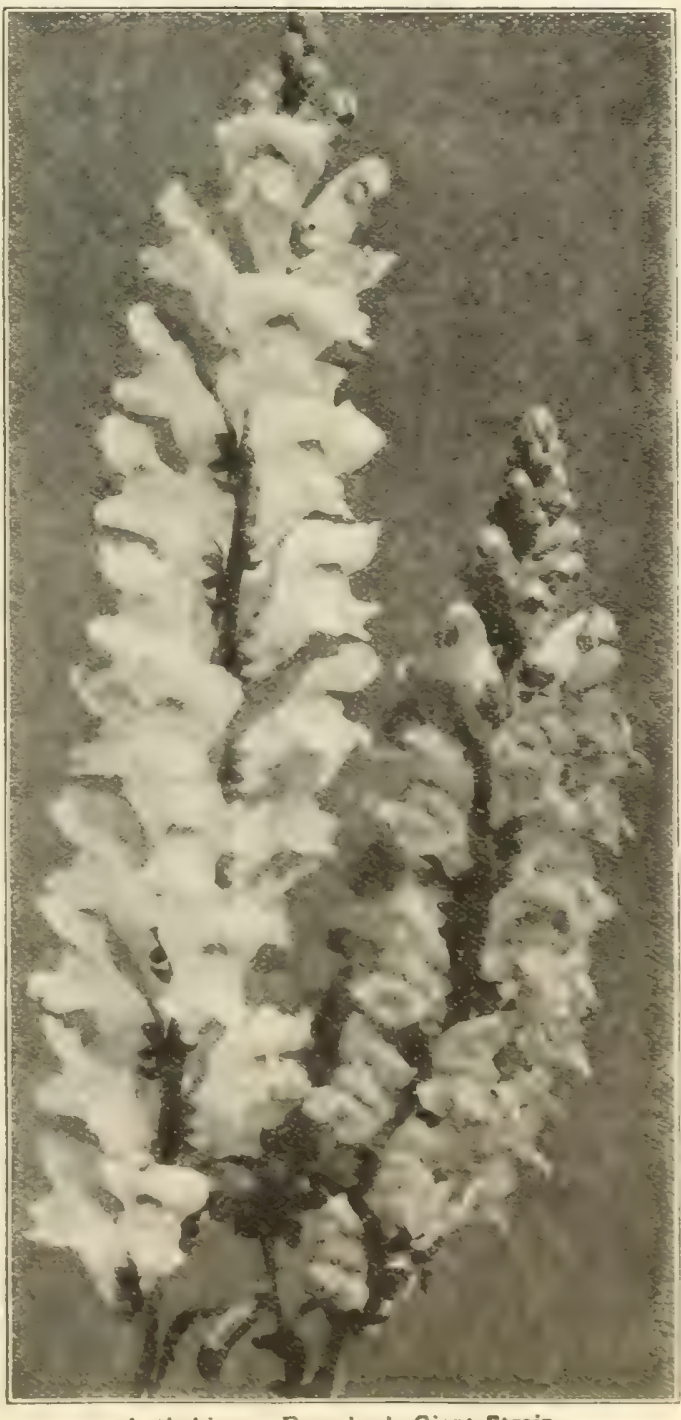

Antirrhisum, Farquhar's Giant Strain, 


\section{R. \& J. FARQUHAR \& CO., BOSTON. ANNUAL FLOWER SEEDS.}

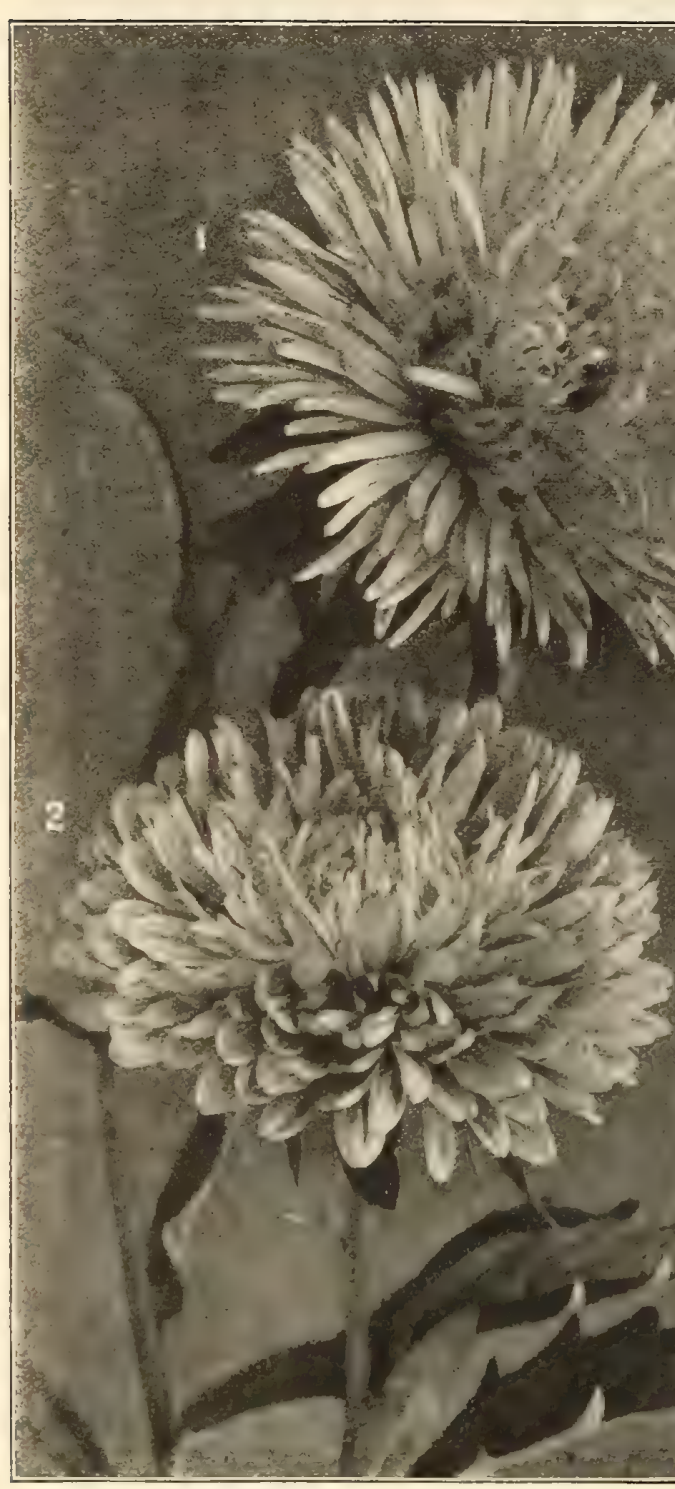

No. 1, Aster Ray No. 1100;

No. 2, Aster Crown or Cocardeau No. $\mathbf{8 4 5}$. large daisy-like flower's of pure white; the reverse of petals pale

lilac. $2 \frac{1}{2}$ feet. Oz., $1.00 ; \frac{1}{4} 0 z ., .35 .10$

705 ARGEMONE GRANDIFLORA. Prickly Poppy. Showy plant, with single white Poppy-1ike flowers. 2 feet Oz.., .50.05

710 ASPERULA AZUREA SETOSA. Yields clusters of fragrant blue flowers; much esteemed for bouquets. 1 foot.... Oz.,.30.0 .05

GEORGE T. WOODMAN, ESQ., Auburn, Maine, Feb. 22, 1908, writes:-“From one collection of American Branching Aster Seed I raised three hundred forty plants. The finest Asters I ever had."

\section{ASTERS.}

AMERICAN BRANCHING. A free-growing type, with immense flowers which are borne on long stems. The finest late sort for cutting. 2 to $2 \frac{1}{2}$ feet.

715 Collection of 6 eolors, separate, our selection . . .50

720 Crimson *. Pkt., .10|725 Dark Blue Pkt., .10

730 Light Blue : " $.10 \quad 735$ Rose-Pink : ${ }^{\circ} 10$

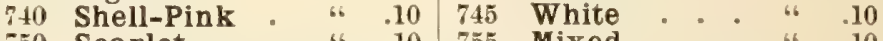

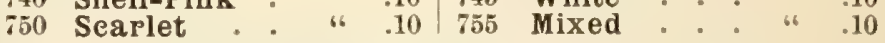
Each of the above colors, Oz., $2.00 ; \frac{1}{4} \mathrm{oz} ., 60$. Mixed, Oz, $1.75 ; \frac{1}{4}$ oz., .50.

BETTERIDGE'S IMPROVED QUILLED. The finest form of Aster having quilled petals; flowers large and quite double. 2 feet.

760 Collection of 6 varieties, separate, imported, . . .50

765 Mixed, . . . . . . . . $\frac{1}{4}$ oz., . $30 ;$ pkt., .10

GIANT COMET. Elegant flowers with long, wavy, twisted petals like Japanese Chrysanthemums They are admirable for vases and table decorations, producing a striking, yet exceedingly graceful effect. 2 feet.

770 Collection of 12 varieties, separate, our selection, . . . .90

775 Collection of 6 varieties, separate, our selection, . . . .50

780 Brill'nt Carmine, Pkt.,.10| 815 Rose . . . . . Pkt., .10

785 Crimson. . . . . . 10820 Searlet. . . . .10

790 Dark Blue : . . . .10 825 Silver-grey . " . 10

795 Azure Blue . . 10.830 Pure White . . 6 .10

800 Lilac . . . . . .10835 Yellow . . . . .10

805 Peach-Blossom .10840 Mixed : . . .10

810 Light Blue and White, 10

Each of above colors and mixture, Oz., $3.00 ; \frac{1}{4} 0 z, 1.00 ; \frac{1}{8}$ oz., .60

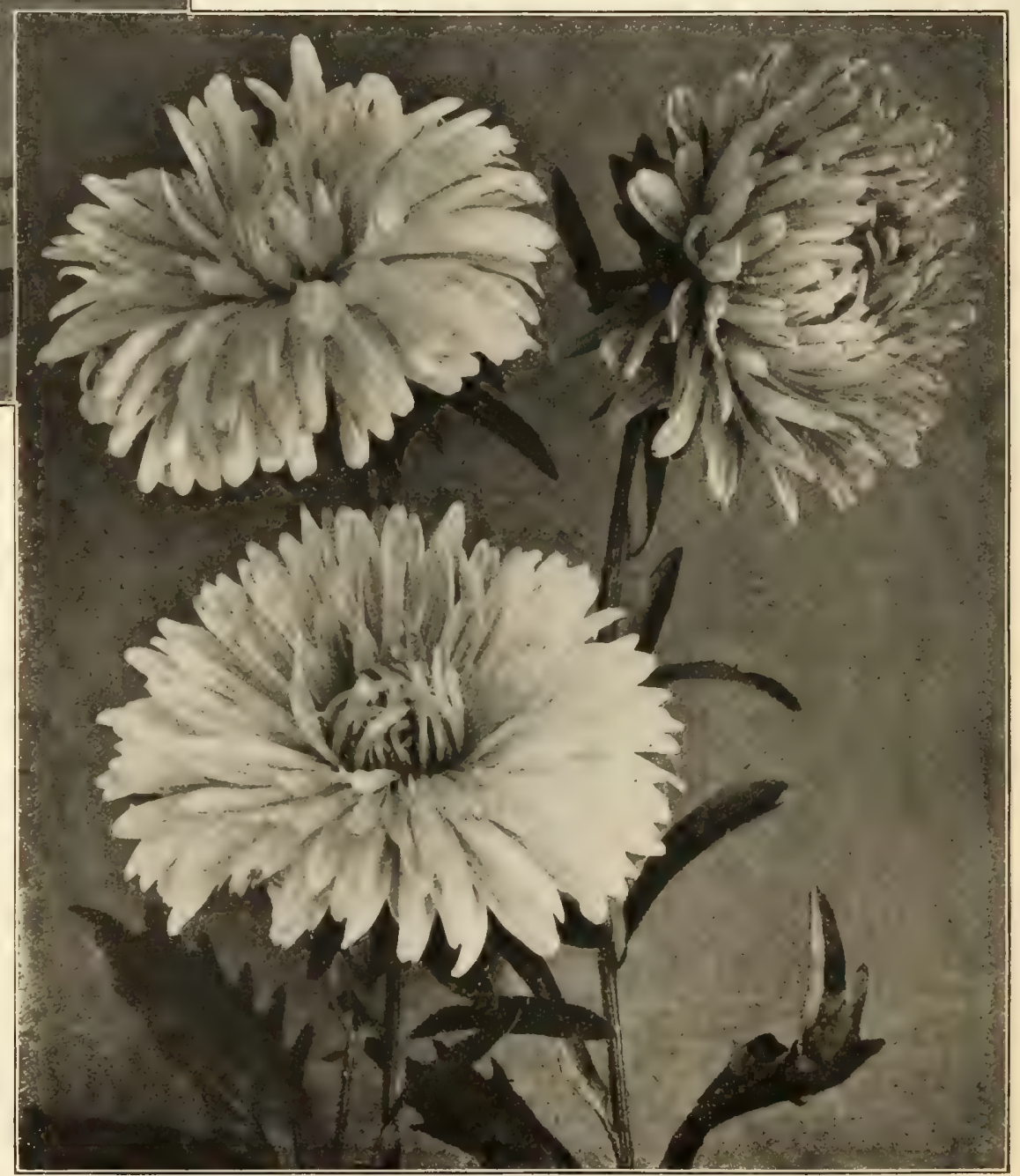


R. \& J. FARQUHAR \& CO., BOSTON. ANNUAL FLOWER SEEDS.

\section{ASTER.-Continued.}

CROWN, or COCARDEAU. Very showy, each flower having a white centre with a wide margin of some brilliant color. $1 \frac{1}{2}$ feet.

815 Collection of 6 varieties, separate, imported,

850 Mixed. Many colors, $\frac{1}{4} \mathrm{oz} ., 1.00$;

$\cdot .50$

855

DAYBREAK. The flowers of this variety are very large and double and of a beautiful shell-pink color. A very attractive shade. 2 feet, $\mathrm{Oz} .4 .00 ; \frac{1}{6}$ oz., $1.25 ;$ Pkt., .10

HOHENZOLLERN. 'A beautiful new elass with long, wavy petals of graceful form. These magnificent blooms are invaluable for cutting. 2 feet.

860 Collection of 6 eolors, separate, our selection, . . .50

865 Crimson . Pkt,, .10|870 Pink . . . Pkt., .10

875 Bright Rose . " .10 880 Dark Blue • " 10

$88 \tilde{5}$ Azure Blue : " .10890 White •. " 10

895 Mixed

Each of the above, Oz., $4.00 ; \frac{1}{4}$ oz., $1.25 ; \frac{1}{8}$ oz., .75

MIGNON. A fine type resembling the Vietoria, but earlier and of more branching habit; the flowers are smaller and very double. The white is exceptionally fine for florist's use. $1 \frac{1}{2}$ feet.

900 Collection of 6 varieties, separate, imported, . . .50

905 Pink. . Pkt., .10|910 White . . Pkt., .10

915 Mixed : " " 10 .

Each of the above, $\frac{1}{4}$ oz., $1.00 ; \frac{1}{3}$ oz., .60.

OSTRICH FEATHER. Extremely graceful Aster, with large feathery heads similar to the Comet, but with longer and more wavy petals. A most effective Aster for table decoration. Flowers double and semi-double. $1 \frac{1}{2}$ feet.

920 Collection of 6 colops, separate, our selection. .50

Crimson

Pkt.

Crimson
Might Blue : $: 10$
White

\begin{abstract}
White .... 10,960 Mixed . .
\end{abstract}
Each of the above, Oz., $3.00 ; \frac{1}{4} \mathrm{oz}, 1.00$.

TRUFFAUT'S FRENCH P\&ONY-FLOWERED. The best incurved variety; splendid for exhibition purposes. The flowers are usually 3 to $3 \frac{1}{2}$ inches in diameter, very double, and of fine globular form. 2 feet.

965 Collection of 12 varieties, separate, our selection, 1.00 970

$$
\begin{array}{r}
97 \\
98 \\
99 \\
100 \\
101 \\
102
\end{array}
$$
Plit.

\section{Amethyst Blue .10}

Brilliant Rose $\quad .10$

Fiery Searlet

Blush

Mauve

Royal Purple.

.10

$\begin{array}{rlr}980 & \text { Blood Red } & \text { Plt. } \\ 990 & \text { Bright Crimson : } & .10 \\ 1000 & \text { Dark Blue } & 10 \\ 1010 & \text { Delieate Rose } & 10 \\ 1020 & \text { Light Blue \& White } & .10 \\ 1030 & \text { Pure White } \quad .10\end{array}$

Each of the above, Oz., $3.00 ; \frac{1}{4}$ oz., 1.00 .

QUEEN OF THE MARKET. A very early elass, with medium-sized blooms borne on long stems. The plants flower from 3 to 4 weeks earlier than the large-flowered kinds, and is extensively grown by florists for cutting. 1 foot.

1040 Collection of 6 eolors, separate, our selection, Pkt.

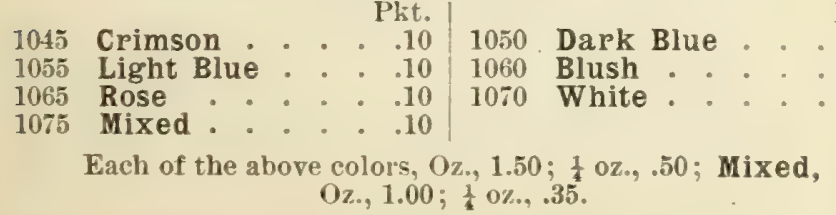

1080 PURITY. A tall branching Aster, with snowy white globular-flowers of large size; a popular florists' variety. 2 feet.

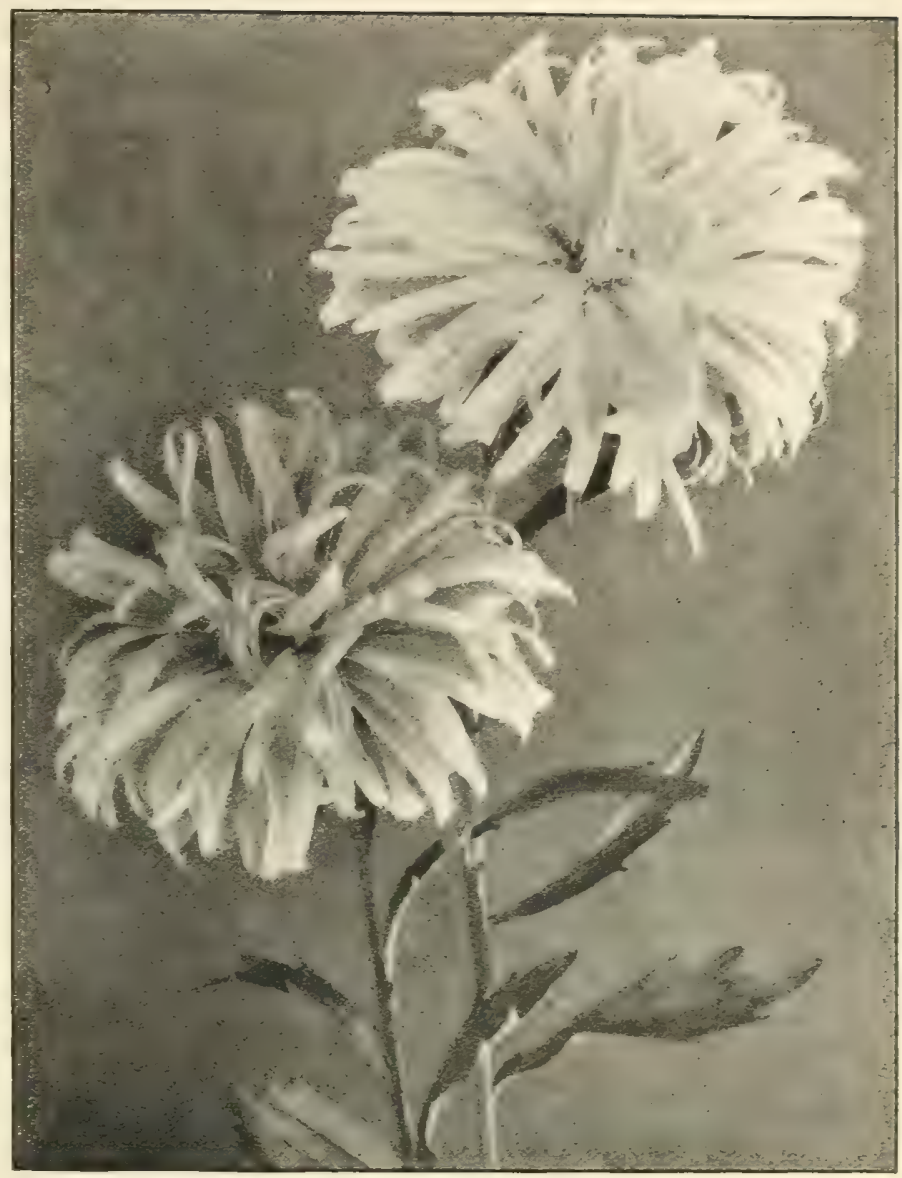

Aster Giant Comet, No, 770

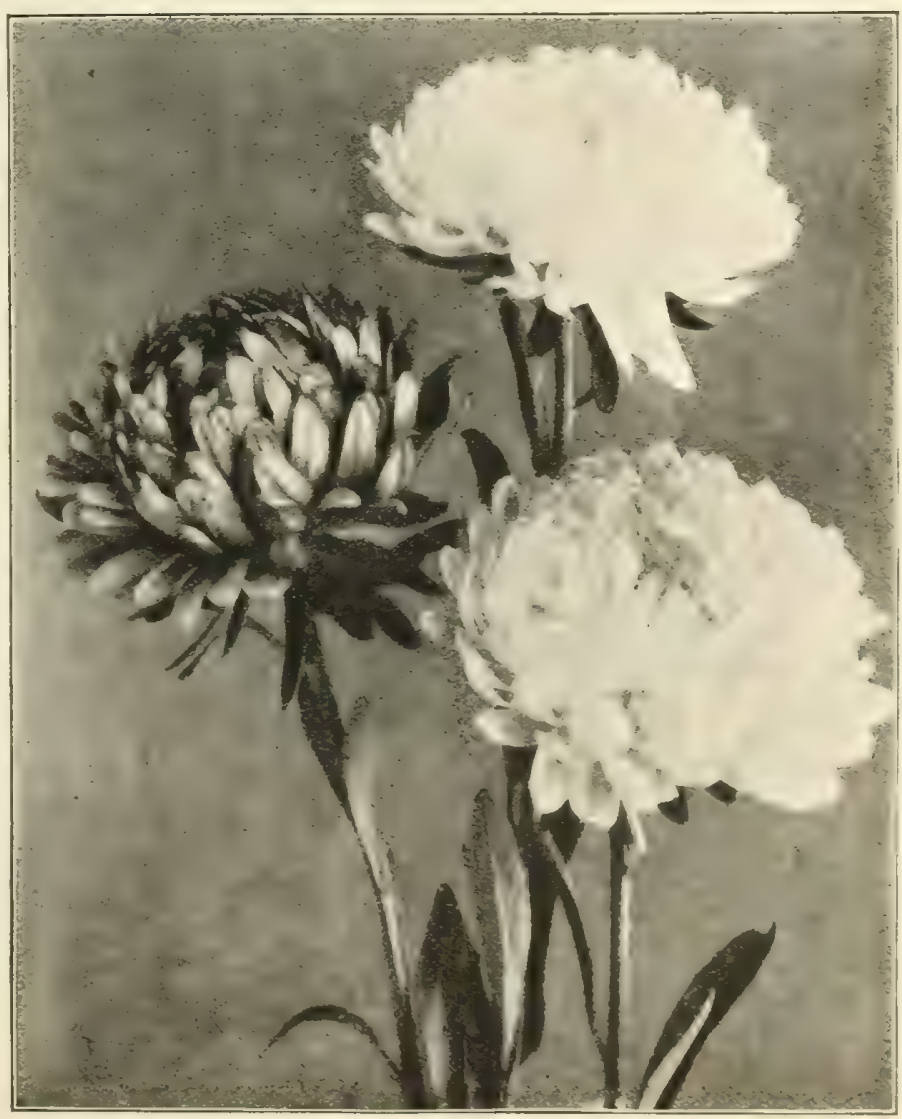

Aster Truffaut's French Pzony-flowered, No, 965. 
ASTER.-Continued.

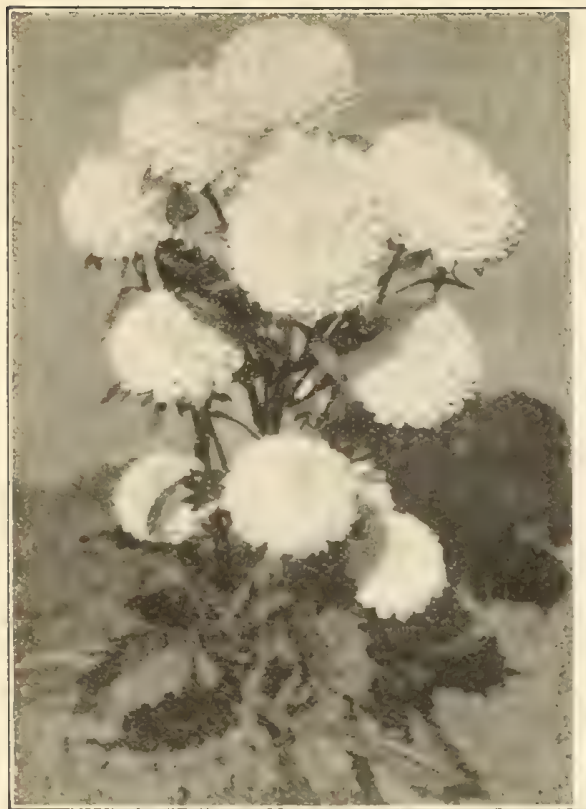

Aster Victoria, No. II05.

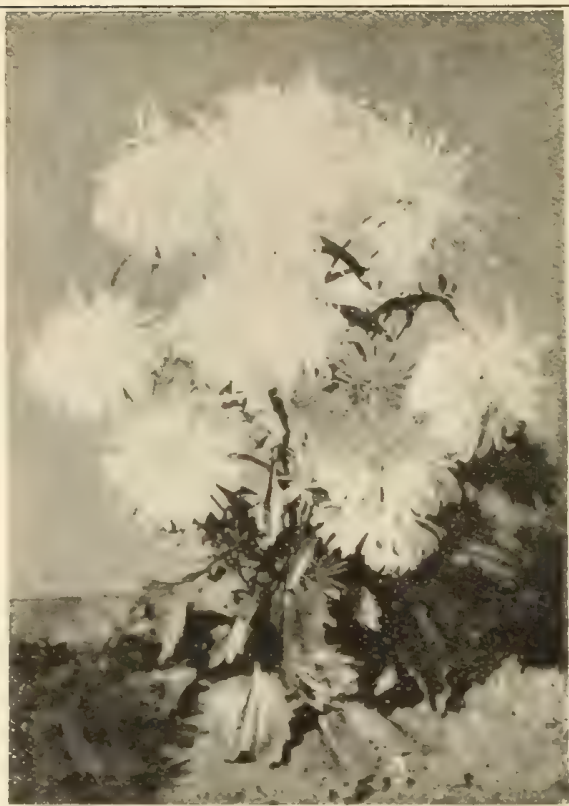

Aster Hohenzollern, No, 860 .

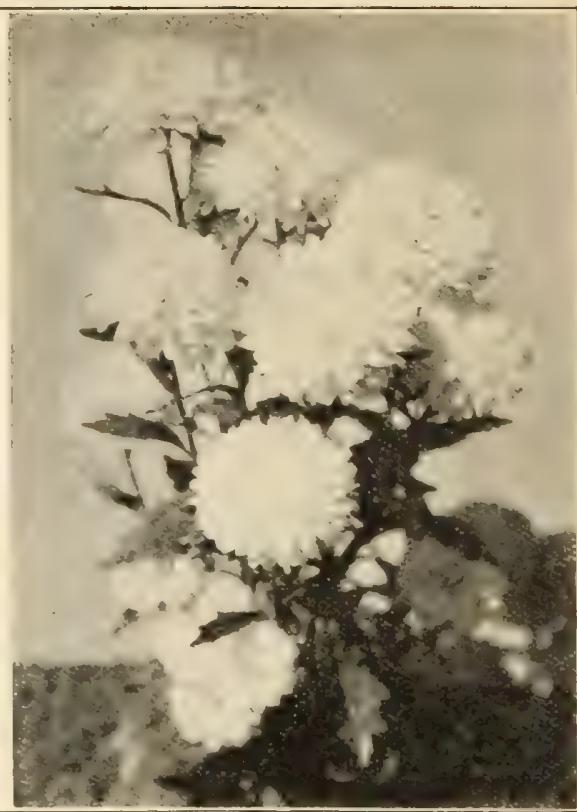

Aster Daybreak, No. 855
RAY. A new type of Aster, with immense flowers, often messuring 4 inches in diameter. 'The petals are long and beautifully quilled. If the blooms are cut before they are fully expanded the will last almost a week in water. 2 feet.

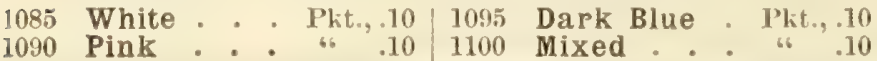

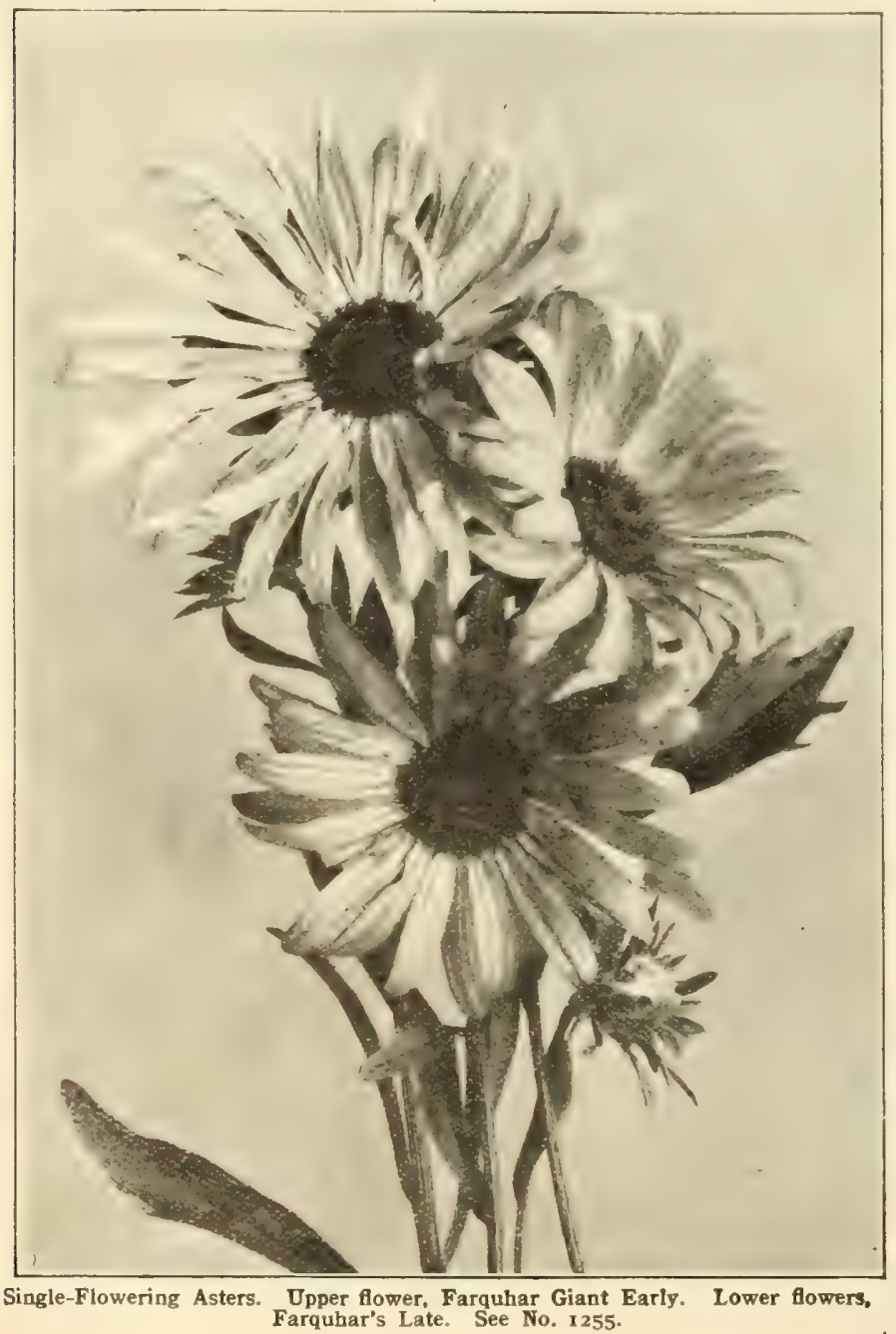

VICTORIA. The flowers are of enormous size, very double, with the petals beantifully jecurved. For bedding or exhibition, the Victoria is unrivalled. 2 feet

1105 Collection of 12 varieties, separate, our selection 1.00 1110 Collection of 6 varieties, separate, our selection .50

1115 Azure Blue Plit. .10|1150 Peach-blossom.Pkt., 10 1120 Crimson. 6 . $10 \quad 1155$ Rieh Purple . 10 1125 Crimson and White .101160 Searlet .10 1130 Dark Blue . "6 .10 1165 Sulphup Yellow . .10 1135 Light Blue . 6 .10 1170 Pure White . .10 $11+0$ Lilac and White $6.10+1175$ Mixed 1145 Pink

Each of the ahove colors, O\%., $4.00 ;$ t $0 z ., 1.25 ;$ t $0 z ., .75$. Mixed oz., $3.50 ; \frac{1}{4}$ oz., $1.00 ; \frac{1}{8} 0 z ., .60$.

DWARF VICTORIA. Compact and free flowering; valuable for borders and long lines. 9 inches.

1180 Dark Blue. Pkt.. 10|1185 Light Blue . I'kt.,.10 11 1) Pink . . .. 10 119\% White

1:()0 Mixed

Fiach of the above, $\frac{1}{8} \mathrm{oz} ., 60$.

FARQUHAR'S GIANT SINGLE, EARLY FLOWERING. An improved type of the original single Aster. For indoor decolation this is a valuable Aster, with long, gracefully curved petals and yellow centres; rivals the better single chrysanthenums. 13 feet.

1205 Pure White . I'kt.. 10, 1210 Pink . Pkt. 10

1215 Light Blue. . 66 .10 | 2220 Dark Blue . 66 . 10 12:5 Mixed . . . $\quad .10$

FARQUHAR'S LATE SINGLE-FLOWERING. 'The original type of Chinese Aster. Large single flowers. Splendid for cutting. $1 \frac{1}{2}$ feet.

1230 Mauve . Pkt.,.10 | 1235 Purple . . Pkt.,.10

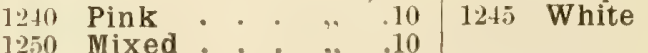

Each of the above, $\frac{1}{4} \mathrm{oz} ., 50$.

1255 COLLECTION OF SINGLE-FLOWERED ASTERS, in 8 VARIETIES, separate, our selection . Pkt., .60

1260 Farquhar's Imperial Prize Mixed. 'The mixture contains only the best of the large-flowering double Aster's in a great variety of color's. This combination enables a customer to get in a single packet a varied selection of the most beautiful sorts in cultivation. $\mathrm{Oz}, 5.00 ; \frac{1}{4} \mathrm{Oz} ., 1.50 ; \frac{1}{8} 07, .75 ;$ Pkt., .15 For Perennial Varieties see Nos.6170-6205. 


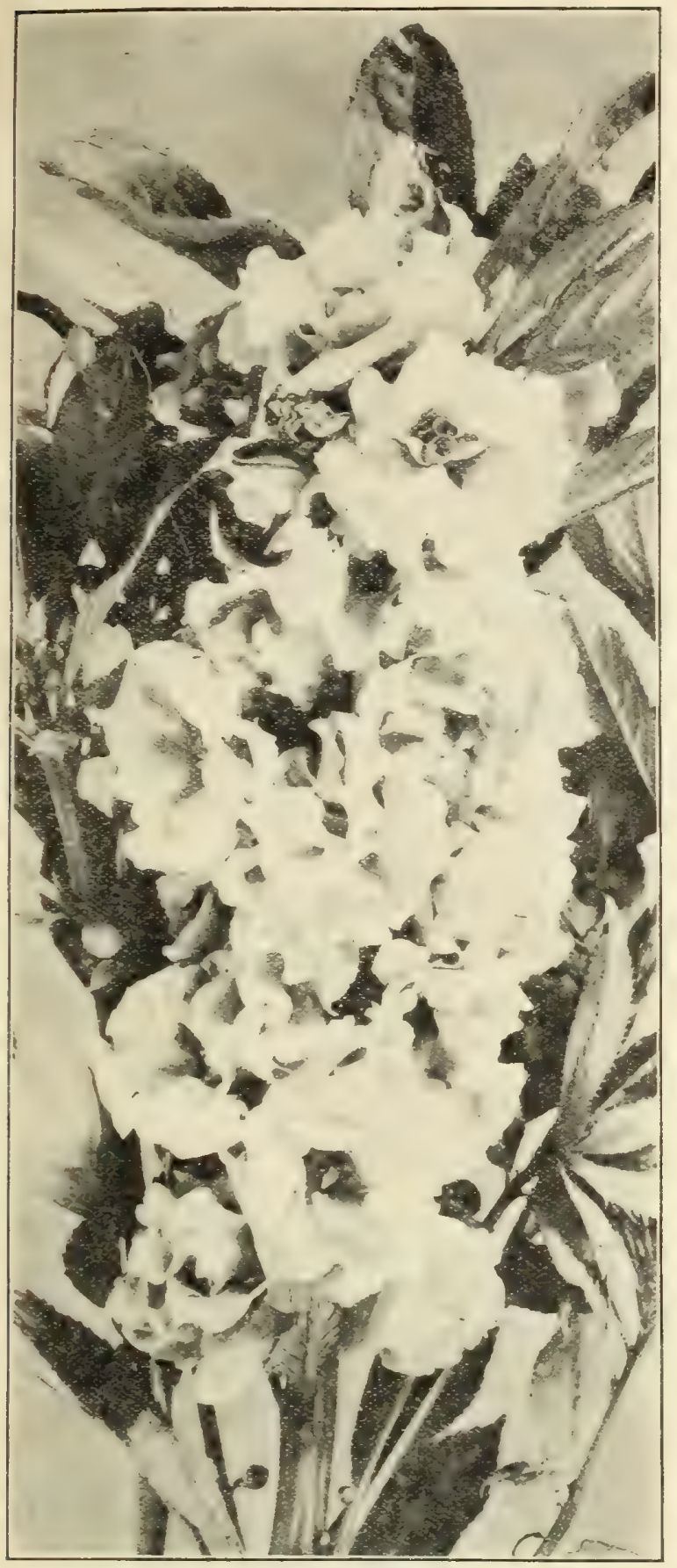

Farquhar's Perfection Balsam.

BALSAM.

Balsams are increasing in popularity for the summer garden. The plants develop much larger flower sprays when set out two feet apart. Splendid for table decoration. $1 \frac{1}{2}$ feet.

1265 Farquhar's Prize Mixed. This strain is unsurpassed in Pkt. variety and brilliancy of color ... Oz., 2.00; $\frac{1}{4} \mathrm{oz} ., .60 ; .25$

\section{FARQUHAR'S PERFECTION.}

1270 Blood Red

1275 Searlet

1280 Pink . .

1285 Violet

1290 Flesh-color

1295 Pure White
1315 BARTONIA AUREA. A free blooming and showy plant with Pkt. large golden yellow flowers; thrives well in partial shade. $1 \frac{1}{2}$ feet

1320 BERIA CHRYSOTOMA. A pretty Californian annual with small golden yellow flowers. 1 foot … Oz, 1.00; 1 oz., .35;

\section{BEGONIA.}

Tuberous-rooted. 1 foot.

The value of the single-flowered Tuberous Begonias for bedding purposes has been fully established, and the gorgeous effects they have produced have readily given them precedence over the more ordinary bedding plants. Seeds sown in February or March will produce nice plants for planting out in June. The double varieties succeed best when grown as pot plants, and are adapted to conservatory and piazza decoration. Pkt. 1325 Farquhar's Giant Singie. Collection of 8 colors, separate 2.00 1330 "6 6" Mixed. First size packet... 50 1335 " $"$ " $"$ Second size " . . 25

1340 Farquhar's Superb Double Mixed

1345 Farquhar's Single Crested Mixed

Fibrous-rooted varieties.

1350 Dwarf Vernon. A fine bedding sort with rich red flowers and glossy bronze-red foliage; 8 inches

1355 Coral Gem. A beautiful shade of clear coral pink; fine bedding variety; 8 inches

1360 White Gem. Satiny white flowers. Very attractive when planted with other colors. 8 inches

GRACILIS. This magnificent new Begonia is considered in Europe the finest variety for groups. It is a vigorous grower and is in constant flower throughout the summer. For conservatory decoration it is equally valuable. 1 foot.

1365 Pink. 1370 Searlet. 1375 White. Each, per packet, 25

1380 Erfordia. A magnificent hybrid variety with small glossy dark green leaves and delicate rosy carmine flowers; one of the Pkt. best for masses. 1 foot

1385 Erfordia Red. A charming plant with deep red flowers and dark coppery foliage. 1 foot

1390 Rex Varieties Mixed. Ornamental-leaved. 'Large handsome leaves, dark green, variegated with red-bronze, red and silverwhite. 1 foot

1395 BRACHYCOME IBERIDIFOLIA. Swan River Daisy. A profuse flowering annual with small blue flowers resembling those of the Cineraria. 9 inches $\ldots . . . \quad 0$ Oz., 1.00;

\section{BROW ALLIA.}

1400 Speciosa Major. A beautiful perpetual-flowering variety with bright violet-blue flowers of large size; suitable for summer bedding. In the greenhouse it is invaluable as a pot plant. $1 \frac{1}{2}$ feet

1405 Elata coorulea grandiflora. " Bright blue; fine for cutting

1410 Jamesoni. Streptosolen. An excellent winter-flowering sort with bright orange tubular-shaped flowers. Very showy as a pot plant 1 foot.

1415 Mixed Shades of blue, purple and white ……

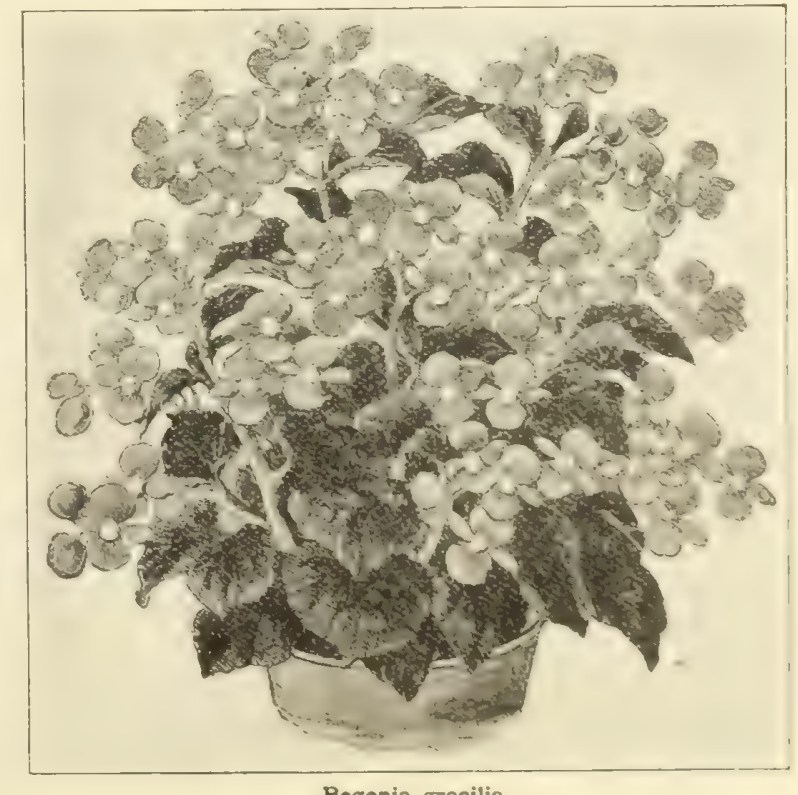

Begonia gracilis. 


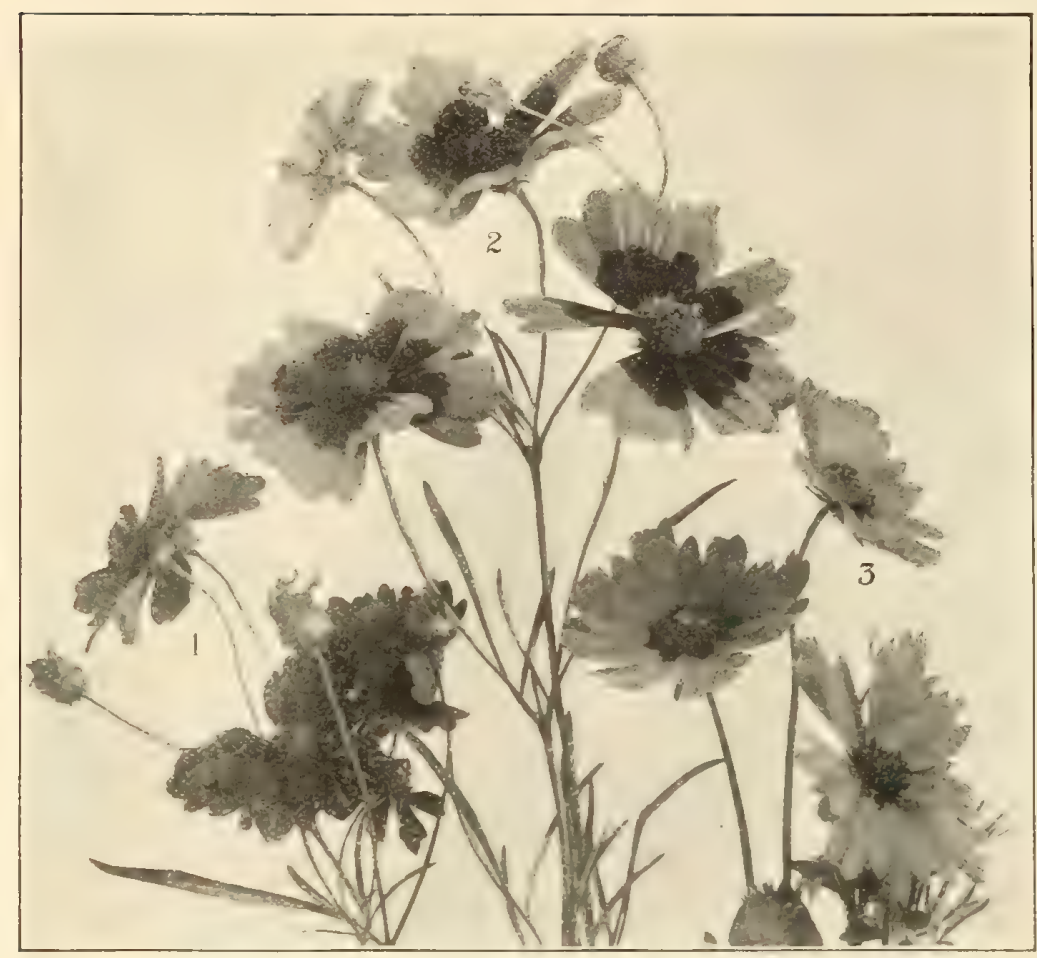

No. r, Calliopsis Atrosanguinea No, 1460. No, 2, Crimson and Gold No. 2465. No. 3, Drummondi No, 1485 .

1420 CACALIA COCCINEA. Tassel Flower. Showy annual Pkt. with trusses of tassel-like scar,et flowers. $1 \mathrm{ft} . \mathrm{Oz}, 50 ; .05$

1425 CALANDRINIA GRANDIFLORA. Fleshy-leaved annuil with bright rose-colored flowers; succeeds well in sunny situations $1 \frac{1}{2}$ feet.

CALENDULA Officinalis. Fl. Pl. Pot Marigntd. Splendid hardy annuals, with large disc-like double flowers, borne in profusion from June to November. They are valuable for cut flower's. $1 \mathrm{ft}$.

1430 Orange King. Ialge flowers, dark orange.

1435 Meteor. Yellow flowers striped with lenaon.

1440 Lemon Queen. Clear lemon-yellow

1445 Mixed. Shades of lemon and orange

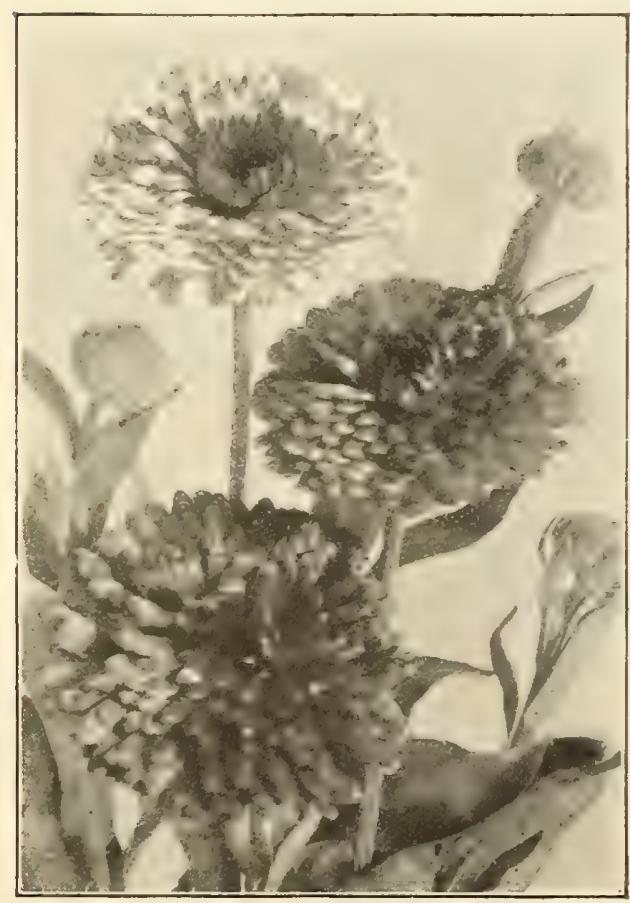

Calendula, Orange King No. 1430.
CALLIOPSIS or COREOPSIS. Charming free-flowering hardy annuals, blooming early and continuing until frost. 'The flowers are showy in the garden and most useful for cutting. 2 feet.

1460 Atrosanguinea. Rich dark red. Oz, .30; .05

1465 Crimson and Gold. Showy crimson flower's broadly margined with deep yellow.

Oz., . $30 ; .05$

1470 Morning Star. A lovely shade of light yellow ... ... ... ... Oz., .0ิ0;.10

1475 Coronata. Yellow spotted crimson. $1 \mathrm{ft}$.

1480 Cloth of Gold. Splendid new variety with large golden-yellow flowers. 1 to $1 \frac{1}{2}$ feet. $. . . \quad \ldots, \ldots, 0 z ., .60 ;$

1485 Drummondi. Golden Wave. Rich goldenyellow, with chestnut-brown centre. 1 foot.

Oz.,.30;.05

1490 Mixed. .... ... ... ... $\quad$ “6 $\quad .30 ; .05$

1495 Collection of 6 Varieties, separate, our selection,

For Perennial Coreopsis see Nos. 6530-6540.

CANDYTUFT. Iberis. 1 foot, Well-known dwarf annuals, valuable for edgings and for cutting.

1525 Carmine. An attractive color. Oz., .50; .05

1530 Dark Crimson. A splendid dark shade.

1535 Flesh Color. Fine delicate tint. 6\% $.25 ; .05$

1540 Rose Cardinal. Bright rosy eardinal; a rich and striking color。 Oz., $1.00 ;+0 z ., 35 ; .10$

1545 Giant White Perfection. A greatly improved strain of Giant White Candytuft producing immense spikes of pure white flowers. It is the finest variety for greenhouse culture, the large trusses frequenty measuring six inches in length. For outdoor bedding this variety is unsurpassed.

Oz., $75: .10$

1500 Empress. A large-flowered white sort with long flower trusses; extensively used for forcing.

$0 \%, .50 . .10$

1555 Purple. Rich shade. ... Oz, .30;.05

1660 Mixed. ... ... ... ... $07 ., 9.25 ; .05$

1565 Collection of 6 Colors, separate, our selection.

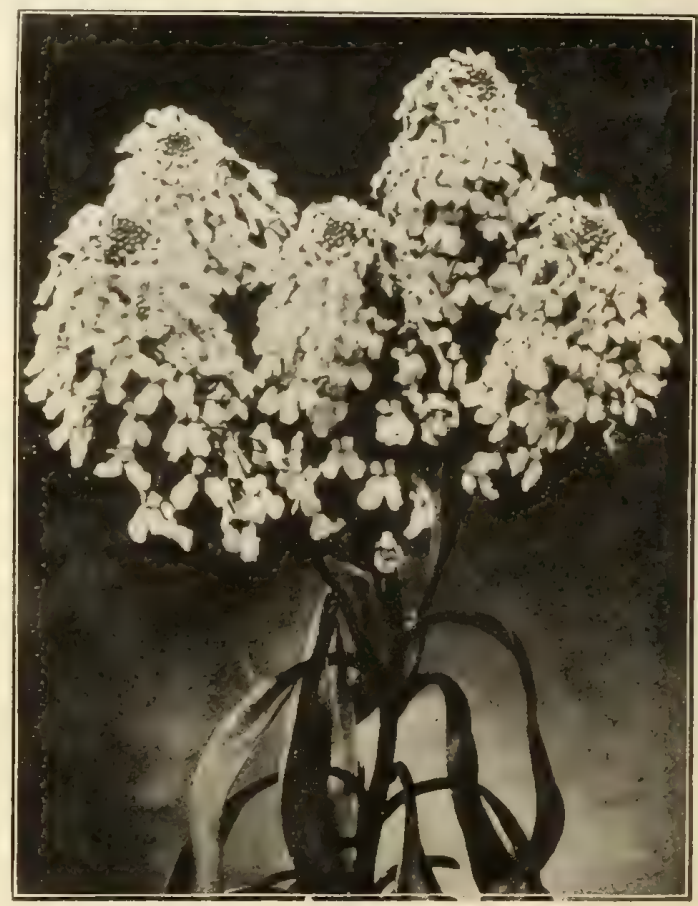

Candytuft Giant White Perfection No. 1545.
1450 Calendula Pluvialis. Cape Marigold. single white flowers. Pkt $0 z, .25 ; .05$

1455 Calendula Pongei. Double white flowers.

$$
\mathrm{O} z, .50 ; .10
$$

CAMPANULA. Bell. Flower. 'The annual varieties of Campauula bloom profusely and remain in flowe for a long period ; tine for bedding. $1 \frac{1}{2}$ feet.

1500 Loreyi Blue

1505 Loreyi White

1510 Maerostyla. A fine branching sort with lovely violet flowers. $1 \frac{1}{2}$ feet. $\frac{1}{8}$ oz., .60 ;
For Perennial Campanulassee Nos.6250-6405

1515 CANNA. Crozy's Dwarf large-flowering varieties, mixed. $3 \frac{1}{2} \mathrm{ft}$.

Oz., .50;

1520 Tall Dark-Leaved Varieties. Mixed. Oz.,.25; .05 
R. \& J. FARQUHAR \& CO., BOSTON. ANNUAL FLOWER SEEDS.

CANDYTUFT. Continued.

DWARF VARIETIES. -8 inches.

$15 \% 0$ Rose.

157 White.

1580 Mixed.

For Perennial Candytufts see Nos. 6410-6420.

CARNATION Marguerite.

Caruations, blooming in July on Au spring, and continuing until frost. Being half-hardy perennials, a slight protection of coarse straw or pine boughs will preserve them during winter and they will flower profusely the next summer.

1585 Farquhar's New Giant Mixed. Seeds of this strain saved from an unrisalled collection producing a large proportion of double flowers, $\frac{1}{8}$ oz., 1.50 ;

1590 Red 1595 Rose. Each color, $\frac{1}{4}$ oz., .60;

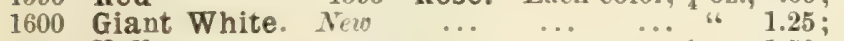

1605 Yellow ... ... ... ... ... $\frac{1}{8}$ oz., 1.50;

1610 Mixed Colors. A fine selection, Oz., $1.75 ; \frac{1}{4} \mathrm{oz} ., .50$;

1615 Giants of Nice. This type originated with the foremost Carnation specialist in France, and our Seed is raised by him. The plants bloom six months after sowing; the flowers are long stemmed and of a large size For Hardy Carnations, see Wos. 6425-6455.

CELOSIA. Cockscomb. 6 inches. Showy annuals of easy cultivation, producing large, brilliant, comb-like flower heads. They prefer a light soil, and should not be allowed to become crowded if a dwarf habit is desired.

1620 Farquhar's Dwarf Prize Mixed

1625 Farquhar's Dark Crimson Glasgow Prize. Very large dark crimson combs $\because . . . \frac{1}{8} \mathrm{oz}, .50$;

1630 Golden Yellow 1635 Light Yellow

1640 Rose

1645 Searlet

1650 Vesuvius

Each of the above colors

1660 Tall Finest Mixed. $1 \frac{1}{2}$ feet ... ... Oz., .60;

Ostrich Plume Cockscombs. Thompsoni Magnifica. A magnificent race of plumed Coxcombs, particularly desirable for bedding. 2 feet.

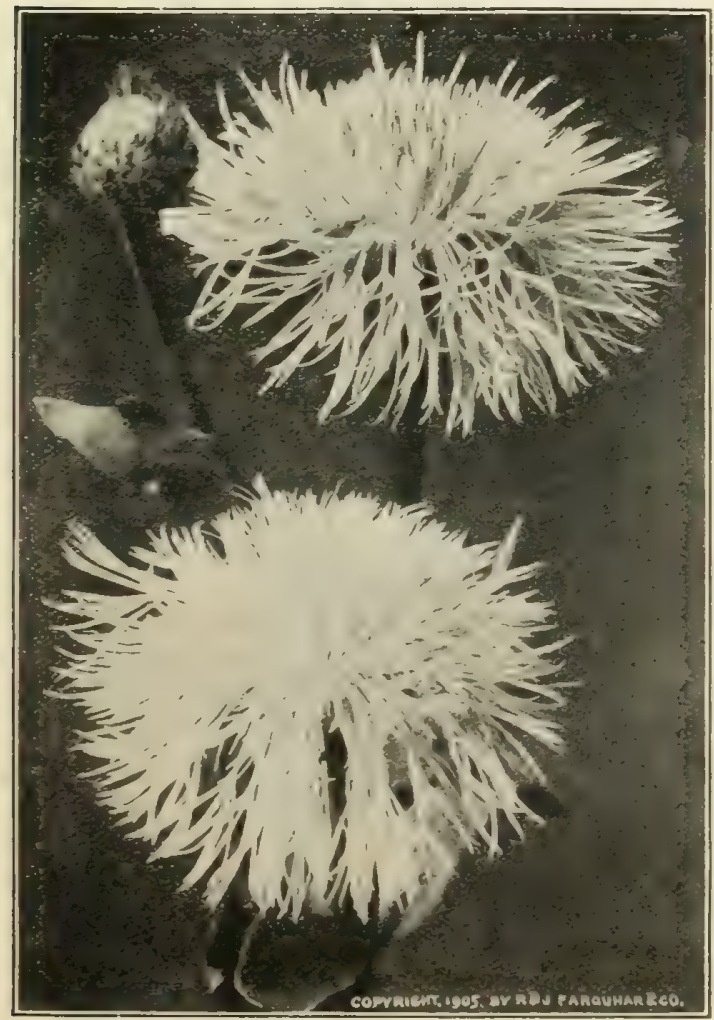

Centaurea Americana No. I795.

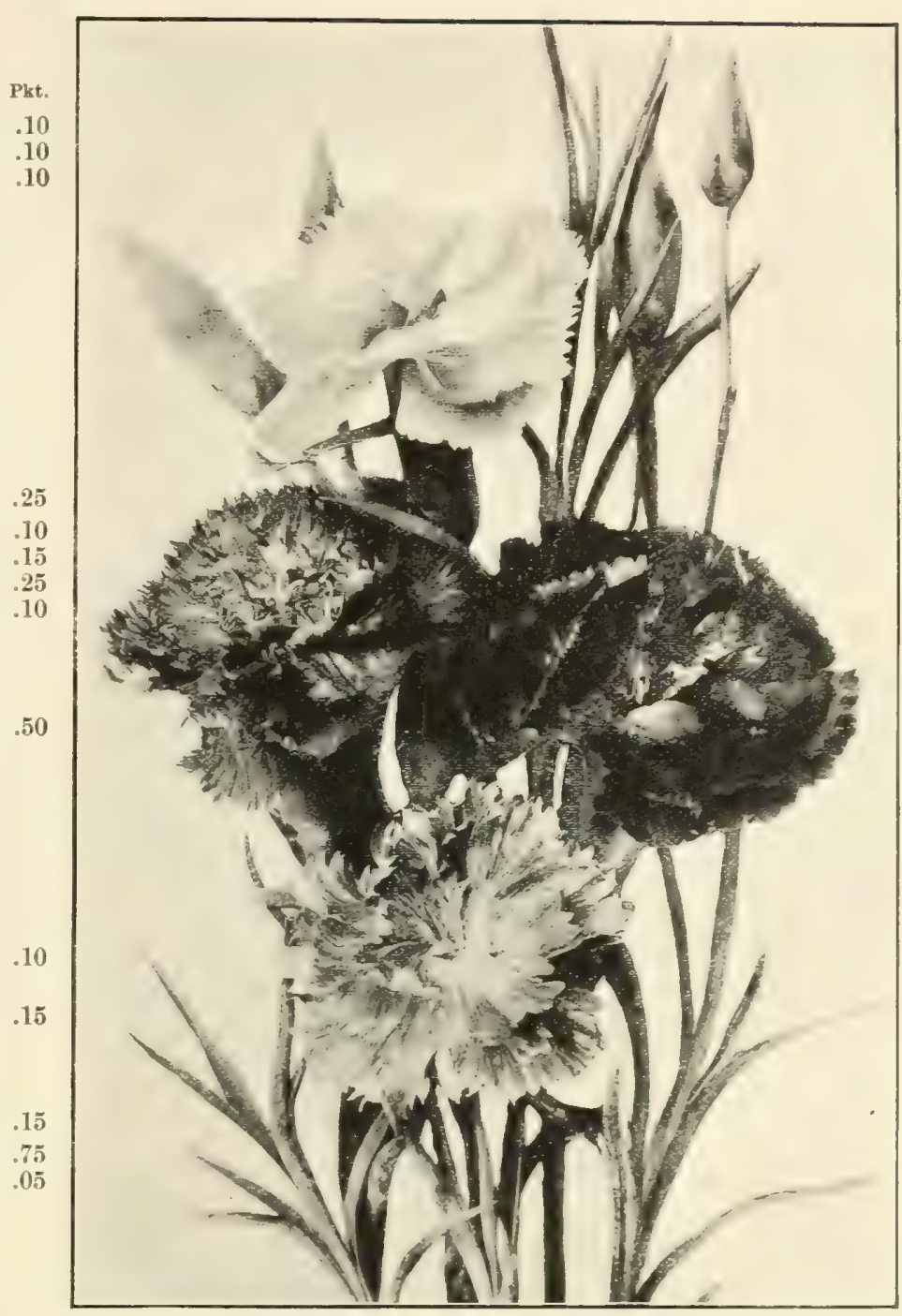

Carnation Marguerite, Farquhar's New Giant Mixed, No. 1585.

1665 Golden Yellow

1670 Lemon Yellow

1675 Carmine

1680 Searlet

1685 Crimson

Each of the

above colors, Pkt. 1 oz., .50;.10

1690 Collection of 5 Colors, separate, our selection

.40

1695 Mixed. All col-

ors, $\quad 0 \%, 1.75$

1 oz.g. .50 ;

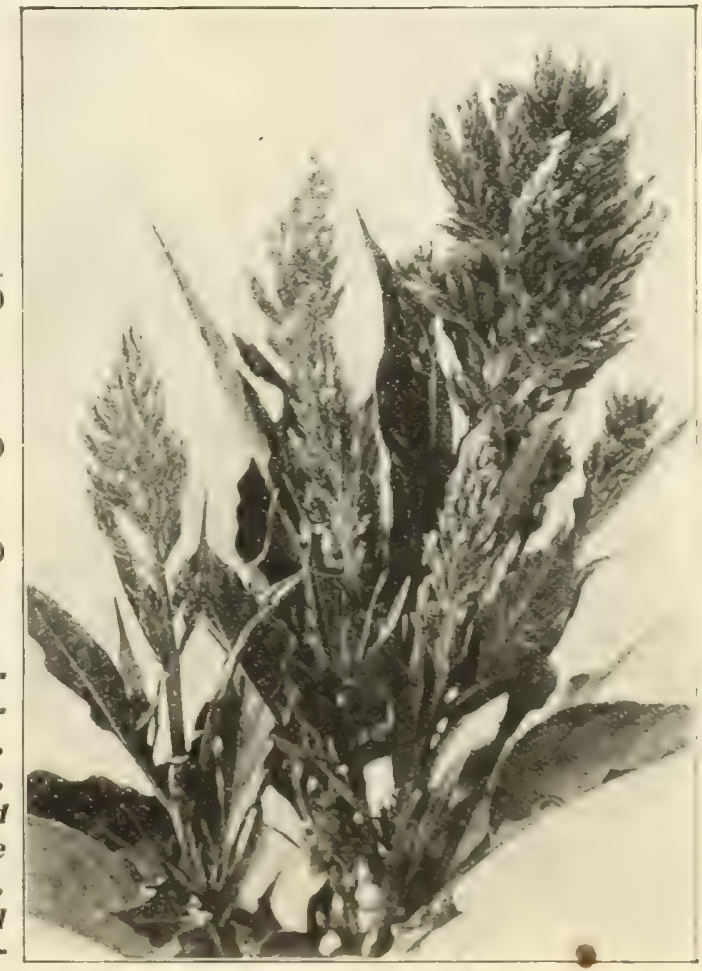

Cockscomb Ostrich Plume, No, 1690.

$M R$ J E DRUM Gar dener to HENRY I. PAR SONS, Esq., Stockbridge, Mass., March 3rd, 1908, writes: "I am well pleased with your Seeds that I have had, especially Pansies, which were the finest I have seen both in color and size." 


\section{R. \& J. FARQUHAR \& CO., BOSTON. ANNUAL FLOWER SEEDS.}

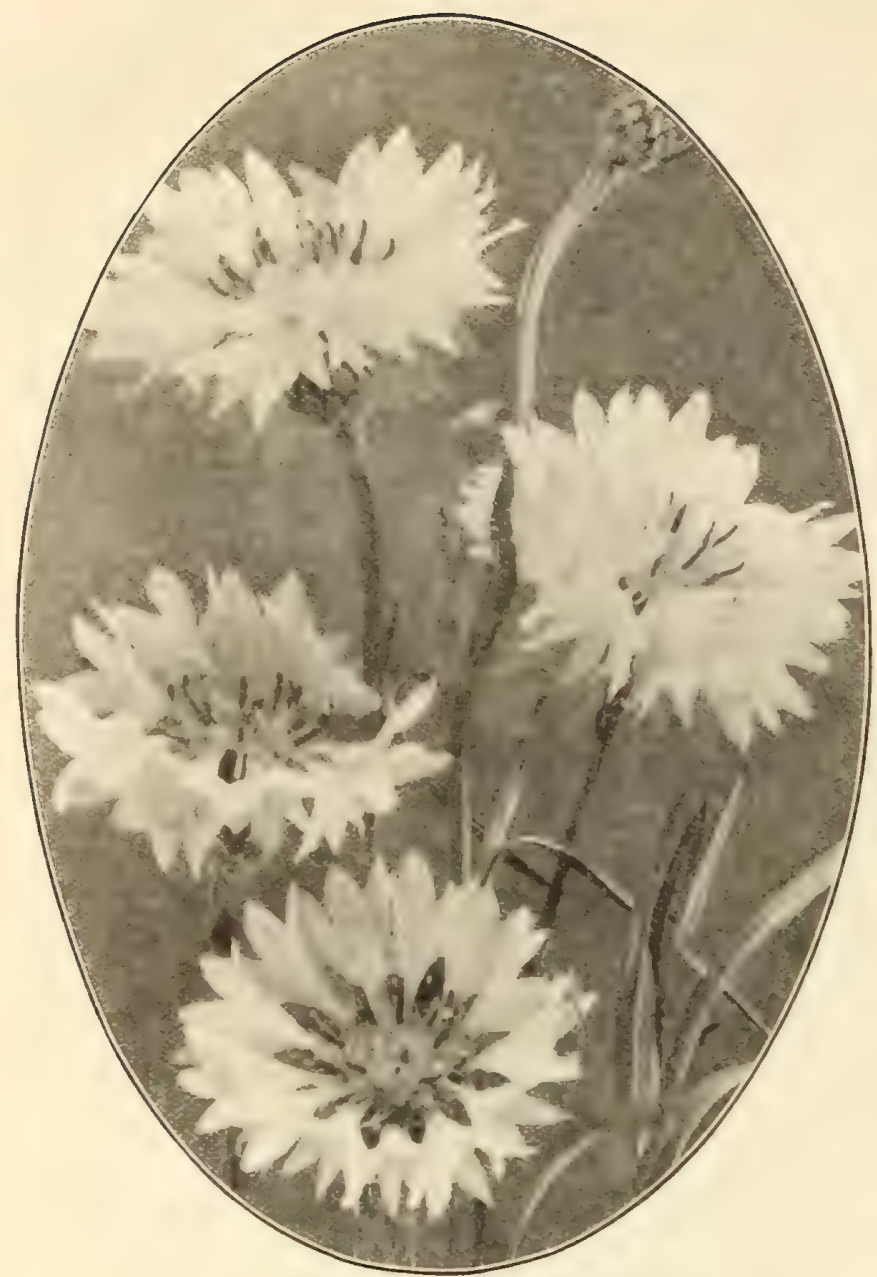

Centaurea Cyanus Emperor William, No, 1755.

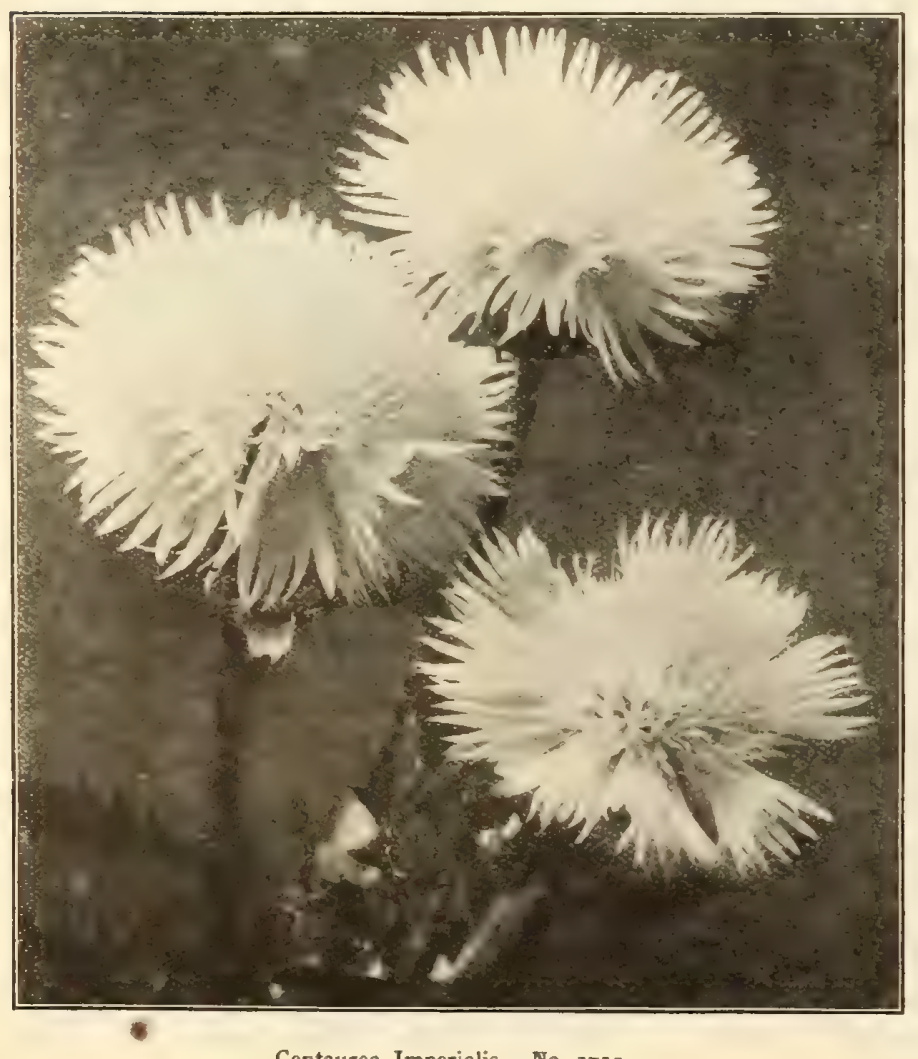

\section{CENTAUREA.}

White-leaved Bedding Varieties. Dusty Miller. Pkt. 1700 Candidissima. Broad foliage. 1 foot $\ldots+0 \%, .60 ; .20$ 1705 Gymnocarpa. Narrow foliage. 1 foot,

Oz., .80; $\frac{1}{4}$ 0z., $.25 ; .10$

CENTAUREA FLOWERING VARIETIES. Cornflower.

Imperialis. Giant Cornflower. The flowers are of enormous size; fragrant and of most charming colors. They are superb for cutting. 2 feet.

1710 Colleetion of 8 varieties, Giant Cornflower, separate, .40

1715 Special Mixture, of many eolors ... $0 \%, .75 ; .10$

1720 Blue 1725 Lilae 1730 Pink, with white eentre

1735 Rose 1740 White

Each of the above color's ... Oz., $1.25 ; \frac{1}{4}$ oz., .40;.10

17t5 ODORATA. Fragrant, purplish-crimsou flowers; very large ... ... ... ... Oz.,. $1.00 ;+0 z ., 35 ; .10$

1750 Odorata Chamæleon. Sulphur-yellow, changing to rosy-lilate $\quad \ldots \quad \ldots \quad \ldots 0 \%, 2.00 ; \frac{1}{1} 0 \%, .60 ; .15$

CENTAUREA CYANUS. Butheror's Button. $2 \mathrm{ft}$.

1755 Emperor William. Blue 1760 Rose

1765 Pure White 1770 Mixed

Each of the above colors and mixed, \& 1b., .75; 0z., .30; .05

1756 Emperor William Double Blue. A new selection of the old-fashioned Barhelor": Button, producing a large percentage of beautiful double flowers

\section{CENTAUREA MOSCHATUS. Sireet Sultan.}

Showy and fragrant. Hardy ammals. Splendid for cut flowers. $1 \frac{1}{2}$ feet.

1755 Blue $\quad 1780$ White 1785 Mixed Colors Each of the above colors and mixed, ... Oz., . $30 ; .0^{\prime}$

1790 SUAVEOLENS. Iellow secet Suttan. Showy, bright yellow flowers sweetly scented ... ... Oz., .50;.05

1795 AMERICANA. Iilac flowers often 4 inches across. 2 feet $\ldots . \quad \ldots \quad \ldots \quad \ldots O$ O 2., $1.25 ; \neq 07 ., .40 ; .10$ Amerieana Alba. White. 2 feet … $\frac{1}{4} 0 z ., 75 ; .25$ For Prennial Centaneas, see Nos.6475-6485.

\section{CHRYSANTHEMUM.}

Frep-flowering hardy ammals blooming from July until frost, "specially desirable for seashore and mountain gurdens. 2 feet.

180 Farquhar's Special Mixture. Double and single; all the most beautiful varieties $\ldots$ Oz., $75 ; .10$

\section{SINGLE VARIETIES.}

1810 Morning Star. Delicate primrose color, 0z., .50;.10 1815̆ Evening Star. Bright golden-yellow, $\frac{1}{4} 0 z . .35 ; .15$ 1820 Lord Beaconsfield. (rimson edged gold, $\% \%, .40 ; .05$ 1825 Eelipse. Golden-yellow, with scarlet ring and brown $\begin{array}{lllllll}\text { dise } & \ldots & \ldots & \ldots & \ldots & \ldots & \text { Oz. .40;.05 }\end{array}$

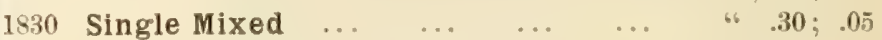

\section{DOUBLE VARIETIES.}

1835 Farquhar's Crimson $\ldots . \quad \ldots \quad \ldots \quad \ldots \quad 0 \%, 1.00 ; .10$

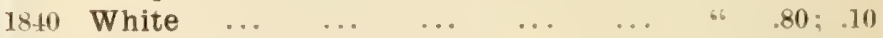

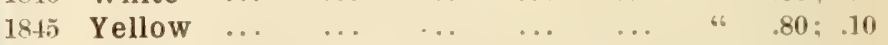

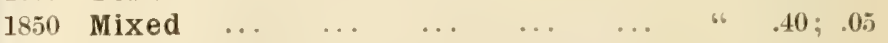
1855 Inodorum plenissimum. White. $1 \frac{1}{2} \mathrm{ft} ., \frac{1}{4} 07 ., .30 ; .10$ CINER ARIA.

White-leaved varieties. Dusty Minler.

1860 Maritima. Silvery-green lacinated foliage. 1 foot, Oz.., . $30 ; .05$

1865 Acanthifolia. Broad silvery-white leaves. 1 foot. Cineraria hybrida, see No.5435. $\frac{2}{6} 0 \%, .30 ; .10$ 


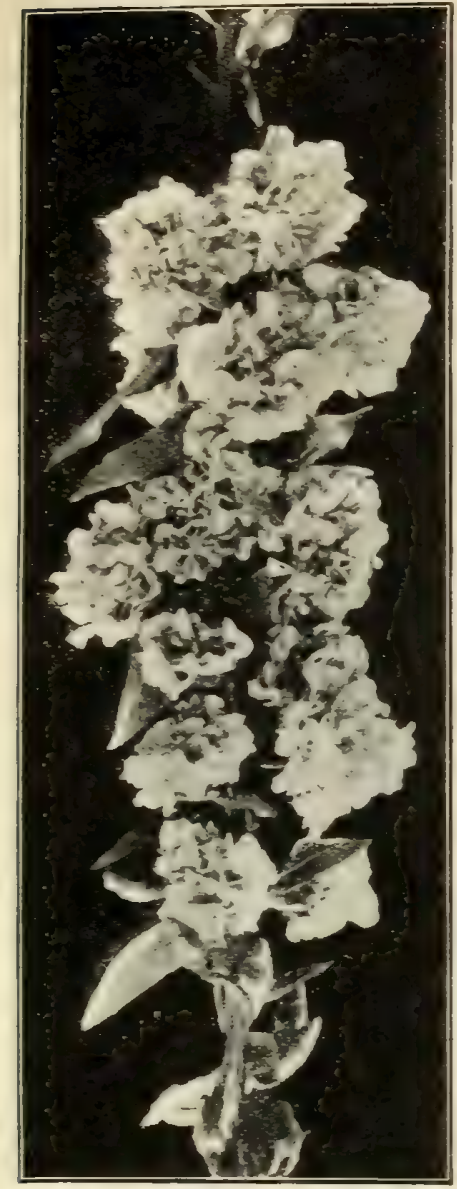

Clarkia elegans, Salmon Queen, No. I870

\section{Clarkia.}

These populai annuals are of easy culture, and in large masses are exceedingly bright and attractive. The long graceful sprays are valuable for table decoration. 1 foot.

\section{DOUBLE VARIETIES.}

1870 Salmon Queen. Long spikes; color Ptst. salmon-pink... ... ... Oz., .40;.10

1875 White Prince. Very large, pure white tlowers

1880 Mixed

Integripetala. Brilliant rose, $: 6$ 25; 05

1890 Pure White... $\quad \ldots . \quad \ldots \quad$ 6 $.30 ; .05$

1895 Mixed $26.25 \%$

1900) CLEOME PUNGENS. Spider Plant. A lobust garden anmual, with cluster's of rose-colored flowers borne in profusion. Fine for shubbers bolders, \pm ft., $\frac{1}{4} 0 z, .50$

\section{COLEUS.}

1905 New Large-leaved Varieties Mixed

1910 Finest Hybrids Mixed

\section{COLLINSIA.}

Charming annuals adapted to dry situations. $1 \mathrm{ft}$. 1915 Finest Mixed

$\mathrm{Oz} . .25$ :

\section{CONVOLVULUS.}

Early blooming hardy annuals, with very brilliant flowers. Excellent for seashore or mountain gardens. 1 foot.

1920 Minor Finest Mixed ... Oz., .25: .05

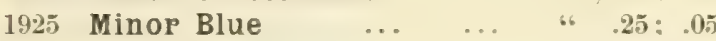
1930 Minor Rose Queen $\quad \ldots \quad$ แ $.25 ; .05$ Major, see Ipomœa, No. 5220 .

\section{COSMOS.}

'This is one of our most useful and beautiful autumn flowers. To get it in bloom early the seed should be sown in May in the open ground where the plants are desired to bloom, and the seedlings allowed to grow and flower without being transplanter.

1935 Farquhar's Early Hybrids Mixed. The earliest strain of Cosmos in existence. If sown in May in the open ground it usually blooms by the first or second week in July. 4 feet.

1940 Farquhar's Early Pink 1945 Farquhar's Early White Pkt. Fach of the above colors and mixed GIANT, or LATE-FLOWERING. 5 feet.

1950 Mixed..Oz...50:1 oz.. .15;.10 1960 Pink...Oz,.50; 10 oz.,.15;.10 1955 Red ... 6 .50; 66 .15; .10 1965 White..6 .50; "6 .15;.10

\section{DAHLIA.}

This popular plant can easily be raised from seed and flowered the same season. 3 feet.

19:-5 Caetus-flowered Mixed. Double and single flowers,

1930 Double Large-flowering Mixed,

198. Double Pompone Mixed ...

1940 Single Prize Mixed

$$
\begin{aligned}
& \text { Oz., 2.50: } \frac{1}{4} \text { oz., .75: .20 } \\
& \text { (6) } 2.50 \text { : } \\
& \text { "6 } 2.00 \text {; } \\
& 66 \quad .75
\end{aligned}
$$

\section{DATURA. Trumpet Flower.}

Ornamental annuals of rapid growth with large trumpet-shaped fragrant flowers. 3 feet.

1995 Arborea. Brugmansin. Pure white fragrant flowers frquently 12 inches long:

2000) Golden Queen. Golden-yellow, sweet-scented

2005

Cornueopia.

Horn-o with purple; fragrant

2010 Mixed
Plenty. Large double white flowers, marbled Oz., .50;. 10

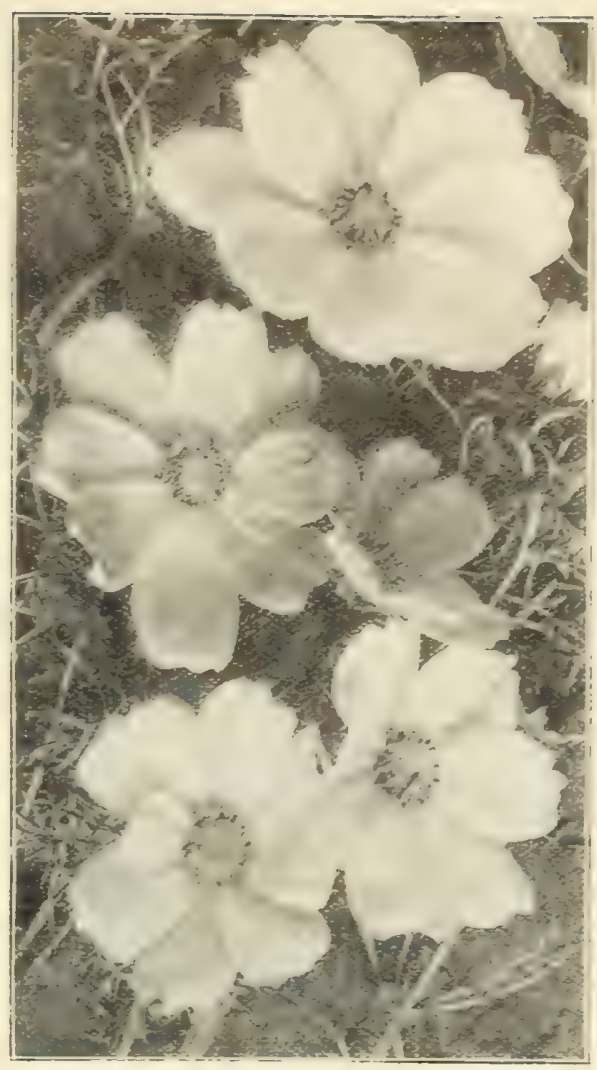

Farquhar's Early Flowering Cosmos. No. 1935

\section{CUPHEA PLATYCENTRA.}

Cigar Plant. A dwarf perennial adapted for bedding or as a pot plant. Small, scarlet and black, tubular flower's. 1 foot. 25 


\section{R. \& J. FARQUHAR \& CO., BOSTON. ANNUAL FLOWER SEEDS.}

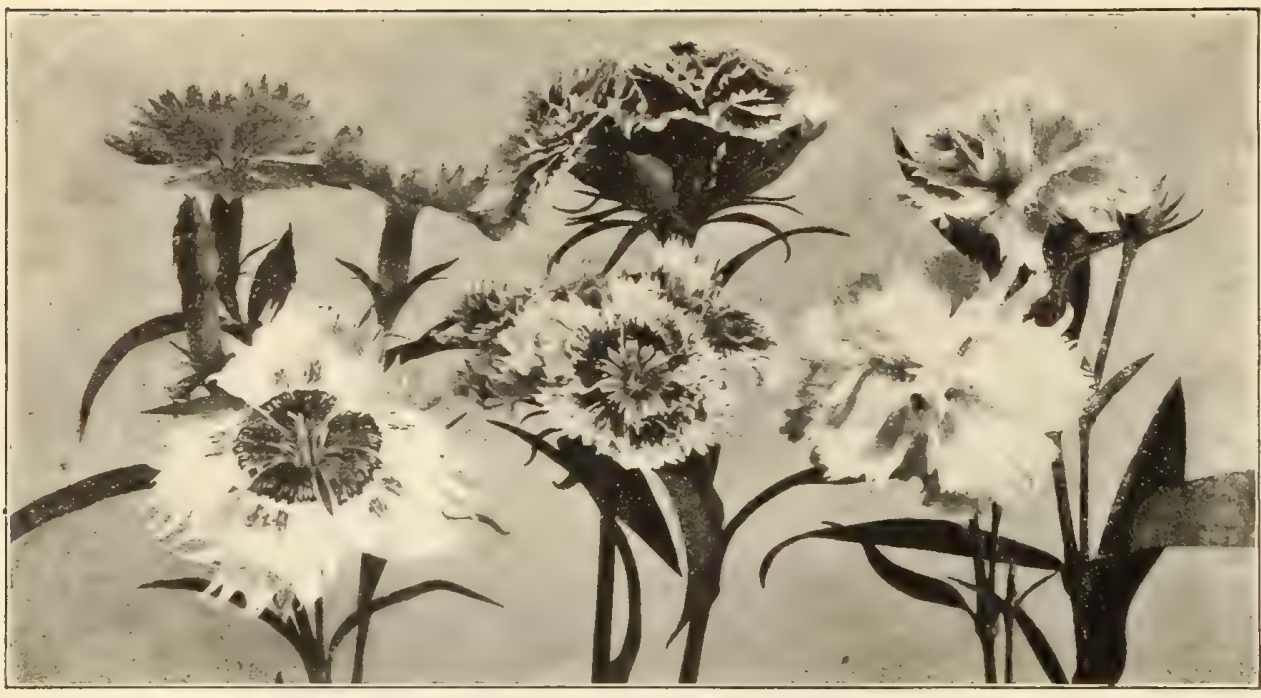

Dianthus Farquhar's Superb Mixed, No. 2095.

DIANTHUS. Indian Pink.

These magnificent hardy border plants deserve a place in every garden. DOUBLE VARIETIES.

2015 Heddewigi. Pure white. Large-fringed flowers

2020 Crimson. Brilliant shade

2025 Crimson with white edge. Mourning cloak

2030 Mixed

2035 Chinensis Mixed. From finest double flowers,

2040 Double Fringed Salmon. Salmon-pink; lovely

20.45 Double Fringed Mixed

2050 Diadematus Mixed. Diadem Pink. Large double flowers, varying in color from

lilac to crimson and maroon, with edges fringed and almost white, $\mathrm{Oz} ., 1.75 \quad \frac{1}{4} \mathrm{oz}, .50 ; .10$

2055 Imperialis Mixed. Imperial Pink. Variegated flowers of many colors, ${ }^{4}$., .50; .05

2060 Latifolius. Hybrids Mixed. A free-flowering type resembling the Sroet Willien, with double flowers, varying in color from rose to crimson and maroon,

2065 Nobilis Mixed. Royal Pink. A charming race of Pinks, of brilliant pure colors,

\section{SINGLE VARIETIES.}

Oz., $1.00 ; \frac{1}{4}$ 0z., .35;.10

2050 Heddewigi. The Bride. Beautiful white flowers, with a rosy purple eye,

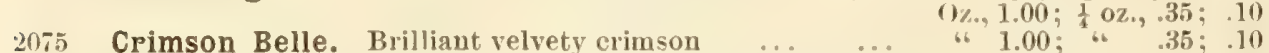

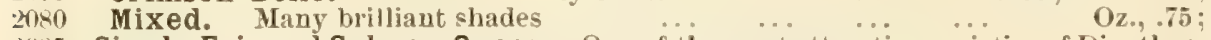

2085 Single Fringed Salmon Queen. One of the most attractive varieties of Dianthus.

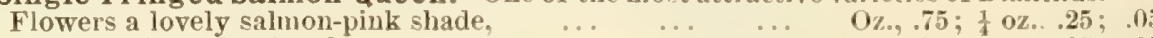

2090 Single Fringed Mixed

$.75 ; 66 \quad .25 ; .05$

2095. Farquhar's Superb Mixture. This mixture contains both double and single

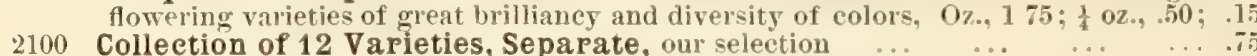

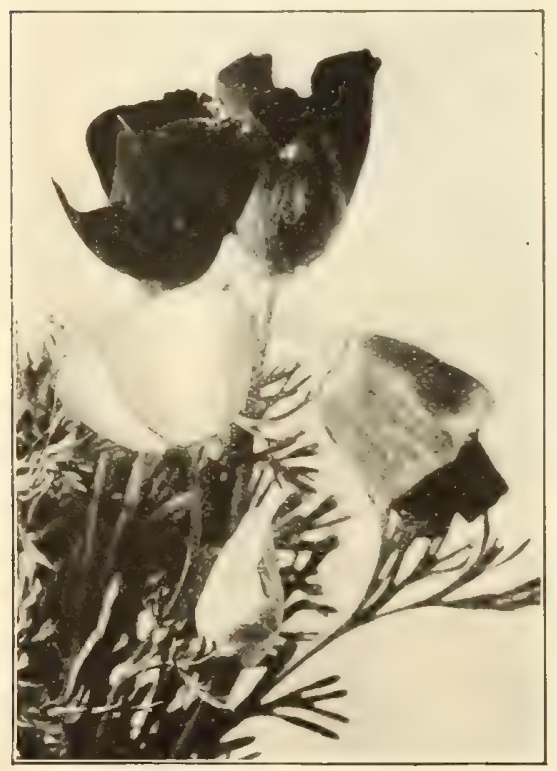

Eschscholtzia, No, 1552 .
ESCHSCHOLTZIA. California Poppy.

One of the best annuals, having delicate silvery foliage and large poppy-like flowers, runuing chiefly in shades of yellow. and is beautiful for borders and for large beds. 1 foot.

2115 Carmine King. Rosy-crimson, $\frac{1}{4} \mathrm{oz} ., 30 ; .10$

2120 Rose Cardinal. Pretty rose-coloredflowers,... ... ... Oz., .50; .05

2125 Golden West. Bright orange-yellow. Very large, ...
$\frac{1}{4} 1 \mathrm{lb}, . .75 ; 0 z ., .30 ; .05$

2130 Mandarin. Bright orange shaded with crimson, ... ... ... Oz., .50; .05

2135 Californiea. Yellow orange centre, $\frac{1}{1} \mathrm{lb} ., 75 ; 0 z, .30 ; .05$ 2140 Californica Alba. Pure white, $\mathrm{Oz}, 30.05$ 2145 Crocea. Large orange flowers, Oz., .30; .05 2150 2155 Mixed. $\frac{1}{4} 1 \mathrm{~b}, .75 ; 07 ., .30 ; .05$

Collection of 6 Varieties, Separate, our selection, It blooms profusely from June until frost.
ERYSIMUM. The plants resemble Wall-flower, and as cutflower's are indispensable. 1 foot.

2105 Arkansanum. Bright yel- Pkt. low ... ... Oz. .30; .05

2110 Perofskianum. Orange yellow, ... Oz., 30;.05

2160 EUPHORBIA Heterophylla. Mexicen Fine Plont. Showy plaut with glossy green leaves, which about midsummer become tipped with orange-scarlet. 2 to 3 feet, ... Or., 1.00; Variegata. Snow-on-theMountain. Foliage beautifully veined and margined with white. $2 \mathrm{ft} ., \mathrm{Oz}, .40 ; .05$

FEVERFEW. Matricaria Eximia. $21 \% 0$ Silver Ball. Double white; $1 \frac{7}{2}$ feet … \& oz., 30;.10 Golden Ball. Large heads of golden yellow flowers, .25

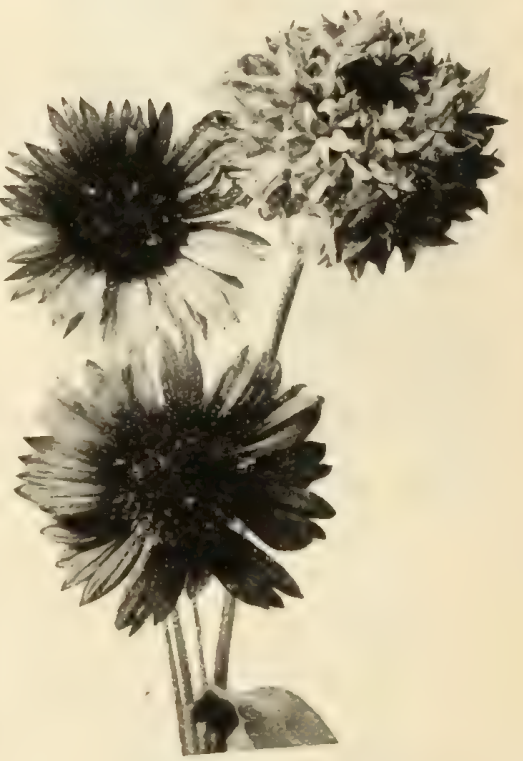

Gaillardia Single, No. 2180. Gaillardia Double. No. 2 rgo.

GAILLARDIA. T3lankit Flower. An exceedingly popular and showy annual, producing throughout the summer an abundance of large, handsome flower's; 2 feet.

2180 Farquhar's Large Sin- Pkt. gle Mixed ... Oz.,.30; .05

21\%5 Amblyodon. Deep red, single $\quad \mathrm{Oz} ., .40$;

2190 Pieta Lorenziana Double Mixed. Large heads of yellow and red flower's, $0 \% . .50 ; .05$

2195 Pieta Lorenziana Golden Gem. Double pure yellow ... Oz., .60;.05 For Perennial Gaillardias see Yos. 6785-6795.

2200 GAURA Lindheimeri. A graceful perennial, flowering the first season from seed and producing long sprays of white, red-tinted flowers. $2 \mathrm{ft}$. Oz., .40;

GILIA. Showy annuals much frequented by bees. 2205 Finest Mixed. $\mathrm{Oz}, .25 ; .05$ 
R. \& J. FARQUHAR \& CO., BOSTON. ANNUAL FLOWER SEEDS.

GLAUCIUM. Horned Poppy. A fine class of plants, remarkably free-flowering and with beautiful glaucous foliage. 2 feet.

2210 Flavum tricolor. Orange, scarlet and black

\section{GODETIA.}

Splendid hardy annnals with large mallow-like flowers, varying from pure white to all shades of pink and crimson. They grow rapidly, flower abundantly, and are exceedingly showy. For displays at the seashore or in the muuntain they are unsurpassed. 1 fout. 2220 Duehess of Albany. Satiny-white flower

2225 Gloriosa. A very showy and effective variety, with deep crimson flowers, "60;

2230 Lady Satin Rose. Rich rose-pink

2235 Double Rose. Long sprays of large, double, rose-colored flowers. One of the

best varieties for eutting

2240

\section{ORNAMENTAL GRASSES.}

2245 Avena sterilis, $1 \frac{1}{2}$ feet ... ... 05

2250 Briza graeilis. 1 foot 0 z.,. $40 ; .05$

22555 Briza maxima. 1 foot " $.40 ; .05$

2260 Bromus Brizæformis. 2 feet ... .05

2265 Coix Lachryma ... Oz., .25; .05

2270 Cyperus alternifolius. 2 feet... .25

2275 Cyperus Papyrus. Eyyptiun P'up'

Plant. 6 feet. .

2280 Hordeum Jubatum.

2285 Isolepis graeilis

2295 Pennisetum longistylum. $2 \mathrm{ft}$.

2300 Ruppelianum. 3 feet $\mathrm{Oz}^{\circ} .40$;

2310 Uniola latifola. 3 feet

2315 Zea Japonica variegata. $5 \mathrm{f} f \mathrm{et}$

Oz...10:

2320 Zea gracillima variegata. $+\mathrm{ft}$

Oz., .10;.05

2325 Zea Quadricolor ... 6 . $20 ; .10$

2290 Lagurus ovatus

Oz. $30 ; .05$

2330 Ornamental Grasses Mixed.

Prrennial varieties, see Nos.6850-6890.

GYPSOPHILA. Baby's Breath.

Pretty free-flowering annuals, with extremely light, feathery flowers; useful for bouquets. $1 \frac{1}{2}$ feet.

2335 Elegans. Pure white

2340 Elegans Rosea. Delicate pink

2:3t5 Muralis. Rose-colored flowers, suitable for rockwork. 9 inches

$0 z ., 25 ; .05$

Oz...25;.05

weed; flowers bright yellow. $1 \frac{1}{2}$ feet Perennial varieties, see Vos.6905-6915.

\section{HIBISCUS. Mallow.}

2355 Afrieanus. A free-growing hardy annual, with rich yellow flower's and purple centre 2 feet

$$
\text { For other varieties, see \os. 5685. 6955-6975. }
$$

Oz. .25; 05

\section{HOLLYHOCK.}

This strain blooms the first year from seed. The plants branch freely and continue to flower throughout the summer. The seeds may be sown in a hot-bed in February.

2360 Double Annual Varieties. Mixed

236 5 Single Annual Varieties. Mixed

$$
\text { For Biennial varieties, see Mos, 6980-7069. }
$$

HUNNEMANNIA. Giant Yellow Tulip Poppy, or Bush Eschscholtzid,

23:0 Fumarirfolia. The flowers are of a rich shade of huttercup-yellow with feathery glaucous foliage. 2 feet

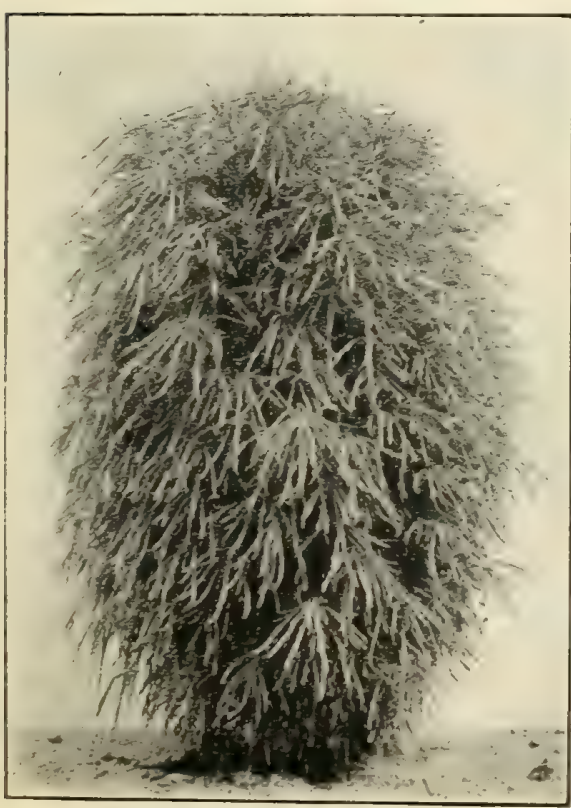

Kochia Trichophila, No. 2375 ,

\section{KOCHIA Trichophila.}

Summer Cypress, or Belvidere.

2375 A rapid growing annual of pyramidal habit with slender green leaves, turuing to bright red in the autumn. $3 \mathrm{ft}$.,

\section{LARKSPUR.}

Farquhar's Invincible. $2 \mathrm{ft}$. This strain is most valuable for cut-flower use. It is advisable to sow at intervals for a succession of bloom.

2380 Rosy Searlet. A superb and popular color

2385 Royal Purple .10 2390 Pink

2395 Flesh-Color 102400 Light Blue 2405 Lilae

102410 White

Each of the above colors, except otherwise priced, Oz.. .50; $\frac{1}{4} \mathrm{oz} ., .15$.

2415 Mixed

2420 Collection of 6 Colors, Separate, our selection

2425 Larkspur Butterfly. A dainty annual with bright blue flowers. Splendid for cutting. 1 foot

2430 Larkspur Tall Rocket Mixed. Iong showy spilies. 2 foet, (1) .30): (1) 2435 Larkspur Dwarf Rocket Mixed. The ealliest of all, lallwe -nike- of dumbe flowers. 1 foot.

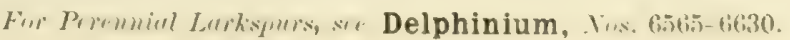

Larkspur Farquhar's Invincible, No. 2420.

$\mathrm{Oz}, .50 ; .10$ $\mathrm{Oz}, .30 ; .05$

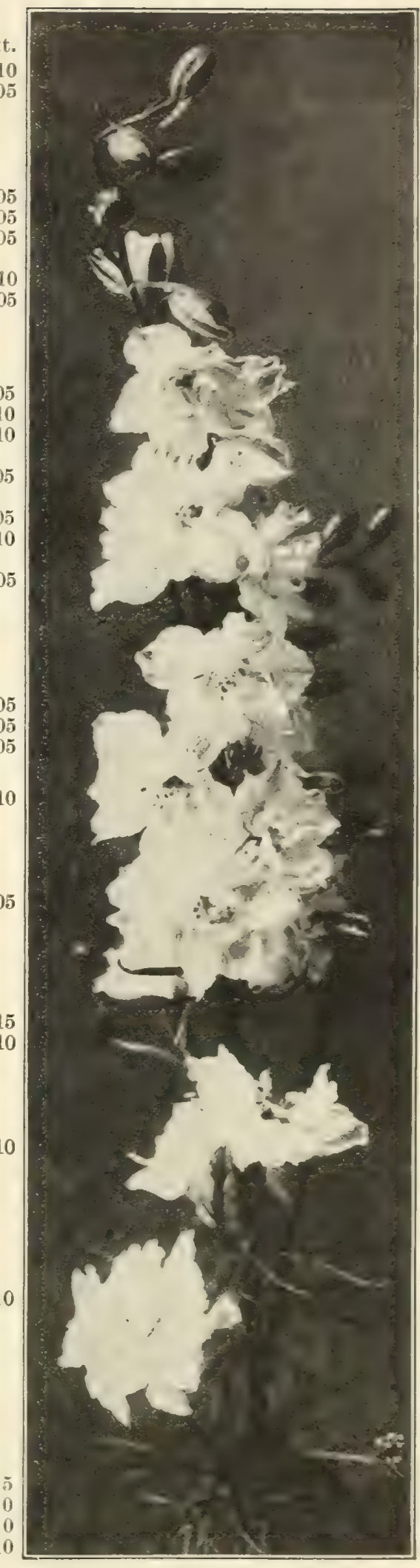

.

20

1,3 


\section{R. \& J. FARQUHAR \& CO., BOSTON. ANNUAL FLOWER SEEDS.}

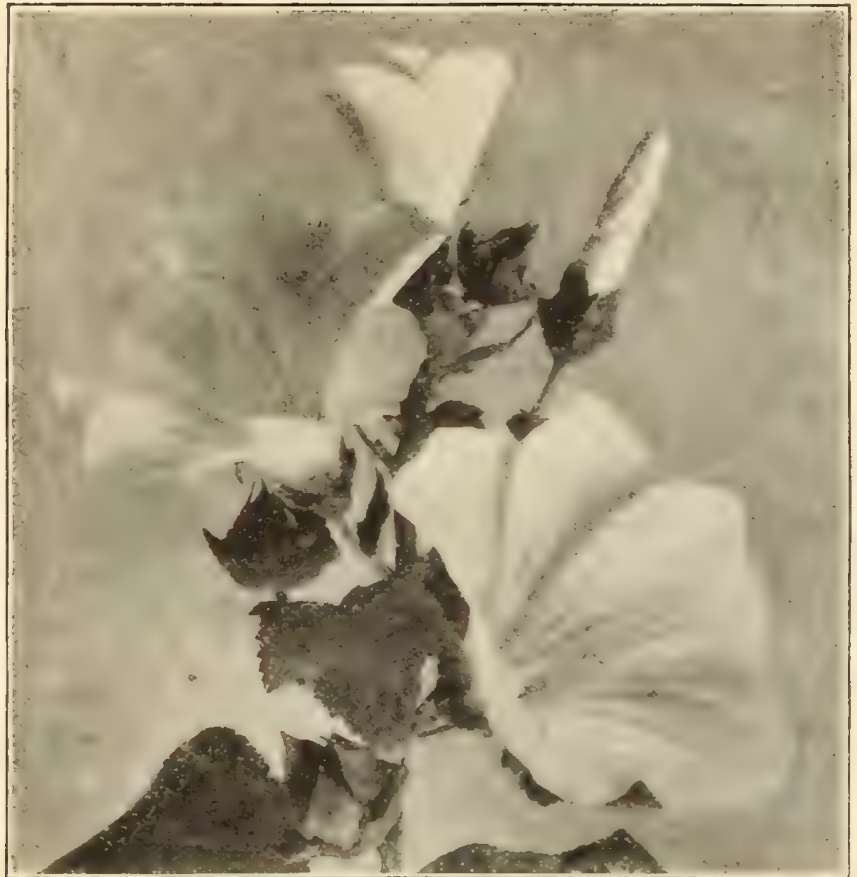

Lavatera Rosea splendens. No. 2245.

240 LAVATERA. Arborea Variegata. Tir Wul, Excellent for sub-tropical beds. Large ornamental leaves piofusely mottled with yellow and white. Pkt. 4 feet. $\quad \ldots \quad \ldots . \quad \ldots \quad \ldots . \quad 0 \%, 1.00 ; .10$

245 Rosea Splendens. Large flowers of brilliant rosy-pink; superb for cutting. $3 \mathrm{ft}$., Oz., .60;.10

2450 Trimestris Pink. Useful for planting in masses or tor cut flowers. 3 feet ... $\quad . . \quad 0 \%$. .30; .05

2455 Trimestris White. . . . . $\quad \ldots \quad$ “ $\quad .30 ; .05$

2460 Trimestris Red. . . . . . . 6 . $.30: .05$

2465 LEPTOSYNE Maritima. Large lemon-yellow flowers rasembling Marguerites, borne on long stems; fragrant and good for cutting. 2 feet

2470 LINUM. Grandiflopum rubrum. Srartet Flas. Valuable for bedding; flowers bright scarlet. $1 \mathrm{ft}$.

$0 z ., .30 ; .05$

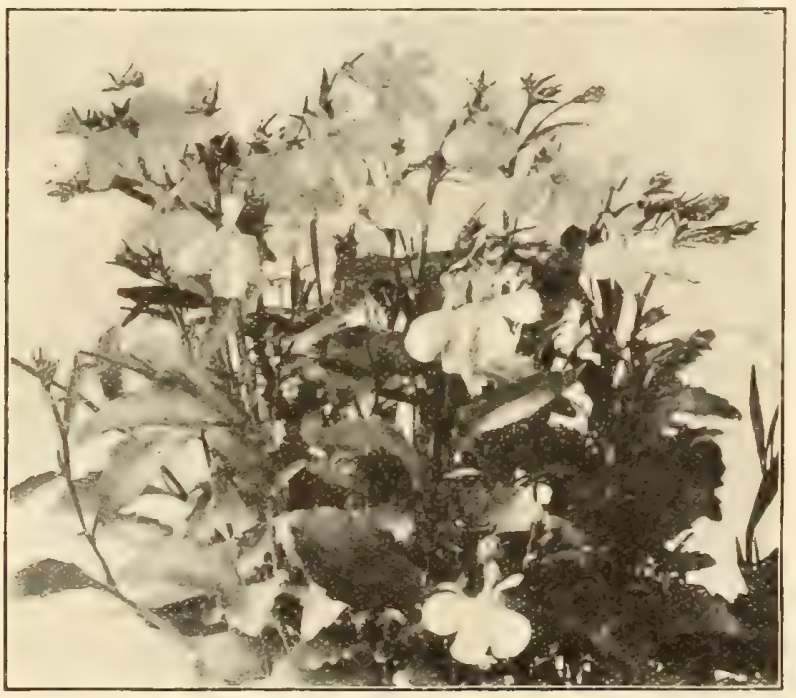

Lobelia Farquhar's Dark Blue, No, 2490.

LINARIA. Tand Flor.

Attractive annuals, useful for bouquets. 1 foot.

2475 Farquhar's Pure White. The long sprays of this Pkt. variety are especially good for cutting ... ... . . . 10

2480 Purple and Gold. A very pretty variety for cut flowers, .10

2485 Maroecana Exeelsior. Varied and beautiful flowers, ranging from white to yellow, pink and blue ... ... .

\section{LOBELIA.}

2490 Farquhar's Dark Blue. The finest dwarf blue Lobelia for bedding. The plants are compact and covered with a profusion of flowers. For earpet beds this variety is unsurpassed. 4 inches $\quad \ldots \quad \frac{1}{4} 07 ., 1.00 ; .25$

2495 Farquhar's Azure Blue. A compact sort, with lovely pale blue flowers popular for edgings. 4 inches,

$+0 \%, .60 ; .10$

2500 Ereeta Crystal Palace Oppight. A bushy-growing variety with dark blue flower's $\ldots . \quad \ldots \quad \frac{1}{4} 0 z, 1.00 ; .20$

2505 Gracilis. A favorite loose-growing sort extensively used for hanging-baskets and vases. Flowers deep blue,

$(1 \%, .75: .0 \%$

2510 Speciosa. Crystal Palace Varicty. Dark blue of spreading growth. Suitable for wide edgings. 6 in. $10 \% .40 ; .10$

2.515 Tenuior. A chamming species srowing a foot in height and bearing numerous bright cobalt blue flowers, with white eye

$\$ 07 ., .60 ; .10$

2520 White Gem. Pure white. $t$ inches.

\section{LUPINUS. Lupin.}

The Lupins are among the most useful of our garden flowers and with their long graceful spikes of pea-shaped blooms in various combinations of red, white, yellow and blue, make a gorgeous display in large beds or borders. 2 to 3 feet.

2525 Hartwegii. White. Splendid for Pkt. bourguets

$0 \% .25: .05$

25:30 Haptwegii. Azure blue. A delicate shade esteemed for cut Hower:

(1)..., $\div:$

253. Farquhar's Pink. This variety is one of the prettiest aunual solts producing handsome spikes of salmon-pink flowers. The flowers are particularly useful for eutting, lasting a week or longer in water. 'This color is ideal for foreing in the greenhouse

Oz., .50;.10

25 40 Royal Blue. Flowers a rich deep blue, $0 \% . .60 ; .10$

2.5t Cruickshanki. Blue and yellow: very attractive $\ldots \quad \ldots \quad 0 \%, .30 ;$

25.50 Hybridus Atroeoceineus. Magnificent variety with large spikes of scarlet flowers tipped with white,

Oz., 30 ;

Mixed

6 $\quad .25 \quad .05$

Perennial Lupins, see Nos. 7165-7190. .05

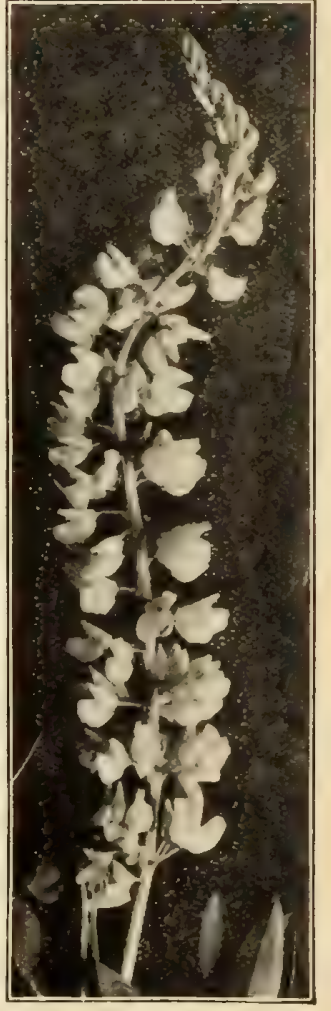

Lupin Farquhar's Pink. No, 2535 . 
R. \& J. FARQUHAR \& CO., BOSTON. ANNUAL FLOWER SEEDS.

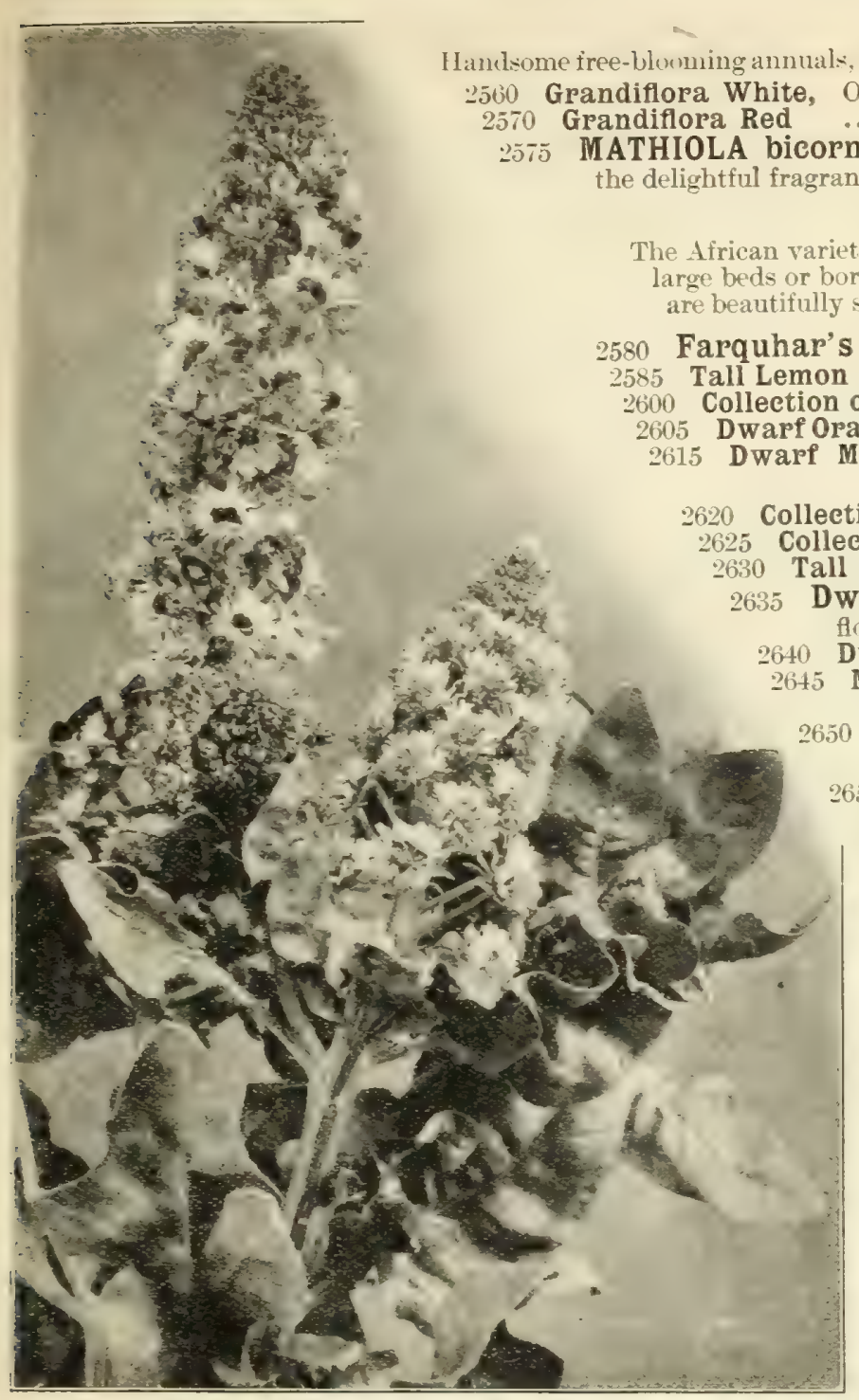

Farquhar's Giant Mignonette

MIGNONETTE. Reseda odorata.

2685 Farquhar's Giant. A robust-growing variety with $\mathrm{Pk}$ enormous flower spikes of a rich reddish-green color and delightfully fragrant. Sown out of doors it produces trusses of the largest size and is prized at the summer resorts for cutting. For forcing in the greenhouse it is unsurpassed

Oz., 1.50 ; $\frac{1}{4}$ oz., .50;

Improved Machet. This strain has been obtained through careful selection for a number of years by a specialist in Europe. It is of strong growth and very hardy, producing dense trusses of reddish-green flowers; very

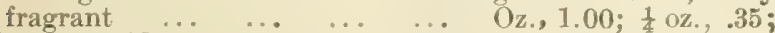

Crimson King. A new variety with immense spikes of deep red flowers deliciously fragrant. One of the finest varieties for the greenhouse

2700 Allen's Deflanee. The spikes of this variety when wellgrown in the greenhouse frequently measure from 12 to 15 inches in length and are very fragrant $\ldots \mathrm{Oz}_{\text {. }}, .50$; Machet. A popular sort with reddish-tinted flowers which are exceedingly sweet-scented. Splendid for general use,

$\mathrm{Oz},, .50 ; .10$

2710 Golden Queen. The best yellow variety; flowers tinted golden-yellow; fragrant ... ... ... ... Oz, .75;

2715 Giant Pyramidal. Large trusses of reddish flowers, extremely fragrant; one of the best for out-door cultivation, $\mathrm{Oz}, .30 ; .05$

2-20 Parson's White. Splendid spikes of whitish flowers;

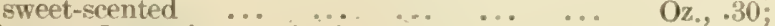
Large-flowering. The best form of old-fashioned sweet Mignonette $\quad \ldots \quad \ldots \quad$ Lb., 1.25 ; ll lb., .40; oz., .15;
MALOPE. Mallow.

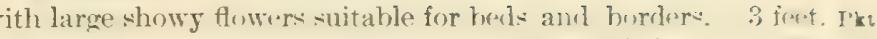
2265 Grandiflora Pink, Oz., .25; Oz. . $25 ; .03$

Vight-scented Stork. This hardy annual is dwairable for

MARIGOLD.

produce large self-colored blossoms and are very effective in

The French have smaller flowers and
DOUBLE AFRICAN. 3 feet.

\section{Eldorado Mixture. Enormous flowers}

$$
\begin{aligned}
& \therefore \quad \mathrm{O}_{4}, .60 ; .10 \\
& \text { Each, } 0 \%, .60 ; .05
\end{aligned}
$$

6 Varieties Separate, imported

DOUBLE FRENCH.
of 12 Varieties Separate, imported

of 12 Varieties Separate, imported

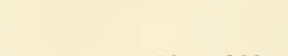

Tall Single Striped. Yellow, with rich brown markings. Splendid for cutting. 2 feet …
Legion of Honor. Flowers

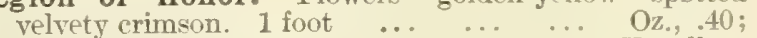

2665 Miniature Golden-yellow. Signata pumila. Excellent for edgings. 9 inches $\quad . . \quad \mathrm{Oz} ., .75 ; \frac{1}{4}$ oz., .25 ;

\section{MESEMBRYANTHEMUM.}

2670 Crystallinum. Ice Plant. Half-hardy amnual, with thick succulent leaves which are covered with sparkling ice-like globules; flowers white. 6 inches

2665 Trieolor. Dwarf annual adapted for dry sunny situations; flowers crimson, pink and white. 3 inches ... flowers rosy-purple; suitable for carpet bedding

2730 MPMOSA Pudiea. Sensitive Plant. An interesting annual with rosy-lilac flowers. The leaves close when touched. $\begin{array}{llllllll}1 \frac{1}{2} \text { feet } & \ldots & \ldots & \ldots & \ldots & \ldots & \ldots & \mathrm{Oz} ., \\ .60\end{array}$

2735 MIRABILIS. Marvel-of-Peru, or Four o'clock. Splendid half-hardy annuals snitable for large beds and borders. Finest Mixed. 2 feet Lb., $.5 ; 0 z, 10$; .0

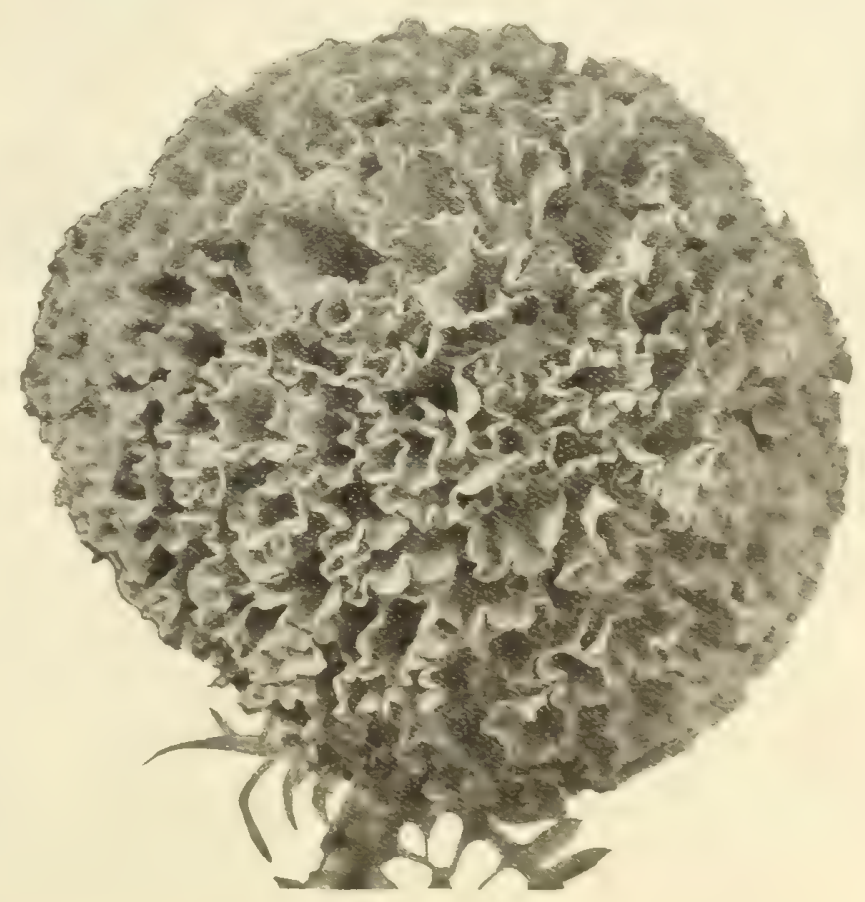

African Marigold Eldorado. 


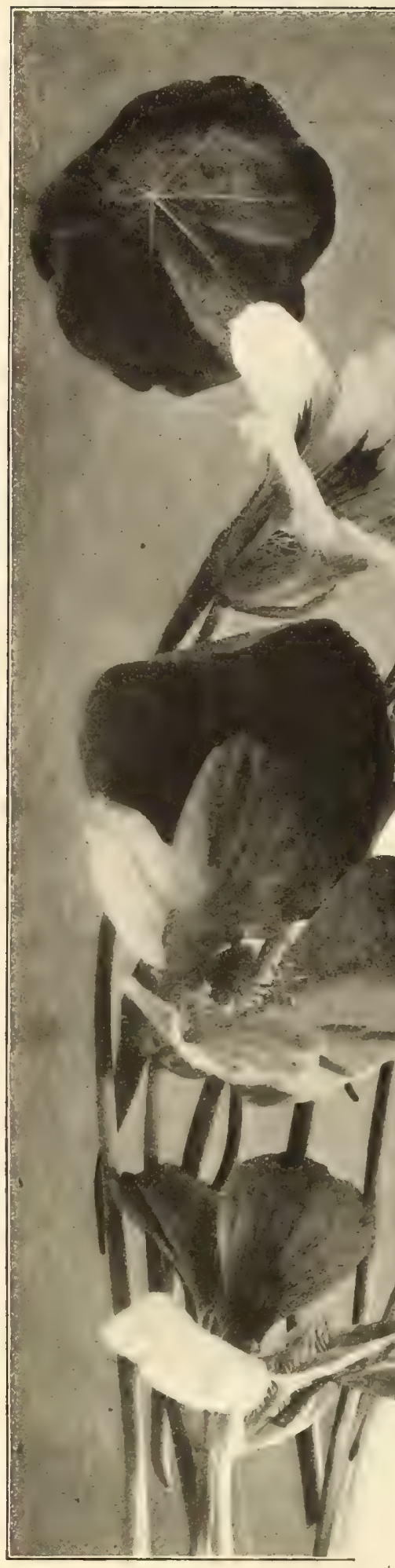

\section{NASTURTIUM.}

DWARF VARIETIES.

These hardy annuals are of easiest cultivation, suceeeding best in rather light soil, withstanding heat and drought and flowering profusely throughout the summer. The dark leaved varieties are particularly adapted for ribbon beds and borders. 1 foot.

2740 Farquhar's Rainbow Mixture. This splendid mixture is composed of the very choicest large-flowering varieties in charming combinations of color and which for size and beauty of flower is unsurpassed ... L Lb., 1.50; 1 lb., .50; oz., .20; 2745 Aurora. Chrome yellow; lower petals veined with dark earmine, Oz., 15; .05 2750 Brilliant. Dark scarlet, Oz., .20; .05 2755 Bronze. Burnished bronze color $\quad . \quad .$. Oz.,.15; Pkt. 760 Chammleon. Pale yellow, $\mathrm{Oz}, .20 ; .05$ 2765 Crystal Palace Gem. Primrose colored flowers, blotched maroon … ... Oz., .15; .05 2770 Dark Crimson. Rich dark shade Oz.,. $15 ; .05$

2775 Empress of India. Deep crimson; rich dark foliage, $\mathrm{Oz}, .25$; Golden KIng. Fine deep yellow; dark foliage ... ... ... Oz, .20; ;

King of Tom Thumbs. Glowing scarlet with dark foliage ... $\mathrm{Oz}_{.}, .20$;

2790 King Theodore. Flowers maroon; dark foliage ... ... O Oz.,.20; .05

279.5 Peach Blossom. Light shade of pink, Oz., .15; .05

2800 Pearl. Creamy white; attractive shade ... ... ... Oz...15; .05

2805 Queen of Tom Thumbs. Rich bright crimson; leaves variegated green and white ...... Oz., .40;

2810 Ruby King. Flowers ruby-red with dark leaves ... ... Oz., .20; 0
05
05 5 5 5

5

j

5

5


TALL NASTURTIUM.-Continued.

2860 Brownish Lilae ...

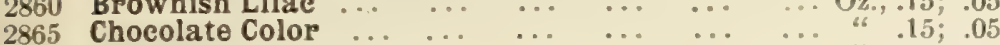

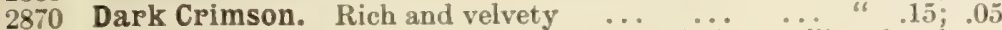

2875 Ivy-Leaved. Bright crimson-scarlet with dark metallic colored leaves; useful for hanging baskets and vases $\quad . .0 \mathrm{Oz}, .25 ; .10$

2880 King Theodore. Deep maroon; dark foliage .. " .20; .05

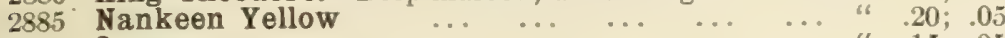

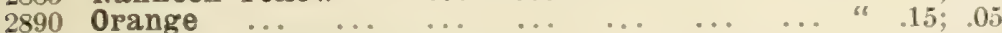

2895 Pearl. Creamy white ... ... ... ... . . « $4.15 ; .05$

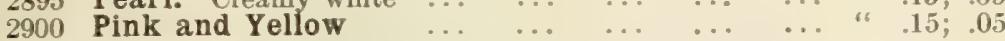

2905 Farquhar's Salmon Pink. Glowing salmon-pink flowers with fine dark foliage $\ldots . \quad \ldots \quad \ldots \quad \frac{1}{4} 1 \mathrm{~b}, 0.60 ; 0 \mathrm{oz}, .20 ; .10$

2910 Scarlet 0 " $.15 ; .05$

2915 Spotted. Straw-color spotted with crimson ... ... " $45 ; .05$

2920 Yellow. Light yellow ... . . . . . . . . “ . .15;.05

2925 Mixed. A superb mixture embracing many colors L.b., 1.00;

2930 Collection of 12 varieties separate

1 lb., .30; oz., .10;.05

2935 Collection of 6 varieties separate

LOBB'S NASTURTIUM. Tropaolum Lobbiunum.

An exceedingly free blooming race embracing the most brilliant colors, with neat dark green or purplish foliage, climbing about eight feet. Excellent for window boxes, vases, hanging baskets, and rockeries; also the most satisfactory class for conservatory or house cultivation during winter.

2940 Asa Gray. Creamy white; very attractive shade ... Oz., 25; 10

2945 Atropurpureum. Deep crimson " " $20 ; 10$

2950 Auroum. Pure golden yellow ... ... ... . . " " .25; 10

2955 Black Prince. Velvety-black, dark foliage ... … “

2960 Cardinal. Cardinal-red " .25;.10

2965 Due de Vicence. Pale lemon-color ... ... . . “ “ $.25 ; .10$

2970 Geant des Batailles. Sulphur yellow with carmine " $.25 ; .10$

2975 Lucifer. Rich dark scarlet ... .. . . . . " . .25;.10

2980 Princess Victoria Louise. Creamy white with orange-scarlet

blotches $\quad . . . \quad \ldots \ldots$. . . Oz., .20;.10

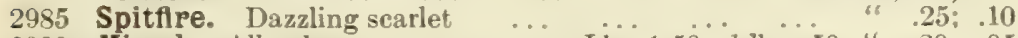

2990 Mixed. All colors … Lb., $1.50 ;+1 \mathrm{lb} ., .50 ; "$ ".20; .05

2995 Collection of 10 separate colors

3000 Collection of 6 separate colors

\section{NEMESIA, Strumosa Suttoni.}

A splendid annual for small beds with very attractive flowers. The colors include white, yellow, orange, pink and crimson.

3005 Finest Mixed

\section{NEMOPHILA.}

Splendid free-flowering, dwarf hardy annuals, with cup-shaped flowers of many bright colors, the blue shades being particularly fascinating. They should be planted in moist soil, partial shade being favorable. $1 \mathrm{ft}$. Pkt.

3010 Finest Mixed. Including white, lilac, brown and many shades of blue

3015 Insignis. Beautiful light blue

Oz., .25;.05

NICOTIANA. Half-hardy annuals.

3020 Affinis. An extremely free and continuous blooming Tobacco with clusters of white tubular flowers, 'fragrant in the morning and evening. 3 feet

$\mathrm{Oz}, 50$;

3025 Affinis Hybrida Mixed. Flowers similar in shape to the Affinis and sweetly scented; the colors varying from creamy-white to mauve and violet including also shades of rose. The finest of the section. 3 feet

3030 Sanderæ. An excellent variety for planting in large beds or borders giving a continuous display of bloom until late in the season; color brilliant carmine-red. 3 feet … Oz, 50 ;

3035 Colossea. Magnificent foliage plant attaining a height of five or six feet with leaves two feet in length and a foot in width; valuable for sub-tropical beds

3040 Sylvestris. A handsome plant of pyramidal habil with glaucous leaves and large drooping clusters of pure white tube-shaped flowers which remain fully expanded throughout the day, fragrant. 4 to 5 feet. Valuable for sub-tropical effects, Oz., .50;

\section{NIEREMBERGIA.}

Half hardy perennials of light and slender growth with large cup-shaped flowers, blooming the first year if sown early. 1 foot.

3045 Frutescens. White tinted with lilac

3050 Gracilis. Purple and white

$$
\text { NIGELLA. Love-in-a-Mist. }
$$

Interesting hardy annuals with finely cut foliage and curious flowers.

3055 Miss Jekyll. The flowers of this attractive plant are of a beautiful shade of cornflower blue, a color seldom seen in annuals. For cutting this variety is unexcelled $\quad \mathrm{Oz} ., .75 ; 1 \mathrm{oz} ., .30 ;$

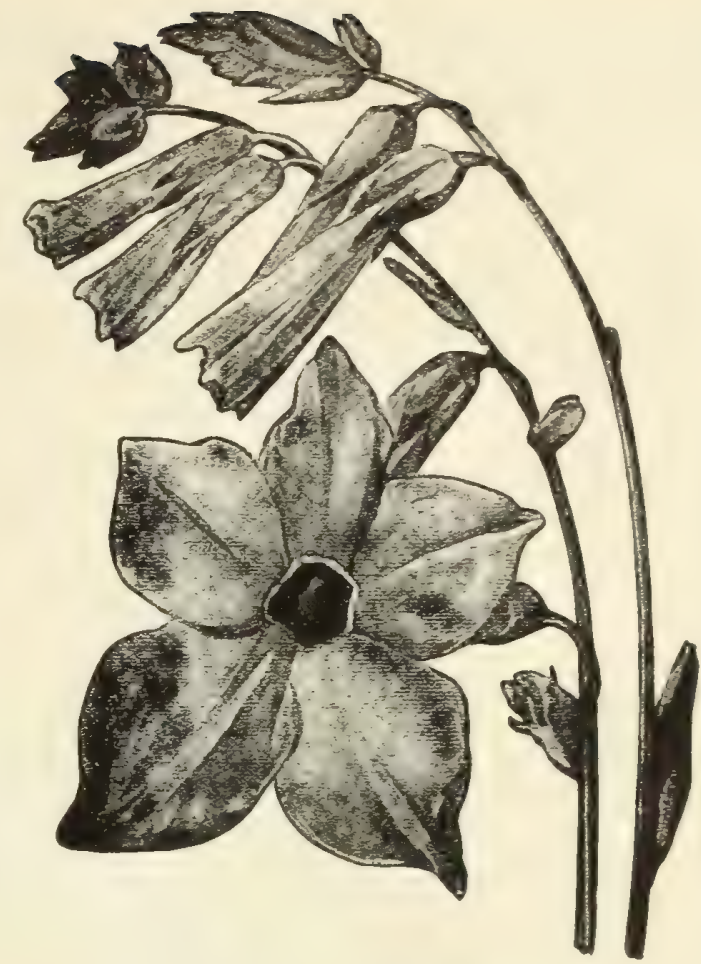

Nicotiana Affinis Hybrida Mixed.

ENOTHERA. Evening Primrose.

3070 Acaulis. Hardy annual with large silverywhite flowers, 6 inches ... ... $\$$ oz., .30; .10

3075 Bistorta Veitehil. Bright yellow flowers spotted with crimson. 1 foot, $\quad+$ oz., .25; . 10 For Perennial varieties see 7320-7335.

OXALIS tropæoloides.

3080 Splendid dwarf bedding plant with dark brown foliage forming a dense mat, the tiny yellow flowers being inconspicuous; excellent for mosaic bedding. 4 inches ... $\frac{1}{4}$ oz.. 50; 15

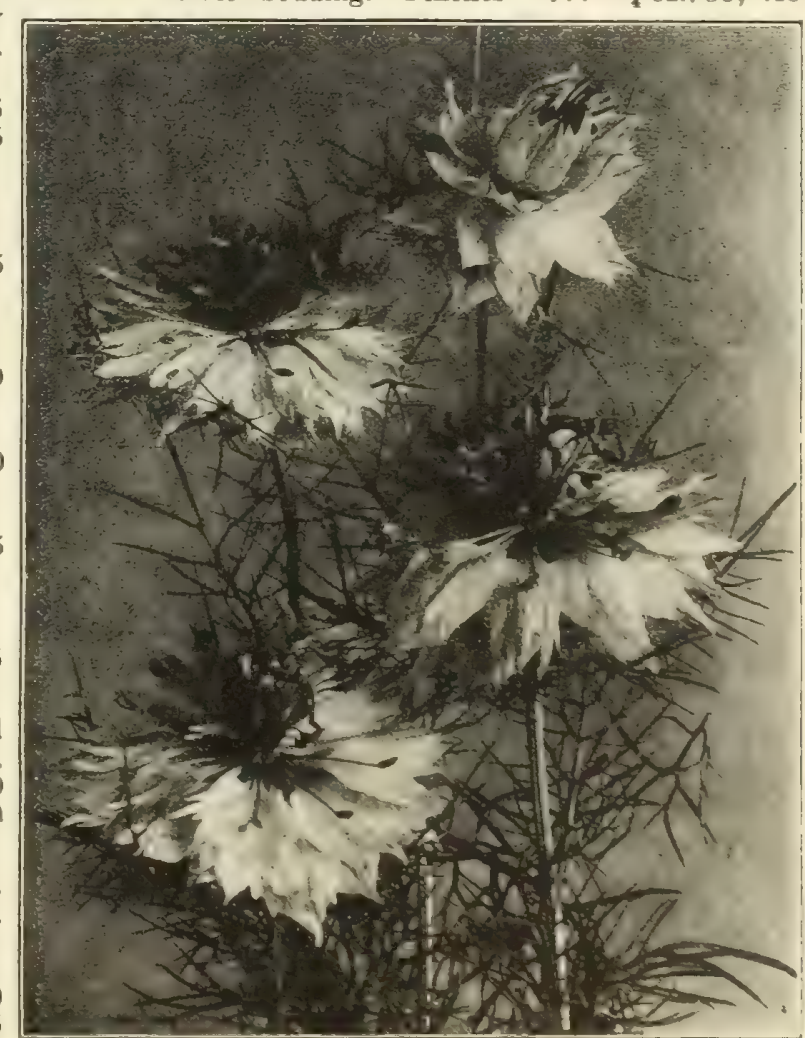

Nigella, Miss Jeky 1 . 


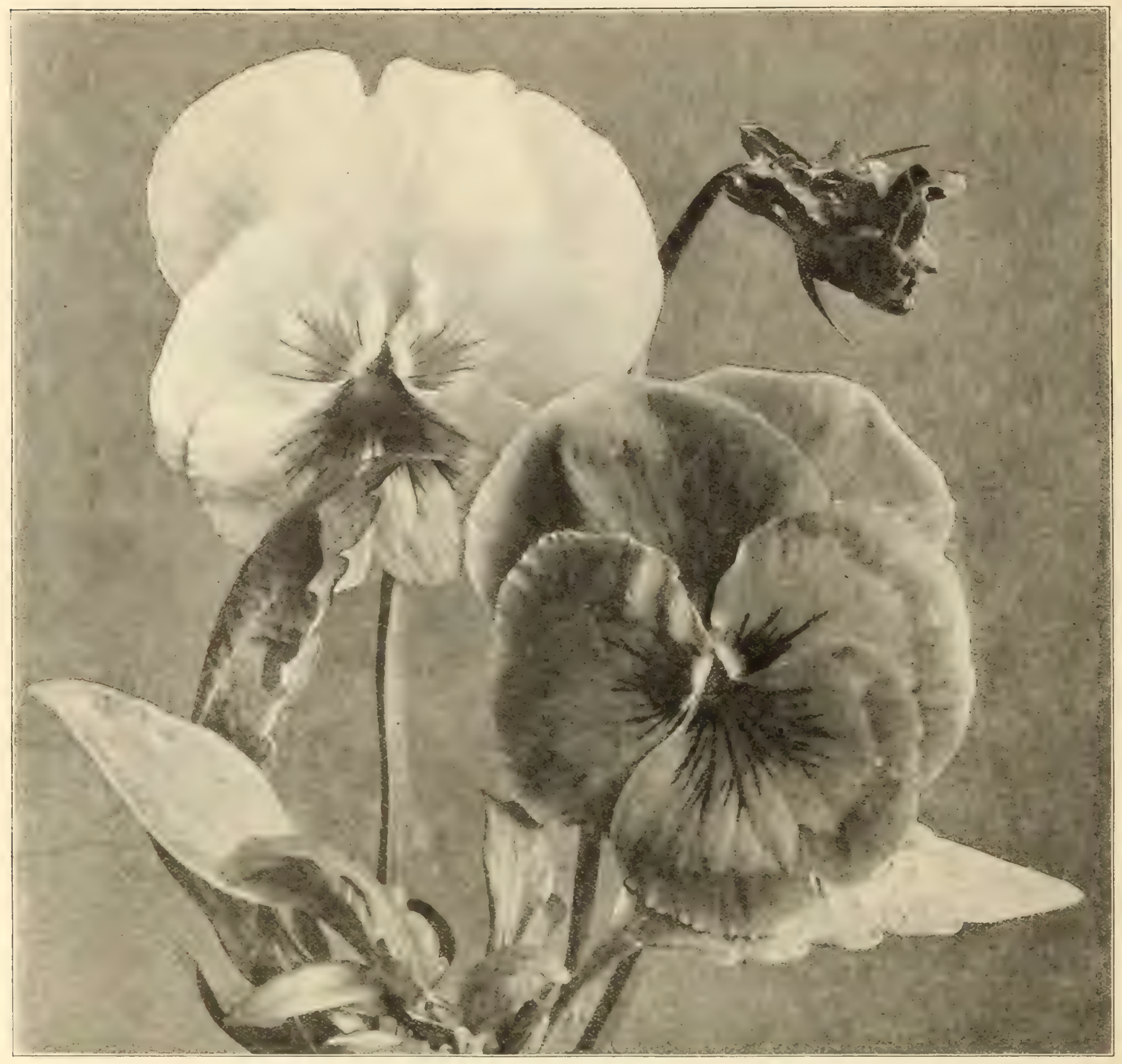

\section{FARQUHAR'S FINEST SHOW PANSIES.}

3085 Farquhar's Finest Show Strain, Mixed. This is a superb mixture of the largest and best types in an immense variety of brilliant colors Finest Show Strain, Mixed

$\ldots \quad \ldots \quad \mathrm{Oz}, 12.00 ; \frac{1}{\mathrm{oz}}, 3.50 ; \frac{1}{8} \mathrm{oz}, 2.00 ;$ packet of about 250 seeds, .50
$\ldots$

$\ldots \quad \ldots \quad \mathrm{Oz}, 12.00 ; \frac{1}{\mathrm{oz}}, 3.50 ; \frac{1}{8} \mathrm{oz}, 2.00 ;$ packet of about 250 seeds, .50
$\ldots$

3090 Farquhar's Finest Show Strain, Mixed frame culture this variety is unexcelled, producing flowers of great size and perfection. It is equally good out of doors. Pkt., 1.00

3100 Special Mixture. Embracing the leading strains, all grown by specialists in Europe and including the finest colors and markings in endless variety. This mixture is extensively used by florists

$\mathrm{Oz} ., 5.00 ; \frac{1}{1} \mathrm{Oz} ., 1.50 ;$ Pkt., .25

3105 Cassier's Giant Mixture. An excellent strain for outdoor or greenhouse cultivation. The plants are of sturdy growth, producing large round flowers, beautifully blotched. The colors are rich and varied ... ... Oz.,5.00; $\frac{1}{4} \mathrm{oz} ., 1.50 ; \mathrm{Pkt}$., .25

3110 Bugnot's Large Blotehed. Finely formed flowers of rich and brilliant colors ... ... ... ...

3115 Madame Perret Giant Hybrids. A new and beautiful race with giant flowers borne on long stems. The colors are mostly rich red and wine shades

Oz., 6.00; $\frac{1}{8}$ oz., $1.00 ;$ Pkt., .25

3120 Masterpiece, Mixed. Frilled Pansy. A large flowering type with beautifully curled or waved petals; very attractive,

3125 Fine Mixed. Many colors ... ... ... . . . . . . . . . . . . . . . . . Oz., 1.00; oz., 1.00; Pkt., .25 Culture of Pansies:- Pansies thrive best in a cool, moist, but well drained soil, enriched with well rotted barnyard manure or fine ground
bone. Seeds sown in spring in a partially shaded situation will produce fine plants for autumn flowering. The finest blooms are to be obtained, however, by sowing in July or August, giving the plants protection during winter, when they will bloom profusely in the spring and summer. 


\section{R. \& J. FARQUHAR \& CO., BOSTON. ANNUAL FLOWER SEEDS.}

PANSIES, GIANT OR TRIMARDEAU.

3130 Emperor William. L'tramarine blue; the finest dark blue variety $\ldots . \quad \ldots \quad \ldots \quad \mathrm{Oz}_{.}, 2.00 ; \frac{1}{4} \mathrm{oz} ., .60 ; .15$ Queen of the Blues. Lavender blue," $2.00 ; "$ " $.60 ; .15$

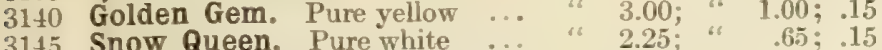

3145 Snow Queen. Pure white $\ldots$ " " 2.25 ; " $\quad .65 ; .15$

3155 King of the Blacks. Coal black, 2.50 ;

3160 Lord Beaconsfield. Violet; upper petals shading to $1 . .00$;

3165 White with Violet Eye ... " $2.00 ; "$ " $60 ; .15$

3170 Rosy Lilac ... ... ... ... " $1.25 ; .25$

3175 Striped. Great variety of colors, Oz., 2.00; " .60;.15

3180 Mixed. Fine assortment of colors, " 1.50 ; " .50; .10

3185 Collection of 6 Varieties Separate, our selection, .75

\section{BEDDING PANSIES.}

3190 Azure Blue

3195
3200 King of the Blaeks

3:0气 Cardinal. Bright red

Or.., $1.25 ; 10 \%, .40 ; .10$

4. $1.20 ;$ "6 $.50 ; .10$

$62.50 ; 46 \quad .75 \div .10$

3210 Emperor Frederick. Deep purple edged with scarlet and yellow: centre golden bronze, Oz., $1.50 ; \frac{1}{4} 0 z ., .50 ; .10$

3215 Emperor William. Deep blue "6 $1.25 ;$ "6 .40;.10

3220 Golden Yellow. With dark eye "6 $1.25 ;$ " $.40 ; .10$

32.5 Lord Beaconsfield. Violet; upper petals shading to white $\ldots$... ... ... Oz., 2.00; 1 0z., .60;.10

32:30 Purple. Rich deep shade $\ldots$ ". $1.25 ; "$ " ${ }_{40} ; .10$

32.25 Psyche. Velvety violet-blue, white margin, $\frac{1}{8} 0 \%, 1.00 ; .25$

3240 Silver-edged. Dark purple with white edge, 0 z.. $1.25 ; .10$

$32+5$ Orchidaefiora, mixed. A new race embracing many interesting combinations of color, not to be found in any other type of pansy; rery effective, $\frac{1}{4} \mathrm{oz} ., 1.00 ; .25$

3250 White. With dark eye ... ... Oz., 1.25; $\frac{1}{4}$ oz., .40; 10

$: 3255$ Pure White. Invaluable for large beds " $1.50 ;$ "6 $\quad .50 ; .10$

3260 Choice Mixture. In splendid variety " $1.50 ;$ " $\quad .50 ; .10$

3265 Collection of 12 Varieties Separate, our selection, 1.00

TUFTED PANSIES. Viola Cornuta.

Elegant free-blooming plants for partially-shaded beds and borders.

3275 Admipation. Rich dark blue .. Oz., 2.50; 1 oz., .75; .10

3280 Blue Perfection. Mauve, yellow eye ${ }^{6} 2.50 ; " .75 ; .10$

3285 Grandiflora lutea. Golden yellow flowers, beautiful. Oz., 1.25 ; $\frac{1}{4}$ oz., .40;

3290 Mauve Queen. Light blue ... ${ }^{6} 2.00 ; " 60^{6}$

3295 Pink. A new and pleasing shade ... ... $\frac{1}{8}$ oz., 1.25;

3300 Papilio. A lovely violet-lilac; very free, $\frac{1}{1}$ oz., .50;

3305 White Perfection. Snowy white, Oz., 2.00; oz. .60;

3310 Mixed. All colors .. ... " $1.50 ;$ "6 50 ;

3315 PERILLA Atropurpurea laciniata. A half-hardy annual, with dark purple foliage, resembling Coleus, 2 feet

\section{PETUNIA. \\ GIANT SINGLE VARIETIES.}

3320 Farquhar's Ruffled Giants, mixed, A Californian strain producing large flowers having the edges deeply ruffled or fluted. They are of fine substance with deep wide throats, and vary in their colors from pure white to dark purple-violet; many of them being beautifully striped or veined ......... $\frac{1}{1}$. 0z, 3.00; large packet

33:25 Farquhar's Ruffled Giants, mixed. Small packet

3330 Farquhar's Giants of California, mixed. Flowers of enormous size and superb colors, plain-edged. $\frac{1}{16}$ oz., 2.00

3335 Giant Crimson, Pkt. .25 3340 Giant Pink

3315 Giant White

3350 Giant Striped and Blotehed

3355 Yellow-throated Varieties Mixed. Intus A ureo. The flowers are very large and of the richest colors with veins radiating from the throats

3:360 Collection of 6 Varieties Separate, imported DOUBLE PETUNIAS.

Seeds of the Double Petunia are obtained by hybridization and only produce a small percentage of doubleflowering plants, the remainder being fine singles of the Grandiflora type. It is important to prick out the smaller seedlings as they are most likely to produce the finest double flowers.

3365 Farquhar's Superb Double Fringed Mixed. The quality of this strain is unrivalled for its magnificent flowers, and brilliant combination of colors,

1,000 seeds. 1.50

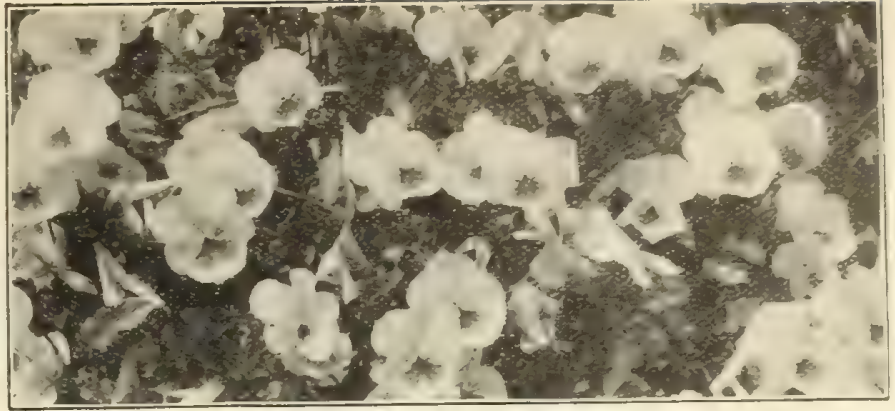

Tufted Pansy, White Perfection.

\section{DOUBLE PETUNIAS.-Continued.}

3370 Lady of the Lake. Double pure white, elegantly I'ks. fringed

3375 Giant Double Mixed, plain-edged. A superb strain, producing a large percentage of double-flowering plants of the finest colors, Large packet containing about 1,000 seeds, 1.00; regular packet

$3: 380$ Choice Mixed

\section{SINGLE BEDDING PETUNIAS.}

338.5 Crimson

3390 Pink. Rosy Morn. A lovely shade, " 3.50

$3: 395$ White

3400 Striped and Blotehed. One of the best for massing in beds, yielding a profusion of beautifully striped and mottled flowers

$\mathrm{Oz}, 1.50 ; \frac{1}{4} \mathrm{oz} ., .50$

3 t05 Howard's Star. A free-flowering crimson variety with a large and distinct five-pointed white star. Splendid sort for vases, borders or edgings, $\frac{1}{4} \mathrm{Oz} ., 1.00$ Dwarf Striped and Blotehed. Nana compacta Multi flora. The flowers are beautifully striped and completely cover the compact little plants. Useful for edgings. 6 inches

3415 Special Mixture. A splendid strain producing flower of medium size in great variety of colors

3420 Fine Mixture. Choice colors

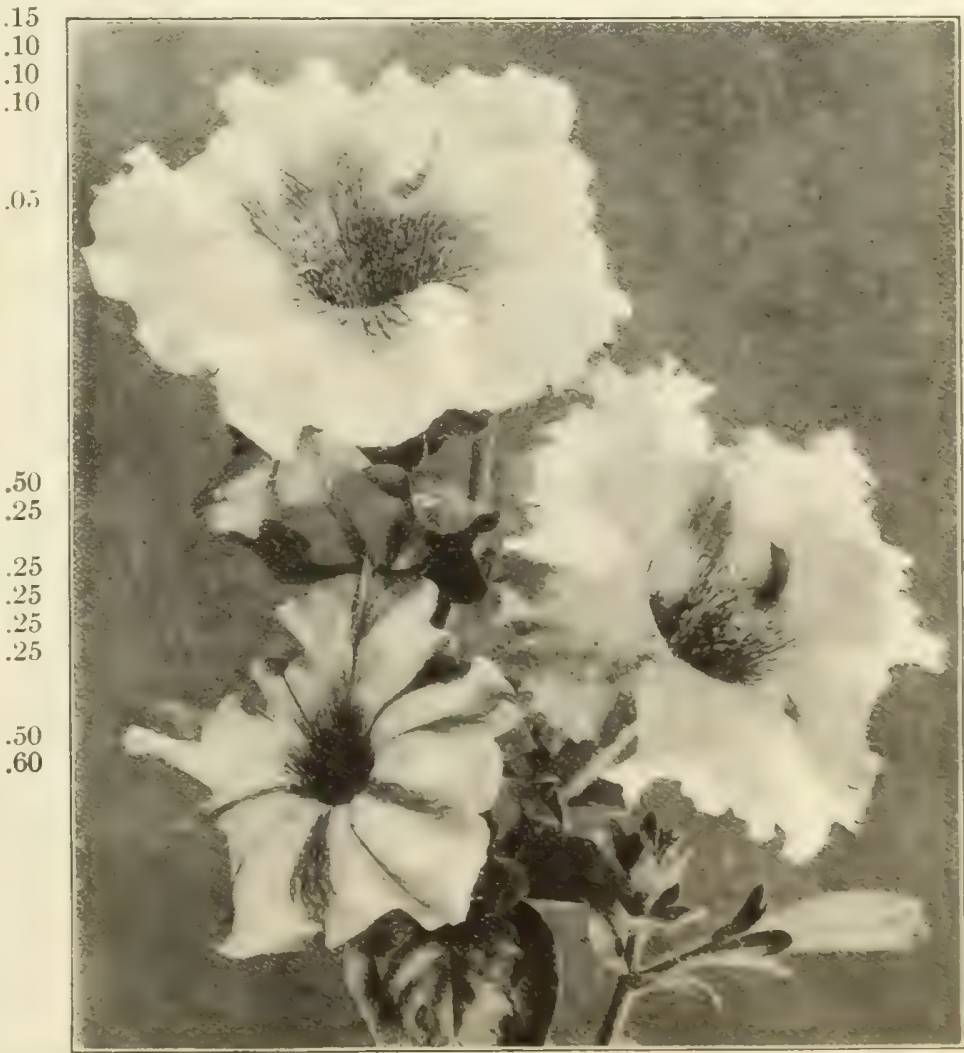

Petunia Farquhar's Ruffled Giants. 
R. \& J. FARQUHAR \& CO., BOSTON. ANNUAL FLOWER SEEDS.

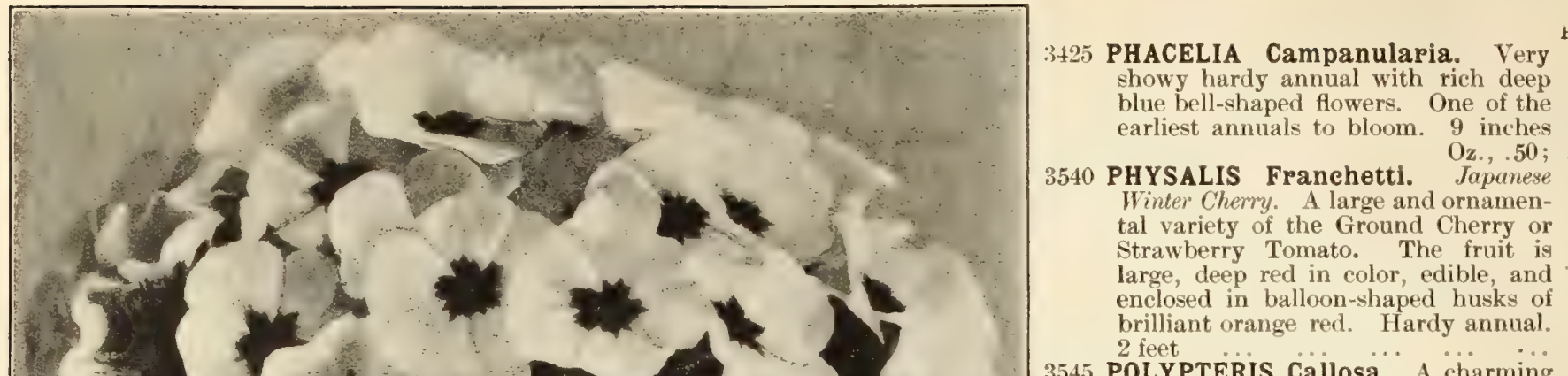

3545 POLYPTERIS Callosa. A charming annual with graceful foliage and pretty rosy-lilac flowers. The plants bloom profusely throughout the summer. $1 \frac{1}{2}$ feet

POLYGONUM Orientale. Persicaria. 3550 Dware Red. Very showy hardy annual with drooping spikes of ruby-red flowers. 2 feet

3555 Dwapf White. A free growing white variety

Farquhar's Perfection Phlox Drummondi.

\section{PHLOX DRUMMONDI.}

This is one of the finest annuals, being hardy, easy of cultivation, and making as a summer bedding plant an effective and brilliant display. The flowers are of long duration and of most gorgeous and varied colors; $1 \mathrm{ft}$.

FARQUHAR'S LARGE-FLOWERED.

Our large-flowering Phlox is an improved strain with extra large flowers of great substance.

$3+30$ Blood Red. Black Warror.

3435 Brilliant Searlet.

$3+40$ Crimson with White Star.

$3+45$ Pink. Light shade

3450 Searlet with White Eye.

3455 White. 3460 Yellow.

Each of the above colors, $\mathrm{Oz}, 1.25 ; 1 \mathrm{oz}, .40 ; .10$

3465 Collection of 12 Varieties. Separate. Im-

3470 Collection of 6 Varleties. Separate. Im-

3475 Farquhar's Special Mixture. Contains all the finest and most brilliant colors,

3480 Fine Mixed. … $\quad \mathrm{Oz}_{4}, 1.00 ; \frac{1}{4} \underset{64}{\mathrm{oz}}, \frac{.35}{25} ; .05$

\section{FARQUHAR'S PERFECTION.}

The most profuse blooming of all the Phloxes

The flowers borne in immense trusses are unusually large and very brilliant in color. For bedding this variety is unsurpassed.

3485 Pink. 3490 White.

3495 Searlet. $\quad 3500$ Crimson.

Each of the above colors, $\mathrm{Oz}, 2.00 ; \frac{1}{4} \mathrm{oz}, .60 ; .15$

3505 Mixed. All colors, Oz, $1.75 ; \frac{1}{4} \mathrm{oz} ., .50 ; .15$

3510 Pink. DWARF VARIETIES. 8 inches.

3515 . Searlet

3520 Pure White $\ldots . \ldots \ldots_{6}, \ldots{ }^{4}, 00 ; .15$

3525 Mixed

DOUBLE VARIETIES.

3530 Double White

3535 Double Mixed

$\frac{1}{4} \mathrm{oz}_{6}, .60 ; .15$
Plkt. 
R. J. FARQUHAR \& CO., BOSTON. ANNUAL FLOWER SEEDS.

350 Farquhar's Peerless Mixture. This mixture consists of a combination of the finest double and single flowering Poppies in an endless rariety of the most brilliant and delicate colors. When planted in large beds it pro- Pkt. duces a gorgeous display $\ldots \quad \frac{1}{4} 1 \mathrm{~b} ., 1.50 ; 0 z ., .50 ; .10$

\section{DOUBLE-FLOWERING VARIETIES.}

Carnation-flowered. The flowers of this variety are very double and finely fringed. 2 feet.

3jo-7 White Swan. Pure white fringed flowers,

Oz. . . $30 ; .05$

3.ii) Searlet

$3 \%$ Pink. A fine light shade

3.jii) Silvep-Grey. Tery attractive color

(3.)...) Mixed. In great variety

3.190 Collection of 12 Varieties Separate, imported PEONY-FLOWERED. Immense globular flower adapted for large beds or shrubbery borders. 2 feet. :79.) Collection of 12 Varieties Separate, imported

(ivi) Nankeen Yellow

3it). Mixed. All colors

Lb. $\ddot{1} .50$;

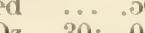

Fench Ranunculus Poppy Mixed. African Rose. A

charming race, with thin paper-like petals, Oz., 25;

i3ril.; American Flag. Large double flowers, white striped with scarlet. 2 feet ... Oz., .30;

(in-2) Chinese flnest Mixed. Very double globe-shaped flowers, with slender, wayy petals, varying from puse white to dark scarlet. $1 \frac{1}{3}$ feet $\quad . . \quad \ldots \quad \mathrm{Oz}, .30$.

36.5 Japanese Pompon Mixed. Beautiful miniature Poppies, with finely fringed flowers of perfect form

:36:31) Mikado. Double fringed flowers, white tipped with crimson ... Oz., .25;

\section{SINGLE-FLOWERING VARIETIES.}

36:- Farquhar's Improved Shirley Mixed. A greatly improved strain of this lovely race of single Poppies with shining flowers of silky texture, varying in color from pure white and delicate pink to rosy carmine and deep crimson, many of them being beautifully striped and edged with white. The blooms if cut while young will keep in water for two or three days, $\frac{1}{4} 1 \mathrm{~b} ., 1.50 ; \mathrm{oz} ., .50$;
3641) Farquhar's Single Hybrids Mixed. A superior strain of the single French Poppy, with gigantic flowers Pst. ranging from white to crimson. 2 feet $\ldots \frac{1}{4}$ oz., 1.00 ; . .

:364.) Danebrog. Danish Flag. Single scarlet flowers, with a large white blotch on each petal. 2 feet .. Oz., .25; .1.5

(Bi.i) Glaucum. Tulip Poppy. A striking variety with dazzling searlet flowers. 1 foot .. $\quad \ldots \quad \ldots \quad \mathrm{Oz}_{2}, .50$;

36.5., Hooker's Single Mixed. A superb strain with large flowers and combining all the brightest colors. 2 feet,

ititio Maid of the Mist. Large single white flowers, beautifully fringed. 2 feet .. $\ldots . \quad \ldots \quad \ldots$ Oz., . 30 ;

:3titi. Mephisto. Single deep scarlet, with blackish-violet spots. $1 \frac{1}{2}$ feet . . . . . . . .. Oz., .25 ;

:360 Shirley Mixed. One of the most popular varieties of the annual Poppy, with petals of delicate texture. This mixture contains many beautiful shades of white, pink, terra-cotta, red and crimson; many of the flowers being flaked and striped with white,

$$
\text { Lb., 3.00; } \frac{1}{4} \text { lb., 1.00; oz., .30; }
$$

36i.5 Scarlet Field Poppy. Papaver Rhoeus. The single Poppy so much admired by tourists in Europe, where it abounds on the railroad banks, and in the fields. $1 \frac{1}{2}$ feet, $\frac{1}{4} \mathrm{lb} ., 1.00 ; \mathrm{oz}_{.}, .40$;

stisi) The Bride. A beautiful variety with large, pure white flowers of perfect form ..... ... ... Oz., .30; Umbrosum. Caucasian Poppy. Enormous s ingle flowers, crimson with a black spot on each petal, $\mathrm{Oz} ., .30$; Isles of Shoals. This renowned mixture of annual Poppies consists of only the finest types of double and single varieties in an endless variety of color,

$\frac{1}{4} 1 \mathrm{~b} ., 1.50 ; 0 \mathrm{oz}, .50$;

36.95 Annual Varieties Mixed. Double and single in great variety ... ... Ib., 2.00; + 1b., .60; oz., .25;

370 Collection of 12 Varieties Annual Poppies Separate. - Our selection Perennial Varieties see Nos. $7+60-753.5$

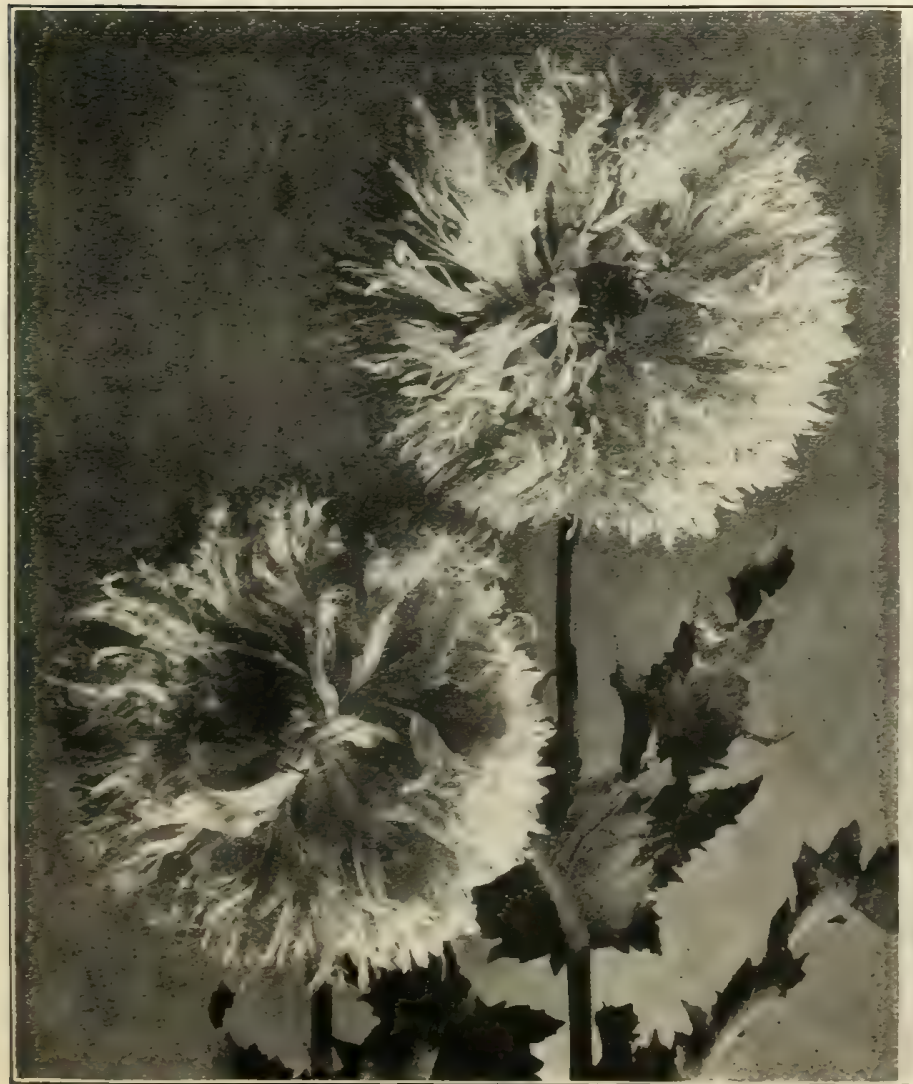

Carnation-Flowered Poppy.

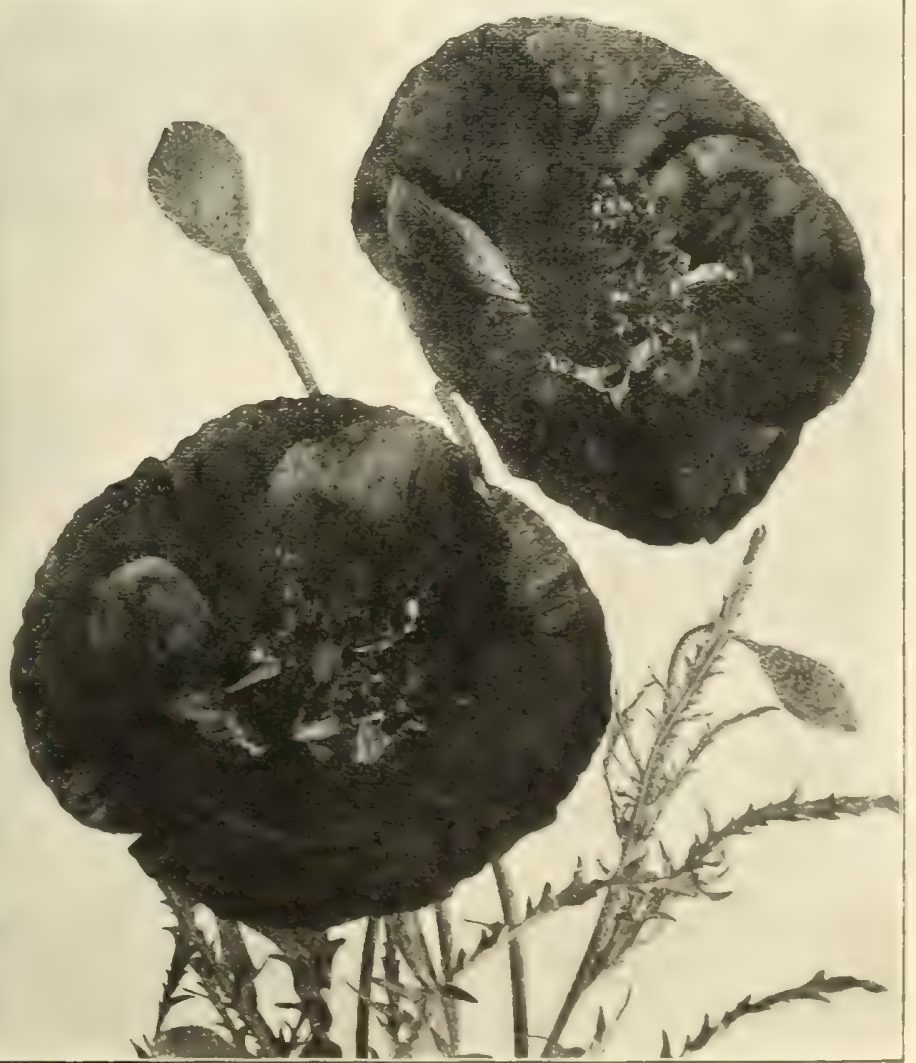

Farquhar's Improved Shirley Poppy. 


\section{R. \& J. FARQUHAR \& CO., BOSTON. ANNUAL FLOWER SEEDS.}

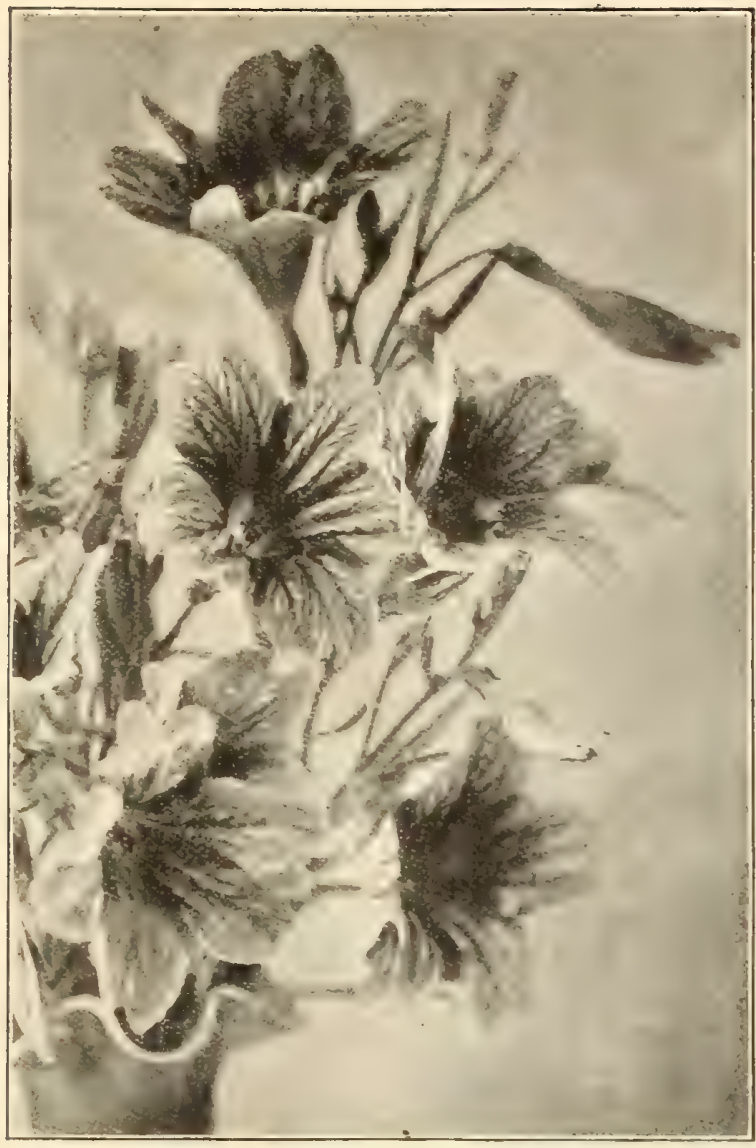

Salpiglossis Farquhar's Large-Flowered.

\section{PORTULACA.}

Charming dwarf annuals adapted for sunny situations or light soils and producing flowers of the most brilliant colors in great profusion. 6 inches.

3705 Double Mixed. Saved from the finest double flowers only and Plt. will produce a large percentage of doubles, $\mathrm{Oz}, 5.00 ; \frac{1}{4} \mathrm{0z} ., 1.50 ; .10$

3710 Collection of 8 Varieties. Double

3i.j Single Rose

;i:-; Single White 3720 Single Scarlet

Each of the ab 3730 Single Yellow

:37;-) Single Mixed

:itil Collection of 8 Varieties Separate, single PYRETHRUM Aureum. Golden Feather.

37 t.) Dwarf bedding plant with yellow Fern-like leaves, useful for edging beds and borders. Half-hardy perennial. 6 to 9 inches,

For perennial varieties see Nos. $7620-7635$

\section{RICINUS. Castor Oil Plant.}

Tender annuals of rapid and gigantic growth producing enormous dark green or bronze-colored palmate leaves; excellent for sub-tropical beds or for massive foliage effects on lawns or backgrounds.

:3.5) Borboniensis arboreus. Tall decorative variety with large purplish leaves. 15 feet ... ... ... ... ... Oz., 15; Cambodgensis. Of compact growth with stens and leaf stalks like shining ebony, foliage varying according to age from bronze-

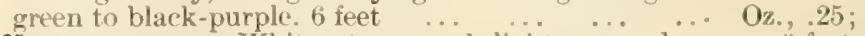

::itil Macroearpus. White stems and light green leaves, 6 feet,

;: iti. Sanguineus. Fine tall variety with red stems and reddish purple leaves. 10 feet ... … ... ... L.h., .60; oz., .10

$: 7,0$ Zanzibariensis Mixed. A distinct race from East Africa producing leaves of enormous size and varying in eolor from light ureen to purplish red, Oz., . $15 ; .05$

::77.; Mixed,

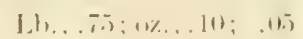

\section{RUDBECKIA. Cone Flower.}

Attractive annuals of compact growth suitable for borders or clumps among shrubs. Excellent for cutting. 22 feet.

3780 Amplexicaulis. Pure golden Prt. yellow ... ... ... Oz., . $30 ; .05$

3785 Bicolor superba. Golden yel-

low with chestnut marking

Premnial varipties se" Nos. $764,5-7660$

\section{SABBATIA Campestris.}

3790 A dwarf hardy annual with charming rose-colored flower foot

\section{SALPIGLOSSIS.}

Exceedingly beautiful half-hardy annuals with large funnel-shaped flowers, beautifully pencilled and veined in rich shades of yellow, crimson and purple. They flower freely from July until frost, and are invaluable for cutting. 2 feet.

\section{Farquhar's Large-flow-} ered Mixed. Including all the finest colors, $\mathrm{Oz}, 1.50 ; \frac{1}{4} \mathrm{oz} ., .50 ; .15$ 3800 Maroon Golden-veined.

3805 Rose Golden-veined.

3810 Sulphur yellow.

Each of the above colors.

$$
\mathrm{Oz}, 1.50 ; \frac{1}{4} \mathrm{oz}, .50 ; .10
$$

3815 Mixed Oz...75; .10

3820 Collection of 6 Varieties Separate. Imported

\section{SALVIA. Flowering Sage.}

The Salvias are among our most popular and useful bedding plants. They are easily raised from seeds sown in February or March in the greenhouse or hot-bed, the seedlings being transferred to the open garden about the end of May. They bloom profusely from July until frost. Half-hardy perennials.

3825 Splendens Bonfire. A mag- Pkt. nificent type of the flowering Scarlet sage with large flower spikes of the brightest scarlet. The plants are of bushy labit and in late summer and fall are literally covered with bloom. 2 feet,

$0 z ., 4.00 ;$ 1 oz., $1.25 ; \frac{1}{x}$ oz. . .75;

Splendens Compaeta. Forms a compact dense bush covered with large brilliant scarlet flowers; blooms very early. 2 feet.

Oz. $3.50 ; \frac{1}{4} 0 \%, 1.00 ; \frac{1}{8}$ oz,, 60 3835 Splendens. A tall growing rariety with immense flower trusses of dazzling scarlet. 3 feet

$\mathrm{Oz}, 2.50 ; \frac{1}{4} \mathrm{Oz} ., \mathrm{Ts}$; 3840 Zurich. A free flowering dwar sort with erect spikes covered with a mass of the most brilliant scarlet flowers. The plants commence to bloom early and continue throughout the season. I foot ... … 845 Patens. Flowers intense bright
blue, of large size and velvety texture, blue, of large size and velvety texture, 8,50 Salvia Argentea. White sil' very foliage lying flat on the ground; flowers yellow. Perennial, 2 feet,

$$
\text { Oz., 25; }
$$

8.5 Horminum Violacea. Ilury. Flowers beautiful violet-blue; useful for bedding. Annual. $1 \frac{1}{2}$ feet,

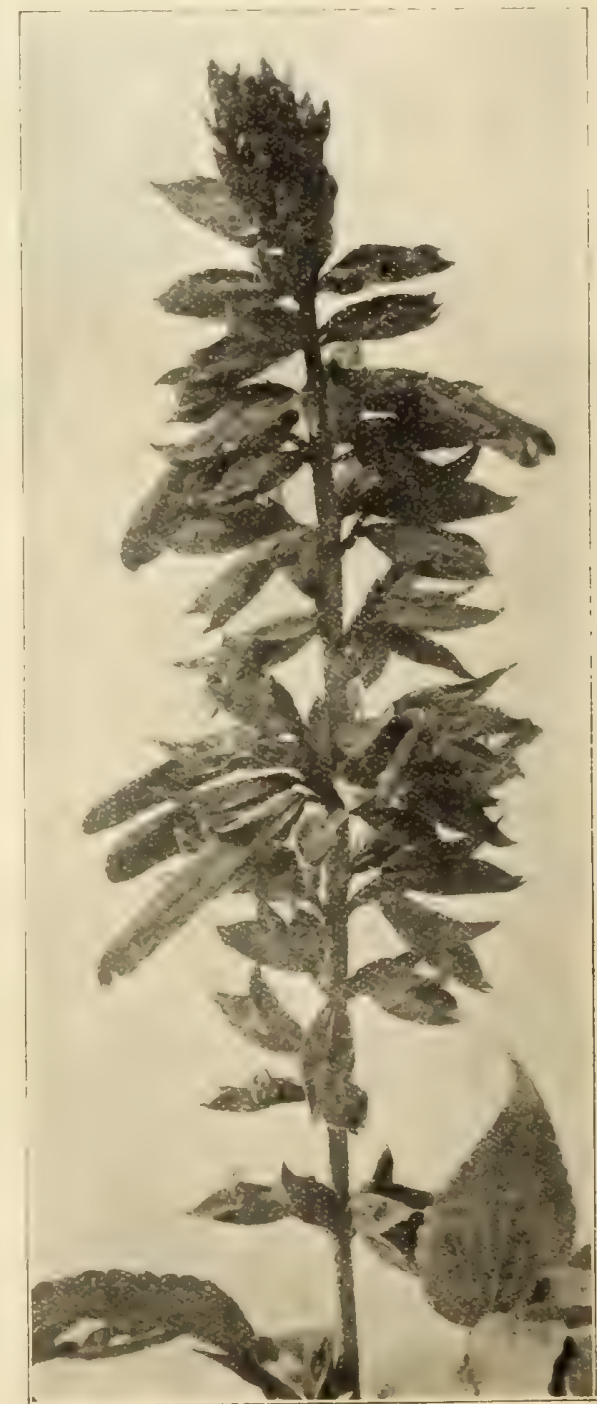

Salvia Splendens Bonfire.

\section{.0 .5} .03 (i.) 
R. \& J. FARQUHAR \& CO., BOSTON. ANNUAL FLOWER SEEDS.

\section{SANTOLINA Maritima.}

$3(40)$ A fine bedding plant with silvery white foliage and yellow flowers; suitable for edgings. Half-hardy perennial. 1 foot.

SANVITALLIA Procumbens fl. pl.

\$6ij Pretty dwarf annual with bright yellow double flowers. It blooms from July until frost and succeeds best in light rich soil. 6 inches

\section{SAPONARIA.}

35:0 Calabrica. Dwarf annual with small pink starry flowers borne in profusion; excellent for edgings or small beds. 1 foot $\ldots . \quad \ldots \quad \ldots$... ... Oz., . 30 ; Vacearia. Splendid tall growing variety of branching habit with pale rose flowers esteemed for bouquets. Annual. 3 feet

SCABIOSA. Mourning Bride or Sweet Scabious.

Magnificent hardy annuals of easy cultivation, blooming freely through the summer and autumn. They are very decorative for beds or borders in the garden and are invaluable for cutting. They comprise a wide range of rich and beautiful colors; $2 \mathrm{ft}$.

3880 Farquhar's Perfection Mixture. Includes only Pkt. the finest colors of the large-flowered Scabious in great

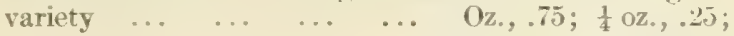

:385. Collection of 6 Colors Separate. Our selection,

$\$ 390$ King of the Blacks. Immense flowers of velvety black purple

3895 White Pearl. Large heads of pure white flowers

\$900 Farquhar's Pink. Beautiful shade of salmon

:905 Cherpy Red.

\$910 Fiery Searlet. Brilliant shade

3915 Light Yellow ...

\$420 Lilae

3925 Pompadour. Petals black-purple margined with white; very beautiful ... ... ... 0 z., $1.00 ; \frac{1}{4} 0 \% ., 35$;

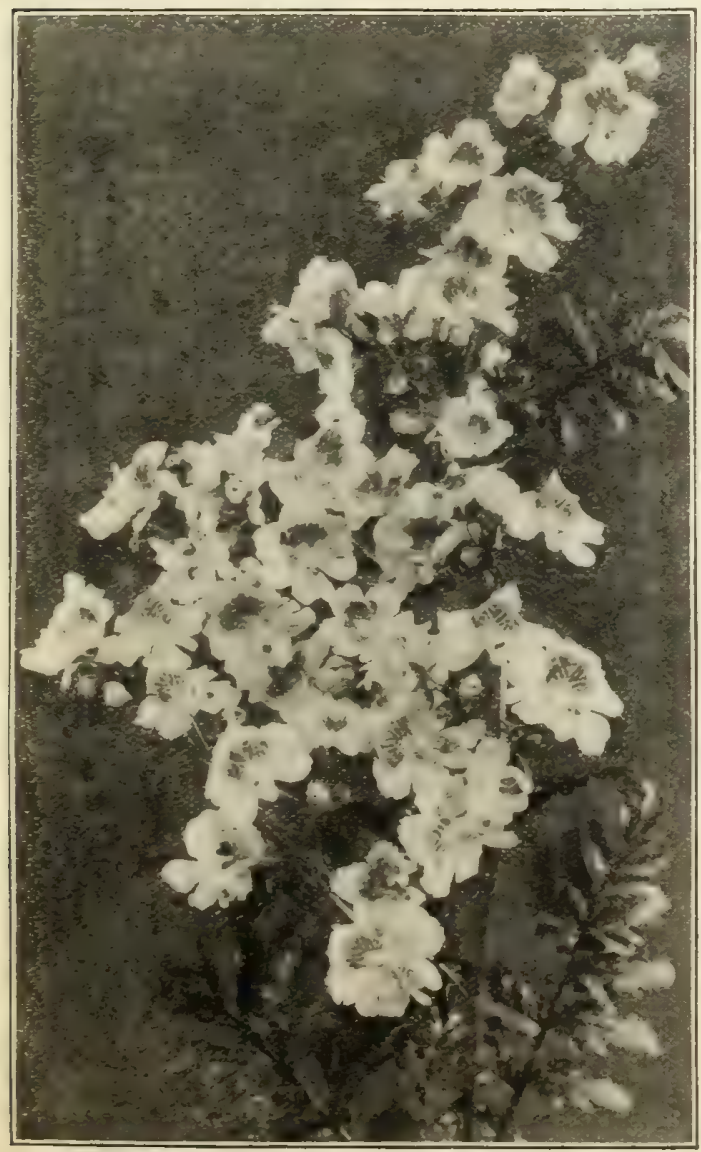

Schizanthu3. Farqunar's Large-flowered Hybrids.

\section{$\mathrm{Oz} \cdot, .50$;}

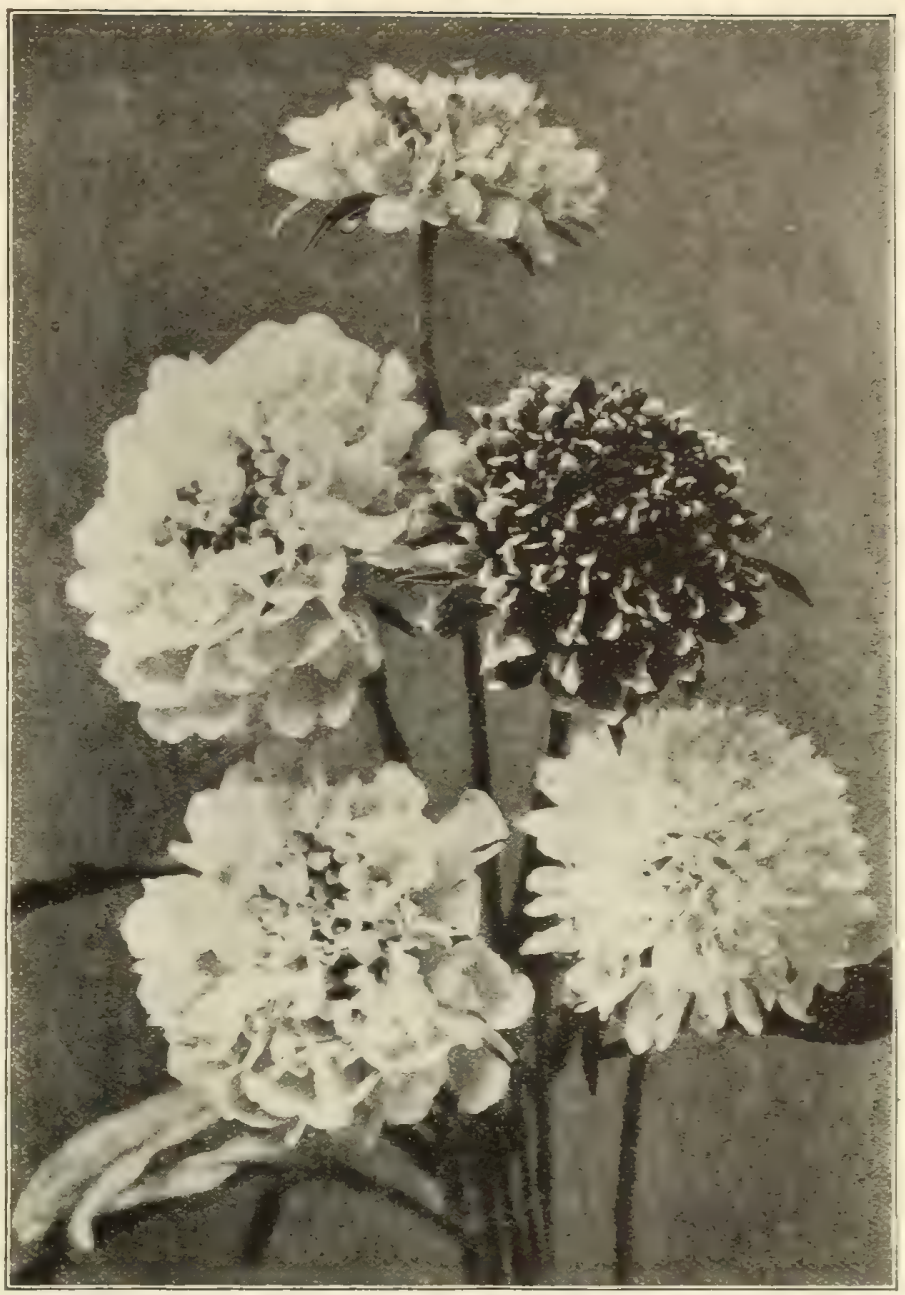

Farquhar's Perfection Scabious.

SCHIZAPETALON Walkeri.

3935 Elegant hardy annual with numerous white almond-scented fringer flowers. It should be sown where intended to bloom; 9 inches

SEDUM. Cœruleum. Blue Annual Stonecrop.

3940 A useful plant for rockwork, edgings, stone walls or dry situations,

\section{SCHIZANTHUS. Butterfly Flower.}

Elegant free-flowering hardy annuals for the garden in smmer or for the greenhouse during winter; $1 \frac{1}{2}$ feet.

344.) Farquhar's Large-flowered Hybrids Mixed. The Schizanthuhas become indispensable for cut Aowers, and for pot culture in the greenhouse. This strain is unsurpassed for size of flowers and variety of colors. It is the result of many years of careful selection on the part of a learling specialist in Europe

Hybridus Grandiflorus Mixed. This strain, like the preceding, is of the large-flowered type and is vastly superior to the schizanthousually offered

Wisetonensis. A mpular variety for forcing in the greenhoust. The colors range from white with yellow centre to pink with brown centre

Grandiflorus Oeulatus. Lilac with large violet bluteh om each petal.

Pinnatus Roseus. Delicate pink with blood red bloteh.

Retusus Albus. White with yellow spots; excellent for forcin

Rosamond. Flowers light pink: very effective

Mixed. In great variety

Collection of 6 Varieties Separate, imported

\section{SILENE. Catchity.}

3960) Armeria Mixed. Fres-bloming hardy annuals; colors, white, pink 3(x). Pendula Dwape Rose. A popular variety for spring beiding. The seeds should be sown in July or Augnet and the yeung plants wintereyt in frames 


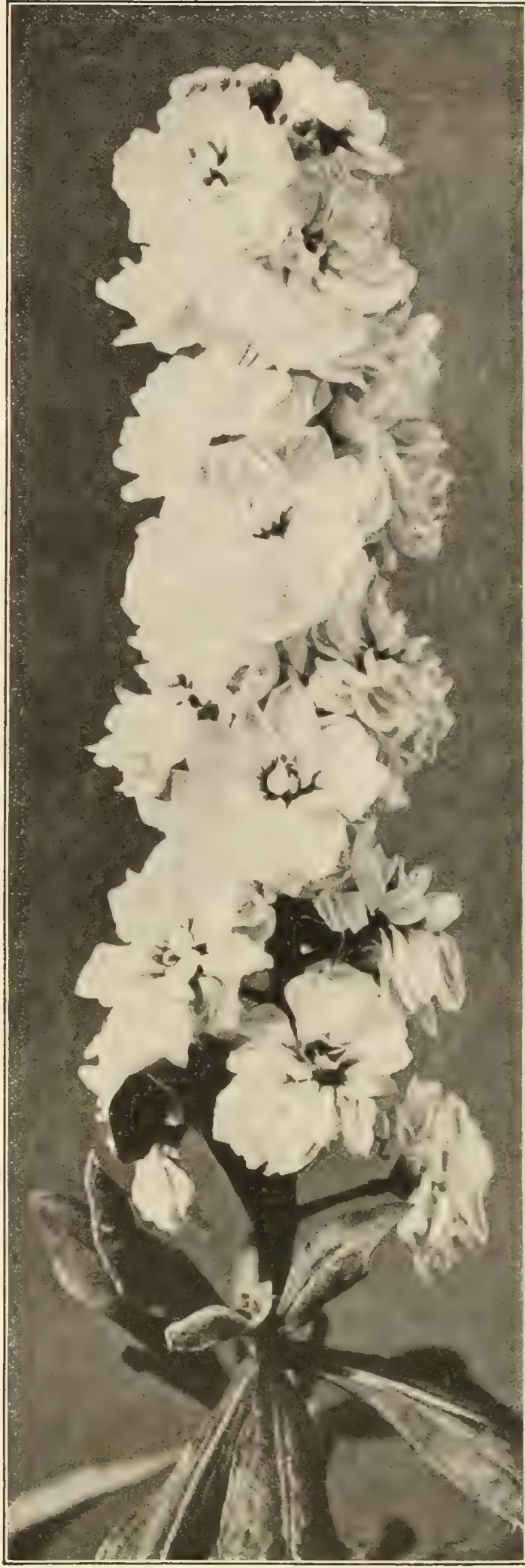

Large-Flowering Ten-Week Stock.

\section{STOCK.- Gilliflower.}

The charming colors, delightful fragrance, and free blooming character of the stocks have made them favorite plants for both summer and winter cultivation. They are very effective for beds and borders, and their handsome flower spikes ar invaluable for bouquets and floral decorations. The large-flowering Ten-wee Section is the earliest to bloom; for succession sow the Cut-and-Come-Again varieties, which bloom abundantly until frost.

\section{Farquhar's Large-flowering Ten-week. 1 foot.}

4000 White.

4015 Brilliant Rose.

4030 Crimson.

404, Dark Violet.

4005 Pink.

4020 Canary Yellow.

4010 Blush-pink.

4035 Dapk Blood Red.

4055 Terra Cotta.

Each of the above colors

4060 Farquhar's Superb Mixture. In great variety,

$40(6.5)$ Mixed

4070

(1). $4.00 ; \frac{1}{4} \mathrm{Oz} ., 1.25 ; \frac{1}{8} \mathrm{Oz} ., .75 ; .10$

Mixed

\section{Farquhar's Improved Cut-and-Come-Again.}

Asplendid early-flowering perpetual stock. It is of tall branching habit, and when the first blooms have been cut, side branches start out bearing large flower trusses. $1 \frac{1}{2}$ feet.

408) Apple Blossom. 4085 Brilliant Rose. 4090 Canary Yellow. 40\%) Dark Blue. 4100 Flesh-eolor. 4105 Light Blue.

4110 Searlet. 4115 White. Princess Alice. 4120 Mixed.

Fach of the above colors and mixed ... ... Oz., 6.00; $\frac{1}{8} \mathrm{oz}, 1.00 ; .15$ 41.5
$41: 0$ 6

Boston Florists' White. A favorite variety, producing a bigh percentage of large double white flowers, excellent for summer and winter (ultivation. $1 \frac{1}{2}$ feet $\ldots . \quad \ldots \quad \ldots . \quad \ldots \quad 0 z ., 5.00 ; \frac{1}{4} \mathrm{Oz}, 1.50$; 414) Farquhar's White Column. This is an early flowering sort, bearing one enormous spike of large double white flowers ... ... $\frac{1}{4} \mathrm{oz} ., 1.50$;

414. Farquhar's Crimson Column. Similar to the preceding except in the color of the blossom, which is bright, rosy crimson ... $\frac{1}{4} \mathrm{Oz}$., 1.50; Victoria. An early branching variety with dense trusses of fragrant double flowers; useful for bedding. 1 foot.

4181) Finest Mixed. 4185 Dark Blood Red.

Each of the above

1 oz, 1.25

\section{New Autumnal or Winter-flowering Stocks.}

A magnificent race of recent introduction, with long trusses of extremely double flowers of delightful fragrance. The plants attain a height of about $1 \frac{1}{2}$ feet, and are of sturdy growth. Seeds sown in early spring under glass produce splendid flowering plants during late summer. For forcing in the greenhouse in winter they are unexcelled.

415) Mauve Queen. A lovely shade of rosy lilac

415.j Farquhar's Christmas Pink. Free branching variety with long trusses of pale pink double flowers

1160 Princess May. The finest pale yellow stock, excellent for forcing thij Queen Alexandria. Color lilac-rose. Very attractive color thil Beauty of Nice. A popular sort with flowers of a delicate flesh pink color

41\% Empress Augusta victoria. A new variety of pyramidal growth with long flower spikes of delicate silvery-lilac

Brompton Finest Mixed. A biennial variety of pyramidal branching habit, producing handsome spikes of showy fragrant flowers. 2 feet,

East Lothian. If sown in March these bloom in the autumn, or if sown in June or July will make handsome pot plants for conservatory decoration in winter. The plants are of dwarf, compact habit, with erect hyacinth-like flower trusses. 2 feet.

Crimson. $\quad 4200$ White.

4205 Mixed.

Each, per packet

\section{SUNFLOWER.-Helianthus.}

"My dealings with your firm have always been very satisfactory and your products in every respect first class,"-S. CARLQUIST, Lenox, Mass.

.


R. \& J. FARQUHAR \& CO, BOSTON. ANNUAL FLOWER SEEDS.

\section{SUNFLOWER.-Cont.}

4215 Double Californian. Califomicus $f$. pl. Large, deep yellow flowers of perfect form. feet $\ldots$ Oz. .20; Pkt. 05

420 Chrysanthemumflowered. A distinct and desirable variety, bearing large and perfectly double golden-sellow flowers with long stems. 7 feet, Oz...40; Pkt...10

429-3 Cucumerifolius. Miniature Sunflower. A very popular sunflower of branching habit, producing an abundance of small golden-yellow single flowers with black centres. It comes into bloom in July and continues till frost. Invaluable for cutting.

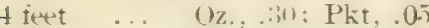

4.30 Giant Russian. Fery tall sort with immense single flowers 6 feet $\ldots$ Oz... .10; Pkt., .05

42.50 Multiflorus fl. pl. Erect growing plant with double flowens of deep sellow, borne on short stems growing from the leat joints. 4 feet. Oz., .40 ; Pkt., .10

4:40 Dwarf Double. Plants of compact growth with large golden-yellow flowers. 3 feet,

Oz., .30; Pkt., .05

42t5 Henry Wilde. Flowers of medium size, yellow with black disc. 9 feet, Oz., .20; Pkt., .05

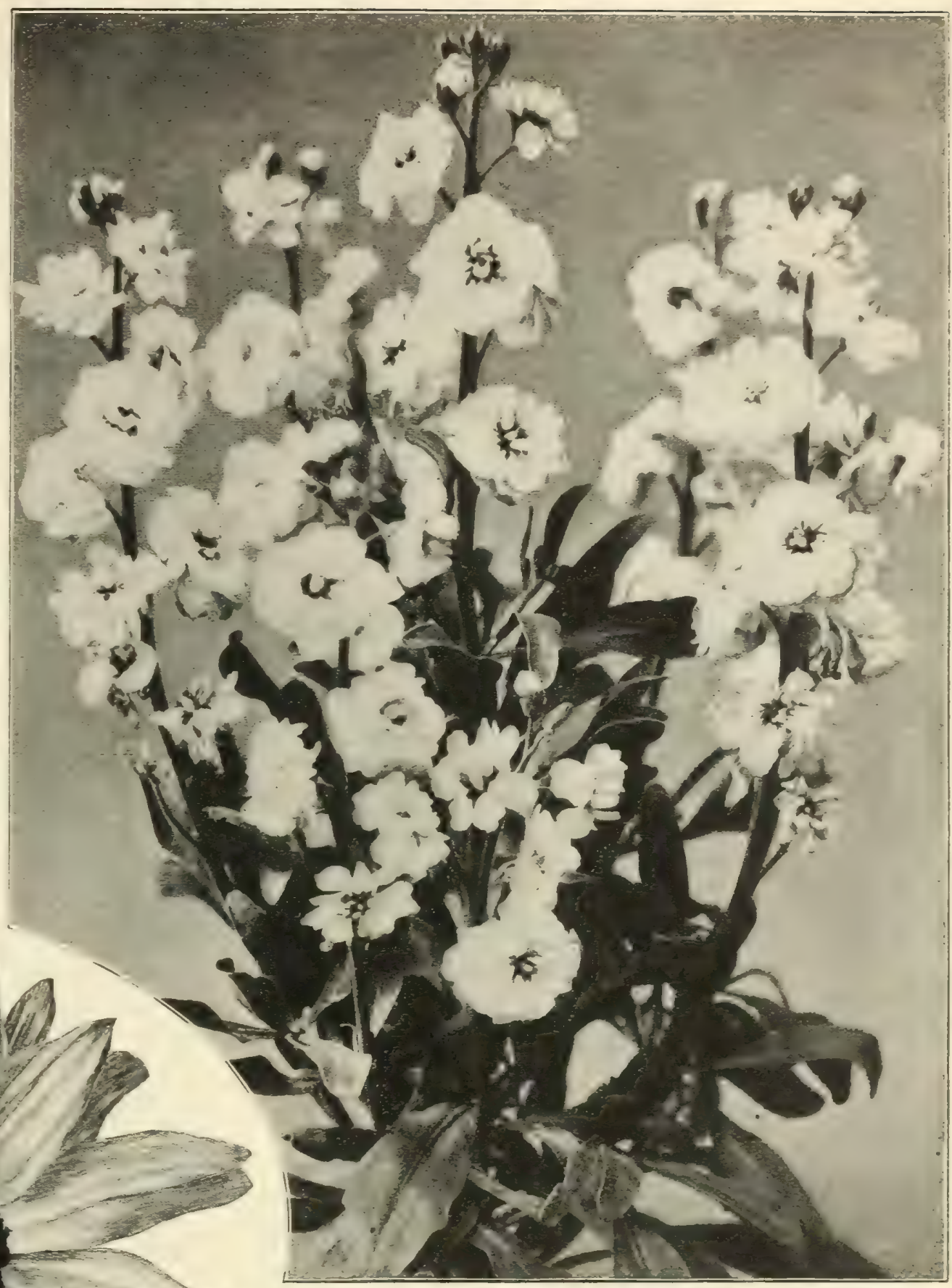

Farquhar's Improved Cut-and-Come-Again Stock.

4250 Primrose Queen. Large single flowers of delicate prim- Pkt. rose yellow; one of the most beautiful sorts ... Oz., . $40 ; .10$

Uniflorus Giganteus. Each plant bears one enormous single flower, yellow with a dark centre, often measuring one foot in

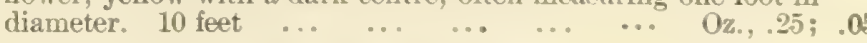

\section{SWEET CLOVER.}

In colonial times the Sweet Clovers were cultivated for their fragrant flowers, which when dried were used to perfume clothes. 


\section{SWEET PEAS.}

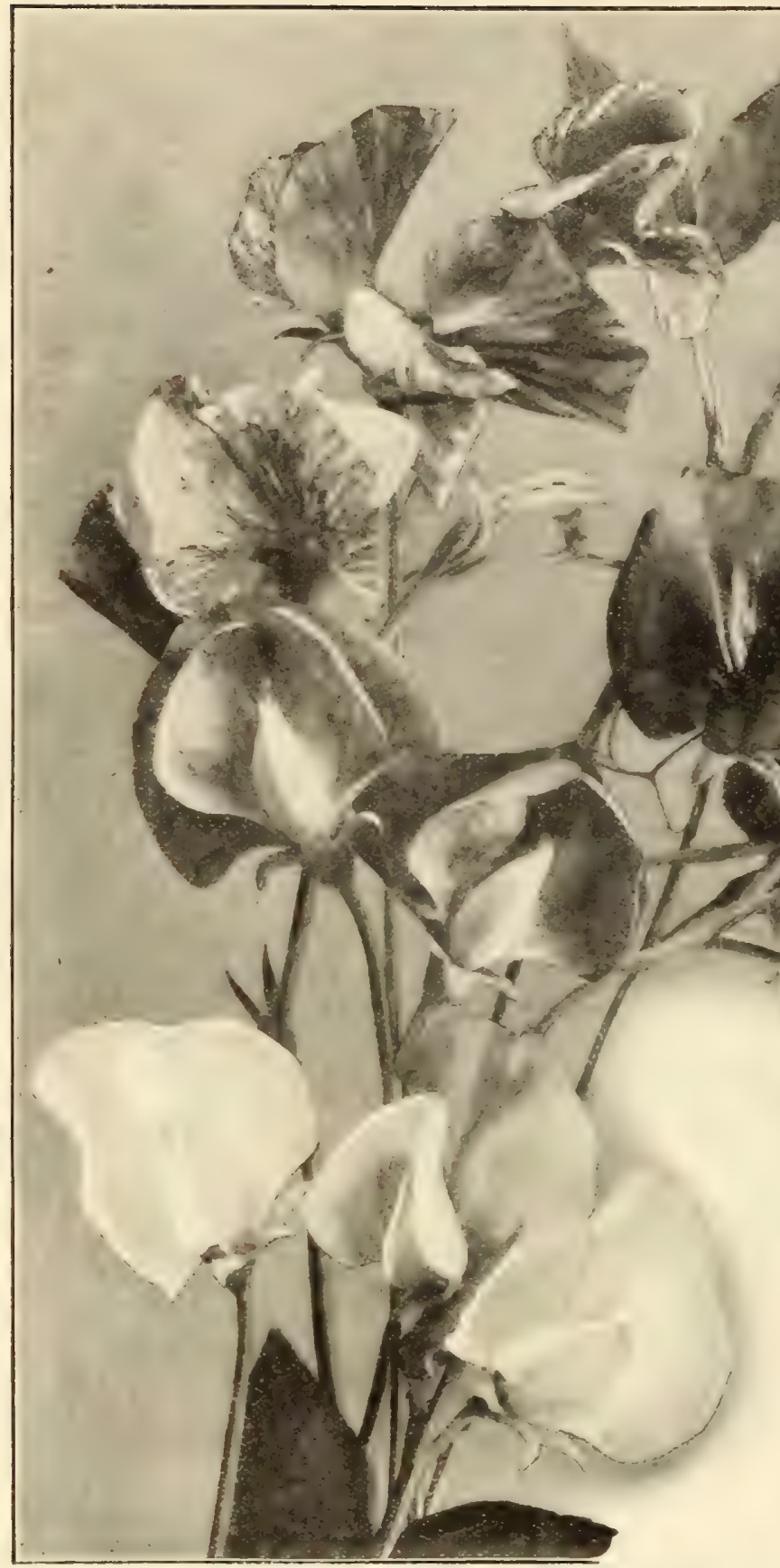

$42 \pi$ Farquhar's Columbian Hybrids, Finest

Mixed. This mixture contains orer fifty of the newest and best large flowering varieties and none of the inferior' sorts. The balance of color is carefully studied and the proportion of each variety weighed out before being mixed. Most of them have long stems each cas'ying thice or four flowers of the tinest substance. 'The more they are picked the more the flowers come, and the better for the vines. Lb., post-paid, 1.00; $\frac{1}{4} \mathrm{lb} ., .30$; ounce pkt, .10.

4280 Farquhar's Bouquet Gems. Collection of 10 splendid colors. We have selected the newest and finest sorts in existence for this collection; all large flowered, fragrant and with long stems. The packets are of good size. Per collection, .40.
4285

Special Mixture of Pink,
Yellow and Salmon
Shades,
Lb., .75; 1 lb., .25;07., .10; .05

4290 Special Mixture of White and Lavender Shades,

Lb...75; $\frac{1}{4} 1 \mathrm{~b} ., .25 ; 0 \%, 10 ; .05$

4295 Special Mixture of Red Shades,

Lb.,.75; 1 1b.,.25; 0z.,.10; .05

4300 Choice Mixed,

Lb.,.50; $\frac{1}{1}$ Ib.,.20; oz., 10; .05

MISS NETTIE L. JOHNSON, Quaker City, N. H., April 9th, 1908, writes: “The Sweet Peas I had of you last year were the finest I ever had; full of blossoms the entire season and perfectly beautiful."

The FOLLOWING SWEET PEAS except where otherwise priced, per Lb., .75; 1 1b., .25; oz.,. .10; pkt., .05.

\section{WHITE VARIETIES.}

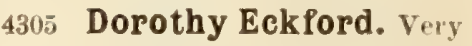
large and massive. 'The' finest white.

4310 Emily Henderson. Large flowers of great substance; pure white.

4315 White Spencer. Enormous flowers of pure Pkt. white; the best of the waved whites, $\mathrm{Oz}, .60 ; .15$

4320 Mont Blane. Extremely early white sort; large flower, fine for forcing $\ldots \quad \ldots$ Lb. $\$ 1.00 ; 0 z, .15 ; .05$

4325 Shasta. Pure White. The petals of both standard and wings are wary on the edges.

4330 Nora Unwin. Large frilled white flowers of the "I'nwin" type $\quad \ldots \quad \ldots . \quad \ldots \quad$ Oz, .60;.15

4332 Earliest White. (Black seed.) One of the very earliest, especially useful for forcing; planis rather

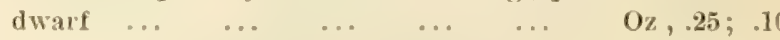

\section{PRIMROSE VARIETIES.}

$4: 335$ Hon. Mrs. E. Kenyon. Light primrose, selfcolored, very large.

4340 Mrs. Collier. Rich creamy yellow, very large

4345 Primrose Spencer. Beautiful pale primrose, yellow flowers ... ... ... ... O $\quad$.., 50;.10

4346 Mrs. Eekford. Delicate shade of yellow.

4350 Sunbeams. 'The earliest pale yellow; forces well.

4355 Queen Victoria. (Black-seeded.) Flower's soft primrose; the buds showing a tint of pink.

\section{BLUSH VARIETIES.}

4360 Lady M. Ormsby Gore. Standard buff and primrose: wings pale yellow; very large.

4365 Modesty. Soft blush; the lightest pink sort.

4370 Stella Morse. Buff with a tint of pink; general effect a rich cream.

MR. SIDNEY BEBB, gardener for F. C. FARWELL, Esq., Lake Forest, III., writes: "The Sweet Pea Seed we gor from you took the Certificate at the Annual Flower Show at Lake Forest." 


\section{SWEET PEAS.-Continued.}

\section{PINK AND ROSE VARIETIES.}

4375 Countess of Spencer. Bright, clear pink: an exquisite flower; the finest of this section.

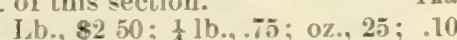

$43 \leftrightarrow n$ Gladys Unwin. A Jorely shade of light rose-pink. Verr large with usually four blossoms to a stem. Lb., $\$ 1.50 ; \frac{1}{4} 1 \mathrm{~b}, .50 ;$ oz., .15; .10

4345 Lovely. Delicate rose and flesh, a beautiful shade with frequently four blossoms to a stem.

$\$ 390$ Sybil Eckford. Blush shading to apricot; very

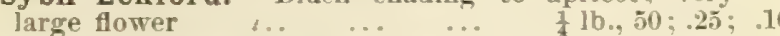

434:2 Agnes Eekford. Soft shell-pink ‥ Oz,.50:.10

4395 Countess of Lathom. Cream-pink; a rich selfcolored shade.

400 Queen of Spain. A delicate pearly pink of medium size $\ldots$... ... ... . . Oz. .35;

440; Prima Donna. Lovely pale pink; self-colored, with nsually four blossoms to a stem.

4410 Dainty. White with pink edges, very pretty.

$\frac{1}{4} 1 \mathrm{~b},, .50 ; \mathrm{oz}, .15 ; .05$

441.5 Earliest of All. The finest pink and white variety for forcing; verv early.

$4+20$ Extra Early Blanche Ferry. The popular pink and white variety.

44.5. Jeannie Gordon. Bright rose with crimson shading; a large flower.

$4+2-$ Marehioness of Cholmondeley. Delicate salmon; wings light buffi.

\section{ORANGE PINK VARIETIES.}

4430 Helen Lewis. A selection of the Spencer type with large wavy flowers of rich orange pink.

$$
+1 \mathrm{lb}, .75 ; 0 z ., .25 ; .10
$$

443.) Bolton's Pink. Rich salmon pink flowers borne on

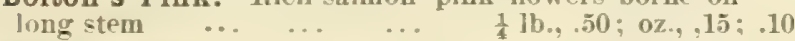

4437 Miss Willmott. Bright orange pink. A grand flower of great substance.

44 Henry Eekford. Intense shining orange: very large

444.5 Gorgeous. Salmon rose. $\frac{1}{4} 1 \mathrm{~b} ., .50 ;$ oz., $.15 ; .10$

\section{DEEP ROSE AND ROSY CARMINE VARIETIES.}

4 4in Janet Seott. A heautiful deep pink of large size.

44.5.) Prince of Wales. Rose crimson, self-colored, often hearing foul blossoms on one stem.

\section{flowers large and wavy}

\section{BLUE AND WHITE VARIETIES.}

4ti:; Helen Pierce. Pure white, veined and marbled bright blne. $\begin{array}{lllll}\text { A very attractive variety } & \ldots & \ldots & \ldots & \frac{1}{4} \mathrm{lb} ., .75 ; 0 \%, .25 ;\end{array}$

44.0 Phenomenal. A new orchid-flowered variety with very large white blossoms shaded and edged with lilac ... $\frac{1}{4} \mathrm{lb} ., .50 ; 0 z ., .15$;

Hi2 Lottie Eekford. Rose and white edged with blue.

44.5) Maid of Honor. White edged with lavender.

\section{STRIPED VARIETIES.}

4tin) America. Crimson scarlet striped on white.

4tro Jessie Cuthbertson. Primrose, sţriped with light pink.

44!f) Golden Rose. Creamy-white, faintly striped with light pink.

44.5.5 Aurora. White striped and flaked orange salmon.

\section{SCARLET AND CRIMSON VARIETIES.}

King Edward VII. Bright red or crimson scarlet with large flowers of fine form. ... ... L Lb., \$1.00; $\frac{1}{1} 1 \mathrm{~b}, . .35 ; 0 z_{.}, .15$ : Queen Alexandria. A new self-colored scarlet of an intense shade; very free flowering,

... $\left.\frac{1}{4}\right] \mathrm{b}, 0.75 ; 0 z ., 25$

John Ingman. Very large wavy flowers of a rich rose-carmine; one of "Spencer" seedlings,

Coecinea. Bright cherry red.

Prince Edward of York. Scarlet and rose.

$\frac{1}{8} 1 \mathrm{~b} ., .75 ; 0 z ., .25 ;$
MAROON VARIETIES.

4 .50 Black Knight. Very deep maroon, large and beautiful.

4540 0thello. Dark maroon showing veins of almost black.

Black Michael. Bright shining reddish maroon.

\section{BLUE AND PORPLE VARIETIES.}

4 aั50 Navy Blue. Fine dark violet blue, one of the best.

4ั.5 Lord Nelson. Rich deep blue self: almost a navy Pkt.

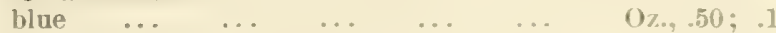

560 Hopace J. Wright. Standard violet-maroon, wings $\begin{array}{lllll}\text { violet, of large size } & \ldots & \ldots & \ldots & \mathrm{z}_{2}, .60 ; .10\end{array}$

4565 Duke of Westminster. Glossy rosy-purple flowers.

${ }_{570}$ Duke of Sutherland. Standard deep claret, wings indigo blue.

57. David R. Williamson. Indigo hlue standard. wings shaded lighter; a grand flower.

580 Romolo Piazanni. Large rosy-purple, changing to lilac and blue when fully expanded.

582 Shahzada. Standard deep maroon; wings dark violet. 'The darkest of the blue shades.

\section{MAUVE AND LAVENDER VARIETIES.}

458. Lady Grisel Hamilton. Pale lavender blue. The largest and lightest of the lavender varieties.

4590 Mrs. Walter Wright. Large mauve blue of fine form.

459.5 Mrs. Geo. Higginson, Jr. A lovely shade of azure blue.

Frank Dolby. A large-flowered lavender self. of the "Lnwin" type.... $\quad \ldots \quad \ldots \quad \ldots \quad \ldots \quad$ Oz.. 50 : . . For New Sweet Peas see Novelty page No. 40

\section{TORENIA.}

A most beautiful genus of free-flowering tender annuals. If started in heat in February or March they commence to bloom in June and continue until frost; height 10 inches.

Bailloni. Flowers golden yellow with purple throat,

4640 Fournieri grandiflora. Sky blue with three large blue spots and a bright yellow throat, $\frac{1}{3} 07 ., 1.25 ; .25$ Fournieri White Wings. Blush white with rellow throat; very beautiful, $\ldots \quad \ldots \quad \frac{1}{5}$ oz., 125 ; 20

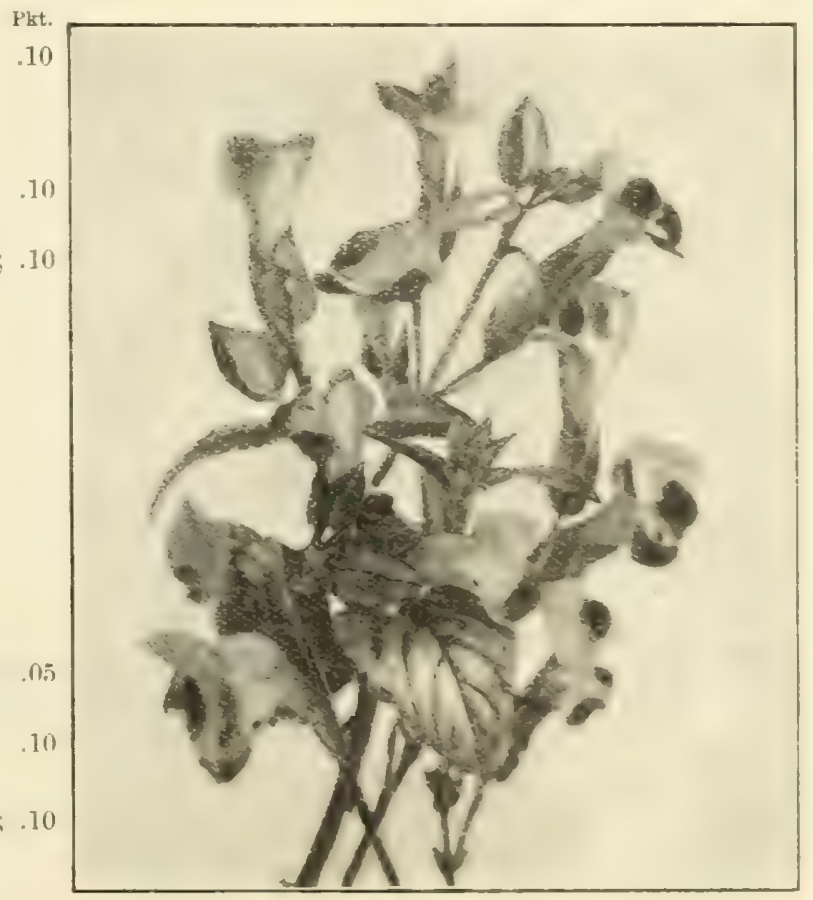

Torenia Fournieri Grandiflora. No. 4640. 


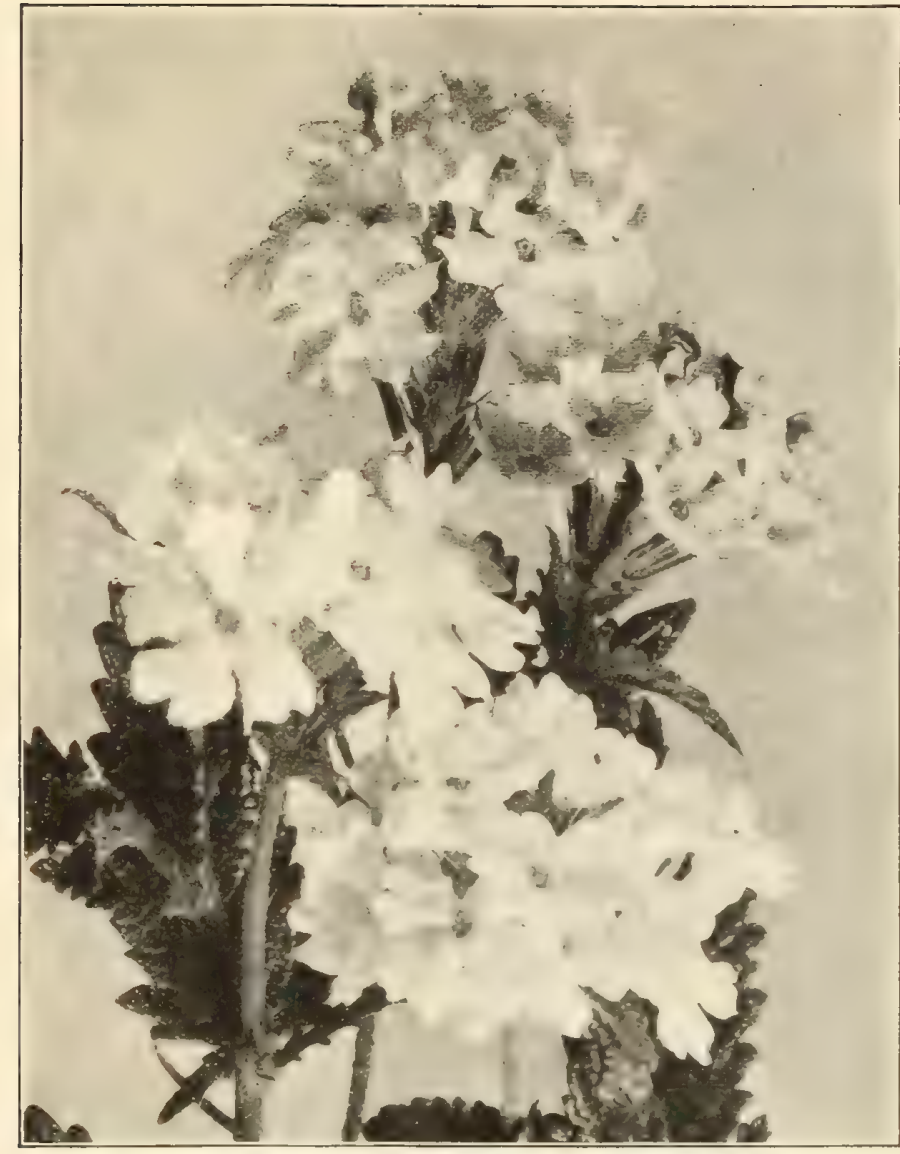

Verbena Farquhar's Mammoth Hybrids. No. 4650.

\section{VERBENA.}

4650 Farquhar's Mammoth Hybrids Mixed. An improved strain of vigorous growth-producing trusses of large Pkt. flowers of many brilliant colors, $\mathrm{Oz} ., 2.00 ;+0 z ., 60 ; .10$

1655 Giant Blue

4665 Giant Searlet.

4660 Giant Pink.

1675 Striped.

Each of the above color 4670 Giant White.

4680 Auricula-flowered mixed. "Large flowers with distinct white eye in each floret ... Oz., $150 ;+0 z, .50 ; .10$

\section{VERBENA.-Continued.}

4685 Mixed. Many beautiful colors, Oz., $100 ; \Varangle$ oz., .35; .05 4690 Verbena Venosa. A handsome half-hardy perennial with purple flowers remaining in bloom for a long

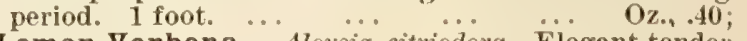
Lemon Verbena. Aloysia citriodora. Elegant tender perennial with fragrant evergreen leaves. The young sprays are useful for combining with other flowers in bouquets

VINCA. Madagascar Periwinkle.

Ornamental free-blooming perennials flowering the first year from seeds sown in February ol March in heat. They have dark laurel-like foliage and handsome pink and white flowers. They are most effective as bedding plants and are particularly adapted for dry sunny situations where they will flower luxuriantly all summer. Seeds are of slow germination. 1 foot.

4700 Bright Rose. 4705 Pure White.

4710 White with rose eye. 4715 Mixed.

Each of all the above color's and mixed

$\mathrm{Oz}, 1.00 ;+0 \mathrm{z} ., .35 ; .10$

\section{VIRGINIAN STOCK.}

Early flowering hardy annuals, largely grown for their bright effect in the garden.

Mixed

$0 \%, .20: .05$

VISCARIA. Rock Lychnis.

Showy and profuse-blooming annuals, effective in small beds or borders. 1 foot

4725

Finest Mixed

\section{WALLFLOWER.}

These new early-flowering varieties may be treated as annuals, and if sown in heat during February or March the plants will bloom freely through the summer and autumn. Excellent for forcing. 2 feet.

4730 Early Parisian or Annual. Light brown. Oz.g.60;.10 4740
Kewensis. The flowers of this new hybrid are borne on long slender stalks and are extremely firgrant. 'The colors vary from sulphur yellow to brownish-violet, with occasionally all shades appearing on one plant. From seeds sown in July plants will commence flowering in early winter

For Perennial Varieties, see Nos.7915-7925.

\section{WHITLAVIA Grandiflora.}

Pretty hardy annuals with bell-shaped flowers borne in profusion on compact plants. 1 foot.

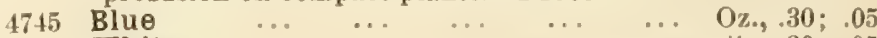
4750

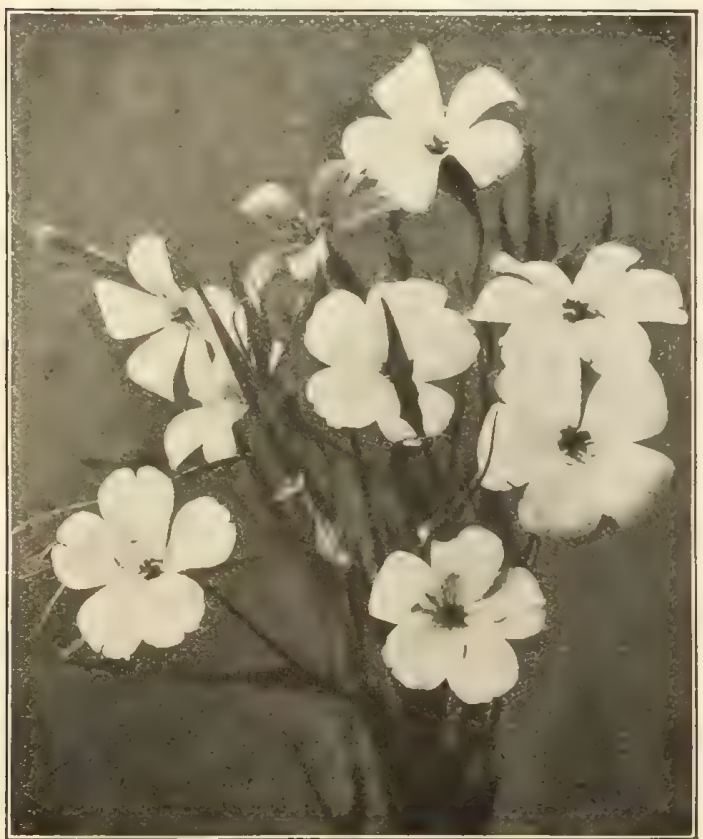

Viscaria, Finest Mized. No. 4725.

\section{WIGANDIA.}

Stately and decorative half-hardy perennials with very large beautifully-veined leaves frequently three feet long: invaluable for sub-tropical beds or lawn groups. Seeds sown in heat during February or Harch produce fine plants for summer. $6 \mathrm{ft}$.

4755 Caracasana. Lilac, Pkt., .10

4760 Imperialis. Very ornamental,Pkt., .10

\section{XIMENESIA}

Enceliodes.

4765 A showing half - hardy annual with broad cluster's of yellow flowers. 2 feet, Pkt., .10 10

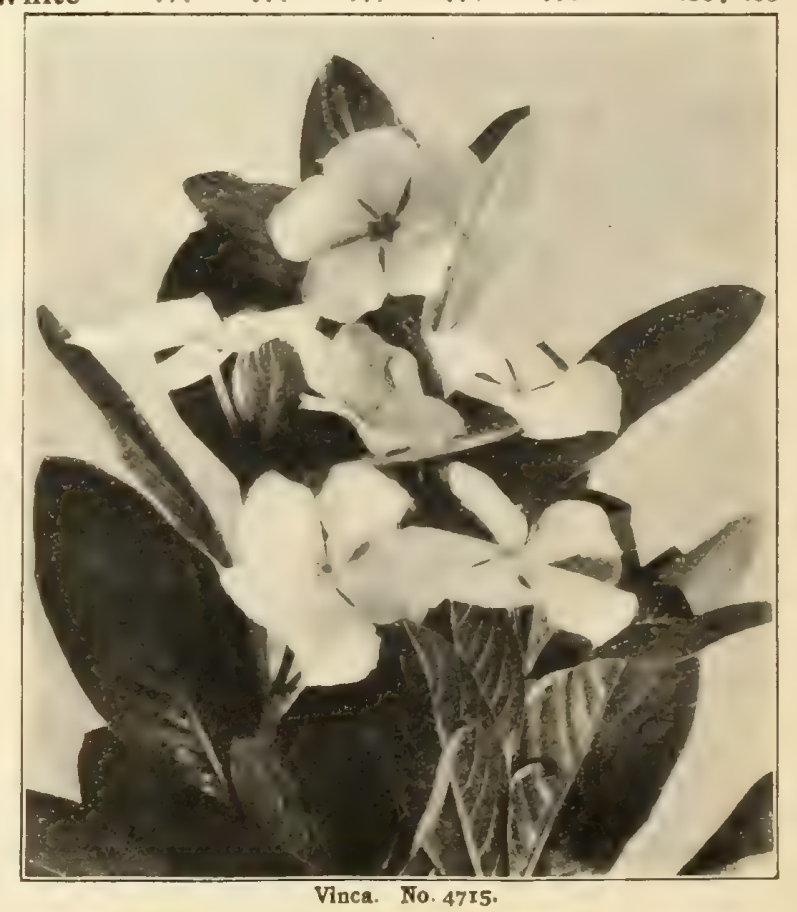




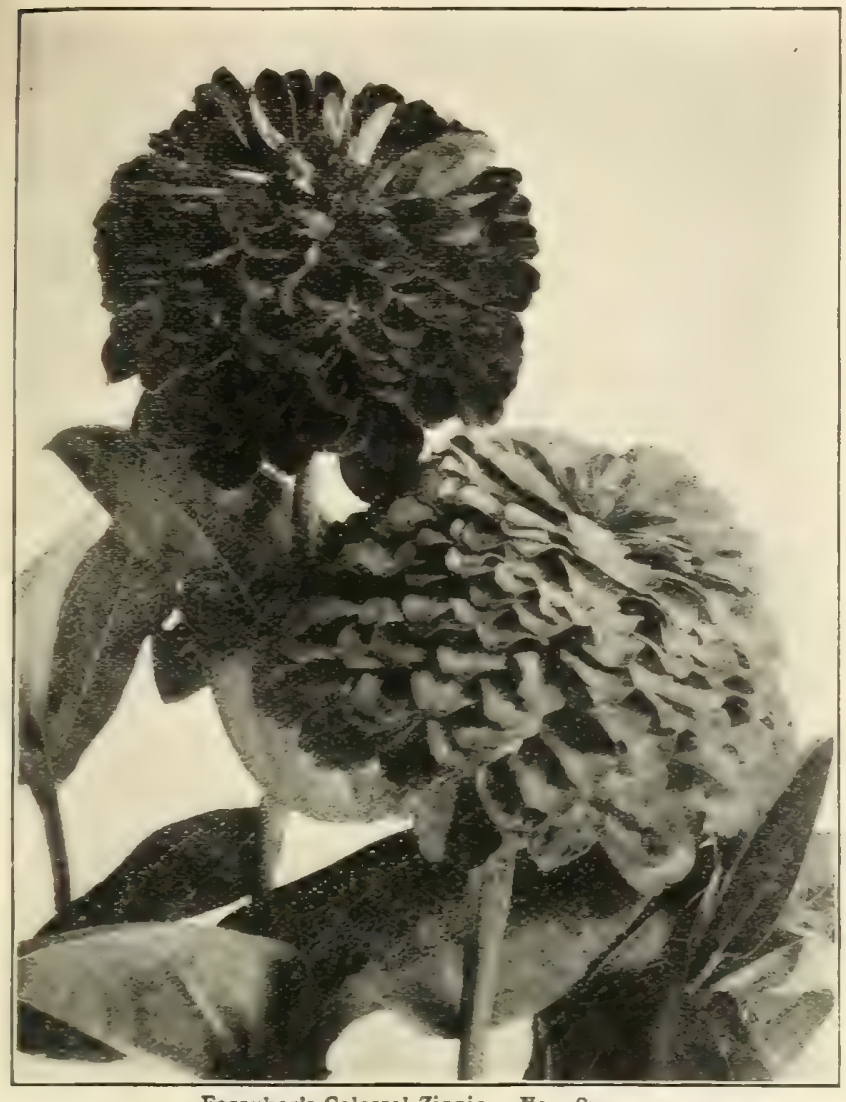

Farquhar's Colossal Zinnia. No. 4870

4310 Farquhar's Dwarf Prize Mixed. Flowers of large Prt. size and splendid colors ‥ Oz., .75: $\frac{1}{4} 0 \% \ldots .25 ; .05$

4915 Collection of 6 Varieties Separate, Our selection, .25

49:20 Zinnia Elegans Curled and Crested Mixed.

Large double flowers with curiously twisted and

curled petals. 2 feet $\ldots .0$ Oz. $1.75 ; \frac{1}{4} 0 z ., .50 ;$

4925 Zinnia Haageana fl. pl. Mesican Zinnic. A dwarf variety with small, double orange colored flowers. 11

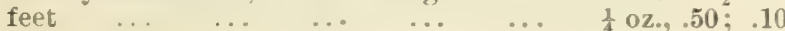

\section{ZINNIA.}

Most desirable and decorative annuals for beds and mixed borders. 'The dwarf varieties from their compact and dense growth are particularly useful for beds, while the tall sorts are well adapted for inside rows in ribbon borders.

FARQUHAR'S DOUBLE LARGE FLOWERING. 2 feet

47 ijo Delicate Rose. 4775 Dark Crimson.

4780 Purple.

4790 Golden Yellow.

4800 Lilae.

4810 Striped.

Each of the above colors

4785 Salmon Pink.

4795 Lemon Yellow.

4805 Searlet.

4815 White.

Pkt.

4820 Farquhar's Exhibition Prize Mixture. Comprising the most beautiful and brilliant color's, 1 Ib., $1.75 ;$ oz., .50; $\frac{1}{4}$ oz., .15; .05

48.5 Collection of 10 Varieties Separate. Our selection, .40

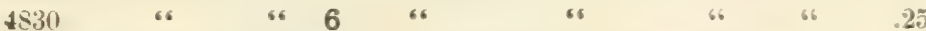

\section{FAQUHAR'S COLOSSAL STRAIN.}

A greatly improved strain with enormous double flowers of fine quality and richness of color. 2 feet.

4835 Delicate Rose.

4845 Searlet.

4855 Salmon Pink.

Each of the above colors

4810 Golden Yellow.

4850 Crimson.

4860 White

4865 Superb Mixed.

Oz., $1.25 ; 1$. 0z., .40;.10

"6 $1.25 ; .6 \quad .40 ; .10$

48.0 Collection of 6 varieties Separate. Our selection, .50

ZINNIA Elegans fl. pl. Dwarf. $1 \frac{1}{4}$ feet.

48.5 Bright Rose.

$4 \times 85$ Dazzling Searlet.

48.15 Orange.

1905 White.

Each of the above colors
4880 Crimson.

4890 Flesh Pink.

4900 Yellow.

$$
\mathrm{Oz}, .75 ; \frac{1}{4} 0 \mathrm{z} ., .25
$$

4930 Zinnia Dwarf Searlet Gem. A charming Zinnia, the compact plants fairly bristling with double blooms of intense dazzling'scarlet. $1 \frac{1}{4}$ feet, $\mathrm{Oz} ., 125 ; 10 \mathrm{co} . .40 ; .10$

4935 Zinnia Liliput or Tom Thumb Mixed. Interesting little plants with small flowers. 9 inches. $\frac{1}{4}$ 0z., .30;

4940 Zinnia Miniature Golden Ball. Dwarf form of Zinnia with golden yellow flowers. 9 inches. $\frac{1}{4}$ oz., $.30 ; .10$

4945 Zinnia Miniature-Searlet Ball. Similar to the preceding with bright scarlet flowers … $\frac{1}{4}$ oz., .30;

\section{EVERLASTINGS.}

These should be grown in everv garden not only to brighten it in summer, but as cut flowers for winter decoration For winter use the flowers should be cut before they are fully expanded and hung with the heads downward in an airy room to dry.

\section{ACROCLINIUM.}

Showy annuals of great value as cut flowers. 1 foot.

Plat.

4250

4.955

Double White

Oz.. .30:.05

Double Rose

$.30 ; .05$

\section{AMMOBIUM alatum grandiflorum.}

4960 Splendid annual with small white flowers. 2 feet ... Oz.. .25:.05

\section{GLOBE AMARANTH.}

Gomphrena.

Desirable annuals adapted for edgings or large beds. 1 foot.

Purple

Oz., .25; .05

$49 \div()$

4975

1980

Orange $\ldots \quad \ldots \quad$ 6 $\quad .75 ; .10$

White $\ldots . \quad \ldots \quad$ แ6 $.25 ; .05$

Mixed

66 $.25 ; .05$

\section{HELICHRYSUM.}

One of the most popular everlastings, embracing many lieautiful shades of yellow and brown. 2 feet.

4985 Collection of 12 Varieties Sepa- Pkt. rate. Imported a.

4990 Double Mixed ... Oz.,.60;.05

4995 HELIPTERUM. Mixed Colors. Pretty annuals with dense masses of white or yellow flowers; 1 foot,

\section{RHODANTHE.}

Half hardy annuals with delicate piuk or white flowers.

5000 Maeulata. Bright pink, Oz., .75; .05

5005 Maculata Alba. Pure white, 6 .75: .05

5010 Manglesi. Brilliant rose, 66 .75; .05

5015 Manglesi fl. pl. Soft piuk; double,

5020 XERANTHEMUM. Pretty annuals

for winter bouquets; colors white

and purple. $1 \frac{1}{2}$ feet ... $\mathrm{O}_{2 ., 5} .50 ; .05$

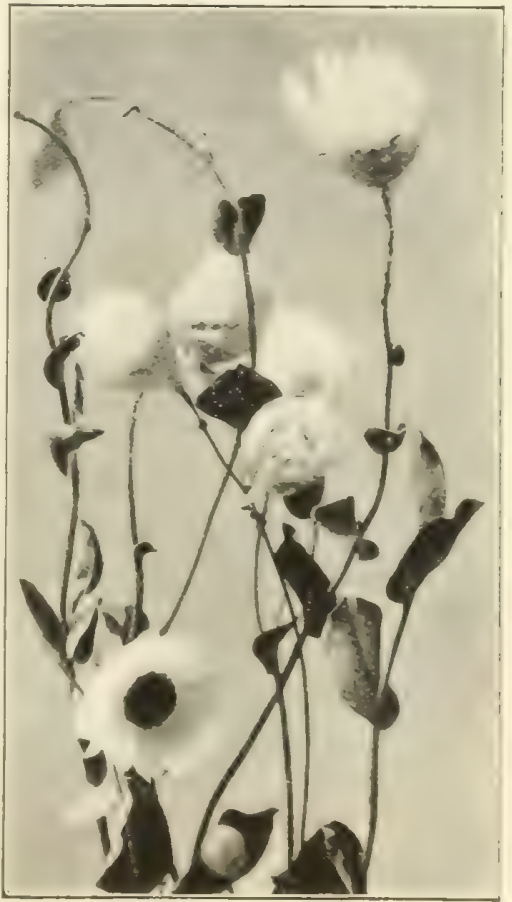

Rbodanthe Manglesi. No. soro. 


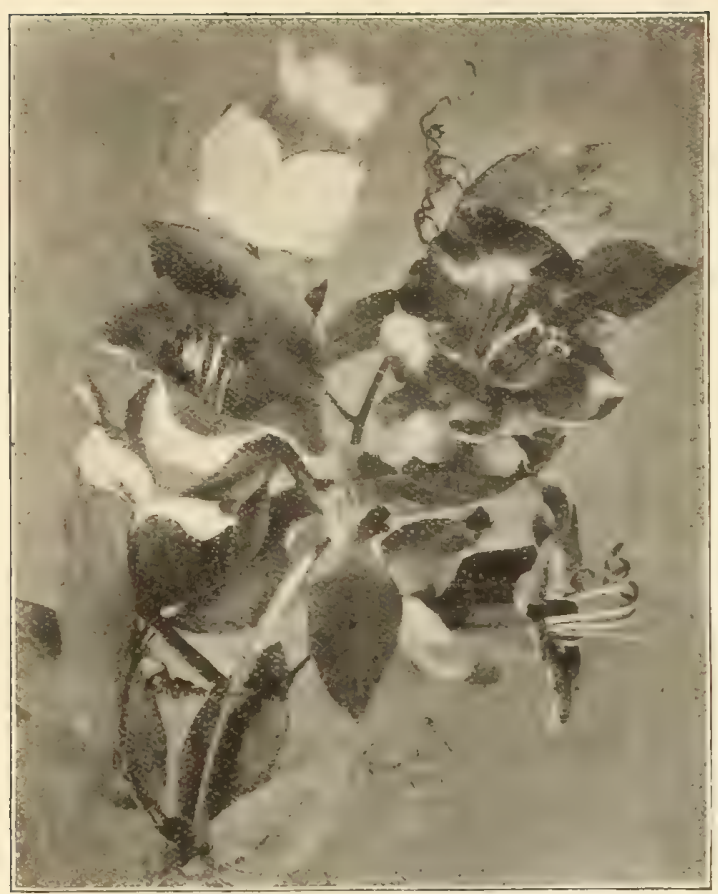

Cobea Scandens. No. 5095 .

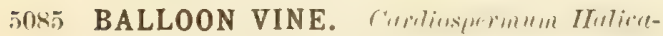
cabum. Rapid growing annual climber, with white blossoms and sead ressels like miniature balloons; succeeds best in light Pkt. warm soil. 8 feet $\ldots . \quad \ldots \quad 07 . .25 ; .05$

5090 BEAN. Searlet Runner. Hardy annual vine with bright scallet Howers. Edil! pods of delicious flavor. $6 \mathrm{ft} . \quad \mathrm{Qt}, .3 \mathrm{D}^{\circ}$ )

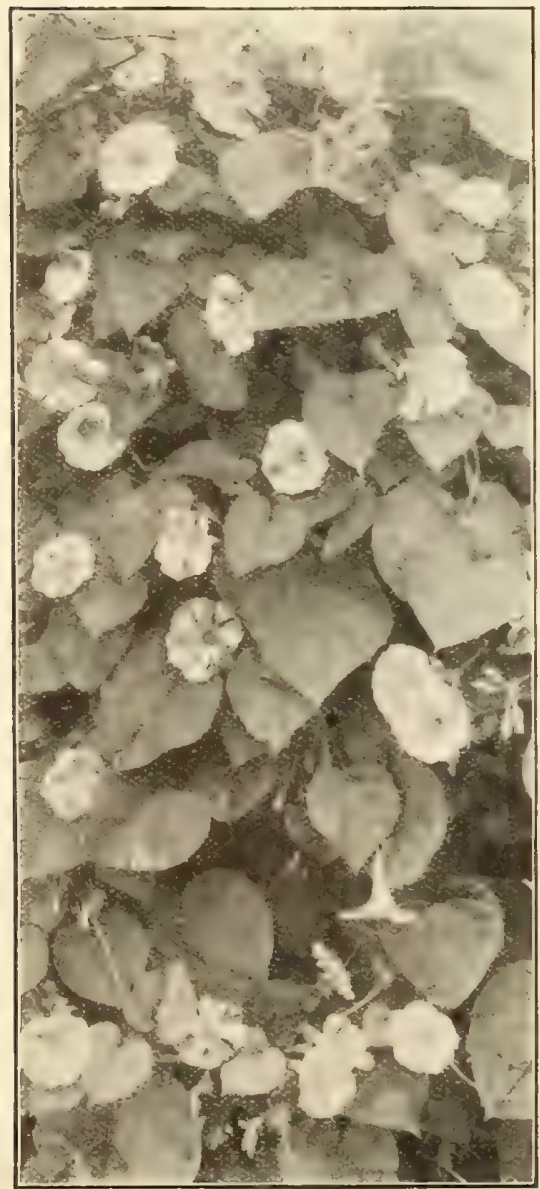

Ipomøa Imperialis. No, 5230 .
5110

5115

5125

5130

\section{5}

CYPRESS VINE. Ipomnea Quamoclit. Very graceful and beautiful twining annuals with feathery dark green foliage and starlike flowers. 20 feet.

5040 Hardy Varieties, Mixed

5045 Tender Varieties, Mixed

5050 Alba. White Pond Lily. Hardy

5055 Cœrulea or Stellata. Light blue; tender

5060 Odorata Rosea. Pink Pond Lily. Beautiful rose pink; hardy.. 25

5065 Zanzibariensis Azurea. Royal Wuter Lity. Large azure blue flowers, very fragrant

5070 Zanzibariensis Rosea. Flowers deep pink

For Cyperus see Nos. 2270 and 2275.

\section{CLIMBERS.}

5075 ABOBRA Viridiflora. A charming climbing gourd for the summer garden, with glossy green leaves, and pretty scarlet fruits. The roots are tuberous and may be kept over winter like dahlias. 10 feet

Oz.., .60;. .05

5080 ADLUMIA Ciprhosa. "Mountain Fringe. A haidy biennial climber, blooming the first season, with delicate foliage and clusters of rosy lilac fiowers. $15 \mathrm{ft}$. ... ... O Oz.., 1.25; $\frac{1}{4} \mathrm{oz} ., .40$;

5095 COBEA Seandens. Well-knowu tender climbing perenuial of rapid growth. flowering the first season; producing large bell-shaped purple flowers. 20 feet $\ldots . \quad \ldots \quad \ldots 0 \%, .75 ;+0 \%, .25$;

5100 Seandens Alba. White ...

$0 \% ., 1.50 ; \frac{1}{4} \mathrm{oz} ., .50 ; .25$

5105 COCCINEA Indiea. Innual climber with white fowers and searlet. COCCINEA Indiea. Inmual climher with white fowers and searlet
fruit ... $\quad \ldots$
... Mixed. Shades of pink, scarlet and white,
Searlet
$\mathrm{O} \% ., .30 ; .05$
5120 White

$02 ., .30 ; .00$

DOLICHOS Lablab. Hyacinth Bern. Rapid growing annual vine with clusters of white or purple flowers. Finest mixed. 10 feet. ... ... O\%, .25:

ECHINOCYSTIS Lobata. California Cucumber. One of the quickest growing anuual vines. The seeds should be sown in autumn, or if sown in spring, first soaked in warm water 24 hours. 20 feet. ... ... ... ... O\%., .50; ECCREMOCARPUS Seaber. An invaiuable half hardy climber for trellis work; orange-scarlet flowers and pretty foliage,

\section{GOURDS. Ornamental.}

Luxuriant climbing annuals, useful in covering arbors, fences or s!opes, and bearing fruits which are of interesting forms and colors. 10 to 15 feet.

5140 Apple-shaped. Small fruit, striped yellow and dark green, ‥ Oz.,.40;.05

5145 Bottle-shaped. Fruit yellowish-white with circles of dark green, 0 \%., .25; .05

5150 Dipper-shaped or Calabash. The fruit is of slender, neck-like form for two-thirds of its length, widening a the apex in the form of a bowl. In tropical countries the shells are dried and used by the natives as dippers, $07, .25 ; .05$

515. Dish-Cloth. Chinese Lonfa or Sponge Gourd. Fruit large and elongated, with a spongy net-work of tough fiber inside, which when dried is used by the Japanese to form the soles of sandals. It is also used like a sponge for bathing,

5160 Egg-shaped. Small white fruit resembling an egg, $\quad \ldots \quad \ldots . \quad 0 z ., 40 ; .10$

5165 Gooseberpy. Very small dark green fruit like gooseberries, . . Oz.,.40;.10

5170 Hereules' Club. Fruit 4 feet long, white $\ldots . . . \quad \ldots . \quad$ Oz., .25; .05

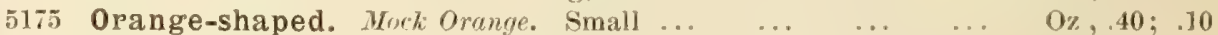

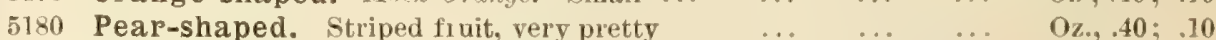

5185 Serpent-shaped. Fruit striped like a serpent. 3 to 5 feet in length and very

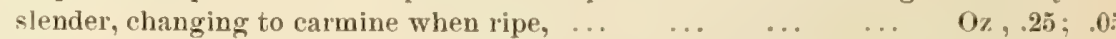

5190 Sugar Trough. Large pumpkin-shaped fruit, shells used as water calabashes, Turks Turban. Iurban-shaped frut, beautifully striped with red, (0\%., .40; .10

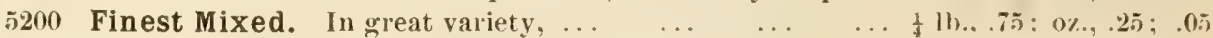
5205 Collection of 12 Varieties, Separate, our selection $\ldots \ldots \ldots \ldots$ 
R. \& J. FARQUHAR \& CO., BOSTON. CLIMBERS.

\section{CLIMBERS.-Continued.}

HUMULUS. Hop.

5210 Japonicus. Japanese Hop. Splendid annual climber of Prt. quick glowth and very ornamental. $12 \mathrm{ft} . \quad \mathrm{Oz} ., .50 ; .10$

5215 Lupulus. The Hop with its luxuriant foliage and rapid growth makes an ornamental and useful hardy climber. $15 \mathrm{ft}$.

\section{IPOMEA.}

Rapid growing twining plants useful for coveriug arbors aud trellises, remarkable for their showy flowers of white, pink, blue,and purple; 5 to 30 feet.

5220 Puppurea. Concolvulus Major. Morning Gilory. Show annual climbers of easy culture indispensable for covering trellises, arbors and fences. Finest mixed, Lb. .60:0z.. 10

5225 Purpurea. Collection of 10 Varieties Separate,

5.30 Imperialis Mixed. Japanese Morning Glory. The flower's are of enormous size and of great variety of color's many of them being beautifully striped, spotted, or edged with distinct colors. 10 feet ... Oz., .30;

5235 Bona Nox. Evening Glory. Large fragrant violet flowers, opening in the evening. 15 feet ... Oz., .30;

5240 Coceinea. Star Ipomoe. Bright scarlet flowers with suluall fuliage. 10 feet $\ldots . \quad \ldots \quad \ldots . \quad \ldots \quad 0 \%$. 25;

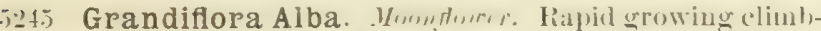
er with large heart-shaped leaves and tragrant white flower s 5 to binches in diameter, expanding in the erening or during dull days. 30 feet, Oz., $1.00 ; \frac{1}{4}$ oz., .35; .10

5250 HeavenIy Blue. Immense flowers of bright sky-blue; very beautiful. 'The seeds should be sown indoors and the plants transferred to the open ground wheu warm,

โ255 Setosa. Brazilian Morning Glory. Vigorous growing variet 5 with large leares and bright rose-(w) lored flower3 to 4 inche in diameter. $15 \mathrm{fpet} \ldots \ldots(1) \ldots . .5 \%$

$\therefore 250$ KENILWORTH or COLISEUM IVY. limerin anmelullaria. A perennial trailing plant with violet flowers useful for hauginu-haskets, vases and pots. 3 inches.

.10

\author{
.05
.60
.10
}

.05

0.5

15

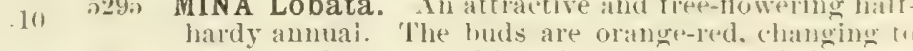

.11

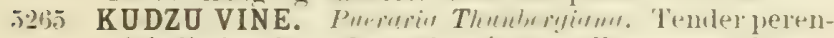
nial climber from Jatuan bearing small racemes of rus lilac flowers late in the season. It makes a growth of 8 to 10 feet the tirst year but when established frequently grows 30 to 40 feet ... ....... . . , .40:

i270 LOPHOSPERMUM Coeeinea. A heatutiful half-hardy elimber with rosy-red flowers. 10 feet

$52 \%$ Seandens, Large pink flowers... . . $1 \frac{1}{4}$ oz., $1.00 ; .10$
ธั290

5:95 MINA Lobata. In attractive and fres-flowering half yellow and creamy white when fully expanded

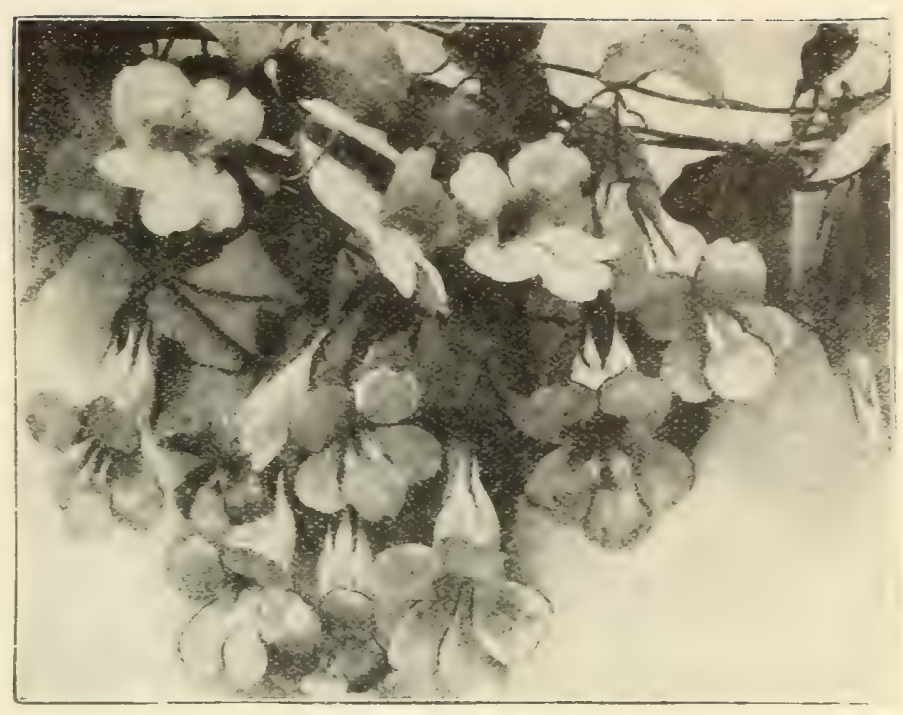

Maurandya No. 5280

52N) MAORANDYA. Finest Mixed. Elegant wreenluma peremial climbers producing the first season imnumarable tube-shaped flowers of purple, rose and white mixed. Cnexcelled as vines for hanging baskets, vases and trellises

$\frac{1}{4} \mathrm{Oz}, .75 ; .10$

White

207,$100 ; .25$

5300 MOMORDICA Balsamina. Bulstme lywe. Remarkalbly handsome climbing anmual with rich areen foliage and golden-yellow warted fruit shaped like an apple. which wheu ripe breaks open displaying its hrilliant rimson interior: 10 feet.

$\mathrm{Oz}, . \overline{0} 0: .10$

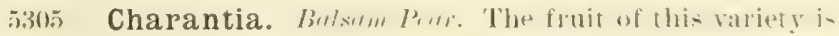
pear-shaped, otherwise it resembles the preceding,

Oz. . 0 :

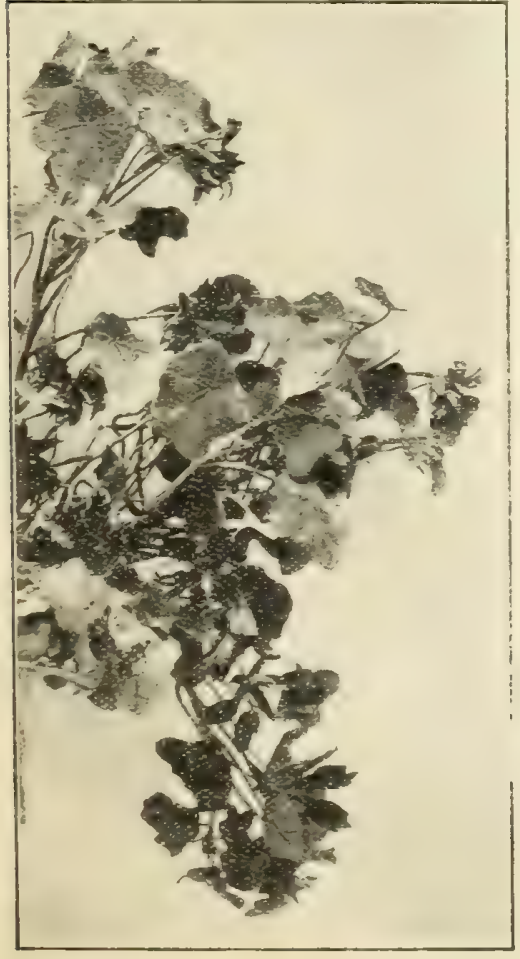

Canary Creeper No. 5320.
Ornamental climbing plants with numerous large showy flowers valuable for the conservatory and garden in summer. Perenuials. 10 to 30 fees,

5310 Cœrulea. Exquisite blue flowers

5315 TACSONIA. Van Volxemi. Scarlet, magnificent

\section{THUNBERGIA.}

Hardy trailing aunuals of ravid growth, useful fol window boxes, hanging baskets and vases. 4 feet

4615 Alata. Flower's yellow with black eve

4620 Alata alba. White with dark eye

4625 Aurantiaea. Orange

4630 Mixed

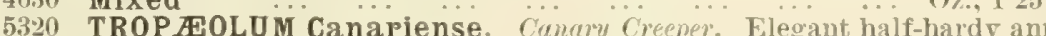
with delicately cut leaves and lovely bright yellow fringed flower's. 10 feet, Oz., .50:

5325 Collection of 8 Annual Climbers. Separate varieties; our selection.

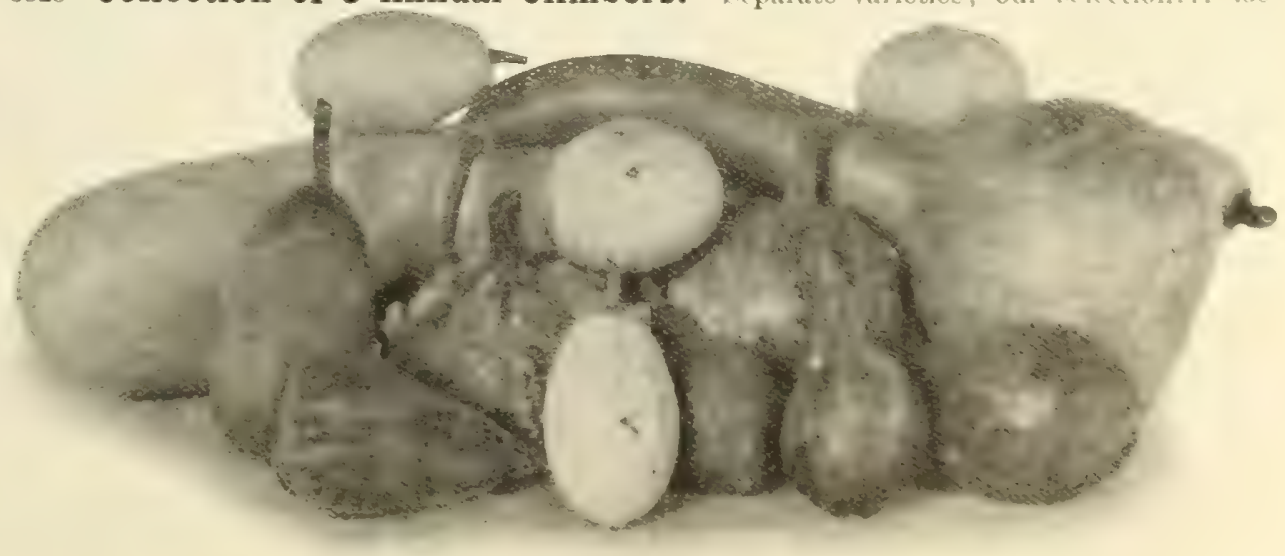

Ornamental Gourds No. 5200. 


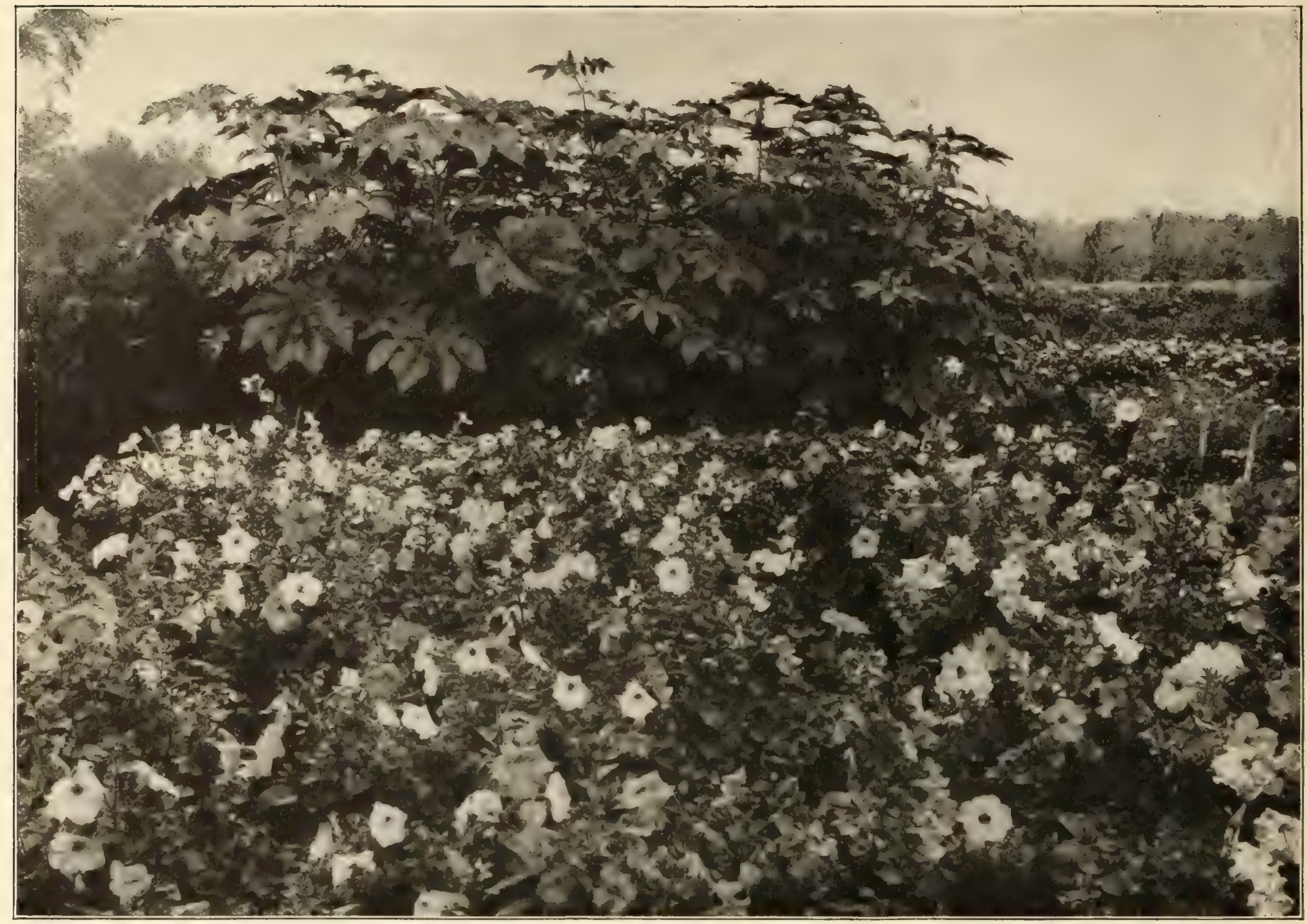

Petunias and Castor Oil Beans at Farquhar's Trial Grounds, Dedham, Mass.

\section{FARQUHAR'S SHORE AND MOUNTAIN COLLECTION OF FLOWER SEEDS.}

\section{A FINE ASSORTMENT AND QUANTITIES SUFFICIENT FOR}

\section{A LARGE GARDEN FREE BY MAIL FOR \$1.00.}

Among the thousands of visitors to the seashore and mountain resorts of New England, many come to us inquiring what flower seeds are most suitable for producing a satisfactory and continuous display of flowers in their summer gardens. Our purpose in offering this collection is to meet this want and to save such purchaser the disappointment of selecting and cultivating varieties quite unsuited to their purpose. It has been our aim to make the assortment large and varied, with ample quantity of the more important flowers. We have also borne in mind the fact that flowers suitable for cutting are preferred, and nearly all are available for bouquets or vase decoration.

The collection includes $\frac{1}{1} \mathrm{lb}$. Farquhar's Columbian Prize Sweet Peas, $1 \mathrm{oz}$. Farquhar's Tall Nasturtiums, $\frac{1}{2} \mathrm{oz}$. Large Fragrant Mignonette, and a liberal packet of each of the following, namely: Sweet Alyssum, Aster, Clarkia, Dwarf Morning Glory, Cornflower, Chinese Pinks, Eschscholtzia, Godetia, Single Miniature Sunflower, Annual Lupins, Mallows, Marigolds, Nemophila, Annual Phlox, Poppies, Seabious, Zinnia. Also one Special Packet Farquhar's Bouquet Mixture of Flower Seeds mixed from over a hundred varieties of the best eutting flowers. One special Packet Flower Seeds for Wild Gardens, mixed Prom over two hundred splendid annuals.

Full Cultural Directions on each Packet.

\section{FARQUHAR'S MIXED FLOWER SEEDS FOR BOUQUETS.}

This mixture embraces a most charming variety of annuals adapted for furnishing a continuous supply of eut flowers from early in summer until frost. Many rarieties not generally known are included making it exceedingly interesting, and all are of the easiest cultivation.

Large Packet

One-ounce Packet

Quarter-pound..

Pound, post-paid

\section{FLOWER SEEDS FOR WILD GARDENS.}

\section{SPLENDID MIXTURES OF MORE THAN ONE HUNDRED} BEAUTIFUL VARIETIES.

These mixtures contain many beautiful and interesting annuals, furnishing a profusion of bloom from early summer until frost. They are intended to produce a display without the care necessary to regularly kept flower beds. We sell annually large quantities of these seeds for beautifying the surroundings of seashore and country hotels and residences. They not only beautify the grounds, but afford many varieties of flowers useful to cut for house decoration; and owing to the larce number of varieties comprising the Mixtures, one finds some new sort of bloom almost every day, anc it is most interesting to watch for them.

Dwarf Wild Garden Flower Seeds. Half-ounce packet with full directions, . 15 ; ounce, .25; quarter pound, .75; pound, 2.50 , post-paid.

Tall Wild Garden Flower Seeds. Half-ounce packet with full directions, .15; ounce, .25; quarter pound, .75; pound, 2.50 , post-paid. 


\section{SEEDS OF GREENHOUSE PLANTS.}

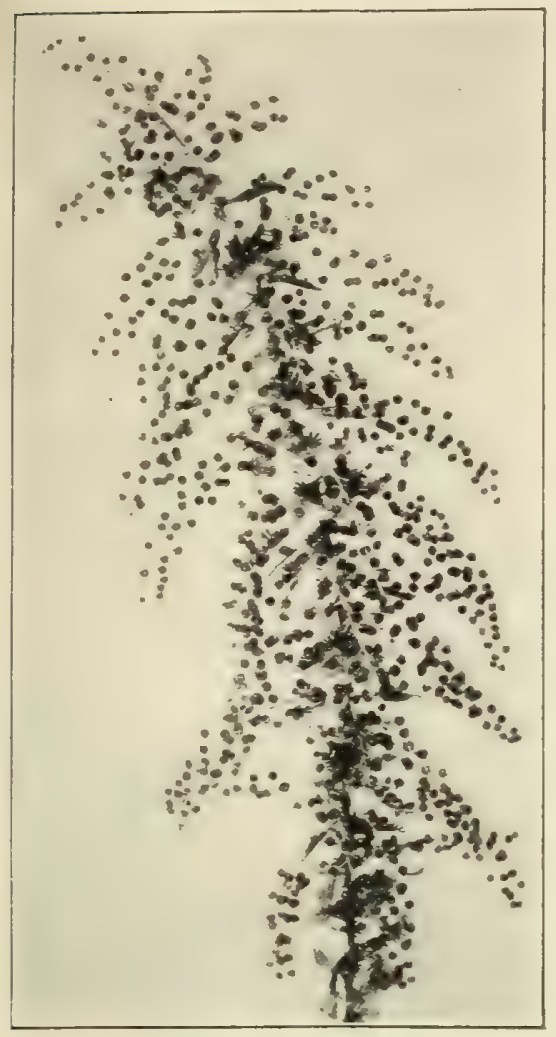

Acacia Baileyana
ABUTILON. Chinese Bell-Flower or Flowering Maple. Perpetual flowering greenhouse shrubs of easiest cultivation, and invaluable for summer bedding or conservatory decoration. Seeds sown in March produce flowering plants the first season. 3 to 4 feet.

5330 Farquhar's Choice Hybrids. Sared from a splendid collection, the colors include shades of white, Pkt. yellow, pink, and crimson

5335 Fine Mixed

\section{ACACIA.}

Tender shrubs with graceful foliage and beantiful racemes of flowers. 8 to 10 feet. The seeds should be soaked in hot water before being sown.

5340 Armata. Yellow, very handsome ... ... ... .10

5345 Baileyana. Long sprays of bright yellow flowers which are excellent for cutting. This variety is of rapid growth and good flowering plants may be had the second year from seeds

5350 Floribunda. A popular variety with lovely orangered flowers.

5355 Lophantha Superba. Flowers yellow, delicate green foliage

\section{ACHIMENES.}

5360 Profuse-blooming tuberous-rooted greenhouse plants valuable for pots or hanging baskets. The flowers vary considerably in size, and are of the most brilliant colors. 1 to 2 feet. Finest mixed ...

5365 AGATHEA Cœlestis. Blue Daisy. Tender perennial with pretty blue daisy-like flowers. I foot

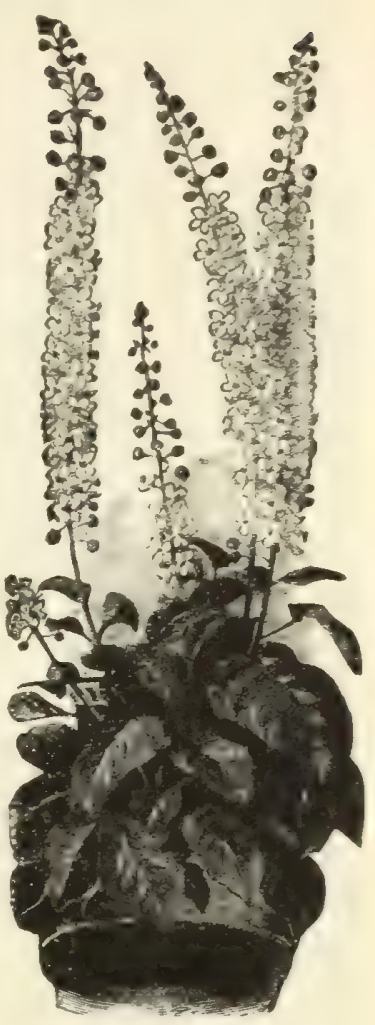

Ceisia Arcturus
5370 AMARYLLIS. Hippeastrum New Hybrids. The Pkt largest and finest race of Amaryllis with immense flowers varying in color from salmon to deep crimson, generally striped and feathered with white $\ldots . . .50$

5375 ARALIA Sieboldi. Futsia Jnprmica. Elegant greenhouse shrub, with large glossy leaves. 3 feet. New seeds are not ready before March or April

\section{CALCEOLARIA. Greenhouse Annuals.}

ASPARAGUS.

Prt

5380 Plumosus Nanus. An excellent pot plant for conservatory decoration or for cutting, on account of its very graceful, finely cut foliage. It will remain fresh in water three or four weeks after keing cut .. 100 seeds, 1.00; .25

5385 Sprengeri. Drooping variety invaluable for suspended baskets or table decoration. The fronds frequently measuring 3 to 4 feet in length $\because 000-10 i 0$.

Our strains of Calceolaria have a wide reputation. They are the result of constant selection and crossfertilization of the best flowers, and no pains are spared to maintain their excellence. The flowers are of large size, of rich and varied colors, including self-colors, spotted, blotched, and laced.

5390 Farquhar's Per- Plkt fection Mixed. First size packet ...1.00

5:395 Second size packet.. .50 BEDDING VARIETIES. Half hardy perennials.

5400 Rugosa or Shrubby Mixed. Charming bedding plants for partial shade or slightly moist situations. The colors range from yellow to brown

5405 Rugosa Yellow. The well-known golden yellow bedding varjety .....

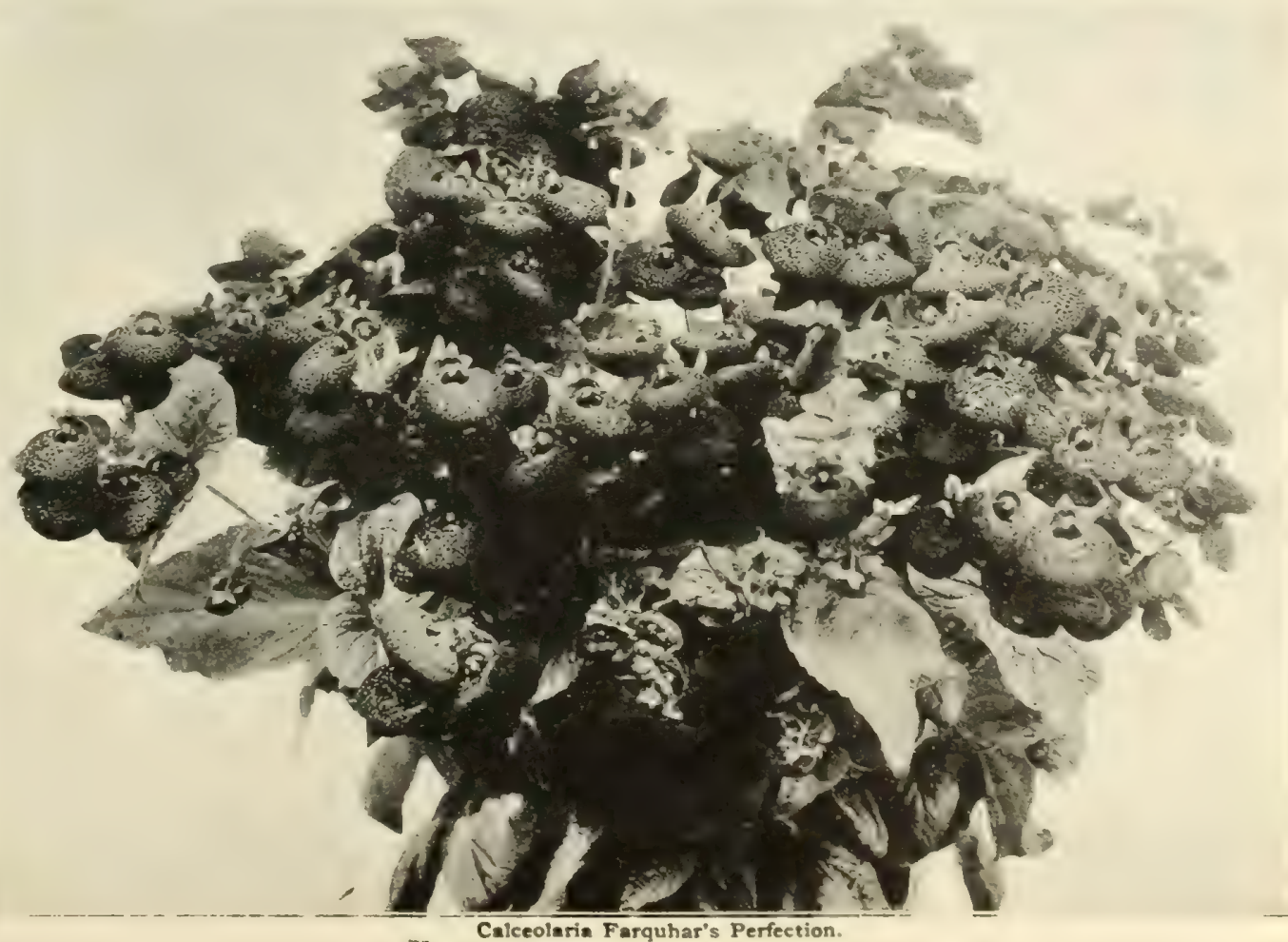


R. \& J. FARQUHAR \& CO., BOSTON. SEEDS OF GREENHOUSE PLANTS.

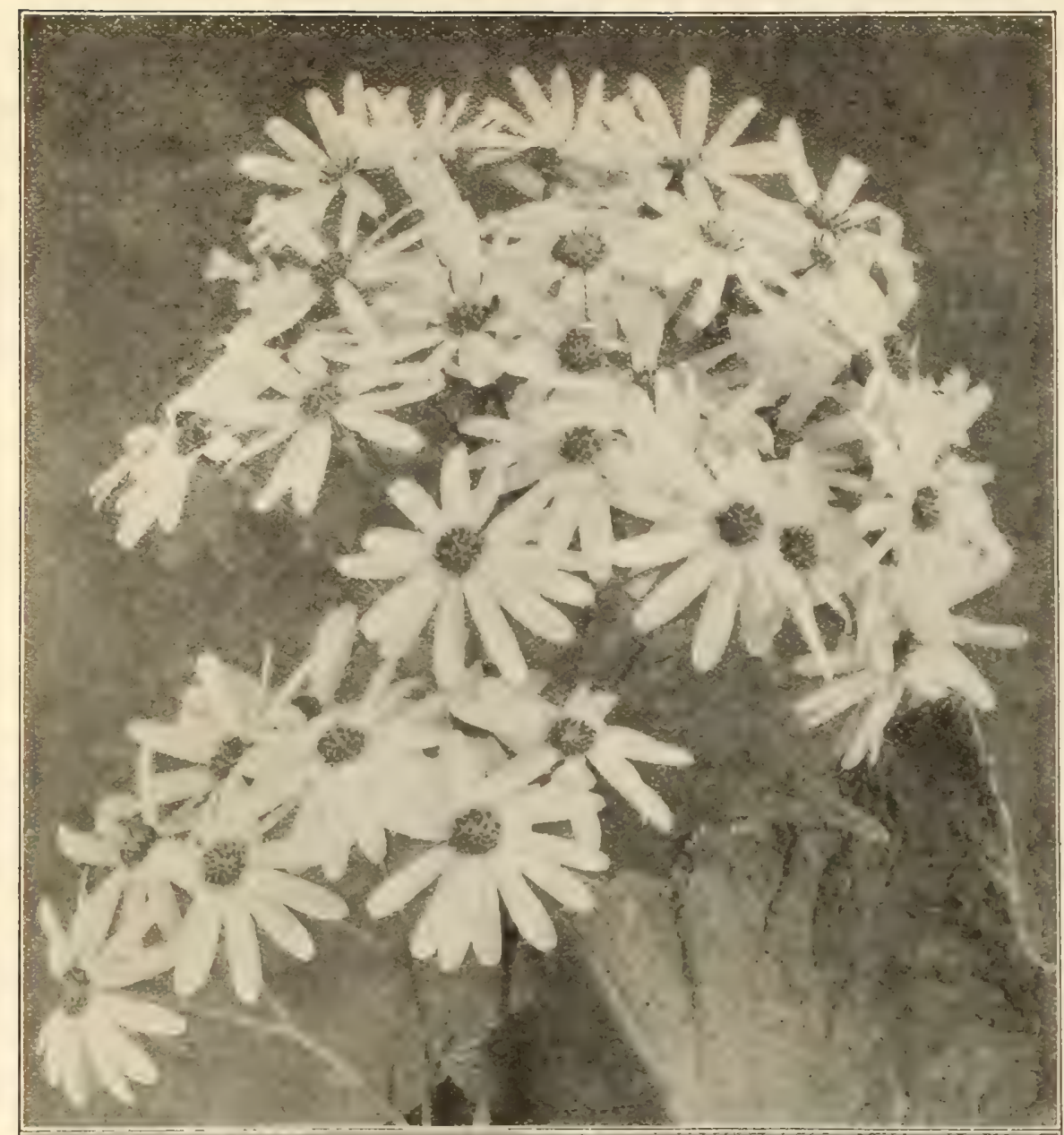

\section{CARNATION.}

$5+10$ Farquhar's French Perpetual.

The finest strain of florists' Carnations, producing a large percentage of full, double, perfectly formed flowers, most of them strongly clore-scented and embracing the choicest colors. Seeds sown in February or March should flower in autumn and throughout the winter
$5+1.5$ Picotee Double Show Varieties. The petals of the large donble flowers are beautifully spotted or laced with some distinct. color. Finest mixed ... ... Pkt., .50

For other varieties see Nos. 1585-1615

54:0 CELSIA Areturus. A splendid halfhardy greenhouse plant with long spikes of bright yellow flowers. It is easily raised from seed and if sown in spring, the plants will blonm the same season. See illustration page

\section{CHRYSANTHEMUM.}

\section{Frutescens. White Paris Daisy.}

Charming plant for the greenhouse or summer bedding out doors; tender perennial. 11 ket .. ... ... ... lkt., 10 5430 Comtesse de Chambord. Golden Paris Daisy. The true Golden Marguerite, a favorite flower; tender perennial, Pkt., .10 5432 Chinese Finest Mixed. The largest autumn flowering variety ... Pkt., 25 For anmual varieties see Nos. 1805-1855; for Hordy Perennials Nos. 6500-6520.

\section{CINERARIA.}

The large-flowered varieties are among the most ormamental and useful plants that can be grown for conservatory and house decoration, and they are of easiest culture. Seed may be sown from May to September for succession but the principal sowing should be made in July. 2 feet.

5435 Farquhar's Superb Strain. The plants are of compact growth, carrying large flower-heads of finest form and substance. The strain includes the richest and brightest self-colors as well as perfectly marked ringed and margined forms of all colors. First size packet ... ... 1.00 No. 540 , fecond size packet... ... $\quad .50$ $5+45$ Farquhar's Dwarf Large-flowering Mixed. Plants of dwarf compact habit, the foliage being almost hidden by the enormois flower trusies ... ... ... Pkt., 1.00 5450 Cineraria Stellata. Star Cineraria. For house and conservatory decoration during winter, few plants equal this new type of Cineraria. The delicate star-like flowers are borne on elegant sprays, rendering it most fascinating as a pot plant and particularly graceful for cut-flower arrangement. The colors run in white, lilac, violet and deep rose. The flowers keep a week or longer in water. Finest mixed. First siz. $\begin{array}{llll}\text { packet } & \ldots & \ldots & \\ \text { No, 5452, Second size packet } \ldots & \ldots & 1.00 \\ \end{array}$ For white-leaved varieties spe .Yos. 1860 and 1865.

\section{CLERODENDRON FALLAX.}

5455 Magnificent greenbouse perennial with scarlet flower-heads resembling the Hydrangea. Seed sown in March will produce flowering plants the same season. 2 feet, Pkt., .75 5460 CLIANTHUS Dampieri. Glory Pea of Australia. A gorgeous greenhouse annual bearing rich scarlet pea-shaped flowers with large glossy black blotch. 2 feet. Pkt.. .25 


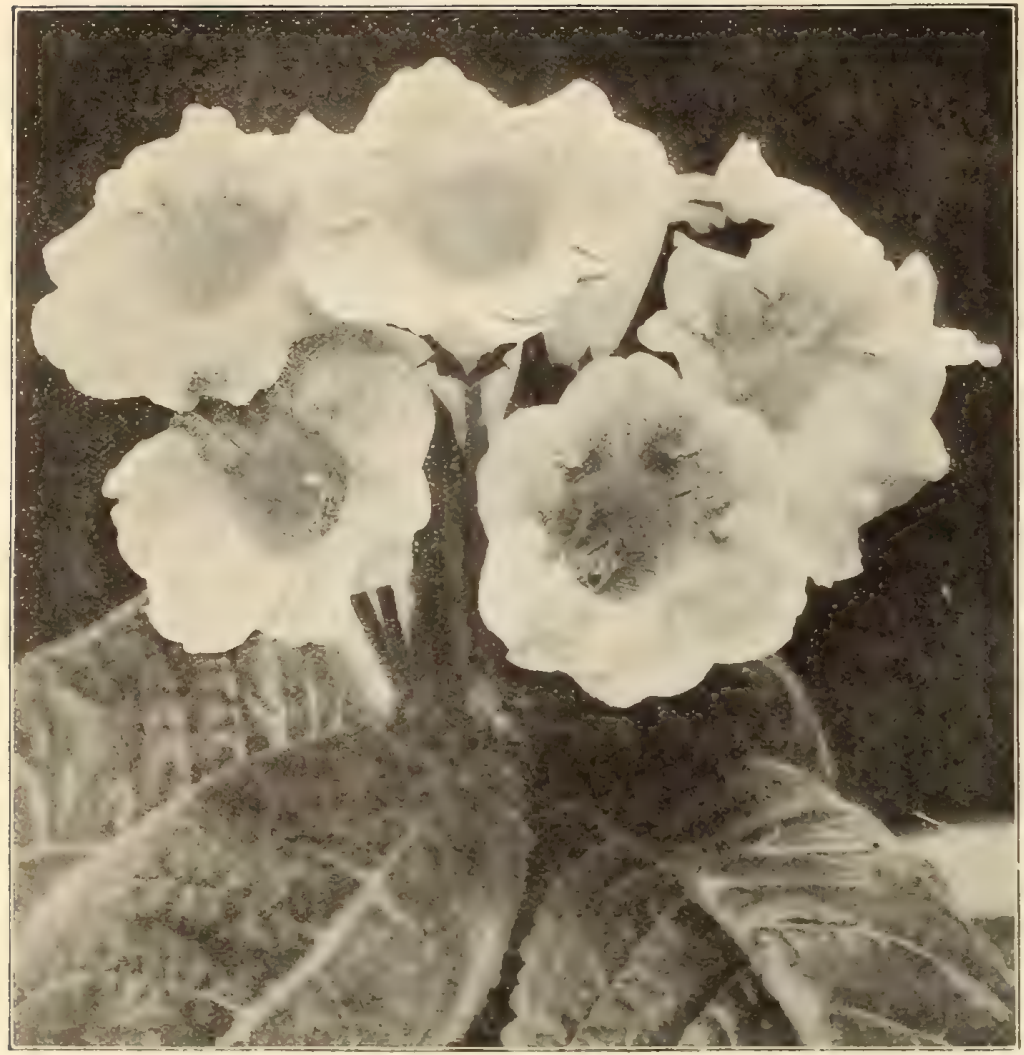

Gloxinia, Farquhar's Giant Strain.

IMPATIENS. Perennial Balsam.

A charming plant for the house or conservatory blooming continnously. The flowers vary in color from pink to red and are freely produced. 1 foot.

5690 Sultani. Bright rocy carmine

5695 Sultani. Farquhar's Pink. Bright rose-pink

l'er l'kt., .25 KALANCHOE FLAMMEA.

5700 Splendid greenhouse plant with large heads of orange-scarlet flowers. $1 \frac{1}{2}$ feet

Per Pkt., .50

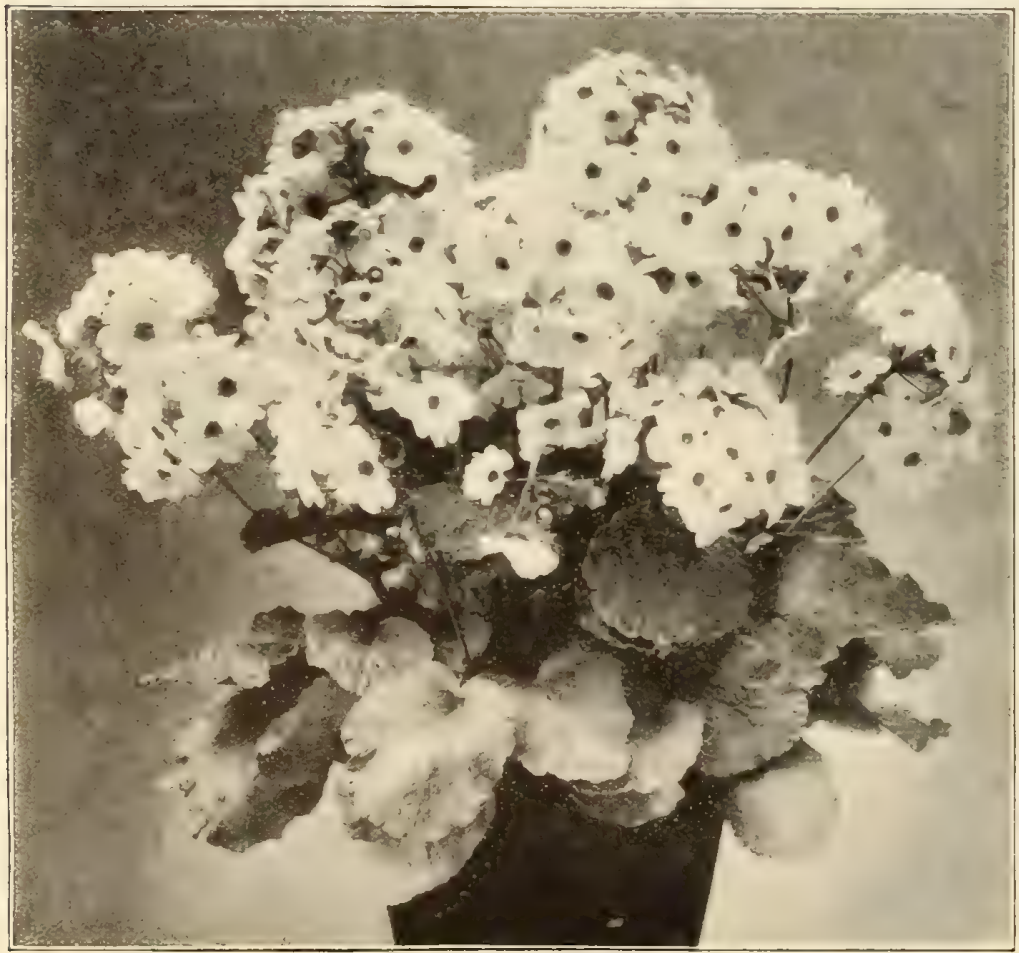

Primula Obconica Grandiflora

\section{GLOXINIA. Tender perennials, $1 \mathrm{ft}$.}

5635 Farquhar's Giant Mixed. This is the Pkv

finest type of Gloxinia. The flowers are of enormous size, massive and upright in growth, with the throat wide open. The strain includes self-colors, spotted and marked sorts, embracing pure white, pink, scarlet, crimson, lilac, violet-purple and deep purple. First size packet

No. 5640 ; second size packet

$56+5$ Farquhar's Avalanche Pure white 50

5 ti50 Farquhar's Sky Blue ... $\quad \ldots \quad \ldots . \quad \ldots \quad .50$

5655 Farquhar's Fire King. Brilliant scarlet, .50

5 titio Farquhar's Superb Spotted. Delicately

spotted; the effect is soft and pleasing ... .50

GREVILlEA ROBUSTA. Silk Oak.

5665 The graceful evergreen, fernlike foliage com-

bines admirably with palms and other massive-

leaved plants. Excellent for table decoration,

HELIOTROPE.

Oz., $1.00 ; .15$

5670 Farquhar's Giant Hybrids Mixed

5675 Dark Vapieties Mixed Shades of blue … . .25

5680 Mixed. In great variety $\ldots$. ....

\section{HIBISCUS MANIHOT.}

5685 A strikingly beantiful greenhouse Hibiseus producing flowers of clear sulphur yellow with a maroon blotch at the base of each petal. It flowers the same season if sown early. 4 feet

For Hardy Hibiscus see Nos. 6955-6075.

\section{LANTANA HYBRIDA.}

5705 Ornamental and free blooming tender perennials of shrubby \& rowth. Excellent for bedding and pot culture. 2 to 3 feet $\mathrm{Oz}, .50$

\section{LIBONIA FLORIBUNDA.}

5710 A handsome plant for honse or conservatory decoration during winter; flowers scarlet and yellow, tube-shaped. $1 \frac{1}{2}$ feet

MIMULUS MOSCHATUS. Musk

5715 The well-known scented variety of Mimulus; useful for hanging pots. Flowers yellow. 6 inches, .10 For other varieties see Nos, 7265 and 7270. MUSA.

5720 Ensete. Abyssinian Bamana. Of all plants available to us for sub-tropical effects, this is the most luxuriant. It is frequently grown here to a height of 15 feet and with leaves 8 feet in length. Seeds sown in January or February produce good plants for summer bedding. Per 100 seeds, 2.00; 5725 Religiosa. Fettish Banana. Magnificent new species recently introduced from the Congo. The plants are more compact than Ensete, the leaves being more erect and thicker render it less liable to be torn by the wind. 10 to 12 feet

PHORMIUM TENAX FOLIIS VARIEGATIS. New Zealand Flax.

5730 Half-hardy perennial with long sword-shaped leaves beautifully variegated; adapted to lawn and conservatory decoration; flowers orange color. $6 \mathrm{ft}$.,

\section{POINSETTIA PULCHERRIMA.}

735 A very ornamental greenhouse shrub, producing large heads of brilliant scarlet bracts valuable for winter decoration. If sown in February or March the seedlings produce splendid scarlet tops

by December ... ... Per 100 seeds, 2.00

\section{PRIMULA OBCONICA GRANDIFLORA.}

Our improved strain of Primula Obconica is vastly superior to the old type; the flowers are nearly twice as large, with many new and exquisite colors.

5738 Collection of 6 Brilliant Colors Separate,

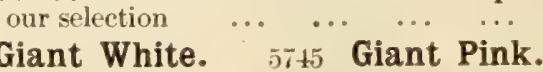

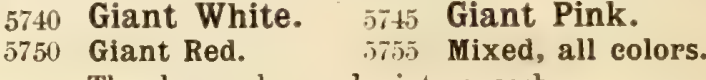




\title{
PRIMULA CHINENSIS.
}

\author{
Chinese Primrose.
}

5760 Farquhar's Giant Pink. One of the Prt. finest Primulas in the Giant section. The flowers are fringed, very large and of a most fascinating bright pink color

5Flowers of large size and deep blue color; the finest blue sort

-..0 Farquhar's Giant Red. A rich velvetycrimson flower with dark eye. The plants are vigorous, free flowering and of fine habit, 1.00

Farquhar's Giant Salmon. A distinct shade, with large and attractive trusses of bloom of a delicate salmon-pink

- Farquhar's Giant White. Extremely large trusses of pure white flowers of great substance, borne well above the foliage .. 1.00

is. Giant Duchess. Large handsome flowers, white, charmingly shaded with a zone of pink surrounding a large primrose eje.

5,90 Ruby Queen. A charming variety of elegant habit with flowers of ruby-red

795 Orange King. This grand new Primula has created great interest abroad on account of its attractive color and vigorous babit. The beautiful orange color in the bud and salmon pink petals are most pleasing

Improved Chiswick Red. Crimson-searlet, beautifully fringed flowers of massive appearance

W.1.5 Alba Magniflea. Pure white fringed flowers, with well-defined yellow eye

is10 Farquhar's Superb Mixture of Brilliant Colors. First size packet

is 15 second size packet

$5 \div 0$ Collection of 6 Varieties Separate, our selection 1.00

2x.25 Farquhar's Double Mixed. Excellent for cutting

5x:3u Farquhar's Double Pink

5\$35) Farquhar's Double White

\section{PRIMULA STELLATA. Star Primula.}

5\&41 Giant White Star. 5845 Giant Pink Star. 5850 Giant Red Star. Each of the above colors

5 5.55 Giant Mixed Star

.inbi) Giant Mixed Star

is 5.5 Collection of 6 Varieties Separate, our selection

Large packet, 1.00

$5 x, 0$ PRIMULA KEWENSIS. Originated at the Royal Gardens, Kew The flowers are a bright yellow in color and fragrant. As a winter flowering decorative plant it is an acquisition Hardy Primulas see Nos. 7550-7615.

SAINTPAULIA IONANTHA. African Violet.

$5 \times 15 \quad A$ very beautiful dwarf greenhouse perennial resembling the violet both in appearance and color. 4 inches

\section{Schizanthus see Nos. 3945-3955.}

\section{SMILAX.}

5880 A popular greenhouse climber with small dark green foliage of great value for floral decoration. 10 feet

\section{SOLANUM CAPSICASTRUM NANUM. Jerusalem Cherry.}

588.5 Ornamental plant for winter decoration in the house or conservatory. The plants are of compact branching habit with small dark-green leaves and numerous bright scarlet berries. Seeds sown in early spring produce fine plants for autumn fruiting. 1 foot

\section{STEVIA.}

Elegant greenhouse perennials furnishing very graceful sprays of tiny flowers exceedingly valuable for cutting. They bloom the first year from seeds. 2 feet.

$58: 0$ Eupatoria. White.

589.5 Serrata. White, fragrant

\section{STREPTOCARPUS. Cape Primroses.}

5900 Charming greenhouse perennials of dwarf, neat habit, with clusters of Achimenes-like flowers borne on erect, slender stems. The colors embrace white, rose, red, purple, and violet, many of the flowers being beautifully blotched and striped. 9 inches ... ... ... ...

\section{Pki.}

1.00

1.00

\section{.75 \\ 2.50} \\ I. 00
}

25

.25
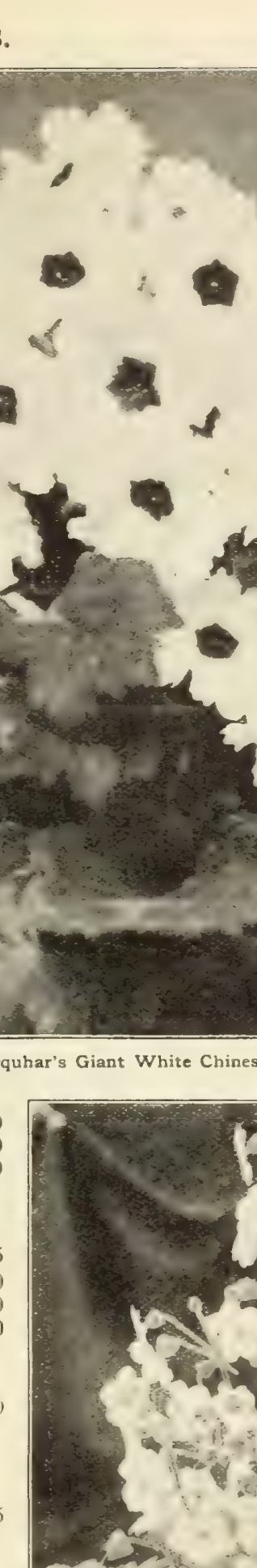


\section{FARQUHAR'S Hardy PERENNIAL FLOWER SEEDS.}

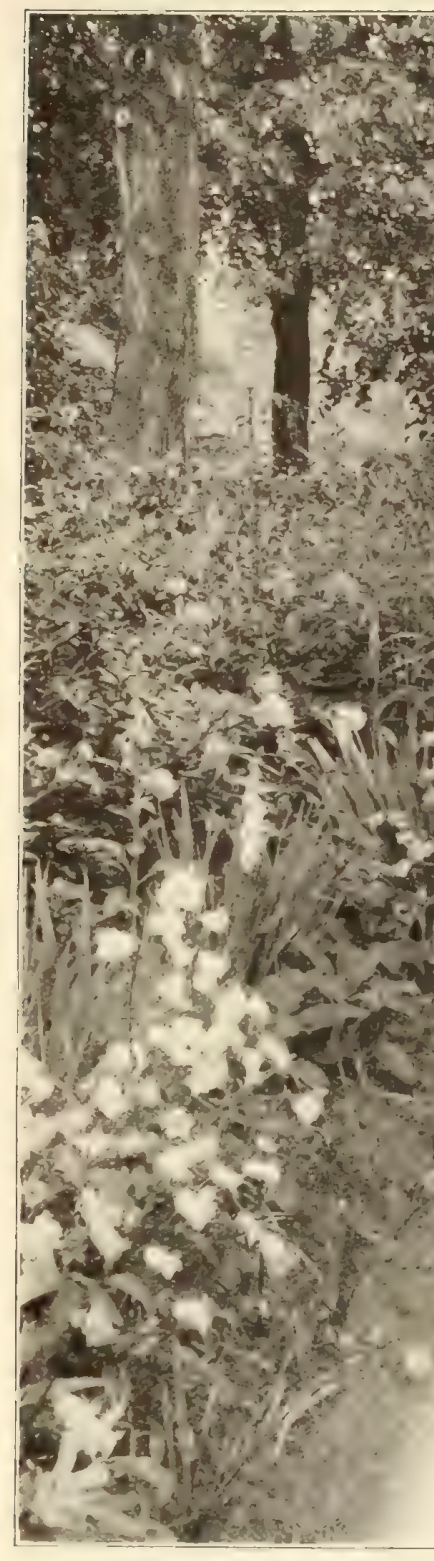

A Border of Perennials

\section{Coxs}

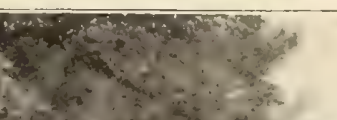




\section{A. \& J. FARQUHAR \& CO., BOSTON. PERENNIAL FLOWER SEEDS.}

\section{AQUILEGIA Columbine.-- Continued.}

$\$ 040$ Californica hybrida. Petals golden yellow, sepal's and spurs Pkt. crimson, magnificent. 2 feet $\frac{1}{1}$ oz., 1.00

6045 Canadensis. The snall scarlet and yellow native species,

Oz., $1.00 ; \frac{1}{4} \mathrm{oz} .$, .35 ;

so50 Chrysantha. Pale jellow long-spurred flowers. 2 feet,

5055 Chrysantha grandiflora alba. Beautiful pure white, long

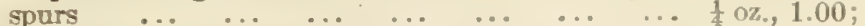

5060 Cœrulea. Rocky Mountain Columbine. Exquisite variety with pale blue and white flowers, long spurs. 3 feet, $\frac{1}{4}$ oz., 1.25 ; long-spurred white' ... ... ... ... ... $\frac{1}{4}$ oz., 1.00;

t):0 Glandulosa. Dark blue with white curulla, fluwers 3 inches across. A superb sort. 2 feet

h075 Haylodgensis. Camulea hybrida. Large-flowered hybrids with long spurs; shades of blue, white and yellow. 3 feet, t oz., 1.00;

solis Jaetschaui. Large yellow blossoms with red spurs. 2 feet,

5085 Nivea grandiflora. Pure white

4090 Olympica. Delicate mauve with white corolla; a lovely shade $1 \frac{1}{2}$ feet

0995 Skinneri. Mexican Columbine. Large scarlet and yellow flowers long spurs. 2 feet

5100 Stuarti. Enormous dark blue long-spurred flowers with white corolla. 2 feet

n105 Truneata. Orange-scarlet with yellow. $1 \frac{1}{2}$ feet,

h110 Double White. 2 feet

1115 Farquhar's Double Hybrids Mixed.

tains only the finest forms of the double Col

3120 Single Mixed. In great variety

3125 Collection of 10 Varieties Separate.

3130 ARABIS ALPINA. Rock Cress. Very early-flowering hardy per ennial with erect spikes of pure white flowers; valuable for edgings and rockeries, 6 to 9 inclies

3135 ARMERIA Maritima. Thrift or Sen Pink. I pretty edging plant with deep pink flowers. 1 foot

3140 Plantaginea. Bright rosy pink

3145 ASCLEPIAS tuberosa. Milkireed or Swallow Tort. One of the finest native perennials with compact umbels of brilliant orangered flowers. Invaluable for border or shrubbery groups. 2 feet,

3150 Hallii. Flowers flesh-colored irs large umbels. 3 feet

3155 ASPERULA odorata. Sweet Woodruff. Pretty hardy plant thriving in partial shade; flowers white. 9 inches. The leaves and flowers when dried have an odor like new hay and when laid among clothes perfume them and keep away insects

3160 ASPHODELUS albus. Stately spikes of pure white flowers suitable for large beds and borders. $2 \mathrm{ft} . \quad \ldots \quad \ldots \frac{1}{ \pm 0}, 0,1.50$;

3165 Luteus. Effective plant with tall spikes of fragrant Pkt. yellow, lily-like flowers

\section{ASTERS. Michaelmas Daisy.}

These showy hardy perennials are easily raised from seeds and if sown early in spring are likely to bloom the following antumn. They may also be siswn from May to July.

6170 Alpinus. Purple, large jellow centre ... $\frac{1}{4}$ oz., .30; .10

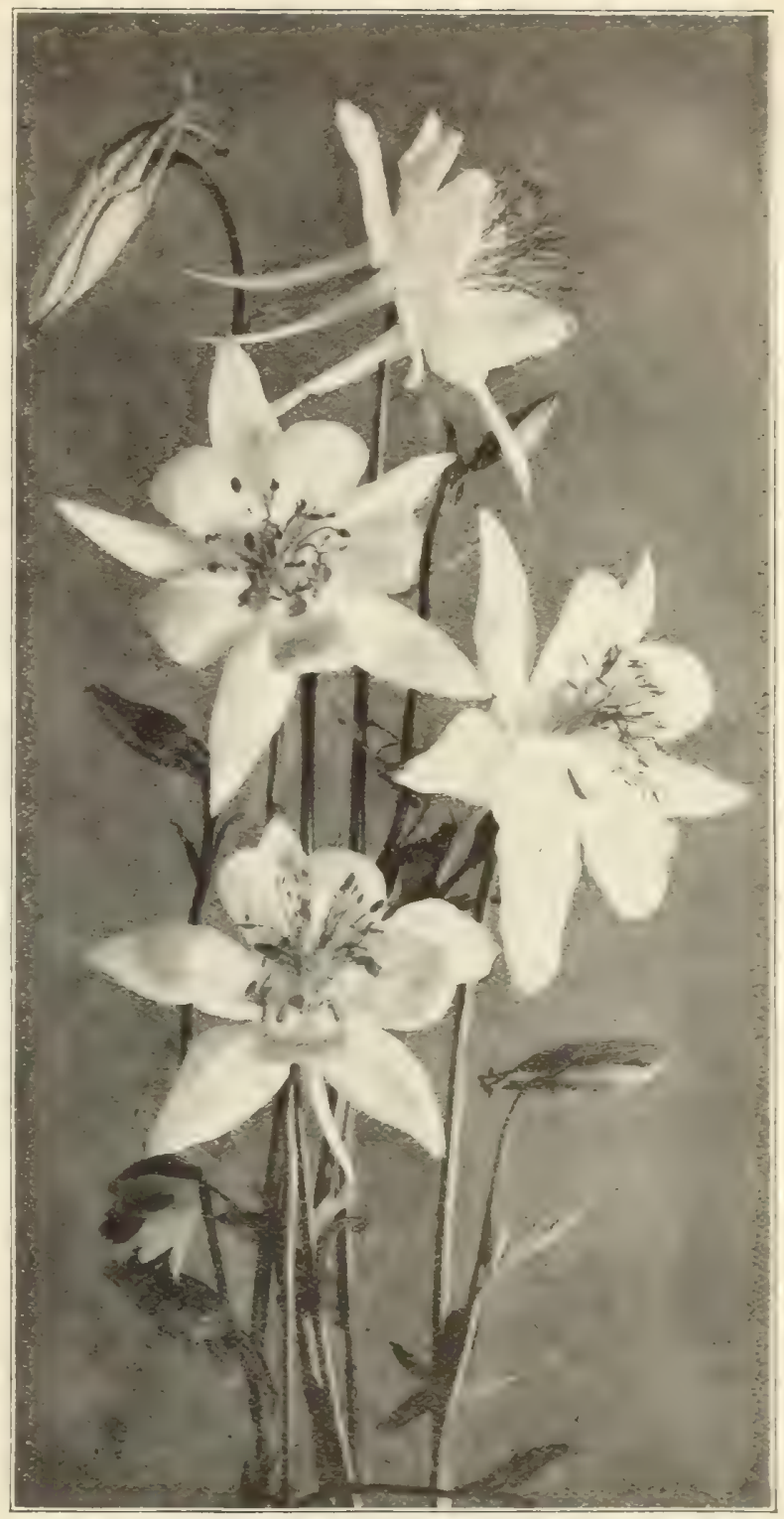

Aquilegia Farquhar's Long-Spurred Hybrids.

Alpinus speeiosus.

180 Bessarabicus.

6185 Novæ Angliæ. Bright violet-purple. \pm it., "6 $.75 ; .15$

ilitu Ptarmicoides. Distinct variety with pure white Huwrers; useful for cutting. $1 \frac{1}{2}$ feet

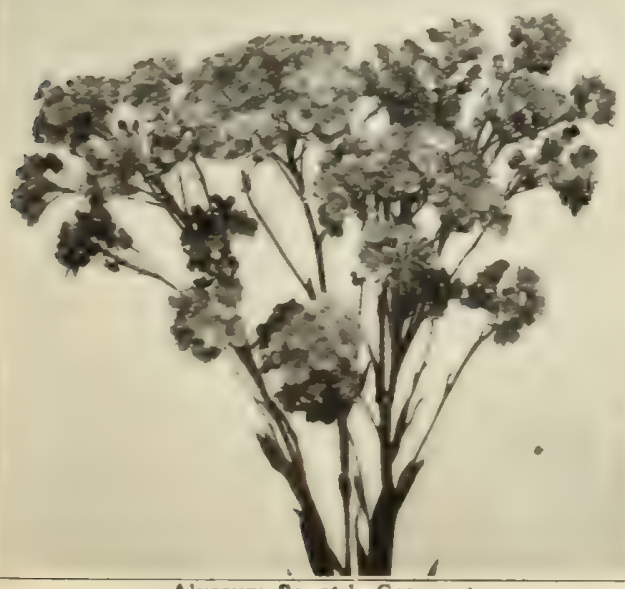

Alyssum Saxatule Compactum

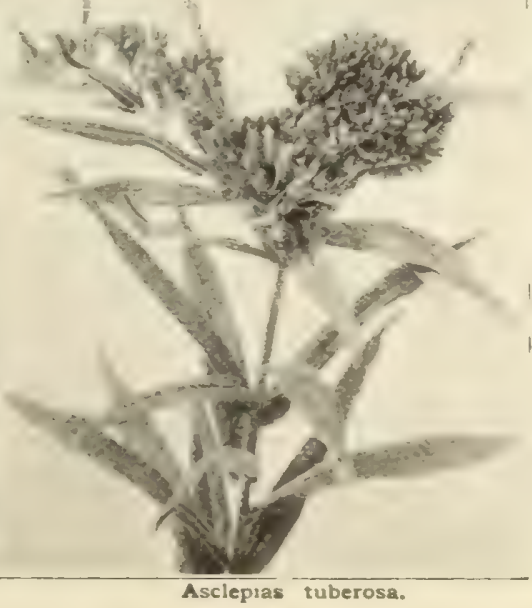

Sub-eœruleus. A new species from India, with giant flowers matuvehorne on long straight stems. The fiowers are from two to thre blooming very early in the segsen. -2 feet

6200 Townshendi. I ires-Hewering viriety bearing a profusion of pinkishlilac flowers which atre

New Hybrids Mixed. Many bean. AUBRETIA deltoidea grandiflora. Very compact: Howers laventer blue. 4 inche's ... ... ... suitalle for rockeries and herbateretz boriters. Flowers a pretty shate of deep rose. 4 inches 


\section{R. \& J. FARQUHAR \& CO., BOSTON. PERENNIAL FLOWER SEEDS.}

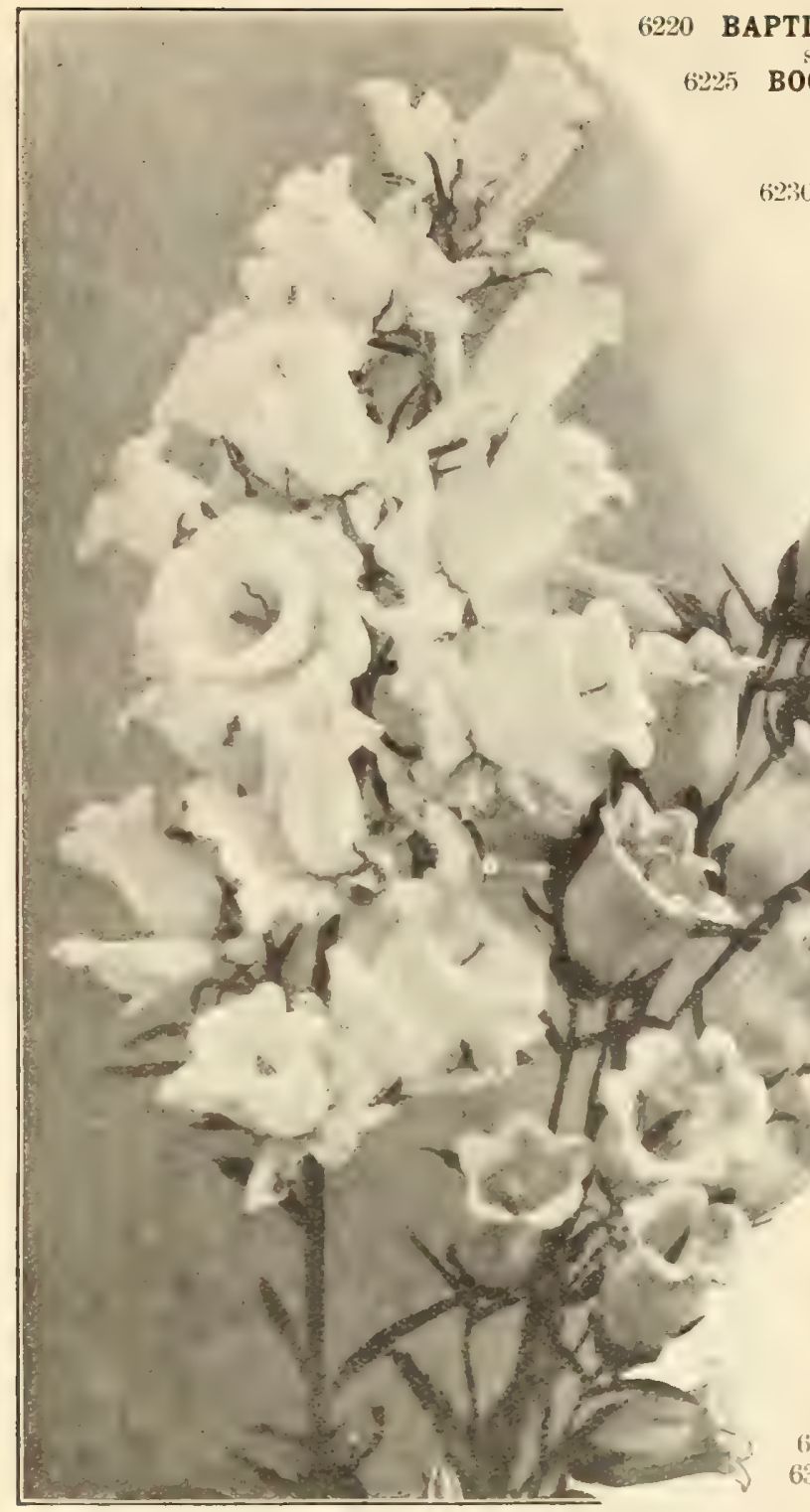

PTISIA Australis. False Indigo. A strong growing plant producing Pkt.
spikes of pea-shaped blue flowers six inches in length. $2 \frac{1}{2}$ ft., Oz., $50 ; .05$ ocCONIA Japonica. Plume Poppy, or Tree Celandine. A noble hardy perennial, with large glancous leaves and tall flower stems with terminal panicles of white flowers. Useful for planting as a background in large beds. 6 to 8 feet ... ... ... Oz., 50

BOLTONIA Asteroides. One of the showiest of our native perennials closely resembling and allied to the hardy Asters; flowers pure white. 6 feet

6235 BOLTONIA latisquama. Flowers pink, slightly tinged with lavender; the finest of the section. 5 feet ....

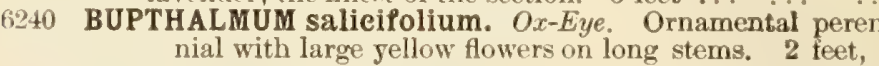
nial with large jellow flowers on long stems. 2 teet,
$\frac{1}{4} \mathrm{oz}, .40 ; .10$

(50) CALLIRHOE verticllata. Poppy Mallow. Elegant hardy Mallow of easy culture and spreading growth, with large crimson Linum-like flowers. $1 \frac{1}{2}$ feet, CAMPANULA. Bell-Flower.

All the species of Campanula are elegant when in bloom and are worthy of being largely grown. They are chiefly hardy biennials and perennials and it is best to sow these two classes in June or July for plants to bloom the next summer.

\section{PERENNIAL VARIETIES}

6:50 Carpatica. Carpathian Blue Bell. Neat hardy perennial growing in compact tufts; flowers clear blue, splendid for mixed borders. $8 \mathrm{in.,} \mathrm{Oz} ., 50$; 6255 Carpatiea alba. White Carpathian Bell. White,

$$
\text { C. grandiflora, see Platycodon, } 7430-7440 \text {. }
$$

6260 Glomerata. Clustered Bell-flower. Dense clusters of funnel-shaped violet-blue flowers. $1 \frac{1}{2} \mathrm{ft}$. , 卖 oz., .50;

(j2) Grandis. Great Bell-flower. Large saucer-shaped violet-blue flowers. $1 \frac{1}{2}$ feet … t oz., .75 ;

6270 Hostil. A giant form of the Scotch Blue Bell. Rich blue. 1 foot $\ldots$....... $\cdots$ ' 2 feet

6275 Macrantha. Purplish-blue; large flowers. "2 feet,

6280 Mirabilis. Very ornamental variety of branching liabit, each branch tipped with numerous large, light blue flowers 2 feet
bilis. Long tubular light purplish flowers of medium 6285 Nobilis. Long tubular light purplish flowers of medium 290 Persicifolia grandiflora Blue. One of the finest Campanulas, with large bright blue cup-shaped flowers. $2 \mathrm{ft}$.,

(6295 Persicifolia grandiflora White. Frect spikes of snow white flowers $107.90 \%$ 6300 Persicifolla Mixed. "Shades of blue and white, " 1.50 ; 2 .2. (i305 Punctata. Whitish spotted with red, droping. $1 \frac{1}{2}$ feet ... 25 6310 Pyramidalis. The

Farquhar's Prize Canterbury Bells.

mula. Stately hardy perennial; very handiome as a border plant or grown Pki. in pots for conservatory decoration. \pm feet $\ldots . \quad \ldots \quad O z_{\circ}, .60 ; \neq 0 z_{.}, .20 ; .10$ 6315 Pyramidalis Alba. White (ii):0) Turbinata

\section{CANTERBURY BELLS. Campanula medium.}

Showy, hardy biennials, growing in pyramidal form and bearing many large, bell-shaped flowers; very effective in mixed borders and in shrubberies. $2 \frac{1}{2} \mathrm{ft}$. Seedlings raised in June or July bloom the following summer.

6325 Farquhar's Prize Mixed. A combination of the finest colors including single, double, and cup-and-sancer varieties $\ldots \ldots \ldots .0 z ., 1.75 ; \frac{1}{4}, 0 z, .50 ;$

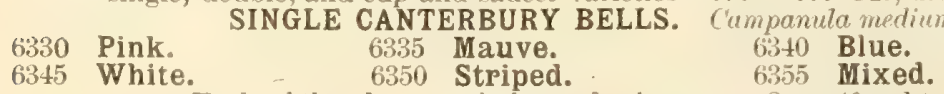
Each of the above varieties and mixture, $\mathrm{Oz}, .40 ; \mathrm{pkt}$, , .0.)
DOUBLE VARIETIES.

6360 Blue. 6365 White $\ldots$... $\ldots$... Each, Oz, 1.00; $\frac{1}{4}$ oz., .30;

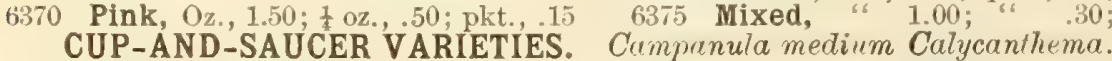
6380 Pink. A charming color ... ... ... ... ... Oz, 2.00; 1 oz, .60; 6385 Blue. 6390 Mauve. $\cdots 6395$ White. 64100 Mixed.

Each of the above colors and mixture, except pink,
640.5 COLLETION OF 8 VARIETIES CANTERBURY BELS SEPARATE, our selection

CANDYTUFT. Free-flowering dwarf perennials, suitable for rockwork and the edges of herbaceous borders. 6 inches.

6410 Gibraltarica. White, shaded with pink

6415 SEMPERVIRENS. A very hardy variety, with glisy, ${ }^{2}$ deep green foliage

which is evergreen; flower white $\ldots \ldots \ldots \ldots \mathrm{Oz}_{*}, 1.00 ; \frac{1}{1} \mathrm{Oz} ., .30$;

$64: 20$ Tenoreana. Pale purple; very early. 6 inches $\ldots \ldots, \ldots .0 \%, .30 ; .05$

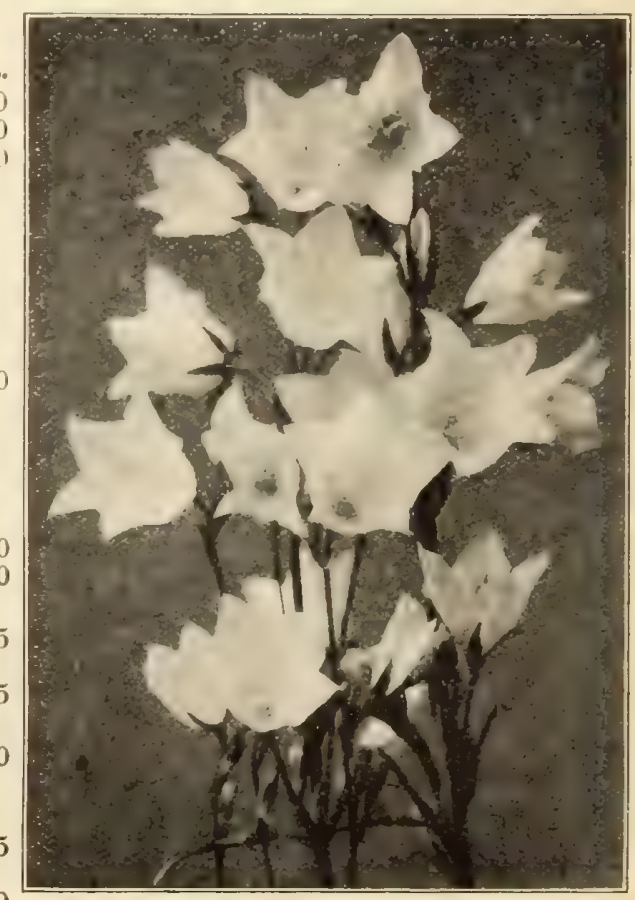

Campanula persicifolia grandifiora white. 
R. \& J. FARQUHAR \& CO., BOSTON. PERENNIAL FLOWER SEEDS.

\section{HARDY CARNATIONS.}

For the open garden. It is advisable to protect these with a light covering of pine boughs or coarse straw during winter. 1 to 2 feet. Pst.

6425 Grenadin Searlet. Double flowers, early. 2 feet ... $\frac{1}{4}$ oz., $1.25 ; .25$ 6430 Grenadin White

'Al:- Farquhar's Prize Strain Mixed. Our Prize Strain is particularly adapted to garden planting and irrcludes only the best types in a great variety of colors

$6+10$ Fine Mixed 6 Plumarius Cyclope Double Mixed. A charming race of double

$\mathrm{Oz}_{6}, 3.00$; $\frac{1}{4} \mathrm{Oz}, 1.00$ Pheasant-Eye pinks. Very fragrant and hardy

6450 Plumarius Double Mixed. Pheasant-Eye Pink ...

H5.5 Plumarius Seotieus. Prisley Pink. This race of ficotch pinks is quite as much in favor for winter forcing as for border cultivation. The flowers resemble the true Carnation and have the strongest spice fragrance

Other Perennial varieties see Dianthus Nos. 6635-6650;

also Carnation Nos. 1585-1615.

5460 CASSIA Marylandiea. American Senna. A decorative hardy plant of shrub-like growth with attractive foliage and large panicles of yellow pea-shaped blossoms 3 to 4 feet $10 z, 30$;

6t65 CATANANCHE corulea. Lovely blue flowers 2 feet . . . . . ... 10

6470 Bicolor. Blue with white margin ... 6 .... 6 . 6 . . . . .

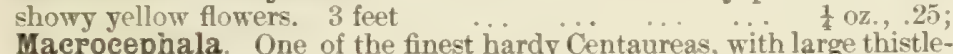
like heads of golden zellow flowers; useful for cutting. 3 feet, $\frac{1}{3} \mathrm{oz} ., 30$; 10

6485 Montana. Large blossoms of deep purple; very showy ... "6 $60 ;$
tit90 CEPHALARIA alpina. An attractive perennial with pretty sulphur yellow flowers especially desirable for large herbaceous borders, 3 to 4 feet $\frac{1}{4}$ oz., $.30 ; .10$

6495 CERASTIUM tomentosum. Snow in Summer. The foliage of this hardy perennial is perfectly white and its dense matted growth makes it valuable for edgings and rockeries. 4 inches

\section{CHRYSANTHEMUM.}

(ivi.) Japanese Double Early-flowering Mixed. These bloom in the open garden from August intil trost.

(i510 Shasta Daisy. A large free-blooming hybrid from California; flowers white. 2 feet

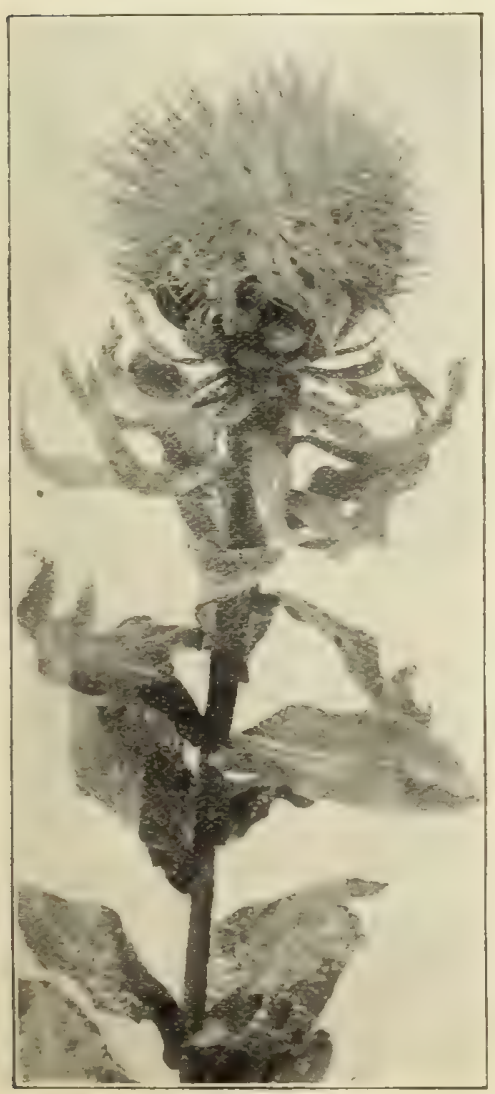

Centaurea macrorephala
6515 King Edward VII. Flowers pure white, the handsomest of all the Maximum varieties. $3 \mathrm{ft}, 25$

6520 Maximum. Ox-Eye Daisy. Hardy Daisy with large white flowers; excellent for cutting. 3 feet, $\frac{1}{4}(12 ., 51)$

6.525 CLEMATIS reeta. Stately hardy or lawn groups; flowers pure white and resembling that of the C. paniculata; fragrant. 4 feet,

Or., .75; .10

COREOPSIS, or Calliopsis.

These frequently bloom the first year from seed sown in spring. It is more satisfactory, however, to sow in June or July, protecting the plants with coarse straw or pine boughs during winter. They will flower profusely the following summer. 3 feet.

6530 Grandiflora. Bright golden yellow flowers, 3 to $t$ inches in diameter, the broad petals overlapping and beautifully fringed,

$$
\text { Oz., . } 50 ; .10
$$

6535. Eldorado. An improved form from California with flowers 4 to 5 inches across, $\frac{1}{4}$ oz. $2.00 ; .25$

6540 Lanceolata. Rich golden yellow flowers with long stems,

$$
\frac{1}{4} \mathrm{OZ} ; .50 ; .15
$$

6545 CRUCIANELLA stylosa. Dwart early-flowering perennial adapted for rockeries; flowers bright rose. 6 inches .10 plant suitable for large borders

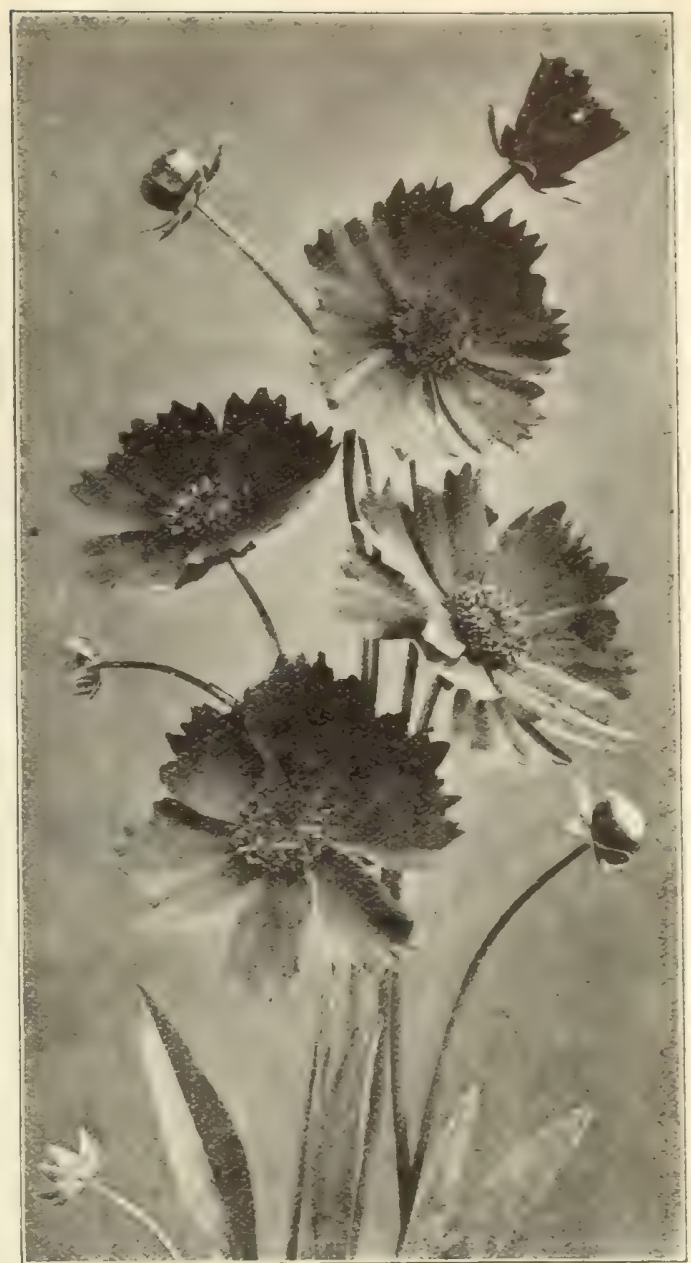

Coreopsis grandiflora.

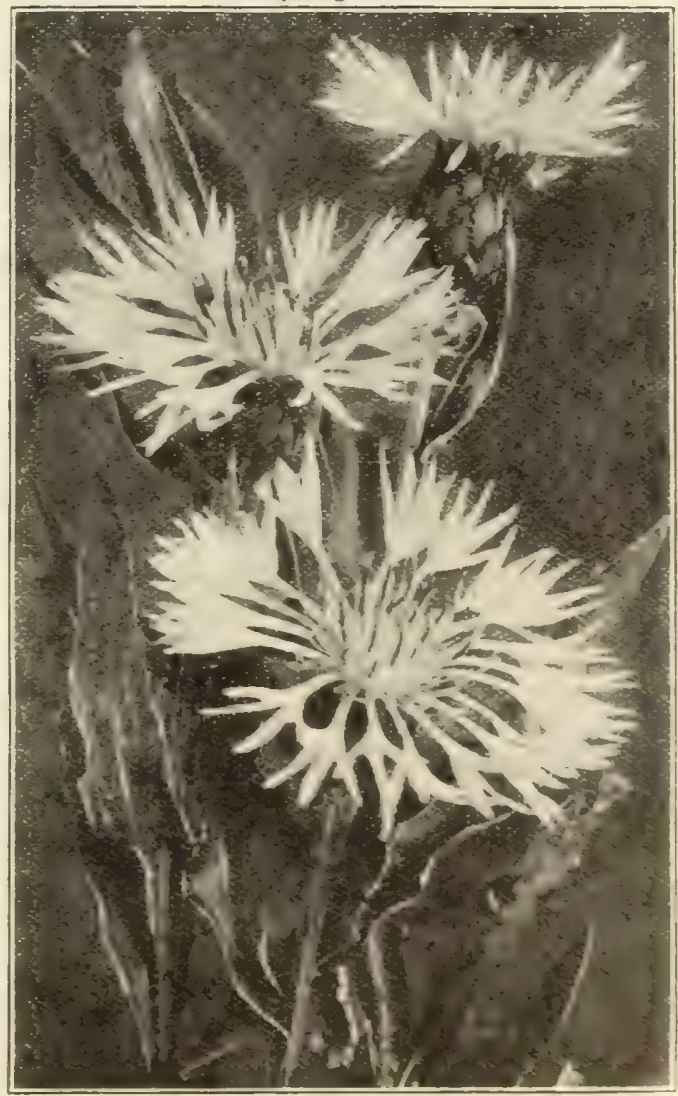

Centaurea montana. 
R. \& J. FARQUHAR \& CO., BOSTON. PERENNIAL FLOWER SEEDS

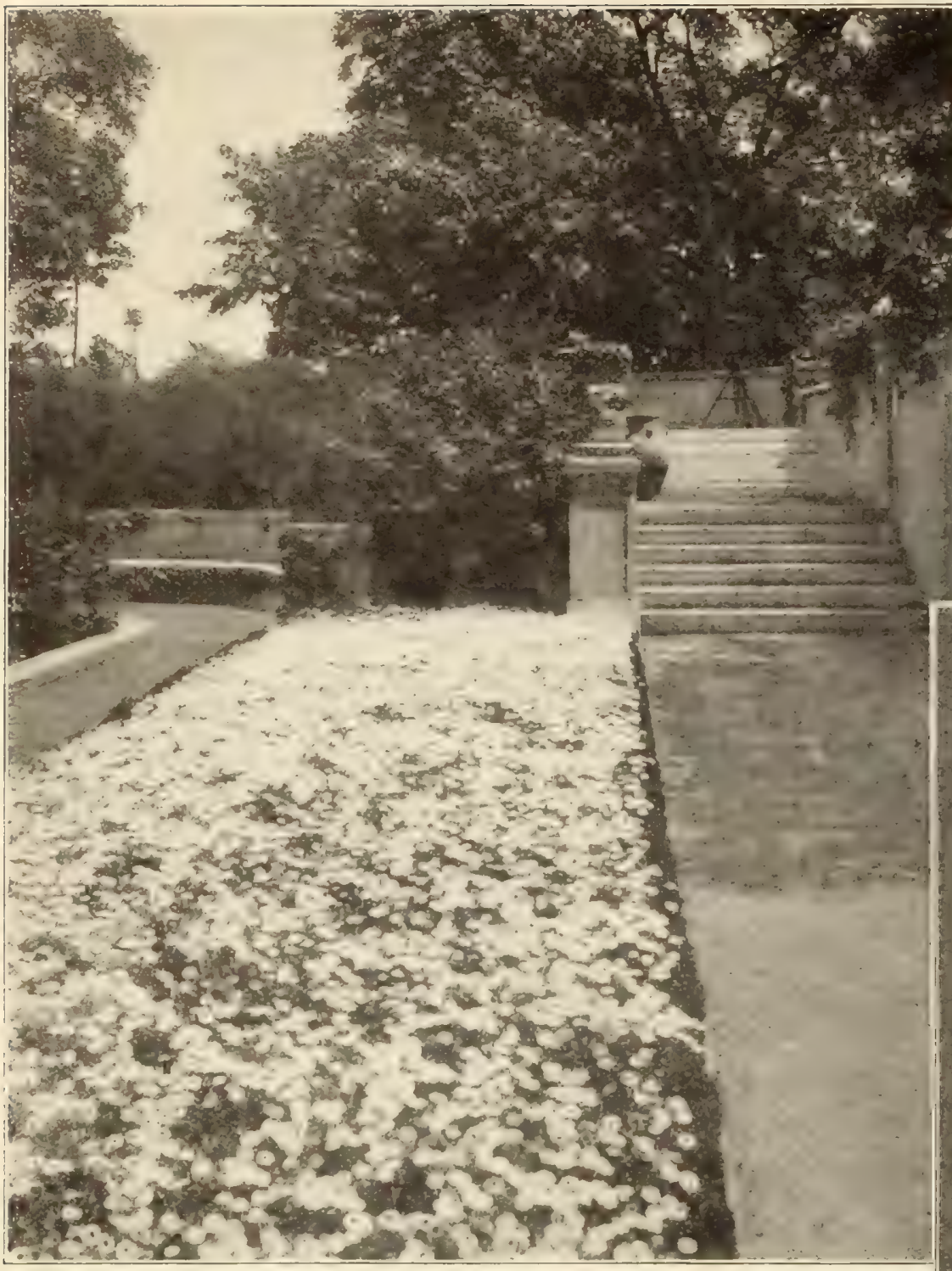

A Border of Farquhar's Double Dalsies.

\section{DELPHINIUM. Larkspur.}

perfectly hardy and can be grown with ease in any garden. When sown in April or May they will usually bloom in September; they may also be sown in June or July to bloom the following season. $1 \frac{1}{2}$ to 4 feet.

(5.565 Farquhar's Selected Hybrids Mixed. This strain includes Pkt. the best of the new single and double varieties; the flower-spikes being large, varying in color from pearly white to lavender and from soft azure blue to rich indiono

- Cardinale. Bright searlet 0575 Cashmerianum. Pale blue flowers, 2 inches across. $1 \frac{1}{1}$ feet.

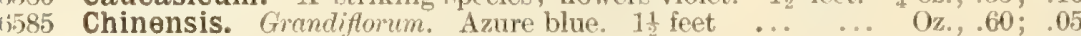

¿590 Chinensis, White.

if600 Elatum. Bee Larkspur. Rich blue shades, with black centres. 4 feet,

bit05 Formosum. Splendid dark blue with white eye. 3 feet, 0 z. $1.00 ; \frac{1}{4} 0 \%, 35$;

161010 Formosum Cœlestinum. Tery beautiful large pale-blue flowers,

6615 Nudicaule. Dwarf habit; flowers bright scarlet. 1 foot. $\frac{1}{8}$ 'oz., .50

6620 Sibirieum Hybridum. Shades of blne; blooms in August if sown in

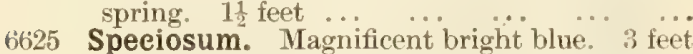

6630 Sulphureum. Zalil. Tall spikes of sulphur yellow; very beautiful 2 feet. This variety is rather tender in our climate and requires protection in winter.
DAISY.-Bellis perennis $\pi$. $p l$.

Favorite spring-flowering perennials, producing charming effects when planted in masses or in combination with Pansies, Forget-Me-Nots, or Silene. They are easily raised from seed, flowering in autumn if sown in spring, although it is better to sow in July or August in cold frames and plant them out the following April. 4 inches.

(5550 Farquhar's Double White, Pkt. $\mathrm{Oz}, 3.00 ; \frac{1}{4} \mathrm{oz} ., 1.50 ; \frac{1}{8} \mathrm{Oz} ., .85 ; .15$

Farquhar's Double Pink, Oz., $5.00 ; \frac{1}{4}$ oz. $1.50 ; \frac{1}{8} \mathrm{oz}, .85 ; .15$

6560 Farquhar's Double Mixed. Saved from the finest double flowers,

$\mathrm{Oz}, 4.00 ; \frac{1}{4} \mathrm{oz} ., 1.25 ; \frac{1}{\mathrm{~B}} \mathrm{oz} ., .75 ; .15$

Mr. Edward J. Canalng, Gardener for the Botanic Garden of Smith College, Northampton, Mass., writes: - Your Finest Show Strain of Pansies has been the admiration of the whole College here for the past tho months. The great variety of colors, large well formed fovers, and wonderful markings, together with the pro. best we have ever grown."

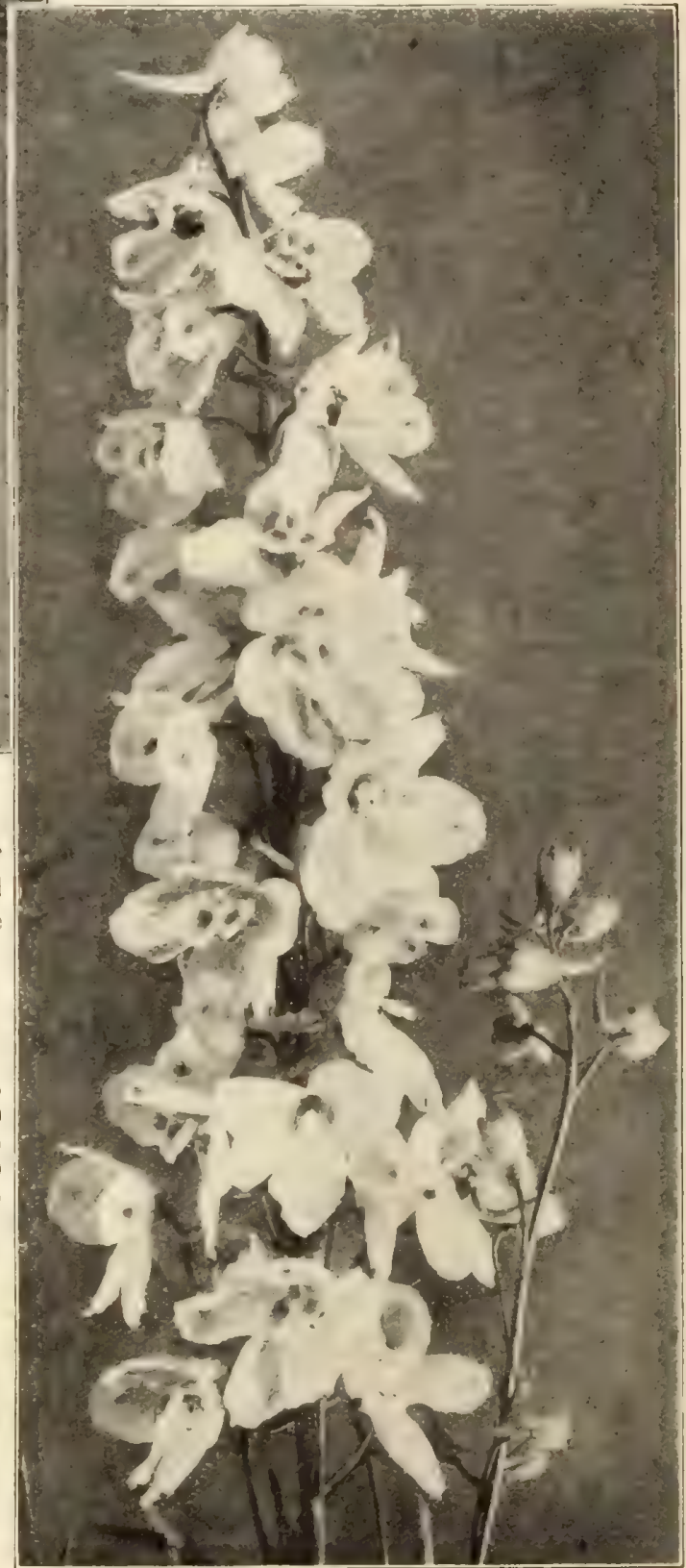

Farquhar's Hybrid Delphinium. 
R. \& J. FARQUHAR \& CO., BOSTON. PERENNIAL FLOWER SEEDS.

oxit; DIANTHUS Atropubens. Dark red, fine rockery plant. Pkt. 1 foot

bitul Deltoides. Maiden Pink. Trailing variety; flowers pink with dark circle. 6 inches $\ldots . \quad \ldots \quad \ldots . \frac{1}{4} \mathrm{oz}, .30$;

(ititi) Deltoides Alba. White, 8 inches ... $\frac{1}{4} \mathrm{oz}, .35$;

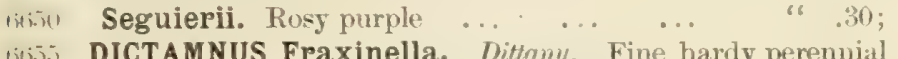

iti-i. DICTAMNUS Fraxinella. Dittany. Fine hardy perennial
with handsone spikes of purplish-crimson flowers. The leaves are fragrant, giving off an odor of balsam when rubbed. 3 feet

$66+5$ Fraxinella Alba. Pure white ... Oz., 1.50; $\frac{1}{4} \mathrm{O} z ., 50$;

\section{DIGITALIS.}

Foxglove.

(6tit:-) Farquhar's Superb Mixed. Includes all the finest Gloxinaflora Mixed. Flowers spotted in the throat,

titio Gloxingflora Mixed. Flowers spotted

titis(1) Grandiflora. Showy flowers of pale yellow

(titis.) Ivery's Spotted. Beautiful spotted flowers of various color:

(inin) Monstrosa Mixed. The tall spikes have a monstrons saucershaped terminal flower … … Oz., $2.00 ; \frac{1}{4}$ Oz., .60; Purpurea. Common red Foxglove

ii,00 Purpurea Alba. White

(505 Mixed. Various colors

510 DODECATHEON Media. American Couslip. Native hardy perennial with rosy-purple flowers in shape resembling the Cyclamen: succeeds best in partial shade. 1 foot

6.15 DRACOCEPHALUM Argunense. Spikes of bright blu

$6 \div 20$ ECHINOPS Exaltatus, Globe Thistle. 'Globular heads of blue flowers; very ornamental. 3 feet $\ldots . \quad \frac{1}{4} \mathrm{oz} ., 25$;

(6.)- Ritro. Magnificent variety with white foliage and metallic blue, thistle-like flowers

6.: EDELWEISS. Gnaphatium Leontopodium. The interesting white leaved plant, so eagerly sought by tourists in the Swiss Alps, easily grown in gardens; hardy perennial. 6 in.

(i.:-) EREMURUS Himaliacus. Stately plant with long rejikes of creamy-white flowers. 6 to 8 feet

6ito Robustus. Flowers soft flesh pink. 8 feet

(i)15 Turkestanieus. Reddish-brown flowers. 5 feet

(i) 50 ERIGERON Grandiflorus Elatior. Very effective perennial with pale lilac star-shaped flowers; excellent for cutting. $11 \mathrm{ft}$.,

6755 Speciosus. Pale manve with bright golden centres. $1 \frac{1}{2} \mathrm{ft}$.,

6ibin ERYNGIUM Amethystinum. Ornamental plant of branching habit with round heads of metallic blue flowers which can be cut and dried for winter bouquets. 3 feet, $\frac{1}{3} 07,1.00$

(iiti) ERYSIMUM Pulchellum. Dwarf perennial with pale yellow flowers: desirable for spring gardening. $6 \mathrm{in}, 4 \mathrm{oz}, .25$

iT:0 EUPATORIUM Ageratoides. A valuable border plant

with tiny white flowers in dense heads. 3 feet, $\frac{1}{4}$ oz., .30 ; flowers: fine for cutting. 2 feet...

6.8i FERNS Hardy Varieties Mixed. Üseful plants for decorating shady nooks, rockeries, or borders, on the northerly sides of buildings

GAILLARDIA Grandiflora. Blanket Flower.

These are handsome summer and autumn flowering plants, quite hardy and easily grown. It is adrisable to mulch them with straw during winter. 3 feet

6.:5 New Hybrids Mixed. Yellow and red,

6790 Maxima. Pure yellow; flowers very large,
Oz, 1.00; 1 oz, .35 : $: .10$

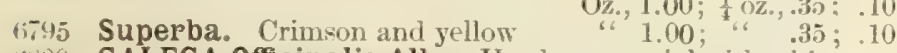

(is)0 GALEGA Officinalis Alba. Hardy perennial with white pea-shaped flowers; very ornamental and useful for cutting

rinos Purpürea. Blue $\cdots$

toz., $.30 ; .10$

in 10 GENTIANA Acaulis. Blue Gentian. Dwarf perennial with intense blue, bell-shaped flowers; snited to moist and shady situations. 4 inches ... ... $\frac{1}{4} \mathrm{oz} ., 40$;

(isi5 Aselepiadea. Flowers purple-blue in long terminal

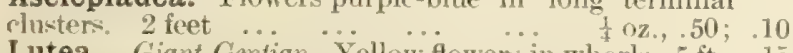

nis20 Lutea. Giant Gentian. Yellow flowers in whorls. $5 \mathrm{ft}$, 15

(6\$25 GERANIUM Sanguineum. A showy plant with finely cut foliage and crimson-purple flowers; blooms all Neason. $1 \frac{1}{2}$ feet

6., GERARDIA Hybrida Mixed. Splendid perennial producing spikes of flowers varying from light pink to dark purple; requires protection in winter. 2 feet

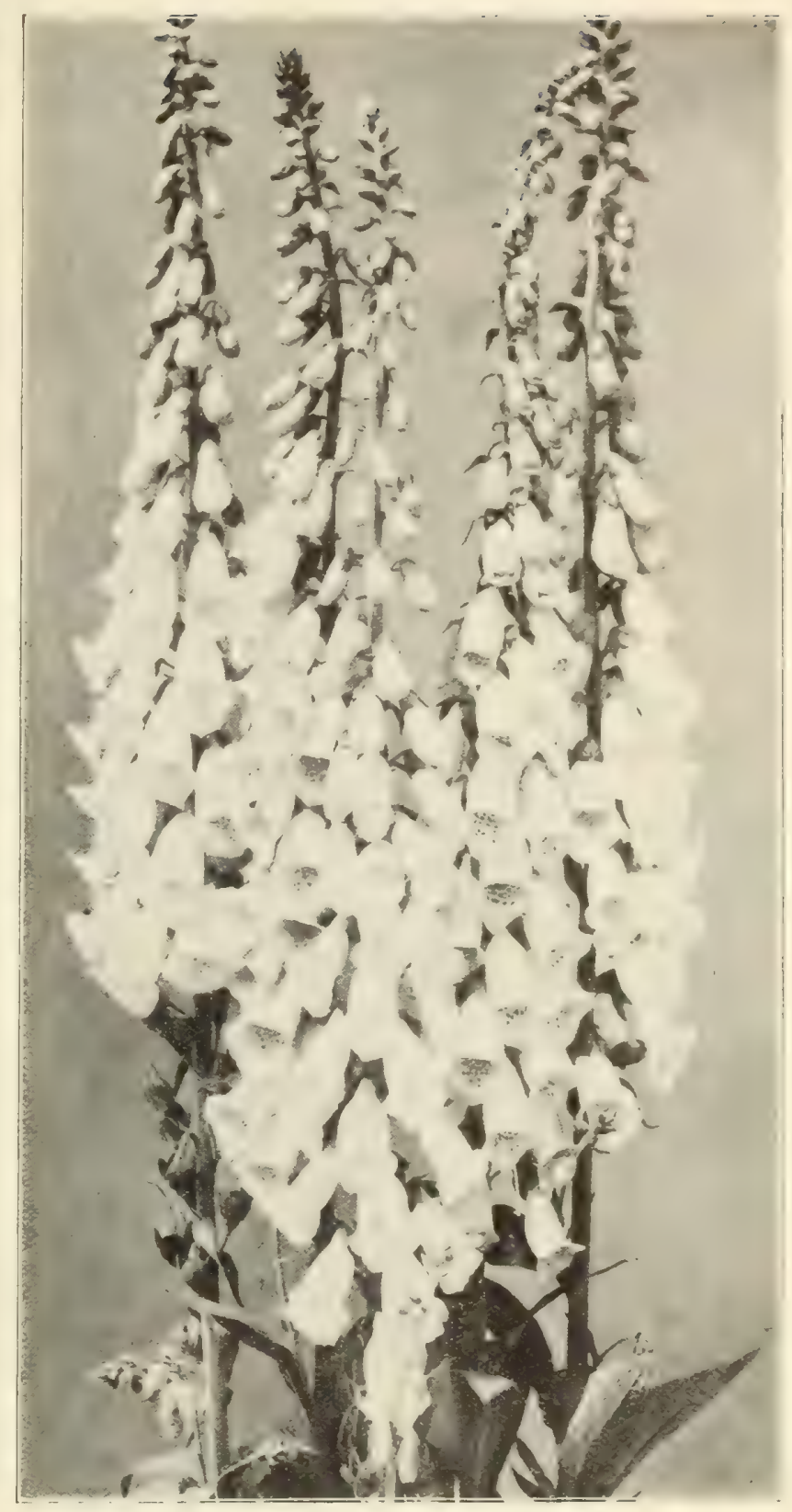

Farquhar's Superb Foxgloves.

68:35 GEUM Atrosanguineum. Large

ers; valuable for cutting. 2 feet

Coceineum. Bright orange-scarlet; singh

GRASSES. Ornamental.

(5850 Andropogon argenteus. Large silvery plumes, 3 feet, .11

(6855 Arundo Donax. Giant Reed. Tall variety with green leaves. 15 feet

6860 Variegata.

6865 Erianthus Ravennæ. Plume Grass. A hardy variety with fine silvery plunes; invaluable for lawn groups. Blooms the first yeur from seed if sown early. \& feet,

6870 Eulalia Japonica. Ornamental variety with long dark green leaves. 6 feet

Variegata. Long graceful leaves, dark gren and white striped. It is one of the most beantiful for forming clumps. 4 feet

6880 Zebrina. Zebra Grass. The dark sreen leaves are barred at intervals with yellowish white. F gated plants equal this in beanty

6885 Gynerium argenteum. Pampas Grass. Magnificent sort with long silvery plumes; requires protection in winter. 10 feet

6890 Stipa pennata. Fealher Gras. Feathery plumes. White 
R. \& J. FARQUHAR \& CO., BOSTON. PERENNIAL FLOWER SEEDS.

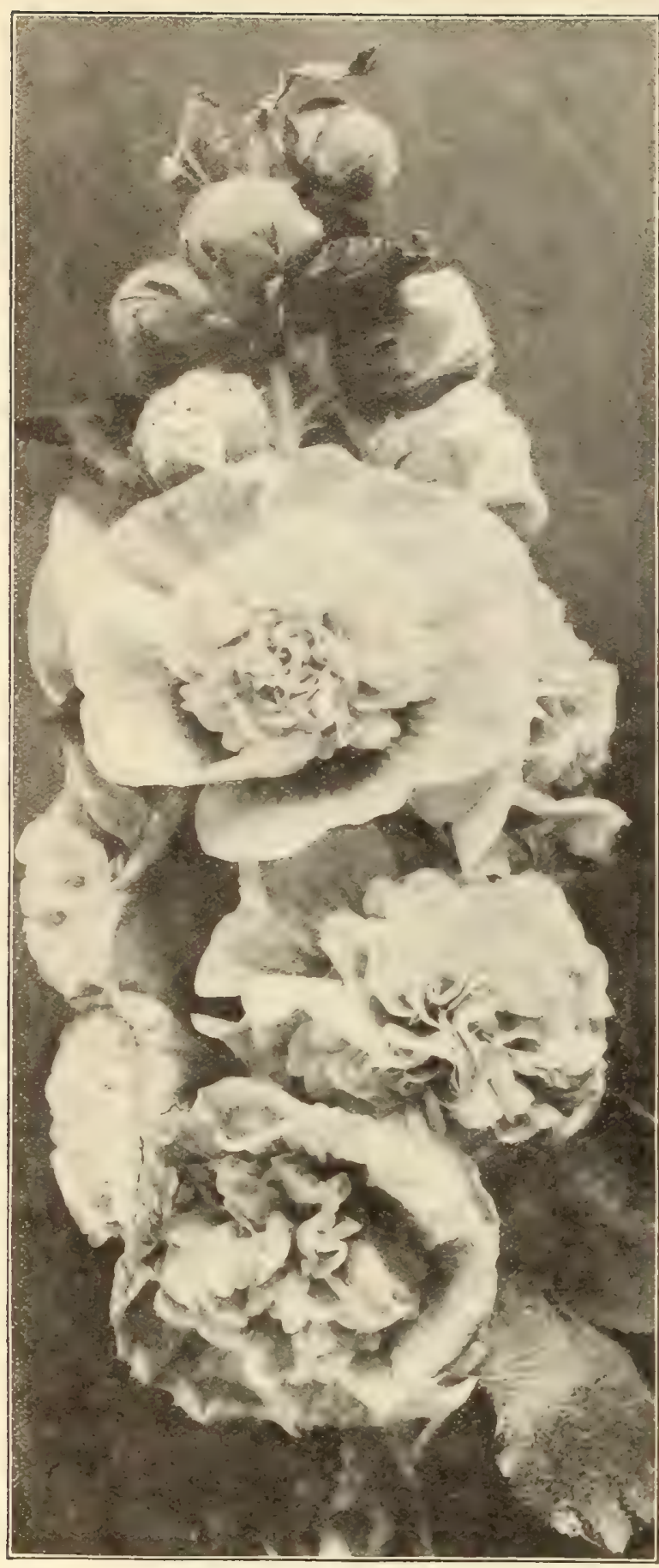

Chater's Double Hollyhock.

6895 GYPSOPHILA repens. A pretty trailing plant, fairly smothered Pkt. with tiny white flowers ... ... ... ... \$ oz. . .30;.10 6900 Panieulata. Small white flowers in light panicles; extensively used in bouquets, 2 feet ... ... ... ... Oz., .40;

6905 HELENIUM autumnale superbum. Striking perennial with broad heads of golden-yellow flowers blooming late in the season. 5 feet

6910

6915

Bigelowi. Rich yellow with brown disc. 4 feet

HELICHRYSUM angustifolium. White foliage; fine plant for edgings. 1 foot toz., .50 : HELIOPSIS Piteheriana. This well-known plant is much esteemed for borders and as a cut flower. The golden-yellow flowers are borne on long stems and are freely produced. $3 \mathrm{ft}$.,

HELlEBORUS New Hybrids Mixed. Christmas and Lenten Roses. Remarkably hardy plants, blooming from December to April. In our climate they should be protected with a frame to prevent the flower buds being injured by frost or ice, and to promote full development of the flowers. 1 foot

HESPERIS matronalis. Purple. Rocket. Spring-fiowering herbaceous perennial, fragrant. $3 \mathrm{ft}$... ... Oz., .30; White. Beautiful as a cut flower ... ... ... " .30;.05 (i) 45 Dwarf White. Tery early. $1 \mathrm{ft} \ldots \ldots \ldots \ldots$ (6950 HEUCHERA sanguinea. Compact hardy premnial producing erect spikes of vivid crimson flowers. 1 foot

\section{HIBISCUS. Mallow.}

Showy plants of vigorous growth, producing large, handsome flowers. They are especially suitable for mixed beds or borders where masvive effects are desired. 2 to 5 feet.

69.5. Crimson Eye. An excellent plant for lawn groups and borders; blooming the first season from seed in the open ground. Flowers pure white with crimson centre. 4 feet, $\mathrm{Oz} ., 1.00 ; \frac{1}{10 z_{0}} .35 ; .10$ Militaris. Large pink flowers shaded with carmine towards the eye, 6 fect

Moscheutos Albus. White Surmp Vallou. None of the hardy Hibiscus are more useful and beautiful than our native Swamp Mallows. They begin to bloom in July and continue to September, producing flowers like Single Hollyhocks, but much larger. They are excellent for moist places, but succed in any good soil. Flowers pure white. 4 feet $\ldots \mathrm{Oz}_{2}, .75 ;$ f oz., .25 ; .10 Moscheutos Roseus. Pink Swamp Mallow. Large pink flowers, $\mathrm{O} z ., 75 ; \frac{1}{4} \mathrm{Oz} ., 25 ; .10$ HOLLYHOCK. Chater's Strain.

Ifollyhocks succeed best in rich, well-drained soil. They should be lightly protected during winter with pine boughs, coarse straw, or other mulch not liable to rot. Seeds sown in June or July produce fine plants for blooming the following summer. Hardy biennials. 6 to 8 feet.

Double Special Mixture.

popular plant

Double Crimson.

Double Salmon.

Double White.

Each of the above color:

A greatly improved strain of this

6990 Double Pink.

7000 Double Purple.

7010 Double Yellow.

702,) White.

7040 Rose.

7045 Scarlet.

\section{SINGLE VARIETIES.}

\section{Collection of 6 Single Varieties Separate}

7035 Salmon.
7050 Crimson.

Oz., $1.00 ; \frac{1}{4} \mathrm{Oz}, .35 ; 10$
HOLLYHOCK.-Continued.

\section{Pkt.}

7060 Single Mixed $0 \%, 1.00 ; \frac{1}{1}(1 \%, .35 ; .11)$

706.) Alleghenny Mixed. Single and semi-double fringed Howers $\ldots \quad \ldots . \quad \ldots \quad \ldots \quad$ Oz., $1.50 ; \frac{1}{4} \mathrm{oz}, .50 ; .10$ HONESTY MIXED COLORS. Lunaria biennis. Hardy biennial flowering the first year from seeds if sown early; flowers purple or white, followed by round seed vessels of silvery appearance highly prized for winter decoration. "2 feet $\ldots . \quad \ldots \quad \ldots$ Oz., $30^{\circ}$

7075 INULA Grandiflora. Large orange-yellow flowers,

4 inches across, borne on erect stems. 2 feet ...
7080 INCARVILLEA Delavayi. A grand variety from Northern China with light green leaves about 2 feet in length, resembling those of the Acanthus. The flowers are produced in long spikes, cup-shaped, and of a bright rose color. The tubers can be taken up in winter and stored like Dahlias. $2 \frac{1}{2}$ feet
7085 JASIONE Jankœ. Pretty free-flowering perennial with erect terminal heads of blue flowers; succeeds best in light soil. 1 foot

LATHYRUS latifolius. Perennial $P e a$. Magnificent hardy perennial climbers with white, pink and erimson pea-shaped flowers in clusters. They are excellent vines for covering old stumps and fences as they bloom all summer. 6 feet.

7090 White. Charming as a cut flower, Oz., $.75 ; 1$ oz., $.25 ; .10$

7095 Giant White. A giant form of the preceding with fowers of the purest white $\quad \ldots \quad \ldots \quad \ldots \quad \ldots \quad \ldots 5$

$25 \quad 7100$ Pink Beauty. Bright rosy-pink ... ... O\%., .60; .10

7105 Splendens. Rosy-carmine in large clusters, " .50;.10

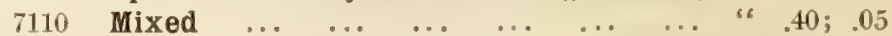

7115 LAVENDER. Lncendula mm. Ornamental plant bearing long spikes of very fragrant blue flowers; should be extensively grown. $1 \frac{1}{2}$ feet ... Oz., 30 
R. \& J. FARQUHAR \& CO., BOSTON. PERENNIAL FLOWER SEEDS.

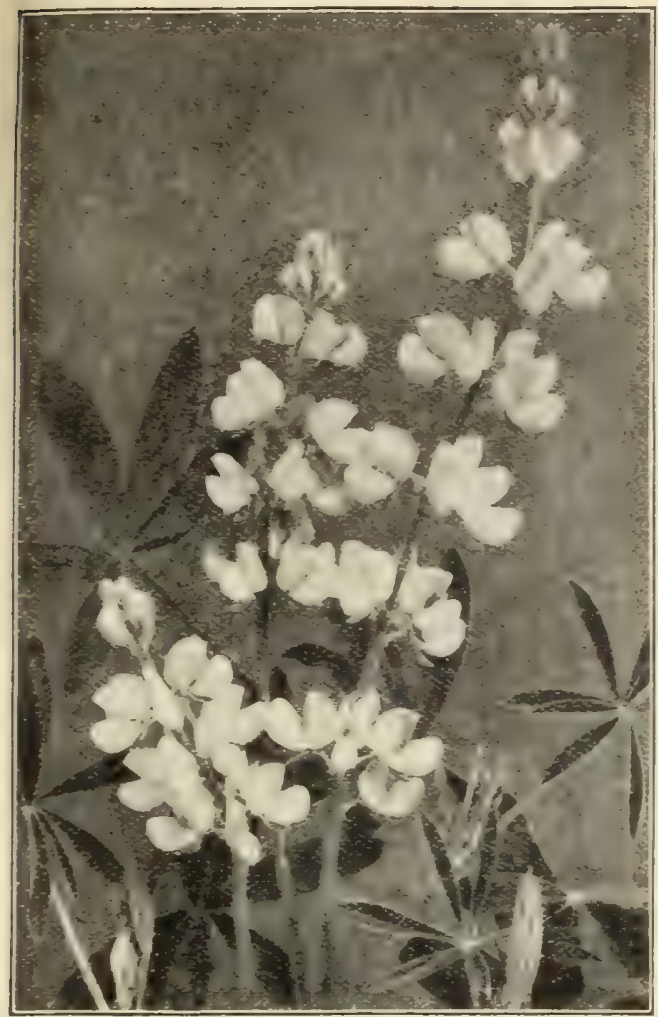

Lupinus polyphyllus.

7120 LEPACHYS pulcherpima hybrida. Handsome plant of the Rudheckia Pkt. family; flowers varying from yellow to brown. Useful as a cut flower. 2 feet

7125 LIATRIS spieata. Extremely showy border plant, thriving in anyordinary soil, with large flower spikes of violet-purpls. 2 feet

7130 LINUM flavum. Golden Flax. Flowers golden yellow; free-blooming 1 foot

7135 Perenne, Blue. Showy variety, suitable for borders. $1 \frac{1}{2}$ feet,

7140 Perenne, White

7145 LOBELIA Cardinalis. Cardinal Flower. A native species, succeeding best in rather moist situations; flowers intense scarlet. 2 feet, $\frac{1}{8} \mathrm{Oz} ., 1.25$;

7150 Nanseniana. Deep crimson; foliage dark red

7155 Syphilitica. Strong growing variety with pale-blue flowers; very effective in partially-shaded borders. 2 feet

7160 Syphilitiea. Bright Red. A new color in this popular herbaceous plant,

LUPINS. Lupinus.

Beautiful spring-blooming plants with long spikes of pea-shaped flowers 2 to 3 feet.

7165 Polyphyllus, Blue

Oz.. .30;. 05

White..

7175 Rose. New and beautiful shade

7180 Mixed..

7185 Arboreus. Bright jellow, fragrant flowers; requires protection in winter. 3 feet ... ........ . . . . . . . . .50;

7190 Snow Queen. Magnificent variety with long spikes of pure white flowers. 3 to 4 feet.

\section{LYCHNIS.}

Profuse-blooming hardy perennials, remarkable for the brilliancy of their flowers; excellent for massing in large beds and borders.

7195 Chaleedoniea. Jerusalem Cross. Large scarlet flower heads. 2 feet, Oz.,.30; 7200 Chalcedonica Alba. Flowers white

Briglit Pkt. red, fringed flowers. 2 feet $\ldots \ldots$ Oz, $1.00 ; .10$
Fulgens. Brilliant scarlet. $1 \frac{1}{2}$ feet $\ldots+10 z ., 1.00 ; .20$

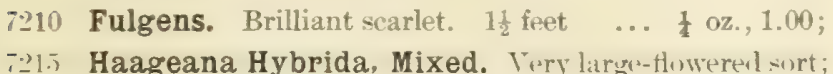
(colurs varying from white to pink and deep red. 2 feet, $\mathrm{Oz} ., 1.25 ; \frac{1}{4} \mathrm{oz} ., .40 ; .15$

$\rightarrow-2$ n Sieboldi. Fine Japanea species: flowers ream enlor.

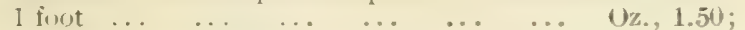

Viscaria splendens. Scarlet; large flowers; 1 foet.

$$
0 \%, .50
$$

;:: $: 1$ LYSIMACHIA punetata. Filendid herder plant with long spikes of bright yellow flowers. 2 feet, $\frac{1}{4} \mathrm{oz}, .50$;

-2.35 Vulgaris. Late-flowering sort with large pyramidal spikes; flowers yellow. 2 feet

i-41) LYTHRUM roseum superbum. Irm: Strifi. A strong-growing plant, thriving in ans gomel soil. Frent

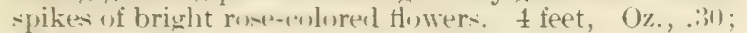

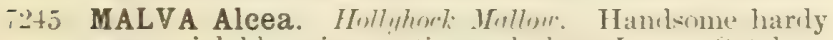

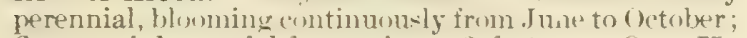
flowers pink; useful for cutting. 3 feet ... Oz., .75;

7250 Mosehata. Musk Mallow. Flowers rose-colored; blooming the first season if sown early. 2 feet, Oz., 1.00;

7.-5.) Mosehata alba. Pure white fluwers ... .. 1.00;

7 in MECONOPSIS integrifolia. A large sellow flowered Poppy from Thibet, the most striking introduction of recent years. The plant forms a rosette, from the centre of which a stout stem arises bearing from six to ten large, pure yellow thowers six inches in diameter. Pro-

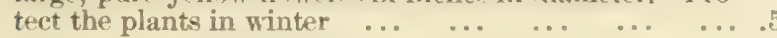

MIMULUS. Monkey Flower.

Very handsome, half-hardy perennials, blooming the first year frum eterl. They thrive lest in rather moist ground. 1 foot.

76h5 Cardinalis Grandiflorus. Large scarlet flowers

F-1) Tigrinus grandiflorus. Fluwer: large, and of rarious sharles of yellow, elegantly spotted and markerd with crimson and maroon. 1 foot $\ldots \ldots \ldots$... $\quad \ldots$

7:-5) MORINA elegans. Harily perennial resembling the acanthus in growth; deep erimson flowers produced in whorls around the stem. 3 feet ... ... ... ... .10

\section{MYOSOTIS. Forget-me-not.}

Most of the Forget-me-nots will bloom the first year from seed if sown early. If sown in July or August in sharded frames fine plants will $x^{2}$ obtained for surine bloming. They are beatutiful planterl in combination with spring bulbs, Daisies, Arabis, or Golden Alyssum.

80 Alpestris Victoria. The plants are of dwari compact growth with long sprays of hright blue fluwers: loroduced in dense umbels. 6 inches, $\mathrm{Oz}, 1.50 ; \frac{1}{4} \mathrm{oz},, 50$; 726.) White. Lareq white flowers, " 1.00 ; ". .3\%:

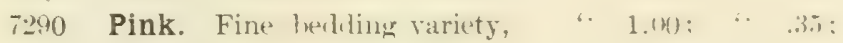

7295 Royal Blue. Flowers deep indigo blue, borne on long sprays; fine for cutting ... .... Oz., 1.25; $\frac{1}{4}$ oz., . 40 ;

7300 Dissitiflora. Large-flowered variety; excellent for pot culture. Flowers rich blue. 6 inches, 1 Oz.. 1.25;

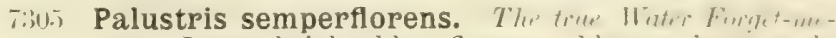

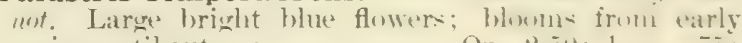

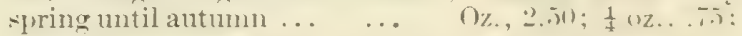

7310 Sylvatiea. I splendid sort of spreating hahit. valuahle. for spring bedeling; Howers bright blue,

$$
\mathrm{Oz} ., 2.00 ; \frac{1}{4} \mathrm{oz}, .60
$$

7315 Mixed. Various shades of blue, white and rose, $\mathrm{O}_{4}, .75$;

ENOTHERA. Emning Primines.

Beautiful hardy plants of easy cultivation, succeeding best in light suil.

7320 Fraseri. Attractive perennial with large yellow flowers. $1 \frac{1}{2}$ feet $\ldots \quad \ldots . \quad \ldots \quad \ldots \quad$ Oz., $1.50 ; \frac{1}{4}$ Oz. . .50;

732. Fruticosa Major. Flewers guhlen-yellow; rery sluwr. Oz., $.75 ;$

7330 Lamarekiana. Enormons yellow flowers, three to four inches in diameter; very free-flowering. 3 feet, $\mathrm{Oz}, .30$

7335 Missoupiensis. I prostrate growing variety with large flowers of a bright yellow color, suitable for large herbaceous borders

734$.$) OROBUS vernus. Bith lik. I pmity dwat bre-$

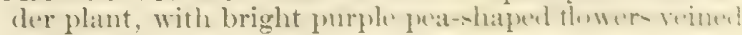
with

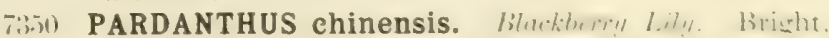
orange-colored flowers resembling the Lily, followed by seed pods like Blackberries. $2 \frac{1}{2}$ feet 


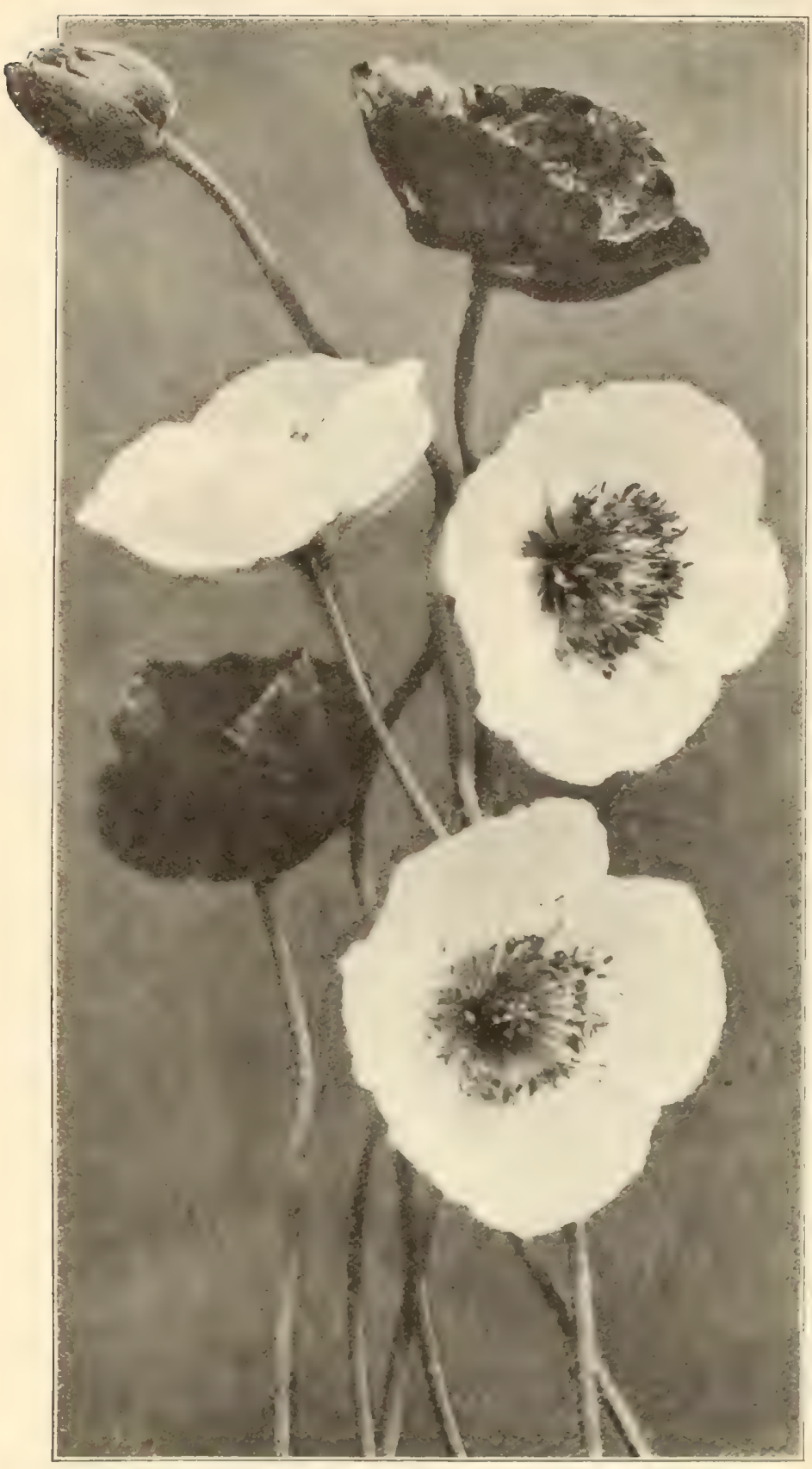

Farquhar's Superb Icelanc Poppies.

PENTSTEMON.

7:.,5,5 Farquhar's Large-flowered Hybrids Mixed. Silver from large-flowered varieties of the most brilliant colors - This stmin is unsurpased for cutting, P, Pkt.

-:360 Gloxinoides. Magnificent variety producing large spikes of Gloxinia-like flowers often 2 inches across and of mont brilliant and varied colur:

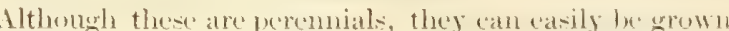
as amnuals. If sown in heat in February or Iarch they will fluwer tredy the first year producing large syikes of handrome flowers. 2 feet.

Fistis Atropurpureus. Bark resl with white throat

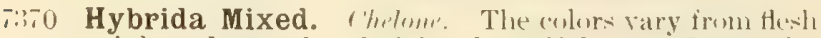
pink to deetl red and violet; beantiful as ant flowers for

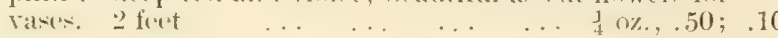

$7:-5$ Hybrida Torreyi. Jxtremely showy hedrling plant with brilliant scarlet flowers. 2 feet ... $\frac{1}{4} \mathrm{oz} ., .50$;

\section{PENTSTEMON.-Contimued.}

Pkt

7380 Diffusus. Violet blue flower, free blooming ... ... .10

7385 Digitalis. Large spikes of pure white flowers; the throat spotted with violet $\ldots \ldots \ldots \ldots, \ldots . . .10$

7395 Murpayanus. Bright scarlet flowers ... ... . . . .25

7400 Pubescens. Rosy-purple. $1 \frac{1}{2}$ feet $\ldots \ldots \ldots . .10$

$7+05$ Secundiflorus. Splendid variety with bright bhe

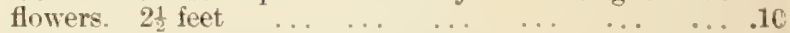

$7+10$ Spectabilis. Flowers blue and red, very beautiful $\cdots . .15$

"7415 PHLOX decussata New Hybrids Mixed. Splendid hardy herbaceous plants producing large trusses of showy flowers on tall stems; the colors range from pure white to deep crimson and purple. 3 feet, $\frac{1}{4} \mathrm{oz} ., .75$;

$7 \pm 20$ PHYSOSTEGIA Virginiea. One of the most beautiful of our summer flowering border plants. The delicate pink flowers are carried on long stems which are much esteemed for cutting. 3 feet $\ldots+$ toz. . .75; .

it25 Virginiea alba. Large white flowers, $\frac{1}{4} \mathrm{oz} ., 1.00 ; .1$ ?

$7+30$ PLATYCODON grandiflora. Japanese Balloon Flower. A most desirable perennial of erect bushy growth and bearing a profucion of large bell-shaped flowers, of deep blue ' 2 feet ... ... Oz.., .75; 7 oz., .25; .16

7435 Grandiflora alba. White form of the preceding " .75; .10

TH10 Mariesi. Dwarf variety of compact habit; flowers rich violet. 1 foot ... ... Oz., $1.00 ; \frac{1}{1} 0 z ., 30 ; .10$

it45 POLEMONIUM cosuleum grandiflorum. Jacob's Ladder, or Greek Talerian. Hardy perennial with deeply cut foliage and clusters of handsome blue flowers. 2 feet $\ldots . \quad \ldots . \quad \ldots \quad \ldots . \quad \ldots \quad \ldots .0 z ., .50 ; .10$

7450 Grandiflorum album. Pure white ... $\$ \quad .75 ; .10$

7455 Reptans. Compact sort with graceful foliage; flowers blue. 6 inches

\section{POPPY. Papaver.}

All perennial Poppies may be sown from June to August, to bloom the following summer.

Alpine Poppy. Papaver Alpinum. Charming dwarf Poppies with delicate flowers including yellow, white, scarlet and pink. 1 foot. White.

7465 Pink.

Orange-yellow.

7475 Mixed.

Each of the above colors and mixed

ICELAND POPPY. Papaver nudicaule. This beautiful species will bloom the first season if sown early in spring. Its delicate form and bright colors render it desirable as a border plant and exquisite for cutting. 1 foot.

7480 Farquhar's Superb Mixed. Shades of yellow, scarlet and white

7485 Bright Yellow

7495 Orange-scarlet. Oz., $1.25 ; \frac{1}{4} \mathrm{oz} ., .40 ; .10$ Each of the above 7490 Pure White. colors $\quad . . . \quad \frac{1}{4} \mathrm{oz}, .50$; BRACTEATUM. Very large orange-scarlet flowers; early flowering. 2 feet ... ... ... Oz, .50;

ORIENTAL POPPY. Papaver Omientale.

The most grorgeous of all the P'oppies. 3 feet.

7510 Orientale. Brilliant orange-scarlet with black spots; very early $\quad . . \quad \ldots . \quad \ldots \quad \mathrm{Oz}, 1.50 ; \frac{1}{4} \mathrm{Oz} ., .50$;

7515 Hybrids. Immense flowers, many of them larger than Orientale, the colors varying from blush white to orange and rleep red. : feet. ... ... ... $\frac{1}{4} \mathrm{oz}, .50$;

7520 Blush Queen. Large pale pink ... ... $\frac{1}{8} \mathrm{oz}, . .75 ; .15$

7525 Parkmani. Rich dark scarlet ... ... " $\quad .50 ; .15$

75:30 POPPY pilosum. Tall branching sort with salmonyred flowers of large size. 2 feet $\ldots \quad \ldots \frac{1}{8} \mathrm{oz}, .75 ; .15$

7.;.) Collection 6 Perennial Varieties Separate,

75+1) POTENTILla Double Hybrids Mixed. Splendid hardy perennials with ornamental foliage and brilliant flowers, chiefly shates of yellow and red, borne in great. profusion. "2 feet.

Single Mixed

MR. DONALD MacQREGOR, Gardener for Frank Lyman, Esq., “Fort Hill," Northampton, Mass., January 14, writes:

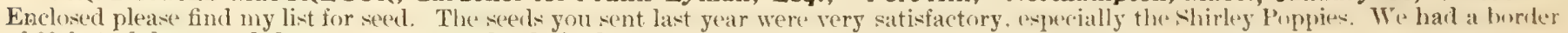
of 60 feet of them, and they were very much admired. 
3. \& J. FARQUHAR \& CO., BOSTON. PERENNIAL FLOWER SEEDS.

PRIMULA, or Primrose.

Hardy and Half-hardy Varieties.

1550 Acaulis. Farquhap's Hybrids Mixed. A greatly Pkt. improved strain with flowers of large size and containing many bright and beautiful colors $\ldots \frac{1}{8}$ oz. 1.25 ; Yellow. Yellow English Primrose. The best sort for forcing and bunching for corsage bouquets

560 Blue. Color rich purple blue ... ...

POLYANTHUS. Primula elatior.

565 Farquhar's Giant Faney Mixed. The colors range from white to deep maroon; the yellow, rose and crimson shades being particularly fine. These larger forms are desirable for winter flowering in the conservatory as well as for bedding out in spring. 9 inches, $\frac{1}{3}$ oz., 1.50;

550 Giant White, Pkt., .257575 Giant Yellow

¿580 Giant Blue, " .50 7585 Giant Crimson

5900 Gold-laced. Flowers of brilliant colors with distinct

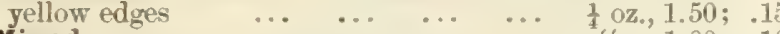

i595 Mixed

600 PRIMULA Auricula Choice Mixed. A lorely race Primroses with large umbels of velvety flowers in many beautiful colors, chiefly yellow, crimson, maroon and purple, frequently edged with gray or green

7605 Japonica Mixed. One of the finest Primroses for the garden, producing several whorls of large flowers, on erect stems varsing from white to crimson. $1 \frac{1}{2}$ feet The seeds serminate sowly and unevenly, $\frac{1}{3}$ oz., 1.00; Sieboldii. Attractive diass -nitable for pot culture, with large du-ters of fower-; whors white to rust-crim sinn. 1 foot

7615 Rosea Grandiflora. 1 charming rariets with flowe. of a clt ar bright rose, 6 inches .

\section{PYRETHRUM.}

Very hanỏsome herbaceous perennials. The flowers are of brilliant colors and very lasting. 2 feet.

7620 Atrosanguineum. Crimson with yellow centre, single,

-625 Roseum Double Hybrids Mixed But $4.0 z ., 50$ like Hower: ranging in (oulur iron white to brilliant row and crimson ... ... ... ... . $\frac{1}{8}$ oz, 2.50

7630 Roseum Single Hybrids Mixed. Dai-y-like flower of brilliant colors with yellow centres ... 1 oz. . .75;

76:35 Uliginosum. Tall late-flowering sort, with large, single

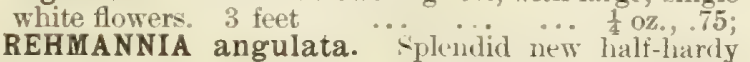
biennial with Gloxinia-like flowers of rosy purple with yellow throat, suitable for pot culture or ont-doors in a sheltered place. 3 feet

$76+5$ RUDBECKIA Fulgida. Cone $F$ lower. An effective variety producing in autumn, mases of orange-yellow Howers. :3 feet ... Nitida, or Autumn Glory. Flowers pale yellow, large. :3 finet

7655 Newmani. Magnificent golden yellow flowers with maroon centre. 3 feet

7660 Purpurea. Giant Purple Cone Flower. A striking plant with very large reddish-purple flowers. 3 feet,

7665 SALVIA Azurea Grandiflora. Exceedingly pretty species with long spikes of sky-blue flowers. 2 feet,

SAPONARIA Offleinalis. Hardy perennial suitable for herbaceous borders; reddish purple. 2 feet, Oz.,.30; Oeymoides splendens. Trailing hardy perennial with small deep red flowers $\ldots . \quad \ldots \quad \ldots .0 z, .40$;

i680 SAXIFRAGA cordifolia. Interesting plant for rock eries or hardy borders; flowers pink. 1 foot ... ... SCABIOSA caucasica. Magnificent perennial with beautiful large, light blue flowers, 2 feet, $\frac{1}{3} \mathrm{oz}, 1.00$; Caucasica Alba. A pure white form of the preceding, Japonica. A hardy variety from Japan of bushy growth; flowers lavender blue. A fine cut flower. $2 \mathrm{ft}$., SEDUM aere. Trailing plant forming a regular green carpet; flowers bright yellow. 4 inches

7705 Spectabile. An erect growing variety with light green foliage and large heads of rose-colored flowers. $1 \frac{1}{2} \mathrm{it}$.,

7710 SCUTTELARIA baicalensis eœlestina. Hard plant of dense bushy habit with an abundance of light blue flowers. $1 \frac{1}{2}$ feet

7715 SENECIO elivorum. A new hardy plant from Northern China, with large leaves and rich orange-yellow flowers well adapted for planting by the sides of lakes or streams. 4 feet.

7720 SILENE aeaulis. Chthfly. Yuat dwarf pereminil with rosy-crimson flowers; fine rock plant. 2 inches,

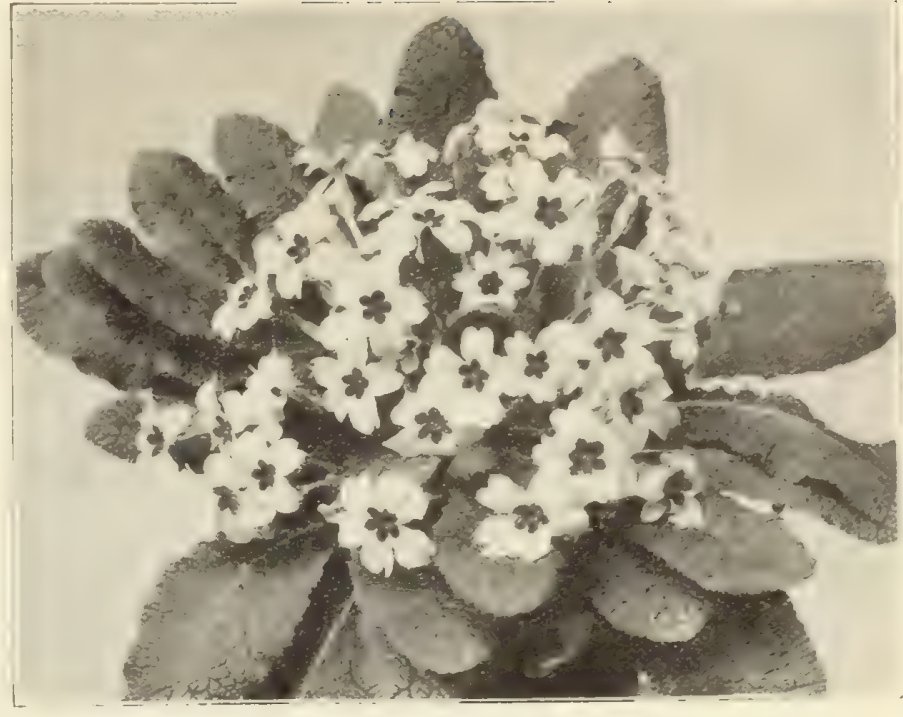

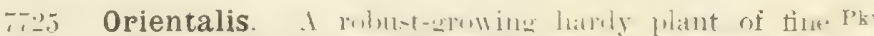

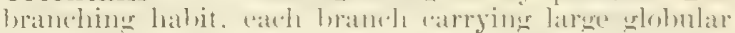

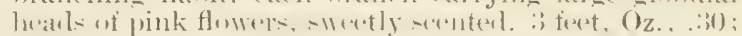
STACHYS lanata. Lamb's Enrs. Ornamental plant largely grown for its silvery-white woully leates; fluwerpurple. 2 feet.

$77 t 0$ STATICE ineana Dwarf Mixed. A charming variety of the Sea Lavender. Esteemed for bouquets. $1 \frac{1}{2}$ feet,

7745 Latifolia. Small lavender-blue flowors in large pan-

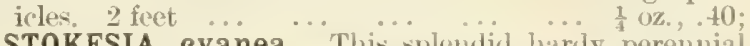

750 STOKESIA eyanea. This splendid hardy perennial

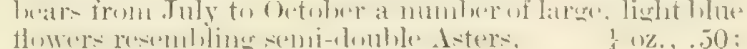

\section{SUNFLOWER.}

7755 Maximiliana. Flowers clear yellow with several row of large ray petals and full centre; continues in

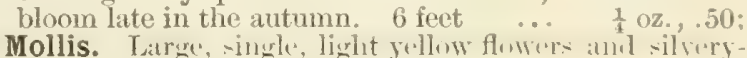

7760 Mollis. Large, -ingle, light yellow fluwe and silvery-

7765 Rigidus. Fine native variety, with rich golden-yellow flowers; valuable for cutting

$$
\text { Annual Tarieties see Vos. } 1210-4+5.5 .
$$

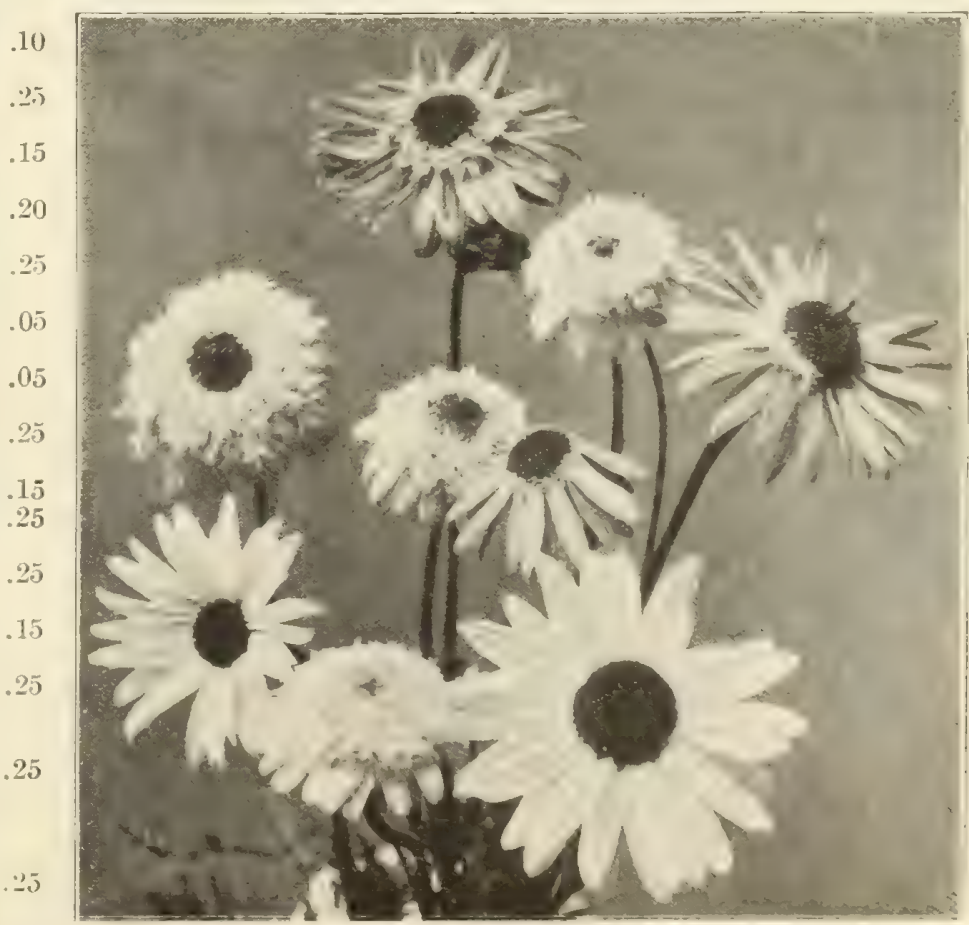

Pyrethrum Hybridum, Single and Double. 


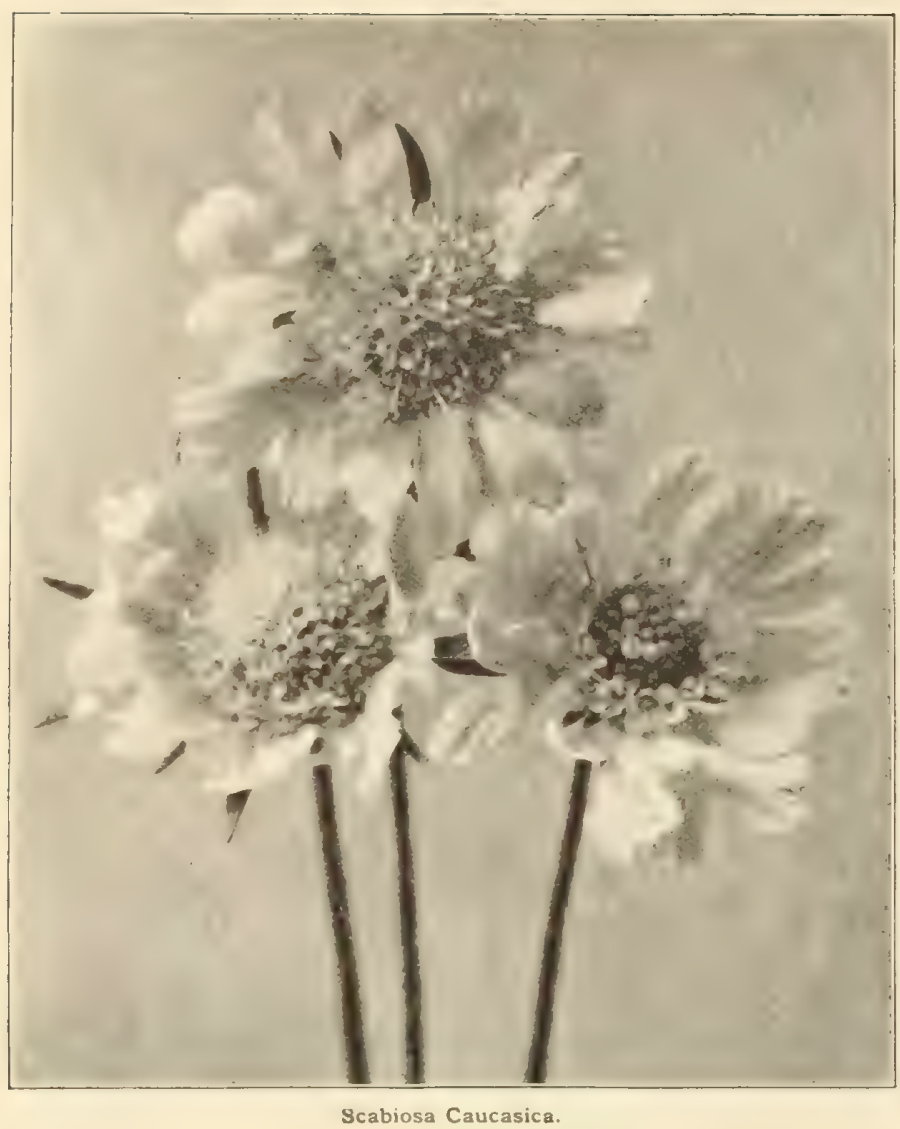

T\$55 VERBASCUM Olympieum. Mullein. Large white Pke. silvery foliage, with grand spikes of yellow flowers. $5 \mathrm{ft}$., $\frac{1}{4}$ oz. $.30 ; .10$

-stio Panosum. Stately plant with large woolly leaves and dense spikes of sulphur yellow flowers. 6 feet, $\mathrm{Oz} ., .40 ; .05$

\section{VERONICA. simederll}

Elegant hardy perennials of easy culture and thriving in any good soil.

7865 Amethystina. Light blue. 2 feet

7870 Longifolia. Long spikes of rich blue flowers. 2 feet, .10

7875 Ineana. Lovely shade of violet. $1 \frac{1}{2}$ fixet

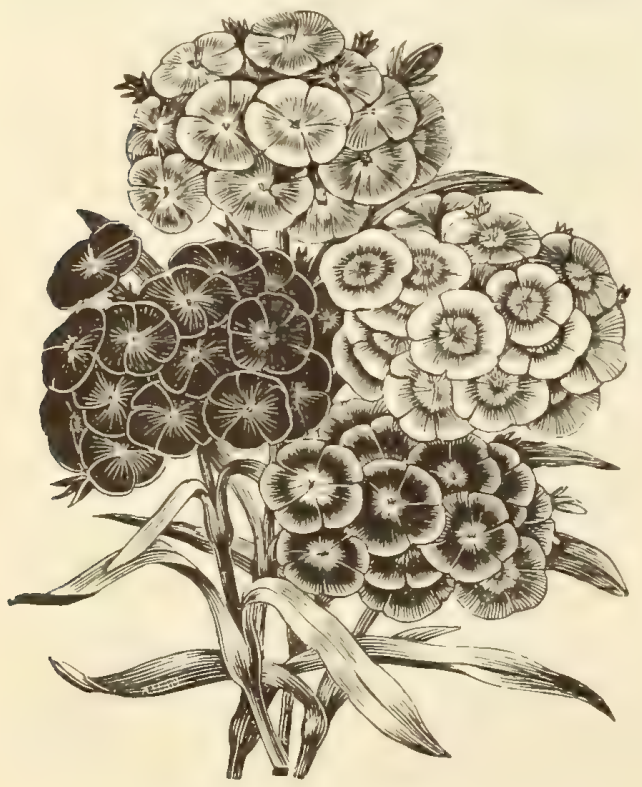

Sweet William, Farquhar's Superb.

7915
SWEET WILLIAM.'Dianthus Barbatus.

Showy hardy biennials of easiest culture; admirable for clumps among shrubs or borders. $1 \frac{1}{2}$ feet.

\section{SINGLE VARIETIES.}

Tito Farquhar's Superb Mixed. A maonificent strain l'k of this popular plant with very large flowers, and containing many attractive shades, Oz., 1.00; $\frac{1}{4} \mathrm{Oz} ., .30$

77,5 Farquhar's Pink Beauty. A new and distinct shade of this well-known flower … $\frac{1}{4} \mathrm{Oz} ., .75 ; .15$

7780 Dark Crimson. Rich dark shade ... Oz.,.50; 115

7585 White. Excellent for cut flowers ... « .50; 41;

7790 Giant Auricula-Eyed. Tarions colors with clearly defined eyes ... ... ... ... Oz., .75;

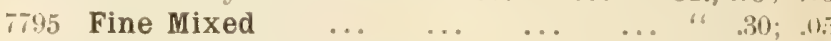

7800 Double Fine Mixed ... Oz, $1.25 ; \frac{1}{4}$ oz., .40;

7805 TEUCRIUM Chamædrys. Fine hardy plant for the herbaceous border; flowers purple. 9 inches,

7810 THALICTRUM Adiantifolium. A graceful plant with finely cut foliage resembling the Maidenhair fern; extensively used for bouqnets. 1 foot

7815 THERMOPSIS Caroliniana. A tall growing hardy perennial with clover-like leaves, and magnificent spikes of golden-yellow pea-shaped flowers. 5 feet,

7820 TRITOMA Hybrida Express. The earliest of all the Tritomas, producing an abundance of elegant orange-scarlet flowers. 3 to 4 feet

-825 Uvaria Grandiflora. Scarlet and orange yellow flowers. 4 feet $\quad . . \quad \ldots \quad \ldots \quad \frac{1}{4}$ oz. .75 ;

7830 TROLLIUS Europæus. Globe Flower. A largeflowered variety of the buttercup with bright yellow globular flowers. 2 feet $\ldots . \mathrm{Oz}_{.}, 1.25$; 1 oz., 40 ;

T835 Caucasicus Golden Globe. Very large, deep orange-colored flowers. 2 feet .... $\frac{1}{8} \mathrm{oz}, 1.00$;

7840 Japonicus fl. pl. Fine globular golden-yellow flowers. 1 feet ... ... ... $\frac{1}{8} \mathrm{oz}, 1.25$;

7845 VALERIAN Red. Faleriana Rubra. Old-fashioned perennial, adapted to wild gardens or large rockeries. 2 feet ... ... ... ... ... O\%. .40;

7850 White. A white form of the preceding ... “' $40 ; .0$ VERONICA.-Continued.

7880 Rosea. Bright rose-colored flowers. $1 \frac{1}{2}$ feet

7885 Spieata. Showy spikes of bright blue flowers

VIOLET. Viola Odorata.

The single varieties only can be raised from seeds; these. however, are very fragrant and quite hardy.

7890 The Czar. Very large, dark blue

7895 White Czar. Pure white, large flower .. Odorata Mixed. Shades of blue and white, " 50 ; 15 Tiola Cornuta see Pansies, Nos. 3275-3310.

7910 VERNONIA Arkansana. Tall growing perennial with large heads of purple flowers, splendid for cutting. $6 \mathrm{ft}$.

\section{WALLFLOWER.}

Hali-hardy perennials of delicious fragrance. If sown in heat in March or April good plants will be obtained for flowering during the following winter in a cool greenhouse, or they may be kept in cold frames and bloomed in the spring and early summer.

\section{SINGLE VARIETIES.}

7920 Primrose Yellow. Fine light shade

7925 Mixed. Shades of yellow and red

$$
\begin{array}{cccc}
\ldots & \text { Oz., } & .50 ; & .10 \\
\ldots & 6 & .50 ; & .10
\end{array}
$$

\section{DOUBLE VARIETIES.}

7930 Collection of 8 Varieties Separate. Imported

Double Mixed. Splendid branching varieties

Anmual Hallflower see Nos. 4730-470.

7940 YUCCA fllamentosa. Adam's Needle. Splendid hardy plants for shrubbery or lawn groups, with elegant spikes of creamy-white flowers; leaves with thread-like filaments on their edges. 4 feet

79:5 ZAUSCHNERIA Californica. Very attractive hardy perennial, with bright vermillion fuchsia-like drooping flowers. $1 \frac{1}{2}$ feet 
B. \& J. FARQUHAR \& CO., BOSTON. DAHLIAS.

\section{DAHLIAS.}

Note.-Uniess otherwise specified, all Dahlias will be supplied in roots, and ve believe our supply this season is ample to meet all demands. However, in case the demand for certain varipties exhausts our supply of roots, we vill send out groving plants ichich will give equally as good results.

\section{LARGE DOUBLE SHOW.}

Each, .20; per doz., $\$ 2.00$; per $100, \$ 12.00$; by mail, each, .25 ; per six, $\$ 1.25$; per doz., $\$ 2.50$, except where otherwise priced.

Collection of Large Double Show Dahlias, twelve ehoice sorts of our seleetion, $\$ 1.50 ; \mathrm{by}$ mail, $\$ 2.00$. Colleetion of 'six sorts, .75; by mail, $\$ 1.00$.

A. D. Livoni. Beautiful soft pink, with quilled petals, free flowering. Admiral Sehley. Rich crimson shading garnet with a baud of white through centre of each petal.

Arabella. Light sulphur yellow, shaded peach blossom on edge of petals.

Chamæleon. Flesh colored centre, shadiug to crushed strawberry with yellowish blending.

Charles Lanier. The rich. deep yellow flowers of this new variety are of enormous size and beautifully quilled. The blooms are freely produced on very long stems which render it valuable as a cut flower. Each 25c., doz. \$2.50.

From HORTICULTURE, Sept. 7, 1907. - "Dahlia Show at Boston. '1'he Dahlia Show at Horticulturai Hall, Boston, this week is unquestionably the finest exhibition of dahlias ever given in America. The sensation of the show is A. H. Wingett's Charles Lanier, a four-year-old, deep yellow in color, which may be appropriately described the Col. Appleton of the dahlias."

David Johnson. Salmon and rose: large flower.

Duchess of Cambridge. Base of petals white, suffused pint heavily tipped dark crimson.

Eloise. White tinted pink, edged with purple.

Emily. Solferino, with white markings, large and beautiful.

Frank Smith. Rich dark purple maroon, petals tipped white.

Hero. Red; very fine.

J. T. West. Yellow tipped purple, fine flower.

John Walker. Finest pure white, splendid for exhibition.

John Thorpe. Solferino pink, large.

\section{POMPON OR BOUQUET DAHLIAS.}

The dainty, small double flowers of these Tahlias are extremely serviceable for entting, and they are produced so abundanty tinas after a liberal number have been gathered for house decoration, the plants are usually still gay with the brilliant ball-like hlonms.

Each, .15; per dozen, $\$ 1.50$; per 100, $\$ 12.00$; by mail, eaeh, .20; per six, $\$ 1.00 ;$ per dozen, $\$ 2.00$

Colleetion of Pompon Dahlias, twelve ehoice sorts of our selection, $\$ 1.50$; by mail, $\$ 2.00$.

Catherine. Pure yellow.

Darkness. Dark velvety maroon.

Elegante. Beautiful soft pink.

Guiding Star. Pure white.

Jessica. Yellow or amber, edged with red.

Jewel. Pale primrose, blotched white.

Kleine Domitea. Olange buff color.

La Petit Jean. Beautiful rich plum color.
Little Bessie. Creamy white quilled petals.

Little Herman. Deep red, tipped white.

Little Naiad. White tipped amarantl red.

Raphael. Deep rich maroon.

Red Piper. Beautiful deep red.

Sunshine. Vivid scarlet.

White Lady. Pure white. 


\section{R. \& J. FARQUHAR \& CO., BOSTON. DAHLIAS.}

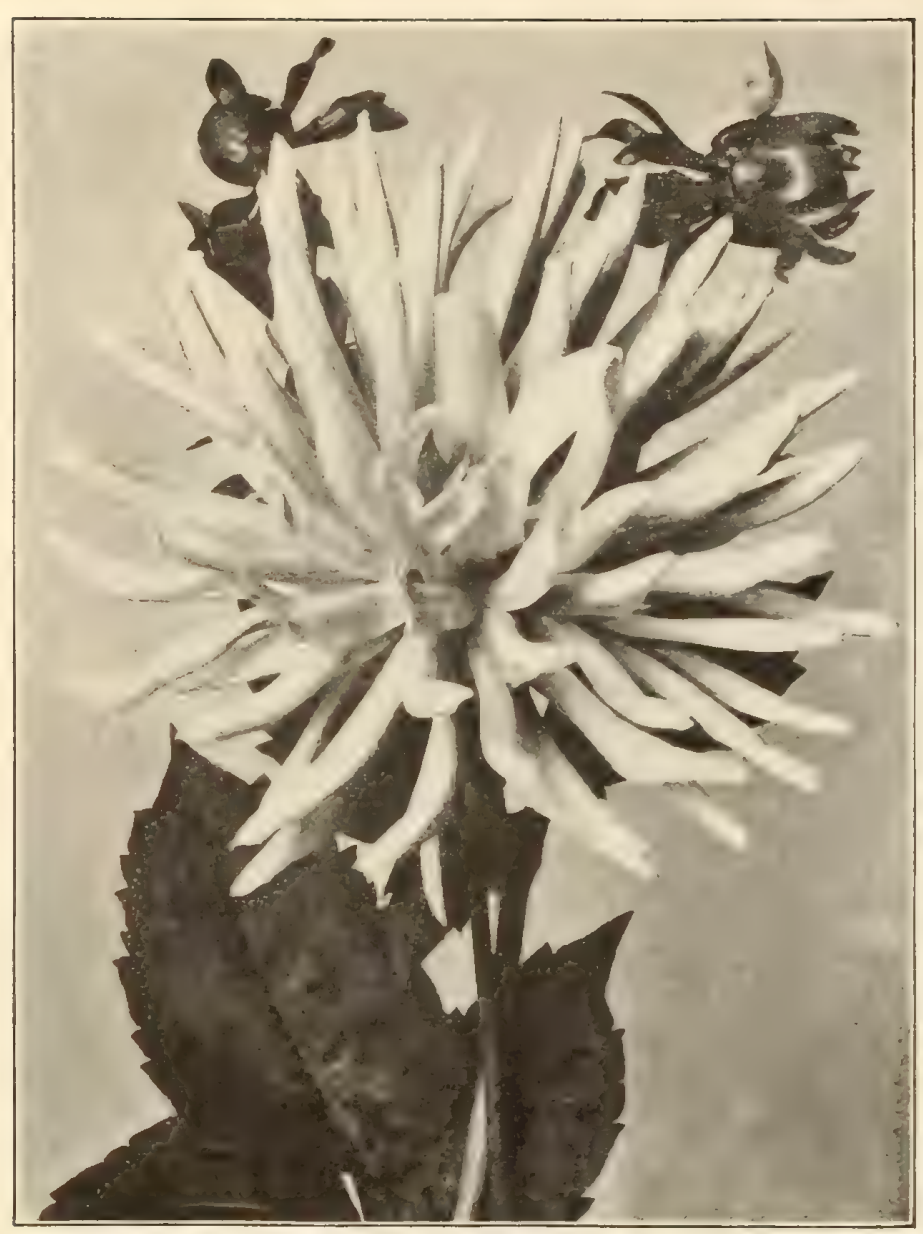

New Cactus Dahlia Rosa.

\section{FARQUHAR'S NEW AND SELECT CACTUS DAHLIAS.}

What the l'xony is to the garden in May and the Rose in June - the Cactus Dahlia is from .July until frost. Its unique elegance of form and the charming brillianey of its surprising colors easily give it first rank among autumnal flowers for decorative usefulness, especially for table decolations.

The following varieties (exeept where otherwise priced) eaeh, .20; per doz., $\$ 2.00$; per $100, \$ 12.00$; by mail, eaeh, .25; per six, $\$ 1.25$; per doz., $\$ 2.50$.

Where special prices are given, add 5 eents each for postage when ordered to be sent by mail.

Collection of Cactus Dahlias, twelve ehoice sorts of our selection, $\$ 1.50$; by mail, $\$ 2.00$.

ROSA. The most beautiful Cactus Dahlia in cultivation which must be seen to be fully appreciated. The flowers are of a soft and pleasing shade of pink with white centre shading to cream color. The effect is that of the popular pink pond lily.

Plants ouly, for delivery in May. Each, .50; doz, $\$ 5.00$.

Ajax. Orange and buff, long narow incurved petals.

Alpha. White spotted and flushed with crimson.

Amos Perpy. Fiery scarlet, large and very free flowering.

Aunt Chloe. Dark maroon, almost black.

Brunhilde. Rich deep plum color, a fine flower and good form. Charm. The base of florets yellow, then red with heavy white tips and edges; very free flowering.

Clara G. Stredwick. Light salmon, shading to salmon-red in the centre; a splendid flower.
Columbia. Bright scarlet, tipped with white.

Comet. Beantiful silvery-lose, speckled and striped with crimson; the largest fancy ('actus.

Cornucopia. Deep leddish-sahnon; large bold fower.

Countess of Lonsdale. Salmou-tinted atpricot; very free-flowering; one of the best dahlias in cultivation.

Dorothy Vernon. Crushed strawbery color

Else. Salmon-pink slightly suffused yellow.

Exquisite. Orange-scarlet with salmon shadings.

Flamingo. Bright rermillion-red, long pointed petals

Floradora. Dark blood-red, very free flowering.

Florence M. Stredwiek. I fine pure white of large size and perfect form.

Frute. Soft rose-pink shading to crean at centre.

Gabriel. Creany-white edged with vermillion.

General Buller. Cardinal-red, shading to crimson, petals tipped with white.

Harbor Light. Vivid orange-led overlaid at tips of the petals with flame color.

H. J. Jones. Delicate primrose shading to pink, fowers large and fine.

Hetty Dean. Light yellow, shading to orange

H. W. Sillem. Vivid erimson-scarlet; flower's of large size.

J. H. Jaekson. Intense blackish-maroon, long narrow-pointed florets.

Keynes White. Pure white; one of the best.

Kingfisher. Carmine-purple, long narrow petals, fiue form.

Kriemhilde. Soft pink shading to white in the centre.

Mareoni. Bronze, runuing to yellow at the base of the petals.

Mr. J. Harrison. Laloge erimson.

Mrs. Clinton. Deep amber, shading to rosy scarlet, one of the best Mrs. E. Mawley. Large clear yellow.

Mrs. H. J. Jones. Rich scarlet with cream-co'ored edge, necasionally comes self-colored.

Mrs. H. L. Brousson. Delicate salmon on a pale-yellow glomm.

Mrs. J.J. Crowe. ('lear yellow

Nero. I plum-colored, massive-built dahlia.

Northern Star. Intense crimson-scarlet.

Ophir. Fawu color.

Princess Von Reise. Deep carmine red.

Prof. D. Zacharias. Pure yellow; free flowering.

Red Rover. Brilliant crimson-scarlet.

Sandpiper. Scarlet-shaded orange.

Sailor Prince. A fine rich crimson, long narrow petals, fine form.

Shooting Star. Pure golden yellow; quite distinct.

Strahlen Krone. Intense cardinal-red.

Thuringia. Brilliant fiery-red flowers of large size.

Unele Tom. Dark maroon, almost black.

Vesta. A fine pink, paler towards the centre

Victor Von Seheffel. A heautiful form of soft pink, similar to Kriemhilde.

Volker. Pure yellow, fine free flowering variety.

Walthari. Light sulphur-yellow, shading to nearly white at the edges; one of the best of the light-colored varieties.

Winsome. A fiue creamy white, very delicate.

Yellow Gem. Fine clear yellow.

\section{CENTURY DAHLIA.}

A gigantic new type of single Dahlia. The flowere measure from four to six inches in diameter, borne on stems two to three feet in length. They are of massive substance and keep long in water when cut. Each, .20; doz., \$2.00; per 100, \$15.00; by mail, add five cents each for postage.

Crimson Century. Rich deep velvety crimson, centre shaded rose.

Lavender Century. Delicate lilac with light shadings.

Pink Century. Delicate shell pink.

Searlet Century. Pure searlet with yellow disc.

Twentieth Century. Rosy-erimson with white tips and white dise.

White Century. Pure white with yellow centre. 


\section{R. \& J. FARQUHAR \& CO., BOSTON. DAHLIAS.}

\section{NEW PEONY-FLOWERED DAHLIAS.}

Plants, delivery in May. Each, .25; doz., $\$ 2.00$; by mail, 5 eents each extra.

This new class has flowers resmuling semintunble Preonies, horne on tall, erect stems. The brilliant flowers make a handsome display in the garden and last well when cut.

Baron G. de Graney. Pure white; rers decorative variety. Dr. Van Gorkon. White shaded rose, rery large.

Duke Henry. Soft red; a lovely shade.

Garibaldi. Very dark maroon.

Germania. Dark searlet with yellow centre.

Glopy of Baarn. Soft pink, large flowers, free and effective. Hollandia. Delicate pink, single and semi-double flowers.

King Leopold. Stilphur yellow; spleudid sort.

Paul Kruger. White streaked and sutlused with rosy maroon.

Pius $\mathbf{X}$. Yellow: taked with rose.

Queen Emma. Rosy salmou, shaded with yellom.

Queen Wilhelmina. Pure white spmi-ulouble flowers, one of the best valipties.

Solfaterre. Rosy searlet with light nukings of yellow

\section{SINGLE-FLOWERING DAHLIAS.}

Each, .15; per dozen, \$1.50; per 100, $\$ 12.00$; by mail, each, .20; per six, $\$ 1.00$; per dozen, $\$ 2.00$.

Collection of Single Dahlias, twelve ehoice sorts of our selection, $\$ 1.50$; by mail, $\$ 2.00$.

Alba Superba. Large white, tinged canary yellow at base of petals.

Ami Barrilet. Rich pure garnet, dark foliage.

Anemone. Pure white; very fiue.

Blackbird. Black velvety maroon with a bright red spot at the base of each petal.

Emma. Blush color.

Fashion. Crimson maroon color.

Gaillardia. Bright golden rayed scarlet.

Graeie. White orange yellww dis, with a primro-e halo.

Lustre. Rosy pink shading to blush in centre.

Polly Eecles. Apricot with yellow shading, and Jellow disc, with poppy red halo.

St. George. Primrose rellow

Wildfire. Brilliant poyl'y scarlet.

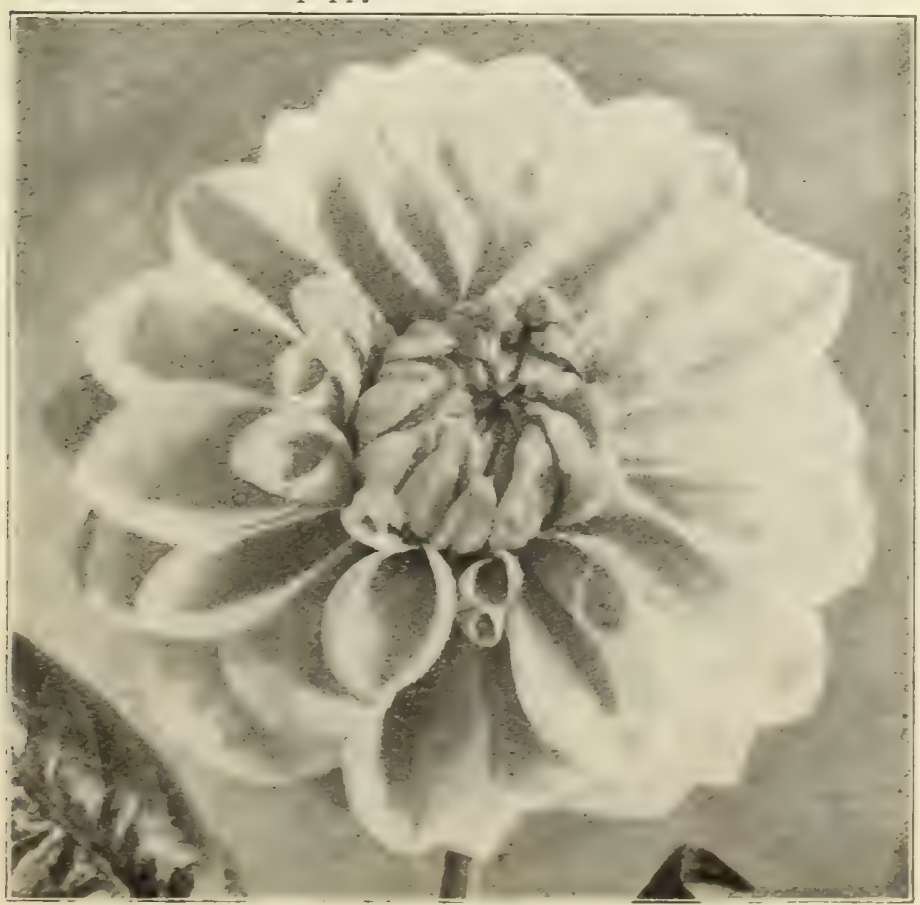

Decorative Dahlia

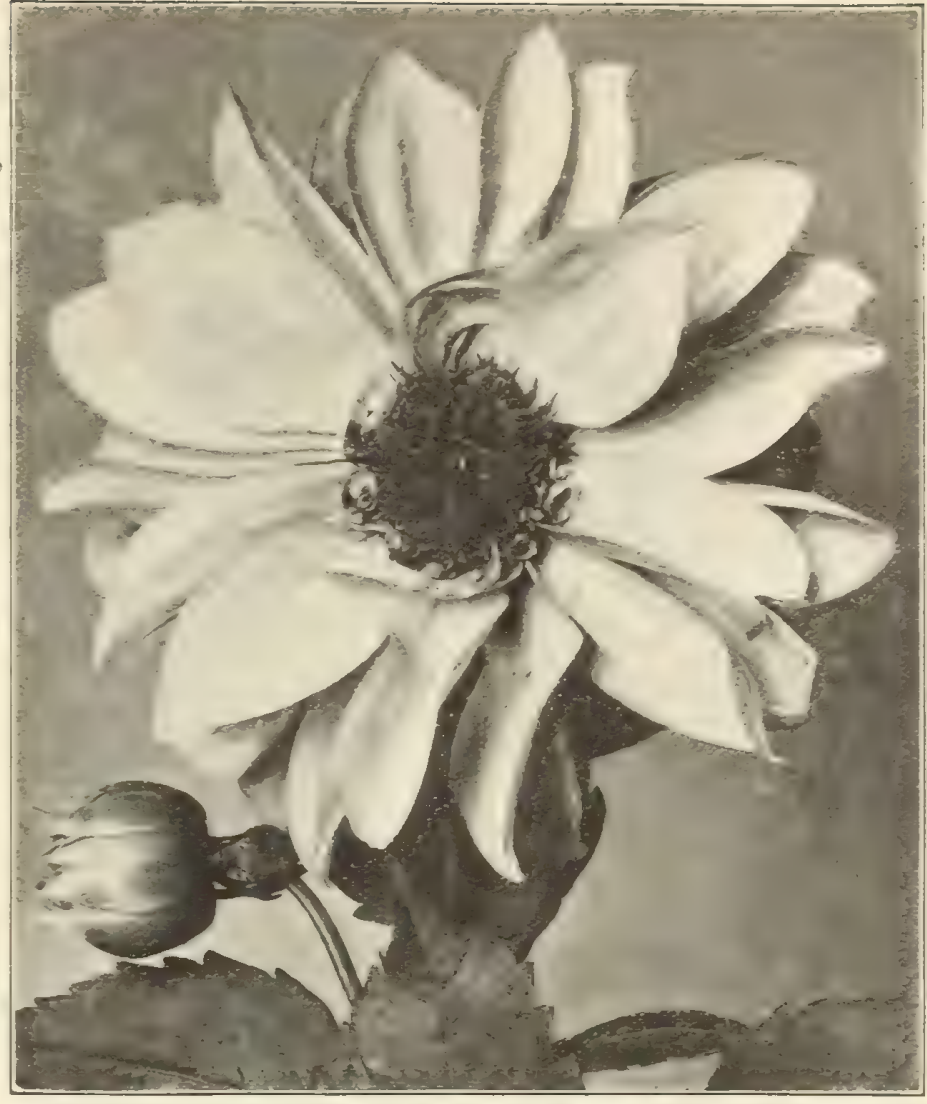

New Prony-Flowered Dablia.

\section{DECORATIVE DAHLIAS.}

These are of artistic graceful form midway between the show and Cactus types. The flowers hare hroal massive fletals and alle lwhe on strong stems maling them most -ervicealile for vat decoration. They are likewise of most decorative effect in the garden.

Prices of the following varieties. Each, .20; dozen. $\$ 2.00$; per $100, \$ 12.00$; by mail add $5 \mathrm{e}$. each for postage. Collection of Decorative Dahlias, twelve choice sorts of Our Selection, $\$ 1.50$; by mail, $\$ 2.00$.

Black Beauty. Deep relvety maroon, almost black.

Catherine Duer. Bright crimson searlet.

Clifford $W$. Bruton. Bright jellow

Effective. Amber with rose centre.

Eureka. Deep rose color.

F. L. Basset. Bright rosy purple, shading to blue.

Fire Rain. Rich cardinal red; very free flowering.

Gettysburg. A bright rich pure scarlet of tine form.

Grand Duke Alexis. Vel'y large, pure white, tinted pal

lavender on the edges of petals.

Henry Patrick. A beantiful pure white.

Lemon Giant. Lemon yellow; rery large.

Lucille. Old gold color.

Lyndhurst. Brilliant cardinal red.

Madame Van Den Dael. Shell pink with deeper marking: shading to white in the centre.

Mrs. Roosevelt. Delicate silvery rose; rery large.

Mrs. Winters. Pure snowy white.

Nymphæa. Delicate mave, shading to nearly pure white in the centie.

Semiramis, Nero. Plants only, delivered in May. soft pink with vellow shading to light in centre, beautiful large free flowering variety.

Souvenir de Gustave Douzon. Pure scarlet; a remarkable variet 5 , the blooms measuring from 6 to 9 inches in diameter under ordinary cultivation.

Sylvia. Soft mauve piuk, changing to white in the centre.

Wilhelm Miller. Deep red, suffused with purple.

William Agnew. Intense scarlet crimson. 
R. \& J. FARQUHAR \& CO., BOSTON. SUMMER-FLOWERING BULBS.

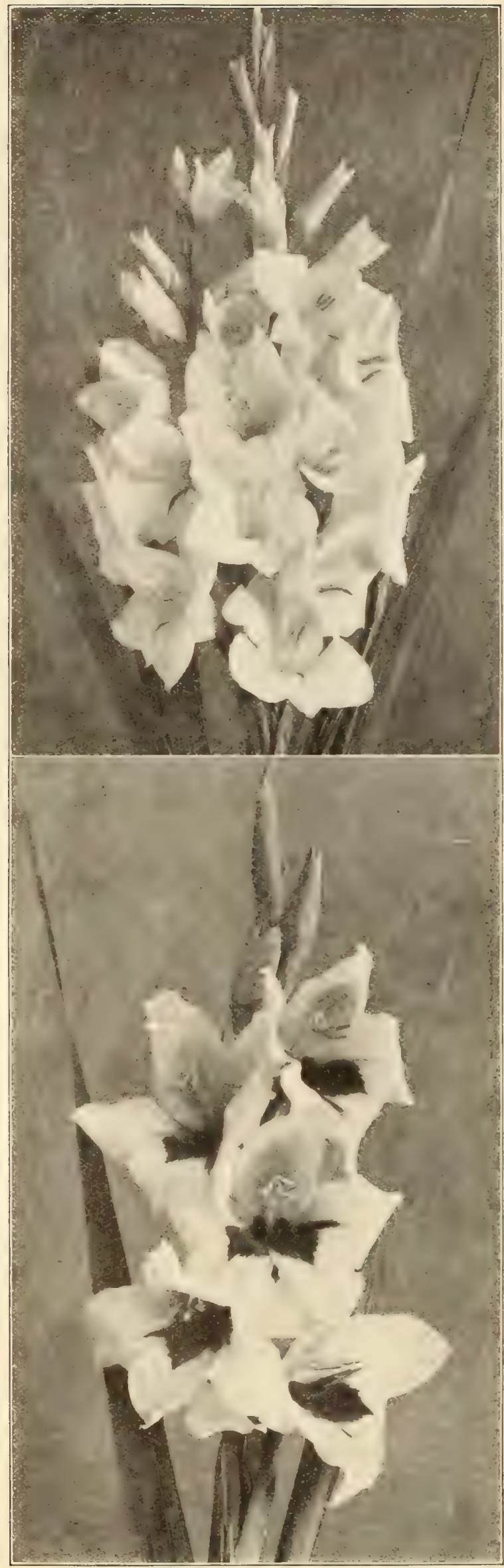

\section{GLADIOLI.}

Farquhar's Prize Seedlings Mixed. A magnificent strain, producing flower' spikes of fine form and substance and of most charming colors. Many of the flowers are self-colored or delicately marked, while others have white or light grounds, beautifully blotched or striped with bright color's

Searlet and Crimson Shades Mixed ....

White and Light Shades Mixed

White and Light Shades Mixed. Seleeted for foreing

Pink and Rose Shades Mixed ....................

Orange and Yellow Shades Mixed ... ... 1

Striped and Variegated Sorts Mixed ...

Lemoine's Spotted Hybrids Mixed. A free-flowering race remarkable for the richness and variety of their color's and for their odd orchid-like markings,

Groff's New Hybrids Mixed. A new race of Canadian origin, resembling the Lemoine Hybrids, but showing greater diversity of colors

$\begin{array}{lll}\text { Doz. } & 100 & 1,000 \\ .50 & 300 & 28.00 \\ .30 & 2.50 & 1800 \\ .40 & 250 & 20.00 \\ & & \\ .50 & 3.50 & 30.00 \\ .30 & 2.00 & 18.00 \\ 1.00 & 7.00 & 60.00 \\ .50 & 3.00 & 26.00 \\ & & \\ .40 & 2.50 & 20.00 \\ & & \\ .30 & 2.00 & 16.00 \\ .25 & 1.75 & 14.00\end{array}$

Extra Fine Mixed. Including all colors in great variety

\section{NEW AND CHOICE NAMED GLADIOLI.}

AMERICA. This variety is of recent introduction and is one of the finest Gladiolus known. The plant is of vigorous growth with laxuriant foliage and producing spikes two to three feet long. 'The flowers are very large and of an exquisite shade of soft lavender pink

AUGUSTA. Lovely pure white, with blue anthers,

BARON HULOT. Syn. Blue Jay. The only real blue gladiolus yet introduced; color rich deep violet blue,

BRENCHLEYENSIS. Vermillion-scarlet; the best sort for planting in clumps among shrubs

CANARY BIRD. A pleasing and attractive shade of canary yellow

CERES. Pure white spotted with purplish rose ...

EUGENE SCRIBE. Large open flowers; tender rose blazed carmine-red

GLORY OF BRIGHTWOOD. Scarlet with lemon throat

HARVARD. Giant flowers of rich velvety maroon,

KATE. Blush white with crimson blotched throat; large open flower's

MADAME MONNERET, Delicate rose

OCTOROON. A beautiful salmon pink; very distinct,

PRINCEPS. This magnificent variety grows from $3 \frac{1}{2}$ to 4 feet high under ordinary garden conditions; its broad, handsome foliage is a grand setting for the brilliant Amaryllis-like blooms which open more widely than any other variety. 'The color is rich crimson with intense shadings in the throat, and broad white blotches across the lowel petals.

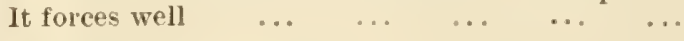

SHAKESPEARE. White, very slightly suffused with carmine-rose; large rosy blotch. Good forcing $\begin{array}{llllll}\text { variety } \ldots & \ldots & \ldots & \ldots & \ldots & \ldots\end{array}$

SNOW WHITE. Pure white with a faint line of
rose on the lower petal; flowers large and handsome

WHITE SANDERSONI. Large open white flowers,

faintly pencilled with purple $\ldots$... ... 


\section{FARQUHAR'S TUBEROUS-ROOTED BEGONIAS.}

The great value of Tuberous-Rooted Begonias for tawn Beds and Borders is now appreciated. They bloom continuously from early summer until frost, producing a profusion of large and gorgeous flowers. Throughout Europe they are used very extensively, particularly in the beautiful parks of Paris.

They are of easiest cultivation, rarely attacked by insects or blight, and succeed in any good soil which is kept moderately moist.

The tubers we offer have been specially grown for us by celebrated European cultivators, and we feel assured that they are not surpassed by any strain in commerce. Maited free at dozen rates.

\section{SINGLE-FLOWERING VARIETIES.}

These are best adapted to outdoor planting.

Mixed, all colors. Doz., .50; per $100, \$ 3.50$; per $1,000, \$ 30.00$. Separate Colors. Crimson, Searlet, Pink, White, Orange, Yellow. Doz., .60; per $100, \$ 4.00$; per 1,000 , $\$ 35.00$.

\section{FARQUHAR'S NEW CRESTED TYPE.}

In this new form the flowers are beautifully ruffled or fringed like a giant Petunia, and the petals are interestingly bearded. An exhibit of these before the Massacbusetts Horticultural Society attracted great interest.

Separate Colors : Crimson, Searlet, Pink, White, Yellow, also Mixture. Doz., $\$ 1.50$; per $100, \$ 10.00$.

\section{FARQUHAR'S NEW FRILLED TYPE.}

In this new race the flowers are very large and massive, borne on erect, stout stems and charmingly frilled.

Separate Colors : Crimson, Searlet, Pink, White, Yellow, also Mixture. Doz.. .80; per 100, $\$ 6.00$.

\section{DOUBLE-FLOWERING VARIETIES.}

These should be grown in pots under glass.

Mixed, all colors. Doz., 80 ; per $100, \$ 6.00$; per $1,000, \$ 50.00$. Separate Colors. Crimson, Searlet, Pink, White, Yellow, Orange. Doz., $\$ 1.00$; per $100, \$ 7.00 ;$ per $1,000, \$ 5 \% .00$.

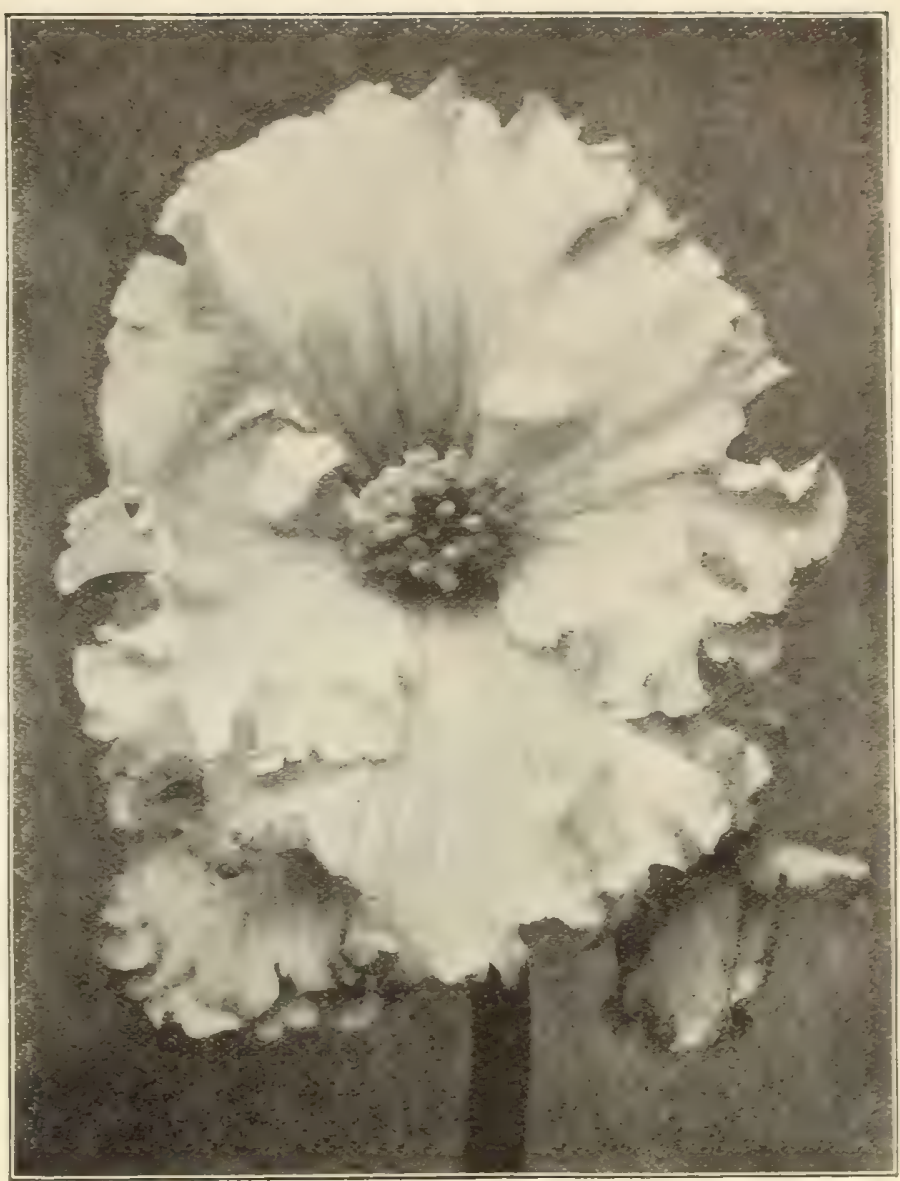

Tuderous Begonia, Farquhar's New Frilled Type.

Cultural Directions. The tubers may be started in February or Yfarch, either singly in small pots, or set two inches apart a flat hoxes. The soil should be light, containing plenty of leaf mould and sand. In planting, care should be taken to set the crown of rhe tuber, which is usually somewhat depressed, upwards. The tubers should be covered half an inch with light soil and waterci sparingly until they start, after which more water may be given. The temperature should be 60 to 70 degrees. The started plants, when intended for bedding purposes, may be transferreil to the beds in the open ground early in June, by which time they should be in bloom. The plants should be set ten or twelve inches apart

Although there is much to be gained by starting the tubers early as just described, they may be plasted unstarted in the open ground beds in the last week of May or later, with excellent results.

They will thrive either in full sunshine or partial shade, but when situation should be avoided.

Allen Winden Farm, Lenox, Mass.

Dear Sirs: It gives me pleasure to tell you that the Tuberous Begonia bulbs we bought of you have given us every satisfaction. I can particularly recommend your strain for fine bold flowers of good forn and color, while the rigor of the bulbs cannot be surpassed.

Tery truly yours,

\section{A. H. WINGETT, supt}

"The Begonias you sent me last spring are the finest I have ever grown, remarlable for their free-flowering and for the size of their blooms. Many of the Flowers have measured six and a quarter Inches in diameter."

\section{C'HARLES SIMPKINS', \\ Oak Hill, Peabody, Mass.}

\section{GLOXINIAS.}

These are desirable summer-flowering plants for both greennouse and window. For cutting purposes they may be very successfully grown during summer in cold frames, with the glass shaded with whitewash or slats to moderate the heat of the sun.

Large-Flowering, in separate sbades, namely, Red with white border, Spotted, Blue, Red, Blue with white border, White, White with blue border. Each, .15; doz., \$1.25; per 100, $\$ 9.00$.

Large-Flowering Varieties, Mixed. Each, .10; doz., $\$ 1.00$; per $100, \$ 7.00$.

six of a kind sold at dozen rates; 25 at 100 rates; 250 at 1000 rates.

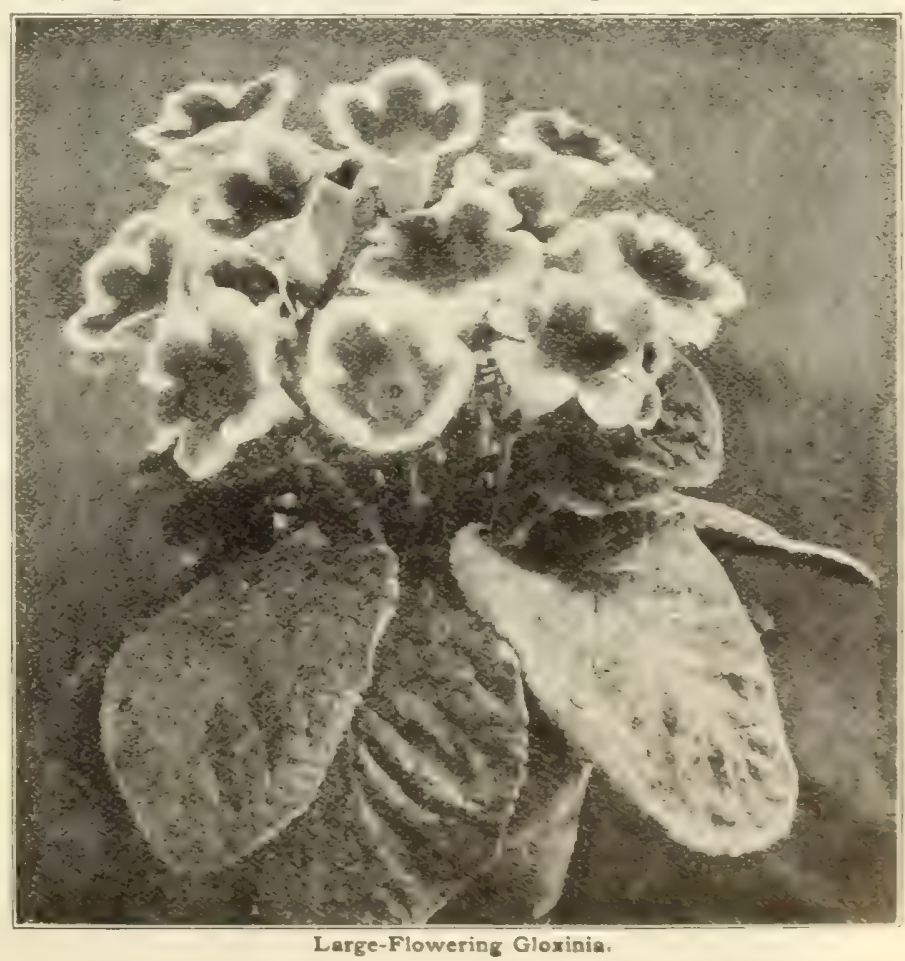




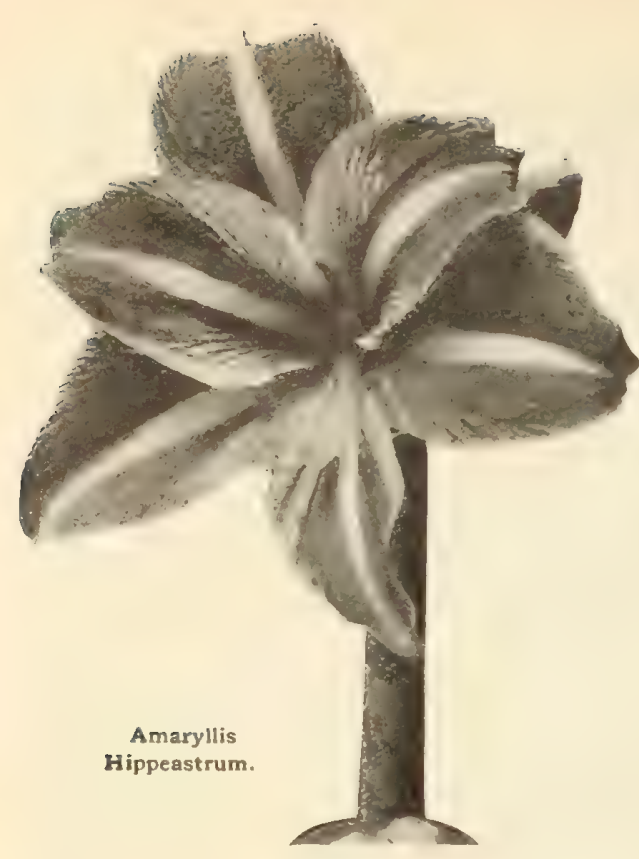

R. \& J, FARQUHAR \& CO., BOSTON. SUMMER-FLOWERING BULBS.

\section{AMARYLLIS.}

Belladonna Major. (Belladonna Lily.) Flowers white, flushed and tipped with deep rose; extra large bulbs. Each, .15; doz., $\$ 1.50 ; 100, \$ 10.00$.

Deflance. Rich carmine, striped and suffused with white. Fach, $.60 ;$ doz. $_{\text {, }} \$ 6.00$.

Equestris. Scarlet, with broad white stripes, extending from the throat to half way up the segments. Each, .15; doz., $\$ 1.50$; $100, \$ 12.00$.

Formosissima. (Jrecobean Lily.) Dark crimson. Fach, .15; do\%., $\$ 1.50 ; 100, \$ 8.00$.

Hallii. Hall's Amaryllis, now known as Lycoris squamigera. A rare bulbous plant with attractive foliage and bright flowers. Rosy lilac, fragrant, 3 or 4 inches across, flowers in August. The foliage appears in spring, disappears in June, and is followed two months later by the naked flowers. Fach, .50; doz.
$\$ 5.00$.

AMARYLLIS Hippeastrum, New Hybrids. (Vittata.) The finest race of Amaryllis in cultivation; exceeding in the size and fine form of their flowers, as well as in the diversity of colors and markings, all former hybrids. The segments are of nearly uniform size, giving the flowers a regular trumpet form. Each, .75; doz. $\$ 7.50 ; 100, \$ 50.00$

Johnsoni. (Barbadoes Spice Lily.) Enormous bright crimson flowers with a white stripe through each segment; magnificent. Each, .50; doz., $\$ 5.00 ; 100, \$ 35.00$.

Lutea. (Hount Etna Lily.) Bright golden yellow; hardy if well covered during the winter. Each, .05; doz., .50; 100, \$3.00.

Prince of Orange. Orange searlet, Each, $\$ 1.50 ;$ doz., $\$ 15.00$.

Reticulatum Stratefolium. Lilae, stripel white. Each, \$1.00. doz., $\$ 10.00$

Vallota Purpurea. (Scarborough Lily.) Vivid scarlet; most effective for piazza pots and vases in summer and autumn. Each, $.30 ;$ doz., $\$ 3.00 ; 100, \$ 22.00$.

Zephyranthes Rosea. Beautiful rose-pink flowers, three to four inches across. Fach, .05; doz., .50; 100, \$4.00.

Zephyranthes Candida. (Fairy Lily.) Pure white, delicately scented. Each, .05; doz., .25; 100, \$1.75.

\section{ACHIMENES.}

Profuse blooming tender perennials for greenhouse or conservatory decoration during summer. The scaly tubers should be potted in the early spring in a compost of turfy loam, leaf mould, and sand. They should be grown in a moist, warm temperature, shaded from the sun until they begin to bloom, when they should be kept cooler to prolong the duration of the flowers. The colors comprise white, shades of lilac, mauve, and crimson.

Named Varieties. The finest sorts. Doz, $\$ 1.00 ; 100, \$ 4.00$.

Mixed Varieties. All colors, Doz, .75; 100, 4.50 .

\section{ACIDANTHERA BICOLOR.}

A valuable bulbous plant for greenhouse or open ground. Each flower stalk produces from four to eight widely expanded fragrant flowers, of creamy white color with broad violet-maroon blotches. The flowers are very lasting, and being borne on long stems are excellent for bouquets and table decorations. The bulbs should be treated like Gladioli. Each, .15; doz., \$1.50.

\section{AGAPAN'THS. (Afican Lily.)}

Handsome summer and autumn flowering plants, throwing up large umbels of twenty to thirty blossoms. They should be grown in pots or tubs. They are particularly suitable for piazza or terrace decoration, and may also be forced in the greenhouse.

Umbellatus. Fine blue. Each, .25; doz., \$2.00.

Umbellatus Albus. White. Each, .25; doz., $\$ 2.00$.

BESSERA ELEGANS. (Coral Drops.)

An elegant bulbous plant with thin rush-like foliage and slender flower stems eighteen inches in height, each bearing several scarlet flowers suspended by thread-like flower stalks. Doz., .50; $100, \$ 2.50$.

\section{FANCY-LEAVED CALADIUMS.}

Wherever high-class decorations are required during summer, these plarts are indispensable. When grown in pots they may be used in thie conservatory or the house with equal satisfaction. For table decorations, for jarlinieres, and for enlivening groups of palms or ferns, they are most serviceable. They are quite as desirable for bedding purposes, and may be planted out after the middle of June in the sunniest situations if well watered, or in partial shade, but they should be sheltered from strong winds. The tubers should be started in the greenhouse in February or March, and if intended for out-door berls gradually hardened off before being transferred to the onen ground.

Dormant Tubers. Fach, 20 ; doz., $\$ 2.00$

Growing Plants. Ready in May. Fach, .30; (1oz., \$3.14).

CALADIUM ESCULENTUM. (Elephant's Ear.)

A magnificent plant for sub-tropical groups or single specimen on the lawn, producing enormous smooth green leaves, often three to four feet in length and two to three feet in width. It thrives best in a warm, light soil which can be liberally watered.

Dry Tubers, 2 to 3 inches diameter. Each, .10; doz., $\$ 1.00 ; 100$, $\$ 5.00$.

Dry Tubers, 3 to $t$ inches diameter. Wach, .20; do\%, $\$ 2.00 ; 100$, $\$ 10.00$.

Dry Tubers, Mammoth. Wach, .35; doz., \$3.50.

Growing Plants in pots; rearly in May. Fach, 20; duz. \$2.00; $100, \$ 15.00$.

\section{CINNAMON VINE. (Chinese Yam.)}

Splendid harly climber of rapid growth, with bright glossygreen heart-shaped leaves and white cinnamon-scented flowers. In China it is cultivated for its edible tubers. $8 \mathrm{ft}$. Each, .10; doz., $.75 ; 100, \$ 5.00$.

\section{CRINUM KIRKII.}

A magnificent bulbous plant, producing usually two purplish flower spikes two feet in height, surmounted by large clusters of Amaryllis-like flowers, which are pure white striped with purple. Fach, .50; doz., \$4.00.

\section{CYCLOBOTHRA FLAVA.}

In habit of growth this plant resembles Bessera Elegans, the flowers, however, being cup-shaped, golden yellow with black spots, and of nodding habit. Doz., .40;100, \$2.00.

\section{HYACINTHUS CANDICANS.}

A hardy summer-flowering Hyacinth producing erect spikes of pure white, bell-shaped flowers, 3 feet in height. It is very effective when planted in clumps among shrubs. Doz., .30; 100, $\$ 1.75 ; 1,000, \$ 12.00$. 
R. \& J. FARQUHAR \& CO., BOSTON. SUMMER-FLOWERING BULBS.

\section{HARDY LILIES.}

The inereased production of many varieties of there in Japan has greatly reduced their cost, and in consequence their use has now hecome very general.

It is our opinion that we should plant the bulbs much deeper than we have done heretofore. IT hile traveling in Japan, we found that the bulbs of the wild lilies were usually twelve to eighteen inches below the surface, and we gathered the finest flowers from -pecimens growing on mountains of decaying lava where they had abundant rainfall and ample drainage. Te believe that varieties like Auratum and Speciosum would be favored by being set ten or twelve inches deep and would be lessaffected by frost and drought. The beds should be thoroughly covered with leaves or litter during winter.

Our Autumn Catalugue contains a complete list of hardy lilies. mast of which can be supplied in spring if desired. The recommend fill planting for all the early flowering sorts.

Auratum. (Golden-rayed Japanese Lily.) Flowers 6 to 8 inches in width, pure white, with a wide band of gold running through the centre of each petal and numerous crimson spots. Each, .25; doz., \$2.50; $100, \$ 15.00$.

Krameri. Pure blush pink, fragrant and beautioul trumpet-shaped flowers. 3 feet; blooms in August. Each, .30; doz. 82.50; 100, $\$ 15.00$.

Longiflorum. Large trumpet-shaped pure white flowers. 2 leet, strong bulbs. Each, .20; doz., $\$ 1.75 ; 100, \$ 1: .00$.

Speciosum or Laneifolium. The most popular class of Japanese Lilies, their hardiness, free growth, and branching habit rendering them most valuable for permanent beds and borders. They grow from 3 to \pm feet in height and continue in bloom from August until frost.

Speciosum Album. Pure white, fragrant. Each, .25; doz., \$2.50; $100, \$ 18.00$.

Speciosum Melpomene. White, suffused with darkest crimson. Each, .20; doz., \$2.00; 100, \$14.00.

Speciosum Rubrum. White, shaded and spotted with rom crimon. Each, .20; doz., \$2.00; 100,\$14.00.

\section{MADEIRA VINE.}

A fuvorite tuberous-rooted climbing plant with dense and keautiful shining foliage and of very rapid growth, twining on strings to a great height or forming garlands in mans fanciful form: It will grow anywhere, but does best in a warm, sheltered, sumny location. It is also a very pretty plant for training around the window: in the house. Doz., $30 ; 100,82.00$. By mili, doz, . 40 .

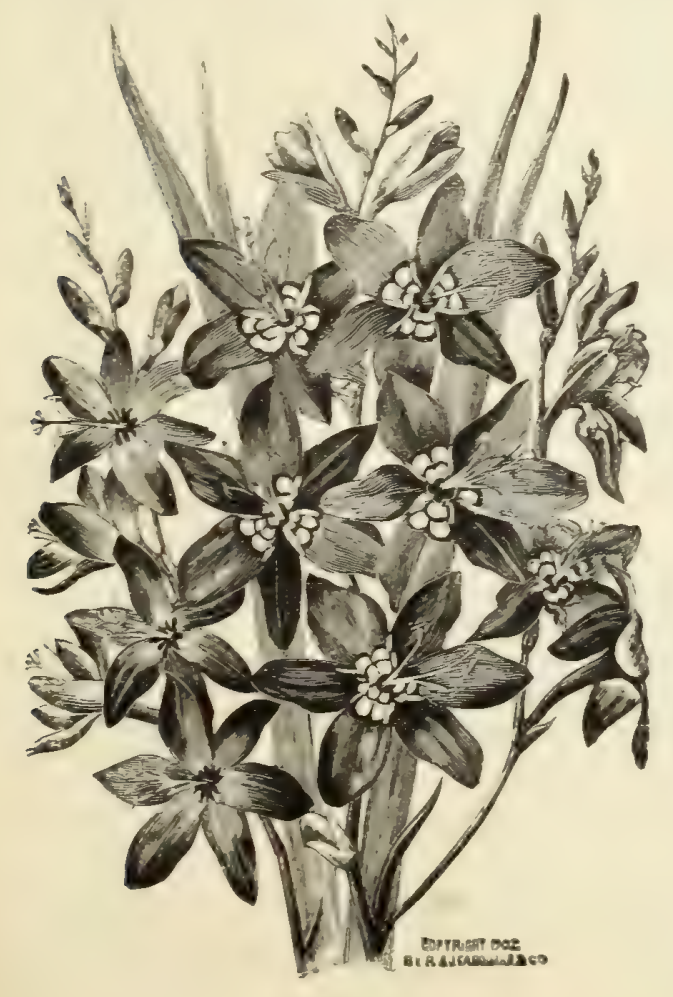

Montbretia.

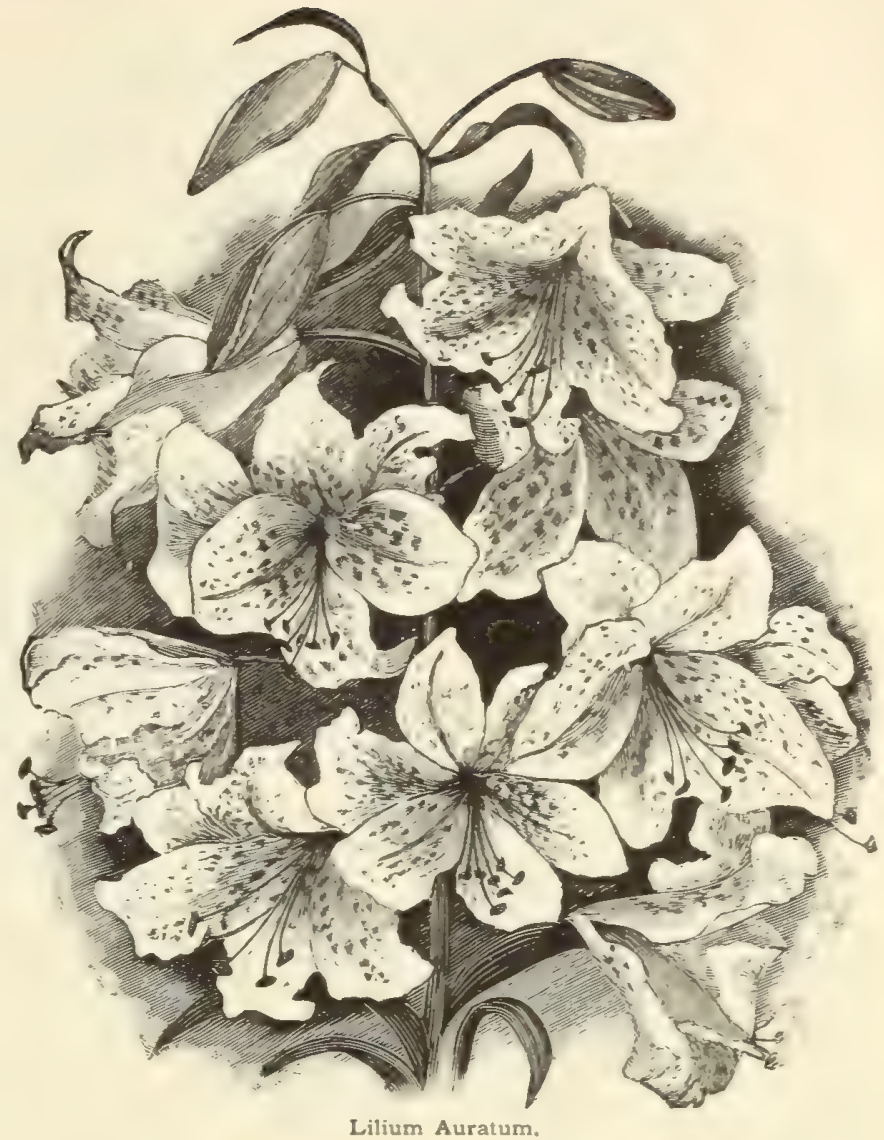

MILLA BIFLORA.

One of the loveliest bulbous plants; most desirable on accoum of its immense pure waxy-white flowers, which are borne in clusterw of two to three on a flower-stalk twelve to eighteen inches high. The petals are very thick and firm, and the flowers will keep in water for a week after cutting. A single bulb will produce as many as six flower-stalks. Doz., .50; 100, 54.00 .

\section{MONTBRETIA.}

Hardy border plants with elegant and gracefully branched Gladiolus-like flowers which are now much prized for cutting during summer. The colors vary from clear yellow to rich scarlet, and the plants grow about 2 feet in height. Plant the bulbe five inches deep and protect them during winter with liberal mulching.

Crocosmiæflora. Orange-scarlet [Noz. $100 \quad 1,000$

Etoile de Feu. Rich scarlet, yellow centre $15 \$ 0.85 \$ 6.00$

Germania. A new hybrid, having large, perfect, bright,

orange-colored flowers. It is much freer in bloom than any

other of this family

Golden Sheaf. Clear yellow, beautifu!

Rayon d'Or. Deep yellow, very large

Rosea. Bright salmon-rose

Transcendent. Large golden-yellow flowers, out-ide bright red

Pottsii. Bright jellow, flushed with red

$\begin{array}{lll}.85 & 6.00 & \\ .20 & 1.25 & 10.00 \\ .20 & 1.25 & 10.00 \\ .30 & 2.00 & 15.00 \\ .30 & 2.00 & 15.00\end{array}$

TIGRIDIA.

Curious and beatutiful shell-like flowers about four inches in diameter, flowering from July to October. The bulbs can be planted about the middle of May, and taken up in October and kept over winter in dry sand.

Conchiflora. Orange with crimson spots.

Grandiflora Immaculata. Pure, spotless white

Grandiflora Lilacea. Rosy lilac.

Grandiflora Rosea. Bright rose-color.
Price for any of the above,

Pavonia Grandiflora. Red, mottletl yollum.

\section{TUBEROSES.}

Before potting the bulbs, remove the small offsets. Cse yood, rich loam, and start in a hot-bed or forcing-pit. They should not be planted in the garden until Jume.

Exeelsior Double Pearl. Large flowering bulbs: spike, $2 \frac{1}{2}$ to i⿱ feet high with large and very double flowers, favorite sort. Duz.. 25: 100. \$1.75. By mail, do\% 


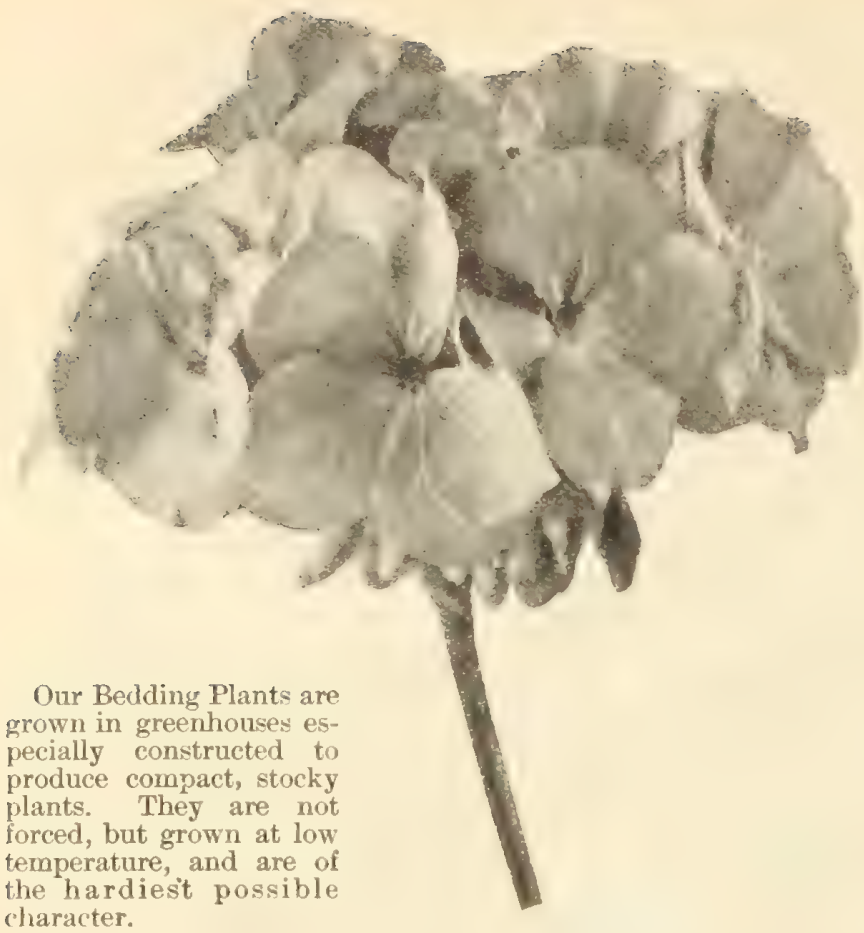

Abutilon. Sorts

Achyranthes, Dark Blood-red

I'ar Doz. Per 100

- Bright Crimson

Ageratum, Princess Pauline. Bhe, white centre,

- Stella Gurney. Bright blue

Alternanthera, Dwarf Searlet

- Dwarf Yellow

Alyssum, White. Sweet scented

Antirphinum, Mixed. Snapitragon

Asters, Ameriean Branching, Improved Vietoria, White, Pink, Crimson, Light Blue and Dark Blue; each color separate

Begonia Graeilis. Magnificent bedding variety; continuous bloomer; a great improvement on B. Erfordia; White, Bright Red, and Rose Pink. $1 \mathrm{ft}$

-Vernon. Flower's red, bronze foliage

-Vesuvius. Bright crimson, blooms all summer, fine bedding sort. 15 inches

-Tuberous-Rooted. May be grown in partial shade or in the full sunlight if kept moist. 'They bloom continually from . July until frost and produce a gorgeous effect. Stroug plants

-Rex. For shady situations

Browallia Speciosa Major. Clear blue

Caladium eseulentum. Strong plants

Calceolaria. Golden Bedder. The best type of the shrubby Calceolaria

Carnations. Strong plants out of 3-inch pots for summer flowering. Vietory, red; Hapry Fenn, crimson; White Perfeetion, white; Enchantress, light pink; Mrs. Thomas W. Lawson, pink; Variegated Lawson ... .... Each, .25c, - Marguerite, Mixed

Centaurea Gymnoearpa. Dusty Miller

Centaurea Cineraria. Nero. Excellent foliage plant for beds, with silvery fern-like leaves. $1 \frac{1}{2} \mathrm{ft}$,

Coekseomb Dwarf. Various colors

Coleus, Versehaffelti. Red foliage

-Golden Bedder. Yellow foliage..

- Princess Royal. Red, goldeu edge

- Faseination. Mottled yellow, red and green

Cosmos, Pink, Red and White

Daisy, English. Assorted

- Paris Golden. An admirable plant both for bedding and eut flowers

Queen Alexandra. White

Dianthus Heddewigi. Jopanese Pink

Echeveria Secunda Glauea. Bluish green leaves,

Feverfew, Double White. Valuable for cutting,

Fuehsias.

$2.50 \quad 16.00$
R. \& J. FARQUHAR \& CO., BOSTON.

BEDDING PLANTS.

\section{BEDDING PLANTS. Delivery}

GERANIUMS. We offer the best bedding varieties in existence; hardy, compact, stocky plants, grown in a cool greenhouse; for delivery May 15 to July. This stock should not be confounded with stock offered at lower prices, which is generally forced at a high temperature. Doz., $1.25 ; 100,10.00 ; 25$ plants and upwards at 100 rate.

\section{DOUBLE VARIETIES.}

Alphonse Rieard. The finest large-flowering scarlet bedding variety; flowers semi-double, bright vermillion-scarlet; large florets and trukses.

Beaute Poitevine. The best semi-double, salmon-pink bedder; enormous flowers, aurora-pink, shading to bright salmon in the centre.

Double Gen. Grant, or Heteranthe. Color bright vermillionscarlet; full, round florets, borne in large trusses on long stems; profuse bloomer.

Jean Viaud. The finest double pink Gerunium. Brilliant rosepink, with white throat. Magnificent semi-double flowers in trusses, sometimes measuring six inches in diameter.

La Favorite. The finest double white; pure color; flower of enormous size; a continuous bleomer, the plants being covered with flowers the entire season.

S. A. Nutt. The standard dark red Geranium; double; brilliant deep scarlet, with maroon shading; stands the sun best of any.

\section{SINGLE VARIETIES.}

Dryden. Bright, soft crimson, pure white at the base of petals, giving it a large white eye; magnificent as a bedder.

L'Aube. Pure, snow white; large, round florets in magnificent trusses. A most satisfactory bedding variety.

Queen of the West. Brilliant orange-scarlet; flowers are large and produced in the greatest profusion throughout the summer.

\section{VARIEGATED LEAVED SORTS.}

Mme. Salleroi. A dwarf variety rarely over 6 inches high; foliage green bordered white; fine for edgings.
$.90 \quad 6.00$

$75 \quad 5.00$

$75 \quad 5.00$

$75 \quad 5.00$

$75 \quad 5.00$

$60 \quad 4.00$

$1.00 \quad 6.00$

$40 \quad 3.00$

$1.00 \quad 8.00$

$1.00 \quad 8.00$

$1.25 \quad 10.00$

$2.00 \quad 15.00$

$.75 \quad 5.00$
0.00

$1.25 \quad 10.00$

$1.50 \quad 10.00$

$1.25 \quad 9.00$

$90 \quad 6.00$

$\begin{array}{ll}1.25 & 9.00\end{array}$

$\begin{array}{ll}.75 & 5.00\end{array}$

$1.00 \quad 6.00$

$1.00 \quad 6.00$

$1.00 \quad 6.00$

$1.00 \quad 6.00$

$50 \quad 4.00$

.50 3.50

$\begin{array}{ll}1.50 & 10.00\end{array}$

$1.25 \quad 10.00$

$.60 \quad 4.00$

$1.00 \quad 6.00$

$.90 \quad 6.00$

$\begin{array}{ll}1.50 & 10.00\end{array}$
$1.00 \quad 8.00$

Bijou. A superb variety much in demand for edgings: foliage bordered and veined with white.

\section{DOUBLE IVY-LEAVED SORTS.}

Col. Baden Powell. The largest flower among Ivy Gerauiums; color varies from pearl white to soft blush.

Etincelant. The finest scarlet variety.

In eomparable. Color rosy carmine.

\section{FINGER BOWL GERANIUM.}

Citriodora. A fine leaved variety of agreeable fragrance, used extensively for finger bowls. Each, 50 cents.

Heliotrope. Tight and dark sorts ... ... ... \$1.00 $\$ 7.00$

Hollyhoek, Double. Crimson, pink, purple, white, salmon and yellow

- Single. Mixed color's

-Allegheny Mixed

Lantana hybrida. Whige and yellow

Lantana delicata. Rosy purple

Lemon Verbena. Very fragrant foliage

Lobelia, Dwarf Blue. For edgings

Marguerite. See Daisy. Paris Golden.

Marigold, Dwarf French. Yellow and maroon .60 4.00

-Tall Afriean. Lemon and orange ... $\quad . .6 \quad .60 \quad 4.00$

Mignonette. Fragrant ...

Musa ensete. Abyssinian Banana. Each, 50 cents, 5.00

- Larger Plants ... .... ... Each. $100,10.00$

Nasturtium, Dwarf. Assorted colors ... $\quad . .6 \quad .60 \quad 4.00$

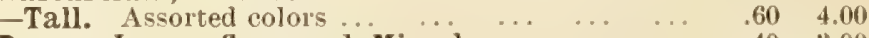

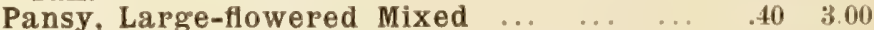

Pennisetum Rueppelianum. Purple Fountain Grass $\quad \begin{aligned} & 1.00 \\ & 6.00\end{aligned}$

Pentstemons. Finest hybrids mixed. Splendid

for cutting

Petunia, Single. Assorted colors

$1.50 \quad 10.00$

Rieinus. Castor Oil Bean. Sorts ... ... ... $1.00 \quad 8.00$

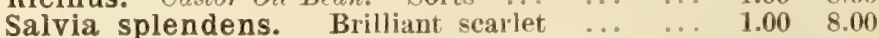

Salvia Zupich. Dwarf; early-flowering ... . . $\quad \mathbf{1 . 2 5} 1000$

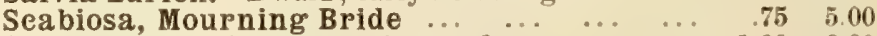

Stoek, Double German. Assorted ... $\quad \ldots \quad \ldots . \quad 1.00 \quad 6.00$

-Perpetual Double White. Excellent for cutting, $1.00 \quad 600$

Swainsonia galegifolia alba. Elegant white peashaped flowers

$1.50 \quad 10.00$

- rosea. Rosy pink ...

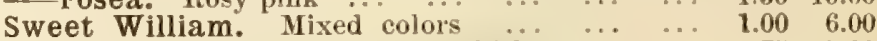

Verbeng. Pink, red, white and blue ... ... $\quad .75 \quad 5.00$

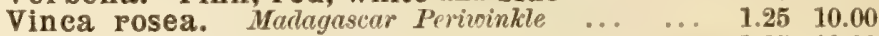

- alba

Zinnia, Assorted . . 
R. \& J. FARQUHAR \& CO., BOSTON. BEDDING PLANTS.

\section{CANNAS.}

The Cannas we offer are plants in growth, out of pots, not dormant roots. Delivery April to July. Prices by Express Only.

\section{FARQUHAR'S COLLECTION OF TWELVE CHOICE FRENCH CANNAS.}

Admiral Dewey. Brilliant salmony red; a fine bedding sort; leaves green. 4 feet.

Beaute Poitevine. Green foliage and large crimson flowers of a beautiful shade. $3 \frac{1}{2}$ feet

Comte de Bouchard. Orange-salmon; foliage green. 4 feet.

Comte de Sack. The finest self-colored crimson sort; flowers of enormous size, with broad massive petals; foliage dark green. 4 feet. Each, .30; doz., 3.00.

G. 0. Quintus. Bright orange-red, edged with crimson; foliage green. 4 feet.

King Edward. A charming variety with enormous yellow flowers shaded bronze; foliage green. 4 feet. Mile. Berat. Flowers of a rich rosy carmine or pink; foliage green. 4 feet.

Richard Wallace. One of the best Cannas; flowers canary yellow, very large; foliage green. $4 \frac{1}{2} \mathrm{ft}$.

Roslindale. Large trusses of golden-yellow flowers, spotted and blotched with carmine; green leaves. $3 \frac{1}{2}$ feet

Sip Thomas Lipton. Gigantic flowers of the richest scarlet; foliage green. 4 feet.

Souvenir de Madame Hardy. Chrome jellow, spotted carmine; foliage green. 5 feet.

William Griesinger. Pure yellow, spotted with carmine; foliage green. $4 \frac{1}{2}$ feet.

Prices (except where otherwise stated): .20 each; $\$ 2.00$ per doz.; $\$ 15.00$ per 100 (set of $12 \$ 2.00)$.

\section{STANDARD FRENCH CANNAS.}

Alphonse Bouvier. Fine tall brilliant crimson; foliage green. $6 \mathrm{ft}$

Alsace. Pale sulphur, changing to creamy white; green foliage This variety when planted with high colored sorts makes a fine contrast. 4 feet.

Antoine Wintzer. A splendid bedding sort with large trusses of crimson flowers; leaves green. 4 feet.

Chicago. Deep vermillion; green leaves. $t$ feet

Charles Henderson. Crimson compact truss; very free. $3 \frac{1}{2}$ feet.

Crimson Bedder. A fine sort with large spikes of glowing crimson; dark metallic leaves. 4 feet.

David Harum. Dark foliage; flowers bright crimson. 4 feet.

Egandale. A favorite bronze leaved sort with soft currant red flowers. 4 feet.

Fair Hope. A superb sort of dwart habit with large trusses of crimson flowers; foliage green. 3 teet.

Florenee Vaughan. Large yellow flowers handsomely spotted; leaves green. $3 \frac{1}{2}$ feet.

\section{ITALIAN OR ORCHID-FLOWERED CANNAS.}

Hyde Park. Large golden-yellow flowers spotterl with rrimson; foliage green. 4 feet.

Madame Crozy. Dazzling crimson scarlet, bordered with golden yellow; foliage green. 4 feet.

Paola Radaelli. Garnet with yellow border; foliage green. ;it $\mathrm{ft}$.

P. J. Berkmans. Rosy carmine; green foliage. 4 feet.

Queen Charlotte. Scarlet with broad yellow margin; a striking flower; green foliage. 4 feet.

Rubin. Ruby-carmine flowers; one of the best for bedding: dark foliage. $3 \frac{1}{2}$ feet

Souvenir de Antoine Crozy. Large massive petals, bright vermillion, broadly margined with golden yellow.

Van den Berg, Jr. Buff red, spotted; green leares. 4 feet. Prices: .15 each; $\$ 1.50$ per doz.; $\$ 10.00$ per 100 .

Useful for tropical effects. Vigorous in growth, 6 to 8 feet, with flowers frequently measuring 6 inches across.

Prices: .15 each; $\$ 1.50$ per doz.; $\$ 10.00$ per 100 . Encept where otherwise priced. Alemannia. Orange-salmon blotched with jellow; wide Musa-
like green leaves.

Ameriea. Large, glowing red flowers; foliage dark red.

Edouard Andre. Large trusses of fiery red flowers with orangeJellow spots; bronze foliage.

H. Wendland. Petals scarlet with golden border; broad green leaves.

CANNA NIGRICANS. Tery dark foliage, one of the best of the tall varieties.

\section{CLIMBING AND TRAILING PLANTS.}

Cobea Seandens. Each, .15; doz., 1.50.

Fieus repens. Excellent for cluthing the walls and pillars of conservatories. Each, .35; doz., 3.50.

Lophospermum Seandens. Pink. Each, .10; doz. 1.00; 100, 1i. 00 .

Maurandya Barelayana. Purplish blue. Each, .15; doz., $1.50 ; 100,6.00$.

Moonflower

Nasturtium. Tall . . . $\quad .10 \quad .6044 .00$

Fach. Doz. 100.

$\begin{array}{lllll}\text { Passiflora Coopulea, Passion Flower }: ~ & .25 & 2.50 & \\ \text { Seneeio Seandens. German Ivy . } & .15 & 1.25 & 8.00\end{array}$

Vinea. Trailing sorts plants play this season

$\begin{array}{lll}.25 & 2.50 & 18.00\end{array}$

King Humbert. Gigantic trusses of orange-scarlet flowers with bright red markings; foliage bronze.

La France. Brilliant orange-fcarlet; lnstrous dark foliage.

Flamingo. Rich brilliant scarlet; foliage green.

Oceanus. Outer petals flame-color with border of golden yellow; inner petals scarlet; leaves green.

\section{PLANTS FOR VASES.}

Dracæna Indivisa. Graveful centre plant for vases, bear: the sun Doz. 5.00:

Extra Large Plants.

Ficus elastica. Rubber "Plane" irakes a good vase centre . . . . t-inch pot, .50; 5 -inch,

Plants in 6 -inch pots. Very tine

Grevillea robusta. Its graceful evergreen, fernlike foliage combines admirably with palms and other masive-leaved

Doz. 5.00:

Hydrangea Otaksa. The variety usually seen in tubs; flowers, pink or bluish. Large plants in pots for dis-

Each.

.31

$3 .(\mathrm{M})$ 

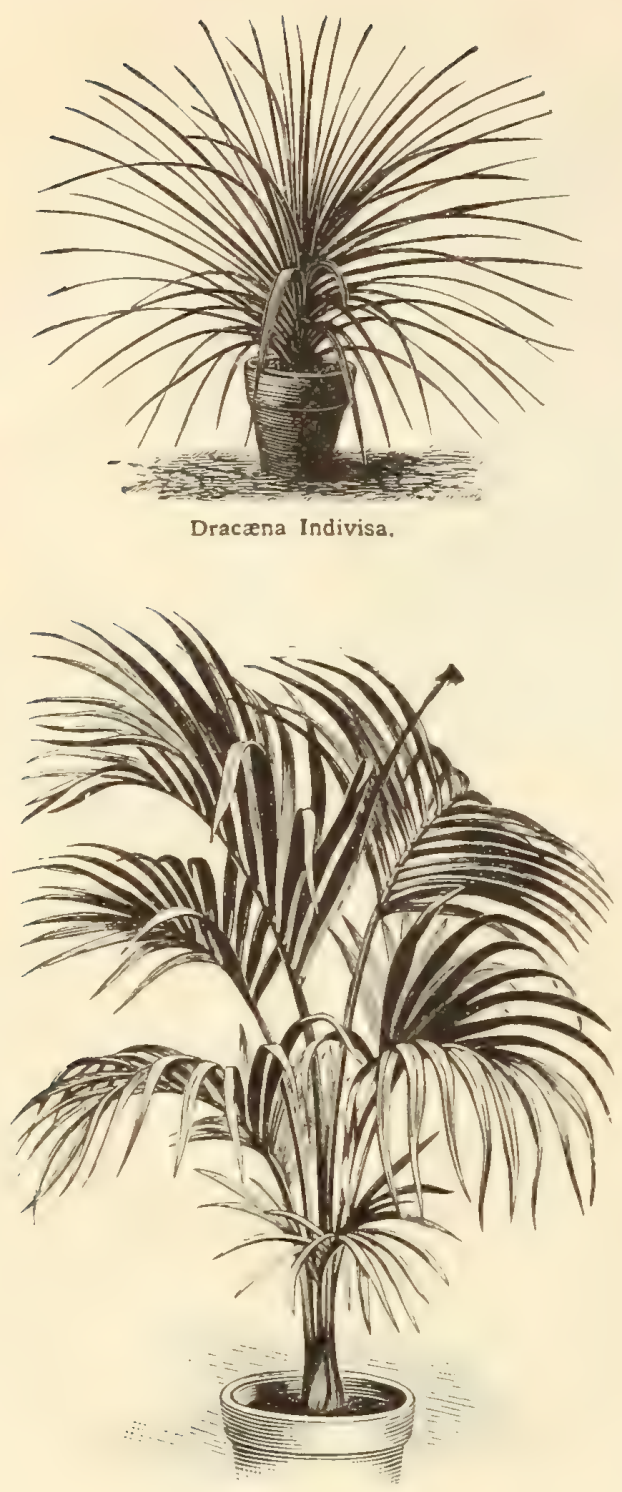

\section{ARAUCARIA EXCELSA.}

The rich, feathery, deep green branches of this charming conifer are arranged it whorls at regular distances on the stem. It is one of the most graceful and beantifu foliage plants grown, and very serviceable for house and conservatory decoration. Plants in 6 -inch pots, 3 tiers, about 12 inches high, $\$ 1.50$ each; $\$ 15.00$ per dozen. Plants in 7-inch pots, 4 tiers, about 20 inches high, $\$ 2.50$ each; $\$ 25.00$ per dozen.

\section{ASPARAGUS.}

Greenhouse climbers, with fine, rich green foliage, of great value in floral work.

Plumosus Nanus. (Climbing Lace Asparagus.) Bright green finely pinnate fern. like foliage ; very lasting; strong plants, 15 cents each; $\$ 1.50$ per donen. Larger Plants, 25 cents each, $\$ 250$ per dozen.

Sprengeri. The green feathery sprays are often three or four feet in length, of droop ing habit; excellent for hanging pots and baskets; 15 cents each; $\$ 1.50$ per dozen.

\section{COCOS WEDDELIANA.}

This most graceful little palm is exquisitely beantiful for fern dishes and jardin ieres, as it grows slowly and holds its delicacy of form for a long time. Fine plants in $3 \frac{1}{2}$-inch pots, each, $\$ 1.00 ; \mathrm{do} \% ., \$ 10.00$.

\section{DRACAENA INDIVISA. (Fountain Palm.)}

One of the hardiest and most graceful foliage plants for jardinieres.

Plants in 6-inch pots, $\$ 1.00$ each; $\$ 10.00$ per dozen. 7 -inch pots, $\$ 1.50$ each; $\$ 15.00$ per dozen. 8-inch pots, \$2.00 each; $\$ 20.00$ per dozen.

FICUS ELASTICA. (Rubber Plant.)

Plants 3 to 4 feet high, $\$ 1.00$ each ; $\$ 10.00$ per dozen. 4 to 5 feet high, $\$ 1.50$ each $\$ 15.00$ per dozell

Ficus repens. Plant: in 4 -inch pots, 50 cents each; $\$ 5.00$ per dozen.

\section{KENTIA BELMOREANA.}

Of the erect-orowing, feather-leaved Palms, this is the best adapted to hous decoration, and it is one of the most beantiful. The foliage is glossy dark green, the segments wide and gracefully recurved.

I'lants in 5-inch pots, 4 to 5 leaves, 18 inches high, $\$ 1.25$ each; $\$ 12.00$ per dozen

l'lants in 6-inch pots, 5 to 7 leaves, 21 inches high, $\$ 2.50$ each; $\$ 2500$ per dozen

l'lants in 7 -iuch pots, 6 to 7 leatres, $\$ 4.00$ esach.

I atrger specimens, each $\$ 6.00$ to $\$ 20.00$.

SAGO PALM. (Cycas Revoluta.)

The Sago Palm is one of the hardiest plants for house decoration, sueceeding in situations where many plants fail. Fine specimens $\$ 3.00$ to $\$ 5.00$ each.

\section{SMILAX.}

Strong young plants. \$1.00 per dozen; $\$ 6,00$ per 100 .

\section{FERNS.}

Nephrolepis Exaltata. (Boston Sumd Fern.) One of the best ferms for cousurva tory and window cultivation.

Plants in 5-inch pots, 50 cents each; $\$ 5.00$ per dozen. 6-inch pots, $\$ 1.00$ each $\$ 10.00$ ver dozen. 7 -inch pots, $\$ 1.50$ each; $\$ 15.00$ per dozen.

Specimen plants, \$2.00 each and upwards

Nephrolepis Whitmani. New. Very finely pinnate fronds, resembling $\mathbf{N}$. Piersoni but finer, 50 cents each; $\$ 5.00$ per dozen. Larger Plants, $\$ 1.00$ each; $\$ 10.00$ per dozen

Sitalobium Cicutarium. Excellent for house cultivation. \$2.00 each.

Ferns for jardinieres, 10 splendid varieties. Plants from 2 to 3 -inch pots 75 cents per dozen; $\$ 4.00$ per 100 .

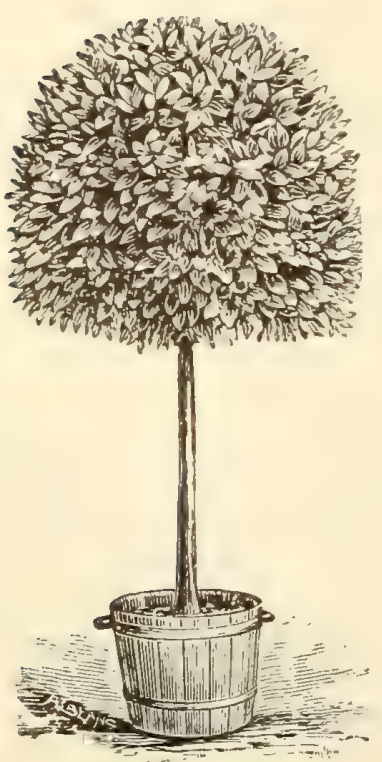

Standard Bay Tree.

\section{BAY TREES AND BOXWOOD TREES. STANDARD BAY TREES. \\ PYRAMIDAL BAY TREES.}

\begin{tabular}{|c|c|c|c|c|c|c|c|}
\hline & Crowns. & & & Each. & Height. & Diameter of Base. & Eacb \\
\hline 22 to & 24 in. diam. & . & . & $\$ 7.00$ & 4 feet & $18 \mathrm{in.}$ & $\$ 7$. \\
\hline $2+t 11$ & 26 ill. di:tun. & $\ldots$ & & 8.00 & 5 feet & 24 in. & \\
\hline $26 \mathrm{to}$ & zs in. diam. & $\ldots$ & $\ldots$ & 10.00 & 6 leet & 24 to 26 ill. & 15. \\
\hline 30 to & 32 in. llitn. & $\ldots$ & $\ldots$ & 12.50 & 7 feet & 30 in. & \\
\hline 36 to & 38 in. diam. & $\ldots$ & $\ldots$ & 17.50 & 7 to 8 feet & 36 iต. & \\
\hline $12[1]$ & tt ill. dianII. & $\ldots$ & $\ldots$ & 25.00 & $s$ feet & 42 in. & \\
\hline
\end{tabular}

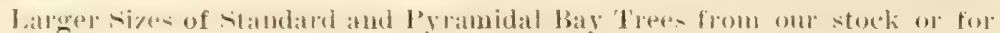
importation can be supplied-prices on application.

Half-Standard Bay Trees. Stem $2+$ inches in height, diameter of heads 15 to 18 inches. Each, $\$ 4.00$ : per pair, $\$ 7.00$.

\section{BOXWOOD TREES. (Buxus Arborea.)}

These are trained in the form of Pyramidal Bay Trees and are used for similar purposes. They have been found to survive the winter out of doors on the Massachusett coast, with slight protection.

Pyramidal. 3 to $3 \frac{1}{\mathrm{ft}}$ Each, $\$ 3.50,3 \frac{1}{2}$ to $4 \mathrm{ft}$ Each, $\$ 4.00,+$ to $5 \mathrm{ft}$. $\$ 5.00$ to $\$ 6.00$.

Standards. 15-inch diam, Each, \$2.50. 18-inch, diam. Each, \$3.50.

Notice. The measurements of the foregoing trees are approximately correct; slight variations are unavoidable.

English Ivy. Extra heavy plants, 6 to $8 \mathrm{ft}$. Each, \$2.00. 4 to $5 \mathrm{ft}$. Each, $\$ 1.00$. 3 to $4 \mathrm{ft}$. Each, .50.

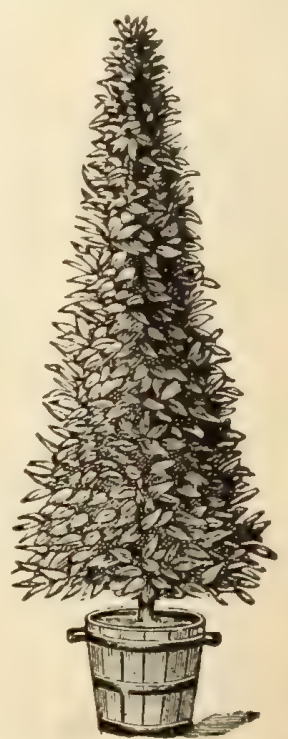

Pyramidal Bay Tree. 


\section{R. \& J. FARQUHAR \& CO., BOSTON. AQUATIC PLANTS.}

\section{AQUATIC PLANTS. \\ NELUMBIUM. (Lotus.)}

Nelumbiums are perfectly hardy provided the tubers are kept free from frost.

Album Grandiflorum (Syn. A. floribunda.) A grand white variety, whose purity, fragrance, noble form, size, majestic foliage and hardiness stamp it as one of the very best. Fach, 2.50 .

Luteum (American Lolus). Superb yellow flowers and massive foliage. Height, six to eight feet. Each, 1.00.

Kermesinum. A distinct and beautiful rariety with large crimson flowers. Each, 1.50.

Speciosum (Egyptian Lotus). Flowers often a foot in diameter, of a beautiful deep rose color and very fragrant. Each, 1.50.

Album Striatum. The flowers of this exquisite variety are pure white, the edge of the petals irregularly striped and tipped rosy carmine; their fragrance resembling that of Magnolia. Each, 5.00 .

Kinshiren. Flowers white shaded pink; comes into bloom early and continues throughout the season. Each, 2.50.

\section{NYMPHÆA.- Hardy Varieties.}

Alba. (White Englisn Water Lily.) Large; continuous bloomer Each, .50.

Candidissima. Flowers pure white; very numerous. Each, .50.

Gladstoniana. Improved variety of N. Alba with glistening white flowers. Each, .50.

James Brydon. Flowers five to six inches in diameter; petals very broad, concave, incurving; color rich rosy crimson, without purplish or magenta shading. Each, 2.50.

Marliacea Chromatella. Hardy; flowers clear jellow. Each, .75 .

Marliacea Albida. Best white. Each, .50.

Marliacea Rosea. Rose; a gem. Each, 1.00.

Marliacea Carnea. Flesh tint. Each, .75.

Odorata. The fragrant Pond Lily, Each, .20.

odorat2 Gigantea. Large, white, free-flowering, fragrant. Each, .20.

Tuberosa Maxima. Large, massive cup-shaped flowers; the petals are broad and of the purest white, being so numerous as to make the flowers appear double. The sepals are bright green. Each, .20.

\section{NYMPH ÆA. - Tender Varieties.}

Bissetil. Flowers of the largest size, of a beautiful glowing rosy pink, cup-shaped, leares deep bronzy red, very large and ornamental. Awarded Silver Medal, Newport Horticultural Society Certificate of Merit, Massachusetts Horticultural Society. Each, 2.50 .

Capensis - Thunb. Flowers rich sky blue; sepals green outside, whitish within, flushed blue. Each, .75.

Ccerulea or Stellata. Clear, light blue; delicately scented; blooms constantly till frost. Each, .75.

Devoniensis. Brilliant rosy red; very large; often ten to twelve inches across; magnificent. Each, 75 .

Dentata. White, with long pointed buds. Each, .75.

Dentata Magnifiea. Flowers very large, cup-shaped, creamy white, of vigorous growth and very free flowering. Awarded Certificate of Merit, Newport Horticultural Society. Each, 3.00.

Dentata Superba. The largest white Water Lily, flowers pure white, ten to fourteen inches in diameter. Each, 2.50.

Frank Trelease. (Crimson Deroniensis.) This superb nightblooming Water Lily surpasses all other red varieties by the brilliancy and depth of the rich, glowing dark crimson of its flowers, which are nine to ten inches in diameter; stamens reddish-bronze, crimson at the base; foliage fifteen inches across, dentated, and of a glossy, dark bronzy-red color. Each, 2.50.

Gracilis. Large white flowers, golden-yellow stamens, and a fragrance resembling Lily of the Valley. Each, 1.00.

If ordered by mail, add ten cents each to above prices for postnge.

\section{VARIOUS}

Limnanthemum Indicum. (Water Snovflake) A pretty floating species with roundish light green leaves and pure white beautifully fringed flowers. By mail, .35. Each, .25.

Water Hyacinth, or Water Orchid. (Eichornia azurea.) Tery interesting and beatiful; floats on the surface of the water and produces fine spikes of light rosy lilac, orchid-like flowers. By mail, .35. Each, .25.
Osiris. A beautiful globular flower of a pure, deep rose, very rict and pleasing; early. Fach. 2.50.

Pekinensis rubrum. This is the best dark-colored variety in cultivation; the flowers are brilliant rosy-carmine, ten to twelve inches across, outer petals well reflexed, foliage large and hand-

Pekinensis rubrum plenum. Identical with the prexterling With immense double blums. Fach, 5.00.

Roseum. Flowers of a uniform deep rose-pink. Fach, 2.50

Roseum plenum. A magnifient variets, with large, full domble bright rose flowers. Fach, 2.50.

Shiroman. This superb variety is unquestionably the grandest ingly domble, and borne on stout stalks well above the foliage. Each, : .00

Odorata Rosea. (The Hardy Cape Cod Pink Huter Lily.) One of the most beantiful flowers; deep pink; highly fragrant. Each. 50 .

Odorata Sulphurea. Large yellow iragrant flowers, leaves mottled reddish purple. Each, .50.

0. Lueiana. This variety is identical with $v$. O. Camlinimna, save in color, which is rosy carmine. Each, 1.25

Helvola (Syn. N. pygmxa Helvola). Sulphur-yellow flowers; leaves green, early stage reddish, blotched with brown; adanted for arnwing in aquariums or tubs. Each, .75.

Richardsonii. Immense white flowers eight inches in diameter flowers a globular form. Each, .50.

Robinsoni. The large, floating flowers hare a ground color of yellow overlaid with purplish red, the general effect being dark nrange red. The foliage is dark green, spotted with chestnut above, dark red on the under side. Each, 1.00.

Wm. Doogue. Flower cup-shaped, shell-pink color, sepals rural pink. Each, 1.00.

Kewensis. Leaves dark gren, slightly bronzy with a few brown blotches; foung leaves more spotted on surface and parplish or underside, Flowers six to eight inches across; light pink. Each, 1.50 .

Mrs. C. W. Ward. Flowers from eight to ten inches in diameter. and borne on stout stems fifteen inches above the water. Color deep rosy-pink with golden-yellow stamens, a most devirahle variety for cutting. Each, 2.50.

0'Marana. Leaves bronzy green; flowers large rosy red; stamens orange red. Each, 2.50.

Pennsylvania. An improvement upon Nymphrea Pulcherrima. the flowers being of deeper color and larger size. Awarded silver Medal, Newport, R.I., Horticultural Society. Each, 2.50 .

Puleherrima. Flowers ten to twelve inches in diameter, bright violet, stamens deep yellow; buds long, pointed, and striped with chocolate-red. Leaves bronzy-green, slightly blotched red. Each, 2.00.

Rubra. Brilliant crimson, large cup-shaped flowers; bloomer. Each, 1.00 .

Rubra-Rosea. Splendid deep rosy-carnine flowers, ten to twelve inches in diameter. Each, 1.50.

Zanzibarensis. Flowers deep purple, sepals green onteide, purple within, margined with red. Each, 1.50.

Zanzibarensis Azurea. Deep, rich, azure blue; one of the largest and best. Each, .75.

Zanzibarensis-Rosea. ever introduced; the enormons flowers are snow white, exceedand quite double. The sepals and onter petals droop, giving the

\section{AQUATICS.}

Water Poppy. (Limnocharis Humboldtii.) Fluwers Inamtitinl. clear yellow with black stamens; must be grown in shallow water; does splendidly in a tub; very attractive. $\mathrm{Br}$ mail. :30 Each, .15.

Cyperus Papyrus. (Egyptian Paper Plant.) Proluces a number of slender stems, surmounted by dark green, shining plumes. By mail, .30. Each, .25. 


\section{HARDY PERENNIAL PLANTS.}

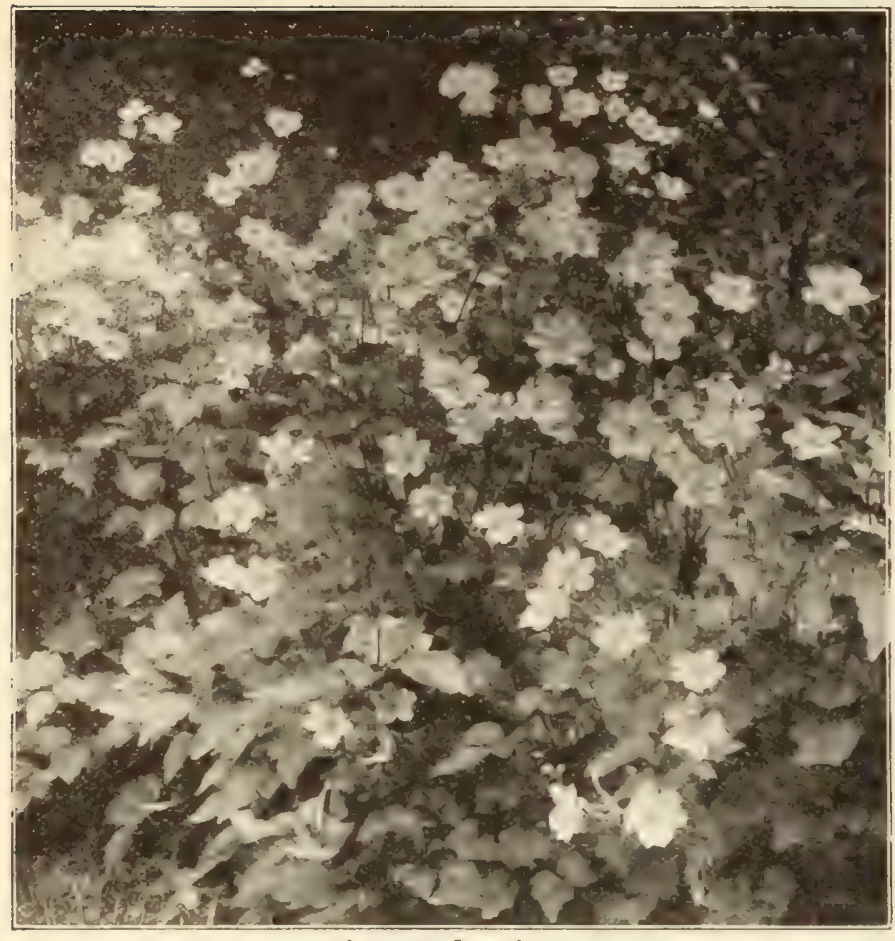

Anemone Japonica.

THE OLD-FASHIONED HARDY FLOWERS. The favorites of old-time gardens are again popular, and deservedly so. No feature of the garden can be more satisfactory than a well-arranged Hardy Plant border, producing from April to November a continuous succession of charming flowers much more interesting than the usua greenhouse assortment, and equally valuable for garden embellish ment and cutting purposes. The Hardy Plants have the advantage of greater permanency, requiring only cultivation, enriching, a slight mulch during winter, and an occasional cbecking of the more robust growers to keep the plantation in good condition for years.

Where early flowers are desired we advocate the introduction of groups of Narcissi, Scillas, which bloom in April and May and should be planted in October, as well as Montbrietias, the hardier species of Gladioli and Lilies for summer blooming, and which may be planted in spring.

We limit our list to varieties which have been found generali hardy and most desirable for the severe climate of New England.

Single plants of Perennials will be furnished at the following rates: Plant sat $\$ 1.00$ per dozen, 15 cents each; plants at $\$ 1.25$ and $\$ 150$ per dozen, 20 cents each; plants at $\$ 1.75$ and $\$ 2.00$ per dozen, 25 cents each: plants at $\$ 2.50$ per doze $\mathrm{n}, 30$ cents each; plants at $\$ 3.00$ per dozen, .3a conts each.

ACANTHUS Mollis. Bear's Breech The rich, massive leaves of this plant are supposed to have

suggested the Corinthian style of architecture

flowers white; fine for lawn groups; July and

ACHILLEA. Ageratum. Goiden Milfoil. Yellow Alowers; June to August. $1 \frac{1}{2} \mathrm{ft}$....
Millefolium Roseum. Pink Yarrow. Rosy pink flowers; blooms all summer; excellent for naturalizing, $1 \frac{1}{2} \mathrm{ft}$. The Pearl. Most effective for shrubbery and edgings; double white flowers, fine for cutting; blooms all summer. $1 \frac{1}{2} \mathrm{ft}$. ...
Tomentosa. Yellow Yarrow. June to August. $1 \mathrm{ft}$

ACONITUM. Monkshood or Ḧlmet Flower.

Autumnale. Large spikes of dark blue flowers; valuable for shady places; July to September. $3 \mathrm{ft}$., Napellus. Dark blue; August and Sept. $3 \mathrm{ft}$. ACT Bicolor. Blue and white 3 . produces in fall a large quantity of erect spikes of feathery white flowers. $2 \mathrm{ft}$. ... Each, .35; ADONIS Vernalis. One of the best spring flowers ; large yellow blossoms. $1 \mathrm{ft}$.
$\$ 2.50 \quad \$ 15.00$

$1.25 \cdot 8.00$

1.25

8.00

1.00

6.00

1.25

8.00

2.50

2.50

15.00

3.50

10.00
AGrostem MA, Coronaria. Mullein Pink. Bright crimson; June to September. $2 \mathrm{ft}$.

AJUGA Reptans. Useful as a ground cover especially for shady places; spikes of purplish blue flowers; May. $1 \mathrm{ft} . . . . . . . . .$.

ALSTROEMERIA Aurantiaca. Chitian tily.
Showy flowers in spikes, orange-spotted crimson; Showy flowers in spikes, orange-spotted crimson;
splendid for vase decoration; July to September. $2 \mathrm{ft}$

ALYSSUM Rostratum. Bright, golden-yellow flowers; splendid for masses; likes the sun ; June and July. $1 \frac{1}{2} \mathrm{ft}$.

Saxatile Compaetum. "iold Drust. "Golden yellow; showy plant for border or rockery masces: April to June. $1 \mathrm{ft}$

ANCHUSA Italiea. Itrlian Alkanet. Large heads of deep blue flowers; broad leaves; June to October. $3 \mathrm{ft}$.

ANEMONE Japonica Alba. Japanese Windflower. One of the best hardy plants, invaluable for garden display and cut flowers during autumn; white. 2 to $3 \mathrm{ft}$. - Queen Charlotte. Strong growing variety with large, semi-double pink flowers … … highly esteemed

- -Rubra. Carmine ... ...

- - Whirlwind. Double white, very fine

ANTHEMIS Tinetoria. Hardy Marguerile. Bright yellow; splendid for massing and cutting; June to September. $1 \frac{1}{2} \mathrm{ft}$.

ANTHERICUM Liliago. St. Bernard's Lily. Elegant spikes of pure white, lily-like fragrant flowers; excellent for cutting; May to August. $1 \frac{1}{2} \mathrm{ft}$. - Liliastrum Major. St. Bruno's Lity. Flowers larger than those of the Anthericum Liliago, otherwise resembling it

AQUILEGIA. Farquha $\mathrm{r}$ 's Long-S̈purred Hybrids. These comprise many new and beantiful shades of lavender, blue, white, yellow, orange, and pink; May to July. $2 \mathrm{ft}$.

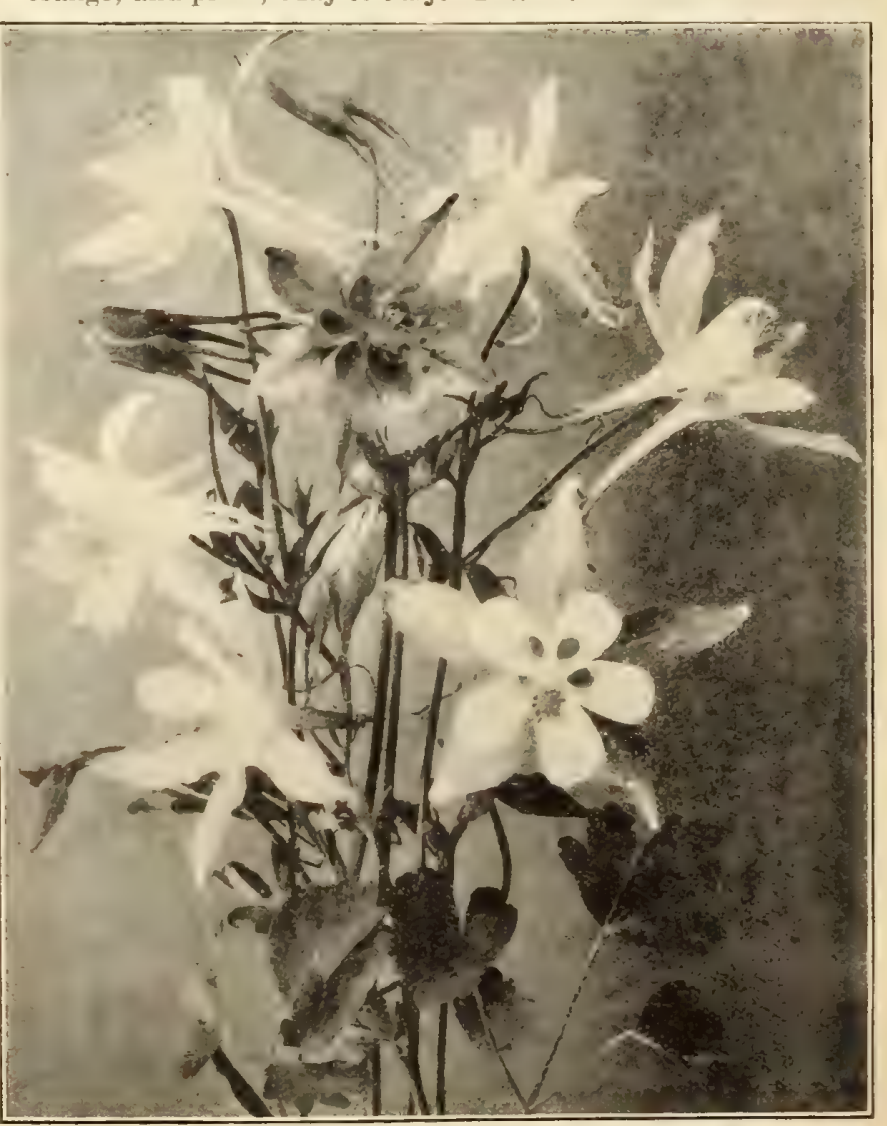

Aquilegia, Farquhar's Long-Spurred Hybrids

Doz. 100. $\$ 1.50 \$ 10.00$

1.85 8.00 


\section{R. \& J. FARQUHAR \& CO., BOSTON. HARDY PERENNIAL PLANTS.}

AQUILEGIA.

Haylodgensis. Hybrids of the Rocky Mountain Blue Columbine; shades of blue, ..

Chrysantha. Golden Columbine. The beautiful, long-spurred, golden yellow Columbine of the mountains of California; May to July. $2 \mathrm{ft}$.

- Alba. White flower's with long spurs

Californiea Hybrids. Petals yellow, spurs pink or red

CœPulea. Rocky Mountain Biue Columbine Beautiful blue and white flowers with long spurs,

- Alba. Large white flowers; long spurs

Nivea Grandiflora. Pure white, very beautiful, Olympiea. Delicate mauve-blue with white curvila

Mixed in great variety

ARABIS Alpina. Rock Cress. Fine rockery and border plant; white flowers; April to June. $\frac{1}{2} \mathrm{ft}$., - Flore Pleno. Double white

ARENARIA Montana. A beatiful trailing evergreen plant for borders or rock-work; flowers white; April and May

ARMERIA Maritima Laucheana. Sea Pink or Thrift. Fine plant for rockeries or edgings; flowers pink. $1 \frac{1}{2} \mathrm{ft}$. .

ARTEMESIA Pontiea. Wormvood. Large yellow flowers; September. $3 \mathrm{ft}$.

ASCLEPIAS Tuberosa. Butterfly Weed. A very showy hardy plant, producing umbels of,brilliant orange-colored flowers; June to September. 2 ft.,

ASPHODELUS Luteus. Asphodel. Fragrant, yellow lily-like flowers; June and July. $3 \mathrm{ft}$., ASTER. Alpine and Mirhaelmas Daisy.

Alpinus Himalaieus. New. Early and large flowering; invaluable for decoration; flower's deep blue; June to July. $1 \mathrm{ft}$.... Each, .35 ; - Speciosus. One of the finest hardy plants for border clumps, rockeries, and for cutting; tine deep blue; June and July. $1 \mathrm{ft}$.

- Albus. White.

Amethystinus. Amethyst-blue ; September and October. $2 \mathrm{ft}$.

Dwarf White Queen. September. 2 ft.

Ericoides Enchantress. Light pink with rellow centre. $3 \mathrm{ft}$.

Lævis. Light heliotrope. $\ddot{3} \mathrm{ft}$

Mackii. Dark blne, yellow centre; August to September. $2 \mathrm{ft}$.

Novæ Angliæ. Blaish purple; September and October. $4 \mathrm{ft}$.

- Alba. White; September, October. 4 ft., - Rosea. Pink: September, October. $4 \mathrm{ft}$., Novæ Belgiæ, Perry's Pink. This new variety grows about $3 \frac{1}{2}$ feet high, having large branching heads, covered with clear reddish pink flowers. September and October

- Robert Parker. Light blue, september, Tataricus. Large white flowers

Tradeseanti. Pinkish white. $4 \mathrm{ft}$.

Tranchii. Purple

\section{Doz. $\quad 100$.}

1.ล0) 10.00

ASTER.

Umbellatum. White flowers in panicles. $4 \mathrm{ft}$.,

BAPTISIA Australis. False Indigo. Large spikes of dark blue flowers; Jume and July. $2 \mathrm{ft}$.

$1.50 \quad 10.00$

BELLIS Perennis fl. pl. English Daisy. Pink and White

$1.50 \quad 10.00$

$1.50 \quad 10.00$

BOCCONIA Cordata. Plume Poppy. A stately plant with fig-like foliage and white flowers effective for lawu groups; June to August. 4 to $8 \mathrm{ft}$.,

$1.50 \quad 10.00$

$1.50 \quad 10.00$

$\begin{array}{ll}1.50 & 10.00\end{array}$

$1.50 \quad 10.00$

$1.50 \quad 9.00$

$150 \quad 1000$

$1.50 \quad 10.00$

$2.50 \quad 1500$

BOLTONIA Astepoides. Fulse Chrmomite. Pure white Aster-like flowers; five for clumps among shrubs: August to October. 5 to $6 \mathrm{ft}$.

Latisquama. Flowers pink, tinged with lavender; valuable for naturalizing and for clumps among shrubs; August to October. 3 to $4 \mathrm{ft}$.

CALLA Alba Maeulata. Spotted Calla. Arrow shaped leaves, spotted white; flowers white June and July. 2 ft.

Calliphœ Involuerata. Poppy Hallow. Showy trailing mallow; crimson, blooms all summer.

CAMPANULA Alliariæfolia. Nodding white flowers in erect spikes; June and July. $2 \mathrm{ft}$. Carpatica. Carpathian Bells. Charming bright 1.5i) 10.00 blne cup-shaped flowers; in bloom all summer; splendid for rockeries and edgings. 9 inches.

1.511 10.00

- Alba. The white $10 \mathrm{~m}$ of the preceding

Glomerata. Clustered Bell-flower. Dense clusters of violet-blue flowers; good for borders and

$\begin{array}{ll}1.50 \quad 10.00 \quad \text { for naturalizing; July to September. } 1 \frac{1}{2} \mathrm{ft} . & \text { Grandis. Great Bell-flower. Iarge saucer-shaped }\end{array}$

$2.00 \quad 12.00$ violet-blue flowers; May to July. $1 \frac{1}{2} \mathrm{ft}$.

Media. Cantertury Bells. We grow annually wany thousands of these favorite flowers in separate colors, Blue, Pink, White or Mixed Media Calyeanthema. Cup-and-Saucer Bellflower. The large cup-and-saucer-shaped flowers are extremely handsome. Separate colors, Blue,

$2.00 \quad 12.00$

$2.00 \quad 12.00$

$1.50 \quad 10.00$

$1.50 \quad 10.00$

$2.00 \quad 15.00$

1.501000

$1.50 \quad 10.00$

$1.50 \quad 9.00$

$1.50 \quad 1000$

$1.50 \quad 12.00$ Pink, White or Mixed

Nobilis. Long tubular light-purplish flowers of medium size; July. $2 \mathrm{ft}$.

Persicifolia Grandiflora Alba. Giant Pecechleaved Bell-flower. A noble border plant with splendid spikes of large salver-shaped, pure white flowers; one of the best hardy plants for cutting; June to August. $2 \mathrm{ft}$.

- C Corulea. The blue form of the preceding; equally handsome for border or cutting

- Humosa. Semi-double blue. $2 \mathrm{ft}$.

- Moerheimi. A very beautiful double white form; June to August. $1 \frac{1}{2} \mathrm{ft}$.

Trachelium. Coventry Bells. Flowers purple. June and July. $2 \mathrm{ft}$.

CARNATION Her Majesty. Hardy Pink. A greatly improved form of old-fashioned spice Pink, having pure white, fragrant flowers almost as large as the true Carnation

Hardy German. Excellent for cutting, the flower's resembling the smaller greenhouse Car. natious; July to October

Doz.

100.

$1.50 \quad 10.00$

1.25 - (111)

ii)

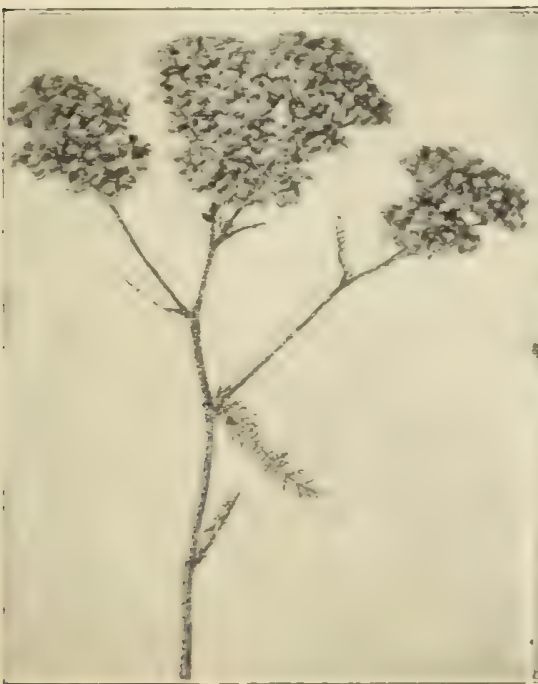

Achillea Millefolium roseum

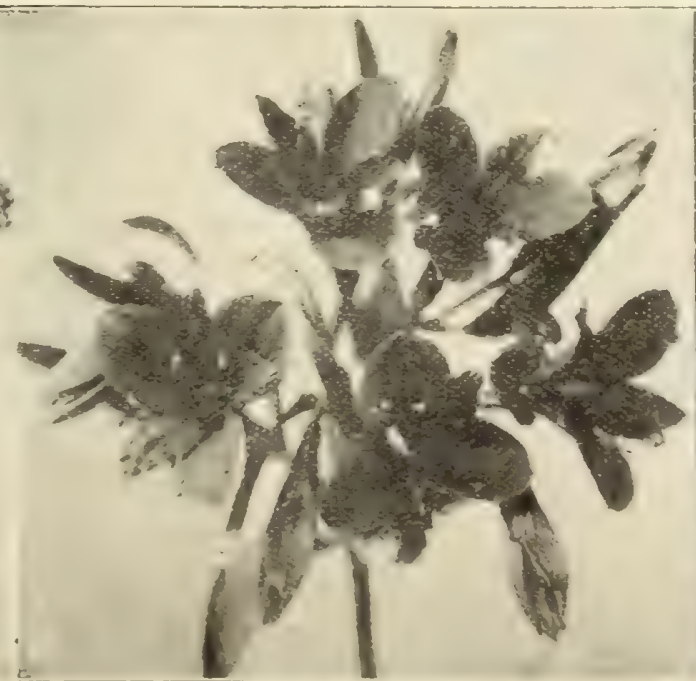

Alstromeria Aurantiaca

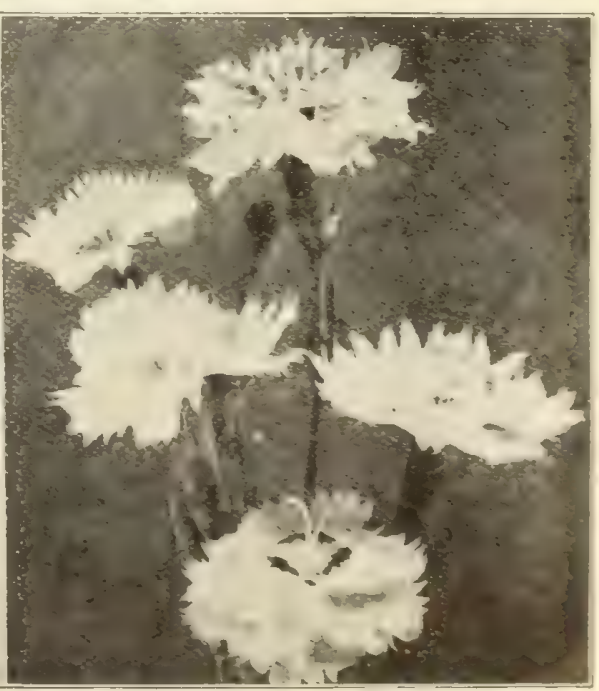

Carnation Plumarius. 


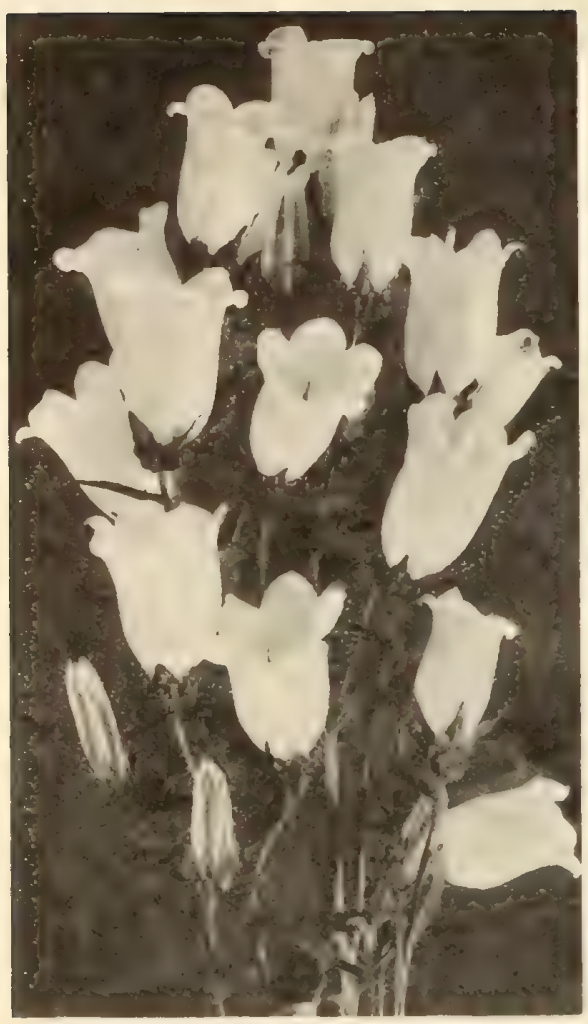

Campanula media. Canterbury Bells.
CARNATION. - Continued. Plumarius Cyelope. Garden Pink. Flowers rosy red with dark centre

- Edith. Iight pink,

- White.

- Mixed Colors.

- Mound or Spie e Pink. The old-fashioned grass or border piuk

CASSIA Marylandiea. American Senna. A eh a rming plant with showy panieles of yellow flowers; July and $\mathrm{Au}$ gust. $3 \mathrm{ft}$.

C E D R O N E L L A Cana. Balm of Gitead. A fine aromatic plant with crimsoln flowers: Jaly to October. $2 \frac{1}{2} \mathrm{ft}$

CENTAUREA. Maerocephala. Large golden-yellow flower. much esteemed for cutting: July to september. $3 \mathrm{ft}$.

Montana. Large violet flowers. valuable for entting as well as for borler clumps; July and $A u-$ gust. 2 ft.

Montana Alba. White. Montana Rosea. Pink.

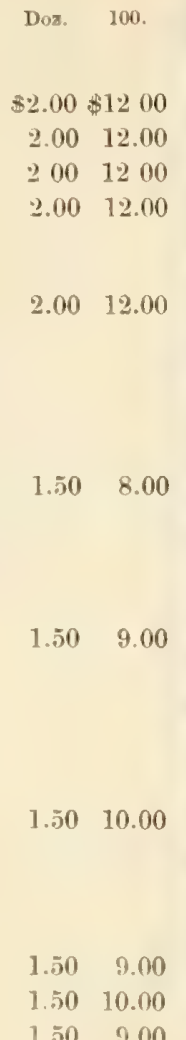

\section{CHRYSANTHEMUM, HARDY POMPONE.}

CERASTIUM Tomentosum. vim, il v"um-
mer. Silvery-white foliage; yood for edgings. 6 in.

$\$ 1.50 \quad \$ 9.00$

2.0015 .00

CHELONE Lyonil. Heads of deep red flow ers; June and July, $2 \mathrm{ft}$.

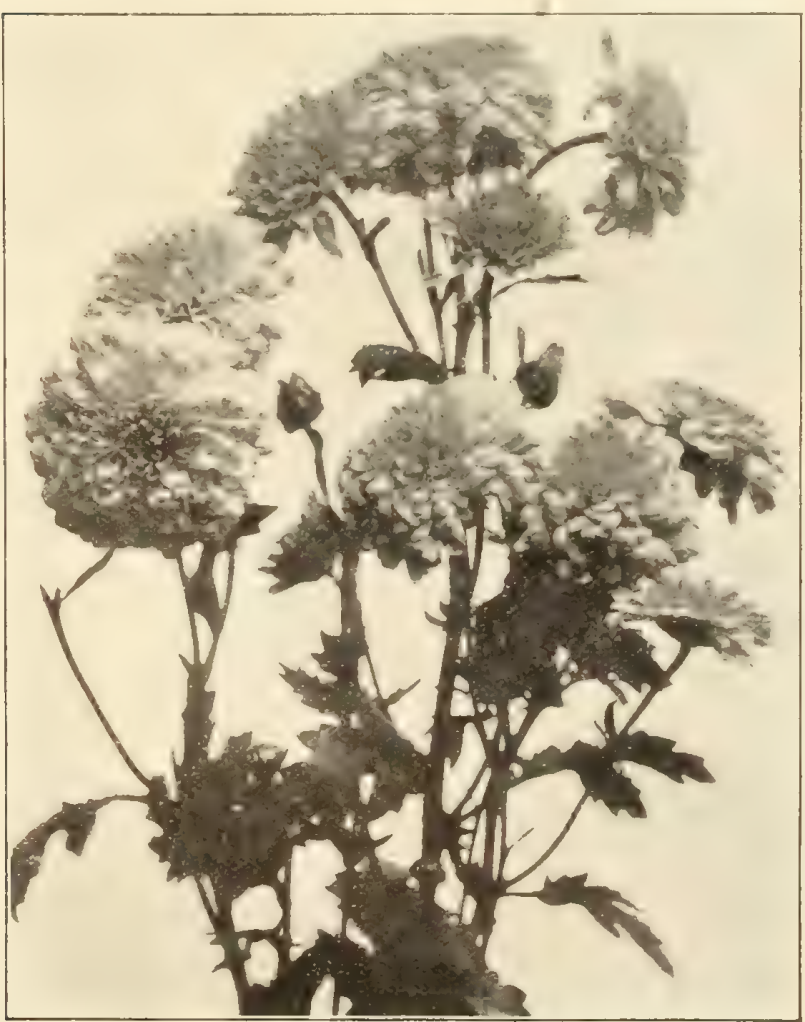

Hardy Pompone Chrysanthemum.

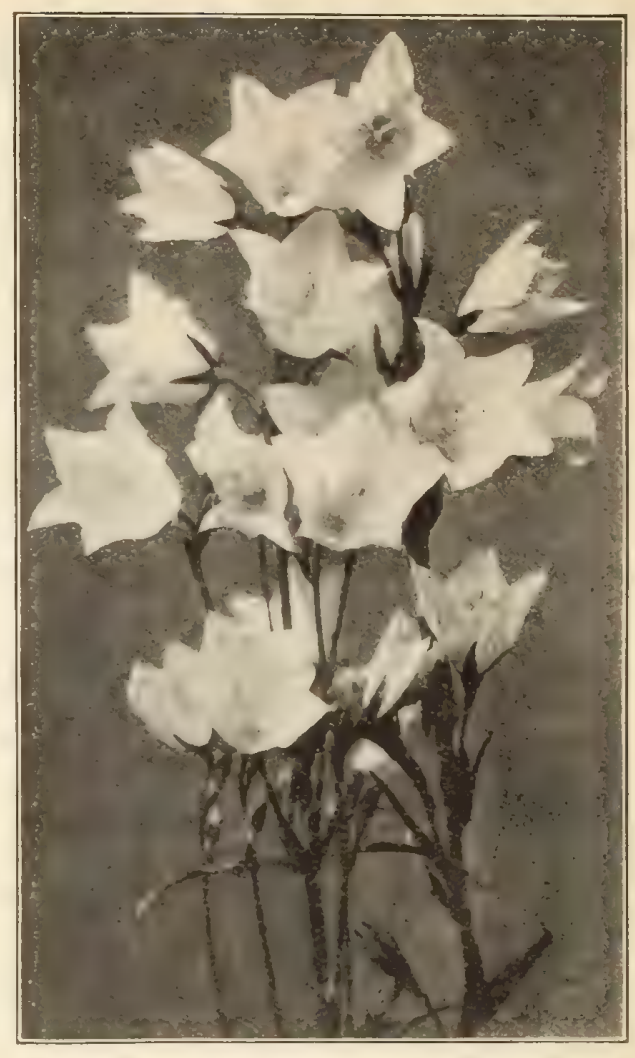

Campanula Persicifolia.
SMALL OR BUTTON VARIETIES

Agalia. Yellow shaded piuk. $3 \mathrm{ft}$.

Blushing Beauty. Pale pink tipped rose, new

variety, very choice.

Cerise Queen. (erise piuk. $1 \frac{1}{2} \mathrm{t}$.

Daybreak. liglı pink. $2 \frac{1}{2} \mathrm{ft}$.

Dinizulu. Violet pink, one of the hest. $2 \frac{1}{\mathrm{ft}}$

Edna. White, shading to cream in the centre. $2 \mathrm{ft}$.

Ermine. Bright orange searlet. $1 \frac{1}{\mathrm{ft}}$.

James Boom. Cream, shading to yellow in centre. $2 \mathrm{ft}$

Luan. Clear yellow $2 \mathrm{ft}$.

Pearl Cluster. White changing to pink. 21 feet

Queen of Bul. Violet rose, 2 feet.

Rhoda. White sladed pink. $2 \mathrm{ft}$.

Trojan. (rimson maroon, bronze tipped. $1 \frac{1}{2} \mathrm{ft}$

LARGE FLOWERING OR ASTER VARIETIES.

Ashbury. Creamy white; usually with open centre,

very free flowering. $1 \frac{1}{2}$ to $2 \mathrm{ft}$.

Aunt Jane. Clear lemon, yellow, fine, $2 \mathrm{ft}$.

Boston. Golden bronze. $2 \mathrm{ft}$.

Gloire de Franee, silver pink, cream centre. $3 \mathrm{ft}$.

Gracie. White, large double flowers. $1 \frac{1}{\mathrm{ft}}$.

Hijos. P'rimlose pink, early flowering. $2 \mathrm{ft}$.

Ida. Jellow, large and fine. $2 \frac{x}{2}$ feet.

Marie Antoinette. Pink, large and fine. $2 \mathrm{ft}$.

Mont Claire, Yellow ground, shading to red. $2 \mathrm{ft}$.

Penelope. White, cream centre, fine, $2 \frac{1}{\mathrm{ft}}$.

Prince of Wales. Pure white. $1 \frac{1}{2} \mathrm{ft}$.

Queen of the Whites. P'ure white, the best late. $3 \mathrm{ft}$.

ANEMONE-FLOWERED VARIETIES

Earl. Pearl white, silvery-rose centre. $1 \frac{1}{4} \mathrm{ft}$.

Irene. Pearl white, open yellow centre. $1 \frac{1}{2} \mathrm{ft}$

Lady Olivia. White with yellow quilled centre. $1 \mathrm{ft}$.

Matilda. Pure white, yellow centre. $1 \frac{1}{2} \mathrm{ft}$.

Northumberland. Bright scarlet, inaroon spen centre,

flowers very larue. $2 \mathrm{ft}$.

oban. Silvery pink, full yellow anemone centre. $2 \mathrm{ft}$.

Peto. Terra cotta red, yellow centre. $2 \mathrm{ft}$.

Success. Silvery lose, white centre, $2 \mathrm{ft}$.

Sunset. Yellow ground, shaded bronze. $2 \mathrm{ft}$.

The Hub. Pure white, yellow centre. $2 \mathrm{ft}$.
$8125 \$ 8.00$ Doz. $\quad 100$ $1.25 \quad 8.00$ 
CLEMATIS Davidiana. l'ale blue flowers in whorls: adapted

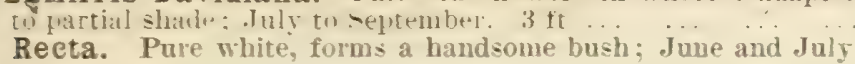
$\mathrm{ft}$
$\mathrm{Recta}$

CONVALLARIA Majalis. Lily of the Talley. Pure white, fiagrant. Large clumps .... ... ... ........ Each, .30; COREOPSIS GRANDIFLORA. Golden yellow flowers of large size; most useful for cutting and eftective in border masses; blooms all summer. $2 \mathrm{ft}$.

Lanceolata. Like the preceding, but somewhat smaller

CRINUM Powellii. Elegant bulbous plant with large trumpetshaped rosy pink flowers. The bulbs should be protected of taken up during winter; July and August. $2 \mathrm{ft}$. Each, .35: Alba, White
Light Rose. Verc. Beautiful pink

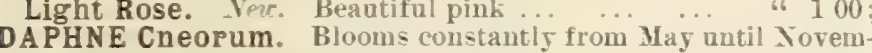
ber. One of the choicest dwarf pereunials, flowers bright pink,

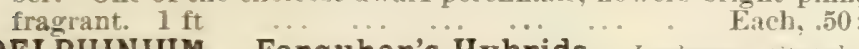

DELPHINIUM. Farquhar's Hybrids. Lithr., stately decorative plant for masses, beds and clumps; flowers ranging in colors from light azure to deep blue, and from delicate lavender to purple; June and July

Bella Donna. Produces spikes on which the lovely sky-blue flowers are borue abundautly. 3 feet $\ldots$. ers; June to Octoher. $1 \frac{1}{2}$ feet

Chinensis Alba. White.

Formosum. Deep blue; July to October. 3 feet.

Formosum Cœlestinum. Sky blue. 3 feet.

DIANTHUS Barbatus. See Srcet Irilliam.

Diadematis. Dirdan Pink. Elegant border plant, white, pink and crimson. blooms all summer. 1 foot

Napoleon III. Intense crimson; June to October. 1 foot

Plumarius. Phersont's Eye Pink. Fragrant and beautiful hardy border pink; June and July. 1 foot

DICTAMNUS Fraxinella. Gas Plant. Rosy crimson flowers: June and Julv. $2 \frac{1}{3}$ feet

Alba. White.

DIELYTRA Spectabilis. Blecting Hrart. Delicate pink heartshaped flowers in graceful racemes; May and June. 2 feet

DIGITALIS. Finiloce. We can furnish these in white, rosy lilae, erimson, spotted varieties and mixed

Grandiflora. Yellow; desirable for partial shade

DODECATHEON Meadia. American Corstip. Rosy purple flowers resembling Cyclamen; April and May. 1 foot ... DORONICUM Caueasieum. Yellow, daiss-like flowers: June. $1 \frac{\pi}{2}$ feet

DRABA Androsacea. Dwarf rock plant; flowers white; May, ECHINACEA Purpurea. Syn. Rudbeckia purpurea. A rosy purple

formo of Cone-flower; July to September. $2 \frac{1}{2}$ feet … … 1.50
ECHINOPS Exaltata. Gilobe Thistle. Showy thistle-like plants with metallic-blue globular flowers; July to September. 3 feet

Ritro. Deep steel blue

EPILOBIUM Hirsutum. Willow Horb. Strong growing plant of willow-like habit. flower's rose color: blooms all summer. 4 feet

ERIGERON Speciosus. Pale mauve with vellow centre, $1 \frac{1}{2}$ feet

ERYNGIOM Amethystinum. Sea Holly. An effective plant for hardy

border, shrubbery and wild gardens, with amethyst-blue thistle-like flowers, and finely-cut spiney leares; July. 2 to $3 \mathrm{ft}$.

EUPATORIUM Fraseri. Delicate white flowers in large terminal heads: useful for cutting: August to October. 2 to 3 feet

EUPHORBIA Corollata. "One of the best hardy plants for cutting. producing delicate sprays of white flowers. $1 \frac{1}{2}$ feet

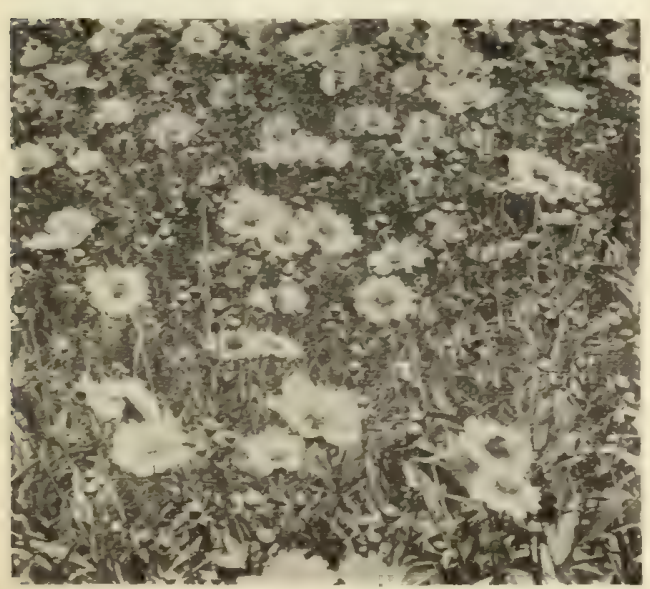

Coreopsis lanceolata.
F U N KIA. Subeordata Grandiflora. Large pure white flowers, resembling Easter Lillies in large clusters; large massive heart-shaped leaves: excellent plant for partial shade: July to September. $1 \frac{1}{2}$ feet Tenuifolia. Ligbt purple; June to AnUust. 1 foot $\mathrm{Ondulata}$ M dia Variegata. A haidy plant, with beautifully variegated foliage valuable for forming ribbons, edgings and masses in formal gardens: flowers lilac: July and Iugust. $1 \mathrm{ft}$,
Doz. 100.

2.50

3.00

.50

.50

.00

5.00

2.00

2.50

50

1.50

50

.00

.50

.00

10.00

10.00

10.00 $\begin{array}{rr}\text { Doz. } & 100 \\ \$ 200 & \$ 1200\end{array}$

$1.50 \quad 10.00$

$1.50 \quad 10.00$

$2.50 \quad 15.00$

1.50

1.50

10.00

10.00

1.50

9.00

$125 \quad 800$

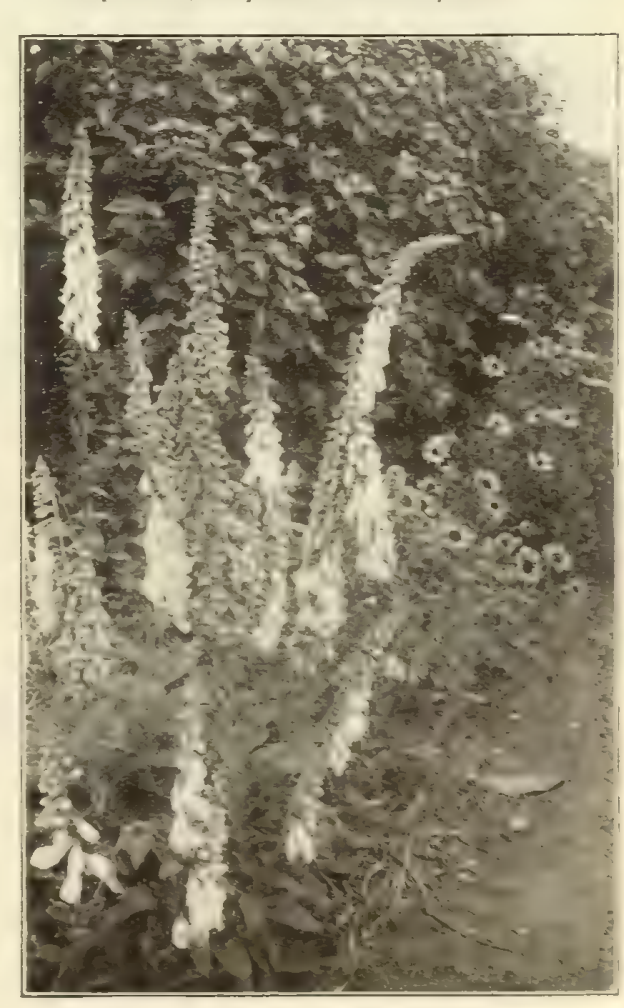

1.25

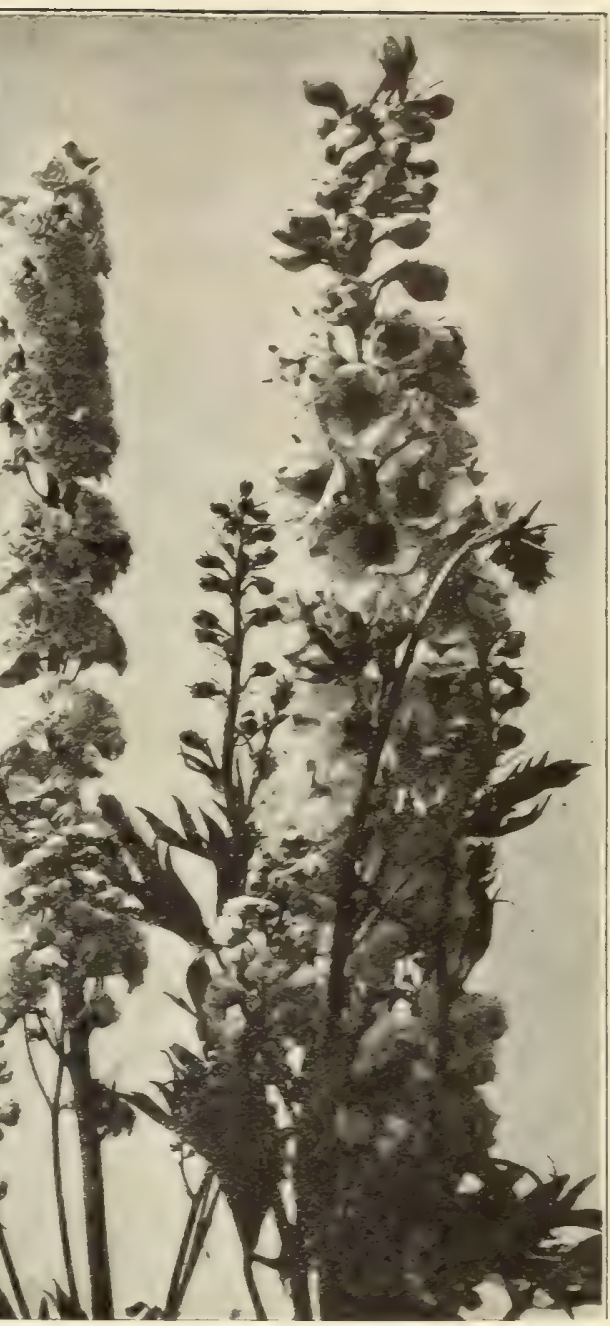

Delph:nium, Farquhar's Selected Hybrids. 

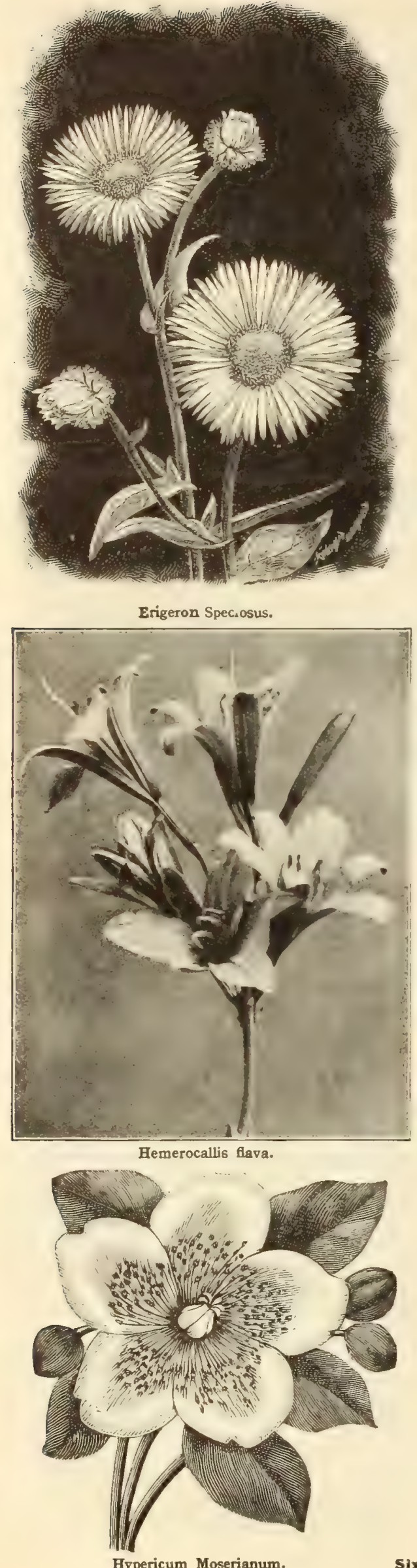

GAILLARDIA Grandiflora. Blanket Flower. Red and yellow; Doz. 100.

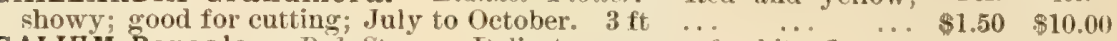

GALIUM Boreale. Bed Strew. Delicate sprays of white flowers prized for eutting; July. $1 \frac{f}{\mathrm{ft}}$.

GERANIUM Willardi. Rosy-red; June. $i \frac{1}{2} \mathrm{ft}$.

GYPSOPHILA Acutifolia. A strong growing variety with large panicles of small white flowers; July. $2 \mathrm{ft}$.

Paniculata. Baby's Breath. Pure white; excellent for cutting; July and August. $2 \mathrm{ft}$.

- Flore Pleno. Double white flowers

HELENIUM Autumnale. Helen Flower. Large heads of deep goldenyellow flowers suitable for beds or shrubbery border's; Angust and September. $4 \mathrm{ft}$.

Autumnale Superbum. "Similar to the above, very showy. $4 \mathrm{ft}$., - Rubrum. Reddish brown

Grandiflorum Striatum. Yellow with reddish stripes. $3 \mathrm{ft}$.

Hoopesi. Bright orange-yellow; blooms from July until frost. $2 \mathrm{ft}$., Pumilum Magnifieum. A fine cross between II. pumilum and $\mathbf{H}$. autumnale superbum. It grows $2 \frac{1}{2} \mathrm{ft}$. high and produces a great number of large yellow flowers from June to October

HELIANTHUS Lævis. - Sunflower. Free-blooming, single variety; July to October; deep yellow. $3 \mathrm{ft}$.

Maximillians. One of the finest and most graceful Sunflowers, with deep yellow single flowers borne in long, elegant sprays; extremely useful for cut-flower decoration; September and October. $6 \mathrm{ft}$. Mollis. Large, single, lemon-yellow flowers and downy silvery-gray foliage; August to October. $4 \mathrm{ft}$.

Multiflorus. FI. Pl. Double Hardy Sunflower. Double golden-yellow flowers, resembling Dahlias;. July to October. $4 \mathrm{ft}$.

Rigidus Miss Mellish. Large, single, golden-yellow flowers; Sejtember and October. $6 \mathrm{ft}$.

HELLEBOROS Niger. Christmes Rose. Large, waxy-white flowers of great beatuty, produced in the very early spring. A sheltered, partially shady situation is most suitable. $1 \mathrm{ft}$. ... .... Each, .50,

HEMEROCALLIS Aurantiaca Major. Large, trumpet-shaped flowers, deep oramge; June to August; 2 to $3 \mathrm{ft}$. ... Filch, .อ̃0, Disticha Flora Plena. Rich orange, double flowers; June to August. 2 to $3 \mathrm{ft}$.

Flava. Tellowo Day Lily. Clear yellow; fragrant; June to August. 2 to $3 \mathrm{ft}$.

Middendorfii. Bright yellow; June and July. $i \frac{1}{2}$ to $2 \mathrm{ft}$.

HESPERIS Matronalis Siceet Rocket. Lilac and white; June. $3 \mathrm{ft}$.

HEUCHERA Sanguinea. Alum Root. Graceful spikes of delicate coral red flowers; July and August. $1 \frac{1}{2} \mathrm{ft}$.

HIBISCUS Crimson Eye. Mallow. Very large flowers, white with crimson eye; July and August. $4 \mathrm{ft}$. Moseheutos. Sroamp Mallow. A useful and showy plant for naturalizing, or background eflects, with rich foliage and showy pink flowers; Doz. 100 July and August. $4 \mathrm{ft}$. . . 1.5010 .00 Moseheutos Albus. White, 1.5010 .00 HOLLYHOCK. We grow a large assortment of choice European strains.

Double Mixed Colors. In choice variety

Double Separate Colors.

White, pink, yellow, scarlet,

crimson, purple

2.0012 .00

...2.00 12.00

Single Mixed Colors ... 2.0012 .00

HYPERICUM Moserianum. St. John's Wort. One of the finest border plants, blooms from June to October; golden yellow. $1 \mathrm{ft}$.

2.0012 .00

IBERIS Sempervirens. Evergreen Candytuft. Adapted to forming edgings and rock. ery clumps; masses of pure white flowers in trusses; Jume to October. $1 \mathrm{ft}$. INCARVILLEA DELAVAYI. ducing pale green leaves about 2 feet in length, resembling those of the Acanthus. Flowers like Gloxinias, of a bright rose color, on long

stems; June to August. $2 \frac{3}{3} \mathrm{ft} .2 .0012 .00$

IRIS CRIST ATA. Crested Iris.

Charming dwarf variety; pale

blue; May. $\frac{1}{2} \mathrm{ft} . \ldots . \ldots 1.5010 .00$ Six of a Kind Sold at Dozen Rates; 25 at 100 kates.
$1.50 \quad 10.00$

$\begin{array}{ll}1.50 & 10.00\end{array}$

$1.50 \quad 10.00$

$1.50 \quad 10.00$

$2.50 \quad 12.00$

1.50

1.50

T. 50

1.50

1.50

1000

10.00

10.00

10.00

100 )

10.00

150

10.00

9.00

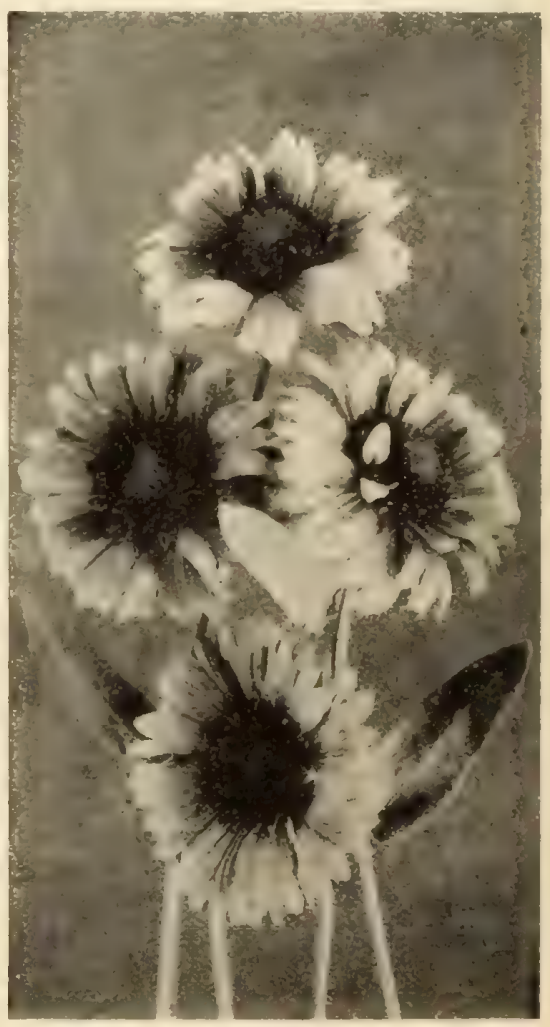

Gaillardia Grandiflora. (Blankel Floner.) 


\section{GERMAN IRISES. Tris Germanica. True Ferer-de-Lis.}

Irises require rich soil and abundance of water. The finest blooms are obtained from established clumps; consequently when planted they should remain undisturbed. Set the roots in clumps of three or more, four inches deep, and protect with leaves or other mulch during winter.

In the descriptions $(\$)$ is used to signify standards or the erect petals; (F) falls or the drooping petals.

Prices: Each, 15 cents; dozen, \$1.50; 100, \$10.00. (except where otherwise given )

Asiaticus. S. violet; $F$. purple; $2 \mathrm{ft}$.

Atropurpurea or Koehi. S. and F. rich claret purple; $2 \mathrm{ft}$.

Bacehus. $\mathbf{S}$. and $\mathbf{F}$. white; crest golden yellow; $2 \mathrm{ft}$

Canarybird. S. yellow; F. bronze, striped white; $2 \mathrm{ft}$.

Comte de St. Clair. F. deep violet margined white; 2 ft

Dubois de Milan. S. lavender; $F$. blue veined purple, $2 \mathrm{ft}$.

Edith. S. porcelain blue; F. purple, striped white; $1 \frac{1}{2} \mathrm{ft}$.

Elizabeth. S. pale blue; $F$. blue shaded violet; $2 \mathrm{ft}$.

L'Esperance. S. bronze; $F$. rich yellow veined crimson; $2 \mathrm{ft}$.

Garrick. S. lilac; F. dark violet blue; $2 \frac{1}{2} \mathrm{ft}$.

Gazelle. White, frilled mauve; $2 \frac{1}{2} \mathrm{ft}$.

Glory of Hillegom. $\mathrm{S}$. and $\mathrm{F}$. clear porcelain blue; $3 \mathrm{ft}$

Graechus. F. crimson, reticulated white; early; $1 \frac{\pi}{2} \mathrm{ft}$.

Honorable. S. golden yellow; F. striped maroon; $2 \frac{1}{2} \mathrm{ft}$.

Hermione. $S$, and $F$. fine pale lilac; $2 \frac{1}{2} \mathrm{ft}$.

Innocenza. S. and $F$. irory white; crest rich golden; $2 \mathrm{ft}$.

John D. Witt. Light lilac blue; F. purple; $2 \mathrm{ft}$.

King Edward. S. light blue; $\mathbf{F}$ purple; $3 \mathrm{ft}$.; one of the best

Madame Chereau. White; frilled azure blue; $2 \frac{1}{2} \mathrm{ft}$.

Maori King S. rich golden yellow; $\mathbf{F}$. rich velvety crimson, margined gold, most effective; $1 \frac{1}{2} \mathrm{ft}$.

Mrs. H. Darwin. F. white, slightly reticulated, violet at base; very beautiful and free-flowered; $2 \mathrm{ft}$.

Panchrea. S. and $F$. yellow: $2 \mathrm{ft}$.

President Carnot. S. light blue; F. deep violet; $2 \frac{1}{2} \mathrm{ft}$.

Purple Prince. Royal purple, very eflective; $2 \mathrm{ft}$.

Queen Emma. Pure white: $2 \mathrm{ft}$.

Queen of May. Soft rose-lilac, almost pink; $2 \frac{1}{2} \mathrm{ft}$.

Sambueina Beethoven. S. rosy-lilac; $\mathbf{F}$. purple with orange crest; $2 \mathrm{ft}$

Sparta. S. bronze yellow; F. maroon, margined old gold; $1 \frac{1}{2} \mathrm{ft}$.

Unnamed varieties, Finest Mixed. Each, 15 cents; dozen, 81.25 ;

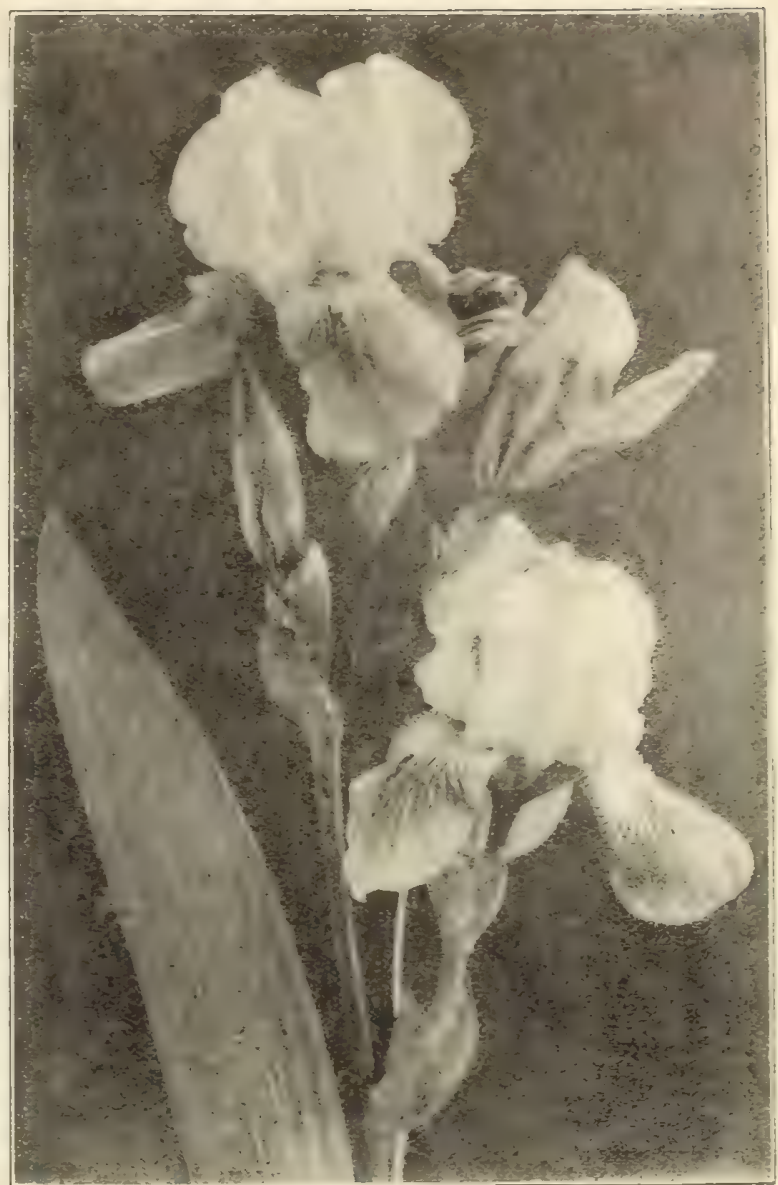
$100, \$ 6.00$.

\section{JAPANESE IRISES. Iris Kumpferi.}

In these we find combinations of form and beauty far excelling any other type. The stately flowers are often 10 to $1 z$ inches in diameter, and of wonderfully varied and beautiful colors. They require rich, moist soil. Our collection is our direct importation from Japan and is remarkably tine. Plants set out now blowm next summer. Each, 25 cents; Doz., \$2.50; $100, \$ 15.00$.

No.

1. Gekka-no-anami. Double, white.

2. Shishi-odori. Light purple.

3. Kumoma-no-sora. White, shaded light blue.

4. Kumo-no-obi. Purple, shaded blue, centre white.

5. Ho-0-jo. Velvety crimson, centre white.

6. Geisho-vi. Double, crimson.

7. Sofu-no-koi. White, shaded and blotched lavender, double.

8. Mana-dsuru. White, veined with blue, centre yellow,

9. Hana-no-nishiki. Cerise, centre white.

10. Yomo-no-umi. White, centre yellow.

11. Moi-ran. White, shaded and blotched pink

12. Kuma-Funjin. Rich, deep purple, double

13. Taihei-raku. Light magenta.

14. Hana-aoi. White, shaded light violet, centre dark vislet.

15. Ulchiu. Sky blue, centre white, double.

16. Oshokun. Dark purple, centre white.

17. Shippo. Light blue, shaded dark blue, wentre retdist purple.

18. Kumo-no-isho. Velvety dark red, centre purple.

19. Kimi-no-megumi. Porcelain blue, veins violet, violet anu red centre.

20. Kumo-no-uye. Deep purple, double.

21. Yezo-nishiki. Heliotrope.

22. Shishi-ikari. Light crimson, maronn centre.

23. Oniga-shima. Deep purple, centre blue.

24. Sano-watashi. Rich purple.

25. Yedo-jiman. Dark purple, shaded light purple.

Unnamed Varieties Mixed. Very fine. Date-dogu. Magenta red.
No.
28. Shiva-Taki. Pure white.
30. Kagaribi. Vermillion.
31. Kosui-no-iro. White, shaded lilac.
32. Komochi-guma. Rich purple.
33. Kaku-jaku-ro. Violet, centre light blue.
34. Momiji-no-taki. Pink, centre purple and maroon
35. Suchiu-kwa. White, edged with red.
36. Yedo-kagami. Red, shaded light purple.
37. Uji-no-hotaru. Light and dark blue', '(entrt' mumb
38. Shimo-yono-tsuki. Double white.
3:4. Tsurugi-no-mai. Purple red, centre lark natrum
40. Iso-no-nami. Light blue, blotched dark blue.
41. Oyodo. Bud pale blue, opens white
4:. Bandai-no-nami. White, centre sellow
4:3. Waka-murasaki. Bright magenta, bletchend white.
4. Kyodai-san. Nary bluce, shaterl brom\%"
45. Kigan-no-misao. White, tinged lilac.
46. Koki-no-ipo. Bright purple.
47. Samidare. White, centre jellow
45. Tora-odori. White, blotehed and shated hine and indender
49. Tsuru-no-kegoromo. White.

IRIS ORIENTALIS. Violet blue flowers on erect sems; very frex; June and July. 2 fert 


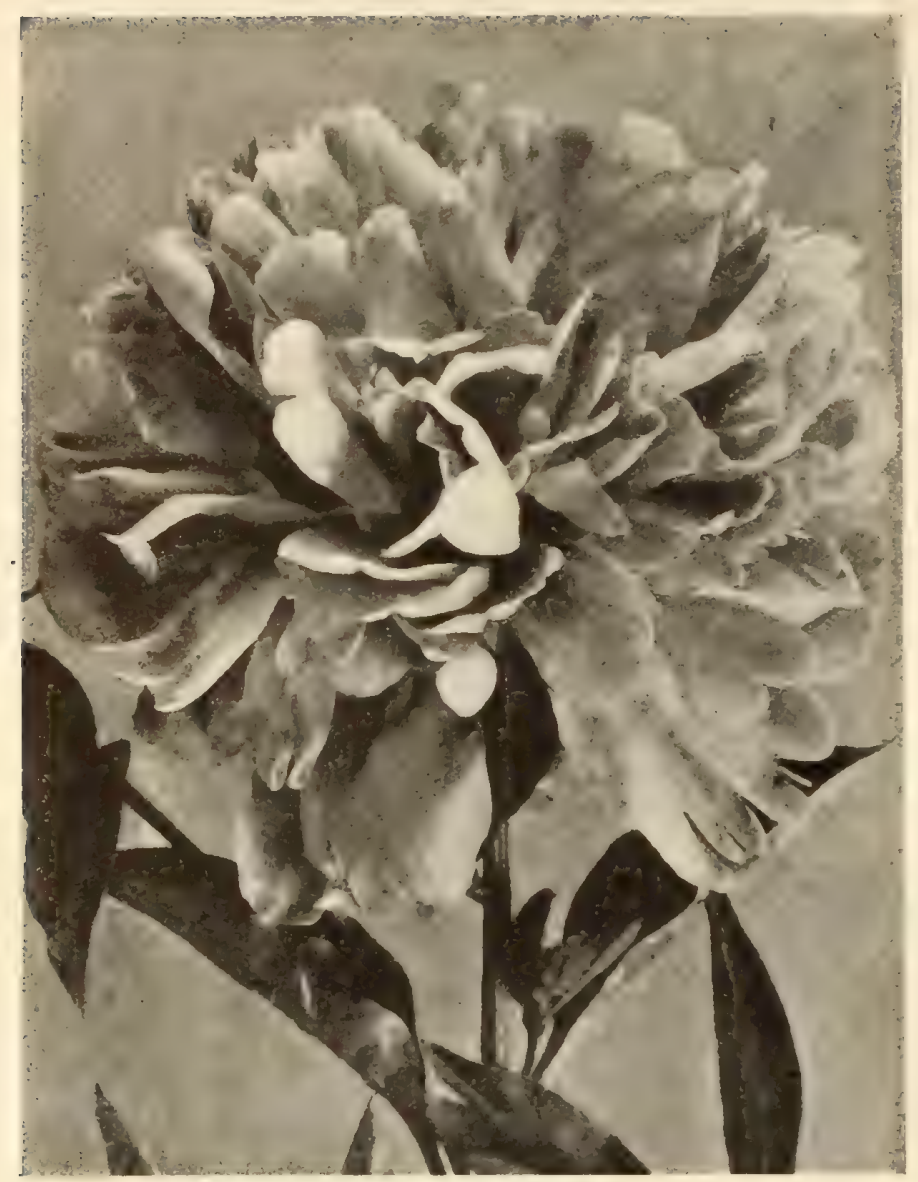

Double Chinese Preony.

LATYHROS Latifolius. Exrlasting Peu. Beantiful Doz. 100 climber for trellises or fences, flowers rosco-colored: July and August. $8 \mathrm{ft}$. Latifolius Albus. Pure white

LAVENDULA Vera The tum 2.2 .5018 .00 grant blue flowers in July aud August. $1 \frac{1}{10} \mathrm{ft}$. . $1.50 \quad 10.00$ LIAT RIS Pyenostaehya. Kanses Gial Feather. Spikes of light rosy-purple flowers; July and August. $4 \mathrm{ft} .1 .50 \quad 10.00$ Spleata. Blazing Ster. Spikes of deep purple flowers; July to Septembel
LINUM Perenne. Flax. A tine border or rockery plant with delicate foliage and bright blue flowers:

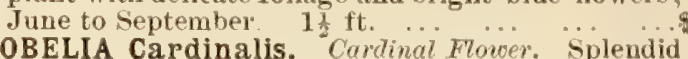
plant for borders or moist situations, flowers cardinal red. August to October. $3 \mathrm{ft}$... … blue flowers; August and September. $2 \frac{1}{2} \mathrm{ft} . .$.

LUPINUS Polyphyllus. Lupin. Robust plant for clumping and naturalizing. Handsome blue flowers in spikes; June to October". $3 \mathrm{ft}$. Pollyphyllus Albus. White Pollyphyllus Lilacina. Iilac

LYCHNIS Chaleedonica. Jerusatem Cross. Intense scarlet flowers in large, erect heads; June to September. $2 \mathrm{ft}$. Flore Pleno, Double scarlet, $2.50 \quad 15.00$ Haageana. Bright orauge scarlet; May and June, $1 \mathrm{ft}$... ... ... ... ... ... ... Vespertina, Double White. Iarge flowers, piscaria Fl. Pl. Ratyed Robin. Ioep red, double iscaria Fl. Pl. ragged Rod

LYSIMACHIA Clethroides. "Loosestrire." Fine spikes of pure white flowers; June to September.

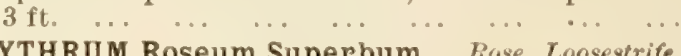

$A$ showy plant for borders and for naturalizing; July to September. $3 \mathrm{ft}$. MERTENSIA Virginiea. Blue Brll. Drooping panicles of bright blue flowers, fadiug to pink; May and June. $1 \frac{1}{2} \mathrm{ft}$.

1.6010 .01 $25015 .(4)$ $1.0010 .(4)$ 1.0010 .00

MONARDA Didyma. Bergamot. Deep scarlet fowers; foliage massive and aromatic; a favorite of

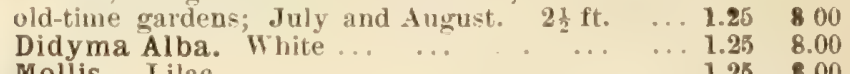
Mollis. Yilac … ... …

MYOSOTIS Alpestris Vietoria. Forget-Me-Not. Bright blue flowers in dense masses; April to June. 6 in. Palustris Grandiflora. Large-thered ForgetMe-Not; April to June. $1 \mathrm{ft}$.

ENOTHERA FRUTICOSA MAJOR. Evening Primrose. Large golden-yellow flowers; July. $2 \mathrm{ft} . .$. Lamarekiana. Yellow flowers. 3 to 4 inches acloss; July to September. $3 \mathrm{ft}$... ...
Speciosa. A raje variety with very large white Howers. $1 \frac{1}{\mathrm{ft}}$. ... ... ... ... ... . . Youngi. Bright yellow; very free; June to september. $\quad 1 \frac{1}{2} \mathrm{ft}$.

\section{PÆONIES. DOUBLE CHINESE.}

\section{RARE RICHARDSON PÆONIES.}

Dopchester. Magnificent, large, broad, double flowers of delicate flesh-pink color; fragrant; late. Fach, \$1.50. Four-year clumps, each, $\$ 5.00$.

Richardson's Perfection. Targe globular flowers; clear rose pink; flagrant; late. Each, \$1 50.

\section{GENERAL COLLECTION.}

Alba Maxima. Fine pink, changing to white. Fach, 35̄.; doz. $\$ 3.50$

Alba Sulphurea. White-shaded primrose; fragrant globular flover. Each, 50c, doz, \$5 00.

Amabilis Speciosa. Pink, fragrant. Each, 250 : doz. $\$ 2.50$.

Anaconda. Blush pink guar petals, centre white. Each, $35 c^{\circ}$. doz, $\$ 350$

Bapon Rothsehild. liose, centre silmon; flagrant. Fach, 250 doz, \$2.50

Canari. Blush shaded with rosy-pink. Each, 35c.; do\%, \$3.50. Delieatissima. Clear rosy-pink with deeper guard petals; fragrant. Each, 35c.; doz., $\$ 3.50$.

Duchesse de Nemours. Criot. One of the very best, pure white, flowers large; fragraut, Each, 75c.; doz., \$7.50.

Duchesse de Nemours. Guerin. Deep losy-pink, large full flower. Each, 50c.; doz.. \$5.00.

Duehesse d'Orleans. Self-colored piuk; very fragraut. Fach, $50 c$; doz., $\$ 5.00$.
Edulis Alba. Guard petals blush, centre primrose. Each, 350 .: doz., $\$ 350$.

Festiva. Pure white; the inner petals usually tipped with curmine. Fach, 35e ; doz, $\$ 3.50$.

Festiva Maxima. One of the finest sorts, with enormous flowers of the purest white; inner petals tipped with bright crimson. Each. $75 \mathrm{c}$; d doz.., $\$ 7.50$.

Fragrantissima. Bright criosson; fragrant. Euch, 35e; do\%, $\$ 3.50$.

Franeis Ortegal. Deep crimson; anthers golden yellow fravint, free bloomer. Each, 50c, doz, \$5.00.

Fulgida. Deep rose guard petals; centre rosy-pink. Each, 35e ; doz. $\$ 3.50$.

Humei. Brilliant rosy-red; large, globular, full fowers. Fach, 50c.; doz., \$5.00.

Humei Carnea. Flush pink, large, full flower with cionamon fragrance, Each, 50c; doz. \$5.00.

Madame Furtado. Deep rose guard petals, centre salmon; fiagrant. Each, 50c.; doz., $\$ 5.00$.

Marechal Vaillant. Deep crimson, large and very double. Kach, 50c.; doz., \$5.00.

Modiste Guerin. Large blooms in clusters of three to six on a stem; deep pink; fragrant. Each, 750.; doz., $\$ 7.50$

odopata. Deep rose, self-colored, fragrant. Each, $25 \mathrm{c}$; doz, $\$ 2.50$.

Perfection. (Dutrh.) Brilliant rose pink flower with large guard petals, centre shaded with salmon. Each. 35e; doz, \$3.50. ates; 25 at 100 Rates. 


\section{R. \& J. FARQUHAR \& CO., BOSTON. HARDY PERENNIAL PLANTS.}

PEONIES. - Continued.

Pottsil Alba. Guard petals pink, centre blush, almost white very fragrant. Each, 35̃c.; doz, \$3.50.

Prolifera Tricolor. Flesh color, shaded yellow, centre primrose. Each, 35̃c.; doz., \$3.50.

Puleherrima. White shaded rellow and salmon pink; centre petals tipped carmine. Each, 3̋̄.; doz., \$3.50.

Queen Victoria, Large full flowel with broad guard petals, open blush white, chauging to pure white, the centre petals frequently tipped with bright red. Each, 3ãc.; doz., \$3.50.

Reine Hortense. Deep rose-colored guards, centre salmon blotched with carmine; fragrant; blooms in clusters. Each. 50c. doz., $\$ 5.00$,

Triomphe du Paris. Buds deep rose, opening with large rosypink guard petals and creám-color centre. Each, 50c; doz., \$5..00.

\section{CHOICE MIXED P\&ONIES.}

White Varieties Mixed ... ... Each, .25; $\$ 2.50$ Pink Varieties Mixed $\ldots . . .66_{6} \quad .25$ : $\quad 2.50$

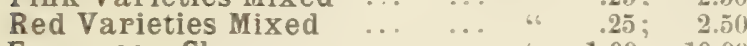

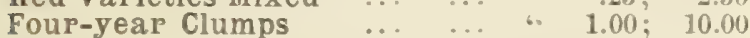

JAPANESE TREE PAEONIES. Monstrous flowers, chiefly single and semi-double; ranging from white to deep crimson ... ... Each. .75;

PFONIA Tenuifolia. Frn-lpaf Peony. CrimGon _- flore pleno. Double-flowered, "6, .50

PAPAVER Nudieaule. Irelanrl Poppy. Charming flowers ranging from white and yellow to deep orange-8carlet; invaluable for table dccoration; April to October. $1 \mathrm{ft}$.

Orientale. Oriental Poppy. Gigantic orangescarlet flowers, good plant for shrubbery borders; Iay to July. $3 \mathrm{ft}$.

Orientale Parkmanii. Rich, dark scarlet Orientale Royal Searlet. Deep scarlet PENTSTEMON Atropurpureus. Beari Tonqu. Dark red with white throat; flowers in graceful spikes; June to August. $3 \mathrm{ft}$.

Barbatus Torreyi. Tall, graceful spikes of brilliant scarlet flowers, giving the effect of clumps of scarlet willows; June to sept. $3 \mathrm{ft}$., Heterophyllus. Lorely azure blue. $2 \mathrm{ft}$. . Lævigatus. Rosy lilac. $2 \mathrm{ft}$.

Pubeseens. Rosy purple. $1 \frac{1}{2} \mathrm{ft}$.

PHLOMIS Tuberosa. Fine plant for naturalizing; rosy purple flowers; June, $4 \mathrm{ft}$.... ...

PHLOX Divaricata. A dwarf-native species with pale blue flowers; May and June. $1 \mathrm{ft}$.... Subulata Alba. White, moss-pink. Suitable for edgings and rockeries, June to August. 4 in.,

Subulata Rosea. Rosy pink

7.50

2.50

5.00

$150 \$ 10.00$

$1.50 \quad 10.00$

$2.50 \quad 18.00$

$2.00 \quad 12.00$

HARDY PHLOX, HYBRID GARDEN SORTS. Among hardy herbaceous plants none are more gorgeous and more easily grown than these. 'They are perfectly hardy, succeeding in any garden soil, and producing magnificent spikes of showy and lasting flowers, year after year, with comparatively little care. $2 \frac{1}{2}$ to $3 \mathrm{ft}$. 'The following varieties, each, -20 ; per' dozen, \$1.75; per $100, \$ 12.00$.

B. Comte. Intense purplish crimson.

Champs Elysee. Fine rich purplish crimson.

Coquelicot. A fine pure scarlet with deep carmine eye; the brightest of all Phloxes.

Crystal Palace. Mauve, white centre.

Eelaireur. Growing erimson, with light halo; large flower.

Esperance. Mauve, with white centre; extra fine.

Eugene Danzanvilliers. Rosy lilac; white eje; very large. F. G. von Lassburg. Pure white, with the individual flowers larger than any other variety.

Henry Murger. White with rose eye.

La Cygne. Pure white; splendid spike; very free bloomer.

Marquis de St. Paul. Salmon-pink with ruse eye.

Moliere. Salmon-rose, with deep rose eje.

P. Bonnetaine. Rosy red.

Pecheur d' Islande. C'rimson red.

Prof. Schlieman. Bright lilac-rose.

Schlossgartner Reichenau. Salmon-pink; carmine eye,

R. F. Struthers. Bright salmon-pink, crimson eye.

Von Goethe. Rich salmon-rose.

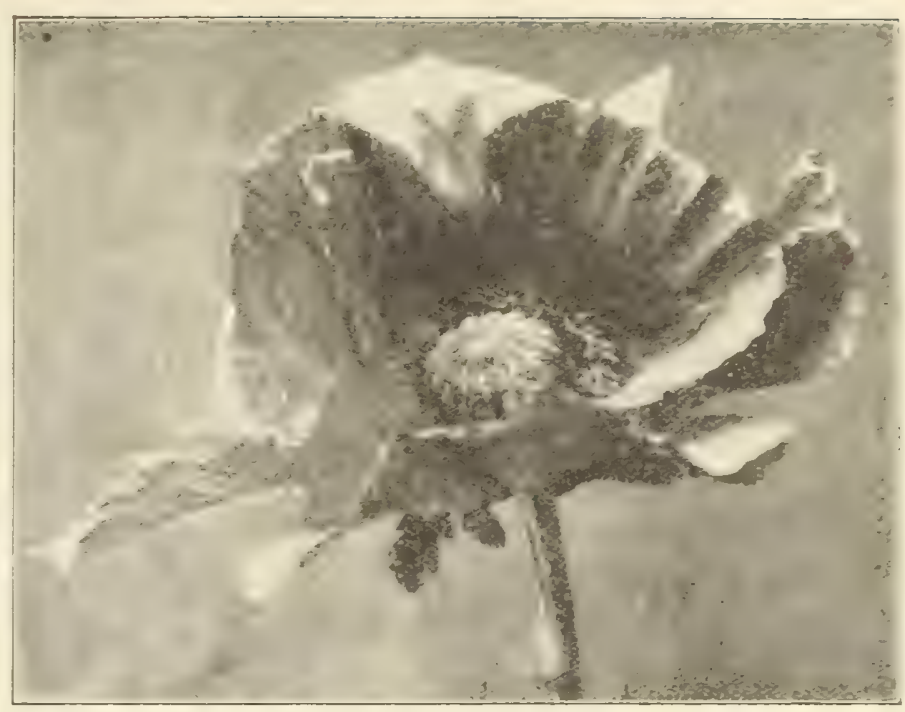

Papaver Orientale-Oriental Poppy.

PHYSOSTEGIA Virginiea. False Dragnn Hered. Elegant spikes of light rosy-lilac flowers; very beautiful and good for cutting; July and August. $4 \mathrm{ft}$.

Virginiea Alba. Purest white; lovely flower,

PLA T Y C O D ON Grandiflora. Chinese BellHower. Magnificent spikes of violet-blue cupshaped flowers of long duration; May to October. $3 \mathrm{ft}$.

Grandiflora Alba. White.

Mariesi. Dimarf Jrprness Bell-Humpr. Large sancer-shaped, violet-blue flower. $1 \frac{1}{\mathrm{ft}}$.

$\$ 1.50 \$ 10.00$

1.51) $\quad 10.00$ Mariesi Alba. White.

PLUMBAGO Lappentæ. Beautiful deep blue flowers. July to October, 6 inches

1 50) 1000

1 i) 10.00

1.511 10.00

$1.511 \quad 10.00$

1.5110 .00

P OL E M O NI U M Cceruleum. Jacnb's Ladder. Deep blue flowers in erect spikes; June, July. $1 \mathrm{ft}$.

Cœruleum Album. White.

Richardsoni. Sky blue

1.511 10.00

$1.511 \quad 10.00$

1.i1) 10.00

P Y R E T H R M Roseum. Single Hybrids. Mixed. Shades of pink, crimson, and white; June. $2 \mathrm{ft}$.

Double Hybrids. Mised. Various colors

Uliginosum. Giant Daisy. White, yellow centre; July to September. $4 \mathrm{ft}$.

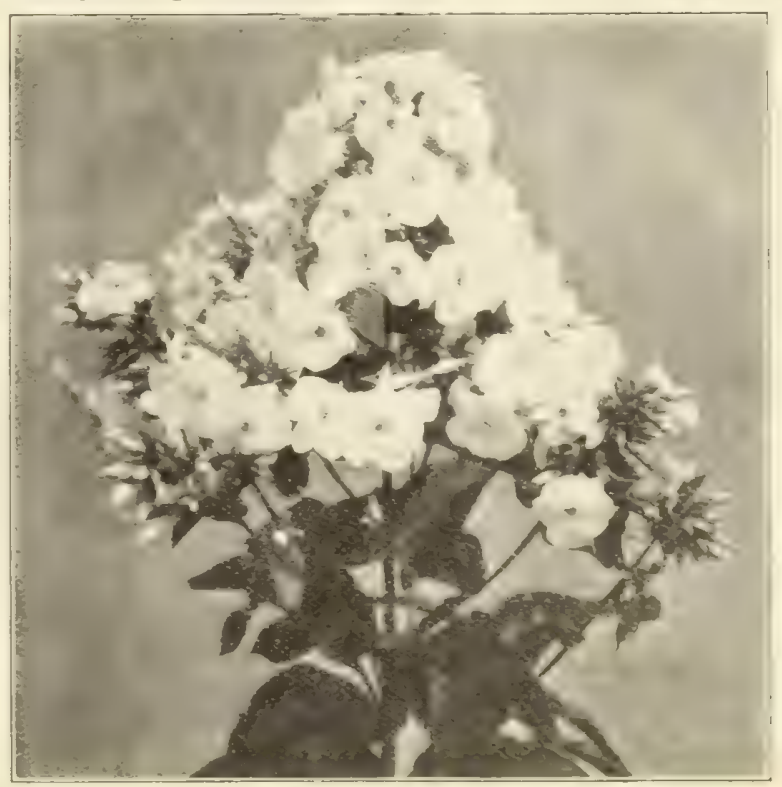

Hardy Garden Pblox. 


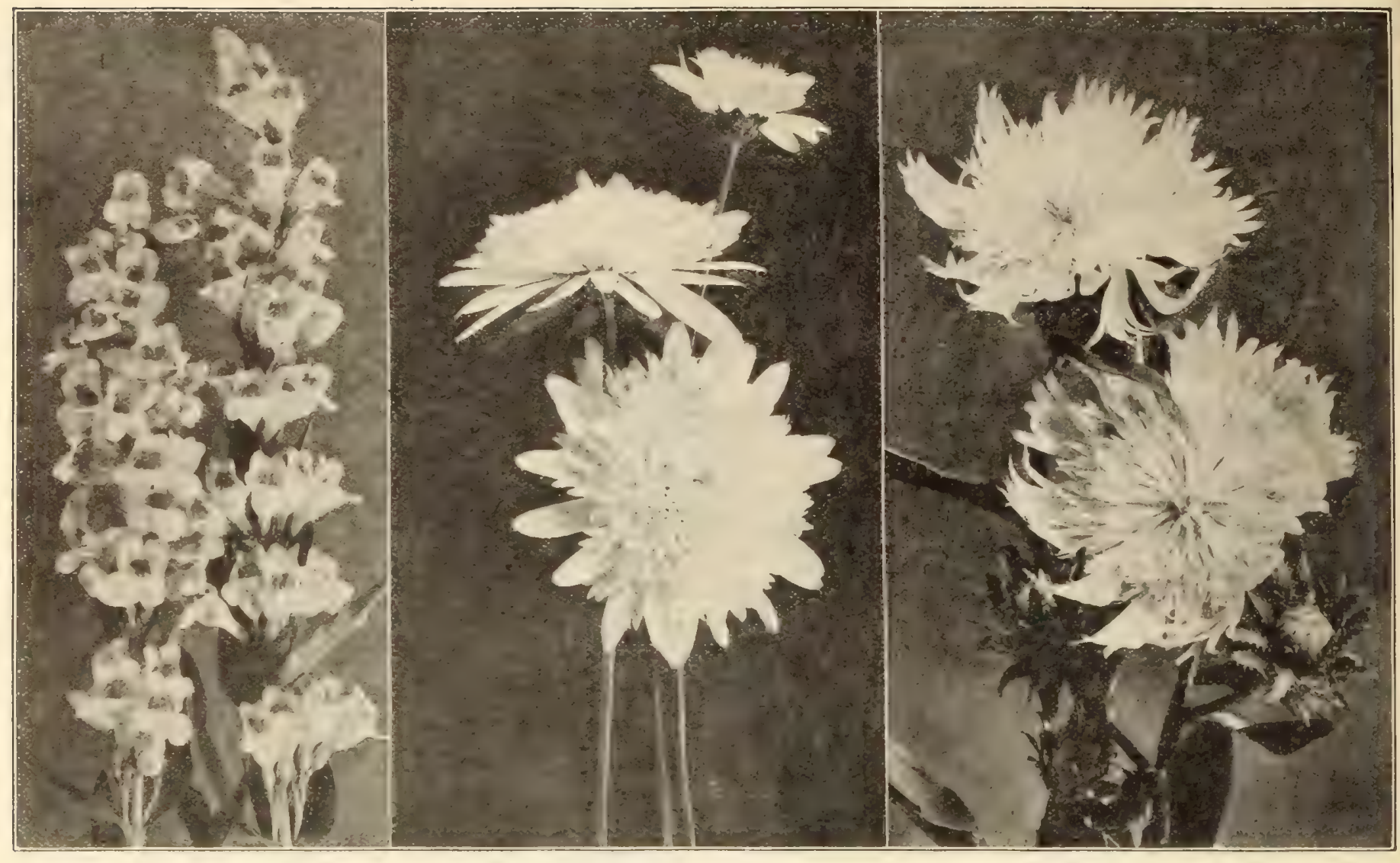

Pentstemon beterophyllus.

Pyrethrum hybridum, Double.

Stokesia cyanea.

RANUNCULUS Aeris fi. pl. Double Buttercup. Double yellow button-like flowers; April to

Jume. $2 \mathrm{ft}$. …....

Doz. $\quad 100$

$\$ 1 .: 0 \quad \$ 8.00$

R ODBECKIA Lanceolata Golden Glow.

Doz.

100

from China with showy spikes of rosy-purple

flower's resembling those of the Foxglove; re-

quires protection in the winter 2 feet

RUDBECKIA Fulgida. Brilliant Cone Flower. Brilliant olange flowers: August and september. $2 \frac{1}{2} \mathrm{ft}$.

$2.00 \quad 12.00$

Flowers golden yellow, like double Cactus Dah-

lias; valuable for shrubbery clumps and for cutting; July and August. 5 to $6 \mathrm{ft}$.

Newmanil. Golden yellow, with maroon cone

July to Octoher. $2 \mathrm{ft}$.

Superba Subtomentosa. Iemon-yellow flowers with dark purple cones. Fine pyramidal form: July to september. $2 \frac{1}{2} \mathrm{ft}$.

SALVIA Pratensis. Yeadow Sage. Large spikes of rich blue flowel's; Julyand August. $1 \frac{1}{2} \mathrm{ft}$.

SANTOLINA Chamæeyparissus. Lavender Catton. Foliage silvery white; a good plant for carpet beds and borders. $\frac{1}{2} \mathrm{ft}$.

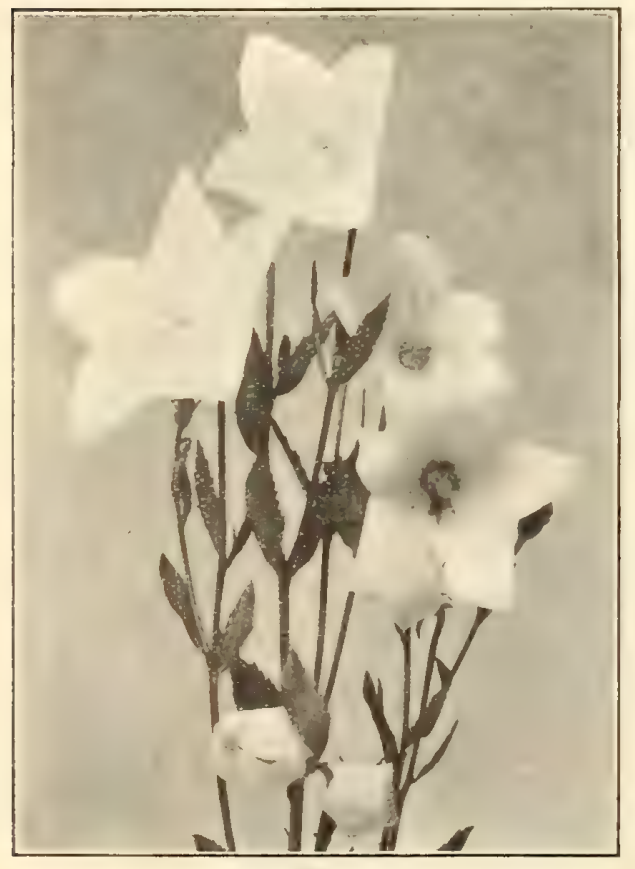

Platycodon Grandiflora.

SAPONARIA 0eymoides Splendens. Snop Wort. A fine rockery $\mathrm{Ol}^{\circ}$ edging plant, producing great masses of rosy crimson flowers; June to July. $\frac{1}{2} \mathrm{ft}$.

Oeymoides Upens. Flowers rosy erimson

SAXIFRAGA Crassifolia. A very hardy plant succeeding in any situation, with handsome large green leaves and large spikes of pink flowers; April to June. $1 \mathrm{ft}$.

SCABIOSA Caucasica. Large lavender-blue flowers borne on long stems; one of the finest perennials; June to August. $2 \mathrm{ft}$.

SEDUM Spectabile var. Brauni. Jight green fleshy leaves and broad heads of bright rosy pink flowers; August to October. $1 \frac{1}{2} \mathrm{ft}$. Sieboldii. Pink. June to July 6 inches

SILENE Virginica. Fire Pink. Good plant for wild gardens and natural grouping; crimson; June to August. $1 \mathrm{ft}$.

SPIRÆA Aruncus. Meadow Srceet. Long feathery panicles of white flowers. June and July. $3 \mathrm{ft}$.

Astilboides. White; June. $3 \mathrm{ft}$.

Aurea Reticulata. Flowers white; leaves green, beautifully

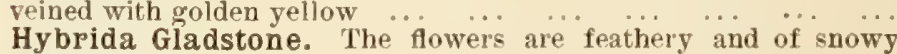
whiteness, borne on erect stems. 18 inches in height

Japonica. White flowers in panicles; June. $2 \mathrm{ft}$... ...

Palmata. Beautiful rosy crimson flowers; June and July. $3 \mathrm{ft}$. 
R. \& J. FARQUHAR \& CO., BOSTON. HARDY PERENNIAL PLANTS.

STELLARIA Holostea. Stitchwort. A plant of dense low growth, suitable for rockeries and edgings; May to July. $\frac{1}{2} \mathrm{ft}$.

STOKESIA Cyanea. Skyblue flowers resembling the chinese Aster; a native plant of great value for borders, wild gardens, and cutting; July to October. 1 ft. $\ddot{\text { Crimson }}$ SWWET WILLIAM. Dianthus barbatus. White, Crimson

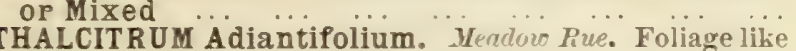
the Maiden Hair Fern; flowers creamy white; May and June. $1 \frac{1}{2} \mathrm{ft}$.

THERMOPSIS Caroliniana. Magnificent free-blooming plant with tall spikes of clear yellow flowers; June and July. $5 \mathrm{ft}$.

TRILLIU M Grändiflorum. Wool Lity. Desirable for shady situations; large white flowers; April and May. $2 \mathrm{ft} . .$.

TRITOMA Express. Red Hot Poker. The earliest variety, blooming from July to October. $3 \mathrm{ft}$. Each, .25; Pfitzeri. Very free-blooming, orange scarlet flowerspikes; August to November. 3 to $4 \mathrm{ft}$.

Uvaria Grandiflora. Crimson, shaded yellow; flowerspikes large and showy; A ugust to November. $4 \mathrm{ft}$. Uvaria Nobilis. Bright scarlet; August to November. $4 \mathrm{ft}$.

TROLLIUS Europæus. Globe Flocer. Bright yellow globe-shaped flowers, like giant buttercups; June to September. $\quad 1 \frac{1}{2} \mathrm{ft}$.

Caueasieus. Orange Gilobe. "Rich orange

Japonieus Exeelsior. Vero Orange Globe Flover. A beautiful new variety with very deep orange flowers; July. $2 \mathrm{ft}$. Each. .35

VALERIANA Offieinalis. Valerian. Aromatic plant with purplish white flowers; June and July. $2 \mathrm{ft}$.

VERNONIA Novæ Boracensis. Stately plant suitable for clumps among shrubs or fol natural gardens; dar'k purple; September and October. 3 to $6 \mathrm{ft}$. ...... VERONICA Amethystina. Speertwell. Flowers amethystblue; May to July. $1 \mathrm{ft}$.

Ineana. Silvery foliage; flowers violet; July to September. $2 \mathrm{ft}$.

Longifolia Subsessilis. Rich blue flower spikes; a very handsome plant; June to October. $2 \mathrm{ft}$.

Repens. A trailing sort, covered in early summer with hlue fowers...

VINCA Minor. Perivinkle or Trailing Vyrtle. Dwarf Evergreen used to cover shady ground; flowers bright blue; Ilay to July. $\frac{1}{2} \mathrm{ft}$.

VIOLA CORNUTA. Tuited Pansy. Blooms constantly from April to November; mauve. $\frac{1}{2} \mathrm{ft}$.

Admiration. Rich dark blue

Blue Perfection. Mauve, yellow eye

Grandiflora Lutea. Golden Yellow

Silver Queen. White

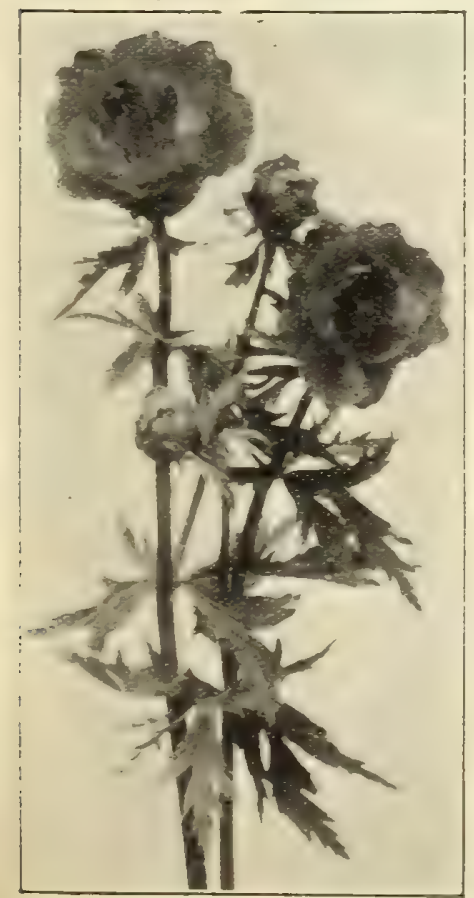

Trollius Japonicus Excelsior. with yellow ......

- Graeillima.

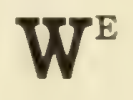

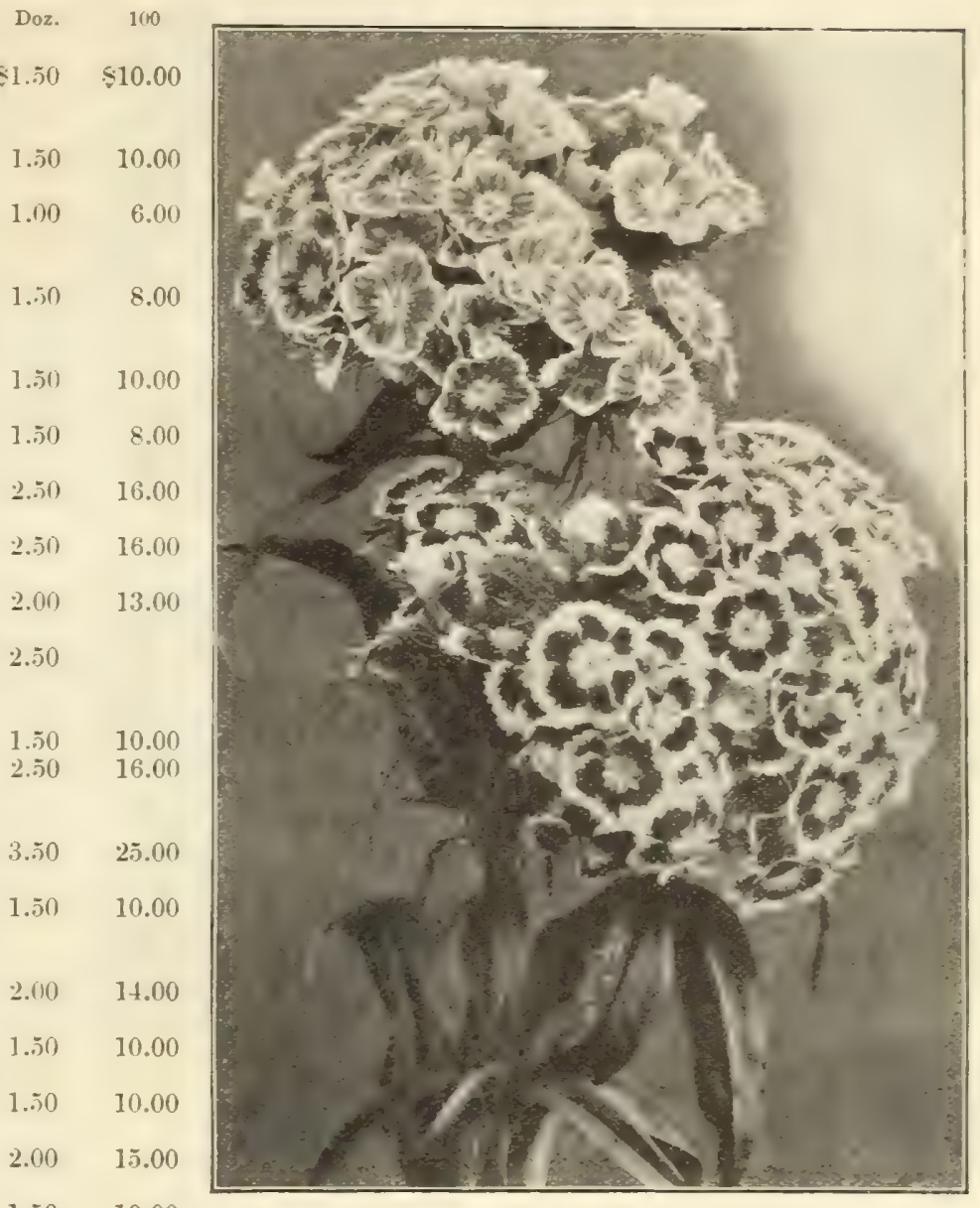

$1.50 \quad 10.00$

Sweet V7:lliam,

1.50 10.00 YUCCA Filamentosa. Arlemis Vealle.

One of the most decorative aud striking

4.00 hardy plants; large spikes of creamy

4.00 white flowers; June and July. $4 \mathrm{ft}$. $\$ 2.50 \quad \$ 15.00$

4.00

4.00

HARDY ORNAMENTAL GRASSES.

Arundo Donax. Grows in dense clumps, Each. Doz. 9 feet in height ... ... ... ... $\quad 8.25 \quad \$ 2.50$ - Variegata. Foliage striped white $\ldots . .25 \quad 2.50$

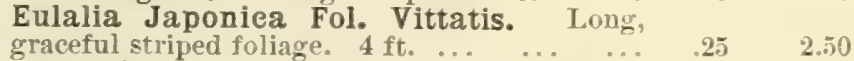
- Zebrina. Long leaves, elegantly barred

$.25 \quad 2.50$ Elegant silvery plumes. $10 \mathrm{ft}$. Pampas Grass. 50.00 $\begin{array}{lllll}\text { Phalarus arundinacea variegata. } & \ldots & .25 & 2.50\end{array}$

\section{Pot-Grown Perennial Plants}

\section{SUMMER PLANTING.}

\section{CAN FURNISH POT-GROWN} HARDY PERENNIAL PLANTS

In great variety for summer planting.

For selection, see our Mid-Summer Catalogue ready June Ist, I909.

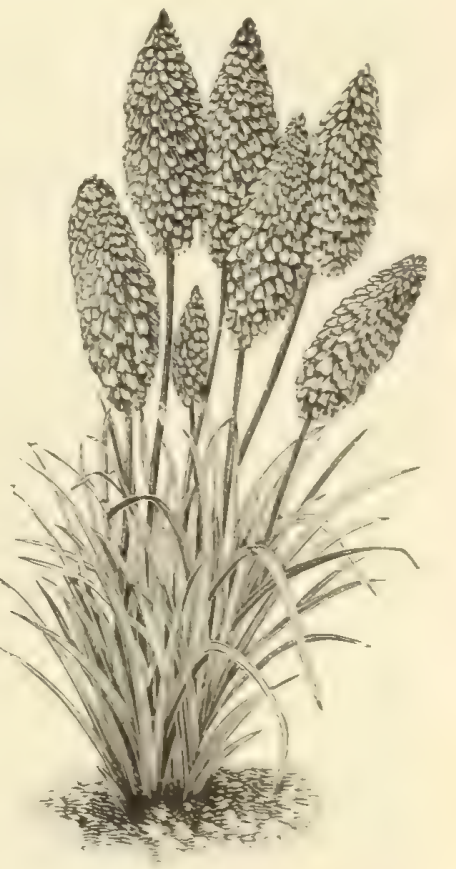




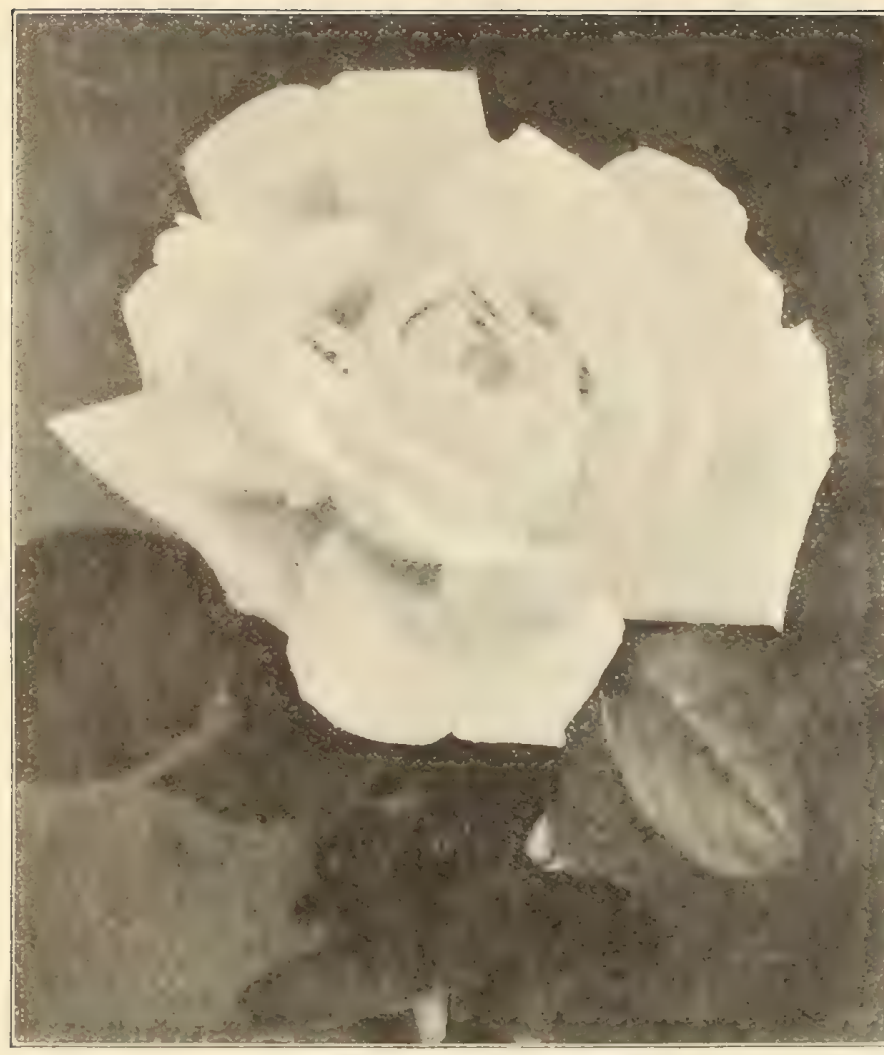

H. P. Rose Frau Karl Druschiki.

\section{HARDY HYBRID PERPETUAL ROSES.}

\section{Seleeted 2-yeap-old plants. Each, .40; doz., \$4.00; $100, \$ 30.00$.}

DELIVERY, APRIL AND EARLY MAY.

We can supply many of the following varieties out of pots for delivery, May to July. Eilch, .50; doz, $\$ 5.00 ; 100,83500$ six at dozen rate, 25 at 100 itute

Abel Carriere. Purple crimson, fiery red centre, double and finc flower, one of the darkest; vigorous.

Alfred Colomb. Bright red, very large, full and globular, free blooming and iragrant; a grand old rose.

Ards Rover. Crimson shaded maroon.

Baron de Bonstetten. Tigorous; red, black, and erimson, large and full.

Baroness Rothsehild. Beautiful light pink, large and fine form, nothing more beautiful, specially good.

Beauty of Waltham. Beautiful bright light red.

Ben Cant. Very large flower. Color deep clear crimson, with slightly darker flushes in the centre, and dark veining throughout Sweetly scented.

Captain Hayward. Scarlet crimson, petals long and smooth, good form, large and sweet scented.

Charles Lefebvee. Fine, brilliant velvety crimson, very large, double and superb form; vigorous.

Clio. Flesh color, shaded in the centre with rosy pink, large, fine, globular form, free bloomer, and distinct.

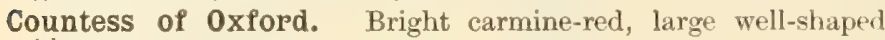
blooms.

Duke of Edinburgh. Very bright vermillion, extra large and full; distinct and splendid variety.

Duke of Teek. Bright crimson-scarlet; large, full, and fine globular flower; an excellent rose; vigorous.

Dupuy Jamaine. Very bright cerise, large, full, and fine form; a distinct rose, very beautiful; vigorous.

Earl of Dufferin. Rich velvety crimson, shaded with dark maroon, very large, full, and fine form.

Fisher Holmes. Shaded crimson-scarlet, large, full, and perfect form, very beautiful and free blooming.
Francois Michelon. Deep rose, reverse of petals silvery, very large and full; vigorous.

Frau Karl Druschki. Pure snow white, very long buds, shellshaped petals, opening to very large flowers; a continuous and free-blooming variety of first-class form; the finest white rose in cultivation.

General Jaequeminot. Brilliant scarlet crimson, very large and full; an old rose that still holds its place as one of the best. splendid for massing on account of its fine color and great triaterance.

Gloire Lyonnaise. Delicate yellow; very free.

Helen Keller. Rosy cerise; flowers large and full.

Hugh Diekson. Crimson shaded scarlet; very tine.

Jean Lebaud. Deep crimson maroon, very dark.

Jeannie Dickson. Silvery rose, long pointed bud, petals large and smooth; distinct and handsome

John Hopper. Bright rose, reverse of petals pale lilac, very large and double, free bloomer.

Jules Margottin. Bright cherry red, large and double, free bloomer, sweet scented, very hardy.

Lady Helen Stewart. Very bright crimson; highly perfumed.

Louis Van Houtte. Deep crimson shaded maroon, most vivid and distinct, large, full, and fine form.

Madame Gabriel Luizet. Light silvery pink, shading off paler to edges of petals, very free bloomer.

Madame Victop Verdier. Clear light crimson, very large and fill, beautiful form, a good grower.

Magna Charta. Bright rose, very large and double, of good form, and fragrant, best of old plants.

Margaret Diekson. White with pale flesh centre, large and of good substance, fine form and growth.

Marehioness of Londonderpy. Color ivory white, petals of great substance, shell-shaped and reflexed, flowers of great size and perfect globular form.

Marie Baumann. Soft carmine-red, very large, full and perfect form, free blooming; vigorous.

Marshall P. Wilder. Cherry-carmine, like a brighter colored Alfred Colomb, very fine in shape

Merveille de Lyon. White, centre slightly rosy peach, a grand full cup-slaped flower.

Mrs. John Laing. Very large, satiny-pink, of fine form; a good grower and abundant bloomer, one of the very best varieticu, c:umnot be too hiohly recommended; vigorous.

Mrs. R. G. Sharman Crawford. Clear rosy pink; the outer petals shaded with pale flesh.

Paul Neyron. Deep rose, flowers of immense size, with fine foliage and growth, free bloomer.

Pride of Waltham. Very delicate flesh color, shaded with bright rose: large and full.

Prince Camille de Rohan. Deep velvety crimson-maroon, full and good form, best of all the very dark roses; should be liberally treated.

Prosper Laugier. Brilliant crimson shaded scarlet.

Sir Rowland Hill. Rich deep port wine color, shaded with deep maroon, changing to ruby claret, large, full.

Tom Wood. Cherry-red, petals large and shell-shaped; good form and large size; vigorous.

Ulpich Brunner. Cherry-red, of immense size, fine form, and most effective; it seems proof against mildew or rust, and is one of the earliest to flower, and lasts well through the season; very vigorous.

White Baroness. Purest white, large full flowers.

\section{TEA-SCENTED AND NOISETTE ROSES.}

2 -year-old plants. Each. .50 ; doz., $\$ 5.00 ; 100, \$ 35.00$.

Bridesmaid. Clear bright pink; a lovely color.

G. Nabonnand. Pale rose, shaded with yellow, very large petals and handsome buds; distinct and good.

Madame Lambard. Salmon shaded rose, very variable in color, fine form, good habit, free bloomer.

Maman Cochet. Light pink shaded with salmon yellow, outer petals splashed with bright rose.

Papa Gontier. Rosy crimson; sweet fragrance.

Perle des Jardins. Deep straw yellow, sometimes deep canary yellow; large and double.

Souvenir de Pierre Notting. Apricot yellow, unsurpassed for bedding.

White Maman Cochet. Creamy white flowers, faintly tinged with blush, long pointed buds, opening to large flowers; an exceedingly pretty and valuable variety. 
R. \& J. FARQUHAR \& CO., BOSTON. ROSES.

\title{
EVERBLOOMING HYBRID TEA-SCENTED ROSES.
}

\author{
2-year-old plants. Each, .50; doz., \$5.00; 100, \$35.00.
}

This class furnishes some of the finest, most constant and best varieties for exhibition and garden decoration. They are very early and late flowering. They require protection during winter, being only half-hardy. Dwarf plants may be readily protected by drawing the soil over the centre or crown to a height of 6 inches: a further covering should be given by mulching with leaves or pine needles to a height of 6 to 12 inches.

Ameriean Beauty. Very double, of a deep crimson color and extremely fragrant.

Augustine Guinoisseau.' White, very lightly tinted with pale rose; valuable for cut flowers and garden decoration.

Bessie Brown. Creams white, flowers of immense size and great substance, sweetly scented.

Captain Christy. Delicate fleshy white, the centre darker, very large and full.

Caroline Testout. Light salmony pink. flowers very large and globular.

Etoile de France. Velvety crimson, very fragrant.

Franz Deegen. Golden vellow.

Gruss an Teplitz. Bright crimson with fiery red centre, cup-shaped semidouble flowers in clusters; free blooming, good for massing and bedding.

J. B. Clark. Deep rich crimson, very fine.

Kaiserin Augusta Victoria. Cream, slightly shaded lemon, deeper in the centre; a distinct and very beautiful rariety.

Killarney. Flesh shaded white, suffused pale pink, long pointed buds, opening to large flowers, petals of great substance; a lovely and distinct variety of great merit.

La France. Beautiful bright silvery rose, with pale lilac shading, full and fine form, one of the sweetest scented roses, most free blooming and very hardy.

Liberty. Brilliant velvety crimson, flowers good size and beautifully formed; a superb variety for decorative purposes, the blooms lasting well when cut. Madame Abel Chatenay. Carmine-rose, shaded deep salmon, long pointed buds, opening to moderate size.

Marquise Litta. Carmine-rose with vermillion centre, large, full and cupped; rery free flowering.

Queen's Searlet or Agrippina. Bright crimson-scarlet.

Richmond. Scarlet-red.

Souvenir de Wootton. Rosy red; very free.

\section{BOURBON AND HYBRID CHINA ROSES. Each, .50; doz., $\$ 5.00$.}

Host valuable as pillar and autumn flowering varieties, ancl only moderate pruning is necessary.

Madame Plantier. Climbing. Pure white; very free bloomer. Souvenier de la Malmaison. Dwarf. Blush white, shaded flesh, large and donble; very sweetly scented.

\section{AUSTRIAN BRIAR ROSES. \\ Each, .50; doz., \$4.00.}

Austrian Copper. Beautiful bright reldish copper; flowers single. Persian Yellow. The deepest yellow; fairly full; double.

Soleil D'or. Color varying from orange yellow to reddish gold, shaded with nasturtixum red; conical shaped buds.

\section{HYBRID SWEET BRIAR ROSES.

$$
\text { Each, .50; doz., } \$ 5.00 \text {. }
$$

Anne of Geierstein. Dark crimson; very vigorous.

Amy Robsart. Lovely deep rose; very vigorous.

Flora MeIvor. Pure white, blushed with rose.

Lopd Penzance. Fawn, passing to emerald yellow in the centre.

SINGLE SWEET BRIER ROSE.

Each, .35; doz., $\$ 3.50 ; 100, \$ 25.00$.

Common. Pale pink; deliciously fragrant,

\section{POLYANTHA ROSES.}

Each, .50; doz., $\$ 5.00$.

Dwari habit; very small flowers. The plants are splendid for bedding, or as edgings for borders. A distinct and charming class. Clothilde Soupert. White, shaded pink

Baby Rambler. Dwarf Everblooming Crimson. Blooms in large clusters, the sturdy little bushes being literally loaded down at times by their covering of small bright red roses; constantly: in bloom from June until late frosts.

\section{WICHURIANA ROSES.}

Each, .50; doz., \$4.00.

Gardenia. Bright yellow; fragrant and free.

Pink Roamer. Single flowers, bright rose to pink.

Wichuriana. White single blooms in clusters.

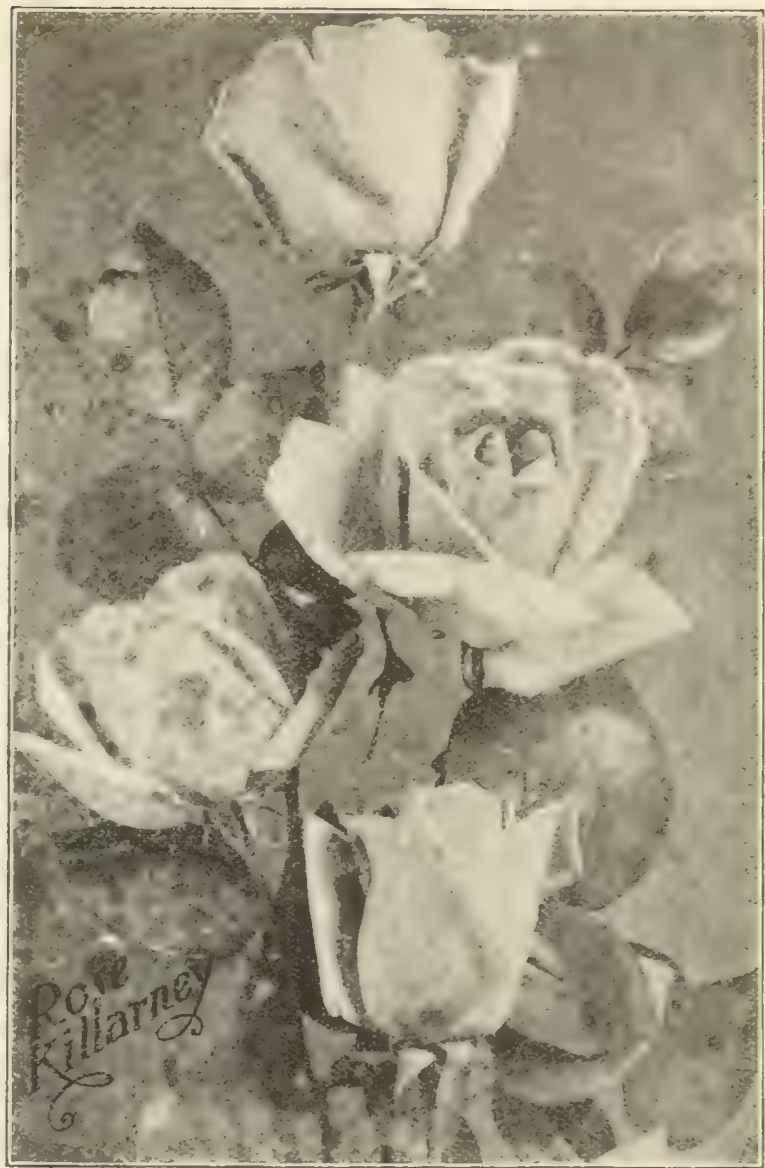

MOSS ROSES.

Each, .50; doz., \$4.00.

Baron de Wassenæer. Light crimson, flowering in clusters Blanche Moreau. Pure white, good size; very well mosserl. Crested. Rosy pink, paler edges, well mosser.

\section{PROVENCE ROSES.}

Each, .50; doz., $\$ 4.00$.

York and Lancaster. The celebrated red and white striped rose so popular in England.

Centifolia or Cabbage. Pale pink; very fragrant; was popular in Colonial times.

\section{ROSA RUGOSA. Japanese Roses. Each, .50; doz., $\$ 4.00$.}

These are excellent for planting in shrubberies, as they make large bushes and the fruit pods produced after flowering a handsome and attractive.

Alba. Single pure white flower; large and very sweet, with retreshing green foliage; vigorous.

Coubert White. Lovely double white flower:

Conrad Ferdinand de Meyer. Fragrant pink fowers, dhuble. Rubra. Deep rose, shaded violet; a red variety of the Alhat

\section{SINGLE ROSE.}

Each, .50; doz., \$5.00.

Rosa Setigera. The bramble-leaved rose; small pink Hower, and landsume foliage in autumn; vigorons.

\section{TREE ROSES.}

These are grafted on hardy stems about $t$ feest in height. Liveh, $\$ 1.00$; six for $\$ 5.00$; doz., $\$ 10.00$.

Caroline Testout. Bright rose-pink, full and fragrant.

Frau Karl Drusehki. Beautiful pure white. Madame Gabriele Luizet. Fine satiny rose.

Ulrich Brunner. Cerise red; large blown.

CHINA ROSE.

Each, .35; doz., $\$ 3.50$.

Hermosa or Armosa. Pale pink similar to C'ommon ('hina, but inore double; effective for masiny. 


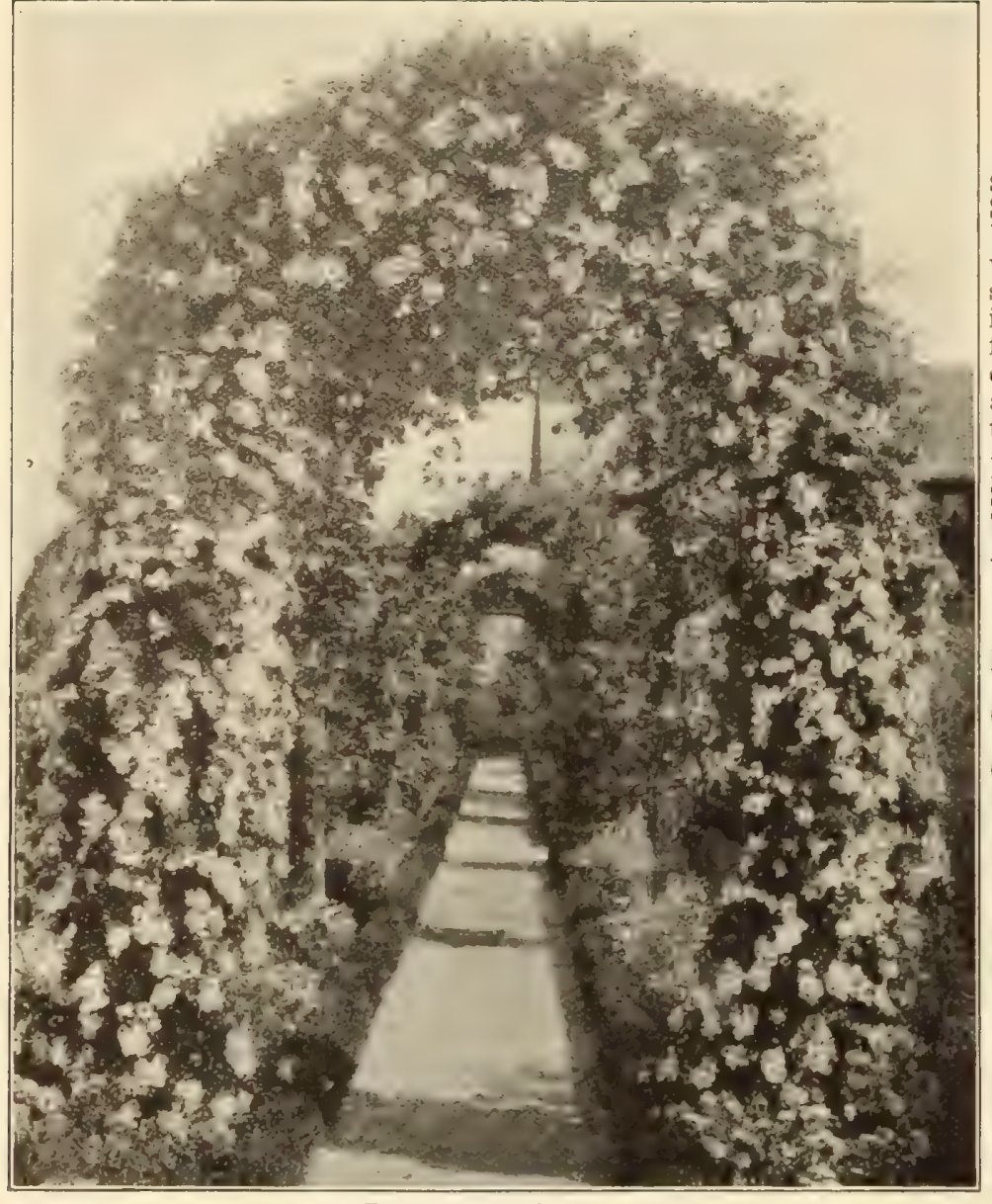

The Farquhar Rose.

Hiawatha. One of the loteliest single climbing roses, flowers intense crimson. Each, $1 .(x)$; de\%. \$9.(x)

Crimson Rambler. Polyantha, loright crimson flowers, proluced in large clusters of pyramidal form; a grand variety for pillar and arehes: it also makes a fine am attractive herlget. Flowering plants. Each, $25 ;$ do\%, $\$ 2.50$. Extra large plants. Fach, .50; doz., \$5.00.

Gloire de Dijon. Tea, buff, orange entre, very large and double, the first $t$ (1) flower, and ketese on to the very last; the liardiest of all Teas, and very sweet scented; good in any position either as a Standard, Bush or Climber. Each, .50; doz., \$5.00.

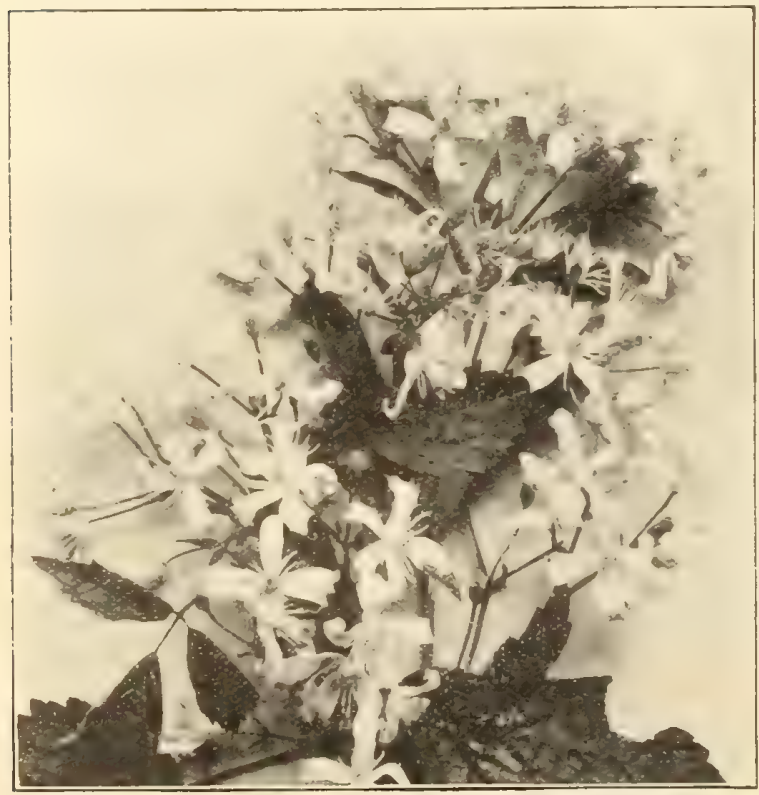

Clematis heracleafolia

\section{HARDY CLIMBING ROSES. THE FARQUHAR.}

A magnifleent Pink Climbing Rose, awarded the silver gilt medal of the Massachusetts Horticultural Society; certifleated by the Horticultural Society, New York. The Farquhar Rose has glossy, bright green foliage which does not drop, and retains its lustre until cut down by severe frost in November or December, a feature which makes it most valuable for covering trellises, pillars, summor houses, fences and rocks. It is perfectly hardy. It bears magnificent clusters of bright pink double flowers on long stems, which are most serviceable for vases and table decorations, while the individual flowers are useful for bouquets and designs.

First Size Plants

Second Size Plants

Each, \$1.00. Doz., \$10.00

. 750.7 .60

Third Size Plants ... $\ldots$. " " $\quad .50$. " 5.00

Aglaia. Bright yellow small full flowers, produced in pyramidal clusters of from fifty to a hundred blossoms: better known as the Yellow Rambler, and is best on pillars and arches. Each, .50; doz. \$5.00.

Baltimore Belle. Pale blush, turning to white; blooms in clusters. Each, .50; doz., $\$ 5.00$.

Queen of Prairie. Flowers double, red, and in elusters One of the best. Each, .50; doz., \$5.00.

Carmine Pillar. Single, bright rosy carmine, free bloomer, flowers produced all up the stems; specially good for pillars and arches, Each, .50; doz., \$5.00.

Lady Gay. The flowers are of a delicate cherry pink color which fades to a soft white. The foliage is very profuse and of a glossy deep green shade. Field-grown plants. Each, .50. Extra strong plants. Each, \$1.00.

Debutante. A beautiful new rambler, bearing clusters of soft pink double flowers having a sweet briar fragrance, and especially suited for climbing or trailing. Each, $\$ 1.00$; doz., \$9.00.

Dorothy Perkins. A fine variety of the Rambler Rose with large clusters of shell pink flowers. The plant is vigorous in growth and perfectly hardy. Each, .50; doz., \$5.00.

Sweet-heart. It is a strong grower with glossy, dark green foliage. The flower bukd are bright pink; the blossoms, however, open white, very double; fragrant. Each, $\$ 1.00$; doz. $\$ 9.00$.

Dawson Rose. Polyantha, brilliant rosy pink, flowering in larye clusters, with dark erreen foliage. Each, .30; doz., $53.00 ; 100$, $\$ 20.00$.

Marechal Niel. Noisette, bright rich golden yellow; extra large, full and fine form; the finest yellow rose; with splendid foliagt. Excellent for conservatory or greenhouse use. Each, \$2.00.

William Allen Richardson. Noirette, very deep orange yellow; small but showy and distinct thomer; a grand rariety of most attractive color. Each, .50; doz., $\$ 5.00$.
Tausendsehon. Beautiful deep rosy pink flowers, each about two inches in diameter, in large clusters; free growing and very floriferous - ? grand trellis rose. Each, .75; dozen, $\$ 7.50$. Larger plants, each, $\$ 1.00$; dozeu, $\$ 10.00$

CLEMATIS HERACLERFOLIA. A new vigorous-growing climber, with luxuriant dark-green foliage and clusters of beautiful light violet-blue flowers during August. Field-grown plants, each, .75; doz., \$7.50. Potgrown plants, each, $\$ 1.00$; doz., $\$ 10.00$.

\section{POT GROWN VINES AND ROSES.}

We have prepared an excellent stock of these this season, suitable for transferring to the open ground from May to July, when field-grown stock cannot be transplanted with safety. We especially recommend this stock for planting in summer-resort localities north of Boston, where it may be inconvenient to plant before June. For list of varieties see our Mid-Summer Catalogue, ready June 1st. 
R. \& J. FARQUHAR \& CO., BOSTON. HARDY VINES,

\section{HARDY VINES.}

Actinidia Arguta. Japanese climber of vigorous growth, dark green, shining foliage and white flowers, with purple centres, which are followed by clusters of edible fruit. Excellent for covering arbors, trellises, etc. Each, .50; doz., \$5.00.

Akebia quinata. A rapid climber of dense growth, with rich green, clover-like foliage and pendulous clusters of dark purple flowers, borne at the opening of the foliage. Each, 35 ; doz. 83.50 .

Ampelopsis quinquefolia (Tirginia Creeper, or IVoodbine). Well-known climber, with broad, deeply cut foliage of a pleasing shade of green, taking on most brilliant autumn coloring. Each, .25; doz., \$2.50. Quinquefolia, var. Englemannii. Choice variety, with small, glossy green foliage, and disk-like tendrils, which enable the rines to attach themselves to stone and woodwork. Particularly desirable where the Boston Iry is not sufficiently hardy. Each, .35; doz., \$3.50.

Veitchii (Japanese or Boston Iry). A charming vine, with handsome, glossy green, deeply lobed foliage, assuming a most brilliant autumnal coloring, and with the habit of attaching itself firmly and closely to stonework, thus enabling it to completely cover the face of the building. One year plants. Each, .25; doz., $\$ 2.00 ; 100, \$ 12.00$. Two year plants. Each. .40; doz., $\$ 3.00 ; 100, \$ 20.00$.

Aristoloehia Sipho (Dutchman's Pipe). A beautiful vine of strong growth, with showy, broad, and handsome heart-shaped, light green leaves, which overlap each other and make a perfect screen. The inconspicuous green and purple flowers are very curious in their resemblance to a Dutch pipe. Each, $\$ 1.00 ; \mathrm{doz}$., $\$ 10.00$.

Bignonia Radicans (Trumpet Creeper.) For covering unsightly places, stumps and rockwork. The flowers are large and attractive; dark red, orange throat; free blooming and very hardy. Each, .25; doz., \$2.50

Celastrus seandens (Roxbury Wax Work). Ovate, glossy green foliage, turning bright yellow in the autumn. Showy, drooping clusters of orange and scarlet fruits in fall, and clinging to the branches throughout the winter. Unique alike in foliage and in fruit. Each, .35; doz., \$3.50.

Clematis Cripsa. Of moderate growth, with glossy green foliage and nodding, thick-petaled, starry, lavender-blue flowers, fragrant. Each, .35; doz., \$3.50.

Coceinea. Nodding, bell-shaped brilliant scarlet and orange flowers; blooms constantly through the summer. Each, .35; doz., $\$ 3.50$.

Henryi. Pure white, broad-petaled flowers, often ten inches across; constant bloomer. Each, .75.

Jackmanni, var. alba. Pure white variety. Each, .75.

Jackmanni. Produces large, deep violet-purple, broad-petaled flowers. Each, .75.

Mad. Edouard Andre. The richest dark crimson variety; very handsome. Each, .75.

Miss Bateman. Showy, large white flowers. Each, .75.

Heracleæfolia. Massive deep green foliage and clusters of pale blue flowers; July and August. $10 \mathrm{ft}$. Each, .50; doz, $\$ 50.00$. Extra large plants, each $\$ 1.00 ;$ doz., $\$ 10.00$.

Paniculata (Japanese). Rapid grower, quickly covering trellises with a dense mass of handsome compound, glossy, dark green foliage, and bearing in late summer an immense profusion of pure white, fragrant starry flowers, quite hiding the foliage. Perfectly hardy, and adapted to all soils. Flowering plants. Each, .25; doz., \$2.50; 100,\$16.00. Extra large, each, .50; doz., \$5.00.

Euonymus Radicans. Japanese evergreen trailer with dark glossy green, dense foliage. A moderate climber, particularly desirable for clothing the foundations of houses and rockwork 3 years old. Each, .25; doz., \$2.50; 100, $\$ 15.00$.

Radicans, var. variegata. A rare form, with foliage handsomely variegated with green, silver and pink. Each, .30; doz., $\$ 3.00 ; 100, \$ 20.00$.

Hedera Helix (English I'y). This well-known climber is desirable where an evergreen climber is required, but requires sheltered, shady situations to succeed best. Foliage broad, thick, dark glossy green. 3 to $4 \mathrm{ft}$, each, .50; doz., $\$ 1.00$. 4 to $5 \mathrm{ft}$., each,
$\$ 1.00$; doz., $\$ 8.00$. 6 to $8 \mathrm{ft}$, extra strong in pots, each, $\$ 2.00$.

Hop vine (Humulus lupulus). A very desirable hardy climber of rapid growth suitable for covering unsightly places. Each, 25 ; doz.. $\$ 2.50$.

Lonicera Brachypoda, var. aurea reticulata (Golden Honeysuckle). A beautiful sort, foliage handsomely marbled with gold, often showing tinges of pink in its young growth. Each, doz., $\$ 3.50$

Brachypoda, var. Halleana (Hall's Honeysuckle). A charming climber, of rapid dense growth with oral, soft green, persistent foliage and a constant succession throughout the summer of extremely fragrant white and yellow flowers borne in showy clusters. One of the finest for covering trellises and walls. Each, .25; doz. $\$ 2.50 ; 100, \$ 15.00$

Belgiea (Monthly Honeysuckle). Thick, oval, glossy green foliage and a nearly continuous succession of clusters of showy, fragrant yellow flowers. Each, .30; doz., \$3.00.

Heckrothi. Deep red flowers with yellow throat; continuou: bloomer. Each, .35; doz., \$3.50.

Sempervirens (Scarlet Trumpet Honeysuckle). Vigorons climber dark green, oval foliage, bright vermillion, tubular flowers blossoms almost constantly. Each, .50; doz., $\$ 5.00$.

Lycium Chinensis (Matrimony Tine). A vigorous species, with large light green foliage and pale purple flowers, followed by large, pendulous showy orange and scarlet fruits, borne along the lengtl of the branches. Each, .25; doz., \$2.50.

Periploca Græca. A rapid growing vine, often growing 10 to 20 ft. in a season. Of slender growth, with lanceolate, rich. dark shining green foliage and small clusters of purple flowers. Each, .50; doz., \$5.00.

Sehizophragma Hydrangeoides (Climbing Hydranger). A tine hardy climber from Japan with large trusses of white flowers similar to the Hydrangea. Each, \$2.00.

Wistaria Chinensis (Chinese Wistaria). A strong, rapid-growin vine with light green compound foliage of an evergrem nature an light blue, pea-shaped flowers, borne in very dense, long. pen
dulons racemes in advance of the opening of the foliage. Each, $.75:$ doz.. 8750

Chinensis, var. alba (White Chines Wistarin.) Fach. 81.00 doz.. 810.00 . 
R. \& J. FARQUHAR \& CO., BOSTON. RHODODENDRONS.

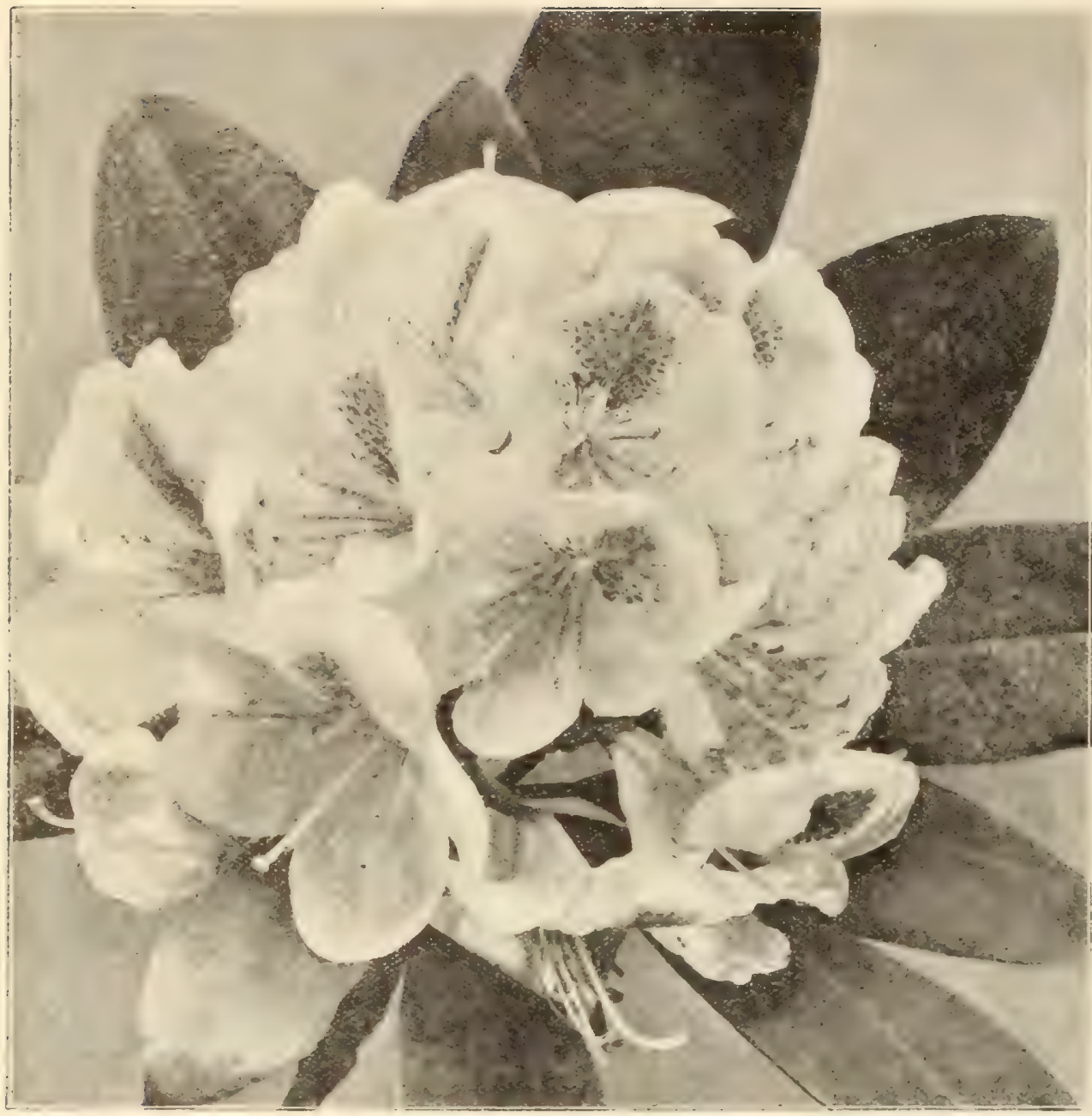

Hardy Hybrid Rhododendron.

\section{RHODODENDRONS.}

Hardy English Hybrids.

We import annually a large assortment of the best English-grown, large-flowering, hardy sorts. These are the most satisfactory of all Rhododendrons for general planting, for lawn groups and for borders near the residence. The colors are brilliant, running chiefly in white, pink, rose, scarlet, and crimson. Fine plants, each, \$1.50; doz., \$18.00; $100, \$ 125.00$. Larger plants, each, $\$ 2.50 ;$ doz., $\$ 25.00 ; 100, \$ 200.00$. Specimen plants, each, $\$ 3.50$ and upwards; doz., $\$ 36.00$ and upwards, according to size.

\section{RHODODENDRONS.}

\section{NATIVE VARIETIES.}

Maximum. Suitable for clumps in shady or partially shady situations. also useful to form backgrounds for R. Catawbiense and the Hardy Hybrid sorts. Plants, 3 feet, bushy, each, $\$ 2.50$; doz., $\$ 25.00$. 4 to 5 feet, bushy, each, $\$ 4.00$ to $\$ 5.00$; doz., $\$ 40.00$ to $\$ 50.00$. Carload price on application.

\section{KALMIA LATIFOLIA.}

Mountain Laurel.

Flowering plants, each, .75; do\%, 87.50. Large imported plants, earh, $\$ 1.00$; doz., $\$ 10.00$. Extra large imported plants, each, $\$ 1.50$; doz., $\$ 15.00$.

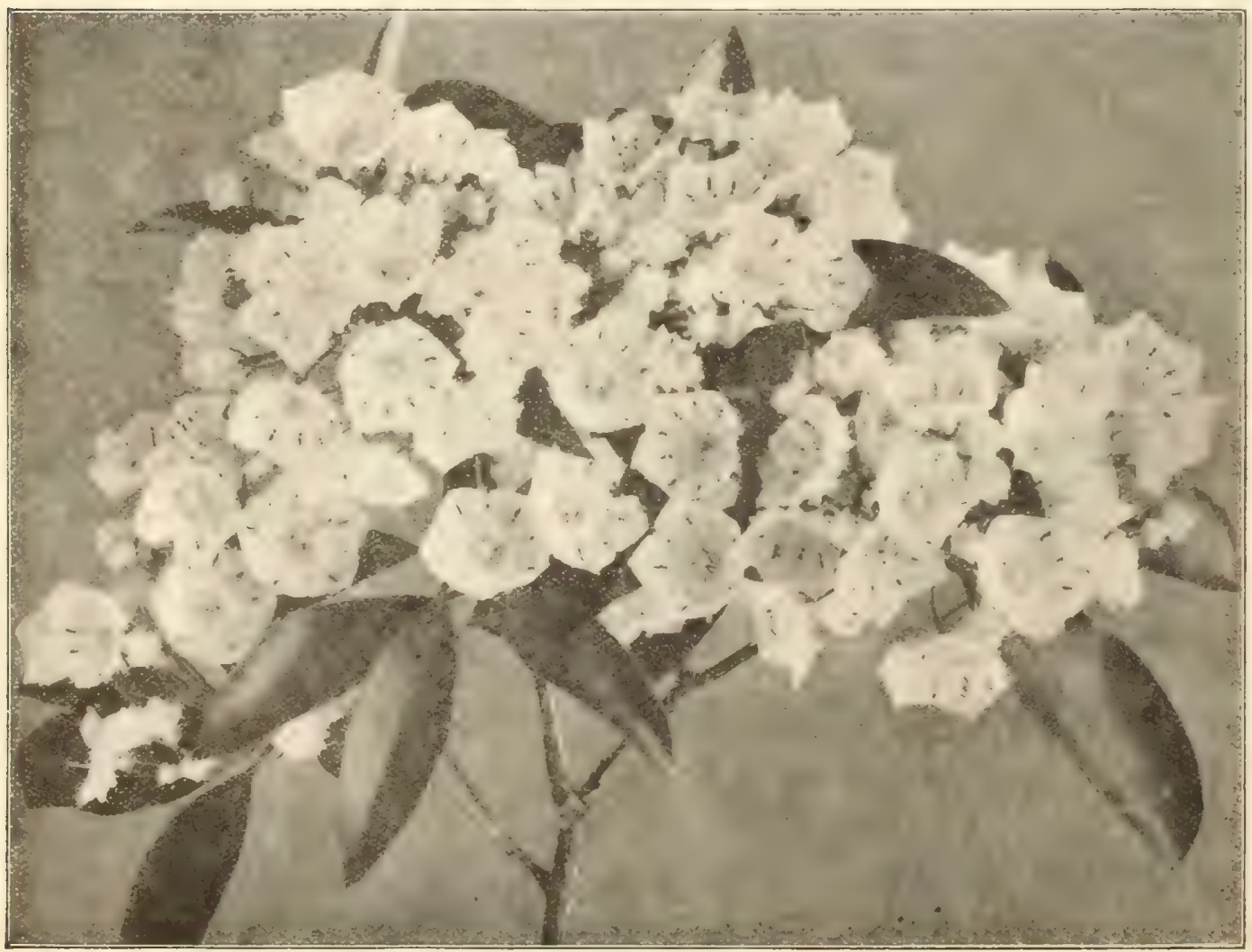

PLANTING AND IMPROVEMENT OF PRIVATE ESTATES AND PUBLIC GROUNDS.

We have a large assortment of the best Hardy Nursery Stock suitable for the Northern States. We invite correspondence from those contemplating improvements or additional plantations of hardy trees, shrubs, vines, and perennial plants. We can also furnish competent gardeners to earry out such work. 


\section{HARDY ORNAMENTAL SHRUBS.}

Almond, Double Pink. May. Each, .35 - - White. May. Each. .35

Althea. Purple, red, or white. September. Each, .85, - Variegated Foliaged. Each, .50 .

- Meehani. In this new variety the variegation of the foliage is even more beautiful than in the old form. Each, $\$ 1.00$.

Amorpha fruticosa. False Indigo. A strong growing *hrub with spikes of indigo-colored flowers; June. Each, .25

- eanescens. Lead' Plant. A dense growing shruh producing an abundance of flowers of a blue color borne on terminal spikes. Each, .25

Aralia pentaphylla. A beautiful Japanese shrub of rapid growth, branches furnished with spines, leares palmate, fire lobed and pale green. Each, .40

Azalea Pontiea, or Hardy Ghent. Milniticent lillw. flowering hybrids in rarious fine colors; Jume. Each, $\$ 1.00$, -Mollis. Large, showr, fragrant. Each,.75

- Larger Plants. Each $\$ 1.00$ to $\$ 2.50$.

-arborescens. Native, white, fragrant variety: : ceeds best in partial shade: June. Each, .60

- Calendulacea. Native yellow. Each. .60 .

- Vaseyi. Fornas a compact bush. corered in oluly with brilliant pink blossoms. Eitch, $\$ 1.00$

Baceharis balmifolia. Feathery white flowers. September. Each, .35

Berberis purpurea. Dark purple foliage. Each, .25 ...

- Thunbergil. Japanese Baiberm. Dwarf, handsum. shining foliage; June. Each, .25

- Vulgaris. Common Barberry. June, Each, .25

Buddleya variabilis. This beautiful new shrub grows from four to five feet high and produces throughout the summer and fall long racemes of rosy lilac flowers with orange centres. Each, .50

Calyeanthus flopidus. Spice Bush. Brown flowers; fragrant; June to September. Ear.h. ....)

Caragana arboreseens. Siberian Pea. An interesting shrub, flowers rellow, pea-shaped: May. Each, .35

Chionanthus virginieus. Fringe Tree. White. Jume. Each. .75.

Clethra alnifolia. Sureet Peyper Bush. White; intensely iragrant; very fine. Each, .355...

Colutea arborescens. Blndder Senna. A handsome and interesting shrub; its bright yellow flowers and large transparent seed pods appearing throughout the summer. Each, .25.

Corehorus, or Kerpia Japonieus flore pleno. Double orange-yellow; June and July. Each, .85

- - variegata. Green and white foliage. Each, .35.

Cornus florida. Dogunor. Large, open, white flowers; Iay. Each, .50

- alba. Red Osier. Bark deep red. Each, .35

- sanguinea. Red bark. Each, .35 ...

- sibirica. Scarlet Doguood. Bark scarlet. Each, .35,

- stolonifera. Red-trigged Dogurood. Each, .35

- Mas, or Mascula. Cornelian Cherry. A very attractive shrub with bright yellow flowers early in spring and shining scarlet fruit in the autumn. Each, .50

- paniculata. Gray Doguood. A very free flowering variety, with white fruits on red penduncles in fall. Eacl, .35,

Daphne Cneorum. A pretty dwarf spreading shrub, prolucing bright pink, sweet scented flowers in May. Excellent for planting in rockeries. Each, .75

Desmodium penduliflorum. Sweet Pea Shmu. Red and violet pea-shaped flowers; Autumn. Each, .50

Deutzia erenata fl. pl. Pride of Rochester. Double, white, very beautiful; June. Each, .35 ... ... ... - - - rosea. Double pink. Each, .35

- gracilis. White; very free; dwarf; Jume. Each, 35 , - Lemoineil. An excellent hardy shrub, producing pure white flowers, borne on stout branches, which are of upright growth. Habit, dwarf and free flowering. Each,
$\$ 3.00$

3.00

3.50

$+.00$

2.5

2.5)

3.00

10.00

7.50

6. 00

6.110

10.00

3.00

2,511

2. ज्ञा

…네

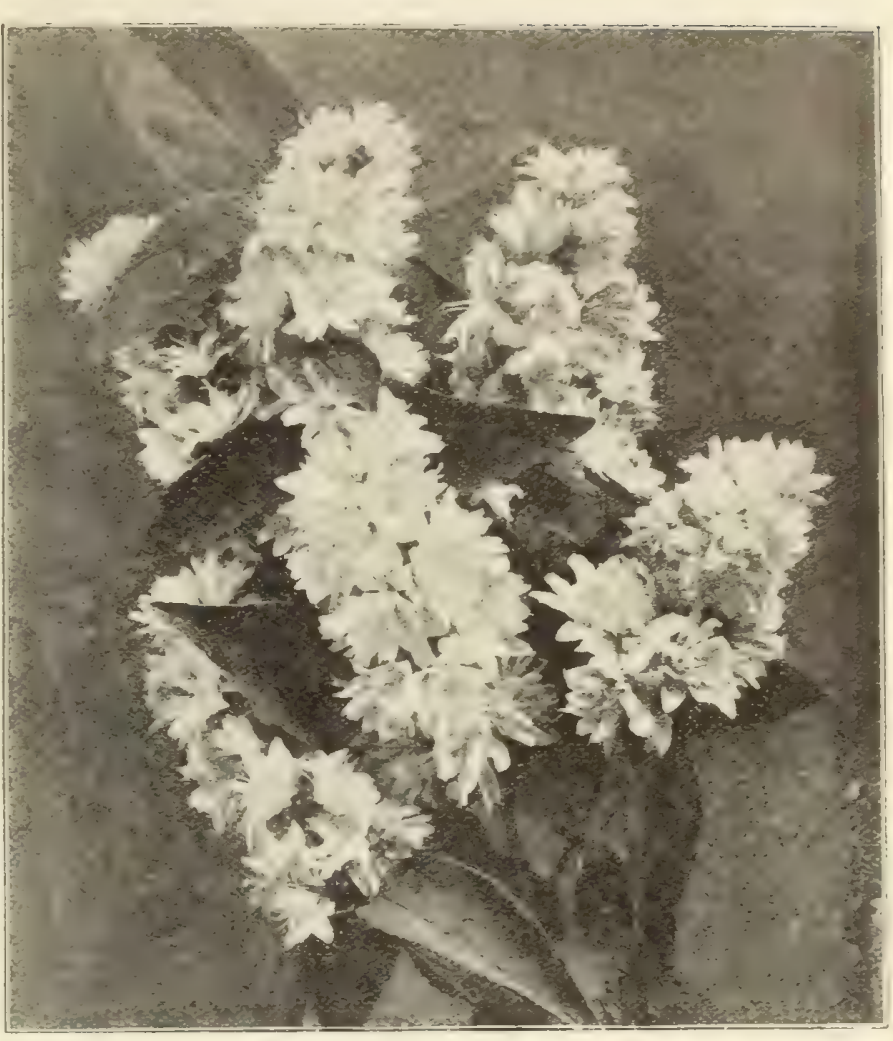

Deutzia, Pride of Rochester.

3. 511

3.511

$3 . .50$

b.(II)

3.50

Eleagnus Longipes. Orange red fruit, edil)le. Each, .50, $\$ 4.00$

Euonymus Europæus. Burning Bush. Purple; in clu:-

ters: June. Faclu, .35

Exochorda grandiflora. Perrl Bush. One of the finest shrubs, with numerous loose clusters of pure white, starry flowers. Highly recommended; May. Each, .50

3.50

Forsythia Fortunei. Trright growing; golden yellow; free; May. Each, .35

- suspensa. Wepping Golden Bell. Pendulous habit, covered with yellow drooping flowers; April. Each, .35, - viridissima. A more compact variety than the preceding with deep green bark and flomering somewhat later. Each, .35

Halesia tetraptera. Snoudrop Tree. A beautiful larg shrub with white bell-shaped flowers borne in protusion May. Each, .35.

5.00

3.511

3.511

3.511

:3.5.1)

4.00

Hydrangea paniculata. The original form of Hardy Hydrangea brought from Japan. The flowers are less dense, more ereet, and more graceful than the paniculate form usually seen. Fach, .35

- panieulata grandiflora. The showiest of autumu shrubs, bearing immense heads of creamy white flowers; turning to pleasing shades of red.

Flowering plants, 2 years old. Each, .35

Extra large plants, 3 years old. Fach, .50

$3.5 \%()$

Ilex verticillata. Winterbery. Beantiful urange

berries which renain during winter. Fiach. .35

Itea Virginica. A pretty native shrub producing racemes of pure white flowers; June. Each, .35

(i. ()()

$+.110$

Lilae, Common Purple. Syminga. Tery fragrant; May.

Erich, .t0.

- Common White. Fragrant; May. Each. .อั0

$5 .(x)$

3.50

3.50

3.00

- Charles X. Reddish purple; trusses large, vigorous

Eideh, .50

- Madame Lemoine. Double, white. Eich. .50)

- Marie Legraye. The finest white sort. Eivh. .5il.

- Persian Pink. Large and tine. Fach. in! . .

- White. Wach, .50 


\section{R. \& J. FAR̃.QUHAR \& CO., BOSTON. HARDY SHRUBS.}

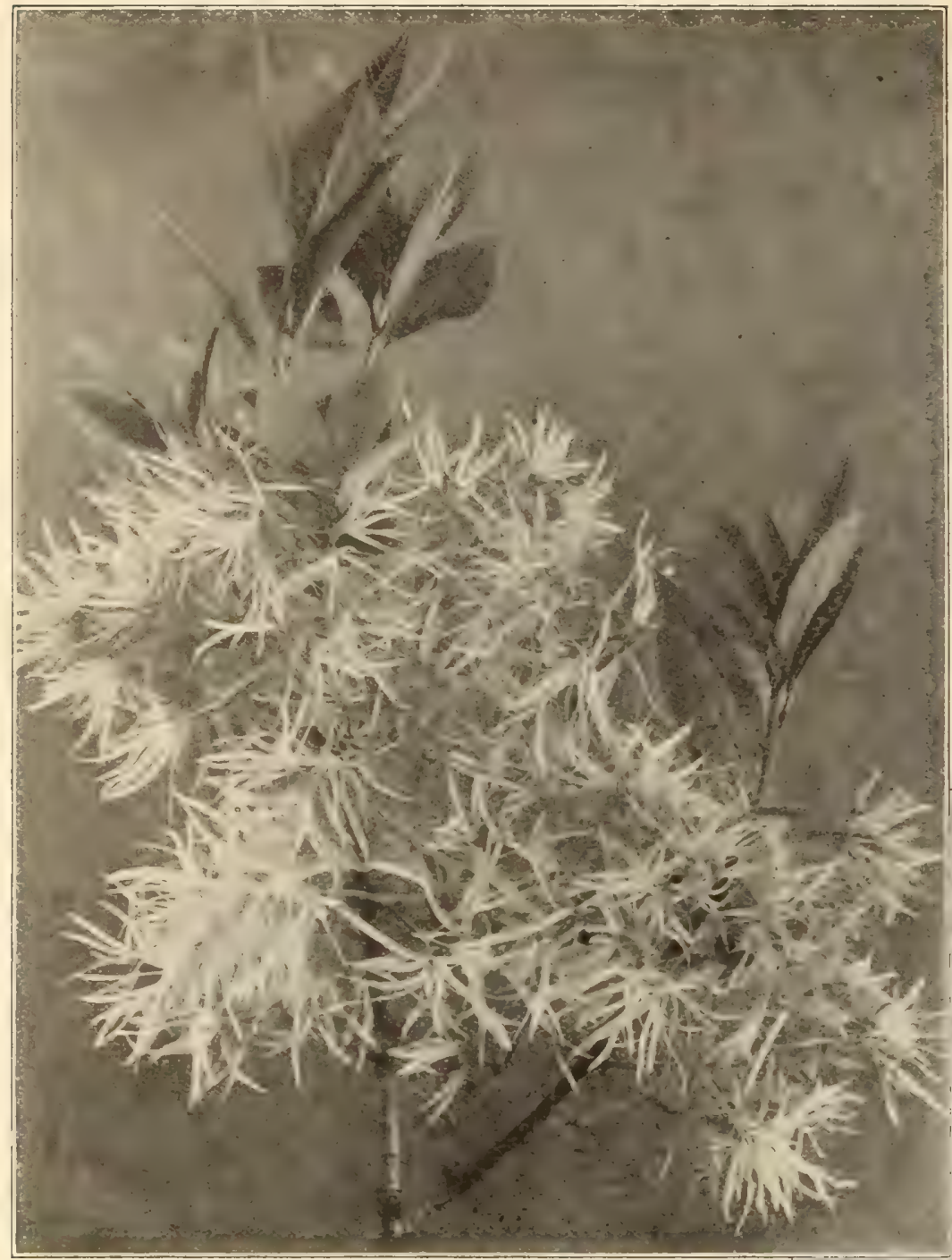

Spirea arguta. This variety rescmbles the S. Thunbergii, but of stronger growth, and is one of the earliest white sorts; May. Each, $.35 \ldots$.... $\cdots$ A $\cdots$ dwarf Japanese variety of vigorous growth. Flowers pink; July. Each, $.35 \quad \ldots \quad \ldots, \quad \ldots \quad \ldots$... - callosa. Deep rose, grows freely, and flowers nearly all summer. Each, .35

- - alba. White. May. Each, .35

- Anthony Waterer. Brilliant rosy carmine flowers in dense clusters. Each, .50

- opulifolia. Strong growing shrub, with white flowers along the stems. Useful for screening purposes. Each, .35

- - aurea. White flowers in clusters; golden foliage; May. Each, .35 ...

- prunifolia flore pleno. Bridal Wrealh. Double white; very free; May. Each, .35

- Reevesii fl. pl. White double flowers.

Each, 35 . Thunbergii. Very ornamental, narrow, willow-like foliage; flowers white. Each, .35. - Van Houttei. One of the finest shrubs; pendulous; pure white flowers in clusters. Each, .35 … … … Each, ..50

\section{LILAC.-Continued.}

- Rothmagensis. Rouen Lilac. mense flower trusses. Each. .50

- Souvenip de Louis Spaeth. Dark purplish red. Each, .75

Lonicera Tatariea. Bush Honeysuckle. Pink; sweet scented; May. Each, .35

- Moprowii. White flowers in May, followed by bright red fruit during summer and autumn. Each, .35 ...

- Ruprechta. Large deep pink flowers in May. Large red fruit. Each, .35

Privet California. Glossy foliage, almost evergreen. Each, .25

Privet Chinese. Ligustrum Ibota. A very hardy shrub from China with dark shining green foliage and pure white flowers, sweetly scented. Invaluable for hedges. Each, .25

Prunus Pissardi. Purple-Leaved Plum. Each, .50 . . - triloba. Double pink flowers; May. Each, .75;

Pypus angustifolia. Bechtels Double Flowering Crab. Each, $\$ 1.00$

Rhodotypus Kerrioides. White Kerria. A bushy shrub with snow white flowers; May. Each, .35

Rhus Cotinus. Smoke Bush. A tall shrub bearing clusters of smoke-colored flowers in June. In fall the leaves change to shades of brown, red and yellow. Each, .50;

Ribes aureum. Yellow Currant. Each, .25 . - sanguineum. Red. Each, .25

Sambueus aurea. Golden Elder. Each, .35

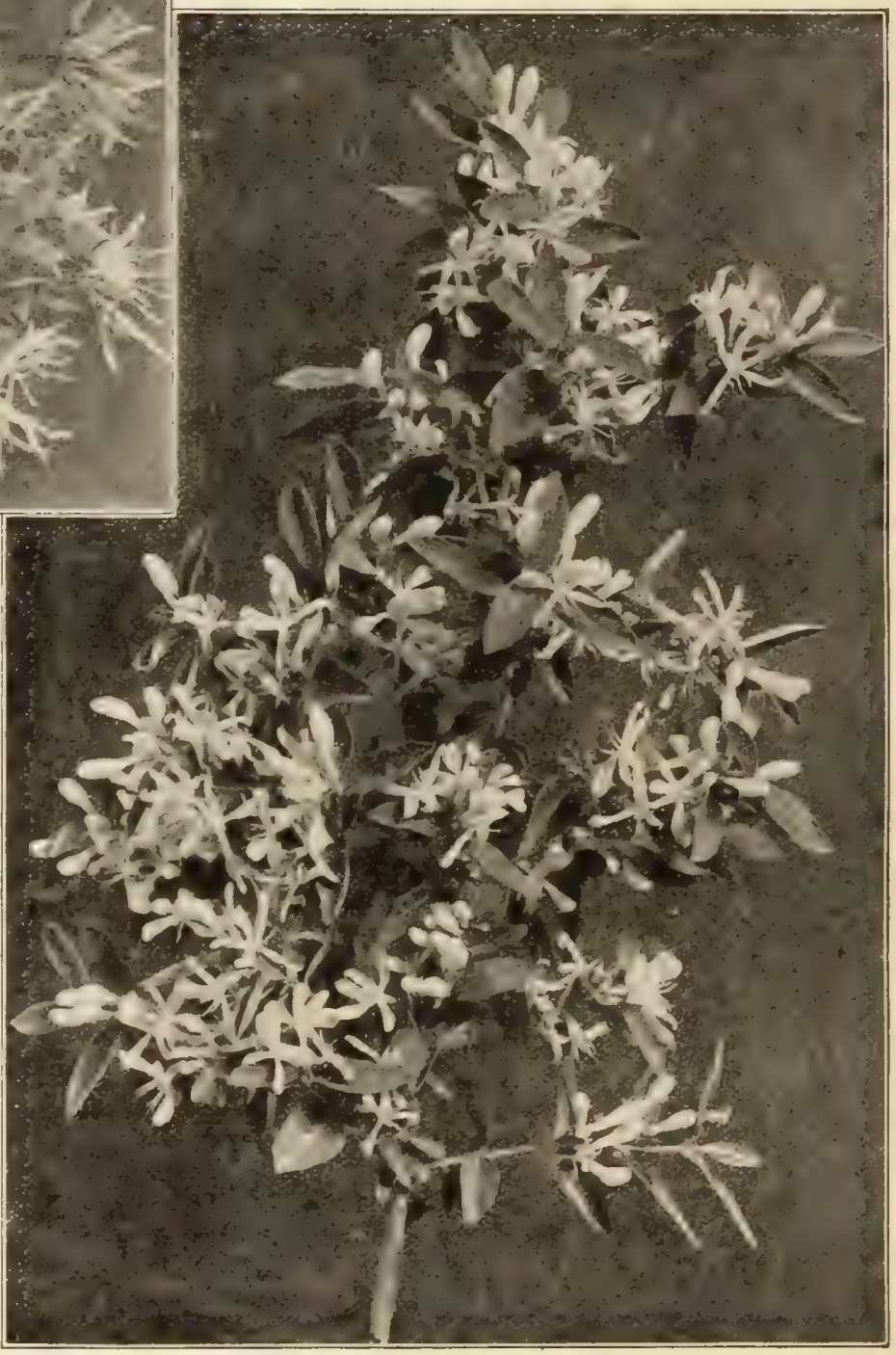

Lonicera Morrowi. Bush Honeysuckle.

Stephanandra flexuosa. Erect growing shrub with elegant fern-like foliage. Each, .35 
R. \& J. FARQUHAR \& CO., BOSTON. HARDY SHRUBS.

Syringa, Golden. Philadelphus aurea. Foliage golden yellow; fine; June. Each, . 35 ... ... ... - Lemoinei. Small, white, fragrant flowers; June. Each, .35 … … … … … W . fragrant, orange-like flowers; June. Each, .35 - Large Flowered. Each, .35

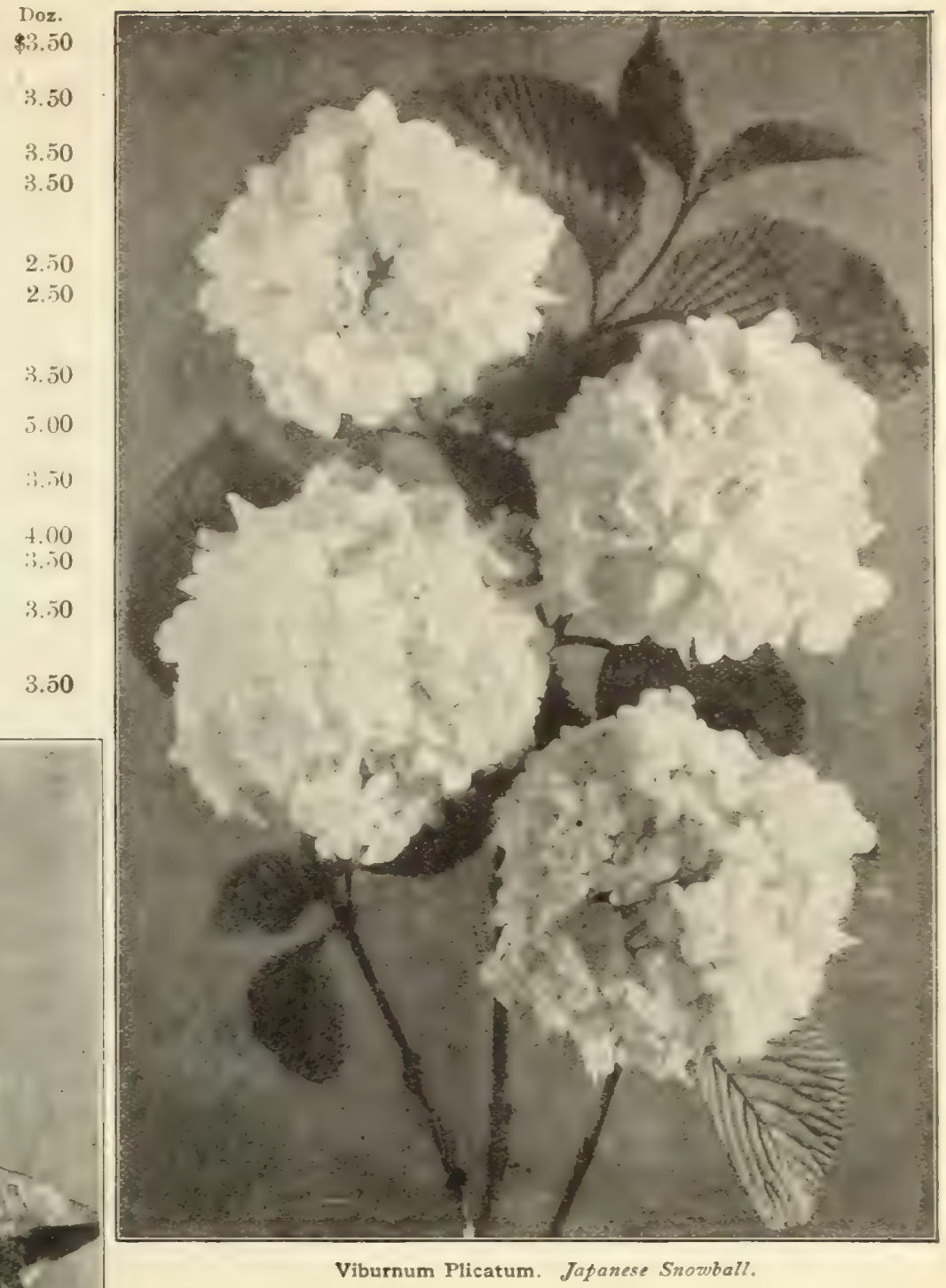

Symphoricarpus racemosus. Snoubery. Flower pink with pure white berries in the fall; July. Each, .25

- vulgaris. Coral Berry. Dark red berries. Each, .25,

Tamarix Africana. Trmarisk. Very graceful shrub of rigorous growth with slender feathery branches and delicate pale pink flowers. Each, .35

Viburnum Lentago. Flowers creamy white, fragrant glossy green leaves. Each, .50

- Molle. A fine native shrub, with rich green foliage, and clusters of blue fruit. Each, .35

-Cassinoides. Rich foliage, flowers white; May and June. Each, .40 ... ... ... ... - dentatum. Clusters of deep blue berries. Each, .35, - opulus. Snowball or Guelder Rose. Handsome in flower and in fruit. Each, .35

- opulus sterilis. Common Snowball. A well-knowr tall growing shrub with large snowball-like flowers; May. Each, .35

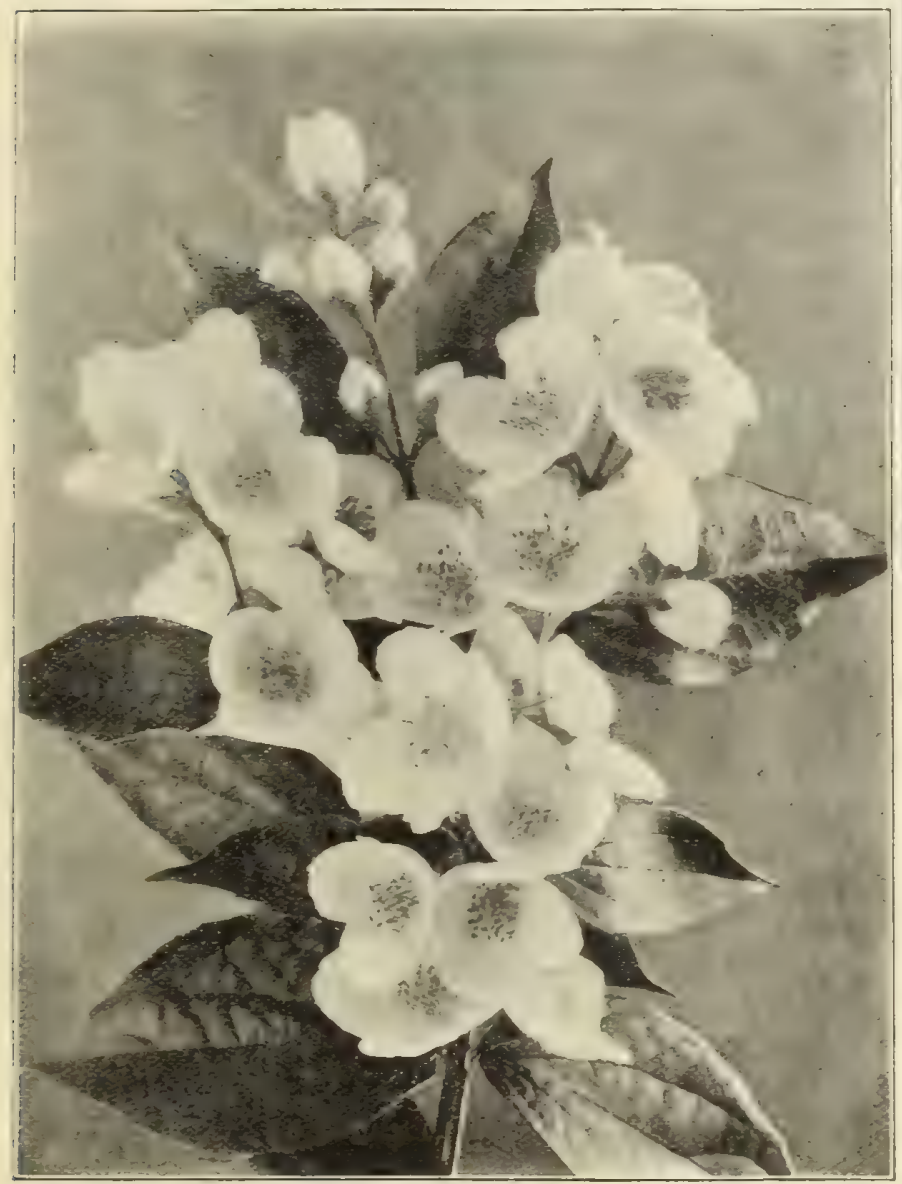

Syringa, Large-flowered.

- plicatum. Japanese Snouball. Pure white flowers in Dos. large round trusses. One of the choicest hardy shrubs on

- var. tomentosum. Pure white, free flower; the single form of the popular Japanese Snowball. Each, .75, Weigelia Abel Carrier. Bright crimson. Each, .50, - Eva Rathke. Fine deep crimson flowers; June to October. Each. .50

- rosea. Large rose flotrers; June. Each, .35

- variegata. Pink, foliage variegated. Each, .35,

Xanthoriza apiifolia. Splendid dwarf spreading shrub

with green feathery foliage. Each, 30

Mr. John Durkin, Bayshore, L.I., N. Y., writes:- "The plants and shrubs I got from you last spring have done remarkably well."

\section{HEDGE PLANTS AND PLANTS FOR HEDGEROWS.}

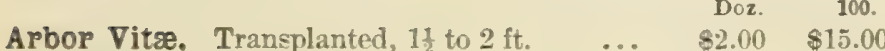

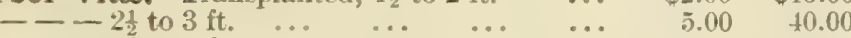

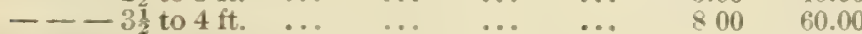

Barberry, Common. $1 \frac{1}{2}$ to $2 \mathrm{ft}$. $\ldots . \quad \ldots \quad 1.50 \quad 10.00$

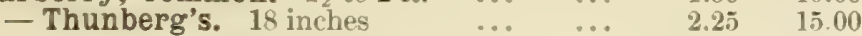

Hemlock Spruce. 2 to $3 \mathrm{ft}$. $\quad$... $\quad \ldots .800 \quad 8000$

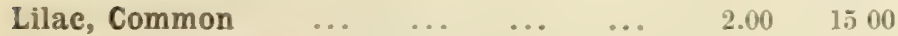

Norway Spruce. $1 \frac{1}{2}$ to $2 \mathrm{ft}$.
Norway Spruce. $2 \frac{1}{2}$ to $3 \mathrm{ft}$.

- $3 \frac{1}{2}$ to $4 \mathrm{ft}$.

Privet, California. $\ddot{i}$ to $1 \frac{1}{\mathrm{ft}}$.

- Chinese. Liqusirum Iboì.

3 years. 30 inches and upward $\cdots$

Rosa Rugosa
Doz.

$\$ 6.00-810.00$

$900 \quad 63.00$

$1.00 \quad 6.00$

1.501000

$200 \quad 1500$

$250 \quad 160(4)$

$+00 \quad 25 .(10)$ 


\section{R. \& J. FARQUHAR \& CO., BOSTON. HARDY CONIFERS.}

\section{HARDY CONIFERS.}

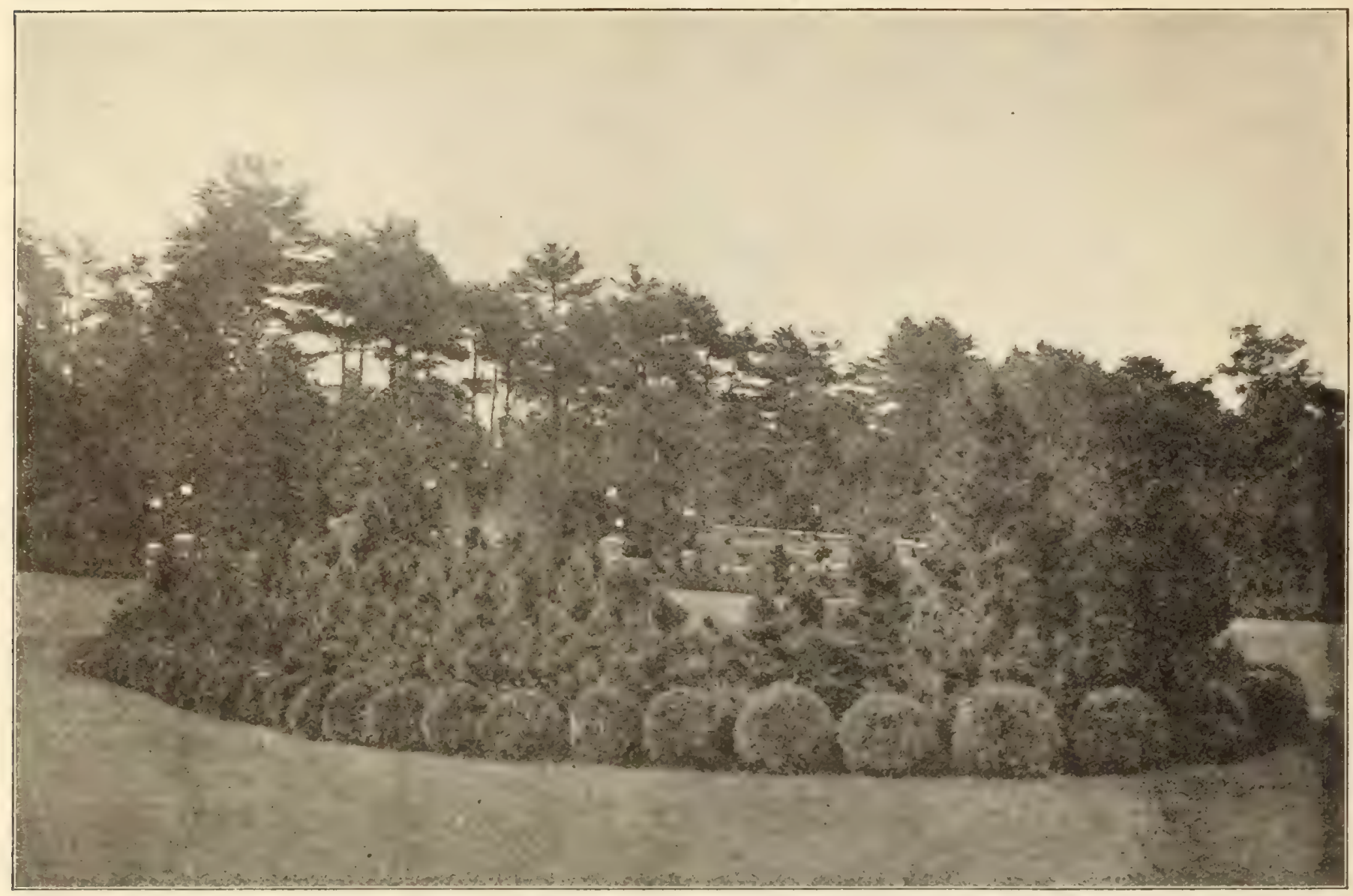

A Ciroup of Farquhar's Hardy Conifers.

ABIES alba. II7ite Spruce. Valuable for planting near the sea. 3 feet. Each, $\$ 1.00$. Sipecimens, $4 \frac{1}{2}$ to 5 feet, $\$ 2.00$

Balsamea. Bulm uf Filent Fir. Rich dark green folialge, silvery underneath. 2 to $2 \frac{3}{2}$ feet

Canadensis. Hemlock Spruce. Mark green foliage, valuable for partial shade. 3 to 4 feut

Coneolor. Colormitn Silup Fir. One of the most beautiful and graceful evergreen trees, growing in symmetrical pyramid form, with long feathery foliage of silvery gremn color which eurves upward. As a lawn specimen, it is one of the most decolative trees. 2 feet

Coneolor violacea. Foliage silvery blue. 2 feet

Excelsa. Norway Spruep. Serviceable for screens, shelter's and clumps. $2 \frac{\pi}{2}$ to 3 feet. Per doz., $\$ 600$

$3 \frac{1}{2}$ to 4 feet. Per doz., $\$ 900$

Sipecimen trees, 5 to 8 feet. $\$ 2.00$ to $\$ 5.00$ each.

Excelsa aupea. Golden Crested Smuce. The leaves on the upper sides of the shoots become golden yellow. 2 to 3 feet. Per doz, $\$ 20.00 \ldots$

Pungens Kosteriana. The finest form of Colorado Blue Spruce. One of the hardiest and choicest everoreens: foliage steel blue, $1 \frac{1}{1}$ feet, each, $\$ 2.50: 21$ feet

Larger specimens, each, $\$ 7.50$ to $\$ 50.00$.

JUNIPERUS Sueciea. Sroctish Tuniper. Grows in the form of a neat compact column; foliage golden green. $3 \frac{1}{2}$ feet. Doz. $\$ 7.50$

Japoniea aurea. Of erect conical habit; golden foliage. 2 to $2 \frac{\pi}{2}$ feet

Virginiea. Red Cedar. Well-formed, cultivated specimens of this native evergreen are highly ormamental. 2 feet. Doz., $\$ 5.00$
PINUS Austriaca. Austrinn Pine. A noble tree of papid growth with massire horizontal branches covered with long, thick, dark green foliage; very hardy. $1 \frac{1}{2}$ feet to 2 fect. Doz., $\$ 4.00$; each, 50 cents. 2 to $2 \frac{1}{2}$ feet. Do\%.. $\$ 9.00$; each, $\$ 1.00$. 3 to 4 feet, bushy. Doz., $\$ 12.00 \ldots$... Mugho. Drenf Mountain Pine. Au Alpine species extremely valuable for exposed situations, of dwarf, spreading habit, seldom over 4 feet in height. 'I'he foliage is of strong deep green color, and the branching growth of this beautiful bushy Pine makes it exceedingly desirable for lawn clumps, evergreen borders and terraces. Itis one of the best evergleens for planting near the sea. 12 to 15 inches. Broad specimens. Doz.. $\$ 8.00 \ldots \ldots \ldots$ Strobus. White or Wrymonth Pine. Useful for screens, windbreaks and backgrouuds. 3 to $3 \frac{1}{2}$ feet. Doz., $\$ 10.00$, Sylvestris. Scotch Pine. One of the best trees for exposed situations. 3 to 4 feet. Doz., $\$ 10.00$

RETINOSPORA erieoides. Folinge coppery violet, turns

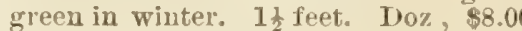

Filifera. Thread-like drooping, light green branches; pyramidal form; graceful aud beautiful. $2 \frac{1}{2}$ to 3 feet. Doz., $\$ 20.00 \ldots$

Filifera aurea. New. A golden-leaved form of the preceding. $1 \frac{1}{2}$ feet

Obtusa. A compact, pyramid tree, dark green foliage, tinted bromze. 3 to $3 \frac{1}{2}$ feet. Doz, $\$ 25.00 \ldots . . . .$. Plumosa. Forms a handsome pyramid of dense, feathery branches, fine, light green foliage. 2 feet. Doz., $\$ 6.00$; each. 75 cents. 3 feet. Doz., \$15.00; each, \$1.50. 4 feet, Doz., $\$ 25.00$.

Plumosa aurea. One of the best Evergreens, forming a pyramid of rich golden foliage which holds its color the year round. It is one of the most brilliant and hardy conifel's. $1 \frac{1}{2}$ to 2 feet. Each, 75 cents. $2 \frac{2}{2}$ to 3 feet. $.50 \mathrm{Each}, \$ 1.50$. Larger specimens, $\$ 2.00$ to $\$ 10.00$ each.

SIX OF A KIND SOLD AT DOZEN RATES.
Fiach. 
R. \& J. FARQUHAR \& CO., BOSTON. HARDY CONIFERS.

\section{HARDY CONIFERS.-Continued.}

Seiadopitys Verticillata. Japanese Limbrella Tree. A beautiful and most desirable Japanese evergreen of erect pyramidal growth with large, shining, deep green foliage in umbrella-like whorls. Protection of pine boughs or coarse matting is necessary during winter in Massachusetts. $2 \frac{1}{2}$ to 3 feet. Each 5.00. 4 foot specimens

$\$ 1200$

Thuja Oeeidentalis. American Arborrita. Extremely useful for screens. clumps or lawn specimens. I feet Doz, $\$ 9.00$

Fine specimens, 5 to 6 feet. Each, \$2.50. Smaller plants for hedges, see page 115 .

- - lutea. Nootka Sound Cypress. Yellow foliage. 2 ts $2 \frac{1}{2}$ fiet. Doz., \$2 $=0.00$

$2 \frac{1}{2}$ to 3 feet...

\section{- Elwangeriana. Yellowish. 2 to 3 feet}

- George Peabody. Golden jellow, rery hardy. 2 feet,

- - pyramidalis. Habit like the Italian Cypress. 4 feet,

- Siberica. Siberian Arboritx. Deep green; very hardy. 2 feet

- Vervæneana. A gracefully drooping, sellow-marked Arborvitze. 2 to 3 feet

Mr. Michael J. Curtin, Gardener for T. M. Adams, Esq., Lenox, Mass., Feb. 7, 1907, writes:- "Please send enclosed list as soon as possible. Everything I had from your house last year gave good satisfaction."

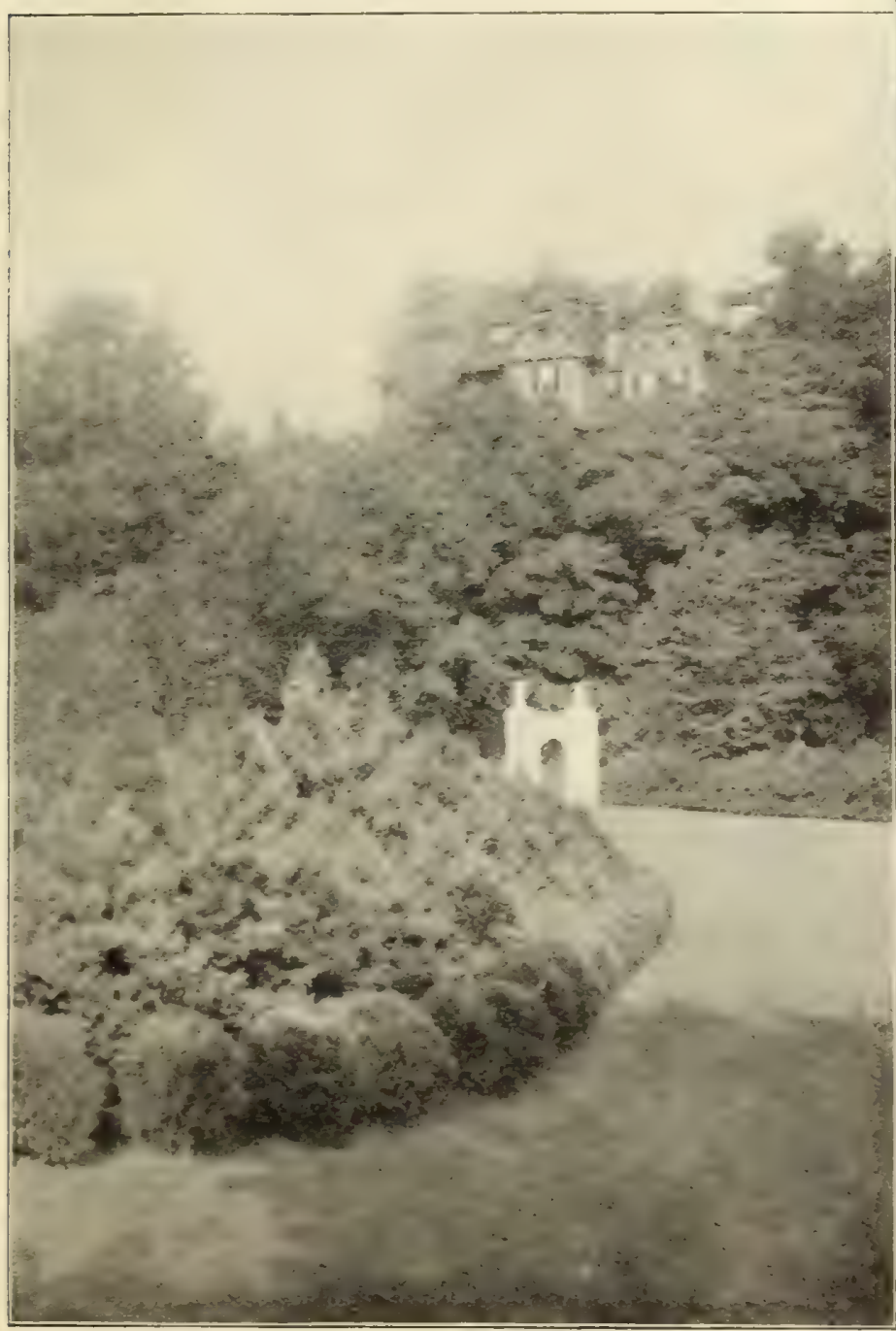

Border of Hardy Conifers.

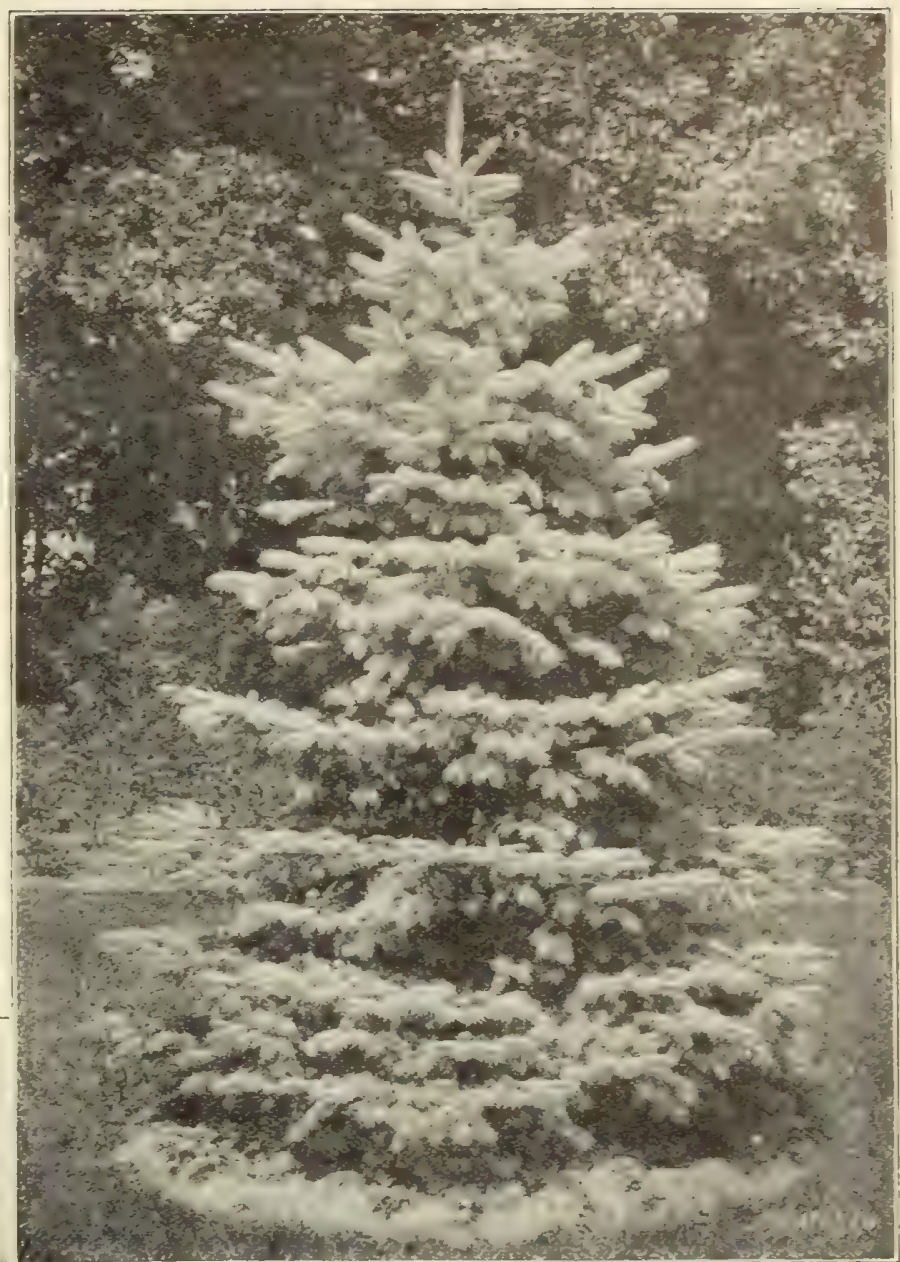

Abies pungens Kosteriana. Colorado Blue Spmuce.

We carry a large stock of specimen trees of the bluest of the Blue Spruces ranging from 3 feet to 6 feet in height. Prices, $\$ 10.00$ to $\$ 50.00$ each.

\section{Fine English Nursery Stock.}

Specimen Ornamental Trees, Shade Trees, Specimen Conifers, Hardy Evergreens of all kinds; Fruit Trees trained for walls, fruit houses and cordon rows, Speclmen Rhododendrons, Hardy Ivies, ete.

We are now U. S. Agents for the famous $\mathrm{H}_{\text {and }}$. Anorth Nurseries of Yorkshire (Messrs Fisher Son \& S1bray, Ltd.), established over 150 years ago and having at the present time about 800 acres under cultivation.

The nurseries being located in the Forth of England, the stock is very hardy and well suited to our rigorous New England climate. The systematic frequent transplanting of the stock is an important feature, developing an abundance of root fibre, which is absolutely necessary to successfully establish large specimens.

A special catalogue will be mailert upon applieation. 


\section{ORNAMENTAL AND SHADE TREES.}

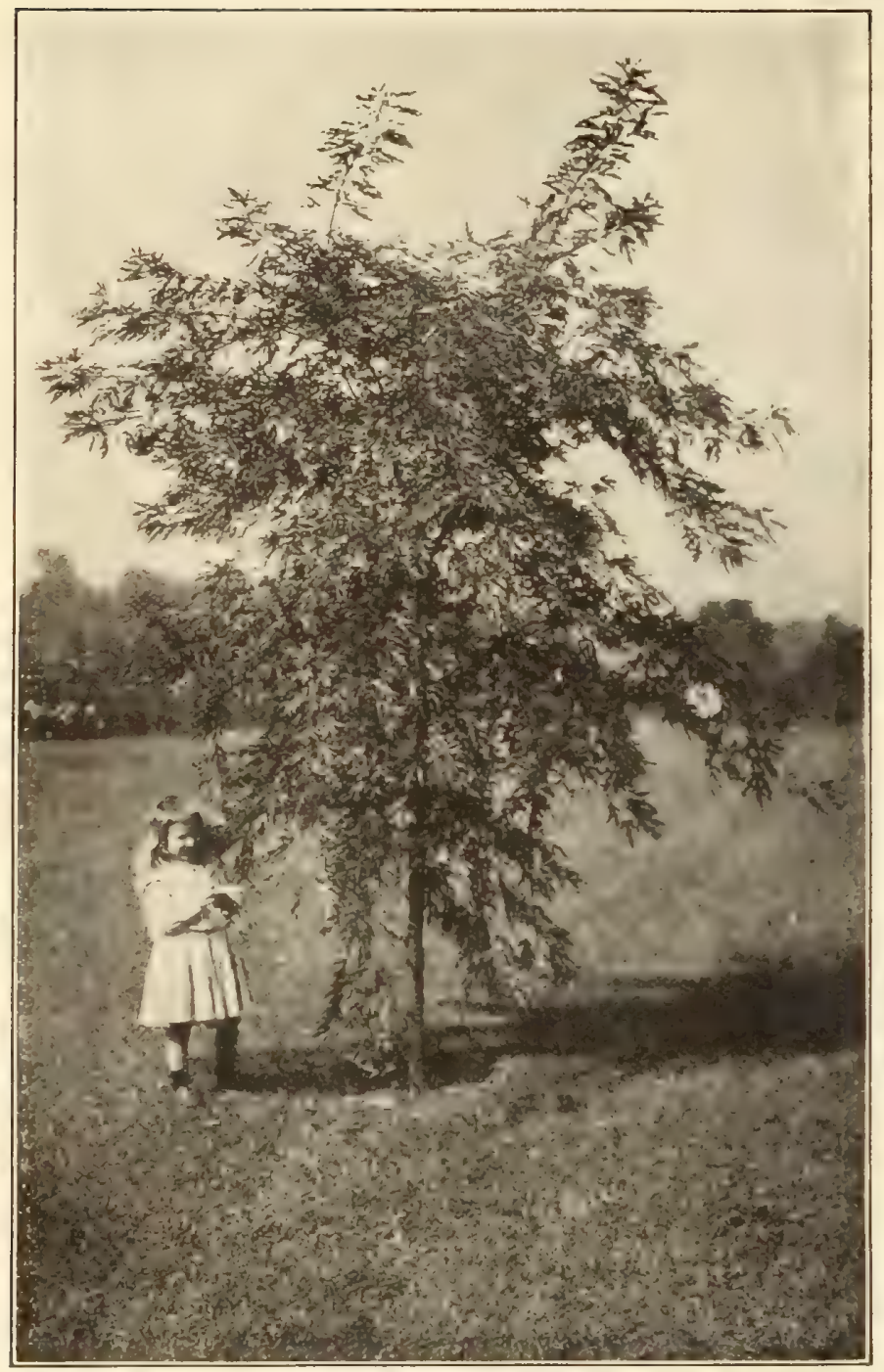

Wier's Cut-leaf Maple.

Aralia Spinosa. Hewiles Club. I small trupicial looking tree with pinnate leaves, prickly stems and large panicles of white flowers in August

Ash, Mountain. 8 to 10 it.

Weeping Mountain

Beech, Purple. 6 to $8 \mathrm{ft}$. .

4 to $5 \mathrm{ft}$.

Weeping. 6 to $8 \mathrm{ft}$.

Birch, Purple Leaved. 6 to $8 \mathrm{ft}$.

Canoe or Paper. 8 to $10 \mathrm{ft}$. ...

White Cut-Leaf Weeping. $8 \mathrm{ft}$.

Catalpa Kæmpieri

Cercis Canadensis. Red Bud

Cratægus Crus-Galli. Cockspur Thorn. A very striking tree, resembling English Hawthorn, the spines being longer and the fruit of larger size. 4 to $5 \mathrm{ft}$.

Each. Doz.

Oxyeantha. Hawthorn, Paul's Double Searlet. 10 to $12 \mathrm{ft}$.

,

Double White. 10 to $12 \mathrm{ft}$.

$\$ 0 . \overline{7}, 5.7 ., 1)$

1. (n) 10.00

$1.00 \quad 10.00$

$3.00 \quad 30.00$

$1.50 \quad 15.00$

$2.00 \quad 20.00$

$2.00 \quad 20.00$

$1.50 \quad 15.00$

$1.50 \quad 15.00$

$1.00 \quad 10.00$

$.75 \quad 7.50$

$75 \quad 7.50$

$1.50 \quad 15.00$

$1.50 \quad 15.00$

1.2512 .50

Elm, American. 8 to $10 \mathrm{ft}$.

10 to $12 \mathrm{ft}$.

Gingko. Salisburia adiantifolia. 6 to $8 \mathrm{ft}$.
Horse Chestnut. $8 \mathrm{ft}$.

$\$ 1.00 \$ 10.00$

$\cdots 200 \quad 20.00$

Double Flowering. 8 to $10 \mathrm{ft}$... $\quad \ldots . \quad \ldots \quad 2.00 \quad 20.00$

Double Flowering White, $10 \mathrm{ft}$... $\quad \ldots \quad 2.00 \quad 20.00$

Sweet Chestnut, American. 6 to $8 \mathrm{ft} \ldots \ldots \quad \ldots \quad 100 \quad 10.00$

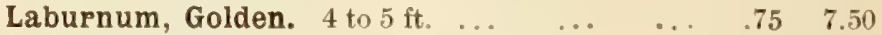

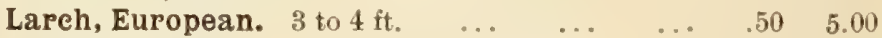

Linden, American. 8 to $10 \mathrm{ft}$... $\quad \ldots . \quad \ldots \quad 1.00 \quad 10.00$

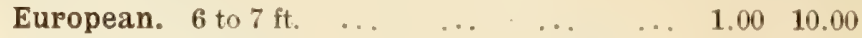

Liriodendron Tulipifera. Tulip Tree, $5 \mathrm{ft} . \quad \ldots \quad 1.00 \quad 10.00$

Magnolia atropurpurea. Chinese purple $\quad \ldots \quad 1.50 \quad 15.00$

Conspicua. Chinese white $\quad \ldots \quad \ldots . \ldots 1.50 \quad 15.00$

Lennei. Dark purple, very fine $\ldots . \ldots 2.00 \quad 20.00$

Soulangeana. Large white and purple flowers, $\quad 2.00 \quad 20.00$

Maple, Nopway. 8 to $9 \mathrm{ft} \quad \ldots . \ldots 1.00 \quad \ldots 10.06$

Silver. 10 to $12 \mathrm{ft}$.

Sugar. 10 to $12 \mathrm{ft}$.

8 to $10 \mathrm{ft}$.

Polymorphium atropurpureum, Japanese.

A most beautiful dwarf hardy tree; foliage coppery-

red. $1 \frac{1}{2}$ to $2 \mathrm{ft}$.

2 to $3 \mathrm{ft}$.. .

- Atropurpureum dissectum. Cut-leaved,

drooping growth, and of almost fern-like character. 2 to $3 \mathrm{ft}$.

Wier's Cut Leaf. 8 to $10 \mathrm{ft}$... ... ... 1.00

12 to $14 \mathrm{ft}$.

Ash-Leaf. Acer negunda. Very hardy and of rapid growth. 6 to $8 \mathrm{ft} . . . \quad \ldots . . .$.

Mulberpy, Tee's Weeping. Very ornamental dwarf weeping tree

Oak, Red. Quercus mubra. 8 to $10 \mathrm{ft}$.

Pin. Quercus palustris. 8 to $10 \mathrm{ft}$. ... ... 1.50

Poplar Bolleana. 10 to $12 \mathrm{ft}$.

Balsam. Balm of Gilead. 8 to $10 \mathrm{ft}$.

Carolina. 8 to $10 \mathrm{ft}$.

Golden. 6 to $8 \mathrm{ft}$.

Lombardy. 8 to $10 \mathrm{ft}$.

10 to $12 \mathrm{ft}$.

$1.00 \quad 10.00$

$1.50 \quad 15.00$

$1.00 \quad 10.00$

$1.25 \quad 13.00$

$2.50 \quad 25.00$

$2.50 \quad 25.00$

$2.00 \quad 20.00$

$.75 \quad 7.50$

$1.50 \quad 15.00$

$1.50 \quad 15.00$

1.2513 .00

1.00 10.00

1.00

$.75 \quad 7.50$

$.75 \quad 7.50$

Sophora Japoniea. Pagoda Tree. A dwarf tree with leaves like those of the Wistaria and long racemes of creamy white flowers... ... ...

Syringa, Japonica. Tree Lilac, 4 to $6 \mathrm{ft}, \quad \ldots$

Virgilia Lutea, syn. Cladrastis Tinetoria. 6 to 8 it.

$1.00 \quad 10.00$

Laurel-Leaved. Rich green shining foliage. $6 \mathrm{ft} ., \quad .50 \quad 5.00$

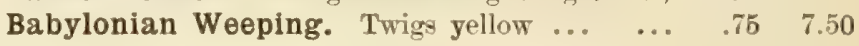

\section{Large Trees and Shrubs.}

We are in position to furnish very large Trees and Shrubs of popular kinds where such may be desired to produce immediately an established effect.

PRICES UPON APPLICATION. 
R. \& J. FARQUHAR \& CO., BOSTON. FRUITS.

\section{FRUIT TREES AND SMALL FRUITS.}

The fruit trees we offer are excellent young healthy stock. Trees when received should be planted at once in rich, prepared soil, the roots being carefully separated and spread. If dry weather follows planting, the trees must be watered and mulched. Branche- of last season's growth should be well cut back, thus encouraging the vigorous growth of new healthy shoots.

APPLES.

Each, .75. Doz., $\$ 8.00$.

SUMMER VARIETIES.

Red Astrachan. Large; deep crimson; fine.

Sweet Bough. Large; pale yellow; sweet, very productive. AUTUMN VARIETIES.

Gravenstein. Very large; yellow, streaked red; fine quality. WINTER VARIETIES.

Baldwin. Bright red: shaded yellow; crisp and juicy. Fameuse, or Snow. Medium; deep crimson; very tender.

Hubbardson Nonsueh. Large, round; yellow and red; rich and delicious.

King of Tompkins County. Very large; yellow, striped, and clouded.

Northern Spy. Large; striped red, very tender; splendid keeper Rhode Island Greening. Large; greenish yellow; excellent flavor.

Roxbury Russet. Medium; yellow russet; productive.

Sutton Beauty. Fruit medium; skin yellow, striped crimson

Tolman Sweet. Medium size; whitish yellow, sweet; excellent for baking.

Hyslop. Large; dark crimson.

CRAB VARIETIES.

Transcendent. Handsome, large, red; excellent quality.

PEARS.

Each, \$1.25. Doz., \$12.00.

SUMMER VARIETIES.

Bartlett. Yellow, with red cheek; productive and popular

Clapp's Favorite. Large, long; rich and juicy. AUTUMN VARIETIES.

Beurre Bose. Large; cinnamon russet; rich and delicions

Duchesse D'Angouleme. Tery large, rich and fine

Sheldon. Russet, with red cheek; fine flavor.

Seckel. Small; yellowish brown.

\section{WINTER VARIETIES.}

Beurre D'Anjou. Large; greenish russet; splendid flavor Dana's Hovey. Small; fine quality, keeps well.

Lawrence. Medium size; fine golden yellow.

\section{CHERRIES.}

Each, $\$ 1.00$. Doz., $\$ 10.00$.

Black Eagle. Large; black; rich and tender.

Black Taptapian. Very large; bright purple; rich and fine

Governor Wood. Light yellow and red; large and tender.

Schmidt's Bigarreau. Fruit deep mahogany color; very fine.

Early Richmond. Medium size; dark red; rich acid flaror.

\section{PLUMS.}

Each, $\$ 1.00$. Doz., $\$ 10.00$.

PLUMS OF EUROPEAN TYPE.

Bradshaw. A large oval; dark violet red; sweet and good. Lombard. Medium; violet red; pleasant flavor.

Oetober Purple. Large; purplish jellow; of superb quality.

\section{JAPAN PLUMS.}

Abundance. Amber, turning to cherry; rich flavor.

Burbank. Beautiful clear cherry red; yellow flesh: sweet.

Wickson. Fruit deep maroon; flesh of fine texture.

\section{PEACHES.}

\section{Each, .50. Doz., $\$ 5.00$}

Alexander. Large, and very early. Freestone.

Crawford's Early. Very large; early, with red cheek. Free. stone

Crawford's Late. Very large; yellow; one of the finest late sorts. Freestone.

Champion. Skin creamy white with red cheek; very early. Free stone.

Elberta. Yellow, with red cheek; excellent quality. Freestone

Mountain Rose. Large; red, with white flesh; early. Freestone.

\section{QUINCES.}

Each, .75. Doz., \$7.50

Champion. Fruit very large and productive; cooks tender.

Orange. Large; golden yellow; fine sort for preserves.
GRAPES.

Each, .50. Doz., $\$ 5.00$.

BLACK AND BLUE VARIETIES.

Campbell's Early. Large black berries; quality rich and sweett. Concord. Vigorous grower; excellent flavor.

Moore's Early. Bunch, and berry large; very early

Worden. Large and sweet. Ripens well in cold localitie-.

\section{RED GRAPES}

Brighton. One of the most desirable of the early rerl grajues.

Catawba. A popular sort with large berries.

Delaware. Superior as a table grape; flesh very tender

\section{WHITE GRAPES.}

Green Mountain. Very hardy and productive; sweet.

Moore's Diamond. Vigorous grower; color greenish white

Niagara. Fine hardy sort; fruit tender and sweet.

Pocklington. Fruit large; color light golden yellow.

\section{CURRANTS.}

Doz., $\$ 1.25$.

Black Naples. Very large; black; splendid for preserves.

Cherry. Fruit large; deep red and rather acid.

Fay's Prolific. Very large; bright red and excellent flavor.

White Grape. Large; yellowish white; fine quality; the best white sort.

\section{RASPBERRIES.}

Doz., \$1.00; per 100, $\$ 5.00$.

Cuthbert. Large dark crimson berries of firm texture; heary cropper.

Loudon. Bright red berries of large size and fine quality

Golden Queen. Large yellow iruit; very productive.

Marlboro. Crimson fruit of large size; very early:

\section{BLACKBERRIES.}

Doz., $\$ 1.00$; per $100, \$ 5.00$

Agawam. Very hardy sort with jet black berries; sweet Erie. An early variety; fruit uniform and sweet.

Snyder. One of the most productive; fruit sweet and naelting.

Wachusett Thopnless. Fruit medium size, and less acid than the others.

\section{GOOSEBERRIES.}

Downing. Large; pale green, strong grower. Doz., \$1.50. Industry. Fruit large, dark red, and good flavor. Doz.,\$2.00.

White Smith. Large; yellowish-green; a desirable variety Doz., $\$ 1.50$.

\section{HOT-HOUSE GRAPES.}

Strong Planting Canes. Each, $\$ 3.50$. Strong oneyear eanes. Each, $\$ 2.00$.

Alicante. Bunches large and usually shouldered; berries large and oval, jet black and covered with a thin blue bloom. An ex cellent grape for late keeping, in flavor resembling the Black Hamburgh.

Appley Towers. Bunches large; berries round and black with a rich blue bloom. An excellent sort for cold graperies; in season following Black Hamburgh.

Black Hamburgh. Bunches large and well shouldered; berries large, roundish oval, deep blue-black with fine blue bloom; flesh tender, juicy, and rich.

Gros Colmap. Bunches large: berries very laroe, nound and black when well ripened. Flesh sweet and juicy but not rich. A handsome grape.

Gros Guillaume. Bunches very large shonklened; berries of medium size; oval, purplish black; flesh swcet and juicy; a late grape of fair quality

Lady Downe's Seedling. Bunches large, berries of medium size, roundish oval and jet black when well ripened; flesh tim, sweet, and of rich flavor.

Madresfleld Court. Black Museat. Bunches very large; berries very large, oval, black; flesh firm, juicy and melting, with rich Muscat flavor.

Muscat of Alexandria. Bunches large, shoulderd, and rather loose: berries large, oval, of transparent pale amber color; flesh firm, sweet and of richest Havor. This is the buest white grank cultivated. 


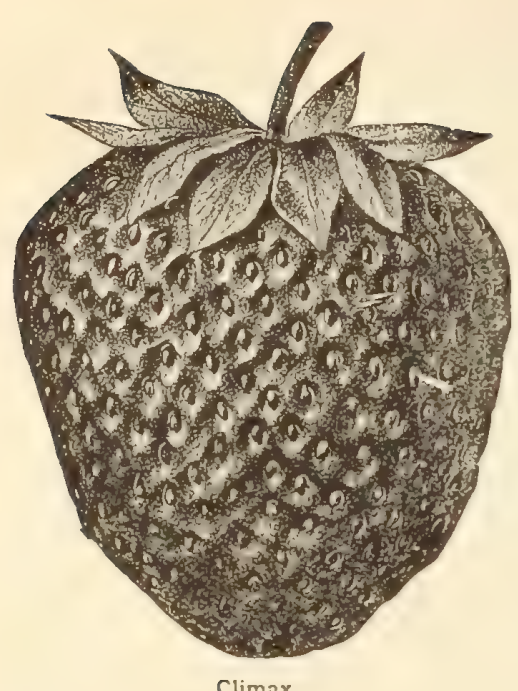

Climax.

\section{STRAWBERRY PLANTS.}

Our strong pot-grown plants give a full crop of fruit ten or eleven months after they are set out. Plant in July and August. We have the best 20 varieties for market and home use adapted to our climate. These, if planted in July and August, produce a large crop the next summer. Being grown in pots they may be shipped to a distance and planted with almost no interruption to their growth. The plants may be set in beds of three rows one foot apart and one foot distant in the rows, with a space of two and one-half feet between the outside rows of adjoining beds left for a pathway. They may also be planted in single rows three feet apart and one foot apart in the rows.

LAYER PLANTS. For Spring planting; de livery April and May. Per 100,\$1.00; 1000, $\$ 7.00$.

POT-GROWN PLANTS. From $2 \frac{1}{4}$ in. pots, well rooted; delivery in July and August. Per $100, \$ 3.00 ; 250, \$ 6.50 ; 500, \$ 12.50$; $1,000, \$ 25.00$, for all varieties.

\section{FIRST EARLY.}

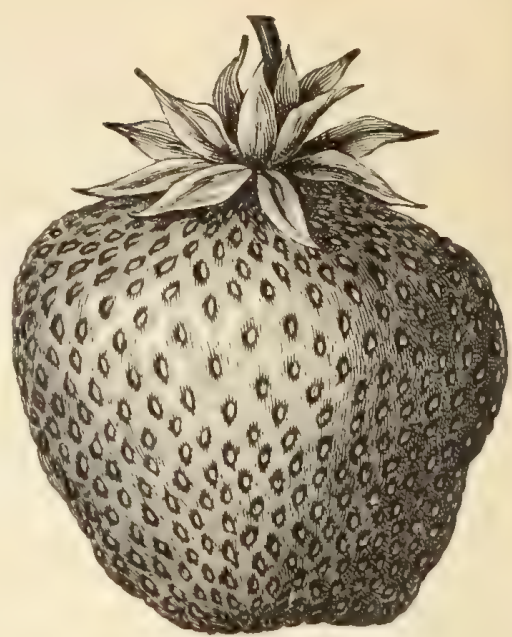

William Belt.
Excelsior. This is decidedly the best early Strawberry and the earliest good strawberry. The fruit is of round conical form, glossy, dark red color, and of mildly acid flavor.

Faipfleld. Mr. Johnson, the introducer, says he has never seen any berry nearly its equal for earliness, large size, attractive color,

Abington. A very prolific sort of Massachusetts origin, learing large bright crimson, firm fruit of fine flavor.

Climax. This is an extremely popular new variety, immensely productive, the berries being slightly over medium size. Plant vigorous, healthy grower, of a peculiar shade of green that can be distinguished from other varieties. Our stock is from plants procured of the originator and is exceptionally fine

Glen Mary. Large, conical, bright red berries; firm and of fine flavor.

Belmont. Large crimson fruit; a popular main crop sort for Boston market.

Bubach. A well known and everywhere popular variety. A large berry of a rich, bright red color; very prolific. Bubach is a fect-flowered sort planted with it for fertilization. Bismarck, Brandy-

wine and Glen Mary are suituble. red in color, firm flesh, red to the centre, and of rich, spicy flavor. A great cropper especially on heary soils, holds its fruit well up from the ground and generally succeeds every where

Bismarek. Bismarck is a safe pollenizing strawberry, possessing all the desirable qualities of Bubach. To those familiar with the Bubach nothing further need be said, since Bubach has been a favorite berry for years. Bismarck makes a much finer growth than Bubach, and, from the fact that it beds up better, it will generally produce a larger yicld per acre. Color a dull scarlet, ripens all over at once, having no green tips. The seeds are prominent, and the berries quite firm.

Mark Hanna. Very large, somewhat resembling Marshall, but till more prolific than that favorite sort.

\section{LATE TO}

Commonwealth. This is the latest of all Strawberries; bearing large conical, deep crimson fruit, sweet and of quality equal to the well-known Bubach. Not only an extra large berry, but also very productive, of deep rich color and solid. It is smooth and quite juicy. The plants are strong, not quite so rank in growth as the Marshall, and free from rust. One of the best introductions of recent years.

Gandy. This popular old variety is probably known by most berry growers. It is more largely grown than any other late variety. It is at home on black swamp land if well drained, upon medium stiff or red clay land. On sandy soils it is unproductive. All late varieties are compared by Gandy, which is the highest praise that could be given it. Large size, fine appearance, and remarkable keeping and carrying qualities. quality and firmness. pistillate or imperfect-flowered variety and requires a stamenate or per-

Brandywine. A large heart-shaped berry, perfect in form, bright
Success. Large, round, bright scarlet, favor always fine.

Virginia. A medium sized berry of recent introduction; flavor excellent; enormous yielder. Made a record of 12,000 quarts per acre at its home in the state of Virginia.

\section{EARLY.}

Sample. Excellent for either market or home use; prolific, large, firm and delicious.

Senator Dunlap. Mr. Crawford, at the time of its introduction by him, said that he doubted if he had ever sent out a berry better than Senator Dunlap. It will keep in fair condition for several days on the vines after being ripe enough to pick. The fruit is large, rich and dark red clear to the centre, with a very rich flavor.

\section{EDIUM.}

Marshall. The fruit of this remarkable sort is of enormous size, of handsome, glossy, dark crimson color, and of delicious flavor. It is one of the best midseason berries, either for private use or market. It is a vigorous grower and requires good soil and high cultivation. As it does not thrive in all soils, it should not be planted extensively until its adaptability is ascertained.

Minute Man. A medium large well-formed berry of bright red color and superior flavor, bearing longer than almost any other sort. The fower is imperfect and requires a staminate sort like Glen Mary planted with it

New York. One of the best sorts for private or market gardens. The berries are large, of long conical form; dark red color, firm texture and of remarkably sweet Havor. In the market they sell at sight.

Pride of Cumberland. The plant is a vigorous grower and free from rust. The bloom is perfect, ripens about one week earlier than Gandy; it is nearly as large, equally as firm, as good in color, will thrive in either high or low land, and generally mor: productive. It thrives on any soil, but owing to the immense crops it sets, the ground shonld be well fertilized to ensure best results.

\section{VERY LATE.}

William Belt. An exceptionally fine berry. In quality it heads the list. The berries are as large, with some specimens larger than the Bubach. It is about as productive as the Bubach, and of nearly the same shape. Its color is a bright, glossy, deep red; its season nearly as late as Gandy.

New Home. As late and large as Gandy, fruit a bright red color that does not lose its lustre and turn dark for a long time after being picked. It is a vigorous grower, and, unlike Gandy, will produce a large crop on either high or low land. The fruit is so firm and keeps so well, it does not need to be picked oftener than three times a week. Its great productiveness, uniform large size, and unsurpassed carrying and keeping qualities make it one of the most desirable on the list.

Steven's Late Champion. A rery productive late sort resembling Gandy, the fruit being considered larger and more freely produced than that sort. 


\section{HIGH GRADE FERTILIZERS.}

Prices subject to change. Net, except where noted, f. o. b. cars Boston.

\section{FARQUHAR'S LAWN AND GARDEN DRESSING.}

The best fertilizer in the market for all garden and farm crops. It is as dry and fine as meal ; made of dried, finely pulverized blood, bone, potash and refuse meat. The mixture is in such good mechanical condition that it can be applied conveniently by any one. For lawns it is most excellent, being not a stimulant merely, but a plant food of lasting, enriching properties. Price, per ton, $\$ 50.00$.

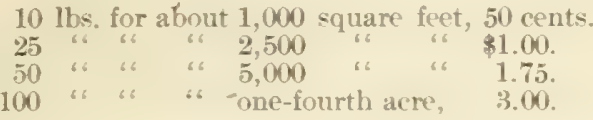

\section{FARQUHAR'S VEGETABLE AND POTATO FERTILIZER.}

A new brand of extraordinary strength, being a complete fertilizer for vegetables and potatoes. It is very rich in phosphoric acid, potash, and nitrogen. Can be used without other manure. Apply 400 to 600 pounds per acre, depending upon the previous manuring, cropping, and present condition of the land. Price, per ton, $\$ 4.00 ; 100$ lbs., $\$ 2.75 ; 50$ lbs., $\$ 1.50 ; 25$ lbs., $\$ 1.00 ; 10$ Ibs., .50 .

\section{PULVERIZED SHEEP MANURE.}

\section{PLRITY BRAND.}

A soluble plant food highly recommended for all purposes where a first-class fertilizer is required. It is a pure natural manure, and has long been recognized as one of the most beneficial. As a top-dressing for lawns it is unequalled. For lawns it should be used at the rate of 500 to 800 pounds per acre. As a fertilizing agent for plants indoors and in the open garden, it is one of the very best. Price, ton, $\$ 40.00$; half ton, $\$ 20.00 ; 500 \mathrm{lbs} ., \$ 10.00$; 100 lbs., $\$ 2.50 ; 50$ lbs., $\$ 1.50 ; 25$ lbs., $\$ 1.00 ; 10$ lbs., .50; 5 lbs. $.30 ; 1 \mathrm{lb}, . .10$

\section{PURE CANADA UNLEACHED HARDWOOD ASHES.}

Ashes lack ammonia and phosphoric acid, but contain potash and lime, which are essential, not only as plant food, but also as sweeteners of the soil and solvents of other plant food ingredients. So far as they supply potash and lime, they are "nature's plant food." These things have been extracted from the soil by the trees, and now we return them in the shape of ashes. Pure wood ashes is one of the best fertilizers for top-dressing lawns, grass lands, and seeding down, imparting a rich, dark shade of green, destroying insects and weeds, particularly moss; also for fruit of all kinds, especially strawberries, peaches and apples. 100-1b. bag, $\$ 1.25 ; 200 \mathrm{lbs} ., \$ 2.00$; ton, $\$ 18.00$. In car load lots of from 15 to 20 tons, at $\$ 11.00$ per ton in bulk or $\$ 16.00$ per ton in 100 -1b. bags delivered at any freight station in Massachusetts, Vermont, New Hampshire, Rhode Island, Connecticut, and to any station in Maine except points on the Maine Central R.R.

\section{PURE GROUND BONE.}

This is made from the best quality of bone, finely pulverized by improved machinery. It is far superior to some ground bone in the market, which is often composed of refuse bones from which the plant food has been largely removed in manufacturing glue and other products. Analysis: Nitrogen, equal to Ammonia, 3 to 4 per cent. ; Phosphoric Acid, 22.80 to 25.23 per cent. ; equal to Bone Phosphate, 50 to 55 per cent. Price per ton in bags, $\$ 30.00$; barrel, 250 lbs., $\$ 5.00 ; 100$ lbs., $\$ 2.00 ; 50$ lbs., $\$ 1.25 ; 25$ lbs., .75 ; $10 \mathrm{lbs}, .35$.

\section{INCH BONE FOR GRAPES, ETC.}

The very best fertilizer for grape vines, fruit trees, shrubs, and trees of all kinds. The pieces of bone vary from one-fourth inch to one inch in size. Should be used at setting out, mixed with the soil to the depth of a foot or more. Price, in bags or barrels, $2 \frac{1}{2}$ cents per pound; ton, $\$ 38.00$

\section{SCOTCH SOOT.}

A fertilizer and fungicide. One of the best remedies and preventatives for mildew, when mixed with sulphur, at the rate of two-thirds soot and one-thind sulphur. As a fertilizer it promotes growth, and heightens color of foliage and flower. Price, 100-lb. bag, \$2.50.
SALT.

Valuable as a top-dressing for asparagus, etc. Apply early in spring. Bag, 140 lhs., $\$ 1.25$.

\section{CLAY'S FERTILIZER.}

Imported. A lasting, productive, economical fertilizer for all horticultural purposes. A reliable vitalizing medium for conservatory, greenhouse, and garden. Highly recommended by leading horticulturists in the cultivation of flowers, fruit, and vegetables for exhibition, pleasure, and profit in the highest perfection. Original bags, 112 lbs., $\$ 7.00$; 56 lbs., $\$ 4.00 ; 28$ lbs., \$2.25; 14 lbs., $\$ 1.25 ; 7$ lbs., .75 .

\section{THOMSON'S GRAPEVINE, PLANT, AND VEGETABLE} MANURE.

Thomson's Vine and Plant Manure is a perfect food for the Grapevine and other food-bearing plants; also for nearly all other Plants and Vegetables, PROPORTIONS IN WHICH THE MANURE MAY BE USED.-Grapevine Border.-For mak. ing up a border, $\frac{1}{2}$ cut to the ton of loam; for surface dreseing, lbs. per yard super, applied early in the season and $1 \mathrm{lb}$. per yard super after grapes are thinned; mix with a little fine soil when roots are quite near the surface; if not very near the surface sprinkle the manure on and fork it in. In both cases give a slight watering. See that the thorough watering of the borders is done some time previous to the top dressing. Peaches, Nectarines, Figs, - For borders for peaches, nectarines, figs, etc., $\frac{1}{4} \mathrm{cwt}$. to the ton of loam. Original bags, $112 \mathrm{lbs} ., \$ 7.00 ; 56 \mathrm{lbs} ., \$ 4.00 ; 28 \mathrm{lbs} ., \$ 2.25 ; 7-\mathrm{lb}$. tin, $\$ 1.00$.

\section{THOMSON'S SPECIAL CHRYSANTHEMUM MANURE.}

Thomson's Grapevine and Plant Manure is admirably adapted for mixing with the soil when potting such plants as Chrysanthenuun

The Speeial Manure is meant to be used as an additional stimulant during the growing season.

A heaped dessertspoonful will be sufficient for a 10-inch pot, sprinkled over the surface of the soil, and watered in with tepid water. This may be given three times during the growing season. 56 lbs, $\$ 7.00 ; 28$ lbs, $\$ 4.00 ; 14$ lbs, $\$ 2.25 ; 7$ lbs, $\$ 1.25$.

\section{BRADLEY'S COMPLETE MANURES FOR ALL CROPS.}

Specially Adapted to Intensive Farming and Market Gardening.

These manures have been abundantly proved by results in the field. They are manufactured from the very best plant-food mate. rials obtainable. In mechanical condition they are unequalled. They drill perfectly in any machine. They are divided into classes, based upon exhaustive field tests, and not upon theoretical experiments of the laboratory, the fault of "special crop fertilizers" in which common sense and practical experience are sacrificed for the sake of theoretical hobbies.

Bradley's Complete Manures are, in the fullest sense, "complete" fertilizers, and the several grades furnish complete plant food in the best forms for all crops grown.

\section{PRICES FOR BRADLEY'S STANDARD FERTILIZERS}

Bradley's X. L. Superphosphate .

Bradley's Pótato Manure

Bradley's Complete Manure for Potatces and Vegetables

$\begin{array}{crr}\begin{array}{cc}\text { int..h. } \\ \text { bag. }\end{array} \text { bag. } & \text { Ton. } \\ \$ 1.00 & \$ 1.80 & \$ 3400 \\ 1.00 & 1.80 & 34.00 \\ & 2.10 & 40.00 \\ & 2.10 & 4000 \\ & \\ 210 & 40.00 \\ & \\ 2.20 & 42.00 \\ 3.00 & 5200 \\ 1.80 & 34.00 \\ 1.50 & 28.00\end{array}$

Bradley's Complete Manure for Corn and Grain

Bradley's Complete Manure for Top Dressing Grass and Grain

Bradley's Complete Manure with 10 pere cent. Potash

Bradley's High Grade Tobacco Manur

Bradley's Seeding-Down Manure

Bradley's Eclipse Phosphate

1.5028 .00

Bradley's Standard Fertilizers are sold in original bags only. 


\section{AGRICULTURAL CHEMICALS, FERTILIZER MATERIALS, AND PLASTER.}

High Grade Sulphate of Potash. 90 to 95 per cent. Sulphate of Potash, 48 to 50 per cent. actual Potash. $10 \mathrm{lbs} ., .50 ; 100 \mathrm{lbs}$., $\$ 3.50$; in original bags, $224 \mathrm{lbs}$. each, $\$ 6.75$; per ton, $\$ 52.00$.

Double Sulphate of Potash and Magnesia. 40 to 50 per cent. Sulphate of Potash, 25 to 28 per cent. actual Potash. $10 \mathrm{lbs} .$, .30; 100 lbs., \$2.00; in original bags, $22+1$ bs. each, $\$ 4.00$; per ton, $\$ 32.00$.

Muriate of Potash. 80 to 85 per cent. Muriate of Potash, 50 to 55 per cent, actual Potash. $10 \mathrm{lbs} ., .50 ; 100 \mathrm{lbs} ., \$ 3.00$; in original bags, $224 \mathrm{lbs}$. each, $\$ 6.00$; per ton, $\$+5.00$.

Kainit. 23 to 25 per cent. Sulphate and Muriate of Potash, 12 to 13 per cent. actual Potash. 100 lbs., \$1.25; 200-lb. bag, \$2.00; per ton, $\$ 15.00$.

Nitrate of Soda. 95 per cent. purity, 19 per cent. Ammonia. 10 lbs., .60; 25 lbs. $\$ 1.20 ; 100$ lbs., $\$ 3.50$; in original bags, a bout 275 lbs. each, $\$ 9.00$; per ton, $\$ 55.00$.

Sulphate of Ammonia. 24.75 per cent. Ammonia. 10 lbs., .75; 100 lbs., \$5.00; 200-lb. bag, \$9.00; per ton, $\$ 70.00$.

Dissolved Bone Black. 15 to 18 per cent. Soluble and Available Phosphoric Acid. 200-lb. bag, \$2.50; per ton, \$22.00.

Plain Superphosphate. 14 to 17 per cent. Soluble and Available Phosphoric Acid. 200-lb. bag, \$2.00; per ton, \$18.00.

Dried Blood. 12 per cent. Ammonia. 200-lb. bag, $\$ 5.50$; per ton, $\$ 46.00$.

Dried Blood. 15 per cent. Ammonia. 200-lb. bag, $\$ 6.25$; per ton, $\$ 57.00$

Fine Ground Tankage. 9 per cent. Ammonia; 20 per cent. Bone Phosphate. 200-lb. bag, \$4.50; per ton, \$39.00.

Fine Ground Tankage. 6 per cent. Ammonia; 30 per cent. Bone Phosphate. 200-lb. bag, $\$ 3.50$; per ton, $\$ 30.00$.

Fine Ground Nova Scotia Plaster. White and fine. 100-lb. bag, .75; 200-1b. bag, $\$ 1.35$; per ton, $\$ 10.00$.

Bowker's Ammoniated Food for Flowers. Made expressly for flowers grown in the house or garden; clean, odorless, and produces early abundant blossoms, greatly adding to the richness and brilliancy of color, health, and luxuriance of the foliage. It is clean and absolutely odorless, thus supplying a long-felt want by ladies and florists. Price, put up in neat packages with directions for use, No. $1, .15 ;$ No. $2, .25$. If ordered by mail add 6 cents for No. 1, and 12 cents for No. 2, to prepay postage.
"Chemieals" for Imperial Plant Food. For high grade growing under glass and out-of-doors. A clean, dry powder which entirely dissolves in cold water. Contains 63 per cent. actual plant foods. Nitrogen, 15.1 per cent $=$ Ammonia, 18,3 per cent ; Phosphoric Acid, 21.5 per cent. ; Potash, 26.1 per cent. Is used dry, mixed with earth or sand, or is first dissolved in water.

$9 \mathrm{oz}$. when dissolved makes

3 lbs.

7 lbs.

$20 \mathrm{lbs}$.

50 lbs.

50 gatl

250
500

1,500

3,600

7,200

$\begin{array}{ccc}\text { allons fertilizer, } & \$ .25 \\ " & " & 1.00 \\ " 6 & " & 1.60 \\ " 6 & " & 4.00 \\ \text { " } & 8.00 \\ & & 14.00\end{array}$

\section{BON ARBOR.}

A liquid plant food good for all living plants. It invigorates, promotes growth, increases the crop and causes it to mature earlier.

It is a wonderful fertilizer.

Put up in 1 and 2 gallon kegs, $\$ 2.00$ per gallon; in 25 gallon barrels, $\$ 1.50$ per gallon; in 50 gallon barrels, $\$ 1.25$ per gallon.

BONORA. Good for flowering plants, vegetables, etc., producing a lasting and healthy growth. 1-1b. tin, .50; by mail, .65; 5 lbs., $\$ 2.50$, by express only.

\section{PEAT, MOSS, POTTING SOILS.}

Charcoal. Price, per lb.,. 10; $100 \mathrm{lbs} ., \$ 5.00$.

Silver Sand. For propagating, mixing with plant soils, etc. Price, per barrel, \$2.50; bush., \$1.50; peck, .50.

Rotted Fibrous Peat. An excellent material for mixing with potting soils for many plants. This peat has been dug from an old bog and exposed for a number of years until it has become thoroughly decayed, and is very fine and light. Price, per barrel, $\$ 2.00$; bush., $\$ 1.00$.

Orchid Peat or Fern Root. Price, per bbl., \$2.75; bush., \$1.50. Prepared Potting Soil. A carefully prepared soil for pot plants; composed of Leaf Mould, Peat, Loam, Sand, and a sufficient quantity of fertilizer. Price, per barrel, \$2.00; bush., \$1.00.

Sphagnum Moss. We furnish a Moss of excellent quality for the gardener's use. We can supply it at most seasons freshly gathered or dried. Price, per bag, $\$ 1.50$; bush., \$1.00; bale, \$6.50.

Cocoanut Fibre. Price, 125 -lb. bag, $\$ 1.25$; per ton, $\$ 15.00$.

\section{INSECTICIDES AND FUNGICIDES.}

Ant Destroyer. A specially prepared powder which will destroy or drive away Black Ants from lawns, trees, plants, houses, or other infested localities. Price, $\frac{1}{2}-1 \mathrm{~b}$. can, .50 ; by mail, .60.

Arsenate of Lead. For spraying trees. A remedy for Elm Leaf Beetle, Gypsy Moth, Brown Tail Moth, ete. Price, 1-lb. jars, .20 ; 5-lb. pail, .95; 10-lb. pail, $\$ 1.80$; 20-1b. pail, $\$ 3.60$; 50-1b. pail, $\$ 8.50 ; 100-\mathrm{lb} . \mathrm{keg}, \$ 16.00$.

Aphis Punk. Nikoteen. It kills bugs under glass. .60 per box 1 dozen rolls, $\$ 6.50$ per case 1 dozen boxes. 3 rolls will fumigate 100-foot house.

Bordeaux Mixture, Concentrated. A valuable and indispensable fungicide for grape growers, ensuring larger crops and finer grades. Successful against black rot, mildew, and rust. Being in liquid form, it is very convenient to handle. One gallon will make 50 gallons of spraying liquid by the addition of 49 gallons of water. Price, 1-gal. patent cans, $\$ 1.00 ; 1$-qt. cans, .40.

Dry Bordeaux Mixture. Ready for use by simply adding water. 1-1b. box makes 5 gallons spray, .30; 5 -1b. box makes 25 gallons spray, $\$ 1.25 ; 10-1 \mathrm{~b}$. box makes 50 gallons spray, $\$ 1.25 ; 30-1 \mathrm{~b}$. box makes 125 gallons spray, $\$ 3.00 ; 300 \mathrm{lb}$. barrel makes 1,500 gallons spray, $\$ 27.00$.

Bowker's Pyrox. A combined insecticide and fungicide for fruit trees, vegetables, and flowers. Kills canker worms, rose worms, caterpillars, etc., and prevents blights, mildews, and rots. 10 lbs. makes 60 gal. of spray. 5-lb.can, $\$ 1.00 ; 10$-lb. can, $\$ 1.75$; $100-1 \mathrm{~b}$. keg, $\$ 15.00$.

Bowker's Disparene. A remedy for elm beetle, potato-beetle, caterpillars, and all leaf-eating insects. Used and endorsed by leading Experiment Stations and park superintendents, 2-lb. jar, .40; 5-1b. pail, .90; 10-1b. pail, $\$ 1.70 ; 100-1 b$. keg, $\$ 15.00$.
Bowker's Boxal. Kills potato bugs and prevents potato blight and rot. Keeps vines green and growing; greatly increases yield. May be dusted on or applied as spray. $5 \mathrm{lbs}$. enough for one acre. 5-lb. can, $\$ 1.00 ; 10-1 b ., \$ 1.75$.

Bug Death. We give this insecticide our fullest endorsement. It is a non-poisonous powder, and can be applied dry just as it comes from the package, or it can be mixed with water and sprayed on vines. $12 \frac{1}{2}$ lbs. to 80 gallons water mixed thoroughly. It is death to the potato, squash, and cucumber bugs, currant and tomato worms, and many other plant-eating pests. As Bug Death contains no arsenic it will not burn or blight the vine, thus giving the potato a better chance to mature, which means a more starchy potato, and one less liable to rot, and the extra yield of marketable potatoes will more than pay the entire expense. Price, 1-lb. package, .15; 3-lb. package, .35; 5-lb. package, .50; $12 \frac{1}{2}-1 \mathrm{~b}$. package, $\$ 1.00 ; 100$-lb. package, $\$ 7.50$. Dickey Shaker, .25.

Copper Solution Ammoniated. A concentrated liquid fungicide, prepared ready for immediate use on trees, vines, or vegetables affected with rot, blight, or scab, and with safety to the foliage. The various plant diseases to which it is applicable are: Rot of the grape, mildew of the grape, and leaf blight, apple scab, potato blight, tomato blight, melon blight. Directions : 1 quart of solution to 25 gallons of water. Per quart, $\$ 1.00$.

Creosote for Gypsy Moths. The most effective protection from caterpillars. Sure death to the eggs. Quart, .25; 1 gallon, $.50 ; 5$ gallons, $\$ 2.25$.

Dalmatian or Persian Insect Powder. One of the best insecticides for all insects. Lb., .50. 


\section{INSECTICIDES AND FUNGICIDES. - Continued.}

Fir Tree 0il. Soluble. For destroying all insects that infest plants and animals, such as mealy bug, scale, red spider, green fly, thrip, lice, fleas, etc. Directions with each package. Price, $\frac{1}{2}$ pint, .50; pint, .75; quart, $\$ 1.50$; half gallon, $\$ 2.75$; gallon, $\$ 5.00$.

Fir Tree 0il Soap, Stott's. A non-poisonous insecticide for destroying scale, mealy bug, aphis, red spider, currant and grape worm, etc. Price, $\frac{1}{2}-1 \mathrm{~b}$. tin, .25; 2-lb. tin, .75.

Flowers of Sulphur. Prevents and cures mildew on roses, grapevines, etc. Apply with gun or bellows. Price, $1 \mathrm{lb} ., 10 ; 5 \mathrm{lbs}$, $.40 ; 10$ lbs., .70; 100 lbs., $\$ 5.00$.

Gishurst's Compound. For destroying red spider, mealy bug, scale, thrip, ete. Boxes, .60; by mail, .80.

Grape Dust, Hammond's. A preparation for destroying mildew on grapevines. Can also be used on plants or trees affected with mould, mildew, or rust mites, either in greenhouses or the open air. Apply frequently by dusting, as atoms of fungi are always spreading or floating. Price, 5-lb. package, .35.

Hellebore Powder, White. We furnish a pure, fresh, very effectire powder. One of the best insecticides for rose slugs, currant worms, green fly, and other insects. Price, lb. package, $.30 ; \frac{1}{2}-1 b$. package, .15.

Kerosene Emulsion Concentrated. Kills the pea louse, San José scale, and all sucking insects. Ready for use by adding water, 25 to 50 parts water to 1 of Emulsion. Quart, 40 ; gal., $\$ 1.00 ; 5$ gals., $\$ 1.50$.

"Imp" Soap Spray. The base is a soap containing vegetable poisons, particularly effective against red spider on fruits, the rhododendron fls, rose bug, and other insects. Quart, ..50; gallon, $\$ 1.50 ; 5$ gallons, $\$ 6.00 ; 10$ gallons, $\$ 10.00$.

Lemon 0il Inseetieide. Destroys scale, thrip, mealy bug, red spider, black and green fly. Dilute with 30 to 50 times the bulk of water before using. Price, $\frac{1}{2}$ pint, .25; pint, .40; quart, .75; $\frac{1}{2}$ gallon, \$1.25; gallon, $\$ 2.00$; כ̇-gallon keg, $\$ 9.00$.

"Nico-Fume." (Registered.) Tobacco-paper Insecticide, for fumigating greenhouses. "Vico-fume" is positively the strongest tobacco-paper on the market; furnishes the easiest method of fumigation ever derised; is packed in special friction-top tins and is sold as follows: 24 sheets, $.75 ; 144$ sheets, $\$ 3.50 ; 288$ sheets, $\$ 6.50$.

Nicotieide Fumigating Compound. For killing all kinds of insects on plants in greenhouses and frames. This compound is used for destroying green and black fly, thrip, mealy bug, red spider, etc. The compound for vaporizing is sold in cans as follows: No. 1, containing 1 pint, sufficient for 32,000 cubic feet of space, \$2.50 each; No. 2, containing pint, sufficient for 16,000 cubic feet of space, $\$ 1.25$ each; No. 3 , containing 4 ounces, sufficient for 8,000 cubic feet of space, .70 each. Fumigators. Price, .50. Each fumigator consists of three parts - the pan, the wire frame, and the lamp.

Nikoteen. All private gardeners recommend this liquid for spraying or vaporizing. Will destroy all insects which infest plants or flowers. Price, \$1.50 per pint package.

New X. L. all Liquid Insecticide. The famous English patented preparation; kills mealy bug, red spider, and all insect pests. The perfect insecticide for spraying; goes farther than any. Price, pint, .75; quart, $\$ 1.25$; $\frac{1}{2}$ gallon, $\$ 2.00$; gallon, $\$ 3.75$.

New X. L. all Vaporizing Compound. An English patent claimed to be the most easy, effectual, and cheapest method of fumigating greenhouses and frames ever invented. Sufficient for 10,000 cubic feet, $\$ 2.25$ per bottle; 20,000 cubic feet, $\$ 4.50$ per bottle. Vaporizing lamp, for above, complete, $\$ 1.00$.

Paris Green. Best grade. For all insects that eat foliage this insecticide is a very effective antidote. $\frac{1}{2} \mathrm{lb} ., .25 ; 1 \mathrm{lb} ., .40$; 5 lbs., \$1.75.

Scalecide. The best remedy known for San José scale. Spray during winter. Use 1 part Scalecide to 20 parts water. Quart, .40 ; 1 gallon, $\$ 1.00 ; 5$ gallons, $84.00 ; 10$ gallons, $\$ 7.00$.
Seal Oil Soap. One of the best insecticides for general use on plants. It is especially effective on green and black flies, red spider, scale, rose thrip, and currant worms. Directions for use are printed on each package. Price, 1-lb. box, .30; 5-lb. box, \$1.25; in tubs, 25 lbs. and upwards, .20 per lb.

Slug Shot, Hammond's. Is a light, composite, impalpably fine powder, easily distributed either by duster, bellows, or in water by spraying. It is thoroughly reliable in killing currant worms, potato bugs, cabbage worms, lice, slugs, sow bugs, etc. and is also strongly impregnated with fungicides. Price, 5 lhs., $.30 ; 10$ lbs., 60 . In kegs, 125 lbs. net, or barrels, 235 to 250 lbs. each, at $4 \frac{1}{2}$ cents per $1 b$.

Sulpho-Tobacco Soap. Quickly exterminates all insect life on plants and flowers in and out of doors. Unsurpassed for rose bushes. For a cheap, clean, effective insecticide for amateur and professional growers this is unexcelled. For domestic purposes it rids the house of cockroaches, and is a superior wash for dogs and all animals. Prevents poultry lice. 3-0z. cake sufficient for $1 \frac{1}{2}$ gallons prepared solution, .10; mailed, postpaid, .13. 8-oz. cake, sufficient for 4 gallons prepared solution, .20, mailed, postpaid, .28

Tanglefoot. A perfect safeguard for trees and shrubs against gypsy and brown-tail moths and other creeping insects. Per lb., $.30 ; 3$ lbs., .85; 10 lbs., $\$ 2.65 ; 20$ lbs., $\$ 4.80$.

Thomson's Styptic. (Imported.) To prevent vines bleeding. Directions on bottle. Price, \$1.25.

Tobaceo Dust. A remedy for green fly. Price, 5-lb. package, $.25 ; 10$-lb. package, .40; 100-lb., \$3 50.

Tobaceo Extract. A powerful extract of tobacco combined with sulphur. Remarkably effective against plant lice, red spider, and insects of all kinds. Dilute one part to ten or more of water and apply with syringe or vaporizer. For insects at the root, prepare as above and apply with watering pot sufficient to reach the roots. Price, half pint, .30; pint, .50; quart, .75; gallon, $\$ 1.50$; כ́ gallons, $\$ 4.25$.

Tobacco Stems. For fumigating. Invaluable as a mulch for rose beds, lettuce beds, etc., where insects frequently do much injury to roots or foliage. Price, barrels, $\$ 1.00$; bale or case, $\$ 3.00$.

Whale 0il Soap. An excellent wash for trees and plants; kills insects and their eggs. Price, in boxes, with full directions for use. 1 lb., .20; 2 lbs., .35; 5 lbs., .75; 10 lbs., $\$ 1.25 ; 50$ lbs., $\$ 5.00$.

Whale Oil Soap. Caustic Potash (Bowker's Tree Soap). For washing and spraying trees, shrubbery, and fowering plants. Applied during winter on hardy fruit trees at the rate of $2 \mathrm{lbs}$. to 1 gallon of water; it is one of the best remedies for San José scale. 5 lbs., .75; $10 \mathrm{lbs} ., \$ 1.50 ; 25-\mathrm{lb} . \mathrm{keg}$, \$3.อ̃0.

“Herbicide," or Weed Exterminator. Perfectly odorless. An occasional application will keep gutters, paths, and roadways clear of weeds, poison ivy, grasses, mosses, dandelions, burdocks, etc. It is the most effectual weed killer known, does the work at a minimum of cost of any other method, and is most conrenient to use. In 2-gallon kegs, sufficient to make 40 gallons of liquid, $\$ 2.75$; in 5-gallon kegs, sufficient to make 100 gallons of liquid, $\$ 5.50$; in 10-gallon kegs, sufficient to make 200 gallons of liquid, \$10.00. Net, f. o. b. Boston.

Wilson's Plant 0il. An antiseptic for use on palms and other decorative plants, preventing scale and other insects. It imparts a healthy lustre to the foliage. Pint, .40 ; quart, .75; 2 quarts, $\$ 1.25$; gallon, $\$ 2.00$; 5 gallons, $\$ 9.00$.

"Electric Worm Eradicator." Perfectly odorlese. For the instantaneous extermination of worms of every sort. The worms will immediately rise to the surface of the ground or flower-bed; or will fall off the trees, fruits, or flowers, and in a few minutes will die. It will be found exceedingly effective. It is highly concentrated, one gallon being sufficient to make 120 gallons of fluid for use, by the addition of water. Full directions for use with each package. Shipped in kegs, \$4.50 each, to make 120 gallons. Also, .50 and $\$ 1.00$ bottles. Yet, $f .0 .6$. Buston. 


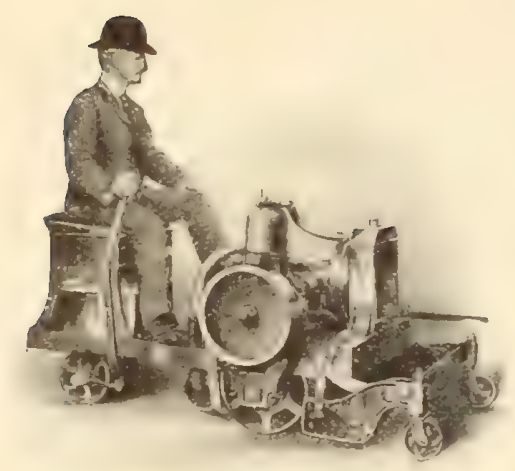

Coldwell Motor Lawn Mower.

\section{LAW N MOWERS. COLDWELL GASOLINE MOTOR LAWN MOWER.}

For use on large lawns, such as are found on golf grounds, parks and large estates, we recommend motor lawn mowers. Besides heing great saver's of time and expense, the beneticial and beautifying results to the lawn obtamed by the constant rolling of the heavy rollers is in itself sufficient to warrant their use. Prices of motor mowers are f. o. b. Newburgh, N. Y.

Style D. Weight, 2,000 pounds Equipped with 2-cylinder, t-cycle, latest improved automobile motor, consumes three-quarters of a gallon of gasoline per hour; cuts 40-inch swath: guaranteed to negotiate 25 per cent. grades; cutting part can be lifted free from the ground by means of at siugle lever. Price, $\$ 1,300$.

Style C. Similar in construction to Style D, but lighter. It weighs 1,300 pounds, cuts a swath 40 inches wide, will negotiate 15 per cent. grades, and consumes about three-quarters of a gallon of gasoline per hour. 'The motor is of the 2-cylinder, 2-cycle, 8 horse-power type, and embodies several of the hest features of Style D; is especially adapted for use on grounds comparaticely smooth and where the going is not too heary. Price, $\$ 850$.

Style B. Motor driven. Recommended for use on smaller lawns. It weighs 1,000 pound:, cuts a swath 35 inches wide, and will negotiate 10 per cent. grades, Equipped with a 4 horsepower, 2-cycle, single cylinder type of motox, which consumes one-half gallon of gatsoline per hour. Price. si50 net

\section{NEW EXCELSIOR HORSE LAWN MOWER.}

New Excelsior Horse Lawn Mower. Unquestionably the Best IJorse Iawn Mower manufactured.

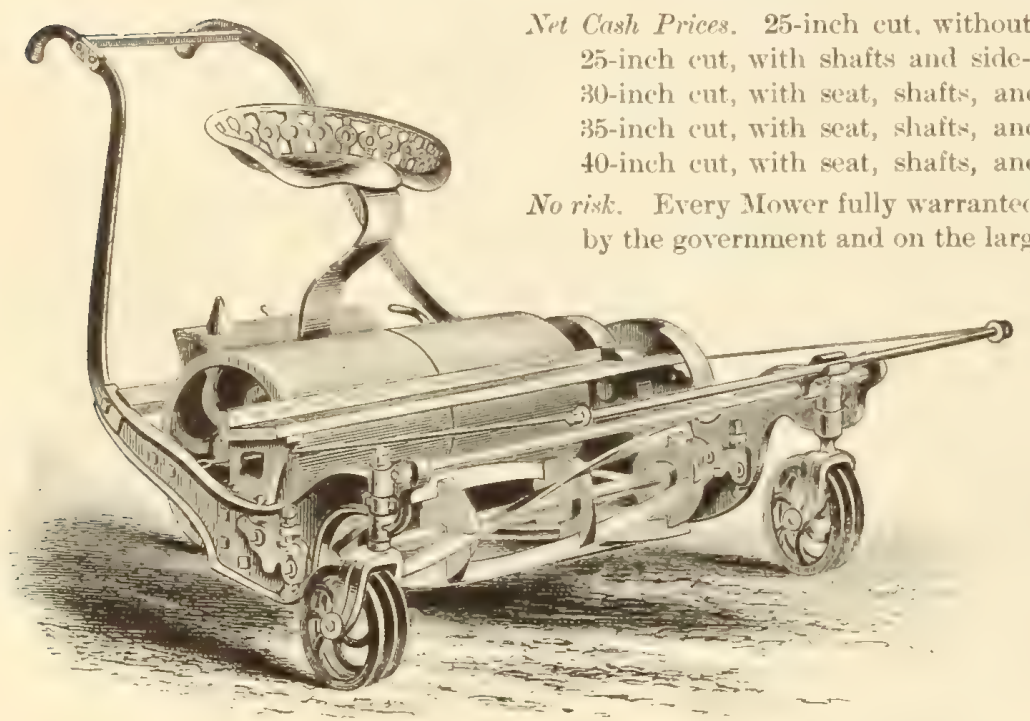

Cash Prices, 25-inch cut, without seat or shafts

$\$ 40.00$

45.00

67.50

82.50

105.00

No risk. Every Mower fully warranted to give satisfaction. These Mowers are used exclusively by the government and on the largest public parks and lawns in the country.

\section{THE VICTORY BALL-BEARING HAND LAWN MOWER.}

10-inch wheel, four-bladed reel, construction light; easily run and almost silent. wer built.
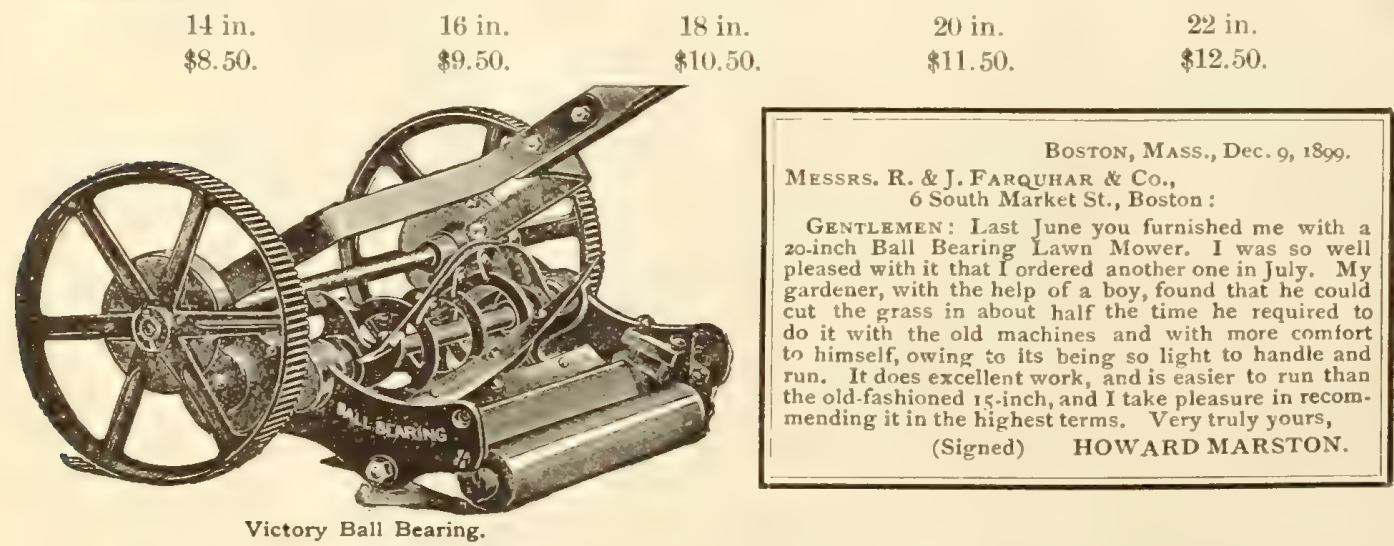

One of the best mowers RIMM R. An indispensable article for Lawn Trimming. Doing away with the shears and sickle. can be worked around where the latwn mower cannot cut: up in corners, along stone walls, fences, around trees, shrubbery, etc. Price $\$ 5.00$.

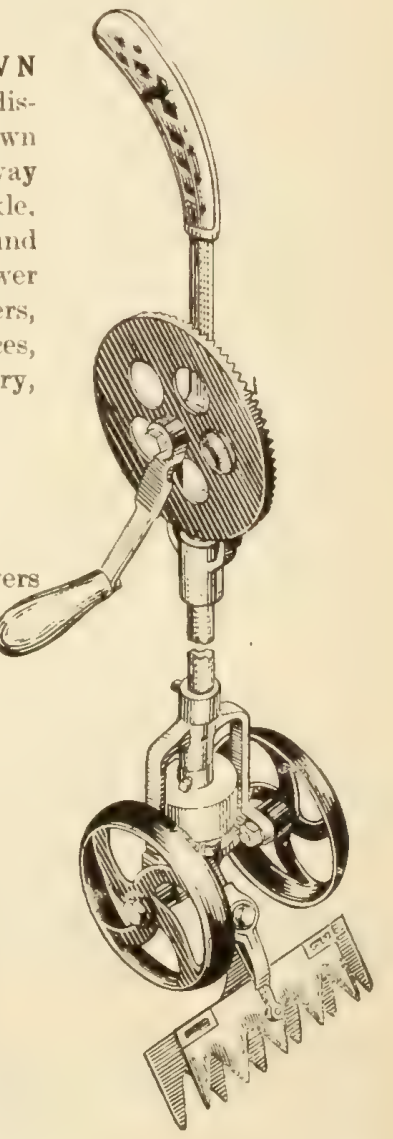

Barton's Lawn Trimmer.

SHARPENING AND REPAIRING OF LAWN MOWERS.

We employ a practical machinist and attend to all orders promptly. The correct adjustment and replacement of worn. out parts requires skllful hands, and as we give first-class work and make low charges, customers are invited to send their Lawn Mowers for repairs to us. Please send EARLY IN THE SEASON So as to be ready to use as soon as wanted. New parts furnished at Manufacturers' list price. 
R. \& J. FARQUHAR \& CO., BOSTON. LAWN MOWERS.

\section{GENUINE PHILADELPHIA LAWN MOWERS.}

\section{E. HIGH WHEEL.}

4. Blades, 10-inch Wheel, 6 -inch Cylinder, Train of 3 Gears, Double Wheel.

One of the lightest draft mowers manufactured; made of iron and steel.

It has one special point of excellence over other mowers of this style, which consists in removing the box caps to the cylinder cutter, and removing the cutter without disturbing the frame of the mower; it therefore has a solid frame, with little trouble in case of repairing same.

15-inch, $\$ 900 ; 1$-inch, $\$ 10.00 ; 19$-inch, $\$ 11.25 ; 21$-inch, $\$ 12.50$.

STYLE C.

4 Blades, 81-inch Wheel, 5 -inch Cylinder, Single Pinion, Geared on both sides.

This is a modium High Wheel Mower which is very popular, for the reason that it has 8.-inch driving wheels and is so geared that with the additional height in wheels it does good work and runs lighter. It is the same style as some makers put on the market for a high wheel mower.

1t-inch, \$6.00; 16-inch, \$6.i5; 18-inch, \$1.50; 20-inch, \$8.25.

\section{STYLE K.}

5 Blades, 10-inch Wheel, 6 Geared on both sides.

14 -inch, $\$ 7.00 ; 16$-inch, \$7.75; 18-inch, \$8.50; 20-inc-1, \$9.25.

For all-round general purposes this is one of the best style mowers on the market. With its high wheels it runs light, and five knives it cuts smooth and aven, with the principles of construction so evenly balanced that it has the greatest amount of durability.

\section{COLDWELL ROLLER MOWER.}

Roller Mowers are especially adapted for cutting fine lawns, golf greens and borders; also for trinming around trees. shrubbery and flower beds.
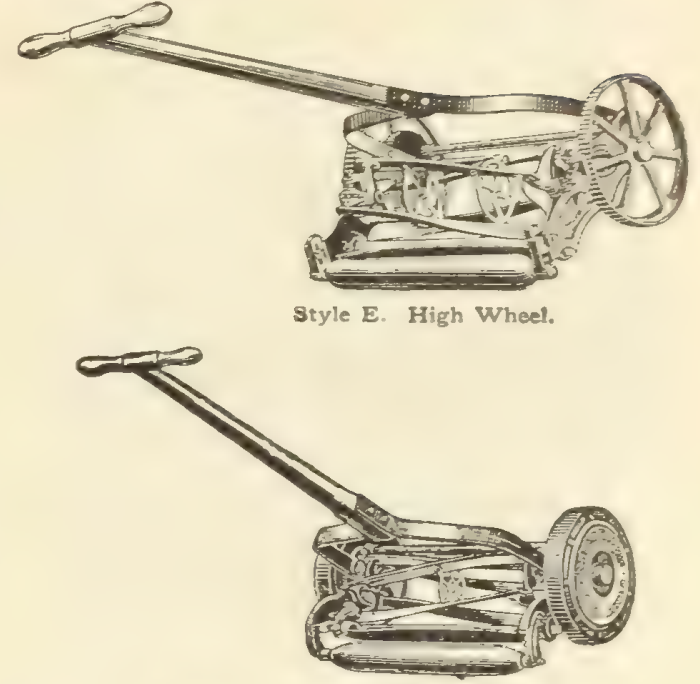

Style C.

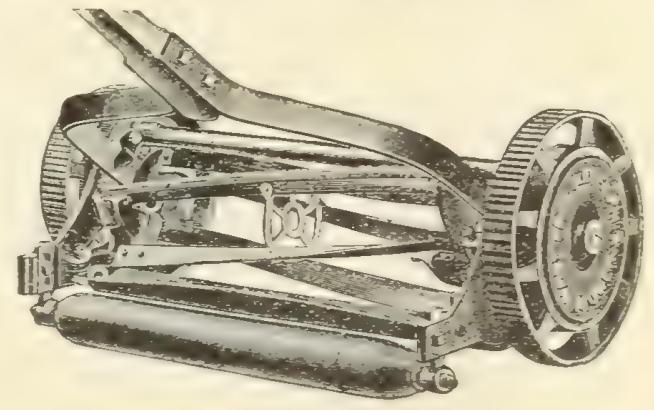

Siyle K.

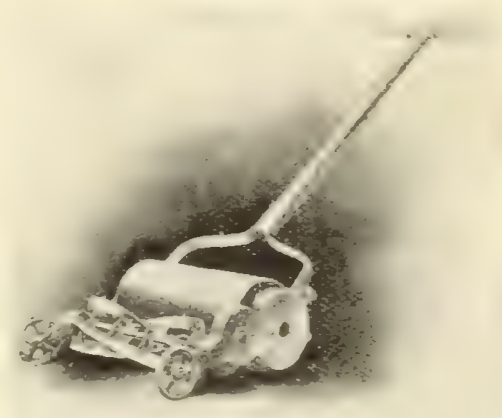

Roller Mower

HORSE DRAWN ROLLERS.

650 lbs. to 5 tons, prices upon application

In writing please state weight of roller required, and the purpose for which it is to be used so that we may quote upon the proper kind.

\section{ABOUT ROLLING LAWNS.}

The benefit derised from the use of a roller on the lawn, especially in the spring, is not fully understood. The action of freezing and thawing causes the ground to heare, and if the sod is not firmly pressed back with a roller before hot weatlier begins, the grass is apt to be killed or injured, leaving the lawn full of bare spots.

The Boss Lawn Roller.

THE "BOSS" HAND LAWN ROLLER.

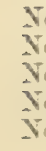

iving

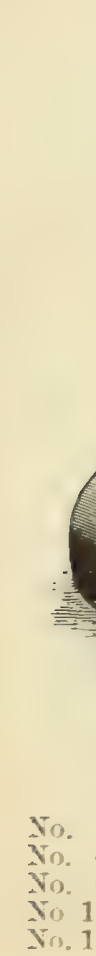

11.24

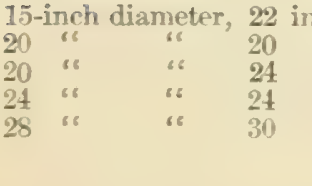

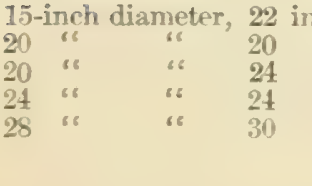

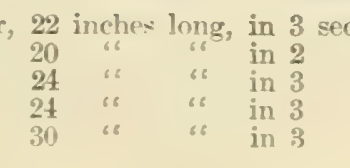

\section{7t-inch face; $200 \mathrm{lbs}$.}

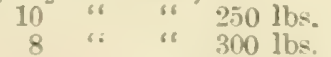

8 " " 450 lhs.

\section{… $\quad \cdots$}

$\cdots \quad \cdots \quad \cdots$

$\cdots$

․ $\quad \cdots, \quad \cdots$ 


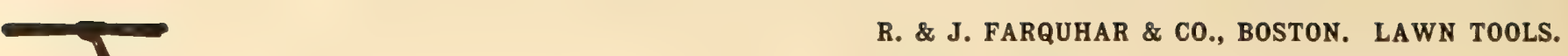

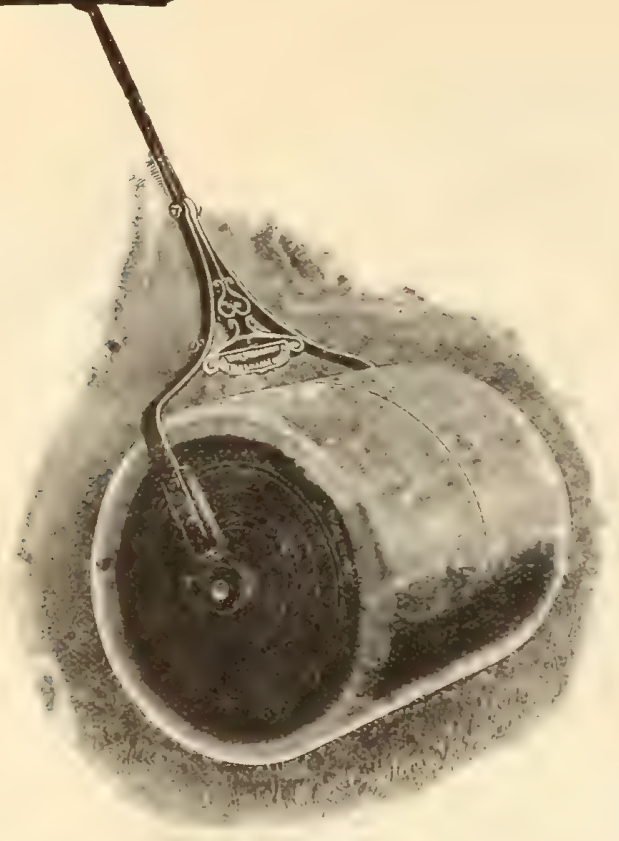

Water or Sand Ballast Roller.

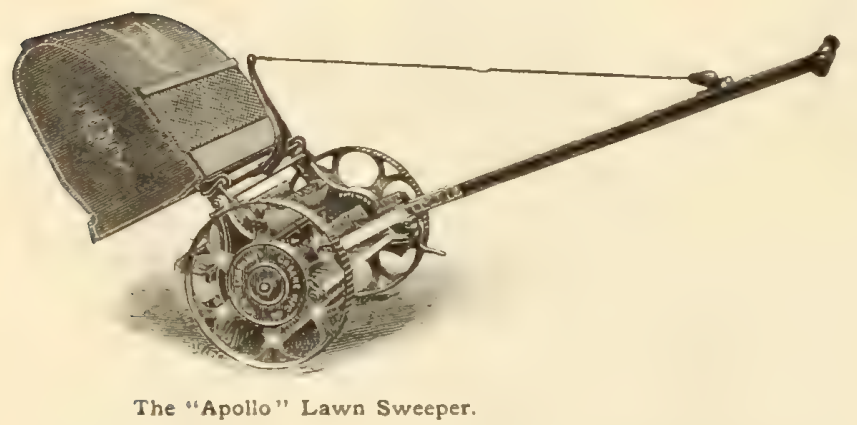

E. Z. GRASS CATCHER.

The 16-inch will fit all sizes from 12 to 16 inches. 20-inch will fit all sizes from 18 to 22 inches.

Each, $\$ 1.50$.

The E. Z. Grass Catcher consists of a galvanized iron bottom, with impossible-to-rip cloth connections; the sides and back are made of very strong canvas, and the frame is made of coppered iron anti-rust wire, with supports made of the same material.

It will fit every style of mower and has a universal attachment that reaches two inches in each direction; that is, a 20 -inch catcher will fit 18 , 20, or 22-inch lawn mower, and can be set from one to four inches from the mower roller, a point that makes it a great seller.

\section{WATER OR SAND BALLAST ROLLER.}

\section{For Lawns, Tennis Courts, Putting Greens, Drives, Gravel Paths, Etc.}

thus a Rollep fully chapged with s about 50 per cent. heavier than when empty.

$$
\begin{array}{cc}
\text { Approximate Weight-Empty. } & \text { Approximate Weight-Full. } \\
475 \mathrm{lbs} . & 675 \mathrm{lbs} .
\end{array}
$$

20 inches diameter by 22 inches long.

Price, ineluding Water Funnel, $\$ 35.00$

Larger sizes can be imported if desired, also heavy weight horse rollers of this style.

\section{APOLLO LAWN SWEEPER.}

A lawn to be beautiful must be clean. The Apollo Lawn Sweeper is one of the best cleaning machines, gathering all loose grass, twigs and rubbish, leaving a perfectly smooth, natural surface. It can be adjusted to any desired height, and is emptied by simply pulling a cord.

20-inch Sweep

\section{PRICES.} 28 " "

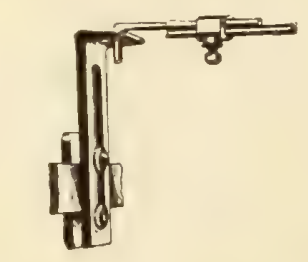

\begin{tabular}{|c|c|c|c|c|c|c|c|c|c|}
\hline 14-inch & . & ... & $\ldots$ & $\ldots$ & $\ldots$ & $\ldots$ & $\cdots$ & $\$ 1.60$ & 15-inch \\
\hline 16 & . & $\ldots$ & $\ldots$ & ... & $\therefore$ & $\ldots$ & $\ldots$ & 1.70 & 17 \\
\hline 18 & $\ldots$ & ... & $\ldots$ & ... & . & $\ldots$ & $\ldots$ & 1.80 & 19 \\
\hline 20 & $\ldots$ & . . & $\ldots$ & $\ldots$ & ... & ... & ... & 1.90 & 21 \\
\hline
\end{tabular}

PHILADELPHIA GRASS COLLECTOR.

A Galvanized Iron Bottom Collector. Never-rip Cloth Connections. It will fit Philadelphia Mowers only. FOR LOW WHEEL MOWERS.

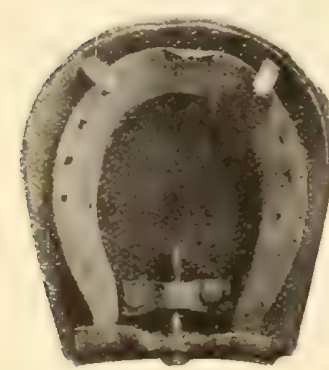

Baker's Lawn Shoe,

\section{THOMSON'S “STUDDED” HORSE BOOT.}

For use on Golf Links. Tennis Courts, and Fine Lawns.

Our boot presents advantages of shape with a rolling toe, thus saving the cutting of the turf. Where care is exercised in ordering by size to fit the horse's feet, perfect satisfaction will be found. Regular sizes, price, $\$ 10.00$, per set of four.

\section{NOTICE - How to Order by Size.}

No. 2 boot measures inside $5 \frac{1}{2}$ inches, correct size for No. 2 Horse shoe. No. 4 boot measures inside $6 \frac{1}{2}$ inches, correct size for No. 4 Horse shoe. No. 6 boot measures inside 7 inches, correct size for No. 6 Ilorse Shoe.

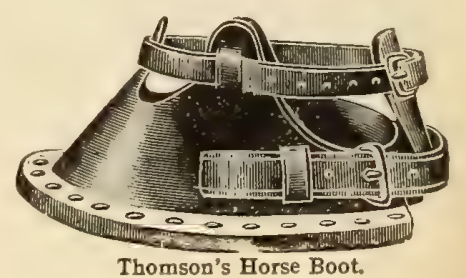

Thomson's Horse Boot.

BAKER'S LAWN SHOES OR SANDALS. A desirable pattern made of a solid steel plate turned up at the toe to protect the turf. They are attached by two iron prongs in front of the shoe and a clamp is screwed firmly to the heel, keeping them in position. Per set of four, $\$ 6.00$. 


\section{LAWN SPRINKLERS.}

CACTUS LAWN SPRINKLER. (Fig. 1.)

With centre spray; no revolving parts; can be moved about the lawn without turning off the water. No. 5 , for $\frac{3}{4}$-inch hose, .85 each; by mail, $\$ 1.15$.

\section{COLUMBIAN LAWN SPRINKLER. (Fig. 2.) \\ Three-arm; \$1.25 each.}

ENTERPRISE LAWN SPRINKLER. (Fig. 3.)

The adrantages of this Sprinkler are as follows:

Each machine is furnished with a cord so that the Sprinkler may be easily moved orer the lawn without turning off the water. The water passes through a strainer before it enters the small perforations, which are thereby prevented from filling up. The weight of the revolving parts is supported by the water. This reduces wear to a minimum. The machine is tinned and nickel-plated, and is of very handsome appearance. $\$ 3.50$.

\section{THE FOUNTAIN LAWN SPRINKLER. (Fig. 4.) Yade of Heary Brass.}

Easily moved over the lawn without turning off the water.

The mist-like spray is a veritable "thing of beauty." Different and better than any other. That's why you should have it.

Price, \$1.25 each; by mail, .15 each extra.

\section{JAPANESE LAWN SPRINKLER. (Fig. 5.)}

Beautiful, cheap; adjustable to suit any pressure. This Sprinkler has no revolving parts to leak or wear out. A Sprinkler that will give satisfaction with a low pressure. For $\frac{9}{4}$-inch hose, .85 each; by mail, $\$ 1.10$.

\section{THE STEARNS REVERSIBLE LAWN SPRINKLER. (Fig.6.)}

This Sprinkler is suitable for use with either high or low water pressure; the cap is reversible, and a high or low spray covering a wide area of ground may be secured by simply reversing the cap. .75 each; by mail, \$1.05.

\section{TWIN COMET LAWN SPRINKLER. (Fig. $\left.\bar{\imath}_{0}\right)$}

The three upper arms revolve rapidly, sprinkling meantrile, and carrying around a slowly revolving nozzle which sprinkles the ground for a great distance. Very substantial and durable. Height, 17 inches. Price, $\$ 5.00$.

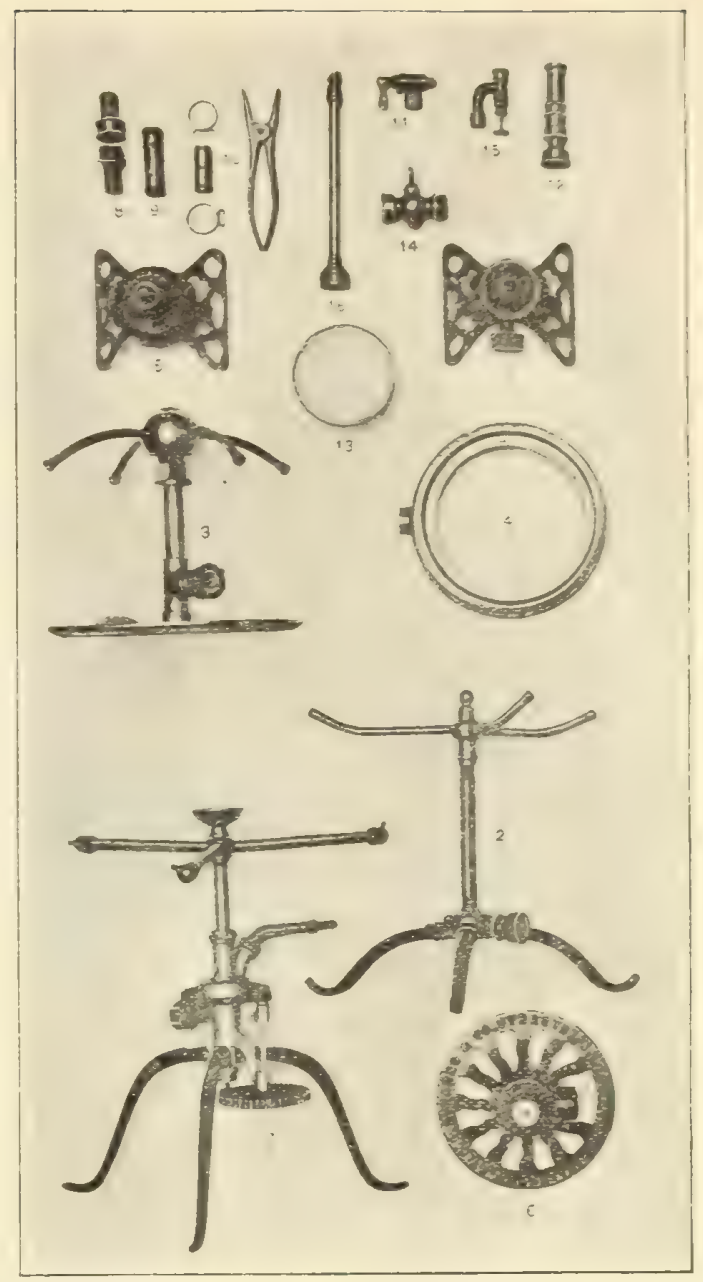

\section{RUBBER HOSE.}

Prices on our "Reliable" and "Extra" brands include couplings.

R. \& J. FARQUHAR \& CO.'S “RELIABLE."

3-inch, 3-ply, at .16 per foot; $\frac{1}{2}$-inch, 3-ply, at .15 per foot.

R. \& J. FARQUHAR \& CO.'S "EXTRA."

$\frac{3}{4}$-inch, 3-ply, at .14 per foot; $\frac{1}{2}$-inch, 3-ply, at .12 per foot.

Chicago Electrie Hose. Strong and durable. Manufactured in continuous lengths of 500 feet. Jointless and seamless. $\frac{3}{4}$-inch, .16 per foot; 25 and 50 -foot lengths, .18 per foot; couplings, .25 per pair.

Cotton Hose. Rubber lined, best quality, couplings included, $\frac{3}{4}$-inch, foot, .12; $\frac{1}{2}$-inch, foot, 11 .

Hose Couplings. (Fig. 8.) Per set, .25.

\section{HOSE MENDERS.}

Electric Tape for Mending Hose. If wound around a leaking wr weak part it will adhere clusely and make the luwe as fetfertive as before. It requires no heat, and can be applied in a minute. ("ines in the form of a ribhon. (vil, .2); large coil, .50.

Hose Menders, Metal. For $\frac{1}{2}$ and $\frac{3}{4}$-inch hose; .50 per dozen.

Hose Menders, Wood. Vers useful and durable; ; ?0 per dizem.

The "Cooper" Hose Menders. (Fig. 4.) Hose mended with

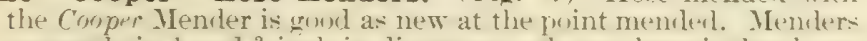
are made in $\frac{1}{3}$ and $\frac{3}{3}$-inch in diameter and are three inches lume. Four two hands are all the towls necessary to make hoses perfect. .75 I $\mathrm{x}$ rlozen; by mail, $\$ 1 .(10)$.

Hose Menders, Hudson's. (Fig. 10.) This Mender is a metallic

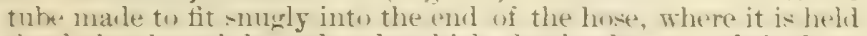

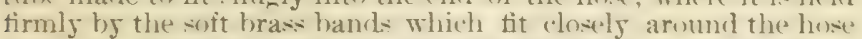
and grooved tules. It is equally valuable for fastening on lowe mup,lings. 1 -inch hose, .35 doz.; by mail, 10 extra; ;-inch hosts, .4) diz.; hy mail, 10 extra; plyer, .25 each; hy mail, .3.5; hamils, .18 per doz. We put the $\frac{3}{4}$ and $\frac{1}{2}$-inch sizes in boxes containing 1 plyer, 6 menders, and 12 wires, at .75 per box; by mail, .90 . In ordering please state size desired.

\section{HOSE NOZZLES}

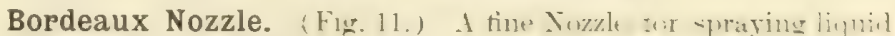
insecticides. $\$ 1.00$; by mail, $\$ 1.10$.

Graduating Spray Hose Nozzle. (Fig. 12.) Fur rum-led, hithell, lawn, or garden, this sprinkler is superior to any. Wi. lates them specially mate of leavy hats. Fath, .50; by inail, dil).

Farquhar's Spraying Nozzle. (Fig. 1:3.) The num -mh-tantial

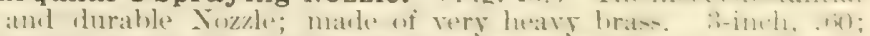
t-inch, \$1.00. Shut-off connection fur same (Fig. 11), ..j.

Improved Vermorel Nozzle. (Fig. 1i.) Arranct with -tup?-

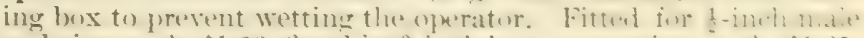

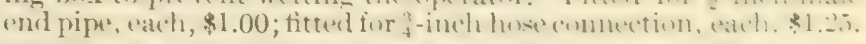

Stott Nozzle. (Fig. li.) Fur errenlunes - fratying. \$1 .2.

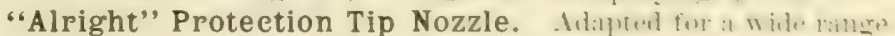
of uses. Contracted sprays and streams, antomatic and positive. subdued and forced as operator desires. It insures a great saving of water and better results. Instautly operated with one hand. Each, $\$ 1.00$. 
HOSE REELS.

The "Auburn" Hose Reel, Six-arm. (Fig. 17.) This reel has six arms with ratchet drum and will carry 100 feet of $\frac{3}{4}$-inch hose. It is made of white ash. Sides are bent. Wheels 9 inches in diameter. Nicely painted vermillion red, striped, ornamented, and varnished. Very strong and durable. Price, \$2.50.

Hose Reel, New, All Iron. (Fig. 18,) A substantial hose reel for garden and lawn use at a low price has long been wanted. The reels are light in weight with high wheels, are constructed entircly of wrought iron pipe and malleable iron, and are almost indestructible. They are entirely frictionless and have none of the objectionable features so numerous in the ordinary wood reels.

$\begin{array}{lcll}\text { No. } & \text { Height of wheel } & \text { Weight. } & \text { Capacity. } \\ 10 & 21 \mathrm{in} . & 18 \mathrm{lbs} . & 100 \mathrm{ft} \\ 20 & 24 " & 22 \% & 150 \% \\ 30 & 30 & 326 & 500 "\end{array}$
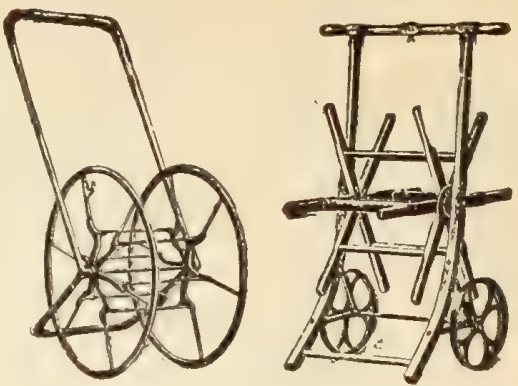

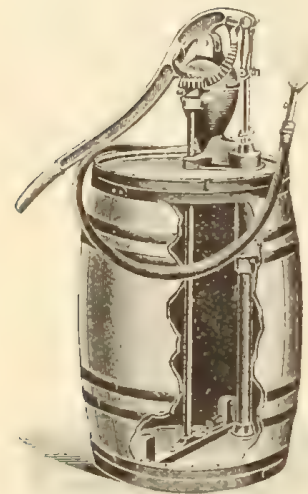

Empire Queen Pump.

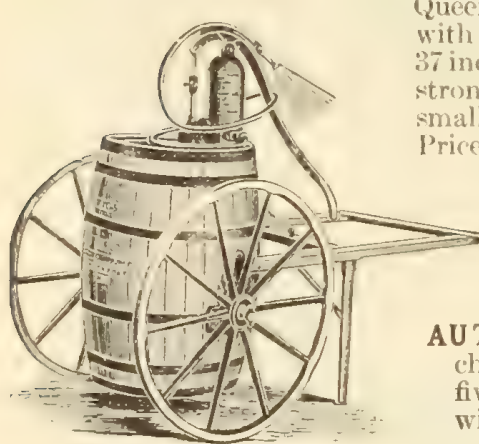

Truck and Barrel Sprayer.

The Empire Queen Spraying Pump. With automatic mechanical agitator. This pump has a seamless brass cylinder two inches inside diameter and eight inches long, brass plunger with leather bucket, brass lower valves, and brass rod, also a brass screw spout to which hose is attached by a screw coupling. It hay a large air chamber, by means of which the spray is strong and continuous.

The Agitator works in connection with cogs from the lever, connecting with a companion gear at the upper end of a steel shaft; at the lower end of the shaft is a horizontal wooden bar, to which are attached two upright padrlles.

This pump has a fine brass strainer at bottom of suction pipe which prerents leaves or dirt from getting into pump or nozzle, and it also has a l,rush on the agitator arm which swings under the strainer, keeps the dirt lirushed off and prevents elogging the pump.

Pump and Outflt "B." Empire Queen Pump, with brass screw spout, and agitator complete, also 10 feet of hest 3-ply hose Niagara spray nozzle and couplings, nicely mounted on 50-gallon barrel, the agitator carefully adjnsted, the whole apparatus ready for use, price, $\$ 15.00$; additional hose, .16 per foot; 5 -foot extension pipe, bamboo, brass lined, $\$ 1.00$.

The Truek and Barrel Sprayer. This machine consists of our Empire Queen Pump mounted on a barrel having a capacity of 32 gallons, together with the cart. The cart has strong iron wheels, 34 inches in diameter, and sinches from outsicle to outside of hubs with tires 3 inches wide; it has trong hardwoor handles, and is at very convenient machine for use in mall orchards or gardens, where it is impracticable to drive a horse. Price. \$23.50.

The Aquapult Hand Foree Pump. (Fig. 25.) Strong and durable; not liable to get out of order. Unquestionably the best bucket spraying pump for garden, greenhomse and orchard use. Heavy hrass cylinder and strong construction throughout. \$4.50.

AU TO-SPRAY, No. 1. A compressed air sprayer, which when properly charged with a few strokes of the plunger will operate antomatically for five to fifteen minutes. Consists of a four gallon air and water tank, within which is contained a brass air pump and discharge connection, ending in a spray nozzle. Price, $\$ 7.65$.

Extension Pipe, Brass, $2 \mathrm{ft}$. length (for use on trees); .45.

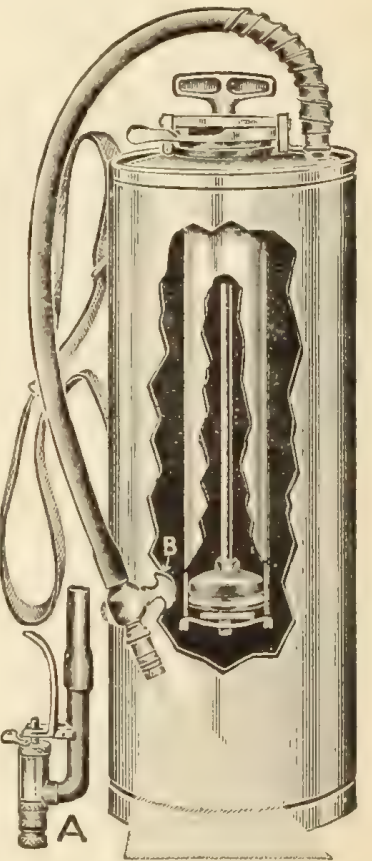

Elbow Extension, Brass (for underside of low growing plants) ; .45.

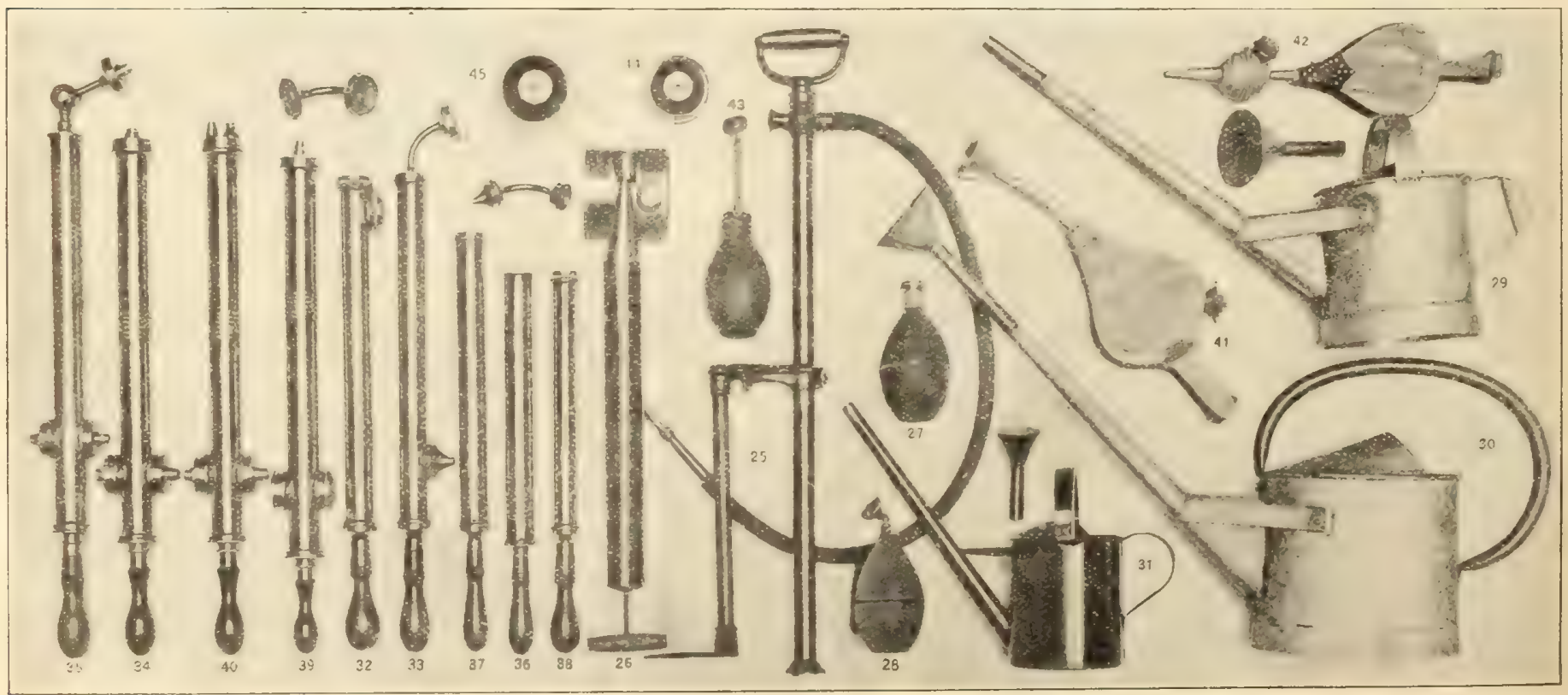


The Faultless Sprayer. (Fig. 26.) Throws a spray as fine as mist. No. 2, all brass, each, $\$ 1.00$.

Scollay's Rubber Plant Sprinkler. (Fig. 27.) Made of rubber, with flat bottona and a finely perforated, detachable top. Very useful for sprinkling, and all purposes where a fine spray is required. Three sizes. $.60, .75$ and $\$ 1.00 ;$ by mail, 10 each extra.

Seollay's Angle Rubber Sprinkler. (Fig. 28.) By means of this new device, liquids can be applied to the under side of the leaves. Price, each, \$1.00.

Pump, Kinney's Atomizer. Used to distribute liquid fertilizer or to mix or temper hot and cold water under water pressure. Connect between sections of hose and lower it into the barrel. Each, $\$ 2.00$.

\section{GALVANIZED IRON WATERING POTS. (Fig. 29.)}

Made from best quality iron and heavily galvanized after being made. Two copper-faced roses go with each pot for fine and coarse watering. 4 quarts, $\$ 1.50$ 6 quarts, spout 21 inches long, $\$ 1.75 ; 8$ quarts, spout 23 inches long, $\$ 2.00$; 10 quarts, spout 25 inches long, $\$ 2.25 ; 12$ quarts, spout 25 inches long, $\$ 2.75$.

Galvanized Iron Watering Pots, French Pattern. (Fig. 30.) With brass bale handle. 8 quarts, $\$ 2.50 ; 10$ quarts, $\$ 2.75$.

Heavy Tin Wateping Pots. (Fig. 31.) Nicely painted green. Made of extra strong, double-thick tin, braced and stayed; very substantial. 2 quarts, .75; 4 quarts, $\$ 1.00 ; 6$ quarts, $\$ 1.15 ; 8$ quarts, $\$ 1.25 ; 10$ quarts, $\$ 1.50 ; 12$ quarts, $\$ 2.00 ; 16$ quarts, $\$ 2.50$.

\section{SYRINGES.}

Farquhar's New Cyclone Rose Syringe. (Fig. 32.) With improved selfoiling piston, barrel 16 inches long. Specially designed by us for the application of insecticides directly upon insects infesting roses and other plants. As the rose is interchangeable with cap, the spray can be thrown straightaway or at a right angle at pleasure. Price, strong brass, with cap and spray rose, $\$ 3.50$; with cap and two spray roses (fine and coarse), \$4.00.

No. G. Garden and Greenhouse Syringe. (Fig: 33.) With elbow joint, stream and spray; excellent for applying liquid insecticides. \$4.75.

No. 5. Garden and Greenhouse Syringe. (Fig. 34.) Stream and two spras roses. $\$ 8.00$.

No. 7. Greenhouse Sypinge. (Fig. 35.) Stream and two spray roses, and knuckle joint turning in all directions; for applying water or other liquids to the under surface of the leaves to destroy insects, etc. $\$ 10.00$.

No. 0. Garden Syringe. (Fig. 36.) For applying liquids, solution, ete. \$2.50.

No. C. Garden Syringe. (Fig. 37.) One stream and one spray rose. $\$ 3.50$.

No. A1. Garden Syringe. (Fig. 38.) With elbow joint spray and stream. 82.75

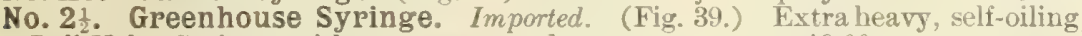
Ball Valve Syringe, with one stream and two spray roses. $\$ 9.00$.

No. 4. Greenhouse Syringe. Imported. (Fig. 39.) Extra heavy, self-oiling, ball valve syringe, with one stream and two spray roses. $\$ 9.00$.

\section{POWDER DISTRIBUTORS.}

French Sulphur and Powder Bellows. (Fig. 41.) The best of all powder distributors; excellent for effectually and economically applying sulphur, hellebore, etc, to plants. No. $1, \$ 2.00$; No. $2, \$ 1.60 ;$ No. 3, with powder receiver in shank, $\$ 1.50$.

Powder Bellows. (Fig. 42.) For applying hellebore, sulphur, slug shot, etc. Small, .75; medium, $\$ 1.00$; large, $\$ 1.25$.

Scollay Inseet Powder-Puff. (Fig. 43.) A new device for applying insect powder of any kind to plants, etc. Very
useful for house-plants and to housekeepers generally. Price, each, $\$ 1.00$; by mail, \$1.10.

Star Powder Gun. (Fig. 44.) For applying insect powders, Each, .10; by mail, .12.

Jumbo Powder Gun. (Fig. 45.) Each, .25.

Little Giant Powder Gun. For applying dry powder, such as Paris Green, Hellebore, ete. The powder is blown through the tube by a revolring fan and the quantity used can be regulated as desired. The outlet tube branches so that two rows cau be eorered at one operation. Price, complete, $\$ 650$.

Asparagus Buncher and Trimmer Combined. With flexible clamp which will not crush stalks. \$3.50.

Asparagus Knife. (Fig. 52.) For cutting Asparagus under the surface of the soil. Each, .50.

BASKETS, WIRE HANGING. (Fig. 53.,

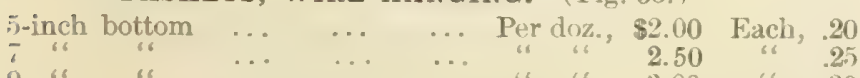

$$
\begin{aligned}
& 9 \text { " } \\
& 3.00
\end{aligned}
$$

Size

4 inch

5 inch

6 inch

7 inch

\section{BASKETS, VERBENA AND PANSY.}

Marston's Pattern. Adjustable wooden handles with tin fastenings on the ends. 10 inches long; 5 inches wide; 3 inches deep. $100, \$ 2.00 ; 1,000, \$ 18.00$.

Marston's Pattern. Large size 1.2 inches lono;

4 inches deep. $100, \$ 3.00 ; 1,000, \$ 25.00$.

Bill Hooks. (Fig. 56.) A pruning-hook and hatehet combined Price, No. 2, \$1.50; No. 3, \$1.75.

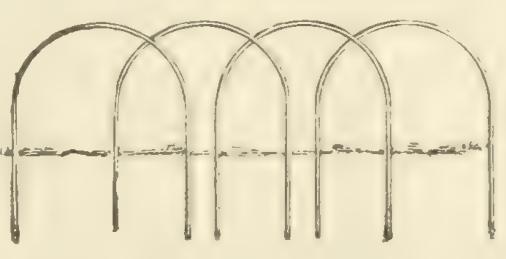

(GARDEN)

\section{BORDERING}

Wrought Iron Borders.

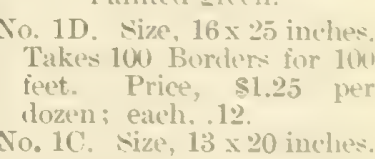

Takes 130 Borders for 100 feet. Price, .65 per dozen; ezch, . $6 t^{3}$ No 1B. Size, $10 \times 15$ inches. Takes 180 Burlers for 100 fext. Price, . 40 per dozen; each, .04.

No. $1 \mathrm{~A}$. Size, $8 \times 12$ inches. Takes 220 Borders for 100 feet.

Price, .25 per dozen; each, .03.

6 inches across top $\quad \ldots \quad \quad \ldots$ Per doz., $\$ 2.00$ Each, .20

Power Sprayers for the use of Towns, Public Parks, Cemeteries, etc., quoted upon applicarion. 


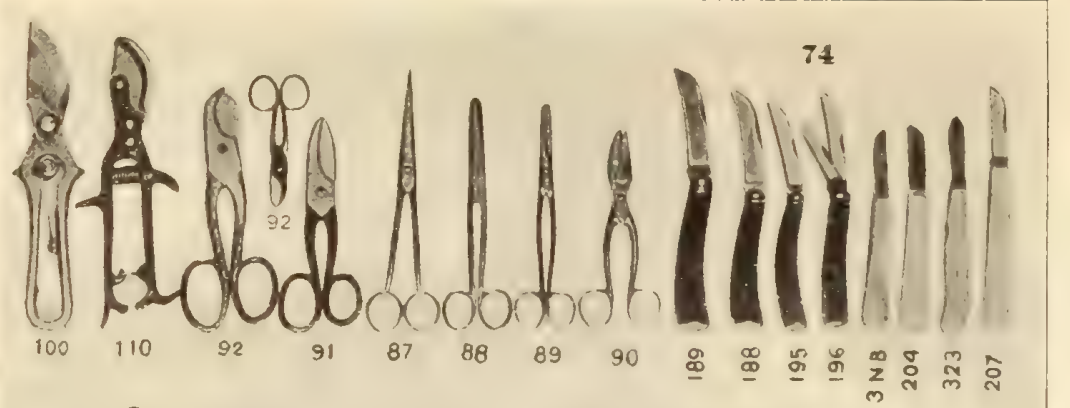

\section{GARDEN TOOLS AND REQUISITES.}

BOXES, CUT-FLOWER.

"C. L." or Corner Lock Style.

E $3 \times 18 \times 5$ inches $\ldots . . . \quad$ Per $100, \$ 2.75$

$\mathrm{L} 4 \times 18 \times 8$

4.00

N $4 \times 24 \times 8$

BOXES, Extra Heavy for Shipping.

Q $5 \times 24 \times 8$ inches ... ... Per $100, \$ 5.00$

U $6 \times 30 \times 12$ "

Y $6 \times 36 \times 14$ "6 $\ldots \ldots \ldots$ "... 11.75

BOXES, Violet, Enamelled Lithographed.

Our Garden Cutlery is chiefly imported and is

from the best manufacturers.
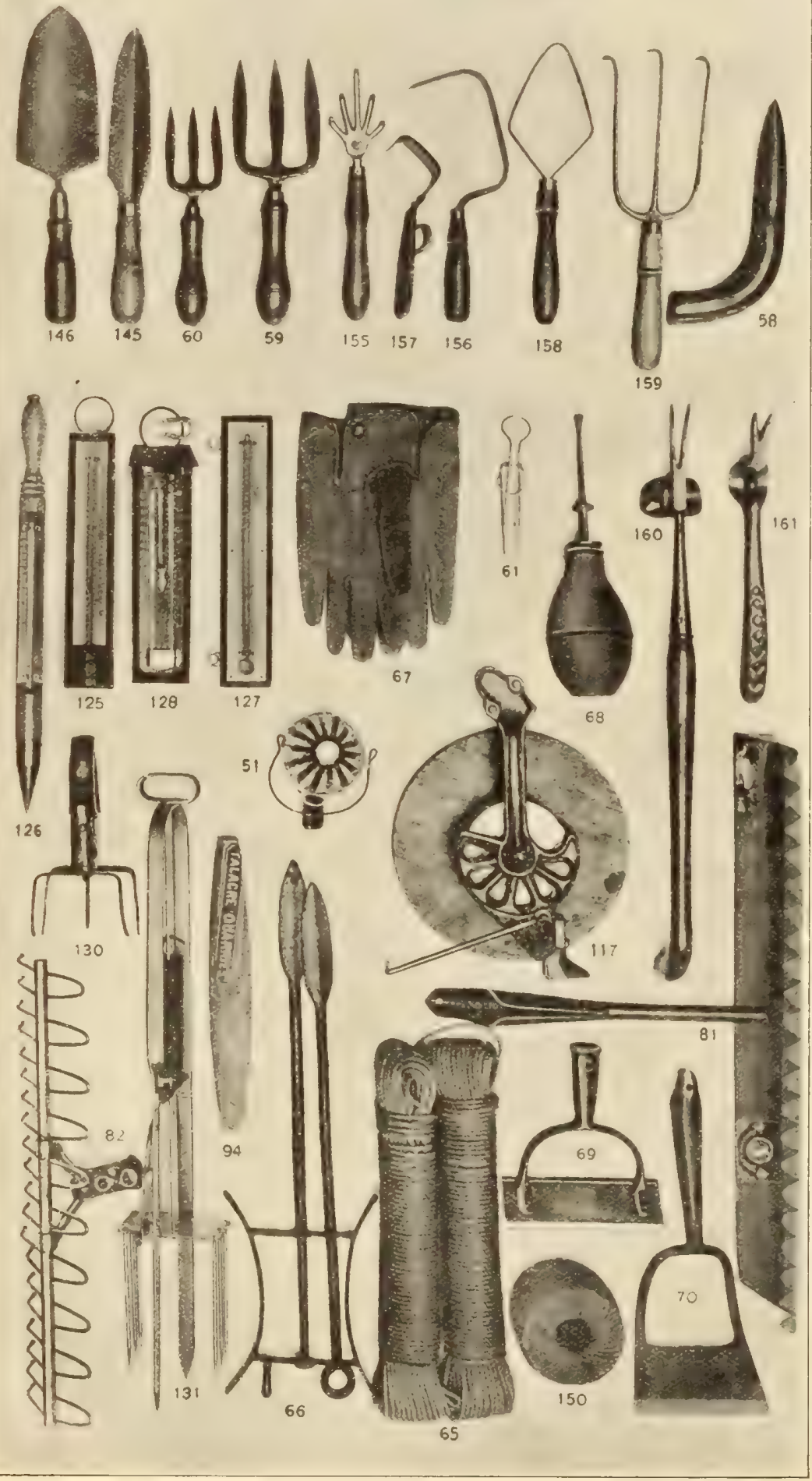

E 5 inches 9 inches 7 inches $\$ 5.50$

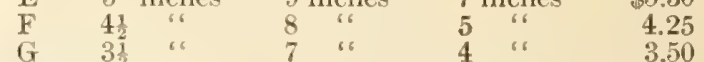

Brooms. For greenhouse and garden use, three

Cotton Batting. For packing; large sheets. Each

.05 ; per doz, .50; per bale, 480 sheets, $\$ 15.00$.

Crow Bars. Best steel, various sizes, Lb., .05 .

Dibbers. (Fig. 58.) Used for transplanting Cabbage and Cauliflower plants, ete. Metal, .35 each Saynor's spade-handled dibber, each, $\$ 1.20$.

Forks, Saynor's Hand. (Fig. 59 and 60.) Suitable for ladies' use. Small size, each, .75; large, each, $\$ 1.00$.

Forks, Hay.

No. 1, 2 tine, 5 foot handle

$\$ .65$

No. 2, 2 tine, 5 foot handle

Forks, Manuro.

4 tine, wood, D handle, strap ferrule, each, .85

4 tine, long handle, strap ferrule, " " .70

5 tine, wood, D handle, strap ferrule, " 1.10

Forks, Spading.

4 tine, wood, D handle, plain ferrule, flat tine, $\quad .85$

4 tine, long handle, strap ferrule, flat tine, .85

Forks, Spading, Ladies'. 4 tine, D handle, $\quad .60$ FLOWER POT HANDLE AND HANGER.

\section{Krick's “Perfect." (Fig. 61.)}

No. 1, will fit from $3 \frac{1}{3}$ to 5 inch pots. Per doz., $\quad .30$

No. 2, will fit from 5 to 8 inch pots. " $\quad .40$

No. 3, will fit from 8 to 12 inch pots. "

Fruit Picker. (Fig. 62.) Made of heavy galvanized wire, easily adjusted to a pole. For picking Apples, Peaches, Pears, ete. Does not bruise the fruit. Price, 35 each.

Fumigator, Farquhar's Standard. (Fig. 63.) For burning tobacco stems, etc., in greenhouses, are made of heavy galvanized iron.

Price, 16 inches high, with cover ... ... $\$ \$ 2.50$ 24 " "थ "

Fumigator, Perfection. (Fig, 64.) The tank should be filled with tobacco water. When in operation a vapor arises from this and mixes with the dry smoke from the stems, producing a dampened smoke more dense and less injurious than from any other fumigator made.

No, 1 , holds one peck of stems

$\$ 3.00$

No. 2 , holds half bushel of stems ... ... 3.50

No. 3, holds three-quarters bushel stems ... 4.00

Garden Lines. (Fig. 65.) Extra quality best Russian hemp. Single, .75 ; double, $\$ 1.25$.

Garden Reels. (Fig. 66.) Small, .50; large, .75.

Garden and Pruning Gloves. (Fig. 67.) Men's pruning gauntlets, $\$ 1.50$; ladies' pruning gauntlets, $\$ 1.00$; men's gardening (Drummond) $\$ 1.25$; ladies gardening, $\$ 1.00$.

Glazing Points, The Peerless. Price, box of 1,000 , $.60 ;$ by mail, $.75 ; .55$ per 1,000 in lots of 5,000 and over. Pincers for driving points, .40; by mail, .50.

GLAZING PUTTY, TWEMLOW'S OLD ENGLISH. (Semi-Liquid.)

This putty is used in machine or bulb. If too thick for bulb thin with a little pure linseed oil, boiled. Gallon cans, 16 lbs., \$1.25.

Glazing Machines. \$1.25, each.

Glazing Puttying Bulb, Scollay's. (Fig.68.) A simple and useful device for applying putty to sashes. Price, $\$ 1.00 ;$ by mail, $\$ 1.10$. 
Grafting Chisels. Fine quality steel. .50 and .75 .

Grafting Wax. The finest quality made as used by fruit growers $\frac{1}{\mathrm{l} b .}, .10 ; \frac{1}{2} \mathrm{lb} ., .15 ; \mathrm{lb} ., 30$.

Hoes, Grub. Finest quality steel. $3 \frac{1}{2}$ and $4 \mathrm{lb} ., \$ 1.15$.

Hoes, Ames' Scuffle. (Fig. 69.) Handled, each, 6 inch, .50 7 inch, .55; 8 inch, .60; 9 inch, .65; 10 inch, .70.

Hoes, English Seuffle. (Fig. 70.) Imported. Each, 4 inch, $.40 ; 5$ inch, $.45 ; 6$ inch, $.50 ; 7$ inch, .55; 8 inch, .60; 9 inch, .70 10 inch, $.80 ; 12$ inch, .90. With handle, .20 each, extra.

đoes, Field Socket. 6 inch, each, .50; 8 inch, each, .55.

Hoes, Street. 5 inches $\times 9$ iaches, each, $.60 ; 6$ inches $x 10$ inches, each, 65.

Hoes, Shank. Ladies', and boys', 40.

Knives, Grass Edging. (Fig. 73.) American, with handle .70 English, with hardle, .\$1.65.

Knives, Saynor's Pruning and Budding. (Fig. 74.) Tllnstrated on page 122. Saynor's garden cutlery is the finest manufactured.

$\begin{array}{rrrrrrrrr}\text { No. } & 189 & 196 & 188 & 195 & 207 & 204 & 3 \mathrm{~N} . \mathrm{B} . & 323 \\ \text { Price, } & \$ 1.75 & 2.00 & 1.50 & 1.50 & 1.50 & 1.50 & 1.50 & 1.50 \\ 207 \text { B. } & \text { Brass capped, } \$ 1.75 . & & & & & \end{array}$

\section{LABELS, COPPER. (Fig. 75.)}

By using a stylus or hard lead pencil the metal is indented and the writing is permanent. No, 1. 1 inch wide by 3 inches long. Price, $\$ 1.00$ per 100 . No. 2. $1 \frac{1}{8}$ inches by 5 inches, suitable for 2 lines of writing, $\$ 1.50$ per 100 .

Labels, Farquhar's Improved Indestructible, with Rod. The best label for permanency. On a strong, neat rod of galvanized iron, 18 inches long. The label is attached by copper wire passed through a drilled eye at the top of the rod. Price, Rods, $100, \$ 3.50$; Zinc labels, No. 21, \$1 25 per 100 .

Labels, Zine. (Fig. 76.) These are unsurpassed, being neat, durable, and indelible. The ink marks a jet black, which remains distinct indefinitely. Use a clean quill pen or pointer stick. Price, per 100 :

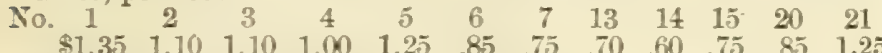

Indelible Ink. For writing on zinc labels. Small bottle, .20 large bottle, .35 .

\section{LABELS, PLANT AND TREE. (Fig. 77.)}

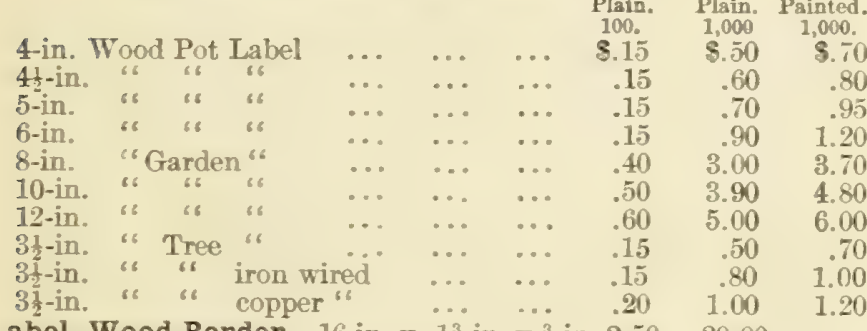

Label, Wood Border. 16 in. $x 1 \frac{3}{4}$ in. $x \frac{3}{8}$ in. $2.50 \quad 20.00$

Mattock Axe. With handle, $\$ 1.10$

oil, Lubrieating, for Lawn Mowers, ete. We supply a very superior article. Quart, .25, gallon, .75. Steel Oilers for applying lubricating oil, .30, each. Copper Oilers, .75 each.

Netting Tanned. For protecting fruit trees and strawberry bed from birds, 1 in. mesh, 2 Jds. wide, 100 yds. long; per piece, $\$ 7.00$

Paper, Brown Manila Tissue. For cut flowers. Sheets, 24 x 36 inches. Per ream, $\mathbf{3 1 . 2 5}$; per $\mathbf{l b}, .15$.

Paper, Parcelling. Sheets $20 \times 30$ inches, $24 \times 36$ inches, 30 $x 40$ inches; per lb., .08; per ream, 50, 60, and $100 \mathrm{lbs}$., respectirely, .06 per $1 \mathrm{~b}$.

Paper, Waxed. Thin, white; aids in preventing the escape of moisture. Sheets $18 \times 14$ inches; per lb., .30; per ream, 5 lbs., $\$ 1.25$

Paper, White. For cut flowers. Sheets $24 \times 36$ inches, per $1 \mathrm{~b} .$, 10; per ream, 47 lbs., \$3.25.

Paper, White Tissue. Sheets, $24 \times 36$ inches; per $1 \mathrm{~b} ., .20$; per ream, 10 lbs., $\$ 1.75$.

Peneils, Wolf's Indelible Garden. For writing on wood labels, in red, black, or blue colors. Each, .15; doz., \$1.50.

Picks, Ames' R.R., with 36 -inch walnut pick handle, $5 \frac{1}{2}$ to $6 \frac{1}{2} \mathrm{lbs}$. each, $\$ 1.00 ; 6 \frac{1}{2}$ to $7 \frac{1}{2}$ los., each, $\$ 1.10$.

Pruner, The Rockdale. (Fig. 78.) Blades made from the best tool steel. Will cut 11 -inch stick with ease. Length, 26 inches, $75 ; 41$ inches, $\$ 1.00$.

Pruner, Telegraph Tree. (Fig. 79.) The blade can be taken out to $b^{*}$ sharpened; there is a steel coiled spring for throwing out the blade; the socket has a thread on the inside, and can thus be easily screwed on to a pole of any length. Sold without handles. To be operated with a cord. Price, $\$ 1.00$ each. Extra blades, .30 each; extra springs, .25 each.
Pruner, Water's Improved Tree. (Fig. 80.) The Wrater' Pruner never fails to cut the slightest twig. The thin blade the Pruner passes through the limb so easily that the grain uninjured, and the bark left smooth. Length, $4 \mathrm{ft}$, each, 75 $6 \mathrm{ft},, .85 ; 8 \mathrm{ft} ., \$ 1.00 ; 10 \mathrm{ft} ., \$ 1.15 ; 12 \mathrm{ft} ., \$ 1.25 ; 16 \mathrm{ft} ., \$ 1.50$ Extra blades, .20 each; $\$ 2.00$ per dozen

Rakes, Hay. Wooden; 3 bow, bent handle, varnished, best quality. 14 teeth. Each,

Rakes, Steel Garden and Lawn. Short and Long Teeth. 10 tooth, each, .45; 12 tooth, .50; 14 tooth, .55; 16 tooth, 60 ; 18 tooth, .65.

Rakes, English Daisy. (Fig. 81.) For lawns, \$3.50

Rake, Gibbs' Lawn. (Fig. 82.) The best rake for cleaning lawns, Light, durable, and easily operated. Each,

Rakes, Lawn. Wooden, 3 bow, bent handle, varnished, 24 teeth, best quality. Each, .55.

Rakes, Steel Wire. For lawns. Each, .50.

Roffea. The best material for tying plants; exceedingly strong, soft, and pliable. Lb., .20; 10 lbs., $\$ 1.75$

Saw, Farquhar's Pole Pruning. (Fig. 83.) For cutting strong, high limbs of trees. Each, handled, \$1.85, without handle, $\$ 1.50$.

Saws, Pruning. (Figs. 84 and 85.) Long, narrow blades for pruning. Single edge, 18 -in., .75; 20-in., .85; 22-in., $\$ 1.00$ Double-edge, 18 -in., $\$ 1.00 ; 20$-in., $\$ 1.25 ; 22$-in., $\$ 1.50$.

Saw, Adjustable Pole Pruning. (Fig. 86.) 18-in, \$1.00

Seissors, Grape Thinning. (Fig. 87.) For thining the bunch Saynor's 6-in., \$1.00; 7-in., \$1.20; 8-in., \$1.50. By mail, .0. each extra.

Seissors, Flower. (Fig. 88.) For cutting and holding flowers. Saynor's 6-in., \$1.00; 7-in., \$1.50; 8-in., \$1.85. By mail, .0: extra.

Seissors, Flower Gathering. New German (Fig. 89.) 6-in. $\$ 1.00 ; 7$-in., \$1.25. By mail, .05 extra.

Seissors, French Flower Gatherers'. (Fig. 90). Superior to all; made on a new principle; of best material and workmanship. Price, each, \$2.00

Seissors, Florists' Snips. (Fig. 91.) 6-in., \$1.25

Seissors, Bow Pruning. (Fig. 92.) Bright; sizes, 4 inches, $75 ; 6$ inches, $\$ 1.25$

Seythes, Sibley's Solid Steel. (Fig. 93.) 32 to 34 inches; 34 to 36 inches; 34 to 38 inches ; 36 to 40 inches at .90 each.

Seythes, Broad English or Lawn. Each, \$1.40.

Seythe, The Waldron. Solid steel (English). \$1.75.

Seythe Snaths. No. 45. Pat. ash grass, Each, .75.

Seythe Rifles. Farmer's friend. Each, .10, doz., .75

Sey the Stones. Silver grit. Each, .10; doz., .75.

Seythe Stones. (Fig. 94.) Genuine Welsh. 25.

Shears, Branch or Lopping. (Fig. 95.) For cutting large branches ; long stout handles. Saynor's, three sizes, $\$ 2.75$, $\$ 3.00$, and $\$ 3.50$ each.

Shears, Grass, with Long Handles. (Fig. 96.) Saynor's best, for cutting the edges of grass borders. Blade, 81-in. \$2.50; 9-in., $\$ 2.75 ; 9$-in., $\$ 3.00 ; 10$ in., $\$ 3.25$.

Shears, Grass. (Fig. 97.) Best stee: from sheffield. Blade, $5 \frac{1}{2}$-in., \$1.25; $7 \frac{1}{2}$-in., \$1.40; 8-in., \$1.j0; 9-in., \$1.80; 10-in., \$.2.25.

Shears, Hedge Notched. (Fig. 98.) Blade, $7 \frac{1}{2}$-in., $\$ 1.60$; S-in., $\$ 1.75 ; 9$-in., $\$ 2.00 ; 10$-in., $\$ 2.50$.

Shears, Grass or Sheep. (Fig. 99.) Best steel, English, Io 120, 7 -in., \$1.00; True Vermonter, No. 05.5, 75.

Shears, New French Pruning. (Fig. 100.) This is the best pruner ever offered; quality unequalled. Price, 64-in., \$1.35 7-in., \$1.50; 81-in., \$1.75; 91-in., \$2.00; 10 -in., \$2.25. By mail, 10 each extra. Extra springs, .30 each

Shears, Taylor's Pruning. (Fig. 110.) The best low-priced pruner. Each, .50. By mail, .10 extra.

Shears, Clyde Draw Cut. No. 1, handle; 24 inches, $\$ 2.50$ each No. 2 , handle 22 inches, $\$ 2.00$ each.

Shovels, Ames'. No. 2, D handle, square or round point. Each. \$1.25. No. 2, long haudle, square or round point. Eiah. \$1.2อ.

Siekles or Grass Hooks. (Fig. 115.) English, .60,.75, and \$1.00. American, .50.

Seed Drill. Eureka Garden and Hot Bed. (Fig. 117.) For sowing vegetable seeds, etc. Superior to work done by the hand. $\$ 1.00$.

Sieves, Wire. For sifting loam, gravel, etc. Strong and well made. Any size mesh. 18 inches diameter. Each, \$1.00.

Silkaline, or Smilax Green Thread. Largely need for tying in bouquet work. Spools, each, .25; box of eight spenols, $\$ 1.2 \%$.

Sod Cutter. For lifting sols. Each, \$3.00.

Spades, Merehants'. \o. 2, D handle, .90. Jo. 2, long handle. .90 .

Spades, Ames' Best. No. 2, D hankle. Each, \$1.25.

Spades, Ladies and Boys. D handle, .90 . 
Stakes, Garden, Square, Green Painted, Tapering.

\begin{tabular}{|c|c|c|c|c|c|c|}
\hline $1 \frac{1}{2}$ & jeet long, & Fach, . & .02 & Doz., & .15 & $100, \$ 1.00$ \\
\hline 2 & " in & & .03 & & .25 & " 1.50 \\
\hline $2 !$ & “. & ." & .04 & .. & .30 & 2.193 \\
\hline 3 & .. & .. & (1.) & . & .611 & 4.00 \\
\hline $3 \frac{1}{2}$ & “" & “c & .06 & " & .70 & 4.50 \\
\hline 1 & ". & ". & .178 & ". & .80 & .50 \\
\hline 1 & .. & .. & .111 & $\begin{array}{ll}\cdots & 1\end{array}$ & 1.10 & 7.50 \\
\hline & .. & .. & $.1 \%$ & $\begin{array}{ll}\cdots & 1\end{array}$ & 1.35 & 9.1 \\
\hline
\end{tabular}

Stakes, Square, Green Painted, Tapering, Extra Heavy Black Points.
4 feet long.
Fach, .10
Doz., $\$ 1.00$
1.75
$100, \$ 7.50$
5
.20
13.00

Stakes, Round, Green Painted, Tapering, Light.

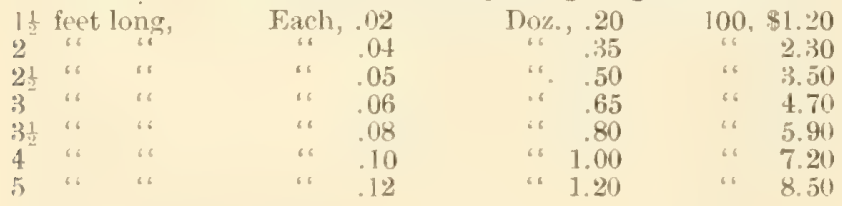

Stakes, Round, Green Painted, Heavy.

\begin{tabular}{lrrr|rrrr} 
Ft. & Each. & Doz. & 100. & Ft. & Each. & Doz. & 100. \\
3 & .10 & $\$ 1.00$ & $\$ 7.00$ & 5 & .15 & $\$ 1.75$ & $\$ 12.20$ \\
$3 \frac{1}{2}$ & .10 & 1.10 & 8.30 & 6 & .20 & 2.00 & 14.80 \\
4 & .12 & 1.35 & 9.70 & & & &
\end{tabular}

Stakes, Unpainted, Square, Hardwood.

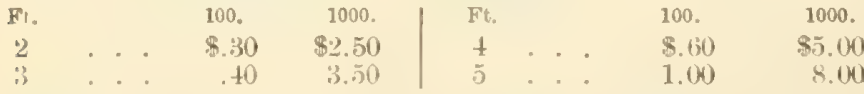

Stakes, Mateh. Plain pine, $\frac{5}{32}$ in. thick, .15 per $100 ; \$ 1.00$ per 1.000

Stakes, Cane.

These resemble the bamboo, and are strong and ilurable. Vary in length from six to ten feet. Bundle of about 250, \$2.50; $100 . \$ 1.25$

Stakes, Galvanized Wire Rose. No. \& Wire.

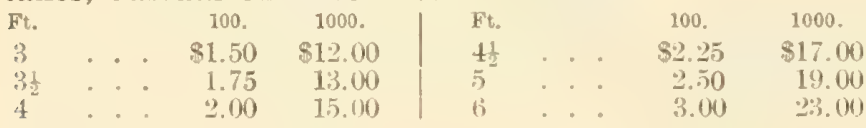

THE MODEL EXTENSION CARNATION SUPPORT.

(Fig. 123.) \$3.00 per 100; \$27.50 per 1,000.

Tape Lines. 100 feet, \$2.50.

\section{THERMOMETERS.}

Heavy Japanned Tin Case. (Fig. 125.) Wilder's 8-inch, .75: 10-inch, \$1.00; 12-inch, \$1.25.

Hot-Bed Thermometers. (Fig. 126.) 16-inch Boxwood Scalc.

Brass Points. Each, \$2.00

Self Registering Thormometers, Minimum. (Fig. 127.) 10inch. Each, $\$ 1.75$.

Taylor's No. 55, B, 8-inch Combined Maximum and Minimum. (Fig. 128.) Each, $\$ 3.00$

Tinfoil. For Bouquets. Price variable. Lb., .17.

Tinfoil. Violet, lb., .60. Green, lb., .60.

Trap, Mole. (Fig, 130.) Iron. Each, 35.

Trap, Mole, The Reddiek. (Fig. 131.) A first-class trap. No Mole can pass under this trap and live. Each, \$1.00.

Tree Serapers. (Fig. 132.) Best steel, .60.

TRELLIS, FAN FOR VINES. (Fig. 1333.)

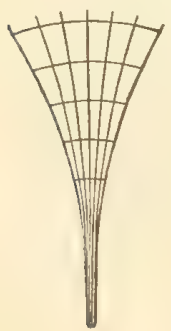

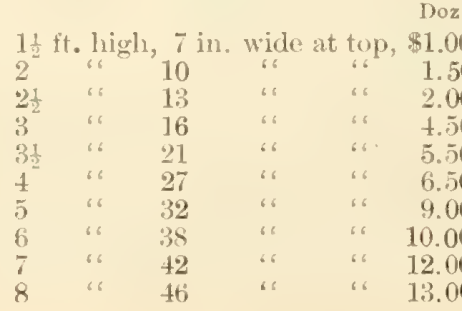

TRELLIS, VERANDA, FOR VINES. (Fig. 134.)

This is by far the most ornamental and substantial Trellimade, and is especially adapted to out-door use. Made of wood and rattan, and painted green.
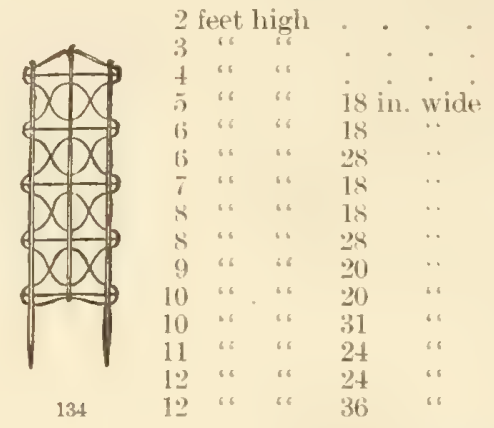

\begin{tabular}{|c|c|}
\hline $\mathrm{I})(0 \%$, & $\$ 4.00$ \\
\hline & 5.00 \\
\hline “. & 6.00 \\
\hline “" & 9.00 \\
\hline .. & 11.00 \\
\hline .. & 15.00 \\
\hline ". & 13.00 \\
\hline . & 15.00 \\
\hline . & 24.00 \\
\hline$\cdots$ & 18.00 \\
\hline . & 21.00 \\
\hline - & 32.00 \\
\hline$\cdots$ & 25.00 \\
\hline .. & $\begin{array}{l}28.00 \\
42.00\end{array}$ \\
\hline & \\
\hline
\end{tabular}

Fidch, \$. 40

". .00

$.00 \quad 3600$

1.00

is 1.25

1.15

" $6-2.00$

8.00 " 1.50

1.85

"

2.35

TRELLIS, VERANDA.

Made of steel and wire. Any size Arches or Trellises made to order. IIcighe, Width. Price each. Beight. Width. Price each.

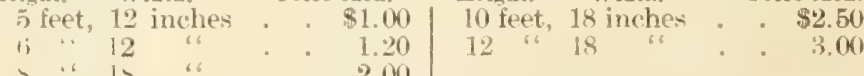

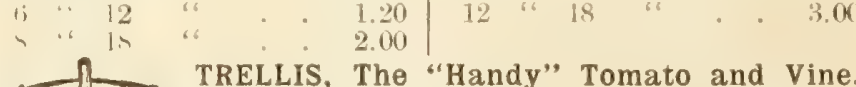

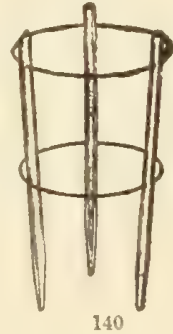

TRELLIS, The "Handy" Tomato an TRELLIS, "Two Barrel Hoop" Tomato.

TRELLIS, Wood Tomato. Price. \$1.00 per doz.

These are made of neatly finished hard wood. Height, two and one-half feet. One and one-hali feet square at top, one foot at bottom. Dozen, $\$ 1.85$

Trowels, Cleve's Angle. (Fig. 145.) It is admirably adapted for digging weeds from lawns, transplanting flowers, cultivating and other purpuses. No. 1,8-inch, tempered and polished, each, .25; No. 2 , s-inch, bright steel, .20; No. 3, 5-inch, bright steel, 15 each. By mail, 5 cents each extra.

Trowels, Flat Steel. Best quality steel. Riveted shank and tempered blade. 6-inch, .75; 7 -inch, . 85 .

Trowels, Garden. (Fig. 141;.) Curved stuel hlade, 5-inch, .15; (i-inch, .15; 7-inch, .20; 8-inch, .20.

Trowels, Garden, Extra, Forged Steel. Folid steel hlade and shank. 6-inch, .30; 7-inch, . 40 .

Twine. Heary and light parcelling. Ball, .25.

Twine, Green. For stringing smilax. Ball, 25.

Twine, Soft. For tying vines, etc; very strong. 3 and 5 ply. Large balls, 20 .

Taped Yaen. Excellent; low priced material for raspberrics, shrubs, ete. Lb., .15.

Tarred Marline. Of better quality than the above; twisted in strankls. In 5 and $10 \mathrm{lb}$. balls. Lb., .1s.

Yacht Mapline. (Fig. 150.) In 1-1b. balls, .50 per ball.

Weeder, Excelsior Hand. (Fig, 155.) For weeding or lousenting the soil. Fach, .15. By mail, .20.

Weeder, Hazeltine. (Fig, 156.) Very uscful for weeding and thinning. Each, .30. By mail, . 40.

Weeder, Lang's. (Fig. 157.) A most useful and practical littie tool, with leather band holder, so that the fingers may be free to pull weeds or thin plants. Price, .25. By mail, .50.

Weeder, Noyes' Hand. (Fig. 158.) Steel. Cutter, diamond shape. Price, 25. By mail, 30.

Weeder, Forged Steel, Three Prong. (Fig. 15\% ) Jiach, .35. By mail, .50.

Weed Grubbers. (Fig. 160.) For removing weeds. Price, \$1.50. Weed Grubber, Metal. (Fig. 161.) .25

\section{AMES GARDEN WHEELBARROWS.}

No. 3, \$3.80; No. 4, \$4.00; No. 5, \$4.70.

WIRE, BOUQUET. Prices Variable.

Florists' Annealed. Nos. 22, 23, and 24 in coils of 12 lbs., $\$ 1.00$. Florists' Bright, Cut in lengths. In boxes of $12 \mathrm{lbs}$. (one stone). 9 inches long, per 12 lbs., No. 22 Wire, $\$ 1.25$; No. 24 Wire, \$1.25.

12 inches long, per $12 \mathrm{lbs} .$, No. 22 Wire, $\$ 1.25 ;$ No. 24 Wire, $\$ 1.25$. Single pounds at 15 cents per pound. 
R. \& J. FARQUHAR \& CO., BOSTON. GARDEN TOOLS AND REQUISITES.

PLANET JR. FARM AND GARDEN TOOLS.

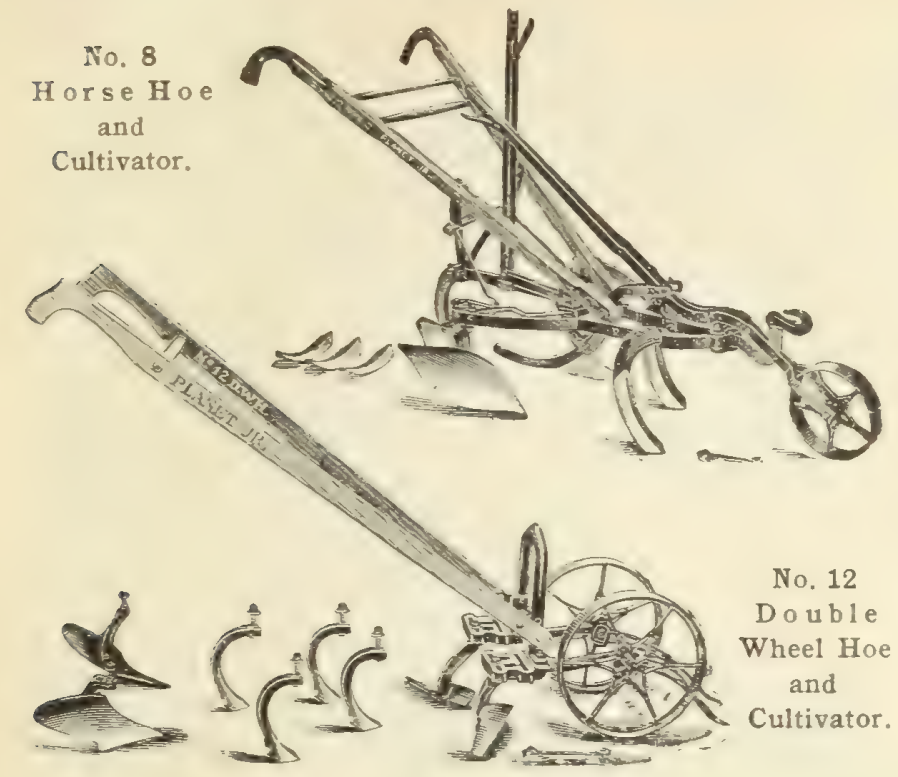

NO. 8 PLANET JR. HORSE HOE AND CULTIVATOR. Price, with Attachments, as shown in eut, \$9.00.

As used for plowing toward the row and for hilling.

Fiuipment: Four 3 -inch plates, one 4 -inch plate, two side hoes, one i-inch shorel.

NO. 12 PLANET JR, DOUBLE WHEEL HOE.

Price, with Attaehments as in eut, - _ - \$7.00

One pail of 6 -inch hoes, two pairs of hollow steel cultivator teeth, one pair of plows, one pair of leaf lifters.

NO. 17 PLANET JR. SINGLE WHEEL HOE.

Price, $\$ 5.00$. Eruipment: One pair 6-inch hoes, three steel cultivator teeth, one large garden plow.

NO. 4 PLANET JR, COMBINED HILL AND DRILL SEEDER, WHEEL HOE, CULTIVATOR and PLOW.

Price, Complete, $\$ 11.00$.

Fquipment: One pair of $4 \frac{1}{2}$-inch hoes, three cultivator teetl], one garden plow, one leaf guard.

NEW UNIVERSAL HAND WHEEL PLOW. Price, $\$ 2.40$.

This labor-saring implement can be used to prepare the ground, to furrow out, to cover, and to cultivate.

THE NEW MODEL SEED DRILL. - - Priee, \$7.75.

The diamond-shaped adjustable hole regulates the discharge, and ean be wade larger or smaller, as oceasion requires. 'The seed "ut-oft" claps up underneath the hole. It does not slide under the same as in other similar drills; on this account it does not clog nor cut the seed. It has a broad wheel and a covering roller. The opening plow is adjustable in depth. The drill is simple and can be worked by any one.

\section{ADJUSTABLE CART AND WATER BARREL TRUCK.}

By a simple arrangement of the axle the barrel can be detached at pleasure, whether full or empty. Useful for carrying water about the garden, for emptying cesspools, and for innumerable other purposes. Price, truck and barrel, complete : wheel, 21 -inch tire, $\$ 10.50$, without barrel, $\$ 7.50$; wheel, 31 -inch tire, $\$ 12.75$; without barrel, $\$ 9.75$. The following extra attachments can be supplied for use on the same truck when the barrel is detached, viz.: Hand-cart box, \$3.25; leaf rack, \$5.50; extra barrel with trunions, \$3.00; sprinkler attachment for barrel, \$3.50.
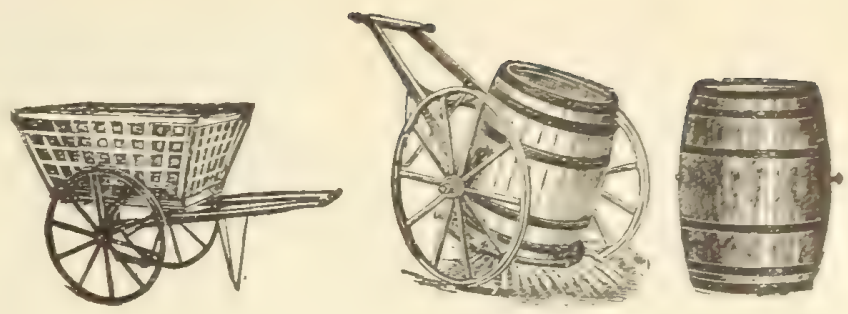

Adjustable Cart and Water Barrel Truck,

\section{HOT-BED REQUIREMENTS.}

Arlington Plant Protector. (Fig. 71.) Simple and cheap arti cle for the protection of young plants from frost and the ravage of all kinds of insects. Width at bottom, 18 inches; height, 10 inches. Price, doz., \$1.50.

Arehangel Mats. Csed for protecting from frost in spring Size, 5 x 8 feet, each, .75.

Palmer's Hot-Bed Mats. Wool filled. Size. $76 \times 76$ inches No. 1, made of jute, stitched through, hemmed with canvas and thickly padded, $\$ 1.3$ a each. No. 2 , Duck cloth outside, filled and quilted same as No. 1, \$1.65 each.

Patent Proteeting Cloth for Hot-Beds. Largely used in place of glass for protecting plants in early spring. P'ieces containing fifty to sisty y ards, one yard wide. Prices, medium grade, yart,

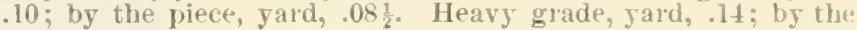
piece, yard, .12.

Farquhar's New Singapore Fibre Hot-Bed Mat. Mouse proof, rot proof, almost indestructilule. Price, 6 feet 2 inches long by 6 feet wide, each, $\$ 2.00 ; 6$ feet 2 inches long by 3 feet wide, each, $\$ 1.20$.

Straw Mats for Hot-Beds. Made by hand from flesh rye straw : thick and well put together. Regular size, $6 \times 6$ feet, each, $\$ 1.75$ extra heary, to order, $\$ 2.50$. $3 \times 6$ feet, $\$ 1.25$; extra heary, $\$ 1.50$. Odd sizes made to order at very reasonable rates.

Hot-Bed Sashes. (Fig. 72.) These are well made, of the rert best quality, thoroughly seasoned lumber, and free from sal or knots and other imperfections. Painted and glazed with double thick glass, $8 \times 10$ inches, in four rows. Frame, $1{ }^{3}$ inches, $3 \times 6$ feet, \$3.75 each; frame, $1 \frac{1}{2}$ inches, $3 \times 6$ feet, $\$ 3.50$ each.

\section{CEDAR PLANT TUBS.}

For Ferns, Palms, and other large plants. Made of thick cedar, nicely painted green. Drop handles on sides. The best made.

\begin{tabular}{|c|c|c|c|c|c|c|c|c|c|c|c|}
\hline \multicolumn{12}{|c|}{ Outside measurements : } \\
\hline No. & & \multicolumn{4}{|c|}{ Diameter across Top. } & \multicolumn{4}{|c|}{ Height Outside. } & \multirow{2}{*}{\multicolumn{2}{|c|}{$\begin{array}{l}\text { Prici } \\
\$ 5,25\end{array}$}} \\
\hline 1 & $\ldots$ & $\ldots$ & 28 & in. & ... & $\ldots$ & 22 & in. & $\ldots$ & & \\
\hline 2 & ... & ... & 26 & "6 & $\ldots$ & $\ldots$ & 20 & "6 & $\ldots$ & $\ldots$ & 4.75 \\
\hline 3 & ... & ... & 24 & $6:$ & $\ldots$ & $\ldots$ & 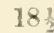 & & $\ldots$ & $\ldots$ & $3.9 \%$ \\
\hline 4 & ... & $\ldots$ & 22 & "6 & $\ldots$ & . & 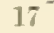 & " & $\ldots$ & ... & $3.4:$ \\
\hline 5 & $\ldots$ & $\ldots$ & 20 & 66 & ... & $\ldots$ & 16 & 6 & $\ldots$ & $\ldots$ & $2.8 \%$ \\
\hline 6 & $\ldots$ & ... & 18 & & .. & ... & 15 & $\therefore$ & $\ldots$ & $\ldots$ & 2.3 \\
\hline 7 & $\ldots$ & ... & 17 & " & ... & ... & 14 & ": & $\ldots$ & $\ldots$ & 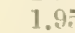 \\
\hline 8 & ... & $\ldots$ & 16 & "6 & ... & ... & 13 & " & ... & $\ldots$ & 1.7 \\
\hline 9 & ... & ... & 14 & "6 & ... & ... & 12 & 6. & $\ldots$ & $\ldots$ & 1.4 \\
\hline 10 & ... & ... & 12 & ". & ... & $\ldots$ & $9 \frac{1}{3}$ & 66 & $\ldots$ & $\ldots$ & $1 \div 0$ \\
\hline
\end{tabular}

\section{OAK PLANT TUBS.}

These are of natural wood finish with galvanized-iron hoops and handles. They are adapted for use on lawns, in halls, etc. 'The bottom is of pine, rendering the tub lighter and more durable.

$$
\text { Outside measurements: }
$$

$12 \mathrm{in.} \mathrm{in} \mathrm{diam.,} 11 \mathrm{in.} \mathrm{high,} \$ 1.2520 \mathrm{in.}$ in diam., $17 \mathrm{in.high.,} \$ 2$. (iñ

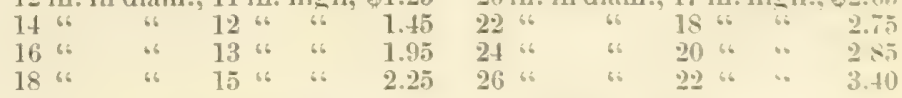

\section{ECONOMIC CEDAR PLANT TUBS.}

These are of white cedar, painted green, with electrically-welded wire hoops. Numbers 1,2 and 3 are provided with haudles.

\section{Outside measurements}

\begin{tabular}{|c|c|c|c|c|c|c|}
\hline No. Diam, at Top. & Height. & Price. & No. & Diam, at Top. & Height. & Price. \\
\hline $16+\mathrm{in.}$ & $15 \mathrm{in.}$ & $\$ 1.75$ & 4 & $13 \mathrm{in.}$ & 13 in. & $\$ 1.00$ \\
\hline $15 \frac{3}{4} 66$ & 14 “6 & 1.50 & 5 & $12: 6$ & 124 & . \\
\hline $1 t^{2} \div$ & $1+6$ & 1.25 & 6 & 116 & 126 & \\
\hline
\end{tabular}




\section{THE MOORE-LIVINGSTON}

PLANT STAND. Made of metal, copper oxidized.

No. 1. Height 8 in.; extends to 12 in. Price, $\$ 1.25$ each.

No. 2. Height $13 \mathrm{in}$; extends to 24 in. Price, $\$ 1.50$ each.

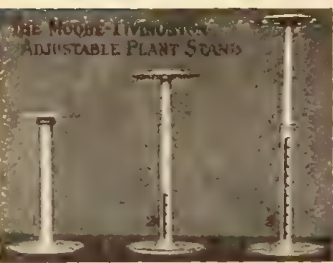

No. 3. Height 25 in ; extends to $45 \mathrm{in}$. Price, $\$ 2.00$ each.

Rustic Stump Box.-Hexagon, diameter 16, 20, 24, and 30 in. Prices, $\$ 1.25, \$ 2.00, \$ 350$, and $\$ 450$.

Round Hanging Rustie Baskets (Fig. 113).-These baskets, filled with flowers, hung in windows, verandas, ete., look very pretty. 8 in. diam., each, $.75 ; 9$ in. diam each, $85 ; 10$ in diam. each, $\$ 1.00 ; 12$ in. diam, each, $\$ 1.50 ; 15$ in. diam., each, $\$ 2.00$.

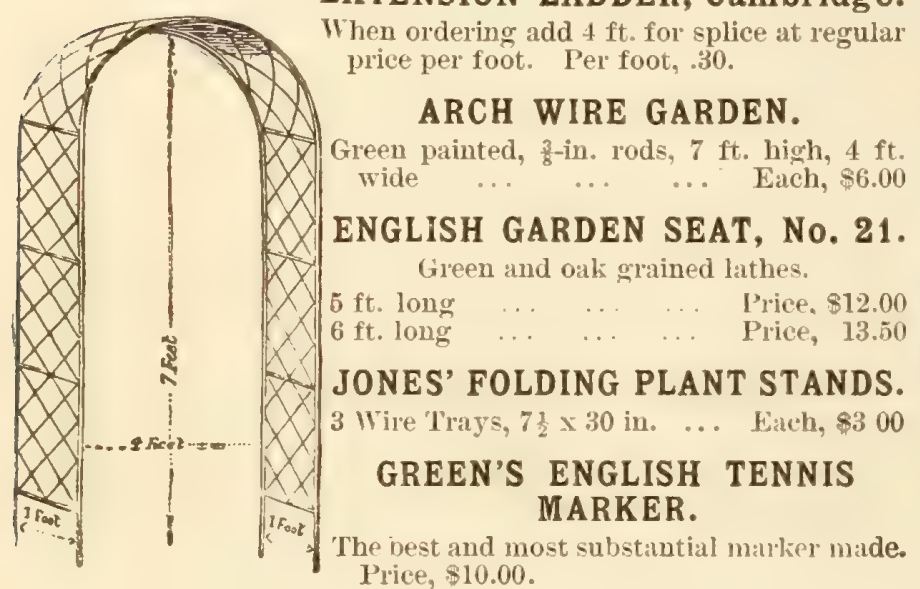

EXTENSION LADDER, Cambridge.

When ordering add $4 \mathrm{ft}$. for splice at regular ARCH WIRE GARDEN.

TREE GUARDS.

Made of Nos. 8 and 9 Galvanized Steel Wire.

Horizontal Wires locked to the upright wires by clamps make the joints rivet tight. 8 -in. diameter, $6 \mathrm{ft} .2$ in. high, each, \$1.00; per doz., \$12.00.

\section{FLOWER POTS, SAUCERS.}

Sizes and shapes as adopted and recommended by the Society of American Florists. They are of perfect shape, with a convex bottom; and drainage is perfect. Breakage is not one-half as great as in other pots, the deep rim protecting them from any ordinary hard usage.

\section{STANDARD FLOWER POTS.}

Measurement from inside to inside. Width and depth equal,

\begin{tabular}{|c|c|c|c|c|c|c|c|c|c|}
\hline ches. & & Doz. & & 100. & Inches. & & Doz. & & 100 \\
\hline 2 & .. & $\$ .10$ & ... & $\$ .60$ & 7 & . & $\$ 1.20$ & & $\$ 6$. \\
\hline $2 \frac{1}{2}$ & ... & .15 & $\ldots$ & .80 & 8 & $\ldots$ & 1.70 & ... & \\
\hline . & .. & .20 & $\ldots$ & 1.00 & 9 & ... & 2.40 & $\ldots$ & 13. \\
\hline $3 \frac{1}{2}$ & $\ldots$ & .25 & ... & 11 & 10 & $\ldots$ & 3.25 & $\ldots$ & 20. \\
\hline . & $\cdots$ & .30 & $\ldots$ & 1.6 & 11 & $\ldots$ & 4.35 & $\ldots$ & 24. \\
\hline $4 \frac{1}{2}$ & $\cdots$ & .35 & $\ldots$ & 2.0 & 12 & $\ldots$ & 6.00 & $\ldots$ & 33. \\
\hline 5 & $\cdots$ & .50 & $\cdots$ & 2.6 & 14 & $\cdots$ & each & $\ldots$ & \\
\hline $5 \frac{1}{2}$ & $\cdots$ & .60 & $\cdots$ & 3.3 & 16 & $\ldots$ & $"$ & $\ldots$ & \\
\hline . & $\cdots$ & .75 & $\ldots$ & 4.00 & 18 & ... & "6 & $\ldots$ & \\
\hline . & $\cdots$ & .95 & ... & 5.35 & & & & & \\
\hline
\end{tabular}

Azalea Pots. These are about two-thirds the depth of the ordinary standard pot and are useful for growing ferns, azaleas and begonias. Sizes, 5, 6, 7, 8, 9, 10, and $12 \mathrm{in}$. in diameter. Prices the same as for standard pots of corresponding sizes.

FLOWER POT SAUCERS.

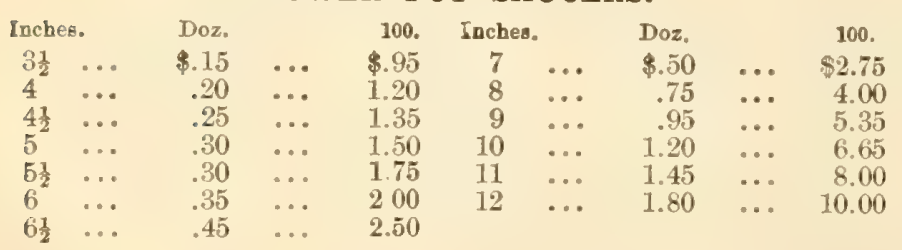

ROUND SEED PANS.

$\begin{array}{rr}\text { Each. } & \text { Doz } \\ 8.07 & \$ .75 \\ .10 & 1.20 \\ .20 & 2.25 \\ .35 & 4.20 \\ .75 & 9.00\end{array}$

FERN PANS.

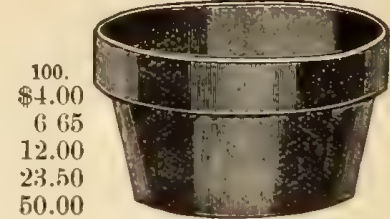

Round Seed Pan.

Something new in Fern Pans and Saucers. These pans are made thin and strong, and the saucers very shallow. They are very popular, and are made in eight sizes, to be sold with or without saucers.

These pans are especially adapted for linings to porcelain and Silver Fern Pans. Dimensions given are outside measurements.

\begin{tabular}{|c|c|c|c|c|c|c|c|}
\hline Bize & Vis & D & 100. & Dox. & & \multicolumn{2}{|c|}{ SAUCERS. } \\
\hline$\times 17$ in. & $\cdots$ & $\$ .35$ & $\$ 2.00$ & $\$ .20$ & & & $\$ 1.20$ \\
\hline$\times 2 \frac{1}{8}$ in. & $\ldots$ & .45 & 2.65 & .30 & $\cdots$ & . & 1.55 \\
\hline$\times 2 \frac{1}{4}$ in. & $\ldots$ & .60 & 3.35 & .35 & $\ldots$ & $\ldots$ & 2.00 \\
\hline$\times 2 \frac{1}{2}$ in. & $\ldots$ & .70 & 4.00 & .45 & $\ldots$ & $\ldots$ & 2.35 \\
\hline$\times 2 \frac{5}{8}$ in. & $\ldots$ & .85 & 4.65 & .50 & $\ldots$ & $\ldots$ & 2.65 \\
\hline$\times 3 \frac{1}{8}$ in. & $\ldots$ & 1.20 & 6.65 & .75 & $\ldots$ & $\ldots$ & 4.00 \\
\hline$\times 3+$ in. & $\ldots$ & 1.45 & 8.00 & .95 & $\ldots$ & $\ldots$ & 5.35 \\
\hline$\times 4$ in. & $\cdots$ & 1.70 & 9.35 & 1.20 & $\ldots$ & $\ldots$ & 6.65 \\
\hline & & & & & & IN & \\
\hline
\end{tabular}

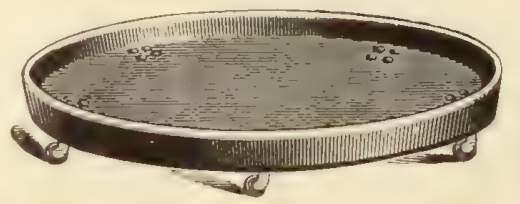

PLANT STANDS.

For Heavy Plants and Palms.

Platforms are Indurated Fibre Ware. Will not soak

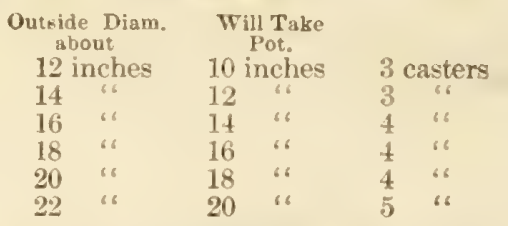
or rust.

INDURATED FIBRE WARE.
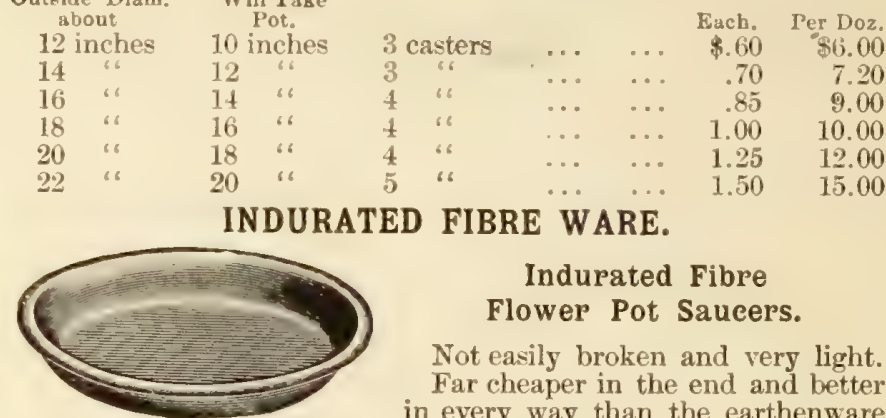

Indurated Fibre

Flower Pot Saucers.

Not easily broken and very light. Far cheaper in the end and better in every way than the earthenware article. Are not porous, and will protect woodwork, tables, etc. on which plants are to stand.

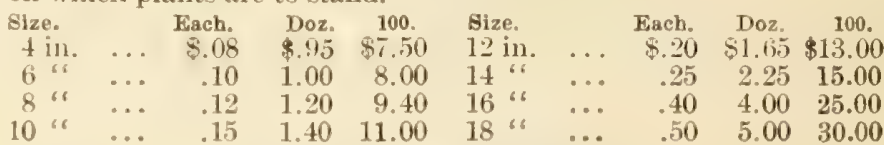

FLORISTS' VASES.

For Displaying Cut Flowers.

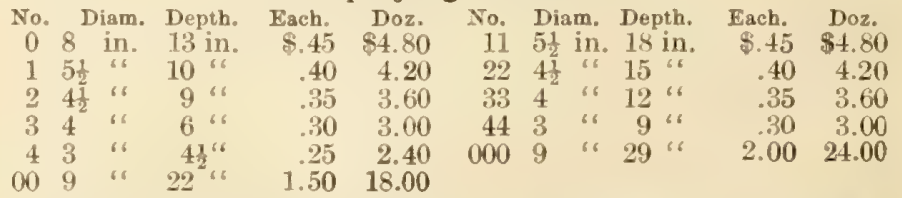

\section{NEPONSET PAPER FLOWER POT.}

Unbreakable, Handsome, Cheap.

$\begin{array}{lllrr}\text { Size. } & & & \text { Per } 100 . & \text { Per } 1000 . \\ 2 \frac{1}{4} & \cdots & \cdots & \$ .25 & \$ 2.20 \\ 2 \frac{1}{2} & \cdots & \cdots & .30 & 2.40 \\ 3 & \cdots & \cdots & .45 & 3.90 \\ 3 \frac{1}{2} & \cdots & \cdots & .60 & 5.15 \\ 4 & \cdots & \cdots & .80 & 6.90 \\ 5 & \cdots & \cdots & 1.20 & 10.35 \\ 6 & \cdots & \cdots & 1.65 & 14.55\end{array}$
1000 rate

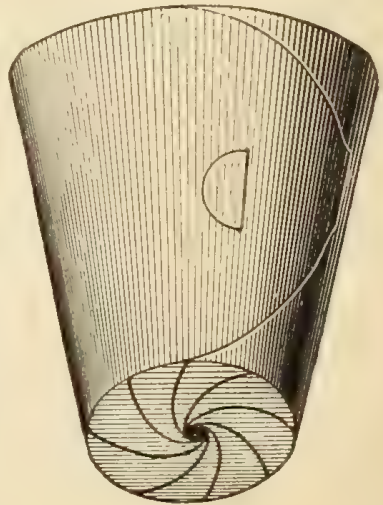




\section{GREENHOUSE CONSTRUCTION.}

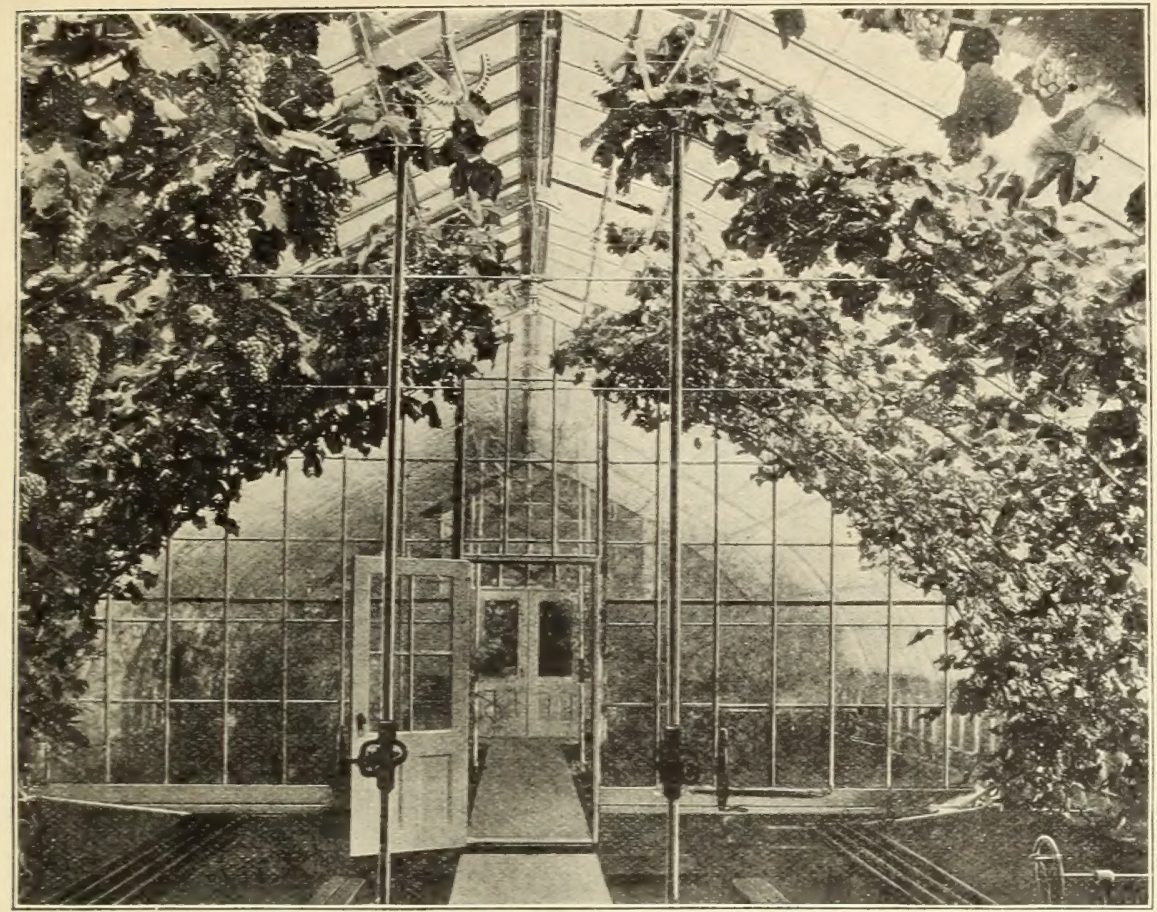

View of Grapery erected at Pomfret, Conn., by Lord \& Burnham Co.

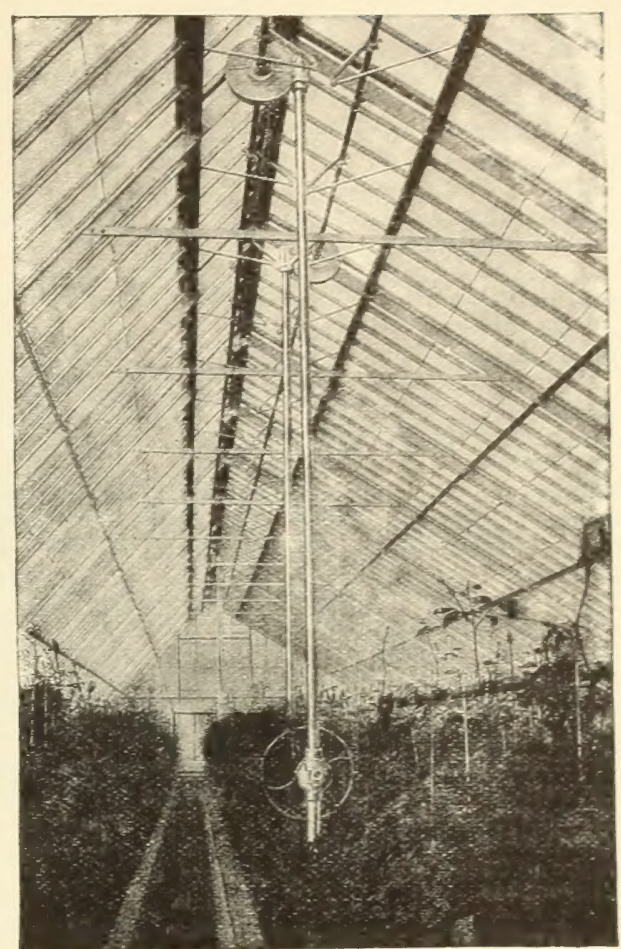

Greenhouse Ventilating Apparatus.

As Representatives of the Lord \& Burnham Co. of New York, we are prepared to furnish estimates of all kinds of greenhouse construction, including ventilating and heating apparatus.

\section{BURNHAM HOT WATER BOILERS.}

The Burnham Boiler is unquestionably the most satisfactory Hot-Water Greenhouse Heater built. Perfect combustion, thorough exhaustion of heat in the boiler itself, economy of fuel, ease of running and facilities for cleaning are special features of this thoroughly up-to-date boiler. Prices of Boilers and Heating Apparatus on request.

\section{R. \& J. FARQUHAR \& CO.,}

6 and 7 South Market Street, Boston, Mass.

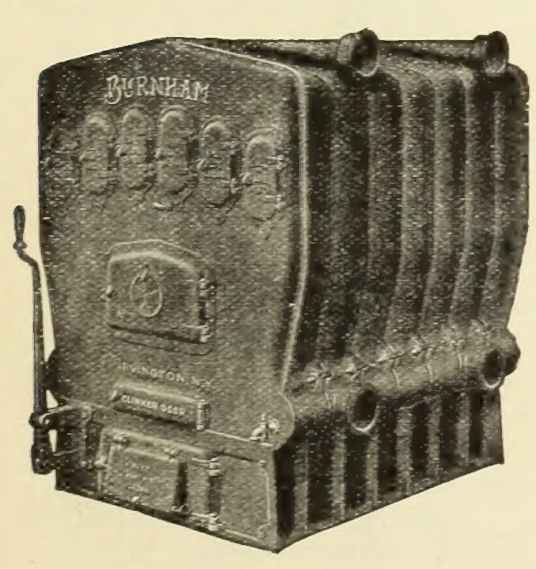

The Burnham Boiler. Exterior View.

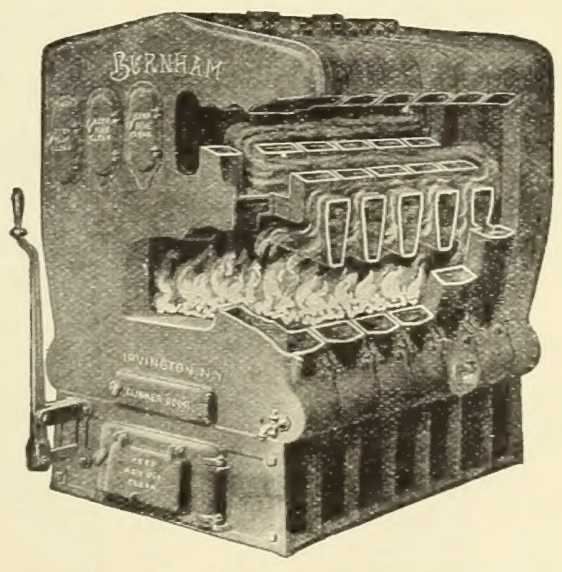

The Burnham Boiler. Interior View.

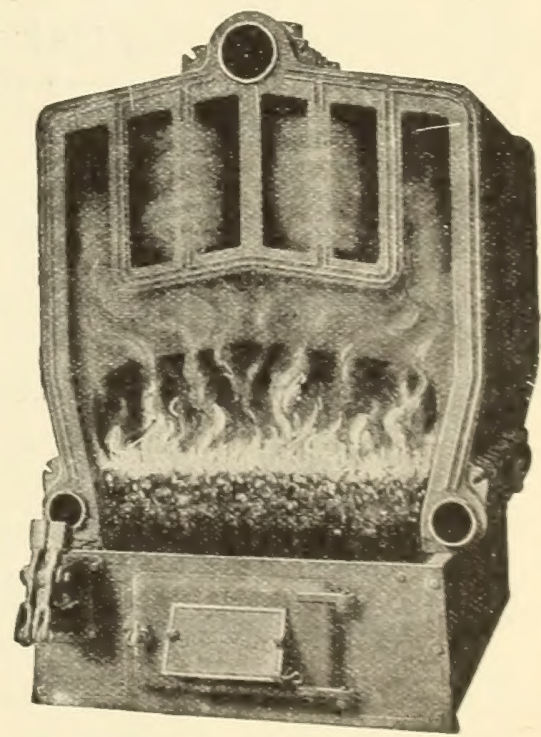

The Burnham Boiler. Cross Sectional View. 


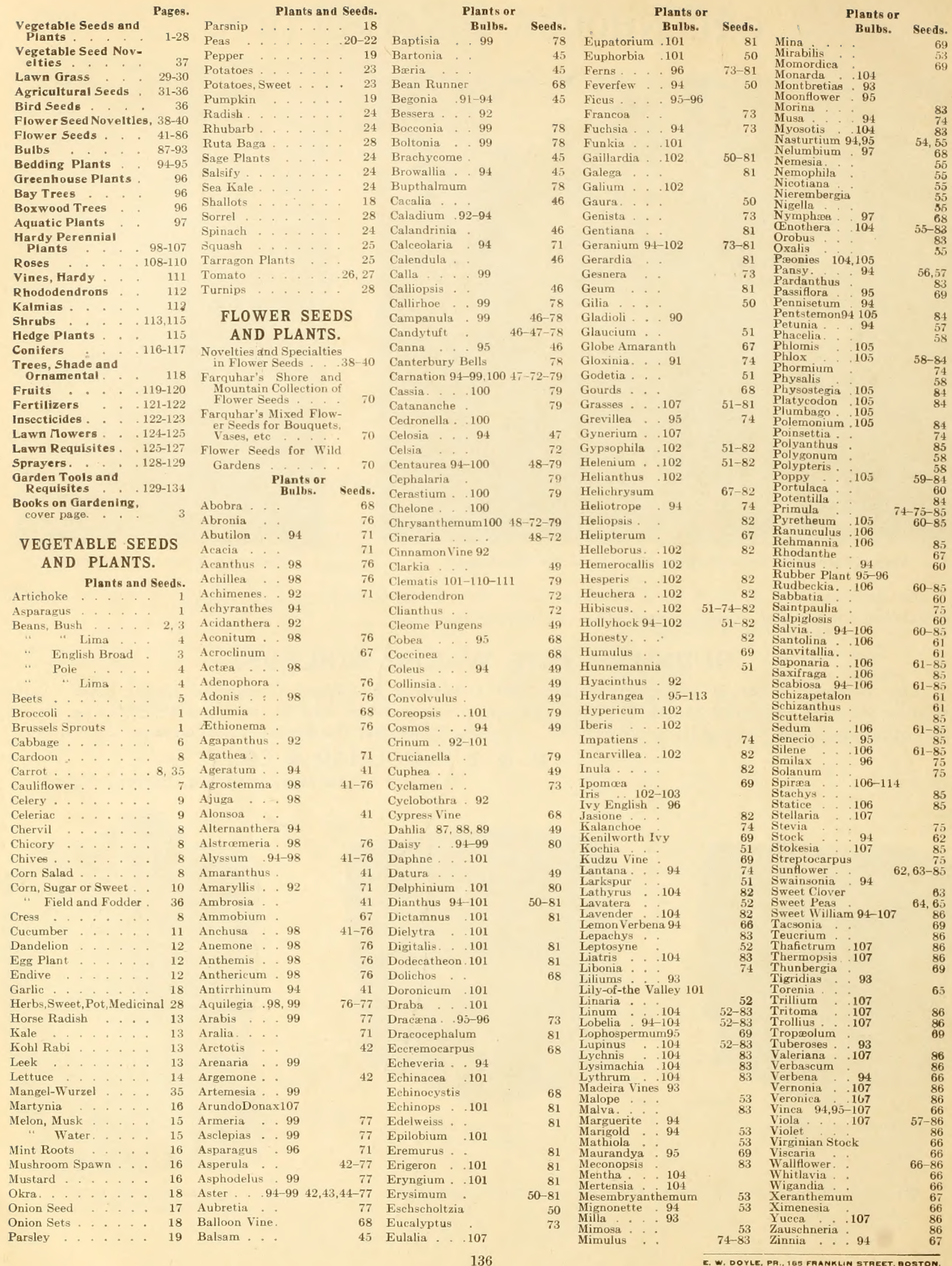




\title{
STANDARD WORKS ON AGRICULTURE, HORTICULTURE, LANDSCAPE GARDENING AND FORESTRY
}

\author{
All books sent post or express paid at prices quoted
}

\section{FARM AND GARDEN.}

Alfalfa. F. D. Coburn, Its growth, uses and feeding value. Illustrated Prearieal Garden Book, The. C. E. Hunn Amateur's Practieal Garden Book, The. C. E. Hunn

Botany, Field, Forest and Garden. Dr. Asa Gray .

Fertilizers. Edward B. Voorhees

Flower Garden, English. W. Robinson . . . 6.00

Gardener's Dictionary, Johnson's

Gardener's Assistant, The. New edition. Under the direction and general editorship of William Watson, curstor, Royal Gardens, Kew. A complete encyclopedia of gardening. Price, 2 vols.

Gardening, The Dietionary of. Geo. Nicholson, A.L.S. 5 vols. Per vol.

Garden, The Wild. William Robinson

Garden Making. L. H. Bailey

Gardening for Pleasure. Peter Henderson

Grasses and Forage Plants. Charles L. Flint

Grasses of North Ameriea. W. J. Beal, Vol. I, \$2.50 Vol. II

Handbook of Plants and General Hopticulture. Peter Henderson

Hortieulturist's Rule Book. L. H. Bailey

How to Make a Sehcol Garden. Hemenway

Irrigation and Drainage. F. H. King .

Manures, Farming with Green. C. Harlan, M.D.

Pastures, Permanent and Temporary. Sutton

Plant Culture. George W. Oliver .

Play and Profit in My Garden. E. P. Roe.

Principles of Agrieulture, The. L. H. Bailey

Pruning Book, The. I. H. Bailey

Silos, Ensilage and Silage. M. Miles

Soil, The; Its Nature, Relations, and Fundamental Principles of Management. King .

Solling Crops and the Silo. Thomas Shaw

The Garden Month by Month. Mabel Cabot Sedgwick .

Weeds, How to Eradieate Them. Thomas Shaw .

\section{FIELD AND GARDEN VEGETABLES.}

Asparagus. G. M. Hexamer . . . . . . . . $\$ .50$

Cabbage, Cauliflower, and Allied Vegetables. C. L.

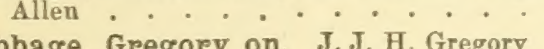

Cabbage, Gregory on. J. J. H. Gregory . . . . . .30

Celery for Proflt. T. Greiner . . . . . . . . . .20

Foreing Book, The. L. H. Bailey . . . . . . . 1.00

Gardening for Profit. Peter Henderson . . . . . 1.50

Market Gardening, Success in. W. W. Rawson . . 1.00

Mushrooms, How to Grow Them. Falconer . . . . 1.00

Mushroom Culture. Robinson . . . . . . . . . .50

Onion Culture. T. Greiner . . . . . . . . . .50

Prineiples of Vegetable Gardening. L. H. Bailey . . 1.25

Rhubarb Culture. J. E. Morse . . . . . . . . .50

Vegetables and Flowers from Seed and Roots, The Culture of. Sutton. Imported . . . . 2.25

Vegetables and Garden Herbs. Allen French. . . . 2.00

\section{FRUITS AND FRUIT CULTURE.}

Ameriean Fruit Culturist. J. J. Thomas . . . . . 82.50

Barry's Fruit Garden. P. Barry . . . . . . . . . 1.50

Grape Culturist, The. A. S. Fuller . . . . . . 1.50

Principles of Fruit Growing. L. H. Bailey . . . . . 1.25

Strawberry Culturist, The. A. S. Fuller . . . . . . .25

Systematie Pomology. F. A. Waugh . . . . . 1.00

Vines and Vine Culture. Considered the best book on Greenhouse Grapes. Archibald F. Barron. Imported

\section{INSECTS AND FUNGI.}

Entomology, Eeonomic. Prof. Smith. Insects easily identified; preventives and machinery

Injurious Inseets and the Use of Insecticides. Frank

Insects and Inseetieides. C. M. Weed

Spraying of Plants. E. J. Lodeman.

\section{FLOWERS AND ORNAMENTAL PLANTS.}

American Carnation, How to Grow It. Ward . . $\$ 3.50$

Bulbs and Tuberous Rooted Plants. C. L. Allen . . 1.50

Carnation Culture, Ameriean. L. L. Lamborn . . 1.50

Cyclopedia of Ameriean Horticulture. Bailey and Miller, 4 vols.

Dahlia, The, Lawrence K. Peacock . . . . . . . . $\quad .30$

Field, Forest and Wayside Flowers. Maud Going . . 1.50

Garden and Farm Topics. Peter Henderson . . 1.00

Greenhouse Construetion. L. R. Taft . . : : : 1.50

Greenhouse Management. L. R. Taft . . 1.50

Hardy Perennials and Old-Pashioned Garden Flowers. J. Wood. Imported. Deseribing the most desirable plants for borders, shrubberies, etc., foliage and flowering

Home Floriculture. E. E. Rexford bith Them. Lizzie
House Plants and How to Sueceed with Page Hillhouse

Notes on Lilies. Second Edition. Dr. Wallace

Plea for Hardy Plants. A. J. Wilkinson Elliot. Cloth

Practical Floriculture. Peter Henderson.

Propagation of Plants. A. S. Fuller

Rhododendrons. E. S. Rand, Jr.

Rose, Parsons on the. S. B. Parsons

Rose, The. H. B. Ellwanger

Roses, Book of the. Imported. Dean S. Reynolds Hole. A guide to Rose Culture. Fourteenth edition, revised

Shrubs of N. E. America, The. Newhall

Shrubs, Ornamental. Lucius D. Davis .

Violet Culture, Commereial. B. T. Galloway

Water Gardening. Peter Bisset

Window Flower Garden, The. Julius Heinrich

Wild Flowers, Field Book of American. F. Schuyler Mathews

\section{LANDSCAPE GARDENING AND FORESTRY.}

Ameriean Gardens. Guy Lowell . . . . . . . 87.50

Hedges, Windbreaks, Shelters and Live Fences. E. P. Powell. Illustrated

How to Plan the Home Grounds. S. Parsons

Landseape Gardening. F. A. Waugh

Landseape Gardening. Samuel Parsons : : : : : 3.50

Landseape Gardening. Edward Kemp.

Trees and Their Leaves, Familiar. F. Schuyler Mathews

Trees of Northeastern Ameriea, The. Chas. S. Newhall 


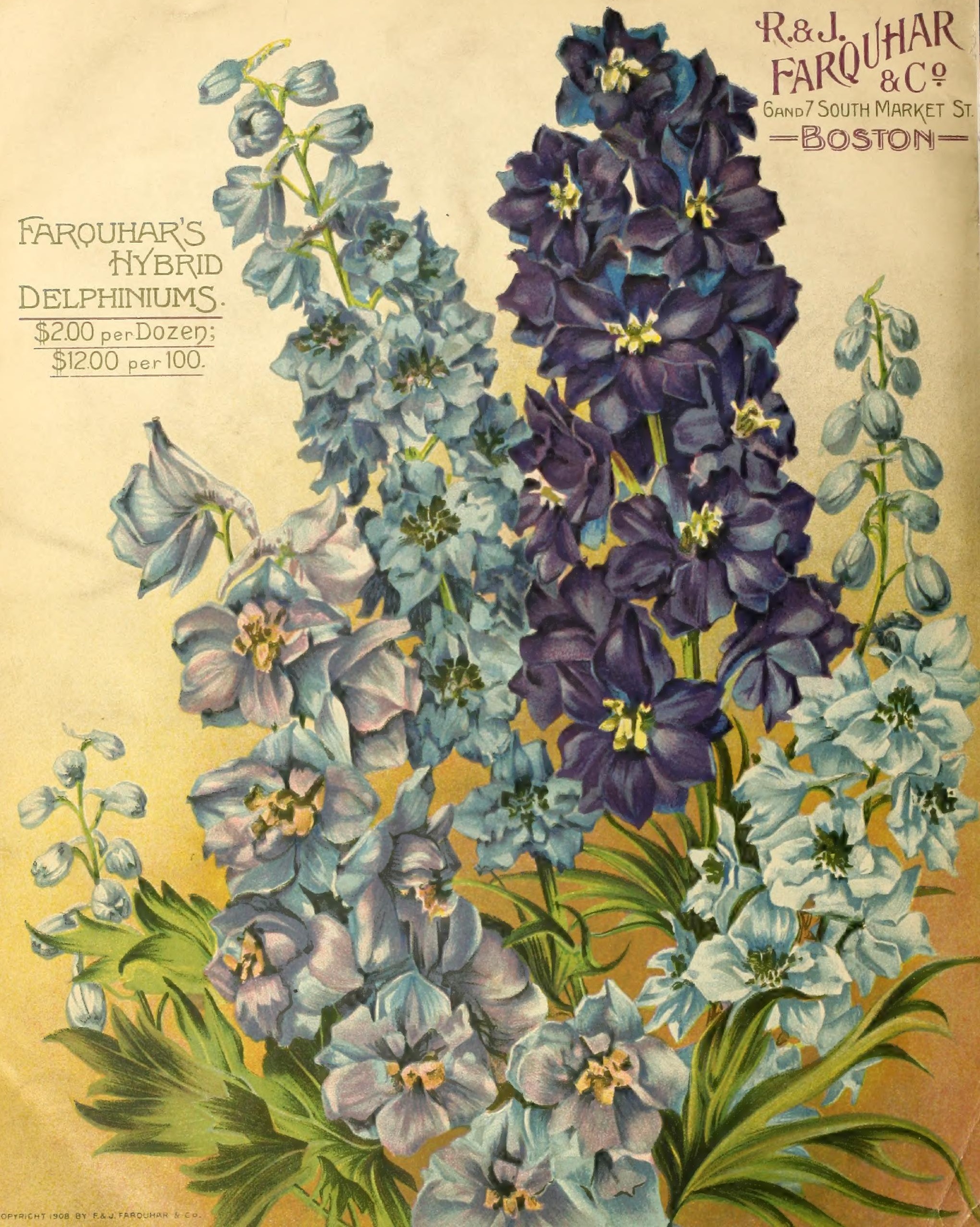

